\title{
COORDINFÂNCIA: 20 AÑOS DE LUCHA \\ POR LA EFICACIA DE LOS \\ DERECHOS DE LOS NIÑOS \\ Y DE LOS ADOLESCENTES
}

ORGANIZADORAS: Ana Maria Villa Real Ferreira Ramos Dalliana Vilar-Lopes Luciana Marques Coutinho Simone Beatriz Assis de Rezende

\section{tiv) MPT | 2021}



MINISTERIO PÚBLICO DEL TRABAJO COORDINACIÓN NACIONAL DE COMBATE CONTRA LA EXPLOTACIÓN DEL TRABAJO DE NIÑAS, NIÑOS Y ADOLESCENTES - COORDINFÂNCIA

\section{COORDINFÂNCIA: \\ 20 AÑOS DE LUCHA \\ POR LA EFICACIA DE LOS \\ DERECHOS DE LOS NIÑOS \\ Y DE LOS ADOLESCENTES}




\section{COMISIÓN EDITORIAL}

Presidente:

Dalliana Vilar-Lopes

Fiscal del Trabajo

Vicepresidente:

Simone Beatriz Assis de Rezende

Fiscal Regional del Trabajo

Miembros:

Ana Maria Villa Real Ferreira Ramos

Fiscal del Trabajo

Luciana Marques Coutinho

Fiscal del Trabajo

Margaret Matos de Carvalho

Fiscal Regional del Trabajo

Jailda Eulidia da Silva Pinto

Fiscal del Trabajo

Nayara Lima Xavier

Asesora de Comunicación 


\begin{abstract}
MINISTERIO PÚBLICO DEL TRABAJO COORDINACIÓN NACIONAL DE COMBATE CONTRA LA EXPLOTACIÓN DEL TRABAJO DE NIÑAS, NIÑOS Y ADOLESCENTES - COORDINFÂNCIA
\end{abstract}

\title{
Organizadoras:
}

Ana Maria Villa Real Ferreira Ramos

Dalliana Vilar-Lopes

Luciana Marques Coutinho

Simone Beatriz Assis de Rezende

\section{COORDINFÂNCIA: \\ 20 AÑOS DE LUCHA POR LA EFICACIA \\ DE LOS DERECHOS DE LOS NINNOS Y \\ DE LOS ADOLESCENTES}

Brasília

Ministerio Público del Trabajo

2021 
Ministerio Público del Trabajo

Fiscalía General del Trabajo

Sede - SAUN Quadra 5, Lote C, Torre A - Brasília-DF

CEP 70040-250

\title{
Fiscal General del Trabajo
}

Alberto Bastos Balazeiro (2019-2021)

José de Lima Ramos Pereira (2021-2023)

\section{Vicefiscal General del Trabajo}

Maria Aparecida Gugel (2019-2023)

\section{Director General}

Luciano Aragão Santos (2019-2021)

Gláucio Araújo de Oliveira (2021-2023)

Coordinación Nacional de Combate contra la Explotación del

Trabajo de Niñas, Niños y Adolescentes - Coordinfância

Ana Maria Villa Real Ferreira Ramos

Coordinadora Nacional

Luciana Marques Coutinho

Vicecoordinadora Nacional

\author{
Secretaría de Comunicación Social \\ Philippe Gomes Jardim \\ Secretario de Comunicación Social \\ Ronaldo José de Lira \\ Subsecretario de Comunicación Social \\ Jocimar Nastari \\ Secretario Operativo \\ Ilustraciones \\ Cyrano Vital
}

Proyecto Gráfico, Editoración e Impresión

Gráfica Movimento

Tiraje

300 ejemplares

Datos Internacionales de Catalogación en la Publicación (CIP)

Coordinfância : 20 años de lucha por la eficacia de los derechos de los niños y de los adolescentes / organizadoras: Ana Maria Villa Real Ferreira Ramos ... [et al.]. - Brasília : Ministerio Público del Trabajo, 2021. 613 p. : il.

ISBN: 978-65-89468-09-7 (físico)

ISBN: 978-65-89468-10-3 (digital)

DOI: $10.51366 / 978-65-89468-10-3$-coordinfancia

1. Derecho del trabajo. 2. Trabajo infantil. I. Ramos, Ana Maria Villa Real Ferreira. II. Ministerio Público del Trabajo. III. Coordinación Nacional de Combate contra la Explotación del Trabajo de Niñas, Niños y Adolescentes.

CDDir 341.6

Los capítulos publicados son de responsabilidad de sus autores.

Cualquier parte de esta publicación puede ser reproducida, siempre que se cite la fuente. 


\section{ÍNDICE}

\section{Prefacio}

Alberto Bastos Balazeiro.......................... 11

\section{Presentación}

Ana Maria Villa Real Ferreira Ramos y Dalliana Vilar-Lopes . . . . . . 15 DOI: 10.51366/978-65-89468-10-3-coordinfancia-1

1. Jugar, herramienta efectiva para el combate al trabajo infantil Ana Elisa Alves Brito Segatti y Claudia Regina Lovato Franco . . . . . . . 21 DOI: 10.51366/978-65-89468-10-3-coordinfancia-2

2. El trabajo infantil por medio de los principios constitucionales relacionados al orden económico y financiero Antonio Alves Mendonça Júnior y Antônio Gomes de Vasconcelos ...... 39 DOI: 10.51366/978-65-89468-10-3-coordinfancia-3

3. De donde partimos en días de nubes grises y lluvias inciertas: iniciativas y desafíos afectos al combate a la explotación del trabajo infantil en la Amazonia Brasileña

Christiana D'arc Damasceno Oliveira . . . . . . . . . . . . . . . . . 57

DOI: 10.51366/978-65-89468-10-3-coordinfancia-4

4. El papel de la protección social en el fomento a la erradicación del trabajo infantil

Denise Ratmann Arruda Colin. . . . . . . . . . . . . . . . . . . . . .89

DOI: 10.51366/978-65-89468-10-3-coordinfancia-5

5. Pensar de otro modo la profesionalización del adolescente a partir de la teoría crítica de los derechos humanos

Dulce Martini Torzecki y Jailda Eulidia da Silva Pinto . . . . . . . . . . 107 DOI: 10.51366/978-65-89468-10-3-coordinfancia-6 
6. El trabajo infantil doméstico, su realidad, enfrentamiento y prevención

Eliane Araque dos Santos. ....................... 125

DOI: $10.51366 / 978-65-89468-10-3-$ coordinfancia-7

7. Trabajo infantil en las calles y racismo estructural: desafios en la actuación del Ministerio Público del Trabajo Elisiane Santos. . . . . . . . . . . . . . . . . . . . . . . . . . . . . . . . . 143

DOI: 10.51366/978-65-89468-10-3-coordinfancia-8

8. La participación política y social de niños y adolescentes en el combate al trabajo infantil

Felipe Caetano da Cunba y Wilson Guilherme Dias Pereira. . . . . . . . 159 DOI: 10.51366/978-65-89468-10-3-coordinfancia-9

9. La prohibición del trabajo del niño y del adolescente y la doctrina de la protección integral en el ordenamiento jurídico brasileño

Fernanda Brito Pereira . . . . . . . . . . . . . . . . . . . . . . 177

DOI: 10.51366/978-65-89468-10-3-coordinfancia-10

10. Infancias brasileñas en colapso: necesitamos rescatar la ética del amor

Gabriela Lenz de Lacerda. . . . . . . . . . . . . . . . . . . . . . 195

DOI: 10.51366/978-65-89468-10-3-coordinfancia-11

11. Las tendencias trágicas del trabajo infantil: la "prostitución" en la infancia

Ivan Roberto Capelatto . . . . . . . . . . . . . . . . 215

DOI: $10.51366 / 978-65-89468-10-3$-coordinfancia-12

12. ¿Por qué luchar contra el trabajo infantil? Un recorrido por los mitos y verdades en busca de las respuestas Kátia Magalhães Arruda . . . . . . . . . . . . . . . . . . . . . . . 229

DOI: 10.51366/978-65-89468-10-3-coordinfancia-13 
13. La Convención 182 de la OIT, sobre las peores formas de trabajo infantil: una jornada memorable y desafiadora

Lelio Bentes Corrêa . . . . . . . . . . . . . . . . . . . . . . . . . . . . . 239

DOI: 10.51366/978-65-89468-10-3-coordinfancia-14

14. El Programa de Erradicación del Trabajo Infantil y la efectividad de las políticas públicas del Estado brasileño en el enfrentamiento de la explotación del trabajo de niños y adolescentes

Luciana Marques Coutinho. . . . . . . . . . . . . . . . . . . . . . . . 251

DOI: 10.51366/978-65-89468-10-3-coordinfancia-15

15. El trabajo infantil y la actuación de los Consejos Tutelares Lydiane Machado e Silva . . . . . . . . . . . . . . . . . . . . . . . . . 277 DOI: 10.51366/978-65-89468-10-3-coordinfancia-16

16. Garantía del derecho fundamental a la profesionalización como estrategia de prevención a la letalidad y al encarcelamiento de jóvenes socialmente vulnerables en el Brasil

Márcio Rogério de Oliveira ......................... 293

DOI: 10.51366/978-65-89468-10-3-coordinfancia-17

17. La explotación sexual comercial de niños y adolescentes como una de las peores formas de trabajo infantil Margaret Matos de Carvalho . . . . . . . . . . . . . . . . . . . . . 309 DOI: 10.51366/978-65-89468-10-3-coordinfancia-18

18. La institucionalización y castigo como política de enfrentamiento al trabajo infantil en el tráfico de drogas

Maria De Fatima Pereira Alberto, Rafaela Rocha da Costa, Manuella Castelo Branco Pessoa y Thiago Augusto Pereira Malaquias. . . . . . . . . . . . 327 DOI: 10.51366/978-65-89468-10-3-coordinfancia-19

19. Los jóvenes en conflicto con la ley y el derecho al trabajo: el cupo alternativo como concreción del acceso al trabajo Mariane Josviak. . . . . . . . . . . . . . . . . . 345 DOI: $10.51366 / 978-65-89468-10-3-$ coordinfancia-20 
20. Trabajo infantil en las cadenas productivas de las grandes empresas: violencia sistémica y falacia discursiva Marques Casara ............................ 367 DOI: 10.51366/978-65-89468-10-3-coordinfancia-21

21. Protección al niño y al adolescente en situación de trabajo: la polémica presente en la (in)comprensión de la competencia material de la justicia especializada Noemia Porto . . . . . . . . . . . . . . . . . . . . . . . . . . . . . . . . . . 379

DOI: $10.51366 / 978-65-89468-10-3$-coordinfancia-22

22. La historia de la lucha contra el trabajo infantil en el Reino Unido

Oscar Guardiola-Rivera y Fernanda Pereira Barbosa . . . . . . . . . . . . 403 DOI: 10.51366/978-65-89468-10-3-coordinfancia-23

23. El Ministerio Público del Trabajo en la lucha contra el trabajo infantil - Proyecto Rescate la Infancia Patricia De Mello Sanfelici Fleischmann. . . . . . . . . . . . . . . . . 429 DOI: 10.51366/978-65-89468-10-3-coordinfancia-24

24. Coordinfância en acuarela: historias y trayectorias de vida Rafael Dias Marques . . . . . . . . . . . . . . . . . . . . 447 DOI: 10.51366/978-65-89468-10-3-coordinfancia-25

25. Informalidad y trabajo infantil: la complejidad de los desafíos a la regulación social del trabajo Renata Queiroz Dutra y Valdemiro Xavier dos Santos Júnior . . . . . . 457 DOI: 10.51366/978-65-89468-10-3-coordinfancia-26

26. La auditoría fiscal del trabajo en el combate al trabajo infantil: evolución e instrumentos de actuación Roberto Padilha Guimaräes. . . . . . . . . . . . . . . . . . . . . 481 DOI: 10.51366/978-65-89468-10-3-coordinfancia-27 
27. Adolescentes en medida socioeducativa: ¿Qué es lo que el trabajo infantil tiene que ver con eso?

Simone Beatriz. Assis de Rezende. . . . . . . . . . . . . . . . . . . 499

DOI: 10.51366/978-65-89468-10-3-coordinfancia-28

28. Los 20 años de Coordinfância: resistencia y lucha en el combate al trabajo infantil

Valesca de Morais do Monte......................... 519

DOI: 10.51366/978-65-89468-10-3-coordinfancia-29

29. Trabajo, infancia y modernidad: ¿Cinco siglos de subalternidad?

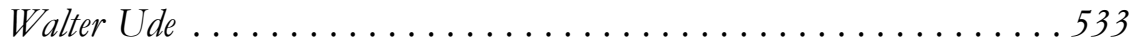

DOI: 10.51366/978-65-89468-10-3-coordinfancia-30

30. El derecho fundamental del niño al no trabajo Xisto Tiago de Medeiros Neto. . . . . . . . . . . . . . . . . . . . . . . . 549 DOI: 10.51366/978-65-89468-10-3-coordinfancia-31

31. El combate al trabajo infantil en el tráfico de drogas: por la construcción de alternativas hacia más allá del estado neoliberal Zéu Palmeira Sobrinho . . . . . . . . . . . . . . . . . . . . . . . . . . 575 DOI: 10.51366/978-65-89468-10-3-coordinfancia-32

32. Sobre las autoras $\mathrm{y}$ los autores. . . . . . . . . 595

33. Dibujos del MPT en la Escuela. ............663 



\section{PREFACIO}

Una de las mayores honras al ser Fiscal General del Trabajo es tener la oportunidad de estar en una posición privilegiada para acompañar el trabajo de excelencia que las y los miembros del Ministerio Público del Trabajo desarrollan en el combate a todas las formas de trabajo infantil. Trabajar activamente con el objetivo de permitir todo el soporte material y no material para el desarrollo pleno de la misión constitucional es, sin duda, uno de los mayores orgullos profesionales que se puede tener.

En efecto, la previsión del art. 227 de nuestra Carta de la República jamás podrá ser transformada en mera promesa constitucional inconsecuente. Ese deber expreso de la familia, de la sociedad y del Estado de asegurar al niño, al adolescente y al joven, con absoluta prioridad, una serie de derechos esenciales a nuestro propio proyecto de humanidad debe ser siempre recordado y verticalizado en conductas individuales, colectivas e institucionales.

Se percibe que la Constitución coloca ese punto como esencial para las esferas privadas o públicas de nuestra sociedad. La protección y la promoción de los derechos del niño y del adolescente se consustancian como uno de los derechos sociales más expresivos, subsumiéndose a la noción de los derechos de segunda generación, cuyo cumplimiento impone al poder público la satisfacción de un deber de prestación positiva (RE 482.611, rel. min. Celso de Mello, j. 23-3-2010, dec. monocrática, DJE de 7-4-2010). Así, es esencial la eterna vigilancia por parte del Ministerio Público del Trabajo, sea en la represión de casos específicos, sea en la inducción de políticas públicas estructurantes, sea incluso en el proceso de concientización social.

Es dentro de ese contexto que se insiere esta obra conmemorativa de la Coordinación Nacional de Combate contra la Explotación del Trabajo de Niñas, Niños y Adolescentes - Coordinfância, creada por la Ordenanza (Portaria) PGT n. ${ }^{\circ}$ 299, del 10 de noviembre de 2000. Son 20 años memorables de construcción colectiva y de combate intenso e intransigente en la preservación de la infancia y de la adolescencia, dándole un lugar concreto a los preceptos fundamentales constitucionales de la protección integral y de la prioridad absoluta. 
A lo largo de esta historia de éxito, la Coordinación Nacional desarrolló numerosas iniciativas de vanguardia, aliando intensa articulación social y/o interinstitucional e ingeniería jurídica para desarrollar un estado de arte en la tutela de derechos difusos y colectivos relativos a la infancia y a la adolescencia. Muchísimos cursos fueron realizados y manuales elaborados para crear verdaderos marcos jurídicos en la actuación de las y los miembros del Ministerio Público del Trabajo e incluso en la de los asociados sociales en la red integrada de protección. De los diversos ejemplos, destacamos la articulación con los Consejos Tutelares y la capacitación de los Consejeros Tutelares y de los profesionales de educación de forma presencial o en plataforma abierta alcanzando a todo Brasil; la institución del Premio MPT en la Escuela; el monitoreo de cadenas productivas donde hay incidencia de trabajo infantil; la actuación en el fomento al aprendizaje profesional, incluso en el ámbito del sistema socioeducativo. Sin contar la implantación de numerosas etapas del Proyecto Rescate la Infancia en diversos municipios de Brasil.

En ese mismo sentido, es que se insiere la presente publicación. Se trata de una antología que refleja bien la extensión y la verticalidad de las cuestiones inherentes a la pauta cotidiana de la Coordinación Nacional. Son temas abordados con excelencia por las y los miembros del Ministerio Público, magistradas y magistrados, auditores fiscales del trabajo, académicos y juristas de proyección nacional e internacional. Temas como la explotación del trabajo infantil en las mafias de tráfico de drogas y de la explotación sexual demuestran como existe toda una estructura que se debe romper a través de la inducción de políticas públicas y de actividad estatal represiva para eliminar las condiciones nocivas donde surgen oportunidades para esas graves violaciones a los derechos humanos que amenazan el proyecto de nación diseñado en nuestro texto constitucional.

En ese punto, la obra se transforma en fuente de investigación indispensable para los que buscan entender el combate al trabajo infantil bajo la perspectiva humanista y que ven en la centralidad de ese debate los conceptos de dignidad humana y de prioridad absoluta como propulsores de la protección de la infancia y de la adolescencia. Además de soporte teórico, los análisis de casos a lo largo del libro traen importantes y sólidos subsidios para el enfrentamiento de situaciones concretas por parte de los juristas y operadores de derecho de nuestro tiempo. 
Finalmente, invito al lector a instrumentalizar todo el conocimiento que va a adquirir para apropiarse del papel activo de constructores del nivel civilizatorio mínimo que permita que nuestros niños y adolescentes puedan desenvolverse de forma plena, digna y sana.

Larga vida a Coordinfância, responsable por promover y rescatar la ciudadanía de tantos niños y adolescentes, por concretar los ideales trazados en la Convención sobre los Derechos de los niños y, finalmente, por luchar para que los niños y adolescentes no sean solamente "ciudadanos de papel”, en referencia a la expresión de Gilberto Dimenstein.

¡Buena lectura!

\author{
Alberto Bastos Balazeiro \\ Fiscal General del Trabajo
}





\section{PRESENTACIÓN}

DOI: 10.51366/978-65-89468-10-3-coordinfancia-1

La Coordinación Nacional de Combate contra la Explotación del Trabajo de Niñas, Niños y Adolescentes (Coordinfância) cumple 20 años de mucha lucha, conquistas y desafíos desde que se ha creado, el 10 de noviembre de 2000, por intermedio de la Ordenanza (Portaria) n. ${ }^{\circ} 299$, de la Fiscalía General del Trabajo. Para celebrar estas dos décadas de persistencia en la defensa de los derechos fundamentales de los niños y de los adolescentes, el Ministerio Público del Trabajo (MPT) elabora y publica la presente obra conmemorativa, que también representa el cumplimiento del objetivo del Plan Nacional de Prevención y Erradicación del Trabajo Infantil y Protección al Trabajador Adolescente, correspondiente al eje estratégico n. ${ }^{\circ}$ 07, por el cual el MPT se comprometió a fomentar la producción de conocimiento sobre la realidad del trabajo infantil en Brasil y sus aspectos jurídico laborales. La obra está publicada con ediciones en portugués, inglés y español, con el fin de que las discusiones trasciendan las fronteras nacionales.

Con la finalidad de rememorar, reconstruir y resignificar la trayectoria de muchas de las acciones desarrolladas por el MPT por medio de Coordinfância, contribuyen para la presente obra actuales y antiguas Coordinadoras y Coordinadores Nacionales y Regionales. Con el mismo paso, sin perder de vista la necesaria construcción democrática del saber y el respeto a la pluralidad de visiones y a las líneas de pensamiento que deben nortear el debate sobre las cuestiones relevantes para la institución y la sociedad, participan de la obra Ministros del Tribunal Superior del Trabajo, Jueces, Fiscales y Auditores fiscales del Trabajo, Profesores e Investigadores nacionales y extranjeros, además de jóvenes integrantes de movimientos nacionales e instancias públicas que defienden la participación activa de la juventud en la defensa y promoción de los derechos fundamentales de los niños y de los adolescentes.

Con un norte transdisciplinario, los capítulos que componen este Libro abordan las diversas facetas del trabajo infantil, su historia y la evolución del problema, en sintonía con las realidades sociopolíticas de estos 20 años, como también rescatan y consolidan la actuación del MPT frente a lo ilícito, además de los proyectos estratégicos desarrollados a lo largo del tiempo, relacionando incluso las perspectivas constitucional e interna- 
cional. Así, entre los 31 escritos que integran la obra, están los que analizan cuestiones introductorias o generales del debate acerca del trabajo infantil y de la profesionalización del adolescente, con abordajes históricos y sociopolíticos o análisis de causas y consecuencias de lo ilícito y de la promoción de los derechos del niño y del adolescente. Otros, a su vez, dirigen su presentación hacia la actuación del MPT a lo largo de ese período, a veces con tono poético o celebrativo, en otros casos con exposición acerca del surgimiento y evolución del Proyecto Rescate la Infancia y acciones específicas de las respectivas gestiones al frente de la Coordinación. También hay capítulos que señalan la discusión internacionalmente instaurada acerca de la protección de la infancia y del derecho a no trabajar, y otros inclinados hacia el examen de temas espinosos que, en realidad de eficacia de derechos, se presentan como verdaderos hard cases - a ejemplo del racismo estructural y su correlación con el trabajo infantil, especialmente en las calles, la explotación sexual comercial de niños y adolescentes y el enfrentamiento al trabajo infantil en el tráfico de drogas. Además, como no podría faltar en la obra, hay un capítulo que enfrenta los desafíos inherentes a la explotación del trabajo infantil en la Amazonia brasileña, otros que, por su turno, presentan pronósticos y perspectivas para el trabajo infantil en Brasil y en el mundo.

Teniendo en cuenta que las discusiones se entrecruzan, a veces constando de un mismo capítulo cuestiones introductorias, análisis de hard cases y pronósticos, se decidió democráticamente organizar los escritos por el orden alfabético del nombre de la primera autora o autor, sin preocupación con el tema abordado.

Ante esa secuencia de disposición de la obra, el primer capítulo, de autoría de Ana Segatti y Cláudia Lovato, retoma la esencia de la infancia concentrada en el acto de jugar (brincar), incluso como política pública a ser ejecutada por el Estado brasileño, y presenta la propuesta de un proyecto para que sea desarrollado por el MPT y pronósticos y prospectivas del trabajo infantil para 2025. El segundo, redactado por Antônio Vasconcelos y Antônio Mendonça Júnior, aborda el trabajo infantil bajo la perspectiva de los principios constitucionales de orden económico y financiero, que fundamentan la prohibición legal al trabajo infantil.

En seguida, Christiana D'arc examina los desafíos y potencialidades para el combate al trabajo infantil en la Amazonia brasileña, con 
lectura a la luz de normas internacionales y nacionales y repercusiones derivadas de la pandemia de Covid-19. Denise Colin, en su turno, aborda el papel de la protección social frente al trabajo infantil, con exposición acerca del Sistema Único de Asistencia Social - SUAS - y del Programa de Erradicación del Trabajo Infantil - PETI. Al lado de ese análisis, Dulce Torzecki y Jailda Pinto analizan la profesionalización del adolescente a partir de la teoría crítica de los derechos humanos, al paso en que Eliane Araque aborda la realidad del trabajo infantil doméstico y mecanismos de prevención y enfrentamiento. Ya Elisiane Santos demuestra el racismo estructural inherente al trabajo infantil en las calles, marcado por la presencia masiva de niños y adolescentes negros.

Los jóvenes Felipe Caetano y Wilson Guilherme introducen en el libro la voz de la juventud, con incursión sobre la participación política y social de niños y adolescentes en el combate al trabajo infantil. Se continúa el debate con el rescate de la doctrina de la protección integral en el ordenamiento jurídico brasileño frente a la vedación del trabajo precoz, realizado por Fernanda Brito, y Gabriela Lenz rescata la ética del amor, al abordar el colapso vivido por las infancias brasileñas en el contexto del trabajo infantil, remunerado o no. Ivan Capelatto, en su turno, trata sobre la explotación sexual comercial de niños y adolescentes, y las tragedias que de ella derivan bajo el punto de vista social, familiar y psicológico.

Kátia Arruda retoma los mitos y verdades sobre el trabajo infantil, mientras que Lelio Bentes centra su discusión en el debate internacional acerca de las peores formas de trabajo infantil y los impedimentos que derivan de la Convención n. ${ }^{\text {o }} 182$ de la Organización Internacional del Trabajo. Retomando la discusión anterior, pero de forma conjugada con las acciones del MPT, Luciana Coutinho analiza el PETI bajo la óptica retrospectiva de los 24 años de implementación de esta política pública, como también la actuación del Parquet laboral en el combate contra la explotación del trabajo infantojuvenil, dándole realce a la intersección entre las iniciativas de Coordinfância y PETI.

En el contexto de la interlocución con actores integrantes de la red de protección, Lydiane Machado resalta la importancia de los Consejos Tutelares para el combate contra la explotación de niños y adolescentes en el trabajo. Márcio Rogério, en su turno, aborda la profesionalización como estrategia de prevención al encarcelamiento de jóvenes en situación 
de vulnerabilidad social, realidad presente en las estadísticas sobre letalidad y encarcelamiento juvenil en Brasil. Aún en el ámbito de los hard cases, Margaret Matos analiza la explotación sexual comercial de niños y adolescentes como una de las peores formas de trabajo infantil; ya Maria de Fátima et all trata el trabajo infantil en el tráfico de drogas y propone reflexiones sobre la política de enfrentamiento en Brasil, al paso en que Mariane Josviak aborda la situación de los jóvenes en conflicto con la ley y la relevancia del aprendizaje profesional, incluso en la Administración Pública, como mecanismo de inclusión.

Marques Casara analiza la presencia del trabajo infantil en las cadenas de producción de grandes empresas y las prácticas de enmascaramiento que impiden identificar sus eslabones. Noemia Porto expone sobre el trabajo infantil artístico, cultural y deportivo, incluso bajo los marcos reglamentarios internacionales y en perspectiva comparada, como también sobre la incomprensión instaurada sobre la competencia material de la Justicia del Trabajo para apreciar y juzgar causas que traten del tema.

Oscar Guardiola-Rivea y Fernanda Barbosa, en su turno, abordan la historia del combate al trabajo infantil en el Reino Unido, traen una perspectiva externa interdisciplinaria, a partir de una visión calcada en bases no puramente jurídicas, sino filosóficas, sociológicas, antropológicas, acerca de temática persistente en la realidad brasileña y que aún guarda presencia y marcas en la sociedad británica.

Patrícia Sanfelici presenta el Proyecto Rescate la Infancia como gran matriz de la actuación de la Coordinación del MPT, y la sigue la lectura poética de la historia de la Coordinfância presentada por Rafael Marques. Más adelante, Valesca do Monte rescata los 20 años de historia de Coordinfância marcada por la resistencia y lucha en el combate al trabajo infantil.

En perspectiva que no podría faltar en el contexto posterior a la reforma laboral, Renata Queiroz y Valdemiro Xavier correlacionan trabajo infantil e informalidad y destacan la relevancia del diálogo entre las políticas públicas para la erradicación del trabajo infantil y las volcadas para la expansión del mercado de trabajo formal. En seguida, Roberto Padilha trata las funciones desempeñadas por la Auditoría Fiscal del trabajo en el combate al trabajo infantil, con abordaje evolutivo e hincapié para sus instrumentos de actuación. En paralelo, Simone Rezende presenta par- 
te de los resultados de su investigación sobre el aprendizaje profesional como mecanismo para el desarrollo humano y la reintegración social de adolescentes en cumplimiento de medidas socioeducativas con restricción de libertad.

Walter Ude analiza el trabajo infantil en el contexto de la modernidad occidental, en un escrito que propone una lectura decolonial del tema. En seguida, Xisto de Medeiros Neto aborda las matrices del derecho fundamental del niño a no trabajar y Zéu Palmeira, finalmente, retoma la discusión sobre el trabajo infantil en el tráfico de drogas, con una propuesta de soluciones alternativas que van más allá del modelo neoliberal.

$\mathrm{Al}$ echarle un vistazo a todos los capítulos que componen el presente libro, criteriosamente elegidos y analizados por la Comisión Editorial designada por las Ordenanzas PGT n. ${ }^{\circ} 631.2020$ y n. ${ }^{\circ} 1.150 .2020$, nos permite extraer la riqueza de los debates instaurados por las autoras y autores y la correspondiente calidad esperada a la obra por sus Organizadoras. Agréguese a todo el contenido escrito la sección destinada a consolidar dibujos de los finalistas del Premio MPT en la Escuela, compuesta por producciones de niños y adolescentes sobre la temática del trabajo infantil, como expresión evidente de la relevancia de promover la concientización pertinente desde los bancos escolares.

Con seguridad este libro va a contribuir para enriquecer sobremanera las discusiones acerca del combate al trabajo infantil y de la promoción de la profesionalización del trabajador adolescente en Brasil y en el mundo, esperamos que todas y todos disfruten la lectura y vengan a integrar los debates y la necesaria construcción colectiva que imponen la defensa y la promoción de los derechos humanos y fundamentales de aquellos que, constitucionalmente, son titulares, con prioridad absoluta, de protección integral.

Brasília, 10 de noviembre de 2020.

Ana Maria Villa Real Ferreira Ramos Coordinadora Nacional de la Coordinfância

Dalliana Vilar-Lopes Presidente de la Comisión Editorial 



\title{
JUGAR, HERRAMIENTA EFECTIVA PARA COMBATIR EL TRABAJO INFANTIL
}

\author{
ANA ELISA ALVES BRITO SEGATTI \\ CLAUDIA REGINA LOVATO FRANCO
}

DOI: 10.51366/978-65-89468-10-3-coordinfancia-2

Resumen. Ya que en Brasil hay cerca de 2 millones de niños y adolescentes involucrados en explotación de trabajo infantil y que una de nuestras metas institucionales es el combate de esa llaga, que afecta la dignidad de la persona humana del trabajador, se pretende con ese trabajo analizar los pronósticos del trabajo infantil para 2025 y, así, responder a la indagación si Brasil cumplirá el Pacto Internacional de erradicar el trabajo infantil. Para ello, buscamos estudios del derecho con otros ámbitos del saber y presentamos el proyecto "MPT-jugar", una herramienta de combate a las explotaciones sexual y de trabajo de los niños brasileños.

Palabras clave: Trabajo infantil. Explotación Sexual. Proyecto MPT-jugar.

\section{INTRODUCCIÓN}

El presente estudio será hecho bajo la óptica del Ministerio Público del Trabajo, pues como miembros de esa institución que integran la Coordinación Nacional de Combate contra la Explotación del Trabajo de Niñas, Niños y Adolescentes en São Paulo, buscamos alternativas para mitigar y extirpar el trabajo que no sea decente, para devolver, o incluso dar en primer orden, la dignidad de la persona humana de niños y de adolescentes. Se trata de investigación documental, en abordaje interdisciplinario en las áreas de la educación; de la sociología; asistencia social y Derecho - constitucional y del trabajo -, trazando un paralelo sobre el derecho de jugar y el trabajo infantil.

El trabajo consiste en la introducción y se divide en 4 secciones. Se inicia la sección I, atravesando por la actuación del Ministerio Público del 
Trabajo, la coordinación en la defensa de preceptos constitucionales; en la sección II, estudiaremos los Fundamentos Jurídicos para el fin del trabajo infantil, los objetivos del Milenio y las perspectivas para niños y adolescentes; en la sección III, introduciremos el juego, como instrumento de combate a la explotación sexual y al trabajo infantil. Las relaciones del principio de protección integral del niño y la educación, la psicología, el psicoanálisis y las políticas públicas; en la sección IV, hablaremos de algunas experiencias internacionales y nacionales desarrolladas para una sociedad más libre, justa y solidaria en la primera infancia. Traeremos un nuevo horizonte, el proyecto MPT-Jugar, para la articulación y actuación del Ministerio Público del Trabajo, en el enfrentamiento de la erradicación del trabajo y de la explotación sexual infantil; al final, concluiremos, que podemos pensar pronósticos y prospectivas para enfrentar las referidas violaciones.

\section{LA COORDINACIÓN NACIONAL DE COMBATE CONTRA LA EXPLOTACIÓN DEL TRABAJO DE NIÑAS, NIÑOS Y ADOLESCENTES DEL MINISTERIO PÚBLICO DEL TRABAJO EN LA DEFENSA DE PRECEPTOS CONS- TITUCIONALES}

El Ministerio Público del Trabajo, en noviembre de 2000, instituyó la Coordinación Nacional de Combate contra la Explotación del Trabajo de Niñas, Niños y Adolescentes - Coordinfância, con el alcance de desarrollar una actuación coordinada y eficaz en la promoción de acciones dirigidas al combate de las diversas formas de explotación del trabajo de niños y adolescentes.

La Constitución Federal (BRASIL, 1988), en sus arts. 1º, III, y 227, asegura la dignidad de la persona humana como principio fundamental de la República Federativa de Brasil y prescribe como

es deber de la familia, de la sociedad y del Estado asegurar al niño y al adolescente y el adolescente, con absoluta prioridad, el derecho a la vida, a la salud, a la alimentación, a la educación, al ocio, a la profesionalización, a la cultura, a la dignidad, al respeto, a la libertad y a la convivencia familiar y comunitaria, además de ponerlos a salvo de toda forma de negligencia, discriminación, explotación, violencia, crueldad y opresión.

Así, el Estado brasileño adoptó el principio de protección integral de los niños y de los adolescentes, los cuales pasaron a ser considerados sujetos de derechos y obligaciones, a quienes el Estado, la familia y la sociedad deben 
proteger prioritariamente. En ese contexto, la Carta Magna (BRASIL, 1988) prescribió una amplia prohibición al trabajo precoz, sellando el trabajo a los menores de 16 años, salvo en la condición de aprendiz, a partir de catorce años, notablemente en el art. $7^{\circ}$, inciso XXXIII.

En el mismo sentido, se destaca la legislación infraconstitucional prevista en el artículo 403 de la CLT, lo cual, en su párrafo único, todavía dispone que "el trabajo del menor no podrá ser realizado en locales perjudiciales a su formación, a su desarrollo físico, psíquico, moral y social y en horarios y locales que no permitan la asistencia a la escuela".

En atención a los principios de la dignidad de la persona humana y de la protección integral de los niños y de los adolescentes, corresponde al Estado, a la sociedad y a la familia, en conjunto, garantizar el efectivo el derecho a la educación, al ocio y a la profesionalización, con rechazo a la explotación del trabajo infantil.

El elevado número de trabajo de niños y de adolescentes exige una actuación efectiva en el combate del trabajo infantil, que, por regla general, ocurre en las actividades urbanas informales, trabajo doméstico o agricultura familiar. Como en esas actividades la fiscalización y la investigación son limitadas, se desarrollan las acciones preventivas dirigidas a las políticas públicas, educación y profesionalización como medidas más eficaces. Necesario concienciar a la sociedad sobre los perjuicios derivados del trabajo infantil, relajando los mitos del trabajo precoz e invirtiendo en la formación de los futuros ciudadanos.

En ese contexto, para el combate a la exploración del trabajo de niños y adolescentes, la actuación de la Coordinfância, actualmente, está orientada para 03 (tres) ejes temáticos que componen el proyecto Estratégico Rescata la Infancia:

- Políticas Públicas: se busca, en ese eje, la actuación del Ministerio Público del Trabajo junto a la Administración Pública a fin de que la elaboración del presupuesto por el Ejecutivo observe el cumplimiento de las disposiciones constitucionales de protección integral de la infancia y de la juventud, así como cumplan la obligación legal de preferencia en la ejecución de políticas públicas y destinación de recursos relacionados con la protección a la infancia y al trabajo decente. 
- Educación: el Ministerio Público desarrolla la capacitación de los educadores respecto al tema trabajo infantil, causas y consecuencias, para que ellos trabajen con los alumnos, objetivando la concienciación y sensibilización respecto al problema y sus mitos y verdades. Los educadores son los profesionales que poseen las mejores condiciones para identificar las situaciones de trabajo precoz, pues, como regla, el trabajo infantil es la principal razón para el bajo rendimiento o abandono escolar. Además, el profesor tiene acceso directo de comunicación con el alumno, y, por intermedio de éste, con los responsables y comunidad. Después de la capacitación, hay distribución del material didáctico y actividades desarrolladas en la escuela, y, al final, hay premiación de los trabajos realizados por los alumnos.

- Profesionalización: busca la eficacia del aprendizaje, en los términos legalmente establecidos, con la articulación y sensibilización de las empresas al cumplimiento de la cuota legal, con foco en la población joven más vulnerable. El aprendizaje es una alternativa de profesionalización regular, dirigida a las personas con más de 14 años y menos de 24 (salvo la persona con discapacidad, que no tiene límite de edad), con obligatoria participación en programa de aprendizaje y formación técnico-profesional metódica, adecuado al desarrollo físico, moral y psicológico del aprendiz.

Estos tres ejes han sido implementados en todas las unidades del Ministerio Público del Trabajo. Ese trabajo sugiere el proyecto "MPT-jugar", en el eje Educación, para el combate efectivo a la explotación sexual, al trabajo infantil y la promoción del trabajo del adolescente.

\section{FUNDAMENTOS JURÍDICOS PARA QUE SE ACABE EL TRABAJO INFANTIL: LOS OBJETIVOS DEL MILENIO Y LAS PERSPECTIVAS PARA NIÑOS Y ADOLESCENTES}

¿Qué es el trabajo infantil? Son actividades laborales realizadas por niños y por adolescentes que aún no han completado la edad para trabajar, según la legislación vigente en el país.

El Ministerio Público del Trabajo, en la lucha contra el trabajo infantil y en la regularización del trabajo del adolescente, encuentra amparo en el or- 
denamiento jurídico Internacional, como la Convención de los derechos del Niño de la ONU y las convenciones n. ${ }^{\text {os }} 138$ y 182 emanadas de la Organización Internacional del Trabajo, y en el Orden interno, sea en la Constitución Federal, sea en la legislación infraconstitucional, como consolidación de las leyes del trabajo y Estatuto del Niño y del Adolescente.

La Convención sobre los Derechos del Niño, instrumento de derechos humanos, la cual fue adoptada por la Asamblea general de la Organización de las Naciones Unidas el 20 de noviembre de 1989 y ratificada por Brasil el 24 de septiembre de 1990, reconoce que "el niño, para el pleno y armonioso desarrollo de su personalidad, debe crecer en el seno de la familia, en un ambiente de felicidad, amor y comprensión", y establece, en su artículo 19, de la necesidad de que los Estados partes adopten:

Todas las medidas legislativas, administrativas, sociales y educativas apropiadas para proteger al niño contra todas las formas de violencia física o mental, lesiones o abusos, descuido o trato displicente, malos tratos o explotación, incluido el abuso sexual, mientras el niño está bajo la custodia de los padres, el tutor legal o cualquier otra persona responsable de la misma (ONU, 1989).

Se garantiza el derecho del niño a estar protegido contra la explotación económica y contra la realización de cualquier trabajo peligroso o interferir en su educación, o que sea nocivo para su salud o para su desarrollo físico, mental, espiritual, moral o social (art. 32 de la Convención sobre los Derechos del Niño de las Naciones Unidas).

Corresponde también a los Estados partes la adopción de medidas para establecer la edad mínima para admisión al trabajo y reglamentación apropiada pertinente a las condiciones y a los horarios de trabajo, así como respetar y promover el derecho del niño de participar plenamente de la vida cultural y artística, y deben estimular la oferta de oportunidades adecuadas de actividades culturales, artísticas, recreativas y de ocio, en condiciones de igualdad (Art. 31, Convención de los derechos del Niño de la ONU).

La Organización Internacional del Trabajo, en la 58 a reunión de la Conferencia (Ginebra, 1973), aprobó la Convención n. ${ }^{\circ} 138$ - Edad Mínima para Admisión (OIT, 1973), la cual, en el artículo $1^{\circ}$, destaca que

[...] todo País miembro, en el que esté vigente esta Convención, se compromete a seguir una política nacional que garantice la efectiva abolición del trabajo infantil y eleve progresivamente la edad mínima de admisión a empleo o a trabajo a un nivel adecuado al pleno desarrollo físico y mental del joven. 
Se trata de una medida importante para impedir el trabajo precoz y garantizar a los niños una infancia sana y a los jóvenes una formación técnico-profesional metódica, adecuada al desarrollo físico, moral y psicológico.

Considerando que el trabajo infantil es una cuestión de dimensión global, la OIT editó también la Convención 182, disponiendo acciones para eliminar las peores formas de trabajo infantil y para su eliminación inmediata. Reza el artículo $3^{\circ}$ que las peores formas de trabajo infantil comprenden todas las formas de esclavitud o prácticas análogas a la esclavitud, utilización, demanda y oferta de niño para fines de prostitución, producción de pornografía o actuaciones pornográficas; utilización, reclutamiento y oferta de niño para actividades ilícitas, y trabajos que, por su naturaleza o por las circunstancias en las que son ejecutados, son susceptibles de perjudicar la salud, la seguridad y la moral del niño.

Brasil ratificó las normas internacionales anteriores y adoptó el principio de protección integral del niño y del adolescente (CF, art. 227), así como prohibió el trabajo de niños y adolescentes con edad inferior a 16 años, excepto en la condición de aprendiz a partir de los 14 años, (CF, art. $7^{\circ}$, inciso XXXIII; CLT, Art. 405 y ECA, Art. 67), siendo vedado el trabajo nocturno y en actividades insalubres, peligrosas y penosas a adolescentes antes de los 18 años o en jornadas de trabajo largas y en lugares o servicios que les perjudiquen el buen desarrollo psíquico, moral y social (CLT, Arts. 403, 411, 412 y 413).

El Estado brasileño también promulgó legislación infraconstitucional, como Leyes n. ${ }^{\text {os }} 10.097 / 2000$ y $11.788 / 2008$, que disciplinan el aprendizaje y la pasantía, para regular el trabajo del adolescente.

Todo este marco jurídico, internacional y nacional, tiene como objetivo eliminar el trabajo infantil, una grave violación de los derechos humanos y promover el trabajo decente para los adolescentes. En este sentido, la OIT, en colaboración con los Estados miembros, las organizaciones de empleadores y trabajadores y las organizaciones de la sociedad civil, ha intensificado los esfuerzos para la erradicación del trabajo infantil y, como el "objetivo 8.7 de la Agenda 2030 para el desarrollo sostenible de las Naciones Unidas", tiene como objetivo la adopción de medidas inmediatas y efectivas para avanzar en la erradicación del trabajo infantil en todas sus formas para 2025 y la erradicación del trabajo forzado para 2030. 
El Gobierno brasileño introdujo la erradicación del trabajo infantil en la agenda pública como prioridad política. En 1996, lanzó el Programa Nacional de Erradicación del Trabajo Infantil, cuyo objetivo conquistó la adhesión de la sociedad civil, sindicatos, empresariado, universidades y organizaciones, como OIT y UNICEF. Acciones estratégicas fueron adoptadas, a fin de alcanzar el objetivo del Programa, como la integración entre el Programa Bolsa Familia y el PETI, institución del SUAS - Sistema Único de Asistencia Social, incorporación del PETI al LOAS y rediseño del PETI.

De acuerdo con la Ley n. ${ }^{\circ} 8.742 / 1993$ (LOAS), el PETI es un programa de carácter intersectorial que, en el ámbito de SUAS comprende transferencia de renta, trabajo social con familias y oferta de Servicios de Convivencia para Niños y adolescentes que se encuentren en situación de trabajo. Posee alcance nacional y es desarrollado de forma articulada por los entes federados, con la participación de la sociedad civil (Art. 24-C).

En Brasil, según la Investigación Nacional por Muestra de Domicilios (PNAD) 2015, del Instituto Brasileño de Geografía y Estadística (IBGE), 2,7 millones de niños y adolescentes de 5 a 17 años trabajaban en todo el territorio nacional.

En 2017, el IBGE divulgó los datos del trabajo infantil en Brasil, con base en una nueva metodología utilizada en la PNAD/continua, la cual indica que 1,8 millones de niños y adolescentes de 5 a 17 años trabajaban, en 2016, en actividades prohibidas por la legislación, o sea, en situación de trabajo infantil, siendo que los datos de niños y adolescentes que trabajan para el propio consumo no fueron considerados. Se trata, pues, de una falsa reducción de aproximadamente 1 millón de niños trabajadoras, con relación al año 2015, conforme Nota Explicativa del Foro Nacional de Prevención y Erradicación del Trabajo Infantil.

Por lo tanto, hay necesidad de avanzar con acciones estratégicas para obtener una efectiva reducción, pues es improbable que conseguiremos erradicar el trabajo infantil en Brasil hasta 2025, o cualquier explotación hasta 2030, principalmente ahora con pandemia del Covid-19. 


\section{JUGAR COMO INSTRUMENTO DE LUCHA CONTRA LA EXPLOTACIÓN SEXUAL Y LAS DEMÁS FORMAS DE TRABAJO INFANTIL. LAS RELACIONES DEL PRINCIPIO DE PROTECCIÓN INTEGRAL DEL NIÑO CON LA EDU- CACIÓN, LA PSICOLOGÍA, EL PSICOANÁLISIS Y LAS PO- LÍTICAS PÚBLICAS}

El principio de protección integral, Art. 227 de la Constitución republicana, como ya se ha dicho anteriormente, trae el deber de la absoluta prioridad al niño, adolescente y joven y señala varios derechos que deben ser observados, entre ellos educación, ocio y profesionalización, y más, los referidos sujetos deben ser puestos a salvo de toda forma de negligencia, discriminación, explotación, violencia, crueldad y opresión.

Así, para cumplir nuestro papel ministerial, de erradicar el trabajo infantil, lo que parece muy difícil incluso para 2030, con los efectos perjudiciales de la pandemia, como dicho, será necesario ir más allá del derecho, buscar posibilidades en otras disciplinas.

Sugerimos el JUGAR, instituto ya previsto en ley desde 2016 (Ley n. ${ }^{\circ}$ 13.257, de 8 de marzo de 2016), como política pública a ser ejecutada por el Estado. La misma ley (BRASIL, 2016), en su art. 5º, coloca el juego como prioridad a ser desarrollada en políticas públicas. Veamos:

Art. $5^{\circ}$ constituyen áreas prioritarias para las políticas públicas para la primera infancia la salud, la alimentación y la nutrición, la educación infantil, la convivencia familiar y comunitaria, la asistencia social a la familia del niño, la cultura, el juego y el ocio, el espacio y el medio ambiente, así como la protección contra toda forma de violencia y de presión consumista, la prevención de accidentes y la adopción de medidas que eviten la exposición precoz a la comunicación mercadológica.

Sobre la primera infancia, el art. $2^{\circ}$ de la referida ley (BRASIL, 2016) define: "[...] se considera primera infancia el período que abarca los primeros 6 (seis) años completos o 72 (setenta y dos) meses de vida del niño", es decir, el período de la edad temprana.

El jugar para nosotros, operadores del Derecho, no es muy conocido, sin embargo, en el campo de la educación, de la psicología, psicoanálisis y Sociología hay muchos estudiosos del asunto, por ejemplo: Pereira, Amparo y Almeida (2006, p. 23). enseñándonos a seguir: 
El juego, ya sea desde el punto de vista social o desde el individual, no es una actividad secundaria en el desarrollo infantil, sino que es ella quien proporciona los principales medios para las articulaciones entre el desarrollo personal y socio-histórico. Además de eso, desde el punto de vista de lo cotidiano escolar, emerge la necesidad de discusiones sobre un tiempo pedagógico, envolviendo el juego, que esté más articulado con las posibilidades objetivas y subjetivas del niño en su desarrollo, aunque la escuela esté principalmente orientada para la adquisición del conocimiento.

Como hemos podido ver, el juego debe ser considerado como instrumento de desarrollo del niño, un medio de insertarlo en el contexto social.

Buscando el concepto de jugar, según encontramos en el diccionario de la Lengua Portuguesa Michaelis (2020), hay seis significados diferentes y los que nos interesan para este estudio serían los de números 4 y 5 , a saber, "ju.gar: [...] 4 divertirse representando el papel de: los niños juegan a los soldados. vti 5 divertirse fingiendo ejercer cualquier actividad: jugar a leer. vtd [...]”. Así, cuando se juega, se desempeñan papeles sociales. [cursivas nuestras].

En lo que concierne a la naturaleza jurídica, en la búsqueda por la esencia de lo que venga a ser jugar, verificamos que varía de acuerdo con la disciplina a estudiar.

Bajo visión socio antropológica, jugar no es una dinámica interna del individuo, sino una actividad dotada de una significación social que, como otras, necesita de aprendizaje.

Por lo tanto, el juego se ve como una actividad presente en la vida del niño en diversas culturas, tiene mucha importancia en su desarrollo personal. Sin embargo, no siempre la importancia es reconocida por los adultos; hecho es que se da énfasis en la educación de los niños a los aspectos cognitivos formales, razón por la cual, para nosotros laicos, se torna difícil visualizar la relación existente entre juego y desarrollo.

El juego, bajo enfoque de la psicología evolutiva, se caracteriza como adaptado y adaptativo de la especie, busca estudiar las posibles relaciones entre cultura y filogénesis en el desarrollo del comportamiento. En esa medida, el jugar, en lenguaje propio, expresa la naturaleza del ser. Por lo tanto, podríamos decir que la ludoteca es un espacio donde el comportamiento puede ser estudiado, estimulado y valorado, en el que podemos rescatar, o 
incluso definitivamente entregar la dignidad de los niños que sufren algún tipo de violencia.

Para los adeptos de la psicogenética, como Dantas (1998), recreo y jugar son dos términos distintos en orden psicogenético, según los cuales uno precede al otro, pues recreo es anterior a jugar, y ese es conducta social que presupone reglas.

En lo que se refiere a la concepción psicoanalítica del niño y del juego, la palabra del niño necesita ser escuchada, ser rescatada, no ser el objeto de los deseos y de las necesidades de los adultos, así podríamos perquirir como el niño piensa, siente, percibe el mundo a su alrededor e intentar saber mejor sobre sus reales anhelos, sus miedos y sus deseos. Cada niño es diferente, incluso entre los hermanos de sangre, hay diferencias; por eso, el jugar también debe ser analizado con el mismo cuidado, buscándose las diferencias.

El jugar trae la historia de cada niño, en él se revelan los efectos del lenguaje y del habla en cada una, bajo la forma de un circuito de transferencia, en términos de inconsciente, que estructurado se extrae un lenguaje. Por lo tanto, usar la actividad de juego, lúdica, como una de las formas de revelar los conflictos internos de los niños, fue sin duda uno de los mayores descubrimientos del psicoanálisis. Es bromeando que el niño revela sus conflictos, sus temores, revela situaciones fácticas buenas y malas. Decimos, entonces, que en las bromas se transfiere, se externaliza, el tipo de lazo social que se tejió en el ambiente familiar del niño, de modo que ella revive los principales contenidos emocionales, relativos a los afectos, que la marcaron, y demostrará actos y hechos que se repiten, no sólo los agradables, sino los no placenteros, complicados y difíciles.

Jugar es central para el desarrollo de la salud y la conducta infantil espontánea, esencial para el desarrollo de la resiliencia. Ofreciendo espacios y ambientes que favorezcan el libre, jugar es proporcionar condiciones para el desarrollo de la creatividad, de las competencias y de las habilidades necesarias para ejercer el papel que le corresponde en la comunidad en que vive, en el presente y en el futuro.

Estudiosos de la temática, en obra colectiva respecto a la importancia de las actividades lúdicas, en la enseñanza fundamental, concluyeron Hartzz, A. et al. (2012, p. 13) que: 
El juego es la vida del niño, es parte de su desarrollo, es el reflejo de su mundo interior, de lo que cree, de lo que sabe y aún de lo que imagina. Es a través del juego que el niño manifiesta su creatividad, expone con naturalidad todo lo que siente, las alegrías, las tristezas, las angustias y ansiedades, las dudas y, también, las certezas. En la escuela, el juego es un medio para ofrecer al niño un ambiente agradable, motivador, planificado y enriquecido, que permita aprender varias habilidades. Por lo tanto, el juego es un mecanismo importante para el desarrollo del aprendizaje del niño tanto en los aspectos intelectuales como sociales. Al jugar, el niño desplaza hacia el exterior sus miedos, angustias y problemas internos, dominándose por medio de la acción.

Añade Marilene Martins Flores, experta en la temática, en reunión telepresencial con las autoras, el día 26/05/2020, que

hay una relación muy cercana entre jugar y resiliencia, en la cuestión de la
prevención de la violencia, investigaciones comprueban que las personas re-
silientes buscan constantemente la realización de sus sueños, no cultivando
heridas o rencores de otras personas y situaciones, que les son o fueron ad-
versas o generaron frustraciones.

Bien por eso, jugar es política pública, cuyo proyecto será implementado, pues puede desarrollar habilidades y resiliencia, un modo de vivir propicio para alejar frustraciones y buscar los logros de los niños.

\section{EXPERIENCIAS INTERNACIONALES Y NACIONALES DESARROLLADAS PARA UNA SOCIEDAD MÁS LIBRE, JUSTAY SOLIDARIAEN LA PRIMERA INFANCIA. ANÁLISIS DE PRONÓSTICOS Y PROSPECTIVAS EN BRASIL. PRO- PUESTA DE PROYECTO MPT-JUGAR}

Como experiencias internacionales, destacamos las medidas adoptadas por Finlandia y Alemania.

En Finlandia, según Beatriz Guedes (2016), la educación infantil no es obligatoria, queda a discreción de los padres inscribir, o no, a los hijos en una escuela, que puede ser pública o privada. La educación infantil se basa en jugar hasta el preescolar, lo que significa que los juegos son muy valorados en el desarrollo del niño y, de acuerdo con el plan de estudios nacional, a pesar de que los niños no juegan para aprender, aprenden por el juego y es muy importante entender este tema para entender la educación infantil en el país. Los niños no tienen más de 2 horas de clase y sin tarea, el plan de estudios 
nacional finlandés idealiza que los niños aprenden por el juego y la relación con los otros niños y maestros a su alrededor y así es como tienen sentido del mundo, desarrollando sus habilidades y construyendo conocimiento.

En Alemania, la pequeña ciudad alemana de Griesheim, con 26 mil habitantes, se convirtió en un modelo juguetón. Con el apoyo del gobierno y de investigadores de la Universidad Técnica de Darmstadt, desde la década de los 90 se decidió equipar los diversos espacios públicos que los niños ya frecuentaban, como la escuela, el gimnasio y los espacios para jugar, con aceras seguras y que ofrecieran equipos para jugar. El resultado fue la creación de 25 parques infantiles sostenibles en las calles, con objetos versátiles que permitieran desde escalar hasta fingir.

En 1961, en Dinamarca, se creó la International Play Association como organización internacional y no gubernamental integrante del ECOSOC-Consejo Mundial de las Naciones Unidas, con la misión de proteger, promover y preservar el juego del niño como derecho fundamental. La IPA Internacional está presente en más de 50 países.

En Brasil, la International Play Association (IPA-Brasil) fue instituida en 1997, como organización sin fines lucrativos, y objetiva también que niños y adolescentes tengan oportunidades para jugar libre y acceso a la cultura y al ocio. La IPA Brasil ofrece programa de capacitación para profesionales dando oportunidad para que niños y adolescentes jueguen libremente, sin ninguna discriminación.

Los Agentes del juego, según se infiere de la sección "Resultados" de la página electrónica de la institución, son las personas que, con conocimiento y competencia, crean las oportunidades para que los niños jueguen libremente. Pueden ser: jóvenes, padres, educadores, profesionales, estudiantes, voluntarios de organizaciones de la sociedad civil, personas en la tercera edad, etc. En un entorno adecuado para jugar, los niños tomarán decisiones sobre lo que juegan y con quién juegan. En esos momentos podrán ser apoyadas y estimuladas por el Agente del juego - un animador y facilitador de las oportunidades lúdicas.

Como se ve, muchas personas pueden ser uno de esos agentes, se destaca que hay diversos cursos y actividades ofrecidas y desarrolladas por el IPA Brasil, una gama de oportunidades. 
La red Marista de Solidaridad, otra organización que actúa en la defensa y promoción de los derechos de niños y adolescentes en situación de vulnerabilidad, desarrolló el proyecto ¿Brincadidiquê? para capacitar educadores y diferentes agentes del Sistema de Garantía de Derechos respecto al fortalecimiento del derecho a jugar en la infancia, en escuelas, ONGs, parques y en otros lugares donde los niños conviven e interactúan.

Como dicho, pretendemos con ese estudio presentar el proyecto MPT-jugar, el cual busca evaluar las condiciones vigentes y los factores actuantes en la crianza de los niños en el ámbito de la comunidad local, aspectos relacionados al trabajo infantil y a la explotación sexual a fin de detectar los procesos de violencias en cara de niños y alejarlos de los caminos que las direccionarían para el trabajo infantil, con la proposición de actividades lúdicas, bromas, todas dirigidas principalmente para Primera Infancia.

Seguramente, las situaciones características de trabajo infantil y de explotación sexual no son retratadas por los niños de manera espontánea. En realidad, se verifican cambios en el comportamiento del niño, alteración del humor, silencio dominante, comportamiento infantilizado, actitudes que pueden ser identificadas por los Educadores.

Así, el mencionado proyecto tendrá como foco la capacitación del Educador, para que él tenga la mirada y el conocimiento específico a fin de utilizar los indicadores a través del juego lúdico, como forma de reconocer situaciones comportamentales que pueden ser trabajadas como forma de acción transformadora para desarrollar vínculos afectivos y relaciones de confianza entre los niños y los grupos sociales, así como para identificar comportamientos, negativos y positivos, recurrentes de los niños vinculados a la convivencia familiar y social. Se pretende, además, invitar a las familias y a la comunidad local a jugar en casa. Los juegos y actividades lúdicas llevan a los niños al diálogo, a los cuestionamientos y a los intercambios de experiencias, así como desarrollan la creatividad y el desarrollo en todos los niveles: social, físico, cognitivo y emocional.

La broma posibilita la reproducción del ambiente en que el niño vive, la identificación de comportamientos o cuestiones experimentadas por el niño, como jugar con una muñeca, puede retratar el comportamiento de la madre en casa; jugar con personajes puede traer comportamientos de los responsables por el niño o de adultos con los cuales ella se relaciona; posibilita 
también la identificación de trabajo infantil, cuando el niño juega de saltar cuerda con una muñeca en los brazos, pues diariamente cuida de su hermana menor o aún rechaza el contacto con un adulto que ya le abusó sexualmente. El niño, en el juego, manifiesta reglas de conducta a partir de realidades vividas o que le gustaría vivir.

Para el inicio del proyecto, es necesario cosechar datos sobre las situaciones adversas experimentadas por la comunidad, como trabajo infantil, explotación sexual, etc. A continuación, el Educador deberá trazar acciones para ser desarrolladas en el proyecto MPT-Jugar, orientado primordialmente para la primera infancia, a partir de la construcción de indicadores y modelos ejemplificativos lanzados en cartilla, que será elaborada por especialistas, como pedagogos, psicólogos, educadores y operadores del derecho. Los Educadores deben involucrar a las familias, a los responsables de los niños y a toda la comunidad, con el alcance de ampliar el proceso.

La cartilla presentará la propuesta del proyecto MPT-Jugar, con contenido específico en cuanto a los puntos iniciales para abordaje y levantamiento, así como deberá sugerir opciones de jugar, actividades de jugar lúdico a ser desarrolladas con los niños o aún presentadas a la comunidad y responsables. El cierre deberá ocurrir en un evento con la presentación de las actividades y resultados obtenidos por los educadores.

Finalmente, con ese proyecto MPT-Jugar, podremos pensar e intentar alcanzar un Brasil menos reproductor de crueldades, bajo el enfoque de las explotaciones y para erradicación de todas sus formas de explotación sea sexual, sea de otras formas de trabajo infantil. Tal vez todavía no conseguiremos erradicar esas llagas hasta 2030, pero podremos mitigar aún más la situación de violencia contra niños y adolescentes; intentar nuevas posibilidades de enfrentamiento y erradicación del trabajo infantil y de la explotación sexual infantil, las llagas que nos atemorizan desde hace años.

\section{CONCLUSIONES}

El alcance del presente trabajo fue presentar propuesta de un proyecto, Proyecto MPT-jugar, dentro de uno de los tres ejes de las actividades de la Coordinfância, eje educación, como una nueva herramienta para el órgano ministerial enfrentar las exploraciones, sexual y otras formas de trabajo infantil, en Brasil, lo que realizamos con base en los pronósticos y prospectivas, 
de órganos nacionales e internacionales, para defender preceptos constitucionales, como la dignidad de la persona humana del niño y del adolescente y el principio de la protección integral como corolario del trabajo decente. Constatamos tristes pronósticos de que todavía tendremos mucha niño y adolescente en situación de explotación, en el trabajo infantil en nuestro país, agravado por la pandemia actual.

Inicialmente, nos propusimos presentar y analizar los documentos internacionales firmados por Brasil, trazando un paralelo con los objetivos del Milenio, en lo que se refiere a las perspectivas para niños y adolescentes, para el término del trabajo infantil. Y hemos podido comprobar que no podremos cumplir con lo pactado, al menos en cuanto al plazo previsto, ya que los índices han disminuido muy lentamente.

Estudiamos varios conceptos del juego, vimos que el tema está afecto al principio de la protección integral del niño, analizamos de manera transversal, bajo la óptica de la educación, de la psicología, del psicoanálisis. Verificamos que hay ley versando sobre la cuestión, Ley n. ${ }^{\circ} 13.257$, de 8 de marzo de 2016, la cual incluyó el jugar como política pública que debe ser efectivamente ofrecida e implementada por el Estado brasileño.

De experiencias internacionales, trajimos las acciones estudiadas en Finlandia y en Alemania y, entre las ya practicadas a nivel nacional, las ejecutadas por organizaciones, tales como, International Play Association - IPA Brasil y Red Marista de solidaridad, que ya están desde hace muchos años cuidando y desarrollando, en nuestro país, el jugar para una sociedad más libre, justa y solidaria, en lo que concierne a la primera infancia.

Analizados los pronósticos y prospectivas en Brasil, constatamos que no será fácil erradicar el trabajo infantil, pero podremos mitigar situación de violencia contra niños y adolescentes a través de la propuesta de proyecto para actuación del Ministerio Público del Trabajo, del Proyecto MPT-jugar, una nueva posibilidad de enfrentamiento y erradicación del trabajo infantil y de la explotación sexual infantil, las llagas que nos atemorizan desde hace años. 


\section{REFERENCIAS}

BRASIL. Constituição da República Federativa do Brasil. Brasília/DF, 1988. Disponible en: http://www.planalto.gov.br/ccivil_03/constituicao/ constituicao.htm. Acceso em: 5 oct. 2020.

BRASIL. Lei n. ${ }^{\circ}$ 13.257, de 8 de março de 2016. Dispõe sobre as políticas públicas para a primeira infância e altera a Lei n. ${ }^{\circ} 8.069$, de 13 de julho de 1990 (Estatuto da Criança e do Adolescente), o Decreto-Lei no 3.689, de 3 de outubro de 1941 (Código de Processo Penal), a Consolidação das Leis do Trabalho (CLT), aprovada pelo Decreto-Lei $\mathrm{n}^{\circ} 5.452$, de $1^{\circ}$ de maio de 1943, a Lei n. ${ }^{\circ} 11.770$, de 9 de setembro de 2008, e a Lei n. ${ }^{\circ} 12.662$, de 5 de junho de 2012. Brasília/DF, mar. 2016. Disponible en: http://www.planalto. gov.br/ccivil_03/_Ato2015-2018/2018/Decreto/D9579.htm. Acceso en: 8 jun. 2020.

BRINCAR. In: Michaelis Dicionário da Língua Portuguesa. [S.1], 2020. Disponible en: https://michaelis.uol.com.br/moderno-portugues/busca/ portugues-brasileiro/brincar/. Acceso en: 8 jun. 2020.

CIDADE amiga da criança: missão técnica em Griesheim, Alemanha. [S.1], [20--], Disponível em: https://criancaenatureza.org.br/noticias/missao-tecnica-griesheim-alemanha. Acceso en: 20 ago. 2020.

DANTAS, Heloysa. Brincar e Trabalhar. In: KISHIMOTO, Tízuko Morchida (org). O brincar e suas teorias. São Paulo: Pioneira Thomson Learning, 2002, p. 111. Disponible en: https://books.google.com.br/books/about/ Brincar_e_Suas_Teorias.html?id=iK3UejO34YYC\&printsec $=$ frontcover\&source $=$ kp_read_button\&redir_esc $=\mathrm{y} \# \mathrm{v}=$ onepage\&q\&f$=$ false. Acceso en: 8 jun. 2020.

DIAS, Júlio Cesar. O Trabalho Infantil no Brasil: Uma leitura a partir da Pnad Contínua (2016). In: Fórum Nacional de Prevenção e Erradicação do Trabalho Infantil (FNPETI), [S.1], 16/5/2019. Disponible en: https:// fnpeti.org.br/media/publicacoes/arquivo/O_Trabalho_Infantil_no_Brasil_-_uma_leitura_a_partir_da_Pnad_Cont $\%$ C3\%ADnua_2016.pdf. Acceso en: 8 jun. 2020.

GUEDES, Beatriz. Como é o Ensino Infantil na Finlândia? In: Brasileiras pelo Mundo, [S.l.], junho de 2016. Disponible en: https://www.brasileiras- 
pelomundo.com/ensino-infantil-na-finlandia-421934074. Acceso en: 8 jun. 2020.

HARTZ, Aline et al.. A Importância do Brincar No Ensino Fundamental: Crianças em Fase de Alfabetização. In: Revista Conhecimento Online, Novo Hamburgo, v. 1, mar. 2012. ISSN 2176-8501. Disponible en: https:// periodicos.feevale.br/seer/index.php/revistaconhecimentoonline/article/ view/261. Acceso en: 8 jun. 2020.

IBGE. Trabalho das crianças e adolescentes. In: Pesquisa Nacional por Amostra de Domicílios - Síntese de indicadores: 2015. [S.1], 2016, p. 62. Disponible en: https://biblioteca.ibge.gov.br/visualizacao/livros/liv98887. pdf. Acceso en: 8 jun. 2020.

IBGE. Pesquisa Nacional por Amostra de Domicílio Contínua - Trabalho Infantil: 2016. Rio de Janeiro/RJ, Coleção Ibegeana, 2017. Disponible en: https://biblioteca.ibge.gov.br/visualizacao/livros/liv101388_informativo.pdf. Acceso en: 8 jun. 2020.

INTERNATIONAL PLAY ASSOCIATION. IPA: Promoting the Child's right to play, 2020. Disponible en: https://ipaworld.org/. Acceso en: 8 jun. 2020 .

IPA BRASIL. IPA Brasil: promovendo o direito de brincar, 2020. Disponible en: https://ipaworld.org/. Acceso en: 8 jun. 2020.

IPA BRASIL. Resultados. IPA Brasil, [S.1], [20--]. Disponible en: www.ipabrasil.org/resultados. Acceso en: 8 jun. 2020.

KISHIMOTO, Tízuko Morchida (org). O Brincar e suas Teorias. São Paulo: Pioneira Thomson Learning, 2002. Disponible en: https://books.google. com.br/books/about/Brincar_e_Suas_Teorias.html?id=iK3UejO34YYC\&printsec $=$ frontcover\&source $=$ kp_read_button\&redir_esc $=\mathrm{y} \# \mathrm{v}=$ onepa ge\&q\&f=false. Acceso en: 8 jun. 2020.

MARISTA REDE DE SOLIDARIEDADE. Cores em composição na educação infantil. 1. ed. São Paulo: FTD, 2010. Disponible en: http:// www.crianca.mppr.mp.br/arquivos/File/publi/marista/cores_participacao_ rms.pdf. Acceso en: 8 jun. 2020. 
MARISTA REDE DE SOLIDARIEDADE. Projeto Brincadequê? Curitiba/PR, 2017. Disponible en: http://www.brincadique.com.br/o-projeto/. Acceso en: 8 jun. 2020.

PEREIRA, Maria Ângela Camilo Marques et al.. O Brincar e Suas Relações com O Desenvolvimento. In: Psicologia Argumento, v. 24, n. ${ }^{\circ} 45$, p. 15-24, nov. 2017. ISSN 1980-5942. Disponible en: https://periodicos.pucpr.br/index.php/psicologiaargumento/article/view/19861. Acceso en: 20 ago. 2020. 


\section{EL TRABAJO INFANTIL A TRAVÉS DE PRINCIPIOS CONSTITUCIONALES RELACIONADOS CON EL ORDEN ECONÓMICO Y FINANCIERO}

\section{ANTÔNIO ALVES MENDONÇA JÚNIOR ANTÔNIO GOMES DE VASCONCELOS}

DOI: 10.51366/978-65-89468-10-3-coordinfancia-3

Resumen. Este trabajo analiza de qué forma los principios constitucionales del orden económico y financiero, previstos en el art. 170 de la Constitución Federal de 1988, pueden ser utilizados como fundamento para la prohibición al trabajo infantil. Para ello, inicialmente, será presentada una conceptualización sucinta de la expresión "trabajo infantil". A continuación, se presentarán motivos legales y sanitarios a menudo mencionados para fundamentar el sellado al trabajo temprano de niños y adolescentes. Por último, se presentarán los principios económicos y financieros, constitucionalmente previstos, que también pueden servir de fundamento para la prohibición legal del trabajo infantil.

Palabras clave: Trabajo infantil. Trabajo temprano. Orden económica. Principios.

\section{INTRODUCCIÓN}

Es común que la fundamentación de la prohibición al trabajo infantil se base en argumentos jurídicos y sanitarios sobre la necesidad de protección del niño y del adolescente. Cualquier Estado que pretenda reducir o erradicar el trabajo infantil colabora, en alguna medida, para la protección de su población de niños y adolescentes. No sin razón los Convenios n. ${ }^{\circ} 138$ y n. ${ }^{\circ} 182$ de la Organización Internacional del Trabajo (OIT) se encargan de garantizar que los países signatarios establezcan una edad mínima para la inserción de los niños ${ }^{1}$ en el mercado laboral, así como de garantizar urgentemente la prohibición y la eliminación de las peores formas de trabajo infantil. 
Para la ciencia médica, en las palabras de Sobrinho (2010), el niño se considera una persona en desarrollo en el período comprendido entre el nacimiento y el advenimiento de la pubertad. El adolescente es la persona que, bajo los aspectos físicos y psicológicos, se encuentra en un estado de maduración y aprendizaje a partir de la pubertad. Para la ciencia jurídica, el niño es la persona de hasta doce años incompletos, y el adolescente es la persona con edad entre doce y dieciocho años de edad, estando, en ambos casos, en etapa de desarrollo físico, mental, moral, espiritual y social, en los Términos de los art. $2^{\circ}$ y $3^{\circ}$ del Estatuto del Niño y del Adolescente (ECA).

Seguramente, los argumentos provenientes de la Medicina o del Derecho, que se basan en la etapa de desarrollo del niño y del adolescente como fundamento para la prohibición al trabajo infantil, tienen amplia aceptación en la literatura jurídica. Sin embargo, este artículo tiene por objetivo recorrer un camino distinto, demostrando que la prohibición al trabajo infantil puede fundarse en principios y conceptos del derecho que no son comúnmente asociados a la protección integral del niño y del adolescente, tales como libre competencia, función social de la propiedad y reducción de las desigualdades regionales y sociales.

En resumen, este artículo pretende demostrar cómo la prohibición al trabajo infantil puede encontrar fundamento en la regulación del orden económico y financiero previsto en la Constitución Federal de 1988 (BRASIL, 1988), yendo más allá de la mención exclusiva a los derechos de la infancia y de la juventud.

\section{2 ¿QUÉ ES EL TRABAJO INFANTIL?}

De una manera grosera, el trabajo infantil sería todo ese trabajo realizado por personas menores de la establecida en la legislación. Sin embargo, conscientes de la imprecisión que una conceptualización tan abierta puede representar, se hace necesario comprender de forma un poco más detenida los elementos que caracterizan el concepto de trabajo infantil.

Para ello, es válido recurrir al III Plan Nacional de prevención y Erradicación del Trabajo Infantil y protección del Adolescente trabajador, elaborado en el ámbito de la Comisión Nacional de erradicación del Trabajo Infantil - CONAETI, vinculada al extinto Ministerio del Trabajo, en 2018. De acuerdo con el plan mencionado, 
El término trabajo infantil se refiere a toda actividad económica y/o de actividad de supervivencia, con o sin finalidad de lucro, remuneradas o no, realizadas por niños o adolescentes en edad inferior a 16 años, salvo la condición de aprendiz a partir de los 14 años independientemente de su condición ocupacional $^{2}$.

Como es posible percibir, para que se caracterice el trabajo infantil, no se hace necesaria la presencia de todos los requisitos exigidos para la caracterización de las relaciones de empleo. Independientemente de ser eventual o no, de ser remunerada o no, de haber subordinación al empleador o a la familia, la actividad de trabajo ejercida por menor de 16 años, excepto en la condición de aprendiz a partir de los 14 años, en los términos del art. $7^{\circ}$, XXXIII, CF/88, caracteriza trabajo infantil.

Vale destacar que la conceptualización anterior aún no agota todas las hipótesis de trabajo infantil, prohibidas por la legislación nacional e internacional. En consonancia con el art. $7^{\circ}$, XXXIII, CF/88 y con la Convención n. 182 de la OIT, las peores formas de trabajo infantil están prohibidas para todas las personas menores de 18 años. Por esta razón, el III Plan Nacional de prevención y Erradicación del trabajo Infantil sigue informando que

toda actividad realizada por adolescente trabajador, que, por su naturaleza o por las circunstancias en que se ejecuta, pueda perjudicar su desarrollo físico, psicológico, social y moral, se encuadra en la definición de trabajo infantil y está prohibida para personas menores de 18 años ${ }^{3}$.

En ese sentido, pues, se concluye que el trabajo infantil consiste (1) en toda actividad de trabajo ejercida por menores de 16 años, excepto por aprendices a partir de los 14 años, así como (2) en toda actividad, clasificada como insalubre, peligrosa, penosa o peor forma de trabajo infantil, ejercida por menores de 18 años.

\section{FUNDAMENTOS JURÍDICOS Y SANITARIOS PARA LA PROHIBICIÓN DEL TRABAJO INFANTIL}

Varias normas nacionales e internacionales trataron de enfatizar la prohibición del trabajo del niño y del adolescente ${ }^{4}$. Este capítulo abordará brevemente frecuentes argumentos jurídicos y sanitarios mencionados en estudios sobre el tema para fundamentar la prohibición legal al trabajo infantil.

La prohibición a la explotación del trabajo infantil se da bajo el fundamento de que, tanto a nivel internacional, con la Declaración Universal de 
los derechos del niño y del adolescente (1959), como a nivel nacional, con la $\mathrm{CF} / 88$ y el ECA/90, se instituyó "una nueva visión jurídica del niño como un "sujeto de derechos" (portadora de todos los derechos humanos)", tal como informa Marchi (2013). En las palabras de Custodio (2002), el trabajo del niño y del adolescente pasó a ser encarado bajo una perspectiva jurídico-social, "fundamentada en los principios y normas de la doctrina de la protección Integral".

Bajo esa perspectiva, pues, la prohibición del trabajo infantil encontraría amparo en la idea de que el niño y el adolescente deberían ser tratados como seres humanos en desarrollo, que necesitan protección especial. Según Martines (2006), a pesar de una serie de documentos internacionales para abordar con anterioridad a la necesidad de un tratamiento especial en la infancia, es sólo a través de la Declaración Universal de los Derechos del Niño y del Adolescente (1959), la Doctrina de la Protección Integral, se pasó a los que efectivamente existe en el ámbito internacional, "ya que entre muchas de las consideraciones anteriores, se estableció que el niño, en función de su grado de madurez física y mental, necesita protección legal adecuada, antes y después del nacimiento del bebé, y es que la humanidad debe al niño lo mejor de sus esfuerzos" (MARTINES, 2006, p. 18).

En el escenario nacional brasileño, la doctrina de la protección integral pasa a estar vigente tres décadas más tarde, con la edición de la $\mathrm{CF} / 88$ y del ECA/90. Hasta entonces, en Brasil, bajo la lógica de la doctrina de la situación irregular, basándose en el Código de Menores de 1979 (Ley n. ${ }^{\circ}$ 6.697), el niño y el adolescente, que no trabajaba o estudiaba, era tratado como un probable delincuente. "El niño pobre era visto como potencialmente abandonado y peligroso, y el trabajo, a su vez, significaba no solo alejarlo de la delincuencia, sino también educarlo para inculcar obediencia” (PASSETI, 1999).

El hecho es que la institución constitucional y legal de la protección integral del niño y del adolescente forzó una superación de la comprensión de que niños pobres deberían trabajar, acarreando un reordenamiento en la correlación entre temas como "infancia", "trabajo" y "pobreza".

De acuerdo con el art. 227 de la CF/88,

Es deber de la familia, de la sociedad y del Estado asegurar al niño y al adolescente y el adolescente, con absoluta prioridad, el derecho a la vida, a la salud, a la alimentación, a la educación, al ocio, a la profesionalización, a 
la cultura, a la dignidad, al respeto, a la libertad y a la convivencia familiar y comunitaria, además de ponerlos a salvo de toda forma de negligencia, discriminación, explotación, violencia, crueldad y opresión (BRASIL, 1988).

Bajo esa óptica, que también impregna todo el texto del ECA/90, el niño y el adolescente son, pues, sujetos de una serie de derechos, debiendo recibir de la familia, de la sociedad y del Estado todo el apoyo necesario para que todos esos derechos sean asegurados. Es forzoso enfatizar que los derechos enumerados, tanto en el art. 227 de la CF/88, como en el ECA/90, alcanzan a todos los niños y adolescentes, en un claro diálogo con el objetivo fundamental de la República de "promover el bien de todos, sin prejuicios de origen, raza, sexo, color, edad y cualesquiera otras formas de discriminación" (BRASIL, 1988).

Bajo esa misma perspectiva, el Pacto Internacional sobre Derechos Económicos, Sociales y culturales, ratificado en Brasil por medio del Decreto n. ${ }^{\circ}$ 591, de 1992, en su art. 10, informa que deben ser adoptadas "medidas especiales de protección y de asistencia en favor de todos los niños y adolescentes, sin distinción alguna por motivo de filiación o cualquier otra condición" (BRASIL, 1992) (cursiva nuestra).

En ese escenario en el que la doctrina de la protección integral pretende alcanzar a todos los niños y adolescentes, sin ninguna distinción, el derecho a la educación gana destaque, mientras el trabajo pasa a ser comprendido como un obstáculo para el recorrido educativo de los niños y adolescentes. No sin razón, el art. 227 de la CF/88 prevé expresamente que el derecho a la protección especial abarcará la "garantía de acceso del trabajador adolescente y joven a la escuela”. Se busca, así, crear una jerarquía entre los derechos, enfatizando que el derecho a la profesionalización no puede perjudicar el derecho de asistencia a la escuela. Siguiendo esa lógica, Grunspun (2000) afirma que el trabajo precoz afecta la educación adecuada, ya que la escuela, cuando existe, es formal e ineficaz, implicando en la percepción del niño y del adolescente de que los estudios no contribuirán en nada para el futuro.

Se destaca que, además de los fundamentos relacionados a la doctrina de la protección integral, que modificaron la comprensión del trabajo en la infancia y en la adolescencia, existen también los argumentos de orden sanitario, que enfatizan los perjuicios del trabajo precoz para la salud de los niños y de los adolescentes. 
En un estudio realizado en 2008 en torno del status de salud autoevaluado de niños y adolescentes, los investigadores concluyeron que las personas que trabajaban en un entorno urbano tenían una percepción de su propia salud inferior, mientras que las personas que no trabajaban entendían que estaban sanas.

En el mismo sentido, la Nota Técnica a la Ordenanza n. ${ }^{\circ}$ 6, de 18/02/2000, del Ministerio de Trabajo, afirma que la osificación se completa, en el sexo masculino, a los 21 años y, en el sexo femenino, a los 18 años. Por esa razón, el trabajo precoz en actividades de carga de peso, por ejemplo, sería contraindicado, pues "podría producir deformaciones óseas en los niños y adolescentes, entre las cuales vale mencionar la Cifosis Juvenil de Scheüermann y el muslo Vara Del Adolescente".

Además, la misma Nota Técnica informa que trabajar con sustancias tóxicas (gases, vapores y polvos tóxicos) tiende a dañar mucho más a los niños y adolescentes que a las personas adultas. Esto se debe a que "la ventilación pulmonar se reduce en niños y adolescentes que generalmente tienen una mayor frecuencia respiratoria para compensar esta menor capacidad de ventilación pulmonar".

Por último, la mencionada Nota Técnica, del Ministerio del Trabajo, informa también los perjuicios del trabajo precoz para la salud psíquica del niño y del adolescente. En la infancia y en la adolescencia, sería importante la realización de juegos y juegos, posibilitando la construcción de un adulto psíquicamente equilibrado y saludable. Teniendo en vista la sucesión de experiencias desagradables a las que están expuestos los individuos explotados por el trabajo infantil, como miedo, inseguridad, responsabilización excesiva, es posible que ocurra un enyesamiento del sistema neuropsíquico de los niños y adolescentes. Como consecuencia de ello, surgiría la incapacidad de esos individuos de "enfrentamiento de nuevas situaciones, aumentando los riesgos de desestructuración de la personalidad y de generación de adultos desequilibrados y sin condiciones de inserción adecuada en la sociedad".

\section{FUNDAMENTOS ECONÓMICOS Y FINANCIEROS PARA LA PROHIBICIÓN DEL TRABAJO INFANTIL}

Aunque los fundamentos anteriores sean en sí mismos suficientes para justificar la prohibición del trabajo infantil, ciertamente hay otros facto- 
res, tanto económicos como financieros, que pueden mencionarse para fundamentar esta prohibición.

Es imperioso recordar que, en las palabras de Custodio (2002, p. 21), en el modelo económico capitalista, los factores económicos son "los principales determinantes de la utilización de la mano de obra de niños y adolescentes”. Para Cervini y Burger (1996, p. 19), en consonancia con la afirmación de Custodio (2000),

es bastante aceptada la idea de que las dimensiones, las condiciones y el contenido del trabajo infantil dependen de dos órdenes de macrofactores [...]: la pobreza, que obliga a las familias a adoptar formas de comportamiento que incluyen la oferta de mano de obra de sus hijos menores de edad; la estructura del mercado de trabajo, que ofrece espacios apropiados para la incorporación de ese contingente específico de mano de obra. Estos dos conjuntos de factores operan a través de las preferencias y los comportamientos de dos unidades de decisión: la familia y la empresa (cursivas nuestras).

Una vez que el sistema económico surge como causa principal de la ocurrencia del trabajo infantil, se muestra necesario comprenderlo para encontrar, en el propio sistema económico brasileño, fundamentos para el sellado al trabajo precoz $z^{5}$. Tal como ocurre en las ciencias naturales, en las cuales el virus de una patología es esencial para la creación de la respectiva vacuna, y el veneno de la serpiente es fundamental para la producción del suero antiofídico, se pretende buscar argumentos económicos para justificar la prohibición de un fenómeno negativo que la propia economía viene produciendo: el trabajo prematuro de niños y adolescentes.

De acuerdo con el art. 170 de la CF/88,

El orden económico, fundado en la valorización del trabajo humano y en la libre iniciativa, tiene por objeto asegurar a todos existencia digna, conforme a los dictados de la justicia social, observados los siguientes principios:

I - soberanía nacional;

II - propiedad privada;

III - función social de la propiedad;

IV - libre competencia;

$\mathrm{V}$ - protección de los consumidores;

VI - defensa del medio ambiente, inclusive mediante tratamiento diferenciado conforme el impacto ambiental de los productos y servicios y de sus procesos de elaboración y prestación;

VII - reducción de las desigualdades regionales y sociales;

VIII - búsqueda del pleno empleo;

IX - trato favorecido para las pequeñas empresas constituidas bajo las leyes brasileñas y que tengan su sede y administración en el País. 
Párrafo único. Se garantiza a todos el libre ejercicio de cualquier actividad económica, independientemente de autorización de organismos públicos, salvo en los casos previstos en ley (BRASIL, 1988). [cursivas nuestras]

Tal como enseña Jorge Miranda (1990, p. 431),

El derecho no es mero sumatorio de reglas sueltas, producto de actos de voluntad, o mera concatenación de fórmulas verbales articuladas entre sí. El derecho es ordenamiento o conjunto significativo y no conjunción resultada de vigencia simultánea; es coherencia o, quizás más rigurosamente, consistencia; es unidad de sentido, es valor incorporado como regla. Y ese ordenamiento, ese conjunto, esa unidad, ese valor, se proyecta o se traduce en principios, lógicamente anteriores a los preceptos (cursivas nuestras).

En ese sentido, es lógico suponer que los principios, constitucionalmente previstos, son orientaciones acerca de un proyecto de Estado, y deben garantizar coherencia y consistencia entre las normas jurídicas. "Tales principios corresponden a decisiones políticas fundamentales del constituyente originario y, por esta razón, subordinan toda la acción en el ámbito del Estado, así como la interpretación de las normas constitucionales e infraconstitucionales” (BARROSO, 2001, p. 189).

Bajo esa perspectiva, los principios constitucionales que rigen el orden económico y financiero brasileño necesitan estar en armonía con las demás normas de la Constitución Federal, y no pueden ser ignorados en la definición de las normas infraconstitucionales. Dicho esto, no se puede apartar la idea de que los principios previstos en el art. $170 \mathrm{CF} / 88$, responsables de la regulación general de la economía en Brasil, dialogan y se armonizan con todas las disposiciones vigentes en territorio nacional acerca de la prohibición del trabajo infantil.

Siendo así, necesario se hace analizar de qué forma esa armonía se da, enfatizando por qué algunos de esos principios económicos y financieros sirven de fundamento para la prohibición al trabajo infantil.

\subsection{Función social de la propiedad}

La Constitución brasileña de 1934 trajo disposiciones sobre el orden económico, enfatizando que la libertad en la economía podría ser ejercida dentro de los límites de la justicia y de la vida nacional. Aunque se sabe que tales disposiciones representaron el inicio de una transición a un Estado Social, solamente con la Constitución Federal de 1988 los dictados de un Estado 
preocupado por intervenir para garantizar la reducción de las desigualdades se efectuaron, elevando la función social de la propiedad al nivel de principio constitucional del orden económico y financiero.

En ese escenario, el derecho fundamental a la propiedad, en los términos del art. $5^{\circ}$, inciso XXII, de la CF/88, encuentra límites en el deber del propietario de asegurar que la propiedad ejerza su función social, garantizando, pues, el orden económico del país. De acuerdo con Fábio Konder Comparato (1986, p. 75), "se concluye que 'si se está ante un interés colectivo, esa función social de la propiedad corresponde a un poder-deber del propietario, sancionable por el ordenamiento jurídico"'.

Aún en esa misma dirección, se encuentra Tomasevicius Filho (2003, p. 39) para quien la función social

[...] significa el ejercicio de un derecho subjetivo, de tal modo que se atienda al interés público, no sólo en el sentido de no imponer restricciones al ejercicio de ese derecho, sino también en el sentido de acarrear una ventaja positiva y concreta para la sociedad. De esa forma, se entiende la idea de que la propiedad obliga o que hay un poder-deber de que el individuo atienda al interés público en el ejercicio de su derecho subjetivo (cursivas nuestras).

Bajo esta lógica, por lo tanto, se concluye que los medios de producción no pueden perder de vista el interés público, aunque estén bajo propiedad de particulares. Siendo así, aunque, según Ronald Coase (COASE, 1937), "el objetivo de la empresa es minimizar los costos de obtención de informaciones, de negociación de los contratos y de cumplimiento de las promesas, a fin de protegerse contra las oscilaciones del mercado", esa búsqueda por la minimización de los costos tiene límites jurídicos asociados a la garantía de los derechos fundamentales asegurados en la Constitución.

De acuerdo con Esteves (2013), los costos de una empresa pueden ser clasificados, entre otras formas, como variables o fijos, siendo que el costo de la mano de obra ora integrará la categoría de los costos variables, ora de los costos fijos. La mano de obra será un coste variable siempre que sea necesario el pago de horas extras o de premios de producción a los trabajadores. A su vez, la mano de obra será un coste fijo cuando consista en la remuneración invariable pagada a los empleados durante el período en que la estructura de personal no sufra crecimiento o disminución. 
Aunque, de acuerdo con esa clasificación, la mano de obra sea un costo de la producción, y aunque, conforme ya mencionado anteriormente, el objetivo de una empresa sea minimizar los costos, existen límites en el propio orden económico para perseguir ese objetivo: la función social de la propiedad, revelada en cada uno de los dispositivos constitucionales y legales, los cuales garantizan la prevalencia del interés público frente al privado.

Por lo tanto, todos los dispositivos ya mencionados, entre ellos el art. $7^{\circ}$, XXXIII, CF/88, que revelan el interés público de erradicar el trabajo infantil en Brasil, son fundamentados por el principio de la función social de la propiedad. Eso porque, siendo la prohibición al trabajo infantil un interés colectivo, consignado en la Constitución, la propiedad de los medios de producción jamás podría olvidar el cumplimiento de su función social, que consiste, entre otras cosas, en no explotar el trabajo precoz de niños y adolescentes.

\subsection{Libre competencia}

No es demasiado recordar, tal como lo hace Barroso (BARROSO, 2001, p. 189), que "la libre iniciativa y la valorización del trabajo son dos de los principios fundamentales del Estado brasileño y los fundamentos del orden económico. Esa es la dicción expresa de los arts. $1^{\circ}, \mathrm{IV}$, y 170, caput' de la $\mathrm{CF} / 88$. En este sentido, es necesario subrayar que el reconocimiento constitucional de la libertad económica está vinculado a la valorización del trabajo.

Por un lado, existe, pues, el fundamento de la libre iniciativa, que, en palabras de Barroso (2001, p. 189):

[...] se puede descomponer en algunos elementos que le dan contenido, todos ellos desplegados en el texto constitucional. Presupone, en primer lugar, la existencia de propiedad privada, es decir, de apropiación particular de los bienes y de los medios de producción (CF.arts. $5^{\circ}$, XXII y 170 II). De parte esto, integra, igualmente, el núcleo de la idea de libre iniciativa la libertad de empresa, concepto materializado en el párrafo único del art. 170, que asegura a todos el libre ejercicio de cualquier actividad económica, independientemente de autorización, salvo en los casos previstos en ley. En tercer lugar se sitúa la libre competencia, lastre para la facultad del emprendedor de establecer sus precios, que han de ser determinados por el mercado, en ambiente competitivo (CF, Art. 170, IV). Por último, es de la esencia del régimen de libre iniciativa la libertad de contratar, consecuencia lógica del principio de legalidad, fundamento de las demás libertades, por el cual nadie será obligado a hacer o dejar de hacer algo sino en virtud de ley (CF, Art. 5, II) (cursivas nuestras). 
Se enfatiza que el principio de la libre competencia es, en la perspectiva anterior, una de las cuatro facetas de la libertad de iniciativa, que consiste en la facultad de los dueños de los medios de producción de fijar sus propios precios, conforme un mercado competitivo.

Por otro lado, es necesario también recordar que la valorización del trabajo también es fundamento del orden económico. En cuanto a la valorización del trabajo, Barroso (2001) afirma que la Constitución de 1998 trató de concretarla, garantizando a los trabajadores un rol de derechos, previstos en el art. $7^{\circ}$. Entre esos derechos, es válido reforzar aquel previsto en el inciso XXXIII, que garantiza una edad mínima razonable para el ingreso de adolescentes en el mercado de trabajo.

Se nota, pues, que la prohibición al trabajo infantil, consignada en el art. 227 de la $\mathrm{CF} / 88$, por medio de la mención a la valorización del trabajo como fundamento del orden económico, es un límite al principio de la libre competencia. Este principio permite al propietario de los medios de producción establecer las mejores estrategias para fijar el precio de bienes o servicios, siempre que no explote la labor temprana de niños y adolescentes, ni falte de ningún otro modo a la dignidad de la persona humana (Art. 1, III, CF/88).

Cabe destacar, sin embargo, que "ningún principio es absoluto. El principio de la libre iniciativa, por tanto, así como los demás, debe ser ponderado con otros valores y fines públicos previstos en el propio texto de la Constitución” (BARROSO, 2001, p. 191). Por lo tanto, es necesario subrayar que el respeto de la legislación nacional, incluso en lo que se refiere a la no explotación del trabajo infantil, es requisito sine qua non de un escenario real de libre competencia. Esa es la razón por la cual el art. 173, \ $4^{\circ}, \mathrm{CF} / 88$, informa que "la ley reprimirá el abuso del poder económico que apunte [...] la eliminación de la competencia [...]", dejando entrever, pues, que la existencia de la libre competencia presupone algún grado de control del Estado sobre el poder económico. Por lo tanto, no es posible que el principio de libre competencia sea efectivo en un contexto en el que parte de los propietarios de los medios de producción respeta la prohibición del trabajo infantil, mientras que otra parte se utiliza de esa mano de obra para abaratar sus costos, generando, por consecuencia, un escenario de competencia desleal. 


\subsection{Reducción de las desigualdades sociales y regionales}

La Constitución Federal informa, en el art. 170, que la disminución de las desigualdades sociales y regionales es un principio que orienta el orden económico brasileño, además de ser uno de los objetivos de la República Federativa de Brasil (Art. $3^{\circ}$ ). A partir de esto, Alves (ALVES, 2008, p. 5) afirma que, según Bagnoli, "el principio de reducción de las desigualdades regionales y sociales debe garantizar la existencia digna de los individuos. Para ello, el poder público debe trabajar arduamente en la implementación de políticas públicas para transformar la igualdad formal en igualdad material”. En el mismo sentido, está la afirmación de Alves (ALVES, 2008, p. 5), según la cual "la idea de reducir las desigualdades regionales y sociales está asociada con la concretización del principio de igualdad material (igualdad de hecho)".

Se verifica, pues, que hay una asociación frecuente entre el principio de la disminución de las desigualdades sociales y regionales y la búsqueda de una "sociedad libre, justa y solidaria" (Art. 3, I, CF/88), ya que, en las palabras de grado (2018), la sociedad brasileña se caracteriza por tres marcas: “pobreza, marginación y desigualdades" (GRAU, 2018, p. 213).

En ese escenario, parece inevitable el reconocimiento de que acciones que tengan por consecuencia el acierto de las desigualdades sociales y regionales caracterizan una afrenta al orden económico brasileño, que debe buscar garantizar un país más igualitario. Desde esta perspectiva, la prohibición del trabajo infantil y el uso de todas las formas estatales posibles para combatir su explotación serían iniciativas adoptadas para asegurar el orden económico, previsto constitucionalmente.

De acuerdo con el texto introductorio al III Plan Nacional de prevención y Erradicación del Trabajo Infantil y protección del Adolescente trabajador, la baja renta de las familias es una de las causas que lleva al trabajo infantil. Al analizar los datos, el plan registra que:

Con relación al perfil económico de las familias en las cuales los niños y adolescentes de 5 a 17 años en situación de trabajo infantil se encuentran, se observa que $49,83 \%$ tienen renta mensual per capita menor que medio salario mínimo, Siendo, pues, consideradas familia de baja renta. Además, $27,80 \%$ se encuentran en familias que tienen renta per cápita inferior a un salario mínimo. De eso, se concluye que $77,63 \%$ de los niños y adolescentes en situación de trabajo infantil se encuentran en familias que reciben renta per cápita inferior a un salario mínimo. 
En el mismo sentido, la Organización Internacional del Trabajo (OIT) asocia el trabajo temprano de niños y adolescentes con la pobreza de sus familias y afirma que:

Es la familia la que debe sostener al niño y no al revés. Cuando la familia se vuelve incapaz de cumplir esta obligación, corresponde al Estado apoyarla, no a los niños. El costo de elevar a un niño al papel de "sostén de la familia" es exponerlo a daños físicos, intelectuales y emocionales. Es un precio altísimo, no sólo para los niños sino para el conjunto de la sociedad al privarlos de una infancia (OIT, [20--]).

Luego, es forzoso el reconocimiento de que el trabajo infantil se da en razón de desigualdades sociales, que hacen que algunos sean obligados a someterse a una explotación laboral precoz para garantizar el disfrute de derechos fundamentales, como salud y alimentación. Según datos del informe de Desarrollo Humano (2019), de la organización de las Naciones Unidas $(\mathrm{ONU})$,

[...] en Brasil, las encuestas a los hogares revelan que el 10 por ciento más rico obtuvo un poco más del 40 por ciento del ingreso total en 2015, pero, cuando se tienen en cuenta todas las formas de ingreso - no sólo el ingreso comunicado en las encuestas - las estimaciones revisadas sugieren que al 10 por ciento de la parte superior cupo, de hecho, más del 55 por ciento del ingreso total (ONU, [2019]).

Se percibe, entonces, que la poca distribución de renta somete una parte significativa de la población brasileña a condiciones de vida muy malas, tornándose vulnerable al trabajo infantil. No sin razón la presencia de la explotación del trabajo de niños y adolescentes es uno de los indicadores laborales, considerados por la ONU en el informe antes mencionado, para dimensionar los riesgos para el desarrollo humano.

Vale, sin embargo, subrayar que las desigualdades sociales no son solamente la causa del trabajo infantil, como son también una de sus consecuencias. Es decir, el trabajo infantil no sólo se da en razón de la pobreza y de la desigualdad social, sino que también las intensifica. Según Mendelievich (1980, p. 52),

Los niños que estudian y trabajan simultáneamente enfrentan muchos problemas. En las áreas rurales, son comunes las ausencias escolares, especialmente en los meses de siembra y cosecha, período en que la mano de obra infanto-juvenil es más solicitada, generando ausencias periódicas. Tales ausencias generan dificultades para la reinserción escolar y, muchas veces, se transforma en abandonos definitivos. 
Esa afirmación es confirmada por los datos del III Plan Nacional de Prevención y Erradicación del Trabajo Infantil y Protección del Adolescente trabajador. Según el documento, 24,33\% de los adolescentes de 16 y 17 años que trabajan afirmaron que no saben leer o escribir, aunque estuvieran en los últimos años de la enseñanza obligatoria.

Como consecuencia de los evidentes perjuicios a la educación, se verifica el mantenimiento de un ciclo de exclusión social, que, en palabras de Goulart (2005, p. 24), ocurre en los siguientes términos:

En la sociedad contemporánea, marcada por la revolución tecnológica, el mundo del trabajo es exigente en términos de calificación. Por lo tanto, la formación profesional adecuada a esa nueva realidad es presupuesto de ejercicio de la ciudadanía. La formación escolar y profesional insuficiente e inadecuada implica, hoy, exclusión del mercado, por lo tanto, exclusión social. Los empleadores están exigiendo una formación mínima de la escuela secundaria incluso para las actividades más simples. Los trabajos de cuño meramente manual o manual están desapareciendo ante la sustitución de la persona por instrumentos mecánicos (mecanización) y electrónicos (automatización).

Se verifica, por lo tanto, que la prohibición al trabajo infantil consiste también en una herramienta de garantía del orden económico del país, que se pauta por la búsqueda de la reducción de las desigualdades sociales. Si el combate al trabajo infantil es un instrumento para garantizar la disminución de la desigualdad de la sociedad brasileña, se puede, pues, afirmar con convicción que la no explotación del trabajo infantil es un instrumento que asegura el orden económico previsto en la Constitución Federal.

\section{CONCLUSIÓN}

Ante todo lo expuesto, es inevitable concluir que la prohibición al trabajo infantil se basa en argumentos jurídicos, que extrapolan la simple protección del niño y del adolescente. Se nota que los principios que rigen el orden económico y financiero de Brasil orientan un funcionamiento de la economía que presupone la no explotación del trabajo precoz de niños y adolescentes. Por lo tanto, los principios de la "función social de la propiedad", de la "libre competencia" y de la "disminución de las desigualdades sociales y regionales", cuando asociados, conducen indudablemente a la comprensión de que el orden económico y financiero brasileño no prescinde de la prohibición al trabajo infantil. 
Las políticas macroeconómicas no comprometidas con el desarrollo social y humano son autofágicas. La ortodoxia del libre mercado, basada en políticas macroeconómicas de austeridad, preocupadas tan sólo en preservar la estabilidad - como políticas monetarias y fiscales orientadas al control inflacionario y del mercado cambiario, para liberación del comercio y del mercado financiero globales - es ampliamente restrictiva a la capacidad de los países en desarrollo de promover el denominado "capital humano", comprendido en los términos de la declaración del derecho al desarrollo, de la ONU, y de los principios que rigen la "Constitución económica" nacional. Países como los del este asiático que experimentaron altos índices de desarrollo económico y social han adoptado políticas económicas complejas prestando atención a las políticas sociales - educación e igualdad, junto con una liberalización cadenciosa de la economía y de inversiones en infraestructura y en tecnología. Estos países han revelado que la desigualdad no es necesaria para el crecimiento y la generación de tasas de ahorro que impulsen el crecimiento. La intervención equilibrada del estado a través de una agenda económica multifacética es esencial para el desarrollo integral de una sociedad.

El trabajo infantil impide la formación de "capital humano" y social, indispensable para el desarrollo, constituyéndose como uno de los elementos de estancamiento económico de los países en desarrollo por cuenta de los efectos económicos y sociales colaterales, además de constituir en factor competidor para el continuo agravamiento de la concentración de la riqueza y de la exclusión social.

\section{NOTAS}

1 En el ámbito internacional, en razón del art. $1^{\circ}$ de la Convención sobre los Derechos del Niño y del Adolescente, ratificada por 196 países, niño es todo ser humano con menos de 18 años de edad. Diferente de lo que ocurre en la legislación brasileña, por lo tanto, no hay necesidad de mencionar el término "adolescente".

2 BRASIL. III Plan Nacional de prevención y Erradicación del Trabajo Infantil y Protección al Adolescente Trabajador (2019-2022). Brasilia: Ministerio de Trabajo, 2019, p. 09.

3 BRASIL. III Plan Nacional de prevención y Erradicación del Trabajo Infantil y Protección al Adolescente Trabajador (2019-2022). Brasilia: Ministerio de Trabajo, 2019, p. 09.

4 Como ejemplo, vale citar, en orden cronológico, la Declaración de los derechos del niño (1959), la Convención de los derechos del Niño (1989), la Convención n. ${ }^{\circ}$ 138, de la OIT (1973), el título “de la protección del trabajo del Menor", previsto en la consolidación de las leyes del trabajo (1967), la Constitución Federal (1988), el 
Estatuto del niño y del Adolescente (1990), la Convención n. ${ }^{\circ}$ 182, el Decreto n. ${ }^{\circ}$ 6.481 (2008).

5 En este trabajo, la expresión "trabajo temprano" se utilizará como sinónimo de "trabajo infantil".

\section{REFERENCIAS}

ALVES, Antônio Cláudio. Princípio da redução das desigualdades regionais e sociais. In: Actio Revista de Estudos Jurídicos, Maringá/RJ, n. ${ }^{\circ}$ 28, v. 1, p. 33-50, jan./jun. 2018.

BAGNOLI, Vicente. Direito Econômico. 6. ${ }^{a}$ ed. São Paulo: Atlas, 2013.

BARROSO, Luís Roberto. A ordem econômica constitucional e os limites à atuação estatal no controle de preços. In: Revista de Direito Administrativo, Rio de Janeiro/RJ, n. ${ }^{\circ}$ 226, p. 187-212, out./dez., 2001.

BRASIL. Constituição da República Federativa do Brasil de 1988. Brasília/DF, 1988. Disponible en: http://www.planalto.gov.br/ccivil_03/constituicao/constituicao.htm . Acceso en: 5 abr. 2020.

BRASIL. Lei n. ${ }^{\circ}$ 8.069, de 13 de julho de 1990. Dispõe sobre o Estatuto da Criança e do Adolescente e dá outras providências. Brasília/DF, 1990. Disponible en: http://www.planalto.gov.br/ccivil_03/leis/18069.htm. Acceso en: 8 abr. 2020.

CERVINI, Ruben; BURGER, Freda. O menino trabalhador no Brasil urbano dos anos 80. In: FAUSTO, Ayrton; CERVINI, Ruben (orgs.). O trabalho e a rua: crianças e adolescentes no Brasil urbano dos anos 80. 2. ${ }^{a}$ ed. São Paulo: Cortez, 1996.

COASE, Ronald. The nature of the firm. In: Econômica, Londres, v. 4, n. ${ }^{\circ}$ 16, p. 386-405, nov. 1937. Disponible en: https://onlinelibrary.wiley.com/ doi/full/10.1111/j.1468-0335.1937.tb00002.x. Acceso: 21 abr. 2020.

COMPARATO, Fábio Konder. Função social da propriedade dos bens de produção. In: Revista de Direito Mercantil, Industrial, Econômico e Financeiro. São Paulo, v. 63, p. 71-79, 1986.

CUSTÓDIO, André Viana. O trabalho da criança e do adolescente no Brasil: uma análise sócio-jurídica. Dissertação (Mestrado em Direito). Faculdade de Direito. Universidade Federal de Santa Catarina. 2002. 
ESTEVES, Filipa Sofia Margarido. A Aplicação do Sistema de Custo Padrão na Indústria Têxtil: $O$ caso da FISIPE-Fibras Sintéticas de Portugal, S.A. Dissertação (Mestrado em Economia). Lisboa. Universidade Autônoma de Lisboa. 2013.

GOULART, Marcelo Pedroso. A convenção sobre a idade mínima e o direito brasileiro. In: Trabalho Infantil e Direitos Humanos: Homenagem a Oris de Oliveira. São Paulo: LTR, 2005.

GRAU, Eros Roberto. A ordem econômica na Constituição de 1988. 19a ed. São Paulo: Malheiros, 2018.

GRUNSPUN, Haim. O trabalho das crianças e dos adolescentes. São Paulo: LTr, 2000.

MARCHI, Rita de Cássia. Trabalho infantil: representações sociais de sua instituição em Blumenau/SC. In: Educar em Revista, Curitiba/PR, n. ${ }^{\circ} 47$, p. 249-265, jan./mar., 2013.

MENDELIEVICH, Elias. El trabajo de los ninos. Genebra: Oficina Internacional dei Trabajo, 1980.

MENDES, Moacyr Pereira. A doutrina da Proteção Integral da Criança e do Adolescente frente à Lei n.o 8.069/90. Dissertação (Mestrado em Direito). São Paulo. Pontifícia Universidade Católica. 2006.

MINISTÉRIO DO TRABALHO E EMPREGO. Nota Técnica à Portaria n. ${ }^{\circ}$ 6, de 18/02/2000. Brasília/DF, 2000. Disponible en: http://www.capecanaveral4045.com/legislacao/port_06_trab_infant_notatec.html. Acceso: 25 abr. 2020.

MINISTÉRIO DO TRABALHO E EMPREGO. III Plano Nacional de Prevenção e Erradicação do Trabalho Infantil e Proteção ao Adolescente Trabalhador. Brasília/DF: CONAETI, 2019. Disponible en: https:// fnpeti.org.br/media/12dejunho/documentos-de-referencia/III_Plano_Nacional_de_Preven $\% \mathrm{C} 3 \% \mathrm{~A} 7 \% \mathrm{C3} \% \mathrm{~A} 3 \mathrm{O}$ e__Erradica $\% \mathrm{C3} \% \mathrm{~A} 7 \% \mathrm{C3} \% \mathrm{~A} 3 \mathrm{O}$ do_Trab.pdf. Acceso en: 10 abr. 2020.

NICOLELLA, Alexandre Chibebe; KASSOUF, Ana Lúcia; BARROS, Alexandre Lahóz Mendonça de. O impacto do trabalho infantil no setor agrícola sobre a saúde. [S.1], [20--]. Disponible en: http://www.scielo.br/ 
scielo.php?script $=$ sci_arttext\&pid $=$ S0103-20032008000300005. Acceso: 21 abr. 2020 .

ORGANIZAÇÃO DAS NAÇÕES UNIDAS. Declaração Universal dos Direitos da Criança e do Adolescente. Genebra: ONU, 1959. Disponible en: http://www.crianca.mppr.mp.br/pagina-1069.html. Acceso en: 10 abr. 2020 .

ORGANIZAÇÃO DAS NAÇÕES UNIDAS. Pacto Internacional sobre Direitos Econômicos, Sociais e Culturais. Genebra: ONU, 1966. Disponible en: http://www.planalto.gov.br/ccivil_03/decreto/1990-1994/d0591. htm. Acceso en: 12 abr. 2020.

ORGANIZAÇÃO DAS NAÇÕES UNIDAS. Relatório do Desenvolvimento Humano 2019. Genebra: ONU, 2019. Disponible en: http://hdr. undp.org/sites/default/files/hdr_2019_pt.pdf. Acceso: 25 abr. 2020.

ORGANIZAÇÃO INTERNACIONAL DO TRABALHO. Convenção n. 138. Genebra: OIT, 1973. Disponible en: http://www.tst.jus.br/documents $/ 2237892 / 0 /$ Conven $\% \mathrm{C} 3 \% \mathrm{~A} 7 \% \mathrm{C} 3 \% \mathrm{~A} 3 \mathrm{o}+138+\mathrm{da}+\mathrm{OIT}++\mathrm{Ida}-$ $\mathrm{de}+\mathrm{m} \% \mathrm{C} 3 \%$ ADnima + de + admiss $\% \mathrm{C} 3 \% \mathrm{~A} 3 \mathrm{o}+\mathrm{ao}+$ emprego. Acceso: 20 abr. 2020 .

ORGANIZAÇÃO INTERNACIONAL DO TRABALHO. Convenção n. ${ }^{\circ}$ 182. Genebra: OIT, 1999. Disponible en: https://www.ilo.org/brasilia/convencoes/WCMS_236696/lang--pt/index.htm. Acceso en: 5 abr. 2020.

PASSETTI, Edson. Crianças Carentes e Políticas Públicas. In: PRIORE, Mary Del (org.). História das crianças no Brasil. São Paulo: Contexto, 1999.

SOBRINHO, Zéu Palmeira. O Trabalho Infantil: um balanço em transição. In: NOCCHI, Andrea Saint Pastous et al. (orgs.). Criança, Adolescente e Trabalho. São Paulo: LTr, 2010.

TOMASEVICIUS FILHO, Eduardo. A função social da empresa. In: Revista dos Tribunais, São Paulo/SP, v. 92, p. 33-50, abr. 2003. 


\section{DE DÓNDE PARTIMOS EN DÍAS DE NUBES GRISES Y LLUVIAS INCIERTAS: INICIATIVAS Y DESAFÍOS EN EL COMBATE A LA EXPLOTACIÓN DEL TRABAJO INFANTIL EN LA AMAZONIA BRASILEÑA}

\section{CHRISTIANA D'ARC DAMASCENO OLIVEIRA}

"Florece en el lugar en que estás sembrado."1 (Ella Grasso)

DOI: 10.51366/978-65-89468-10-3-coordinfancia-4

Resumen. El artículo examina adversidades y potencialidades del Combate al Trabajo Infantil en la Amazonia brasileña. Bajo los prismas del Derecho Internacional del Trabajo, del Derecho Constitucional del Trabajo y de la legislación ordinaria, además de los elementos de la Sociología y de la Economía del Trabajo, de modo aliado a iniciativas interinstitucionales, se plantean vías de optimización de incidencia del referido instituto en el siglo XXI y de la noción de trabajo vivaz, consideradas también las repercusiones traídas por la pandemia vigente generada por el COVID-19.

Palabras clave: Trabajo infantil. Amazonia. Derecho del Trabajo. Trabajo vivaz. Dignidad humana.

\section{INTRODUCCIÓN}

Abundan cuestiones permeadas por la multidisciplinariedad en lo que atañe al enfoque de los desafíos que involucran la Amazonia.

El cuadrante se maximiza cuando la lupa de análisis se dirige de modo específico a la intersección en el mundo del trabajo de la fuerza laboral tanto 
de niños como de adolescentes en edad inferior a la prevista normativamente, en un grave escenario que afecta la existencia de seres humanos de los más diversos puntos de partida e itinerarios.

En este breve estudio, se examinarán diversos matices relacionados al camino desafiante y al robustecedor actuar cotidiano, en latitud y longitud, respecto al Combate al Trabajo Infantil en la Amazonia Brasileña, con matices del Derecho Internacional del Trabajo, del Derecho Constitucional del Trabajo y de la legislación ordinaria, más allá de elementos de la Sociología y de la Economía del Trabajo, de modo coadunado a interesantes aportes interinstitucionales.

\section{RADIOGRAFÍA DEL TRABAJO INFANTIL: RECORTE EN LA AMAZONÍA BRASILEÑA, ÁMBITOS NORMATIVOS NACIONAL E INTERNACIONAL}

En su actual configuración (cuyo nacedero legislativo remonta a las décadas del 60 y 70, a través de las Leyes n. 1.806, de 6/1/1953, y n. 5.173, de 27/10/1966), la Amazonia Legal Brasileña está compuesta por nueve estados de la Federación, en una superficie de cerca de 5 millones de kilómetros cuadrados, que alcanza aproximadamente el 61\% del territorio de Brasil.

Abarca los estados de Acre, Amapá, Amazonas, Pará, Rondônia, Roraima y Tocantins (siete estados de la Región Norte) y Mato Grosso, de modo integral, además de parte del estado de Maranhão (oeste del meridiano de $\left.44^{\circ}\right)$. En el plano internacional, la selva amazónica está presente en el territorio de otros ocho países, además de Brasil.

Conforme a lo que registra el Fondo de las Naciones Unidas para la Infancia (UNICEF), además de ser ampliamente divulgada por su preciosa biodiversidad natural, la Amazonia Brasileña es también el hogar de 9,1 millones de niños y adolescentes, que representan el 32,9\% de los 27,7 millones de sus habitantes. Desde luego, en suelo amazónico está la población más joven de Brasil (UNICEF, 2019).

Estudio realizado por UNICEF, divulgado en septiembre de 2019, basado en indicadores sociales, revela sin embargo que los niños nacidos en la Amazonia enfrentan desafíos adicionales respecto a aquellos de otros puntos del territorio nacional, con mayor riesgo de muerte antes de completarse un 
año de edad, y aún mayor probabilidad de no completar la enseñanza primaria.

El panorama de privación múltiple está potencializado por la falta de accesibilidad y difusión, en gran parte del territorio, amazónico de asistencia médica, educación, seguridad alimentaria y saneamiento, dados los contornos de densidad demográfica regional y de repertorio urbano, lo que es aún más difícil en algunas áreas por las dificultades de acceso geográfico para quienes habitan las regiones.

Según el mismo análisis, en añadidura, hay elevado porcentual de embarazo de adolescentes, así como alta vulnerabilidad en la región de niños y niñas a las más diversas situaciones de violencia, entre las cuales el abuso y explotación sexual, homicidio y trabajo infantil.

¿Y cómo impacta el trabajo infantil a niños y adolescentes en la Amazonia Brasileña?

El análisis con base en la Encuesta Nacional por Muestra de Domicilios (Pesquisa Nacional por Amostra de Domicílios) (PNAD) 2015 apunta que, en Brasil, $6,2 \%$ de los niños y de los adolescentes de 5 a 17 años estaban sometidos a trabajo doméstico y/o remunerado, en desacuerdo con la legislación vigente. De estos, 64,1\% eran negros.

Agrega UNICEF que "entre los estados amazónicos, la situación se agrava aún más. Entre las cinco grandes regiones brasileñas, la Norte es la que posee el mayor porcentaje de niños y adolescentes trabajando $(7,7 \%)$. Siguiendo la misma tendencia, todos los estados de Amazonia Legal, sin excepción, se encuentran sobre el promedio nacional" (UNICEF, 2019).

A firma aún UNICEF que "Cuando todas esas variables son evaluadas a partir de un recorte de raza y etnia, se percibe que entre los grupos minoritarios, como indígenas y quilombolas, el cuadro es aún más grave" (UNICEF, 2009).

En ese particular, en un informe publicado en febrero/2020, en conmemoración del $30^{\circ}$ aniversario de la importante Convención n. 169 de la OIT, Sobre Pueblos Indígenas y Tribales, de 1989, la Organización Internacional del Trabajo aduce ser inexorable aportar soluciones para el elevado 
nivel de pobreza y las desigualdades a la que están expuestos los pueblos indígenas.

Constata la OIT que los pueblos indígenas presentan casi tres veces más probabilidades de vivir en situación de pobreza extrema, independientemente de residir en área urbana o rural, en comparación con los habitantes no indígenas.

En el referido documento, nombrado Aplicación del Convenio sobre pueblos indigenas y tribales núm. 169 de la OIT: Hacia un futuro inclusivo, sostenible y justo, se subraya que los indígenas en todo el mundo equivalen a 476 millones de personas, aproximadamente $6 \%$ de la población mundial. A pesar de ello, los indígenas corresponden a $30 \%$ de todas las personas del mundo cuya vida se sitúa en la pobreza extrema.

Asimismo, se retrata que $86 \%$ de los pueblos indígenas del globo terrestre se activan en trabajos informales, diferentemente de lo que ocurre en cuanto a los pueblos no indígenas (en los que el porcentaje es del 66\%), con condiciones laborales desfavorables y ausencia de sistema de protección social.

En efecto, a pesar de las previsiones normativas avanzadas, y sobre todo en la Amazonia Legal Brasileña, tanto en lo que respecta a indígenas como a no indígenas, aún es inquietante la configuración de trabajo precoz ilegal en la agricultura, en la ganadería, en el trabajo doméstico, en los basurales, en las ferias, en las minas, en el comercio ambulante y en otras actividades laborales vulnerables en las calles (por ejemplo, limpiabotas), en el plantío y tráfico de narcóticos, a los cuales se unen la desafortunada explotación sexual y comercial y la neoesclavitud infanto juveniles, entre otros focos de incidencia.

Además de eso, en cuanto a las intersecciones con cadenas productivas de valor global, el trabajo infantil se revela de modo agudo, entre otras, en la producción de castaña, cacao, algodón y en la ganadería. Ya bajo el prisma de cadenas productivas con mayor enfoque en el ámbito nacional, también se presenta el trabajo precoz ilegal de niños y adolescentes en la cosecha y producción de azaí.

No obstante, conforme el Censo Agropecuario, Forestaly Acuicola de 2017, efectuado por el Instituto Brasileiro de Geografía y Estadística (IBGE), 580.052 ni- 
ños y adolescentes con hasta 13 años trabajaban en la agropecuaria. Un cuantitativo consistente de esos niños y adolescentes (más de 194 mil) activados en la agropecuaria en la Amazonia Legal Brasileña (FNPETI, 2020b, p. 20).

Como se nota, extensos son los desafíos y las fallas de protección social que subyacen al trabajo infantil en territorio amazónico.

Recuérdese que el combate al trabajo infantil emerge como medida de naturaleza estratégica, transversal y multifacética, siendo que el trabajo precoz ilegal consiste en incisiva violación de derechos humanos y de derechos fundamentales, revelándose como causa y consecuencia retroalimentadas de vulnerabilidad socioeconómica.

Además del carácter pluridimensional de la pobreza, el trabajo infantil tiene como propulsores la cultura en algunas regiones que lo ven con naturalidad, el interés patronal en la reducción de costos con mano de obra (ante el despojo de derechos) y la falta de acceso a la educación, entre otros aspectos.

Se trata de una pérdida de oportunidades y desigualdad que se efectiva, para utilizar la feliz expresión de Herrera Flores (2008, p. 154), "tanto en el punto de partida como en el recorrido vital", provocando reflejos que se explayan más allá del individuo, generando tensión y pérdida de potencialidades en el medio social.

Estudios apuntan el eslabón visceral entre el trabajo infantil y las condiciones que generan comunicación, tanto a la época de su ocurrencia como ya en otras fases de la vida del sujeto trabajador, con los riesgos de mayor exposición a la sumisión al trabajo en condiciones análogas a las de esclavo (neoesclavitud o trabajo esclavo contemporáneo), al tráfico de personas, a la precarización laboral en general, flexibilización deletérea, subempleo, discriminación etc. Es decir: las situaciones aludidas inciden de modo más pujante cuanto a trabajadores que, en fase primera de la vida, estuvieron sometidos al trabajo precoz ilegal (OIT; OCDE; OIM; UNICEF, 2019).

Por lo tanto, darse cuenta de los fenómenos que reverberan en el campo del trabajo infantil y en el respectivo combate revela mucho sobre cómo construir en el mundo del trabajo, desde la base, relaciones que puedan generar de ahora en adelante la maximización de la dignidad humana en la trayectoria del sujeto que trabaja y el respeto a la normativización establecida para 
ello, conforme a lo que ya tuvimos la oportunidad de investigar más despacio en otro campo (OLIVEIRA, 2010, p. 74-96).

A la par, comprender las faces del mundo del trabajo bajo el sesgo de la adolescencia y de la juventud, abarcado el instituto del aprendizaje profesional (uno de los mecanismos de lucha contra el trabajo infantil), puede contribuir para el entendimiento holístico del fenómeno laboral, para la búsqueda de soluciones destinadas al fortalecimiento de una cultura de elevación del trabajo digno como derecho fundamental, bien como para la implementación duradera de una agenda de trabajo decente.

Según la OIT y UNICEF, tras 20 años de reducciones progresivas en los indicadores de trabajo precoz, hay grandes chances de que el referido curso se interrumpa como consecuencia de la situación desoladora causada por el COVID-19, en el caso de que políticas públicas intersectoriales y medidas urgentes no sean adoptadas, de modo a garantizar en el momento post pandemia el retorno de niños y adolescentes a la escuela (incluso con busca activa escolar), propiciar formación técnico-profesional en la edad adecuada y una opción de renta para las familias (OIT y UNICEF, 2020; OIT y CEPAL, 2020).

Como consecuencia, si no se implementan las providencias: incorporación no solo de miles de niños y adolescentes más sujetos al trabajo infantil, como también incremento de carga horaria y peores condiciones para los que ya trabajaban irregularmente (ONU, 2020a).

Justo señala la Organización Internacional del Trabajo (OIT) que el virus causador del COVID-19 tiene potencial de alcanzar a todos, sin hacer distinción entre ricos y pobres, sin embargo, evidentemente, sus efectos son extremadamente desiguales para los más pobres y vulnerables, que no tienen acceso a servicios basilares (OIT, 2020, p. 2).

En congruencia, las agudas observaciones de Saggese (2009, p. 242):

[...] en una sociedad cuya organización económica de recursos posee una extraordinaria potencialidad, y cuyos balances económicos comerciales - además - alcanzan resultados superavitarios, existan personas que literalmente mueren de hambre, es un hecho aberrante, imperdonable y absolutamente injusto desde una perspectiva tanto política como moral. 
El horizonte parece opaco en ese inmenso caudal de fenómenos de contornos grises.

Como ya dicho, mayor alcance el tempestuoso universo y sus efectos lesivos tiene entre los niños y adolescentes de familias vulnerables. En la Amazonia brasileña, el fenómeno se da en escala agudísima respecto a niñas y niños, adolescentes y jóvenes indios, negros, pobres.

En el mundo, antes del COVID-19, había cerca de 152 millones de niñas y niños sometidos al trabajo infantil, aproximadamente uno de cada diez de esos pequeños seres humanos (OIT, 2017, p. 5). En territorio nacional, antes de la pandemia, ya emergía la preocupante escena de más de 2,4 millones de niños y adolescentes de 5 a 17 años sometidos al trabajo precoz ilegal2.

De acuerdo con la última PNAD con periodicidad anual, de 2015, la concentración más abarcadora de trabajo precoz ilegal en el país se ubicaba en la franja de 14 a 17 años (83,7\%), demostrando cantidad exponencial de público que, aunque apto a beneficiarse del instituto del aprendizaje profesional, resultaba sometido a esa grave violación de derechos humanos.

Paradojalmente, el tratamiento y el análisis de los datos consolidados en el ámbito de la Iniciativa SMARTLAB - Promoción del Trabajo Decente Guiada por Datos -, en lo que toca al Observatorio de la Prevención y de la Erradicación del Trabajo Infantil (solución de tecnología conjunta de la OIT y del MPT), revela que, en febrero de 2019, el potencial de cupos para la contratación de aprendices correspondía a 962,8 mil vacantes.

Además de eso, datos recientes divulgados por el Fórum Nacional de Prevención y Erradicación del Trabajo Infantil, con parámetros en el Sistema de Información de Agravios de Notificación (Sinan) - Ministerio de la Salud, apuntan que, en el periodo de 2007 a 2019, 46.507 accidentes de trabajo han acometido a niños y adolescentes con edad entre 5 a 17 años. De estos, 27.924 han constituido accidentes de trabajo graves y 279 han provocado la muerte de niños y adolescentes (FNPETI, 2020a).

En lo que toca a Brasil, es nítida la disparidad existente entre la grave realidad fáctica presentada y la circunstancia de hace mucho tiempo el país ha ratificado la Convención sobre los Derechos del Niño, adoptada por la Organización de las Naciones Unidas (ONU) en 20/11/1989; la Convención n. 138 de la Organización Internacional del Trabajo (OIT), sobre la Edad 
Mínima para Admisión al Empleo (1973), y la Convención n. 182 de la OIT, en lo que se refiere a la Prohibición de las Peores Formas de Trabajo Infantil y a la Acción Inmediata para su Eliminación (1999); a las cuales se unen la Recomendación n. 190 de la OIT, que trata de las peores formas de trabajo infantil (1999), y la Declaración de la OIT sobre los Principios y Derechos Fundamentales en el Trabajo (1998); la vehemente veda del trabajo precoz en el ordenamiento patrio en razón del principio de la protección integral en el atendimiento al niño y al adolescente, además del tenor de la Constitución Federal.

En el mismo sentido, Brasil está sujeto a otras normativas internacionales igualmente importantes y de cariz más general cuanto a la materia, entre las cuales la Declaración Universal de los Derechos Humanos, de 1948; el Pacto Internacional de Derechos Económicos, Sociales y Culturales, de 1966; y el Pacto Internacional de Derechos Civiles y Políticos, de 1966; todos de la ONU.

Como se infiere, respecto a la temática de la infancia, de la adolescencia y de la juventud bajo el sesgo del mundo del trabajo, las normas en foco refuerzan el bloque de constitucionalidad (OLIVEIRA, 2010).

Destáquese que el bloque de constitucionalidad lo integran elementos y diplomas normativos dotados de aspecto constitucional, los cuales se vuelven tanto para la protección de la dignidad de la persona humana como se constituyen como parámetro de confrontación en relación al cual se debe proceder a la verificación de la compatibilidad vertical de las normas inferiores y de los actos judiciales y del ejecutivo, es decir, el conjunto o plexo de normas que se considera como modelo constitucional para dicha confrontación.

La figura del bloque de constitucionalidad tiene destacada importancia en la actuación cotidiana de los que trabajan con el Derecho, sean abogados, jueces, auditores, integrantes del Ministerio Público, sindicatos, porque permiten la optimización de los parámetros que deben ser utilizados en la concreción de los derechos fundamentales en las relaciones de labor y en la efectivización de la dignidad de la persona humana.

Vale decir que la observancia del bloque de constitucionalidad se impone lógicamente también a los actores sociales, como paradigma para observarse para fines de incidencia de la autonomía privada y colectiva, en especial 
en el ámbito de las relaciones de trabajo, sea en la formación de contratos individuales, sea en las estipulaciones en ámbito colectivo.

En Brasil, prescribe el art. . $^{\circ}$, inciso XXXIII, de la CF de 1988, el nivel de 16 (dieciséis) años como edad mínima para el inicio de relación de trabajo y de empleo, excepto en la condición de aprendiz, a partir de los 14 (catorce) años. Si el trabajo es nocturno, peligroso o insalubre, dispone la Ley Mayor cuanto a su prohibición para personas con menos de 18 (dieciocho) años (arts. $7^{\circ}$, inciso XXXIII, parte final, y 227, \$3. ${ }^{\circ}$, inciso I).

Cabe registrar la existencia de posición doctrinaria en el sentido de que, a partir de la vigencia en Brasil de la Convención n. ${ }^{\circ} 138$ de la OIT, en 28/6/2002, la edad general mínima para admisión al empleo pasó a ser de 17, y no más de 16 años. Para tanto, se apunta la interpretación aliada del art. 208, I, de la Constitución Federal (que fija la educación básica obligatoria de los 4 a los 17 años) - cuyo tenor se replica en el art. 4º I, de la Ley n. 9.394/1996 (Ley de Directrices y Bases de la Educación Nacional) - y del art. $2^{\circ}$, ítem 3, de la Convención n. 138 de la OIT (que determina que la edad mínima para admisión al empleo no deberá ser inferior a la edad en que cesa la obligación escolar).

Además, la legislación ordinaria nacional prohíbe a la persona con edad inferior a 18 años las actividades que sean dañosas a su formación y a su desarrollo físico, psíquico, moral y social, de modo que impidan la respectiva frecuencia a la escuela, conforme los arts. 403, parágrafo único, 405, inciso II y $\iint 2 .^{\circ}$ a $4 .^{\circ}$, así como arts. 406 a 408 de la CLT. En el mismo sentido el art. 67, incisos III y IV, del ECA.

Por su parte, los arts. 3. ${ }^{\circ}$, apartado “ ' $d$ ', y 4..$^{\circ}$, de la ya citada Convención n. 182 de la OIT, disponen que no podrá aún el trabajador con edad inferior a 18 (dieciocho) años activarse en las denominadas peores formas de trabajo infantil (Lista TIP), siendo explicitado el tenor de tales artículos en el ordenamiento brasileño a través del Decreto n. 6.481, de 12/6/2008, que pasó a vigorar en el 13/9/2008.

En Brasil, en el plano normativo, prevalece el principio de la protección integral del niño, del adolescente y del joven, con nivel de derecho fundamental amparado en la misma Constitución (arts. $6^{\circ}$, caput, 24, inciso XV; 203, incisos I y II; 227 y párrafos; todos de la CF de 1988). 
Según Oliva (2006, p. 110-121), con soporte teórico en Fonseca, la doctrina de la protección integral contiene seis despliegues: a) principio de la ciudadanía; b) principio del bien común; c) condición peculiar de persona en desarrollo; d) atención prioritaria; e) acción paritaria; y f) protección especial al trabajo y a la educación del adolescente portador de discapacidad.

El principio de la protección integral del niño, del adolescente y del joven tiene amparo en la circunstancia de que la infancia es el periodo destinado en especial a actividades lúdicas y culturales, a la práctica deportiva, a la convivencia familiar y comunitaria y a la educación.

Este vector también se junta a la concepción de la adolescencia y de la juventud como periodos dirigidos al aprendizaje académico y de la profesionalización, incluso vía aprendizaje profesional, con previsión en los arts. 428 y siguientes de la CLT, art. 53 del Decreto n. 9.579, del 22/11/2018; y art. 15 de la Ley n. 13.840, del 5/6/2019, entre otros.

En ese aspecto, es clara la premisa de que el manantial intelectual de un país pasa sobre todo por la educación, que se trata de mecanismo para el ejercicio de la ciudadanía, sin el cual se reproduce y se eterniza la esfera del Estado como nación menos favorecida.

Se concibe, de ese modo, que sólo es posible la colaboración del adolescente en la asunción de encargo de sustento propio y del grupo familiar en las hipótesis expresamente previstas en ámbito constitucional y legal, observados los parámetros fijados.

A pesar de ello, los números anteriormente indicados revelan que sigue existiendo una acentuada percepción de crisis de desempleo respecto a la franja etaria que contempla adolescentes y jóvenes, sea bajo el aspecto cuantificativo sea bajo el prisma cualitativo (informalidad, remuneraciones y condiciones de trabajo precarias etc.).

La inserción más dificultosa en el mercado laboral formal también recrudece en un escenario de inestabilidad económica globalizada (que perdura ya hace algunos años y se agravó mucho por la pandemia), a la cual se incorporan con frecuencia la escasez de habilidades y un estigma de que la inexistencia de experiencia profesional previa en la adolescencia y/o en la juventud sería equivalente a la ausencia de responsabilidad y compromiso. 
Como camada adicional, surge la ecuación sobre cómo promover la mejor formación de habilidades y la inclusión de adolescentes y jóvenes cuanto a los denominados "puestos de trabajo del futuro", que requieren profesionales permeables a la evolución tecnológica incesante y exponencial, en un escenario de $4 .{ }^{a}$ Revolución Industrial, dada la sustitución de extenso número de empleos por la automatización y por la inteligencia artificial, con la generación, por otro lado, de amplias y nuevas oportunidades de formateo de empleos aún hoy no pensados.

Trazado este escenario y lanzando una mirada más vertical al recorte de temática objeto del estudio, ¿se puede validar la afirmación de que, respecto al trabajo infantil en la Amazonia, el panorama se acentúa solo bajo perspectiva de grises nubes, en interminables gradientes, de modo inevitable?

En otras palabras, en un cuadro desalentador y a despecho de las recurrentes y enigmáticas nubes grises, cabe examinar como contribuir para la potencialización de lluvia límpida, acogida y desahogo - metafóricamente representativos de empatía y compasión, sensibilidad al sufrimiento del otro y actuar comprometido -, en lo que atañe a niños y adolescentes expuestos a la infame explotación del trabajo infantil en la Amazonia brasileña.

¿Hay medidas efectivas en contrapunto a los desafíos de la aridez que permea corazones, aniquila esperanzas, "plutoniza"3 movilizaciones en lo que respecta al combate al trabajo infantil, sobre todo en la Amazonia, y a los efectos nocivos de ese mismo trabajo precoz incluso en la reproducción de relaciones de trabajo destituidas de dignidad en la vida adulta?

Las dificultades no pueden ser paralizadoras.

En el tópico siguiente, de modo propositivo y en un rol no taxativo, se expondrán mecanismos orientados a contribuir para la optimización de los ambientes de debate y del actuar concreto frente a la llaga del trabajo precoz en la Amazonia, considerando iniciativas que, más allá de lluvia aliviadora, intentan dar lugar al surgimiento de la esperanza de claridad, por medio de heramientas destinadas a multiplicar espacios duraderos de autonomía humana y entereza del ser, con el objetivo de deconstruir el ciclo de miserabilidad social y perfeccionar las capacidades/habilidades de los involucrados, con enfoque en relaciones de trabajo permeadas por dignidad, en la edad oportuna y de forma protegida. 


\section{BUENAS PRÁCTICAS ORIENTADAS A COMBATIR EL TRABAJO INFANTIL Y A ESTIMULAR LA PROFESIONALI- ZACIÓN DEL TRABAJADOR ADOLESCENTE, CON DES- DOBLAMIENTOS EN LA REGIÓN AMAZÓNICA}

Frente a los meandros que subyacen tanto al presente como al llamado futuro del trabajo, conformar la ola exponencial de estímulos y el grave panorama empírico que cada día nos instan a encarar, con sinceridad, las iris de millones de niños y adolescentes sometidos a la grave violación de derechos humanos consistente en el trabajo precoz ilegal en Brasil, en especial en la Amazonia Brasileña, exige la observancia del principio de la participación, por medio de conciencia y protagonismo constantes de la sociedad, de las instituciones, de los emprendimientos y de los gobiernos.

El referido intento pasa por el análisis del fenómeno del trabajo infantil y de la dinámica del aprendizaje profesional, además de la adecuación de este último instituto a las modificaciones ocasionadas por los nuevos modos de producción.

Respecto al aprendizaje profesional, cabe notar que el trabajo se ha presentado cada vez más cambiante (perfeccionamiento de competencias productivas y habilidades técnicas), razón por la cual es indispensable la integración de contenidos que desarrollan en pro del aprendiz la percepción como ser humano globalmente considerado (competencias socioemocionales y cognitivas, protagonismo, autonomía, fortalecimiento de la dimensión de la ciudadanía, también la incorporación de la dimensión profesional en el proyecto de vida)4, asegurando la búsqueda por aprendizaje profesional de mejor calidad, con programas benéficos tanto para aprendices como para empleadores.

El Ministerio Público del Trabajo, por medio de la Coordinación Nacional de Combate contra la Explotación del Trabajo de Niñas, Niños y del Adolescente (Coordinfância) - que, en este año de 2020, festeja dos décadas - y de la actuación local de los Fiscales del Trabajo, ha desarrollado medidas paradigmáticas destinadas a la implementación de políticas públicas protectoras de niños y adolescentes, bien como de estímulo a la profesionalización del trabajador adolescente. 
El MPT tiene destacado rol aun en el campo de sensibilización por medio del Programa "MP'T en la Escuela", planteando la temática del combate al trabajo infantil y del estímulo al aprendizaje, al que se une la consagrada premiación anual de mismo nombre, que alcanza a centenares de niños y adolescentes en el País, incluso con beneficios a los residentes en la Amazonia Brasileña.

Además, se pueden destacar los proyectos que implican aprendizaje profesional con foco en adolescentes y jóvenes que cumplen medidas socioeducativas y en situación de acogida institucional, en perspectiva que convierte en oportunidades el escenario inicial de ocio y desesperanza con relación al futuro, con prioridad al público más vulnerable.

A propósito, en la región amazónica, el Programa Se a Vida Ensina, Eu sou Aprendiz. (Si la Vida Enseña, Yo soy aprendia), que resulta de la actuación en conjunto entre el Ministerio Público del Estado de Rondônia, el MPT (PRT de la $14^{\text {a }}$ Región), el Tribunal de Justicia del Estado de Rondônia, entre otras instituciones, desde 2014.

El Programa atendió a más de 800 socioeducandos de Rondônia, en los dos últimos años, y, en 2019, fue premiado por el Consejo Nacional del Ministerio Público (CNMP), en 1er lugar, en la Categoría "Inducción de Políticas Públicas".

La Justicia del Trabajo igualmente ha aportado expresiva contribución al panorama en Brasil, tanto en su actuar jurisdiccional como bajo el sesgo de planificación estratégica y responsabilidad social, incluso ante el deber institucional de actuar en la implementación de políticas públicas afectas a la erradicación del trabajo infantil y a la protección del trabajo decente en la adolescencia y en la juventud.

En ese aspecto, desde 2012, las iniciativas que condujeron a la actuación de Comisiones y a la creación del Programa Nacional de Combate al Trabajo Infantil y de Estímulo al Aprendizaje, actualmente coordinado por la Ministra Kátia Magalhães Arruda, en el ámbito del Tribunal Superior del Trabajo (TST) y del Consejo Superior de la Justicia del Trabajo (CSJT).

Además, la Inspección General de la Justicia del Trabajo agregó importante contribución en el área, al editar la Recomendación n. 4/CGJT, del 18/11/2019, suscrita por el Ministro del TST Lelio Bentes Corrêa y entonces 
Contralor General. La Recomendación preceptúa que Jueces y Desembargadores del Trabajo deben garantizar "prioridad en el procesamiento y juzgamiento de los procesos individuales y colectivos, sujetos a su competencia, que impliquen los temas del aprendizaje profesional, del trabajo esclavo y del trabajo infantil, tanto en la fase de conocimiento como en el ámbito del cumplimiento de la decisión" (destaque nuestro).

Además de ello, aunque no sea obligatoria la contratación de aprendices en el ámbito de la Administración Pública directa de cualquiera de los Poderes de la Unión, el Tribunal Superior del Trabajo (TST) ha implementado medida central en la promoción de política pública efectiva en el área de la adolescencia, en 2013, adoptando una providencia histórica con la implementación del Programa Adolescente Aprendize en el TST.

En la región amazónica, en semejante sentido, se ha creado el Programa Adolescente Aprendiz en el TRT14, en agosto/2019, por iniciativa de la Comisión Regional de Combate contra el Trabajo Infantil y de Estímulo al Aprendizaje del Tribunal Regional del Trabajo de la 14 Región (AC y RO), con apoyo de la Presidencia del Regional, por medio de contrato con el Centro de Integración Empresa Escuela - CIEE.

El Programa busca promover la inserción calificada y protegida en el mercado de trabajo de adolescentes entre 14 y 18 años incompletos, franja etaria en la cual las oportunidades laborales son más escasas, estadísticamente hay más exposición al trabajo precoz ilegal y en que la permanencia en la escuela (requisito para ingreso en el programa) es decisiva para un futuro promisor. El programa contiene incluso vacantes reservadas al público en situación de mayor vulnerabilidad social y en cumplimiento de medidas socioeducativas.

En el ámbito del TRT 14, los adolescentes seleccionados y beneficiados por el Programa residen en sitios con múltiples realidades geográficas, en unidades de la Justicia del Trabajo situadas tanto en las capitales como en diversos municipios del interior de los estados de Acre y Rondônia, en los cuales hay Tribunales de Trabajo que hayan manifestado interés en participar del programa, propiciando oportunidades de aprendizaje profesional en locales alejados de la Amazonia, en los que no hay sede física del CIEE, con formación técnico-profesional metódica a través de la Educación a Distancia. 
Como se nota, respecto a la Administración Pública Directa de los diversos Poderes, apenas se muestra un hiato de regulación que podría ampliar las oportunidades de aprendizaje profesional en Brasil. En cuanto al Legislativo, en lo que toca a la promoción de empleo para la adolescencia y la juventud en la franja etaria adecuada, emerge sólida oportunidad para la consolidación de marco legal de obligatoriedad del aprendizaje profesional también en el ámbito de la Administración Pública Directa de los Poderes, tal cual se presencia hace ya algún tiempo en algunas ciudades en el territorio nacional, a fin de promover la respectiva expansión y refundación de ese aspecto del instituto.

Además de ello, también en la región amazónica, se ha implantado una iniciativa piloto por la Jurisdicción del Trabajo de Plácido de Castro, en Acre, ciudad ubicada en la frontera entre Brasil y Bolivia, en el primer semestre de 2019, consistente en el Curso de Formación y Multiplicadores para la Educación en el Mundo del Trabajo: Combate contra el Trabajo Infantil y Estímulo al Aprendizaje.

El curso está certificado por la Organización Internacional del Trabajo (OIT), por medio de la Coordinación del Programa de Principios y Derechos Fundamentales del Trabajo, y por el TRT 14, con el apoyo institucional de la Comisión Regional de Combate al Trabajo Infantil y de Estímulo al Aprendizaje.

La iniciativa ya tuvo dos ediciones, en mayo/junio y en noviembre/2019, teniendo como blanco: profesores de las redes públicas de enseñanza municipal y estadual, coordinadores pedagógicos, gestores escolares, gestores de las Secretarías Municipales y Estaduales de Educación, funcionarios y practicantes de la Justicia del Trabajo, Procuraduría Jurídica Municipal, agentes comunitarios de salud, integrantes del Centro de Referencia de la Asistencia Social (CRAS), miembros del Centro de Referencia Especializado de Asistencia Social (CREAS) y Consejeros Tutelares.

El curso se destina a integrantes de la red de protección y del Sistema de Garantía de Derechos del Niño y del Adolescente, considerados en sus interrelaciones, de modo a profundizar la práctica de trabajo conjunto y horizontal, diseminar conocimiento, organizar flujos, articular la red y mejorar protocolos de atención en la incidencia local, bajo el sesgo del mundo del trabajo. 
El Curso de Formación y Multiplicadores para la Educación en el Mundo del Trabajo: Combate al Trabajo Infantil y Estímulo a la Aprendizaje aporta contribución a las políticas públicas afectas al Combate a la Explotación del Trabajo Infantil, en estrecha e indisociable sintonía con el Estímulo al Aprendizaje, revelando densificación concreta del actuar del Judiciario Laboral en las acciones que se orientan para la materia, de todo compatibles con la Agenda 2030 para el Desarrollo Sostenible y la Meta 8.7 de los Objetivos de Desarrollo Sostenible (ODS), de la Organización de las Naciones Unidas (ONU).

Además, en 2019, también en Acre, la Justicia del Trabajo ha implementado las Olimpíadas de Derecho del Trabajo.

En iniciativa piloto desarrollada e implementada también por la Jurisdicción del Trabajo de Plácido de Castro - AC, la $1 \mathrm{r}^{\mathrm{a}}$ edición de las Olimpiadas de Derecho del Trabajo ocurrió del 29/11 al 18/12/2019, con el tema "Combate al Trabajo Infantil y Estímulo al Aprendizaje”, bajo el eslogan "iLa Justicia del Trabajo cerca de mí!”.

Las Olimpiadas de Derecho del Trabajo consisten en torneo de conocimientos sobre derechos y deberes en las relaciones de trabajo, considerando el tema de la edición, con contenido compatible con la Base Nacional Común Curricular - BNCC (Temas Contemporáneos Transversales en la BNCC: Educación en Derechos Humanos; Derechos del Niño y del Adolescente; Economía; Trabajo).

Las alumnas y los alumnos recibieron información sobre el tema previamente, por intermedio de sus profesores y del material pedagógico disponible, generando la diseminación y la fijación de conocimientos ante la comunidad estudiantil y la sociedad en general. Tanto los alumnos vencedores como los profesores multiplicadores fueron premiados con notebooks, trofeos y medallas de honor al mérito.

Más de dos centenas de alumnas y alumnos de la red pública de enseñanza municipal y estadual (5. a 9. ${ }^{\circ}$ año de la Enseñanza Básica) se inscribieron en la realización institucional operada por la Jurisdicción del Trabajo integrante del TRT 14. La iniciativa ha contado con apoyo institucional de la Organización Internacional del Trabajo (OIT) y de la Comisión Regional de Combate al Trabajo Infantil. 
Además, en las más diversas localidades de Brasil e igualmente en distintos espacios amazónicos, la Justicia del Trabajo ha reafirmado su compromiso visceral con el trabajo decente y la dignidad humana, en el campo del enfrentamiento al trabajo infantil y estímulo al aprendizaje, a través de las correspondientes Comisiones Regionales.

Representativas de ese fenómeno, las amplias y articuladas movilizaciones populares ocurridas en los estados de Pará y Amapá, bajo el liderazgo de la Comisión Regional del TRT de la 8. ${ }^{a}$ Región y con crecientes y sólidas colaboraciones.

Ilustran las diversas acciones desarrolladas en el TRT 8 tanto las realizadas durante la Campaña contra el Trabajo Infantil en el Cirio de Nazaré (una de las más grandes fiestas religiosas brasileñas), hace muchos años, como en el decurso de las Marchas de Belém Contra el Trabajo Infantil. Miles y miles de personas han adherido a las iniciativas, en una cadena virtuosa ascendente, siendo el tema ampliamente debatido y repercutido por la sociedad (REDE PETECA, 2020).

En el estado de Amazonas, el proyecto "Gente Grande" se destaca como una iniciativa más digna de nota. Actúa en la prevención del trabajo infantil y en la elisión de la mendicidad, retirando niños, adolescentes y jóvenes de la calle y de trabajos informales, además de promover la capacitación de los que ya tienen edad adecuada para ingresar en el mercado laboral. La iniciativa está desarrollada por la Asociación Benéfica O Pequeno Nazareno (OPN), con apoyo del Ministerio Público del Trabajo, de la Justicia del Trabajo (TRT de la 11. Región, Amazonas y Roraima) y de otros órganos.

Asimismo, en la Amazonia y Brasil afuera, la actuación del Judiciario laboral ocurre también en programas de sensibilización en ponencias en los programas Justicia del Trabajo va a la Escuela, Justicia del Trabajo de Puertas Abiertas y Justicia del Trabajo Va a la Empresa; o por medio de la Asociación Nacional de los Magistrados de la Justicia del Trabajo (ANAMATRA), en el sólido programa Trabajo, Justicia y Ciudadanía.

Todas las medidas revelan una alineación proactiva y estratégica de entes públicos y de la sociedad con compromisos transversales mundiales y nacionales de protección al niño, al adolescente y al joven. 
A su vez, como contribución para la solución de panoramas desastrosos que comprometen la dignidad humana, incluso en el área de enfrentamiento al trabajo infantil, con repercusiones en la Amazonia Brasileña, la Organización de las Naciones Unidas (ONU) ha protagonizado medidas específicas orientadas a maximizar la implementación de los derechos consagrados en la Declaración Universal de los Derechos Humanos de 1948.

A propósito, la Agenda 2030 para el Desarrollo Sostenible, adoptada en la ONU, a través de la cual los países se comprometieron a cumplir 17 Objetivos de Desarrollo Sostenible (ODS) y 169 Metas para transformar el mundo hasta el año 2030. Se trata de un plan de acción para las personas, para el planeta y para la prosperidad, bajo el eslogan: "no dejar a nadie para atrás".

Respecto a las relaciones de trabajo, se destaca el Objetivo 8: "Promover el crecimiento económico sustentado, inclusivo y sostenible, empleo pleno y productivo y trabajo decente para todas y todos."

La meta 8.6 de los Objetivos de Desarrollo Sostenible de la ONU dispone respecto a la juventud: "hasta 2020, reducir sustancialmente la proporción de jóvenes sin empleo, educación o formación". La meta 8.7 de los Objetivos de Desarrollo Sostenible prevé la adopción de medidas inmediatas y eficaces para asegurar la prohibición y eliminación de las peores formas de trabajo infantil, y acabar con el trabajo infantil en todas sus formas hasta 2025, espacio en que el aprendizaje profesional se presenta como importante vector.

En lo que atañe a la prevención del trabajo precoz, merece ser señalado el rol de la Organización Internacional del Trabajo (OIT), mediante campañas, publicaciones y asistencia técnica, en especial a través del Programa Internacional para la Erradicación del Trabajo Infantil (IPEC - International Programme on the Elimination of (bild Labour), cuyas acciones se robustecieron en 2019, año en el que se celebró el Centenario de la OIT.

Asimismo, por medio de la iniciativa Empleos Decentes para la Juventud, incluso en el área rural, la OIT y la UNESCO han compilado iniciativas y colaboradores orientados a fortalecer los llamados programas de aprendizaje de calidad, que tratan de ser benéficos mutuamente para empresas y jóvenes (OIT, UNESCO, 2019). 
Además, en 2015, UNICEF firmó un pacto con los nueve gobernadores de los estados que componen la Amazonia Legal Brasileña en relación a la Agenda Criança Amazônia, con objetivo de la promoción, la protección y la garantía de derechos en favor de niños y adolescentes que viven en la región, por medio de la articulación de políticas de asistencia social, salud y educación en las esferas de gobierno municipales, estaduales y federal. Para impulsar la Agenda, se utilizan los instrumentos estratégicos relativos al Sello UNICEF y a la Plataforma de los Centros Urbanos (PCU) (UNICEF, 2019).

Otra vía contribuidora consiste en el sistema de certificación (sello) social de emprendimientos, como el Sello Empresa Amiga da Criança, concedido por la Fundación Abrinq a las empresas que: 1. no se aprovechan de mano de obra infantil; 2. incentivan la profesionalización de adolescentes y jóvenes y el ingreso en el mercado de trabajo de modo protegido, respetando la Ley del Aprendizaje; 3. contribuyen a perfeccionar las condiciones de vida de niños y adolescentes en territorio nacional.

Los sellos sociales consisten en mecanismo adicional de acceso a la información por la ciudadanía, siendo necesario igualmente por otras instituciones el fortalecimiento del sistema de atribución de sellos, de modo enfático, tanto a los emprendimientos que no se benefician de trabajo precoz ilegal y cumplen las cuotas de aprendizaje profesional, como los que (aunque no obligados legalmente), incorporan el instituto del aprendizaje voluntariamente a su complexión.

La medida se revela estratégica y conforme con la visión del emprendedor contemporáneo, sobrepasando el aspecto de la responsabilidad social corporativa y de un marco de conducta empresarial adecuada a las normas, responsable y preventiva (compliance).

Rigurosamente, la incorporación sólida de un programa de aprendizaje profesional impacta el mismo marketing positivo y en el incremento competitivo que se agregará a los emprendimientos, sobre todo los que insertan el aprendizaje profesional en su realidad y modelo de negocio a pesar de no estar sujetos al cumplimiento de cuotas de aprendizaje.

También se correlaciona la materia al fortalecimiento del sistema de due diligence (o diligencia debida) por parte de los emprendimientos, incluso respecto a la administración de riesgos y toma de decisión, así como de 
transparencia en la conducta empresarial, en cuanto a la prevención de consecuencias graves en sus operaciones, en el medio ambiente del trabajo y en lo que toca a los derechos humanos en virtud de la explotación de poblaciones vulnerables en la respectiva cadena productiva (lo que suele ocurrir en la región amazónica, incluso en perjuicio de ribereños e indígenas, niños y adolescentes, en la producción de castaña, cacao, algodón etc.), englobando tanto el combate al trabajo infantil como la formalización adecuada de vínculos de aprendizaje profesional en situaciones en las cuales la medida sería pertinente.

En ese aspecto, tanto los Principios Orientadores sobre Empresas y Derechos Humanos (POs), 2011, de la ONU, entre los cuales se destaca el de n. 15, como, igualmente, la Declaración Tripartita de Principios sobre Empresas Multinacionales y Política Social, adoptada por la OIT en 1977 y alterada, recientemente, en marzo de 2017.

Los referidos instrumentos constituyen directrices muy interesantes no solo para el sector privado acerca de la materia, sino también dirigidas a los Gobiernos, con el fin de estimular el diálogo social y el buen comportamiento corporativo.

Véase que, en un contexto de economía globalizada, todos los partícipes que interactúan y se benefician de las cadenas productivas globales (CPG) (incluso como propietarios de empresas, proveedores de crédito y de préstamos y compradores de bienes y servicios) tienen el deber y la responsabilidad de tratar de los efectos y actuar para que sean solucionados los déficits de trabajo decente verificados en el itinerario respectivo, de modo cotidiano, sobre todo en lo que respecta a la explotación de mano de obra infantil (bien como de trabajo forzado y trata de personas), abarcados los eslabones más bajos de las cadenas y los segmentos tercerizados que se activan en el mercado informal.

De este modo, se aseguran cadenas productivas económica y socialmente responsables, de modo a propiciar condiciones de trabajo decente a todas y todos y Justicia Social, de modo congruente con el ODS n. 8, por medio de acciones coordinadas de segmentos privados y públicos, incluso reduciendo la competencia desleal y envilecimiento de la dignidad humana.

A la par, es necesario el fortalecimiento de políticas públicas y programas multidimensionales que alcancen la infancia, la adolescencia y la ju- 
ventud de modo general y actúen en el combate a la miseria, concediendo oportunidad educacional y empleo en la edad correcta, y deben concretizarse por el Poder Ejecutivo en ámbito federal, estadual y municipal (principio de la descentralización), con carácter no asistencialista, y que sí sea promotor del incremento de potencialidades.

El enfoque debe ser dirigido a la rehabilitación, inserción social y educación integral dinámica con calidad, englobando el concepto complementar de jornada ampliada, que no se limite solamente a la instrucción formal escolar, además de enfoque profesionalizante para los adolescentes, bajo el manto del aprendizaje; todo ello aliado a mecanismos jurídicos y sociales para que se cumplan los derechos ya establecidos, incluso la revitalización del 3er Plan Nacional de Prevención y Erradicación del Trabajo Infantil, porque la infancia y la adolescencia son fundamentalmente los periodos de vida que deberían ser dirigidos al perfeccionamiento físico y mental.

Del mismo modo, conforme destacado en una publicación reciente conjunta de la OIT y del UNICEF, denominada COVID-19 and Child Labour: A Time Of Crisis, $A$ Time to Act (COVID-19 y Trabajo Infantil: un Tiempo de Crisis, un Tiempo para Actuar), con el fin de contribuir para la reducción de los riesgos de incremento del trabajo infantil, acorde con políticas públicas intersectoriales y del conjunto de medidas urgentes, es ineludible garantizar el retorno de niños y adolescentes a la escuela en el contexto pospandemia (incluso con busca activa escolar), propiciar formación técnico-profesional en la edad adecuada, bien como concentrar esfuerzos para "expansión de la protección social, facilitación de crédito para familias en situación de pobreza, promoción de trabajo decente para adultos [...] y ampliación de la fiscalización de la aplicación de leyes dirigidas al enfrentamiento del trabajo infantil en cada país" (OIT y UNICEF, 2020; ONU, 2020b).

Ante los datos pretéritos anteriormente señalados en este estudio, las medidas son extremadamente urgentes en cuanto al prisma ya fragilizado de los más vulnerables de la Amazonia. 


\section{HORIZONTES PARA LA INFANCIA Y LA ADOLESCEN- CIA Y DIGNIDAD HUMANA EN EL MUNDO DEL TRABAJO}

Al estar de acuerdo con Agatón, en Ética a Nicómaco, libro VI, Sección 2, Aristóteles (1991, p. 125) señaló que el pasado es inmutable. Concluyó el filósofo, sin embargo, que cabe a nosotros moldear el futuro, lo que puede hacerse basando nuestras elecciones en la razón:

Por lo tanto, la elección o bien es raciocinio desiderativo o deseo raciocinativo, y el origen de una acción de esa especie es un hombre. Debe observarse que nada de lo pasado es objeto de elección; por ejemplo, nadie elige haber saqueado Troya, porque nadie delibera respecto del pasado, sino solamente respecto de lo que está para suceder y puede ser de otra forma, mientras lo que es pasado no puede dejar de haber ocurrido.

En una perspectiva más optimista, y ante todas las lecciones colocadas por el complejo período aún en vigor impuesto por la emergencia pandémica, referido catalizador mundial tiene el poder de, bajo los prismas de racionalidad y de supervivencia evolutiva, hacer aflorar un proyecto vital primoroso, apoyado en más fraternidad, solidaridad colectiva y equidad social y ecológica, con perfeccionamiento humano integral y sostenible también en las relaciones de trabajo.

En se sentido, las buenas prácticas que se vienen realizando a partir del interior de la región amazónica brasileña en el combate al trabajo infantil y en el estímulo al aprendizaje profesional, de modo aliado a las experiencias enriquecedoras efectivadas en otros espacios, pueden dar buenas señales para ampliación de frentes y replicación en múltiples realidades nacionales y mundiales, sin perjuicio de los vectores adicionales para superación de los desafíos en esa misma área a la que ya se hizo detallada referencia en los tópicos anteriores.

A propósito, la replicación de buenas iniciativas en otros locus puede presentar la virtud de maximizar el recrudecimiento de trabajo decente. Respecto a ese punto, conforme a lo que subraya Sen (2000, p. 288), “es necesario atribuir particular importancia al papel de la discusión y de las interacciones públicas en la emergencia de valores y compromisos comunes".

De otra forma, tampoco se descarta el posible escenario de avance de proyecto letal, con intensificación de las desigualdades, por medio de ultraliberalismo de sacrificio o de catástrofe, en un sistema y en unas relaciones que 
dan prioridad a la economía sobre la vida, variando las densidades en que se encajan cada uno de esos componentes, de modo atento aún a los conceptos de "Doctrina del Choque" y "Capitalismo de Desastre" explicitados por Klein (2008, p. 15-16).

En ese punto, parece factible constatar que, si no se adoptan medidas consistentes, se agravarán cuestiones severas que ya involucraban a la infancia y a la adolescencia en el mundo del trabajo.

Observándose los aspectos críticos de civilización por que pasamos ante la pandemia mundial y las posibilidades de enfrentamiento, señala Satyarthi (2020), laureado con el Premio Nobel de la Paz en 2014 (al lado de Malala Yousafzai) y activista indiano reconocido por la lucha mundial en favor de los derechos de los niños qué "desafíos e incertidumbres también pavimentan el camino para soluciones innovadoras. El escenario actual no es diferente [...] Es por eso que defiendo fuertemente la globalización de la compasión”.

Ya Francisco (2020), en pronunciamiento en el 10 de junio, en las inmediaciones del Día Mundial y Nacional de Combate Contra el Trabajo Infantil, aludió que "los niños son el futuro de la familia bumana: todos tenemos la tarea de promover su crecimiento, salud y serenidad" (destaque nuestro).

Establece la Constitución Federal, en su art. $1^{\circ}$, inciso III, que la dignidad de la persona humana constituye fundamento de la República Federativa de Brasil, sobresaliendo su calidad de eje axiológico-normativo y pilar fundante del Estado Democrático de Derecho, y aún de muchos otros dispositivos constitucionales, a ejemplo del art. 170, caput, de la CF.

Esa idea de imposibilidad de violación de la dignidad, al impedir que la persona (sobre todo niño o adolescente) sea utilizada como instrumento de la voluntad ajena de forma deletérea a su propia condición humana, incide especialmente en el campo de las relaciones de labor, ya que el ser humano no puede ser tratado como cosa y el trabajo no es mercancía5.

La relevancia del primado del trabajo es, por lo tanto, evidente, lo que no se limita al ámbito meramente individual, resbalando hacia la esfera de interés del orden público, ante el estuario ya mencionado. Pero no se trata de cualquier trabajo. Trabajo digno, decente, saludable, en la edad adecuada, pleno, vivaz. 
Bajo el aspecto constitucional, el derecho fundamental al trabajo digno se revela como categoría central (DELGADO, 2006, p. 241-242), siendo impostergables las herramientas institucionales que lo promuevan, para viabilizar la solidificación de la democracia en la actualidad.

Para la OIT, trabajo decente puede ser concebido como un trabajo productivo y adecuadamente remunerado, ejercido en condiciones de libertad, equidad y seguridad, en que se respeten los derechos fundamentales y que garanticen una vida digna a todas las personas que viven del trabajo y a sus familias, y así también la protección social cuando no pueda ejercerse (desempleo, enfermedad, accidentes, entre otros), permitiendo satisfacer las necesidades personales y familiares de alimentación, educación, vivienda, salud y seguridad, englobando aún el derecho a la representación y a la participación en el diálogo social (CEPAL/ PNUD/OIT, 2008, p. 7).

Un ideario compatible está albergado en el art. XXIII de la Declaración Universal de Derechos Humanos.

A partir de una perspectiva que considera originariamente la noción de trabajo vivo, Ferreira, Martines y Oliveira Vieira (2016, p. 31, 32 y 41) aclaran: "[...] el trabajo vivo se rinde al trabajo muerto, extraño al trabajador, contenido en las mercancías, cuyo principal objetivo es la creación de plusvalía, la valoración del valor, la reproducción y autovaloración del capital."

La relectura de las referidas orientaciones posibilita extraer la noción de trabajo vivar:

Trabajo vivaz así considerado como la labor con sentido y propósito, que contribuye para el perfeccionamiento de la subjetividad y plenitud del ser, a la vez que transforma alrededor, contribuye a la dignidad humana y produce valor económico y empleo sostenible de recursos naturales.

En este punto, sobresale con exponencial importancia el combate al trabajo infantil.

No se olvide que el empleo sostenible de los recursos naturales (ampliamente denominado desarrollo sostenible), como concepto sistémico, abarca el inseparable aspecto de la promoción del trabajo decente y de las relaciones humanas, sin ser posible alcanzarse la Justicia Social en un escenario de existencia de trabajo infantil, una condición de explotación que reproduce 
ciclos intergeneracionales de extremada vulnerabilidad social, y que se agrava por la baja incidencia concreta del aprendizaje profesional.

Cabe decir que diversos estudios pos desarrollistas de los últimos años, en contrapunto con la idea de desarrollo (aunque denominado como sostenible), han hecho referencia a la teoría del "decrecimiento", a ejemplo de los aportes de Serge Latouche, bien como a la concepción relativa a Buen Vivir, tal como aluden Leonardo Boff y Alberto Acosta (éste de modo interrelacionado con la idea de sumak kawsay, expresión de origen quechua).

Para Latouche, por ser obviamente finitos los recursos del planeta, no es viable haber crecimiento/desarrollo infinito. Luego, es indispensable la solidificación de una sociedad que produzca en menor cantidad y consuma menos, de modo atento a la equidad social y ecológica.

En la apertura del Sínodo de los Obispos para la Región Panamazónica o Sínodo para la Amazonia, ocurrido del 6 al 27 de octubre de 2019, en el Vaticano, se registró que "el grito de la Amazonia surgió de la oscuridad de la selva para alcanzar la luz del mundo. el grito de los marginados, presos en las cuerdas de una vida precaria, bajo constante amenaza de depredadores sin respeto por sus derechos y por la Creación" (SÍNODO DE LOS OBISPOS PARA LA REGIÓN PANAMAZÔNICA, 2019b).

En el Documento Final del Sínodo, titulado "Amazonia: nuevos caminos para la Iglesia y para una Ecología Integral", recibieron enfoque, entre otros puntos, "la voz y el canto de la Amazonia como mensaje de vida", además del "clamor de la tierra y el grito de los pobres", considerados incluso, en la perspectiva de la Casa Común, los rostros de los pueblos amazónicos bajo el sesgo indígena, campesino, afrodescendiente, migrante y joven, preservando los respectivos valores culturales y los derechos de los pueblos, hacia una ecología integral a partir de la Encíclica Laudato Sí, Sobre el cuidado de la casa común (2015), del Papa Francisco (SÍNODO DE LOS OBISPOS PARA LA REGIÓN PANAMAZÔNICA, 2019a).

A su vez, en la Exhortación Apostólica Postsinodal "Querida Amazônia", el Papa Francisco (2020) plantea directamente los conceptos de "Bien Vivir" y "Justicia", tratando aún de la población joven, y aludiendo al concepto de Ecología Social. 
Independientemente de la orientación doctrinaria a adoptarse (sea la de desarrollo sostenible o de las teorías pos desarrollistas), es inexorable repensar los modos de acumulación y de devastación social y ecológica provocados por el ultraliberalismo, de modo que permita llenar los huecos de protección social, con horizontes ampliados de dignidad para la infancia y para la adolescencia, incluso bajo la perspectiva del mundo del trabajo.

\section{CONSIDERACIONES FINALES}

Cada niño importa. Cada adolescente importa.

La transformación de la vida y de la realidad de una persona desde luego ya basta.

En medio del claroscuro que ha implicado el combate al trabajo infantil (y el correlato estímulo al aprendizaje profesional/profesionalización del trabajador adolescente), la revisión de los modos de aplicar y de estimular los variados aspectos anteriormente considerados puede promover un fulgor renovado a la materia, sea en el espacio amazónico, sea en ámbito nacional e internacional.

Un procedimiento diverso corrobora la ironía asertiva de Saramago (2006, p. 39-40), en su obra El Hombre Duplicado, para el cual "el mejor camino para una desculpabilización universal es llegar a la conclusión de que, porque toda la gente tiene culpa, nadie es culpable" (destaque nuestro).

Que las nubes grises que juegan a traer lluvia a la Amazonia descubran en el firmamento un sol radiante cuyos rayos luminosos de Justicia Social, en un ambiente de Estado Democrático de Derecho, calienten acciones concretas orientadas hacia la entereza, a la equidad, a la plenitud y a la dignidad del ser humano, con incidencia no solo para todos nuestros niños y niñas, sino también para niñas y niños de todas y todos.

\section{NO'TAS}

1 NT: "Florece en el lugar en el que estás sembrado".

2 A pesar del disenso resultante de la alteración por el IBGE de la metodología de la PNAD, en 2016, se sigue considerando igualmente, por amplia gama de investigadores y demás instituciones, de modo mayoritario, para fines de erradicación del trabajo infantil, la suma de la cantidad de niños y adolescentes trabajadores de 5 a 17 años, 
que se refiere también a las "actividades en la producción para consumo propio o en la construcción para uso propio".

3 El neologismo "plutonizar" viene siendo adoptado para indicar la circunstancia de rebajar el nivel o desvalorizar algo o a alguien, en clara referencia a Plutón, ex Planeta del sistema solar, que pasó a ser considerado planeta enano. (dwarf planet).

4 El texto de presentación del interesante Programa Estadual "Aprendiz na Escola", desarrollado por el Gobierno del estado de Ceará (Secretaria de Estado de Educación) y por el Instituto Aliança, menciona de modo expreso las referidas habilidades y competencias.

5 Directriz consonante insertada en el Anexo de la Constitución de la OIT (Declaración de Filadelfia de 1944), cuya pertinencia aún permanece hoy día, en el sentido de que la política de los Miembros de la OIT debe estar inspirada, entre otros, por los principios de que "el trabajo no es una mercancía" (I, apartado "a") y "la penuria, sea dónde sea, constituye un peligro para la prosperidad general" (I, apartado "c").

\section{REFERENCIAS}

ACOSTA, Alberto. O Bem Viver: uma oportunidade para imaginar outros mundos. Tradução Tadeu Breda. São Paulo: Elefante, 2016.

ACOSTA, Albert. O Buen Vivir: uma oportunidade de imaginar outro mundo. In: SOUSA, C. M., (org). Um convite à utopia. Campina Grande: EDUEPB, 2016, v. 1, p. 203-233. Disponible en: http://books.scielo.org/id/ kcdz2/epub/sousa-9788578794880.epub. Acceso en: 5 de ene. 2020.

ANTUNES, Ricardo. Os sentidos do trabalho: ensaio sobre a afirmação e a negação do trabalho. São Paulo: Boitempo, 2006.

ARISTÓTELES. Ética a Nicomâco; Poética: seleção de textos de José Américo Motta Pessanha. 4. ${ }^{a}$ ed. São Paulo: Nova Cultural, 1991.

ARRUDA, Kátia Magalhães. O trabalho infantil doméstico: rompendo com o conto de Cinderela. In: Revista do Tribunal Regional do Trabalho da 3a Região, Belo Horizonte, v. 45, n.75, p. 199-206, jan./jun.2007.

BOFF, Leonardo. Sustentatibilidade: o que é - o que não é. Petrópolis: Vozes, 2012.

DELGADO, Gabriela Neves. Direito fundamental ao trabalho digno. São Paulo: LTr, 2006.

DELGADO, Maurício Godinho; DELGADO, Gabriela Neves. A reforma trabalhista no Brasil com comentários à Lei n. ${ }^{0}$ 13.467/2017. São Paulo: LTr, 2017, p. 39-40. 
FERREIRA, João Batista; MARTINS, Soraya Rodrigues; VIEIRA, Fernando de Oliveira. Trabalho vivo como apropriação do inapropriável e criação de formas de vida. In: Revista Trabalho (En)Cena, Palmas, v. 1, n. 1, jan./jun. 2016. Disponible en: file:///C:/Users/Administrador/Downloads/Trabalhovivocomoapropriacaodoinapropriavelecriacaodeformasdevida.pdf. Acceso en: 29 de sept. de 2019.

FONSECA, Ricardo Tadeu Marques. O direito à profissionalização, corolário da proteção integral das crianças e adolescentes. [S.1]. Disponible en: http://www.latec.com.br/consia/artigos/P01a.html. Acceso en: 9 de jun. de 2009.

FNPETI. Mais de 46 mil crianças e adolescentes sofreram acidentes de trabalho e agravos à saúde nos últimos 12 anos no país. [S.l]. Disponible en: https://fnpeti.org.br/noticias/2020/04/28/mais-de-46-mil-criancas-eadolescentes-sofreram-acidentes-de-trabalho-e-agravos-saude-nos-ultimos12-anos-no-pais/. Acceso en: 2 mayo 2020a.

FNPETI. Trabalho Infantil na Agropecuária Brasileira: uma leitura a partir do Censo Agropecuário de 2017. Brasília: 2020, p. 20. Disponible en: https://fnpeti.org.br/media/publicacoes/arquivo/publicacao_ti_agro.pdf. Acceso en: 31 mayo 2020b.

FRANCISCO. Carta Encíclica Laudato Sí. Tradução livre. Vaticano: 2015. Disponible en: http://www.vatican.va/content/francesco/pt/encyclicals/ documents/papa-francesco_20150524_enciclica-laudato-si.html\#49. Acceso en: 11 feb. 2017.

FRANCISCO. Exortação Apostólica Pós-Sinodal: Querida Amazônia. Tradução livre. Vaticano: 2020. Disponible en: www.vatican.va/content/ francesco/pt/apost_exhortations/documents/papa-francesco_esortazione-ap_20200202_querida-amazonia.html. Acceso en: 21 mar. 2020.

HERRERA FLORES, Joaquín. La reinvención de los derechos humanos. Sevilla: Atrapasueños, 2008.

INSTITUTO BRASILEIRO DE GEOGRAFIA E ESTATÍSTICA - IBGE. Pesquisa Nacional por Amostra de Domicílios: Síntese dos Indicadores Sociais 2015. [S.1]. Disponible en: https://biblioteca.ibge.gov.br/visualizacao/livros/liv98887.pdf. Acceso en: 15 de mar. de 2018. 
INSTITUTO BRASILEIRO DE GEOGRAFIA E ESTATÍSTICA - IBGE. Pesquisa Nacional por Amostra de Domicílios Contínua: 2016. [S.l]. Disponible en: https://biblioteca.ibge.gov.br/visualizacao/livros/liv101388_informativo.pdf. Acceso en: 15 de mar. de 2018.

INSTITUTO BRASILEIRO DE GEOGRAFIA E ESTATÍSTICA - IBGE. Indicadores IBGE: Pesquisa Nacional por Amostra de Domicílios Contínua Terceiro Trimestre de 2019 JUL.-SET. 2019. [S.l], 19 nov. 2019. Disponible en: https://biblioteca.ibge.gov.br/visualizacao/periodicos/2421/pnact_2019_3tri.pdf. Acceso en: 25 de nov. de 2019.

KLEIN, Naomi. A Doutrina do Choque: A ascensão do Capitalismo de Desastre. Rio de Janeiro: Nova Fronteira, 2008.

LATOUCHE, Serge. As vantagens do decrescimento. In: Le Monde Diplomatique Brasil, [S.1], 1. ${ }^{\circ}$ nov. 2003. Disponible en: https:/ / diplomatique.org. br/as-vantagens-do-decrescimento/. Acceso en: 7 dic. 2019.

LATOUCHE, Serge. Pequeno tratado do decrescimento sereno. São Paulo: Martins Fontes, 2009.

LATOUCHE, Serge. La sociedad de la abundancia frugal: contrasentidos y controversias del decrecimiento. Barcelona: Icaria editorial, 2012.

OIT; CEPAL. Nota Técnica n. $^{\circ}$ 1: La pandemia por COVID-19 podría incrementar el trabajo infantil en América Latina y el Caribe. [S.1]. Disponible en: https://www.ilo.org/wcmsp5/groups/public/---americas/---ro-lima/ documents/publication/wcms_747653.pdf. Acceso en: 14 jun. 2020.

OIT; OCDE; OIM; UNICEF. Erradicar el trabajo infantil, el trabajo forzoso y la trata de personas en las cadenas mundiales de suministro. Genebra: OIT, 2019. Disponible en: https://www.ilo.org/ipec/Informationresources/WCMS_716932/lang--es/index.htm. Acceso en: 16 de nov. de 2019.

OIT; UNICEF. Relatório conjunto "COVID-19 and Child Labour: A Time Of Crisis, A Time to Act”, [S.1], 2020. Disponible en: https://data. unicef.org/resources/covid-19-and-child-labour-a-time-of-crisis-a-time-toact/. Acceso en: 14 jun. 2020.

OLIVA, José Roberto Dantas. O princípio da proteção integral e o trabalho da criança e do adolescente no Brasil. São Paulo: LTr, 2006. 
OLIVEIRA, Christiana D'arc Damasceno. (O) Direito do Trabalho contemporâneo: efetividade dos direitos fundamentais e dignidade da pessoa humana no mundo do trabalho. São Paulo: LTr, 2010.

ORGANIZAÇÃO DAS NAÇÕES UNIDAS. Crise pode lançar até 326 mil crianças ao trabalho infantil na América Latina e Caribe. [S.1]. Disponible en: https://nacoesunidas.org/crise-pode-lancar-ate-326-mil-criancas-ao-trabalho-infantil-na-america-latina-e-caribe/. Acceso en: 14 jun. 2020a.

ORGANIZAÇÃO DAS NAÇÕES UNIDAS. Policy Brief: The Impact of COVID-19 on children. [S.l], 15 abr. 2020, p. 2. Disponible en: https:// www.un.org/sites/un2.un.org/files/policy_brief_on_covid_impact_on_ children_16_april_2020.pdf. Acceso en: 18 abr. 2020b.

ORGANIZAÇÃO INTERNACIONAL DO TRABALHO. Estimaciones mundiales sobre el trabajo infantil: Resultados y tendencias 2012-2016. Genebra: OIT, 2017. Disponible en: www.ilo.org/wcmsp5/groups/public/--dgreports/---dcomm/documents/publication/wcms_651815.pdf. Acceso en: $1{ }^{\circ}$ mar. 2018.

ORGANIZAÇÃO INTERNACIONAL DO TRABALHO. Social Protection Spotlight: Social protection responses to the COVID-19 pandemic in developing countries: Strengthening resilience by building universal social protection. [S.1], 2020. Disponible en: https://www.ilo.org/wcmsp5/groups / public/---ed_protect/---soc_sec/documents/publication/wcms_744612. pdf. Acceso en: 17 mayo 2020.

REDE PETECA. II Marcha de Belém contra o trabalho infantil reúne mais de 200 mil pessoas. [S.l]. Disponible en: https://www.chegadetrabalhoinfantil.org.br/noticias/materias/marcha-de- belem-contra-o-trabalho-infantil-reune-mais-de-200-mil-pessoas/. Acceso en: 30 mar. 2020.

SAGGESE, Federico. El derecho a um nível de vida adequado: discurso jurídico y dimensión judicial. Perspectivas desde el Derecho Constitucional y Administrativo. La Plata: Libreria Editora Platense, 2009.

SARAMAGO, José. O homem duplicado. 5. reimp. São Paulo: Companhia das Letras, 2006. 
SARLET, Ingo Wolfgang. Dignidade da pessoa humana e direitos fundamentais na Constituição de 1988. 6. ed. rev. e atual. Porto Alegre: Livraria do Advogado, 2008.

SATYARTHI, Kailash. Redefinindo a civilização no mundo pós-Covid-19. [S.1]. Disponible en: https://fnpeti.org.br/artigos/redefinindo-civilizacao-no-mundo-pos-covid-19/. Acceso en: 21 jun. 2020.

SEN, Amartya Kumar. Desenvolvimento como liberdade. Tradução de Laura Teixeira Motta. São Paulo: Companhia das Letras, 2000.

SÍNODO DOS BISPOS PARA A REGIÃO PANAMAZÔNICA. Documento final - Amazônia: novos caminhos para a Igreja e para uma Ecologia Integral. Tradução livre. Vaticano: 2019. Disponible en: http://www. vatican.va/roman_curia/synod/documents/rc_synod_doc_20191026_sinodo-amazzonia_po.html. Acceso en: 21 mar. 2020a.

SÍNODO DOS BISPOS PARA A REGIÃO PANAMAZÔNICA. Instrumentum laboris. Tradução livre. Vaticano: 2019. Disponible en: http:// www.synod.va/content/sinodoamazonico/pt/documentos/instrumentum-laboris-do-sinodo-amazonico.html. Acceso en: 21 mar. 2020b.

TRIBUNAL REGIONAL DO TRABALHO DA $14^{a}$ REGIÃO. Justiça do Trabalho brasileira lança Olimpíadas de Direito do Trabalho. Disponible en: https://portal.trt14.jus.br/portal/noticias/justica-do-trabalho-brasileira-lanca-olimpiadas-de-direito-do-trabalho. Acceso en: 2 de dic. de 2019.

UNICEF. Bem-Estar e Privações Múltiplas na Infância e na Adolescência no Brasil. [S.1], 2019. Disponible en: https://nacoesunidas.org/ unicef-aponta-principais-desafios-para-criancas-e-adolescentes-que-vivem-na-amazonia/. Acceso en: 14 sept. 2019.

VATICAN NEWS. O Papa: trabalho infantil, fenômeno que priva meninos e meninas de sua infância. [S.1]. Disponible en: https://www.vaticannews.va/ pt/papa/news/2020-06/papa-francisco-audiencia-geral-apelo-contra-trabalho-infantil.html. Acceso en: 14 jun. 2020.

VIEIRA, Oscar Vilhena. Direitos fundamentais: uma leitura da jurisprudência do STF. São Paulo: Malheiros, 2006. 



\section{EL PAPEL DE LA PROTECCIÓN SOCIAL EN EL FOMENTO DE LA ERRADICACIÓN DEL TRABAJO INFANTIL'}

\section{DENISE RATMANN ARRUDA COLIN}

DOI: $10.51366 / 978-65-89468-10-3$-coordinfancia-5

Resumen. El presente artículo tiene por objeto elucidar el papel desempeñado por la política de asistencia social, como integrante del sistema de seguridad social, en la perspectiva de garantizar protección social no contributiva a los niños y a los adolescentes en situación de trabajo infantil y sus familias, y de fomentar la estructuración de una red intersectorial e interinstitucional para erradicación de esa práctica en Brasil. Está subdividido en el abordaje de tres enfoques: la protección social ofrecida por el Sistema Único de Asistencia Social - SUAS - frente a la temática; la constitución y el proceso de reordenación del Programa de erradicación del Trabajo Infantil - PETI, como estrategia nacional para intervención integrada e intersectorial, caracterizándolo como una política pública de Estado y; los principales desafíos y el elenco de posibilidades vislumbradas delante del escenario actual de desmantelamiento de derechos sociales y del sistema de protección social, notablemente del SUAS.

Palabras clave: Protección Social. Sistema Único de Asistencia Social. Programa de Erradicación del Trabajo Infantil. 


\section{LA CONTRIBUCIÓN DE LA PROTECCIÓN SOCIAL DEL SISTEMA ÚNICO DE ASISTENCIA SOCIAL (SUAS) EN EL PROCESO DE REDUCCIÓN DEL TRABAJO INFANTIL}

\subsection{Contextualización del sistema de protección social brasileño y de la política de asistencia social después de la Constitución Federal de 1988}

El sistema de protección social brasileño puede ser comprendido como el conjunto de iniciativas públicas, ofertadas directamente o reguladas por el Estado, para viabilizar la provisión de bienes, servicios y beneficios sociales, con el objetivo de promover la cobertura de riesgos o privaciones sociales, igualar las oportunidades y garantizar el acceso y usufructo de los derechos sociales (JACCOUD, 2009).

Su característica principal trae la marca indeleble de una política pública que, al asumir como función precípua la atención de situaciones de vulnerabilidad y riesgo personal y social por violación de derechos, requiere el establecimiento de consenso societario en torno a un nivel de civilidad reconocido como inherente a la condición de dignidad humana, por lo tanto, basado en valores y principios de equidad y justicia social, conforme incorporados en el texto constitucional.

Hay que destacar que en la seguridad social, que se manifiesta en las diferentes formas de actuación que, a lo largo de la historia de la humanidad, a pesar de que la responsabilidad de la familia, de la caridad y de la filantropía está influenciada por la doctrina judeo-cristiana y en la sociedad actual, frente a la hegemonía de un modelo de desarrollo capitalista y de consumo, se ha ganado el contorno de la política pública resultante de la lucha de contradicción entre las clases sociales en el proceso de la reproducción social en y para el trabajo, mientras que la respuesta del Estado, en sus dos vertientes: i. en respuesta a las demandas de la clase trabajadora, que provenían de la desigualdad (POULANTZAS, 2000); ii. en el de la ayuda a la producción colectiva y el de la capital, con la apropiación privada del trabajo y de las condiciones de su realización y sus resultados (MARX, 1978).

Sin embargo, en Brasil, el Estado sólo se hizo presente en la esfera de las políticas públicas después de la década de 1930, y a pesar de la Cons- 
titución Federal de 1988 deliberar por un Estado Democrático de Derecho, adoptó sesgos diferenciados de intervención (liberal y social), que se encuentran en permanente disputa a depender de las presiones, de los intereses y de las correlaciones de fuerzas en cuestión. Tal posición repercute directamente en los arreglos organizativos de gestión (burocrático, gerencial, democrático), y está sometida a las consecuencias de las nuevas versiones de la sociedad contemporánea (globalizada, "financiarizada", individualizada, con constantes innovaciones tecnológicas) y de las crisis cíclicas del sistema capitalista.

En el caso de la política de asistencia social, esa evidencia está intrínsecamente vinculada a riesgos sociales generados por la crisis del capital y por la forma de la producción y distribución de la riqueza en la contemporaneidad, causando erosión en el sistema de protección social no contributivo, bajo la óptica universal, lo que ha exigido la comparecencia de un estado Social fuerte en la reducción de las desigualdades sociales, económicas, políticas y culturales, mediatizadas por disparidades en las relaciones de género, étnico-raciales y territoriales, objetivando el enfrentamiento de las inseguridades sociales (CASTEL, 1998; SPOSATI, 2009) y la carencia de derechos (Oliveira, 1994).

Así, la protección social de la política de asistencia social es asegurada por medio de la prestación de servicios, programas, proyectos y beneficios socio asistenciales, incluyendo la transferencia de renta, consustanciados en la oferta de bienes materiales, que posibilitan la supervivencia, y de bienes inmateriales, culturales y simbólicos, que promueven la inserción en la vida social, teniendo por eje central de intervención la dimensión relacional y protectora de los individuos y familias, la convivencia comunitaria y la incidencia política en el territorio, con foco en la primacía de la responsabilidad estatal con participación y control social.

Asumió como objetivos, según el art. $2^{\circ}$ de la Ley Federal n. ${ }^{\circ}$ 8.742/93 - Ley Orgánica de Asistencia Social/LOAS, asegurar la protección social, en la garantía de la vida, de la reducción de daños y de la prevención de la incidencia de riesgos; la defensa de derechos, objetivando el pleno acceso a los derechos en el conjunto de las provisiones socio asistenciales; y la vigilancia socioasistencial, al analizar territorialmente la capacidad protectora de las familias y en ella la ocurrencia de vulnerabilidades, de amenazas, de victimizaciones y daños. 
Para dar concreción, se organizó como sistema único y público, descentralizado y participativo, por niveles de protección social ${ }^{2}$, con todos los elementos constitutivos de una política pública:

I. constitución de marco regulatorio y normativo propio; II. delimitación de las responsabilidades y atribuciones específicas en las modalidades de protección social básica y especial, de media y alta complejidad; III. estructuración de equipamientos públicos, orientados para la provisión de un conjunto de servicios continuados y tipificados nacionalmente, con programas y proyectos complementarios, y beneficios (continuados, eventuales y de transferencia de renta); IV. formateo de equipo de referencia calificada; V. repase regular y automático de recursos fondo a fondo; vi. establecimiento de actuación en red, por medio de la articulación con las demás políticas sectoriales y de defensa de derechos, con los órganos del Sistema de Justicia, con organizaciones de la sociedad civil y con movimientos sociales.

Actualmente posee capilaridad en todo territorio nacional, presente en los 5.570 municipios brasileños, 26 estados y el Distrito Federal, siendo integrada por una red de asistencia social que cuenta con 11 mil equipamientos públicos, 17 mil entidades de asistencia social, 600 mil trabajadores del SUAS, 93 mil consejeros de asistencia social, 4,5 millones de beneficiarios del beneficio de prestación Continuada, 13 millones de familias beneficiarias del Programa Bolsa Familia, 60 millones de personas atendidas directa o indirectamente por los servicios y beneficios socio asistenciales.

Se parte de la premisa de que las vulnerabilidades, los riesgos y las violaciones de derecho comparecen de forma imbricada y están sometidas a determinantes macroestructurales y coyunturales, vinculados a cuestiones complejas y multifacéticas, cuyo abordaje siempre requiere un análisis preciso de las multicausalidades y demandan por un conjunto de ofertas que puedan corresponder cualitativamente a las necesidades humanas presentadas, o sea, es necesario considerar los orígenes de las desprotecciones, en sus vertientes política, económica, social, histórica y cultural, de género, étnico-raciales, además de los impactos de los daños sufridos, en sus dimensiones relacionales, institucionales y sociales. En ese sentido, estar alerta para las particularidades personales, trayectoria de vida, anhelos y perspectivas de los sujetos involucrados, en la búsqueda de construir colectivamente alternativas de superación de esas situaciones y de resignificar sus proyectos de vida, con la claridad de que se constituyen en sujetos históricos.

En esa estera, la exposición al trabajo infantil gana cobertura en la atención a las seguridades socioasistenciales de renta, autonomía, conviven- 
cia, acogida, tanto para los niños y adolescentes como para sus respectivas familias, cuya concepción, prevista en la Política Nacional de Asistencia Social y en la Norma Operacional Básica del SUAS de 2005, abarca más allá de los lazos consanguíneos y de parentesco y se extiende para el reconocimiento de un núcleo afectivo, con vínculos establecidos por obligaciones recíprocas y mutuas, y de alianzas y afinidades organizadas en torno de relaciones intergeneracionales y de género. La protección social, por lo tanto, implica la incidencia de políticas sociales que contribuyen para la reducción del elenco de determinantes que demarcan la realidad desnuda y cruda del trabajo infantil en Brasil.

\subsection{La contextualización del trabajo infantil en Brasil}

Nueva configuración del trabajo infantil puede ser identificada a partir de levantamientos efectuados con base en el CENSO de 2010 y en la PNAD/2012/2014/2016 (Encuesta Nacional por Muestra de Hogares), demarcando profundas alteraciones en su génesis y forma de expresión. El recorte temporal se justifica porque orientó todo proceso de revisión de las acciones públicas, impulsadas por el gobierno federal a la época, y destinadas a la reducción del trabajo infantil en ámbito nacional.

Estudio comparativo entre 1992 y 2015 (MONTAGNER, 2017) confirma la disminución de 68\% en el número de ocupados de 5 a 17 años, pasando de 8,4 millones a 2,7 millones de niños y adolescentes, y, si excluidos los aprendices, el cuantitativo rebaja para $80 \%$. Incluso adoptando la regla de grupo único, la suma de las situaciones típicas de trabajo infantil hasta 15 años y de adolescentes en trabajo irregular de 16 y 17 años muestran una caída de $70,65 \%$ en ese período.

Quedó evidenciado que, si, por un lado, ocurrió la disminución del trabajo en la industria y en extensas propiedades rurales, además de la desvinculación con la necesidad de apoyo en el mantenimiento de la familia, por otro lado, hubo la mutación para las actividades en el ámbito familiar y para los emprendimientos informales, notablemente en las regiones metropolitanas y en los grandes centros urbanos, o sea, de niños de 5 a 13 años, que auxilian en tareas domésticas o en la agricultura de subsistencia, y de adolescentes en pequeños comercios, servicios y actividades de reparación. 
Otro cambio sustantivo recayó en la inserción de los niños y de los adolescentes en la escuela, marcado por frecuencias regulares hasta la enseñanza fundamental, resaltando una preocupación generalizada con el nivel de abandono y evasión escolar en la enseñanza media, aunque la legislación condicione la autorización para actividad laboral después de los 16 años de edad y la posibilidad de aprendizaje entre los 14 y 16 años, siempre con articulación entre la formación en el trabajo y en el campo educacional.

El perfil de la población en situación de trabajo infantil se concentraba en el sexo masculino (66\% en 2015), de la raza negra, parda o indígena, en el intervalo de edad entre 14 y 17 años, mayoritariamente oriundas de las áreas urbanas, que frecuentaban la escuela, y obtenían remuneración por las actividades desempeñadas, con un promedio de 25 a 30 horas semanales. Se observó, también, una inversión en la edad de la población en trabajo infantil, con elevado descenso en el caso de niños con hasta 13 años (de $40 \%$ a menos de $20 \%$ ), mientras que para los adolescentes de 14 a 17 años se identificó una elevación de $60 \%$ a $82 \%$.

Hay niños y adolescentes en situación de trabajo en todos los rangos de renta, aunque se centran en familias que reciben hasta un salario mínimo $(81.22 \%)$. En cuanto al perfil del cabeza de familia en el que los niños están ocupados, se puede decir que son en su mayoría hombres, de 31 a 50 años, ocupados y con educación primaria incompleta.

Cuando se observan las actividades ocupacionales, se presentan las especificidades de cada área. En el medio rural, la concentración se da en municipios de pequeño porte I (hasta 20.000 habitantes), en emprendimientos familiares y actividades no especializadas y en el intervalo etario hasta 15 años. Las actividades en el ámbito doméstico están circunscritas al sexo femenino, en edad entre 14 y 17 años. Ya la participación en el comercio y talleres de reparación absorbieron a los adolescentes, normalmente en emprendimientos familiares o de personas cercanas, pero en la informalidad y con jornadas más largas.

Vale mencionar la existencia de un sistema de información estadística, coordinado por el Instituto Nacional de Geografía y Estadística - IBGE, desde 1990, con abordaje de la temática de forma regular. En 2016, el IBGE promovió cambio metodológico en la PNAD continua, adoptando nuevos conceptos, nomenclaturas y mediciones, incluso para adecuarse a las reco- 
mendaciones de la OIT, emanadas de la 19. ${ }^{a}$ Conferencia Internacional de Estadísticos del Trabajo, celebrada en Ginebra (Oct/2013). Sin embargo, tal procedimiento culminó en dificultar ciertas comparaciones con la serie histórica anterior, porque separó el cómputo de la inserción en trabajo para subsistencia y también el intervalo etario para las actividades permitidas legalmente, causando hasta manifestaciones contrarias de representantes del Foro Nacional de erradicación del Trabajo Infantil.

Frente al cuadro arriba descrito, cabe un análisis más profundo sobre las condiciones presentadas en la fase de la adolescencia, con el aumento de la informalidad, de la tasa de abandono y evasión escolar y de la fragilidad en la formación profesional y de aprendizaje. Ese aspecto merece un destaque, porque la literatura (SAGI, 2012 y 2015; MONTAGNER, 2016) ya comprobó que los ciclos de pobreza y desigualdad son también realimentados por la distorsión edad, años de estudio, cualificación profesional y formación continuada, lo que induce a concluir que estarán sujetos a reducidas oportunidades de desarrollo integral y de satisfacción de sus necesidades en diferentes dimensiones.

$Y$ varios fueron los condicionantes señalados como justificación para el compromiso en el trabajo: i. La atracción por el rendimiento financiero propiciado por el trabajo, principalmente por la capacidad de consumo que él propicia; II.la autonomía en relación a los adultos y demás miembros de la familia; III. la intención de contribuir con el mantenimiento de los gastos domésticos promovidos por las madres, especialmente en los casos de familias monoparentales; IV. el reconocimiento social de inserción en una actividad económica y productiva, aunque en detrimento de los estudios; V. el compromiso en emprendimientos, aunque informales, pero que despiertan el interés de los adolescentes, como en pequeños talleres mecánicos, de computación o en espacios abiertos y que les dan sensación de libertad.

Parte de los cambios observados puede ser imputada al esfuerzo desencadenado desde la década de 1990, con la inserción de la propuesta de erradicación del trabajo infantil en la agenda pública, especialmente con la estructuración de la fiscalización, la ampliación de los servicios prestados por la red de protección social y la introducción de la transferencia de renta para las familias, de modo a retardar la entrada en el mundo del trabajo y/o disminuir las horas a él dedicadas. De lo que se concluye que las condiciones concretas de calidad de vida y de acceso a derechos quedan bastante mejoradas cuando 
existe la presencia de una actuación pública integrada, con efectivas políticas sociales y económicas que abordan la totalidad de los aspectos que inciden sobre los determinantes de las situaciones y que envuelven mayor número de ciudadanos brasileños.

En este sentido, la persistencia de este fenómeno apunta a la necesidad de la implementación de innovadoras y el establecimiento de alianzas entre la sociedad civil y el gobierno, como, por ejemplo, de acciones articuladas, dirigidas a la inspección de trabajo, así como la rendición de cuentas, a la reducción de la pobreza, la ampliación de las oportunidades de empleo para los jóvenes y los adultos, y a la difusión de la información, a la lucha contra la "naturalización del trabajo infantil, el fomento de la cultura de la protección de los niños, niñas, adolescentes y sus familias, y siempre desde la perspectiva de la ampliación del acceso a los derechos y a las políticas sociales, la atención de la salud, la educación, la asistencia social, el trabajo, la cultura, el deporte, la vivienda, la colaboración con las políticas de desarrollo económico, lo que se tradujo en la reordenación de un conjunto de programas destinados a la calle.

\section{EL TRABAJO INFANTIL COMO CUESTIÓN DEL ESTADO BRASILEÑO}

\subsection{El proceso de reordenación del Programa de Erradicación del Trabajo Infantil/PETI}

El combate al trabajo infantil fue contemplado en la Constitución Federal de 1988, pero ganó mayor envergadura y compromiso estatal en función de las noticias degradantes de inserción de niños en ocupaciones peligrosas y de extrema explotación, como en carbonerías en la región de Três Lagoas, en Mato Grosso do Sul, y en cadenas productivas agrícolas (algodón, cacao, sisal) en la región sudeste y nordeste del país.

Fueron intensificadas las fiscalizaciones del Ministerio de Trabajo y del Ministerio Público del Trabajo, editadas normativas específicas y que consideraban la peculiar condición de desarrollo de los niños y de los adolescentes con demandas para políticas sociales, que repercutieron en la estructuración del Programa de Erradicación del Trabajo Infantil - PETI, en 1996, en cooperación del gobierno federal con centrales sindicales, confederaciones 
patronales, organizaciones no gubernamentales, entre otros, y que prontamente se expandió para los demás estados federados.

El modelo inicial del PETI fue regulado por la Ordenanza n. ${ }^{\circ}$ 458/2001/MPS y consistió en:

I. implantar actividades complementarias a la escuela, por medio de jornada ampliada; II. conceder una complementación mensual de renta a las familias, a través de la beca Niño Ciudadana; III. proporcionar apoyo y orientación a las familias beneficiadas; IV. promover programas y proyectos de cualificación profesional y de generación de trabajo junto a las familias.

Con el objetivo de conferir organicidad a la intervención, mediante la Ordenanza n. ${ }^{\circ}$ 365/2002, fue instituida la Comisión Nacional de erradicación del Trabajo Infantil - CONAETI, que desempeñó su papel con mucha propiedad hasta su disolución en 2019.

La creación del Sistema Único de Asistencia Social en 2005 impulsó la integración del PETI con el Programa Bolsa Familia, con el objetivo de racionalizar el registro y perfeccionar la gestión de los programas de transferencia de renta en Brasil (Ordenanza GM/MDS n. ${ }^{\circ}$ 666/2005). El compromiso asimilado por el gobierno brasileño estuvo inscrito en la Agenda Nacional de Trabajo Decente/2006 (ANTD) y en el Plan Nacional de Trabajo Decente/2010 (PNTD), al señalar la prioridad de erradicar el trabajo esclavo y eliminar el trabajo infantil, en especial en sus peores formas, y al establecer como meta el aumento de la inclusión de niños y adolescentes en situación de trabajo infantil en el PETI.

Para garantizar una mayor transparencia y eficiencia en la ejecución presupuestaria del Programa, el Consejo Nacional de Asistencia Social -

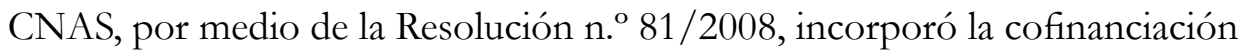
al traspaso regular y automático fondo a fondo por el Piso variable de media complejidad del SUAS. Con la edición de la tipificación Nacional de los Servicios Socioasistenciales y del Protocolo de Gestión Integrada de Servicios, Beneficios y Transferencias de Renta, en 2009, quedó consignada la responsabilidad de los equipamientos públicos - Centros de Referencia de Asistencia Social/CRAS y Centros de referencia Especializados de Asistencia Social/ CREAS, con sus respectivos servicios, en la atención preferencial a las familias con situación de trabajo infantil, ya que también en ese año fue regulada la lista de ocupaciones que traen peligro físico, mental o moral para la población infanto-juvenil. 
En la intención de calificar las ofertas socioasistenciales de trabajo social con familias, transferencia de renta y atenciones socioeducativas para niños y adolescentes, hubo la asimilación del PETI al servicio de convivencia y fortalecimiento de Vínculos - SCFV, estableciendo el trabajo infantil como una de las situaciones prioritarias para atención, conforme Resolución CNAS n. ${ }^{\circ}$ 01/2013. Las indicaciones para reformulación del PETI versaban sobre:

I. movilización intersectorial y definición de estrategias conjuntas; II. intensificación de la identificación del fenómeno y realización de audiencias públicas para abordaje diagnóstico; III. cofinanciación a municipios y estados con incidencia de trabajo infantil; IV. establecimiento de metas para acompañamiento en la red socioasistencial; $\mathrm{V}$. institución de parámetros de cobertura y calificación de la red de protección; vi. perfeccionamiento de los procesos de gestión, con definición de metodologías propias, conforme la realidad local y el intervalo etario.

Adoptando como referencia el Plan Nacional de prevención y Erradicación del Trabajo Infantil y Protección al Adolescente trabajador y la Carta de Constitución de Estrategias en Defensa de la Protección Integral de los Derechos del Niño y del Adolescente, fueron acordados cinco ejes de articulación intersectorial, englobando numerosos órganos gubernamentales ${ }^{3}$ y la CONAETI, cuales sean, información y movilización; identificación; protección; defensa y responsabilización; monitoreo. Como resultados de la convergencia de los ejes, se puede registrar:

E1 Eje de la Información y de la Movilización: i. el fortalecimiento de los Foros Nacionales y Provinciales para la Prevención y Erradicación del Trabajo Infantil; ii. el de la organización de las campañas y de la difusión de las principales actividades identificadas en el territorio, iii. la movilización de los funcionarios públicos, los movimientos sociales y la sociedad civil organizada, iv. el diseño y la realización de la audiencia pública; v. la construcción de la agenda de los distintos sectores de la PETI, para la definición y planificación de las acciones estratégicas en el ámbito federal, estatal y municipal; vi. de la creación de la Coordinación Nacional de la Agenda Integral del PETI, compuesta por el Ministerio de Desarrollo Social y Combate al Hambre - MDS, del Ministerio de Salud - MINSA, el Ministerio de Educación/ MEC, el Ministerio de Trabajo y Promoción del Empleo - MTE y de la Secretaría Especial de Derechos Humanos de la jerarquía digital síncrona, y de los subcomités de la CONAETI; vii. de la entrada en vigor de la reunión, el 6 de encuentros regionales y en los 26 encuentros estatales de la PETI; viii. el establecimiento de una cooperación técnica con la OIT (Organización Internacional del Trabajo) - Oficina en Brasil para la elaboración de un diagnóstico de los indicadores, así como de la red de protección, así como de la metodología analítica en el Modelo de la Identificación de los Riesgos del Trabajo Infantil. 
Eje de la Identificación: i. el incremento de la búsqueda activa, por medio de equipos volantes y abordaje social, y la correspondiente inclusión en el Registro Único; ii. la realización y la publicación del diagnóstico del trabajo infantil en los 5.570 municipios, con verificación de las especificidades regionales, actividades ocupacionales, intervalo ETARIO y prestaciones dispensadas, como forma de orientar las acciones Estratégicas del PETI (AEPETI); iii. el mapeo y compilación de políticas, servicios, programas, beneficios, equipamientos y recursos existentes y necesarios.

El eje de la Protección: i. la adecuación de las ofertas a los nuevos índices de trabajo infantil, incluso, evitar la estigmatización de la población; ii. el de la ampliación de la cobertura y la ampliación de los públicos, el fortalecimiento de la prevención, así como en el seguimiento de los niños, niñas, adolescentes y sus familias, en 1.913 los municipios que concentraban el $80 \%$ de la mano de obra infantil en Brasil; iii. la integración de la seguridad de los ingresos y el acceso a los servicios y programas complementarios; iv. la expansión de los fondos federales, subsidiando el mantenimiento y la gestión de los servicios de la convivencia y fortalecimiento de vínculos a 5.039 los municipios y con la participación del resto de los seres en la co-financiación; v. el fomento, la gestión y la organización de las Secretarías Municipales y Provinciales, con el equipo técnico de referencia para la PETI; vi. el establecimiento de los flujos y procesos de trabajo de las distintas políticas y de los actores involucrados; vii. de la articulación y el uso del espacio para la atención de las demás políticas sectoriales que conforman la red de protección; viii. el fomento de la formación y el fortalecimiento de un Programa de Educación.

Eje de la Defensa y responsabilización: i. la intervención de las Superintendencias, Gerencias y Agencias Regionales del Trabajo y Empleo en el fomento de las acciones de fiscalización; ii. la efectiva actuación del Ministerio Público del Trabajo y de los Ministerios Públicos estatales para desencadenar acciones de prevención, defensa y responsabilización; iii. la articulación del Poder Judicial y del Ministerio Público para asegurar la debida aplicación de medida de protección para niños y adolescente en situación de trabajo infantil; iv. el compromiso de los Consejos Tutelares.

Eje del Monitoreo: i. La definición de objetivos claros, tangibles y verificables para el monitoreo de las situaciones de trabajo infantil, de los posibles agravios y de las atenciones realizadas; ii. el registro de los niños y adolescentes y sus familias en los sistemas de información de sus y de otras políticas; iii. el monitoreo y acompañamiento de las acciones estratégicas constituyentes de la Agenda intersectorial; ivV. la integración con diversas bases de datos oficiales (CENSO 2010, PNAD, CadÚnico, Censo sus, RAIS y CAGED, bases de datos del Ministerio de salud, del Ministerio de Educación, entre otros).

\subsection{La III Conferencia Mundial sobre el trabajo Infantil ${ }^{4}$}

Brasil es signatario de tratados internacionales que reafirman su compromiso con los derechos humanos, la garantía de la vida y de un determina- 
do nivel de dignidad en condiciones de equidad y de justicia social. En ese espectro, asisten los convenios n. os 138 y 182 de la OIT, acompañados del gran desafío de, frente a una coyuntura socioeconómica absolutamente adversa en la sociedad contemporánea del siglo XXI, de elevada desigualdad, flexibilización de las relaciones de trabajo, producción globalizada y financiarización del capital, desencadenar una cooperación mutua para viabilizar la propuesta indicada en la hoja de ruta de La Haya, durante la II Conferencia Global, de reducción del trabajo infantil, con la fijación de metas para eliminación de las peores formas hasta 2016 y de todas las formas hasta 2020.

En 2013, por ser reconocido como un case de éxito en la articulación interinstitucional para el enfrentamiento del trabajo infantil y en la implementación de una red de protección social, Brasil acogió la III Conferencia Global sobre Trabajo Infantil realizada en Brasilia en octubre de 2013, bajo la coordinación del Ministerio de Desarrollo Social, Ministerio de Trabajo y Empleo y Ministerio de Relaciones Exteriores, en la intención de evaluar los esfuerzos gastados por la comunidad internacional, promover un balance de los resultados alcanzados, compartir las 84 experiencias exitosas enumeradas en las áreas de educación y transición escuela-trabajo, legislación, trabajo infantil doméstico, protección social, movilización y concientización, inserción en el mercado de trabajo e inspección/fiscalización y profundizar el debate sobre los temas: trabajo infantil agrícola y urbano; cadenas productivas; papel de sistema de Justicia; producción de estadísticas; violación de derechos; migración, entre otros.

Contó con la participación de cerca de 1.700 personas, oriundas de 155 Naciones, 36 representaciones de nivel ministerial, 78 liderazgos no gubernamentales, 93 representantes de organizaciones de trabajadores y 64 de empleadores, 15 de organizaciones regionales e internacionales, así como de especialistas, parlamentarios, operadores del sistema de Justicia, adolescentes y periodistas nacionales y extranjeros. Fue construido un documento base internacional para consulta y validación de la dinámica, contemplando análisis de la evolución del fenómeno, de las prácticas adoptadas y de posibles sugerencias en plataforma informativa, cuyo contenido fue discutido en salas virtuales a lo largo de 2 meses y presentado en el evento presencial. Internamente ocurrieron encuentros preparatorios regionales y la exposición de un memorial con las principales acciones y alianzas desarrolladas. 
Como producto final fue aprobada la Carta de Brasilia, que demarcó el imperativo de la implementación de políticas públicas integradas, con foco en la garantía de Educación para los niños y los adolescentes y de generación de trabajo en renta para los jóvenes y adultos. Además, propuso la continuidad de las conferencias, eligiendo como sede Argentina, en noviembre de 2017, donde nuevamente fue refrendado el compromiso con la promoción de políticas públicas integradas (trabajo, justicia, educación, agricultura, salud, Formación profesional y protección social); el fortalecimiento de la participación de gestores públicos, de la sociedad civil, de las comunidades locales y de las empresas en la implementación de las estrategias y planes de acción; y el fomento a los ejes de la prevención, identificación y eliminación del trabajo infantil y del trabajo forzado. Esas deliberaciones fueron adosadas a los Objetivos de Desarrollo Sostenible/ODS, a partir de 2015, y pasaron a componer la Agenda 2030, en el ODS $8^{5}$ y en la Meta $8.7^{6}$.

\section{CONSIDERACIONES FINALES}

El fenómeno del trabajo infantil se ha configurado, en la sociedad contemporánea y en el mundo globalizado centrado en el capital, como uno de los principales desafíos a superar. Paradójicamente, se une a la exigencia de una mayor cualificación en el ámbito del trabajo, lo que conlleva a la formación ampliada en el ámbito educativo, cultural, tecnológico, político, basado en un modelo en el que se alinea con las tres dimensiones del desarrollo económico, social y ambiental, al mismo tiempo, en el que se produce la eliminación de una gran parte de la población, por la vía de la negación de los derechos, y el recrudecimiento de las desigualdades y de la inviabilização de acceso al consumo, a pesar de todas estas condiciones deben ser reconocidos como fundamentales para la construcción del mercado, así como para la mejora de la facilidad de uso.

Clama por atención el estrechamiento de la escolaridad con la capacidad de inserción productiva, la mejoría de la calidad de vida, la incidencia política y comunitaria, y el ejercicio de la ciudadanía, ya que esa es una demanda recurrente en innumerables países y en la vida de muchos niños y adolescentes y de sus familiares. En contrapartida, el diagnóstico demostró un elevado índice de evasión y abandono escolar, especialmente de jóvenes en la enseñanza media, señalando la importancia de ampliar la cobertura en los te- 
rritorios más vulnerables y de la institución de formatos y metodologías más adherentes a los intereses y necesidades de la población involucrada.

También como señal de alerta fue señalado como un gran desafío, en especial durante los encuentros estatales, la baja efectividad en la prevención y erradicación del envolvimiento de niños y principalmente de adolescentes en el tráfico de drogas. Muchos de estos cumplen medidas socioeducativas en medio abierto o cerrado por cometer actos infractores; sin embargo, la explotación de estos adolescentes como situación de trabajo infantil es poco reconocida y problematizada. Es necesario el diseño de estrategias de salida con protección social del Estado. Se evidencian las dificultades de diagnóstico preciso en cuanto al cuantitativo en los diferentes territorios, así como el sentido común de criminalización de los hechos en detrimento de la comprensión de las causas y del nivel de dependencia de las sustancias psicoactivas, así como el desarrollo de políticas integradas, desde el combate, la prevención y la atención de los usuarios de sustancias psicoactivas.

Como puede ser observada, una de las requisiciones que se mostró esencial en diversos contextos se remonta en la fuerte presencia del Estado como proveedor de servicios y beneficios y agente mediador frente a la sociedad y el mercado, como estrategia para propiciar la producción y reproducción de la vida, del trabajo y de las relaciones sociales. Particularmente en los casos que se refieren a situaciones de vulnerabilidad y riesgo, la finalidad mayor vislumbra el aseguramiento de la protección social por medio de ofertas públicas que protagonizan el acceso a bienes, servicios y riquezas, incrementada desde la perspectiva de la distribución y redistribución de la renta socialmente producida, aunque individualmente acumulada.

Así, se tornan imprescindibles la constitución de redes intersectoriales de protección, compuestas por un conjunto de políticas públicas sociales y de defensa de derechos, capaces de perfeccionar el desarrollo de oportunidades a los individuos y familias, agregando valores y potencialidades, de modo a desvestirse de la cultura meritocrática, que acaba por culpar a las personas por las dificultades experimentadas, estigmatizar como "familias desestructuradas" e incluso por trivializar la pobreza.

A su vez, en ningún momento se puede descuidar a los determinantes que condicionan las explotaciones y las desprotecciones, particularmente en Brasil, que se moldeó por una trayectoria esclavocrática, patriarcal, colonial, 
patrimonialista y segregadora, lo que en mucho impulsa el agravamiento del cuadro de trabajo infantil. Se torna apremiante la consolidación sistemática de análisis histórico-crítico, que desvele las diversas realidades, desnude las causalidades y monitoree la efectividad de las políticas implementadas, además del continuo perfeccionamiento y reordenamiento de las acciones.

En la actual coyuntura nacional, de aniquilación de los derechos y del acelerado desmantelamiento de los sistemas públicos y universales de protección social, hay que frenar una organizada movilización para el regate de los principios constitucionales, buscando la equidad, la participación ciudadana y la justicia social. Cabe, por lo tanto, como actitud impositiva, la revocación inmediata de la EC N. ${ }^{\circ}$ 95/2016, que establece el techo de los gastos para las políticas sociales de asistencia social, educación y salud, fragilizando la cofinanciación federal para la prestación de los servicios y la concesión de los beneficios; la presión para la reanudación del traspaso regular y automático fondo a fondo; el retorno de las discusiones de la política pública junto a las instancias de pactuación, deliberación y control social; la ampliación de la cobertura de las atenciones; la implementación de los planes decenales y de capacitación continuada, entre tantas otras cuestiones.

\section{NOTAS}

1 El artículo contó con la colaboración técnica de Telma Maranho Gomes, que fue directora del Departamento de Protección Social Especial de la Secretaría Nacional de Asistencia Social/MDS en el período de 2011 a 2016. Asistente social de la Universidad Estatal de Maringá. Directora de Asuntos Comunitarios PRH-UEM. Maestro en Servicio social por la PUC / SP.

2 La protección Social Básica tiene como servicios: Servicio de Protección y Atención Integral a la familia (PAIF); Servicio de Convivencia y Fortalecimiento de Vínculos; Servicio de Protección Social Básica en el domicilio para personas con discapacidad y ancianas. La Protección Social Especial de Media Complejidad presta: Servicio de Protección y Atención Especializada a Familias e Individuos(PAEFI); Servicio Especializado en Abordaje Social; Servicio de Protección Social a Adolescentes en Cumplimiento de Medida Socioeducativa de LA y PSC; Servicio de Protección Social Especial para Personas con Discapacidad, Ancianas y sus Familias; Servicio Especializado para Personas en situación de Calle. La Protección Social Especial de Alta Complejidad oferta: Servicios de Acogida en las modalidades (Institucional; República; Familia Acogedora); Servicio de Protección en Situaciones de Calamidades Públicas y de Emergencias.

3 Ministerio de Desarrollo Social y Lucha contra el Hambre/MDS; Ministerio de Trabajo y Empleo / MTE; Ministerio de Salud/MS; Ministerio de Educación y Cultura/ MEC; Secretaría Nacional de Derechos Humanos / SDH; Ministerio de Justicia / MJ; Ministerio de Turismo/MTur; Ministerio de Desarrollo Agrario/MDA; Ministerio de Hacienda/MF; Ministerio Público de Trabajo/MPT; Ministerios Públicos Estatales/ 
MPEs; Consejo Nacional de los Derechos del Niño y del Adolescente/Conanda; Consejo Nacional de Asistencia Social/CNAS.

4 Las informaciones fueron obtenidas junto a la Comisión Organizadora y al Informe Técnico Final de la OIT, en el Programa de Asociación OIT/Brasil para la promoción de la cooperación Sur-Sur, junto al proyecto estrategias para Acelerar el Ritmo de la Erradicación de las Peores Formas de Trabajo Infantil, de 2012 a 2018.

5 Promover el crecimiento económico sostenido, inclusivo y sostenible, pleno empleo y productivo, y el trabajo decente para todas las personas.

6 Tomar medidas inmediatas y eficaces para erradicar el trabajo forzoso, poner fin a la esclavitud moderna y la trata de personas, y garantizar la prohibición y eliminación de las peores formas de trabajo infantil, incluida la contratación y el uso de niños soldados, y para 2025 poner fin al trabajo infantil en todas sus formas.

\section{REFERENCIAS}

CASTEL, ROBERT. As metamorfoses da questão social: uma crônica do salário. Petrópolis: Vozes, 1998.

JACCOUD, Luciana. Proteção Social no Brasil: Debates e desafios. In: Concepção e Gestão da Proteção Social Não Contributiva no Brasil. Brasília: Unesco, 2009.

MARX, Karl. Manuscritos econômico-filosóficos e outros textos escolhidos. São Paulo: Abril Cultural, 1978, Coleção Os Pensadores.

MINISTÉRIO DAS RELAÇÕES EXTERNAS. Documento preparatório para a Cúpula do Desenvolvimento Social de Copenhague. Brasília/DF: Ministério das Relações Externas, 1995.

MONTAGNER, Paula. O Trabalho Infantil e o Programa Bolsa Família. In: Cadernos de Estudos Desenvolvimento Social em Debate. Brasília: SAGI/MDS, n. ${ }^{\circ}$ 25, maio/2016.

MONTAGNER, Paula. Trabalho Infantil no Brasil: como a política social mudou essa realidade. São Paulo: Fundação SEAD, 2017.

OLIVEIRA, Francisco. Vulnerabilidade social e carência de direitos. In: Seminário Integração Social. Brasília: out. 1994.

ORGANIZAÇÃO INTERNACIONAL DO TRABALHO (OIT). Relatório Técnico Final do Programa da Cooperação Sul-Sul. Brasília: Agência Brasileira de Cooperação/ABC, fev. 2019. 
POULANTZAS, Nicos. O Estado, o poder, o socialismo. São Paulo: Paz e Terra, 2000.

SECRETARIA DE AVALIAÇÃO E GESTÃO DA INFORMAÇÃO (SAGI). Revisão de experiências e programas de combate ao trabalho infantil no Brasil e em outros países. Brasília: SAGI/MDS, Estudo Técnico n. ${ }^{\circ}$ 08, 2012.

SECRETARIA DE AVALIAÇÃO E GESTÃO DA INFORMAÇÃO (SAGI). Trabalho Infantil no Brasil: evolução e características de 2004 a 2014. Brasília: SAGI/MDS, 2015.

SPOSATI, Aldaíza. Modelo brasileiro de proteção social não contributiva: concepções fundantes. In: Concepção e Gestão da Proteção Social Não Contributiva no Brasil. Brasília: MDS/UNESCO, 2009. 



\section{PENSAR DE OTRO MODO LA PROFESIONALIZACIÓN DEL ADOLESCENTE A PARTIR DE LA TEORÍA CRÍTICA DE LOS DERECHOS HUMANOS

\author{
DULCE MARTINI TORZECKI \\ JAILDA EULIDIA DA SILVA PINTO
}

DOI: 10.51366/978-65-89468-10-3-coordinfancia-6

Resumen. El presente trabajo analiza el derecho a la profesionalización como instrumento de acceso del adolescente al trabajo protegido. A partir de la teoría crítica de los derechos humanos, examina el contrato de aprendizaje como instrumento apto para proporcionar una remuneración mínima al adolescente de baja renta, históricamente marginado. La formación profesional debe tomar como base la realización del ser humano, convirtiéndose en instrumento de emancipación que lo convierta en agente social de cambio. En razón de las transformaciones del mundo del trabajo, ha de ser propiciada una calificación más amplia, la cual incluya el desarrollo de competencias socioemocionales, a ser promovida por actuación del Ministerio Público.

Palabras clave: Teoría Crítica de los Derechos Humanos. Adolescentes. Profesionalización. Aprendizaje. Ministerio Público.

\section{DEFINICIÓN DE DERECHOS HUMANOS A PARTIR DE LA TEORÍA CRÍTICA}

El proyecto de ley que resultó en la Ley de aprendizaje - Ley n. ${ }^{\circ}$ 10.097/2000 - se justificó con el argumento de que

la enmienda propuesta redundará en beneficio de unos siete millones de jóvenes de entre 14 y 16 años que necesitan ingresos, educación y formación para entrar en el mercado de trabajo, cada vez más exigente en cuanto a la 
cualificación profesional y personal. La profesionalización es un derecho primordial del adolescente y es la alternativa posible a estos jóvenes ${ }^{1}$.

La justificación del referido proyecto de ley es el punto de partida para el presente trabajo, que tratará de la formación profesional como alternativa a los adolescentes de baja renta, con poca - o casi ninguna - posibilidad de obtener trabajo, situación que acaba por ampliar la desigualdad y exclusión social tan intensas en el Brasil contemporáneo. Con este fin, nos proponemos abandonar el negativismo, romper con la idea de que "no se puede hacer nada", y afirmar nuestras diferencias políticas, sociales y culturales para construir una alternativa. El foco es el adolescente, que tiene el derecho de estudiar, de no trabajar hasta los dieciséis años, de acceder al aprendizaje profesional a partir de los catorce años, de convivir con personas de su edad, de tener ocio etc.

Bajo la óptica propuesta, los derechos humanos son un producto cultural, nacido en un determinado contexto y momento histórico (todo concepto creado puede ser modificado en el transcurso de la historia justamente porque surge de un contexto, y no al revés). Surgieron en Occidente, donde se predica una hipotética universalización de los derechos humanos, relacionada con la cultura dominante y con el poder, siendo, pues, expresión cultural occidental hegemónica de lucha por la dignidad humana, ya que cada sociedad construye, cultural e históricamente, sus caminos hacia la dignidad.

Al proponer una "reinvención" de los derechos humanos, Herrera Flores ${ }^{2}$ escribe sobre la complejidad de definir estos que son productos culturales, y no naturales. Por eso resultan de un conjunto de pautas (toda Formación social contiene pautas culturales propias), reglas y propuestas de acciones humanas y formas de articulación de estas acciones. Y convivir con otros caminos de dignidad implica, necesariamente, en un fuerte grado de compromiso ante la multiplicidad y diversidad de sufrimientos que los seres humanos sufren en sus vidas cotidianas (HERRERA FLORES, 2005, p. 32). La complejidad de la definición de los derechos humanos debe aclararse para que podamos comprender de dónde partimos, con el fin de crear una nueva cultura de los derechos humanos. Según el autor, debemos construir criterios emancipadores que nos permitan abordar las situaciones de crisis, teniendo conciencia de que estamos en posiciones desiguales con respecto al acceso a los bienes. 
Por el "criterio de la riqueza humana", que parte de una concepción íntegra del ser humano, todos los puntos de vista son válidos, permitiéndonos establecer un diálogo entre todas las culturas. Se demuestra de la siguiente manera: a) desarrollo de las capacidades, y b) construcción de condiciones que permitan la Real apropiación y desarrollo de dichas capacidades por parte de los individuos, grupos, culturas y cualquier forma de vida que viva en nuestro mundo (HERRERA FLORES, 2007, p. 121). Utilizar este criterio nos advierte que los derechos son algo previo a la construcción de condiciones sociales, económicas, políticas y culturales. Es decir, en lugar de universalizar una concepción de los derechos, el universalismo que se defiende por medio de este criterio no es un universalismo de partida, sino un universalismo de llegada, donde todas las culturas pueden ofrecer sus opciones, discutiendo en un plano de igualdad.

Estar abiertos a una propuesta crítica dentro del derecho significa romper el discurso y el conocimiento jurídico tradicionales, reflexionar y cuestionar la "legalidad tradicional mitificada", en palabras de Wolkmer (2002, p. 79). Esto se vuelve imperioso si consideramos que la evolución constante del mundo hace que cada período o momento histórico posea un conjunto de verdades que se edifican, se estructuran y se extinguen. Buscar un pensamiento crítico, según el autor (WOLKMER, 2002, p. 78), representa

buscar otra dirección u otro referencial epistemológico que atienda a la modernidad presente, pues los paradigmas de la fundamentación no acompañan las profundas transformaciones sociales y económicas por que pasan las modernas sociedades políticas industriales y postindustriales.

La construcción de una teoría crítica requiere un gran esfuerzo y necesita nuevos hitos teóricos. Como condiciones básicas, tenemos que adoptar un criterio de valor, hacer un análisis del contexto y actuar de forma interactiva en nuestro entorno, que es representado por los otros, por nosotros mismos y por la naturaleza. Después de tomar conciencia de las paradojas y contradicciones de la teoría tradicional, y para construir una teoría crítica, afirmativa y contextualizada de los derechos humanos, sugiere Herrera Flores que tomemos un conjunto de decisiones iniciales, que nos empoderarán ${ }^{3}$ en ese proceso de lucha por la dignidad.

A partir de una nueva teoría crítica de los derechos humanos, construida a partir de decisiones como "pensar de otro modo", "salir de la negatividad dialéctica para la afirmación ontológica y axiológica”, "problematizar la 
realidad"4, es que podremos construir un espacio de lucha para buscar la dignidad de todos los adolescentes ${ }^{5}$ en el proceso de preparación para el trabajo.

El instituto del aprendizaje tiene como objetivo dar formación profesional a los adolescentes y jóvenes, siendo necesariamente constituido por tres partes: aprendiz, empresa y entidad formadora. Esta entidad formadora será, por regla general, integrante del Sistema Nacional de aprendizaje, conocido como Sistema "S", pudiendo ser de la Industria, SENAI, del Comercio, SENAC, de los Transportes, SENAT y Rural, SENAR. Ocurre que la formación profesional por las vías tradicionales del Sistema "S" todavía está restringida a un número reducido de adolescentes, siendo de ella excluidos los de baja escolaridad, en general oriundos de familias de precarias condiciones financieras. Trabajar con una conciencia crítica emancipatoria implica visibilizar, desestructurar y transformar esa realidad. Y, siendo el adolescente pobre el protagonista en ese proceso, debemos abrirnos a él, escuchando sus historias, sus necesidades, sus intereses, sus expectativas y sus narraciones, dentro de los contextos en que están insertados. Debemos considerarlos no como subciudadanos, sino como seres dotados de capacidad y potencia para actuar por sí mismos.

El acceso a un bien, material o inmaterial, no es un proceso neutral, está condicionado a un conjunto de valores, de posiciones, de un proceso de división de trabajo. Si la ley dice que todos somos iguales ante la ley, es porque no lo somos. No basta con estar garantizado el derecho. Es necesario que se tenga conciencia crítica para evolucionar en la efectividad de los derechos.

Para una nueva cultura de derechos humanos es fundamental que abandonemos la idea de naturalización de los conceptos y de los valores. Los valores surgen de un consenso, son preferencias sociales las que se generalizan. Valoramos algo del entorno de las relaciones que vivimos. En esta línea de razonamiento, los principales enemigos de los derechos humanos son los iusnaturalistas (no los positivistas), pues sostienen que todo está más allá, es abstracto, es "natural". Si un fenómeno es "natural" como, por ejemplo, el trabajo precoz para los niños pobres, no se puede hacer nada, sino aceptar, pues "lo es asî". En ese caso, ¿Dónde está la capacidad que el ser humano tiene de transformar constantemente las cosas? ¿Cómo ignorar la influencia política e ideológica en la construcción de estos fenómenos? Tengamos cuidado, pues, con lo que la teoría tradicional llama un fenómeno natural. Tratemos de superar la "cultura de la impotencia" (SÁNCHEZ RUBIO, 2007, 
p. 12), excesivamente conformista, que adopta la actitud de dejar las cosas como están.

Otro aspecto importante para comprender la teoría crítica de los derechos humanos es estar atentos a la diferencia existente entre "bienes" y "derechos". Los derechos son los medios por los cuales se busca garantizar el acceso a los bienes, materiales e inmateriales, necesarios para una vida digna. Los bienes, por lo tanto, que satisfacen las necesidades, vienen antes de los derechos. De lo que se extrae que los bienes (alimentación, Salud, educación, vivienda, saneamiento básico, etc.) están en un nivel de importancia más elevado que los derechos, o sea, los derechos vendrán después de las luchas que se imponen para acceder a todos estos bienes.

Tenemos que superar los sistemas de garantías jurídicas que por sí solos no solucionan las situaciones de desigualdades e injusticias, y asumir compromisos y deberes, ante los demás, ante nosotros mismos y ante la naturaleza, para conseguir el tan deseado acceso igualitario a los bienes.

A partir de una visión crítica, los derechos humanos son un proceso, un resultado - siempre provisional - de luchas sociales por la búsqueda de espacios que posibiliten a todos y a todas luchar por su dignidad, a partir de una igualdad material, que permita poner en práctica una libertad positiva y una fraternidad emancipadora, o sea, por intermedio de las luchas libradas por las personas, individual o colectivamente, es que se posibilita el acceso a los bienes, materiales e inmateriales, necesarios para vivir dignamente. $\mathrm{Al}$ considerar los derechos humanos como un producto cultural, frente al cual se puede reaccionar política, social o jurídicamente, dejamos entrar la realidad en el concepto, abandonando los fenómenos naturales, metafísicos y trascendentales.

Conforme a la capacidad humana que todos y todas tenemos de transformar el mundo, debemos buscar un universalismo de dignidad en el que cada uno y cada una tenga poder suficiente para poner en práctica la capacidad humana de luchar. En el caso específico de nuestro estudio, la propuesta es crear condiciones para que el adolescente pobre o y baja renta sea empoderado en ese proceso de lucha por el acceso a un bien inmaterial - formación para el trabajo - para, a partir de ahí, alcanzar una vida con dignidad. 


\section{EL CONOCIMIENTO COMO INSTRUMENTO DE EMAN- CIPACIÓN Y TRANSFORMACIÓN SOCIAL}

La trayectoria de la educación como proceso de perfeccionamiento de la existencia humana en sus diferentes grados de desarrollo y formaciones sociales ya pasó por diferentes concepciones, variando de acuerdo con las necesidades y los valores prevalentes en ese contexto histórico. Ya ha sido considerada un privilegio de la "clase ociosa", después, por necesidad de mano de obra especializada, fue extendida a las clases menos favorecidas, siendo actualmente una inversión económica, mayor o menor conforme su retribución al sistema capitalista que la sostiene (BARREIRO, 2000, p. 24-25). Luego, ¿cómo conseguir realizar una educación para la ciudadanía dentro de ese pensamiento dominante, con fuerte tendencia al individualismo? ¿Cómo enfrentar el conjunto de fuerzas políticas y económicas que actúan en todos los niveles para mantener ese sistema, incluso mercantilizando la educación?

Repensar los valores de la educación en la sociedad moderna, en la cual los intereses están claramente definidos en el sentido de perpetuar y reproducir el sistema, con múltiples desafíos en nuevas demandas económicas y sociales, es pensar en construir una educación amplia, que respete las diversas formas de conocimiento y recupere la humanidad de los hombres o pueblos (FREIRE, 2005, p. 34). Dentro de esa visión, su carácter utilitario e instrumental pierde espacio para que su objetivo central sea la realización del ser humano.

Las propuestas de la Comisión Internacional sobre la Educación para el siglo XXI, representadas por los llamados cuatro pilares de la educación, guardan profunda relación con la propuesta de formación profesional que idealizamos para los adolescentes. "Aprender a conocer", desde el dominio de una cultura general a partir de ahí a continuación, trabajar específicamente en un área determinada. "Aprender a hacer", dentro del contexto específico brasileño, en que es amplia la economía informal, razón por la cual la calificación deberá ser más social que para un área profesional restricta. "Aprender a vivir juntos", al superar el clima de competitividad e individualismo instaurado; desarrollar la comprensión del otro, después de descubrirse a sí mismo, para poder respetarlo y hacer armónica la convivencia. "Aprender a ser" desde el desarrollo de todas las potencialidades del individuo, de forma integral, al abarcar cuerpo y mente, utilizar todas las posibilidades de descubrimiento y 
experimentación de la imaginación y creatividad, especialmente por medio del arte.

Educar es hacer pensar, pensar de otro modo (HERRERA FLORES, 2005, p. 43) y buscar alternativas para las situaciones de desigualdad que hoy presenciamos en todas las partes del mundo. Una propuesta de educación transformadora y emancipadora es audaz, pero el resultado puede (y debe) ser positivo. Las acciones educativas necesitan estar dirigidas a cuestiones como, por ejemplo, los desequilibrios sociales traídos por el sistema de acumulación de capital, que ha conducido a una situación de pobreza 4/5 de la población mundial.

En la evolución del proceso de aprendizaje necesitamos superar, también, la tendencia actual de especialización, que impide de ver lo global, de pensar los problemas en sus contextos, de posicionar esos problemas en ámbito universal. Según Morin, "los problemas esenciales nunca son fraccionales, y los problemas globales son cada vez más esenciales” (MORIN, 2000, p. 14). Por lo tanto, es necesario revisar la enseñanza de la escuela primaria, que separa las disciplinas en lugar de reconocer sus correlaciones, haciendo que las mentes de los niños pierdan sus aptitudes naturales para contextualizar los saberes e integrarlos en sus conjuntos. El problema de la enseñanza debe ser pensado, según el autor, considerando, por un lado, la gravedad de los efectos de la partición de los saberes y, por otro, que la mente humana tiene plena aptitud para contextualizar, desde que desarrollada.

También dentro de una concepción humana de la educación, las ideas pedagógicas de Paulo Freire, para el cual la deshumanización del oprimido es actualmente el problema central, cuyo enfrentamiento se dará con la recuperación de su "humanidad robada" (FREIRE, 2005, p. 32). Según él, la tarea humanista e histórica de los oprimidos es liberarse a sí mismos y a los opresores, pues la clase dominante busca mantener la situación de desigualdad y el mantenimiento de sus privilegios por medio de la inferioridad intelectual. La propuesta del pedagogo pernambucano es que los oprimidos, reconociendo su condición e identificando a su opresor, luchen por su liberación, en primer lugar, a partir de la alfabetización, pues por ella comienza un camino de conocimiento crítico de la realidad y de asumir posturas frente al mundo. Es a partir de la reflexión que ocurrirá la acción, con la consecuente inserción crítica del oprimido en la realidad opresora, posibilitando la transformación de esa realidad, o sea, la superación de la contradicción opresor-oprimido. No le 
cabe al opresor sólo reconocer su papel y solidarizarse con el oprimido, pues así acaba realizando mero asistencialismo, manteniendo la sumisión de los oprimidos, impidiéndoles organizarse de forma autónoma. Esa dependencia, esa práctica de dominación, que sirve solamente para minimizar la culpa del opresor, debe ser interrumpida con la transformación que ocurre por la inserción crítica del oprimido (FREIRE, 2005, p. 42-43).

Luchemos, por tanto, por la ampliación del acceso de todos y de todas a una educación profesional, con propuestas que rompan el paradigma del individualismo y Privilegien los diversos saberes. Esta nueva formación deberá basarse en un modelo de desarrollo humano en detrimento del económico, superando una formación puramente especializada, realizada dentro de un proceso de robotización. Deberán superarse los cursos profesionales que preparan al joven para ejercer una función "A" o "B" dentro de la empresa. Al contrario, además de aprender lo que se ha convenido llamar "oficio", debemos desarrollar una pedagogía que valorice el trabajo como un bien al que todos y todas, indistintamente, deben tener acceso.

Hay que repensar la formación profesional hoy realizada por el "Sistema S", elitista ${ }^{6}$, que objetiva primeramente la satisfacción de los intereses económicos de las empresas. Por eso la importancia de fortalecer la profesionalización realizada por otras entidades calificadas en formación técnico-profesional metódica, que tengan por objetivo la asistencia al adolescente y a la educación profesional ${ }^{7}$.

Nuestra propuesta es fortalecer ese aprendizaje realizado por las escuelas Técnicas y demás entidades sin fines lucrativos, y así ampliar la formación profesional entre los adolescentes de baja renta, los "sin diploma", a fin de reducir la desigualdad de acceso al mundo del trabajo.

El desarrollo de una educación profesional-por el Sistema "S", por las escuelas Técnicas de Educación o por las entidades sin ánimo de lucro (como, por ejemplo, las ONGs), ha de concebir, además, los principios defendidos por la $\mathrm{UNESCO}^{8}$, sin olvidar el criterio de la riqueza humana. Estas propuestas deben integrarse en los programas curriculares de los cursos de formación profesional, que deben ser reformulados para abarcar estos nuevos principios educativos. 
La oferta de cursos profesionalizantes destinados a esos adolescentes debe ser discutida con las comunidades locales, las asociaciones de barrio y los demás agentes sociales comprometidos con la lucha por la dignidad humana. La fuerza de estas acciones podrá generar políticas públicas destinadas a garantizar una nueva formación profesional defendida en este trabajo.

\section{APRENDIZAJE PROFESIONAL COMO FORMA DE ROMPER CON EL CICLO INTERGENERACIONAL DE LA POBREZA}

La inclusión precoz en el mundo del trabajo hace visibles historias caracterizadas por la exclusión, falta de perspectivas, reiteración del ciclo intergeneracional de la pobreza, falta de escolaridad y de acceso a la educación. El bajo rendimiento y la evasión escolar a menudo son consecuencias de esta inserción temprana. Las razones de la discontinuidad de los estudios de adolescentes pobres o de bajos ingresos a menudo están relacionadas con las opiniones negativas sobre el valor de las escuelas en las vidas de sus madres y sus padres. El apoyo familiar y la creencia en el valor del estudio pueden ser determinantes para que estos adolescentes busquen logros escolares.

A fin de romper con el proceso de naturalización de la transmisión intergeneracional de la pobreza y de la falta de escolarización ${ }^{9}$, y de romper con la reiteración y el movimiento de trayectorias como algo hereditario, se torna esencial la presentación de esos adolescentes a otras fuentes de socialización externas a la familia. La ampliación de los vínculos sociales puede estimularlos a creer en la posibilidad de emancipación educativa y económica, así como a realizar sus potencialidades y a ver el estudio, y no el trabajo precoz, como un mecanismo de ascensión social.

El aprendizaje profesional es una forma de ingreso protegido en el mundo del trabajo, que unifica oportunidad de renta al acceso a un programa de formación y cualificación profesional, además de elevar el grado de escolarización. Este último aspecto se obtiene, ya que uno de los requisitos de validez de este contrato especial es la matrícula y la asistencia del aprendiz a la escuela si no ha completado la escuela secundaria. Por esta razón, este instituto garantiza al mismo tiempo el derecho a la profesionalización y fortalece el derecho a la educación. Si el aprendizaje se concede en los términos propuestos en este artículo, puede constituirse en una forma de romper con 
el ciclo intergeneracional de la pobreza y de producir diferencias significativas en el enfrentamiento al trabajo infantil. ${ }^{10}$

En el contexto específico de la legislación laboral, contrato de aprendizaje es el contrato de trabajo especial, ajustado por escrito y por plazo determinado, en el que el empleador se compromete a asegurar al mayor de 14 (catorce) y menor de 24 (veinticuatro) años inscrito en programa de aprendizaje, formación técnico-profesional metódica, compatible con su desarrollo físico, moral y psicológico. Tal obligación está prevista en el art. 429 de la CLT para todos los establecimientos de mediano y grande portes, y es facilitada a micro y pequeñas empresas, así como a órganos de la administración directa sobre la base de las mismas premisas legales.

Alrededor del $80 \%$ de las personas que hoy se encuentran en el trabajo infantil ${ }^{11}$ son adolescentes con edad superior a 14 años, los cuales pueden, por lo tanto, celebrar contratos de aprendizaje profesional, por los cuales se garantiza la protección en el trabajo y se respeta la condición peculiar de persona en desarrollo. En atención a este último aspecto, además de la formación técnica y profesionalizante, es importante la inversión también en la formación socioemocional y en el desarrollo de las habilidades comunicacionales a fin de despertar en esos adolescentes la autoestima, el fortalecimiento de los vínculos familiares y una nueva mirada por la vida ${ }^{12}$.

Con las constantes transformaciones en el cada vez más exigente mercado de trabajo, se estableció la creciente recaudación de buena formación escolar, conocimientos técnicos y competencias socioemocionales. Estas últimas son prestigiosas en el contexto actual y garantizan un alto nivel de empleabilidad para un trabajador. La revolución digital impone a los adolescentes preparación para seguir algunas profesiones aún inexistentes. Delante del avance tecnológico y de la creación de la inteligencia artificial, las actividades antes realizadas en fundamentos cognitivos pasaron a exigir la habilidad de relacionarse en grupo, la empatía, la comunicación clara y asertiva, la creatividad, la ética en la toma de decisiones, la antifragilidad ${ }^{13}$ más que la resiliencia, entre otros saberes.

Un aprendizaje profesional formateado bajo estos moldes desarrollaría la autonomía, el sentido crítico y la toma de decisiones desde un punto de vista ético, mejoraría las habilidades y competencias, prepararía al adolescente para el mundo del trabajo y la vida. Cumpliría el principio según el cual el 
aspecto formativo debe superponerse al productivo, sobre el cual se sustenta el aprendizaje, así como se constituiría en una rica contribución en la lucha por el fin de la desigualdad económica y social prevaleciente en Brasil desde la colonización, así como impediría que los adolescentes pobres sean inseridos en actividades precarias, informales, desprotegidas y sin expectativa de un futuro mejor.

Todas esas proposiciones vienen al encuentro de las Prioridades y líneas de acción de la Agenda Nacional de Trabajo Decente para la Juventud ${ }^{14}$, la cual dialoga con el Plan Nacional de erradicación del Trabajo Infantil y de Protección al Adolescente trabajador, así resumidas: Prioridad 1: Más y mejor educación; Prioridad 2: Conciliación de los estudios, trabajo y vida familiar; Prioridad 3: Inserción activa y digna en el mundo del trabajo, con igualdad de oportunidades y de tratamiento y Prioridad 4: Diálogo Social - Juventud, Trabajo y Educación.

El trabajo decente aquí comprendido como el trabajo productivo y adecuadamente remunerado, ejercido en condiciones de libertad, equidad y seguridad, capaz de garantizar una vida digna, siendo condición fundamental para la superación de la pobreza y la reducción de las desigualdades sociales.

\section{LA PROMOCIÓN DEL DERECHO A LA PROFESIONALI- ZACIÓN POR EL MINISTERIO PÚBLICO}

En el escenario brasileño, la Constitución de la República establece que al Ministerio Público le corresponde la defensa del orden jurídico-democrático y la promoción de los derechos fundamentales, en dimensión individual y colectiva, en las variadas y complejas áreas de intereses esenciales de la sociedad.

En esa perspectiva, la prioridad absoluta al derecho del adolescente a la profesionalización para el ingreso adecuado en el mercado de trabajo (artículo 227 de la Constitución) puede ser garantizada a partir de la actuación conjugada en el ámbito del Ministerio Público brasileño ${ }^{15}$.

Por otro lado, la verificación de la atención de la cuota legal de aprendices por las empresas ${ }^{16}$ es una de las metas prioritarias de actuación del Ministerio Público del Trabajo (MPT), que ocurre de forma articulada por su Coordinación Nacional de Combate contra la Explotación del Trabajo de 
Ninõs, Niñas y Adolescentes - Coordinfância, creada por medio de la Ordenanza n. ${ }^{\circ} 299$, de 10 de noviembre de 2000. La Coordinación tiene como objetivo promover, supervisar y coordinar acciones contra las variadas formas de explotación del trabajo de niños y adolescentes, dando tratamiento uniforme y coordinado al tema.

El contrato de aprendizaje ${ }^{17}$ es un importante instrumento de acceso de adolescentes al mundo del trabajo, con derechos laborales garantizados, además de la formación profesional correspondiente. Para su efectividad, el adolescente también deberá estar frecuentando su escuela regular, siendo que el carácter educacional debe siempre preponderar sobre lo productivo.

La regulación del aprendizaje profesional fue unificada por el Decreto Federal n. ${ }^{\circ}$ 9.579, de 22 de noviembre de 2018 (artículos 43 a 75), que establece, de forma expresa, el medio alternativo de cumplimiento de Cuota - también llamada cuota social, priorizando la inclusión de adolescentes y jóvenes en situación de vulnerabilidad o riesgo social. La fiscalización del cumplimiento de las normas relativas al aprendizaje profesional es disciplinada por la instrucción Normativa SIT n. ${ }^{\circ}$ 146, de 25/07/2018.

A fin de efectuar la prioridad en la contratación de aprendices en la modalidad de cuota social, conforme ejemplificado en el $\ 5$. $^{\circ}$, del artículo 66, del Decreto n. ${ }^{\circ}$ 9.579/2018, fue realizado el estudio que resultó en la publicación del documento "profesionalización y trabajo protegido: subsidios para la actuación del Ministerio Público en la promoción del acceso de adolescentes y jóvenes en condición de vulnerabilidad a programas de aprendizaje y cursos de calificación profesional"18.

La compilación preconiza la actuación interinstitucional de los ramos del Ministerio Público, a partir del reconocimiento de buenas prácticas de cooperación interinstitucional que están siendo desarrolladas en algunas regiones del país, para inspirar su multiplicación, así como reúne el marco legal envolviendo el tema, con ejemplos de acciones propuestas objetivando su efectuación.

Con los instrumentos constitucionales garantizados, tienen los miembros del Ministerio Público plenas condiciones de actuar para promover el acceso del grupo con prioridad de protección - adolescentes y jóvenes en cumplimiento o egresados de medidas socioeducativas, en acogida institu- 
cional o en situación de explotación de trabajo infantil - a programas de aprendizaje y calificación profesional que consideren sus potencialidades, alejándolos de trabajos precoces dañoso, que no respetan su condición peculiar de persona en desarrollo.

\section{CONCLUSIONES}

5.1 - Hay que romper la idea de que nada se puede hacer, de que es inútil esforzarse, de que cada uno sigue siendo lo que es, que en el fondo nada cambia. Es necesario superar la tendencia humana a la estabilidad, que nos hace ciegos ante las posibilidades de transformación del mundo, en razón de la preponderancia de la "voluntad de la verdad" (dogmas) sobre la "voluntad de poder" (potencia humana de cambio y transformación).

5.2 - Se torna imperioso romper el discurso y el conocimiento jurídico tradicionales, afirmando nuestra diferencia y apropiándonos críticamente de la lucha jurídica, utilizando el derecho como instrumento de positivación de las luchas sociales, ampliadas a partir de articulaciones a ser hechas dentro de los contextos político, económico y social.

5.3 - El adolescente tiene plenas condiciones de transformarse a sí mismo y a su entorno, por lo que debe ser empoderado para que sea un agente social en la lucha por la emancipación y por la ciudadanía. Para ello, la formación profesional debe estar fundamentada en un paradigma del desarrollo humano, ser transformadora y privilegiar los diversos saberes, superar la formación técnica, puramente especializada, que robotiza al adolescente y visualiza tan sólo los intereses económicos de las empresas.

5.4 - La educación profesional debe ser construida en valores que tomen por base el criterio de la riqueza humana, el cual permita el desarrollo de las capacidades y la apropiación de tales capacidades. El objetivo central debe ser la realización del ser humano al considerarse los cuatro pilares de la educación, "aprender a conocer", "aprender a hacer", "aprender a vivir juntos" y "aprender a ser". Las entidades que realizan profesionalización deben revisar los programas curriculares de los cursos de Formación Profesional para abarcar estos nuevos principios educativos.

5.5 - Nuestra propuesta para reducir la desigualdad de acceso al mundo del trabajo y ampliar la formación profesional entre los adolescentes de 
baja renta es el fortalecimiento del aprendizaje realizado por las escuelas Técnicas de Educación y demás entidades sin fines lucrativos, pues son esas entidades que, por regla general, acogen a los adolescentes oriundos de la clase baja.

5.6 - Los cursos de aprendizaje deben ser revisados a fin de atender a las transformaciones del mundo del trabajo que pasaron a exigir, además de la buena formación escolar y conocimientos técnicos, también las competencias socioemocionales (habilidad de relacionarse en grupo, empatía, comunicación clara y asertiva, creatividad, ética en la toma de decisiones, antifragilidad), las cuales garantizan un alto nivel de empleabilidad.

5.7 - En el ámbito de la actuación del Ministerio Público se debe promover, con base en los instrumentos legales, asociación interinstitucional amplia y permanente, con la finalidad de ampliar la oferta de programas de aprendizaje y calificación profesional a adolescentes en situación de vulnerabilidad, sobre todo a aquellos en cumplimiento o egresados de medidas socioeducativas, en acogida institucional o en situación de explotación de trabajo infantil, que integran nuestro grupo de protección prioritario.

\section{NOTAS}

1 Proyecto de Ley de la Cámara n. ${ }^{\circ}$ 74, de 2000. Diario del Senado Federal, Brasilia, DF, p. 21.739-21.751, 2 nov. 2000.

2 Joaquín Herrera Flores fue el idealizador del Programa de Máster Oficial / Doctorado en Derechos Humanos, Interculturalidad y Desarrollo, de la Universidad Pablo de Olavide de Sevilla (España).

3 La constante utilización del neologismo "empoderamiento" en este trabajo proviene de la fuerza que representa la palabra "empowerment", originaria del idioma Inglés, cuya definición, entre otras, es la de conferir poder a las personas. Y ese poder significa, dentro de la teoría crítica, tener la fuerza para luchar por una vida con dignidad (MERRIAM-WEBSTER en línea, 2020).

4 Las seis decisiones iniciales propuestas por Herrera Flores, que instigan un trabajo crítico con los derechos humanos, se encuentran en el primer capítulo de Los derechos humanos como productos culturales, p. 43-66.

5 La Declaración Universal de los Derechos del Niño, ratificada por Brasil en 24 Sep. 1990, menciona tan sólo el término "niños" para abarcar a las personas con edad hasta 18 años. Utilizamos el término "adolescente", pero, siguiendo la conceptualización definida en el Estatuto del Niño y del Adolescente, que considera niño a la persona hasta 12 años de edad incompletos y adolescente los que están en el intervalo de edad entre 12 y 18 años (artículo 2. de la Ley n. ${ }^{\circ} 8.069 / 90$ ).

6 Muchos adolescentes de bajos ingresos no cumplen con los requisitos de escolaridad impuestos por cursos ofrecidos por el Sistema S. Por ejemplo, el curso de aprendizaje Industrial básico del SENAI, para el cual "los jóvenes deben estar cursando educación 
regular o haber completado la escuela secundaria". Disponible en: http://www.fieb. org.br/senai/pagina/3308/aprendizagem-industrial-basica.aspx. Acceso en: 28 jun. 2020.

7 Artículo 430, II, de la consolidación de las leyes del trabajo.

8 La propuesta figura en el informe presentado a la UNESCO por la Comisión Internacional sobre la educación para el siglo XXI, que resultó en la obra coordinada por Jacques Delors, Educación: un tesoro por descubrir, 9. ${ }^{\mathrm{e}} \mathrm{ed}$.

9 Con el objetivo de mapear la relación entre el nivel de escolaridad de las madres y el trabajo precoz de los hijos en la sociedad brasileña, se investigó el nivel de instrucción de las mujeres responsables por los domicilios con niños de 5 a 17 años ocupadas [...]. Los resultados de la encuesta indican que la ocupación de los niños de 5 a 17 años se centró más en los niveles elementales de educación de las mujeres. La escolaridad de la mujer responsable del domicilio presentó correlación con la situación de ocupación de los niños, conforme la Investigación Nacional por Muestra de Domicilios Continua - PNAD Continua 2016. Disponible en: https://biblioteca.ibge.gov.br/visualizacao/ livros/liv101388_informativo.pdf). Acceso en: 28 jun. 2020.

10 Muchas pueden ser las causas del trabajo infantil. Ellas pueden estar vinculadas a la pobreza, que lleva a las familias a ofrecer la mano de obra de los hijos muy temprano; a un sistema educacional deficiente, que torna la escuela poco interesante para los alumnos y promueve elevadas tasas de repetición y evasión; a la estructura de la familia; a la escolaridad de los padres; a la incapacidad de los padres de asumir las responsabilidades del domicilio; al lugar de residencia; o incluso al sistema de valores y tradiciones de la sociedad, conforme la PNAD continua 2016. Disponible en: https:// biblioteca.ibge.gov.br/visualizacao/livros/liv101388_informativo.pdf). Acceso en: 28 jun. 2020.

11 La PNAD 2015, del Instituto Brasileño de Geografía y Estadística (IBGE), señala que 2,7 millones de niños y adolescentes de 5 a 17 años trabajan en todo el territorio nacional. En Brasil, el trabajo está prohibido para aquellos que aún no han cumplido los 16 años, por regla general. Cuando se lleva a cabo en la condición de aprendiz, se permite a partir de los 14 años. Si se trata de trabajo nocturno, peligroso, insalubre o actividades de la lista TIP (peores formas de trabajo infantil), la prohibición se extiende a los 18 años incompletos.

12 A modo de ejemplo, el proyecto Jóvenes Profesionales del Futuro, elaborado por la ONG Red Ciudadana de Belo Horizonte, considera esa preparación más amplia para el mundo del trabajo, que abarca una formación socioemocional que estimule el interés de esos jóvenes por la vida y por el trabajo y aumente sus posibilidades de contratación. En esta propuesta, vida y trabajo son un solo valor y deben andar juntos para promover la realización profesional y personal del ser humano, a partir de tecnologías pedagógicas terapéuticas e innovadoras. Disponible en: http://www. redecidada.org.br/mundo-do-trabalho/jovens-profissionais-do-futuro/. Acceso en: 27 jun. 2020.

13 Antifragilidad, concepto acuñado por Nassim Nicholas Taleb, se puede entender que cuanto más alguien se expone a condiciones de estrés, más se fortalece esta persona. En cuanto la resiliencia sería algo así como recibir estímulos negativos (presión, errores, competencia) y no sacudirse.

14 Brasil lanzó la Agenda Nacional de Trabajo Decente en 2006. Tres años después, un decreto presidencial instituyó el Comité Ejecutivo Interministerial, responsable de su implementación, y creó un Subcomité para promover una Agenda Nacional de Trabajo Decente específica para la juventud, coordinado por la Secretaría Nacional de la Juventud y el Ministerio de Trabajo y Empleo, con asistencia técnica de la OIT. 
Disponible en: https://www.ilo.org/brasilia/temas/emprego/WCMS_301824/lang-pt/index.htm. Acceso en: 28 jun. 2020.

15 En este sentido, la Recomendación n. ${ }^{\circ}$ 70, de 11 de junio de 2019, del Consejo Nacional del Ministerio Público (CNMP). Esta recomendación enfatiza la importancia de la actuación conjunta entre el Ministerio Público del Trabajo y los Ministerios Públicos de los Estados y del Distrito Federal, objetivando al enfrentamiento del trabajo infantil y a la profesionalización de adolescentes y jóvenes.

16 Conforme al artículo 429 de la consolidación de las Leyes del trabajo, los centros de cualquier naturaleza están obligados a emplear e inscribir en los cursos de los Servicios Nacionales de aprendizaje un número de aprendices equivalente al cinco por ciento, como mínimo, y al quince por ciento, como máximo, de los trabajadores existentes en cada centro, cuyas funciones demanden formación profesional.

17 CLT, Art. 428.

18 Disponible en: https://www.cnmp.mp.br/portal/todas-as-noticias/12394-publicacaodo-cnmp-traz-orientacoes-para-promover-acesso-de-jovens-em-condicoes-devulnerabilidade-a-programas-de-aprendizagem-2. Acceso en: 27 jun. 2020.

\section{REFERENCIAS}

BARREIRO, Júlio. Educação popular e conscientização. Porto Alegre: Sulina, 2000.

BRITO DE ARAÚJO, Tatiana. Educação profissionalizante - questões sociais e mercado de trabalho. 2005. 275 p. Tese doutoral (Ciències Socials). Universidade Autônoma de Barcelona, Barcelona, 2005.

CONSELHO NACIONAL DO MINISTÉRIO PÚBLICO (CNMP). Publicação do CNMP traz orientações para promover acesso de jovens em condições de vulnerabilidade a programas de aprendizagem. Brasília/DF, 19 ago. 2019. Disponible en: https://www.cnmp.mp.br/ portal/todas-as-noticias/12394-publicacao-do-cnmp-traz-orientacoes-para-promover-acesso-de-jovens-em-condicoes-de-vulnerabilidade-a-programas-de-aprendizagem-2. Acceso en: 27 jun. 2020.

DELORS, Jacques et al. Educação: um tesouro a descobrir. 9. a ed. São Paulo: Cortez/UNESCO, 2004.

EMPOWERMENT. In: MERRIAM-WEBSTER. [S.1.], 2020. Disponible en: http://www.merriam-webster.com/dictionary/empowerment. Acceso en: 27 jun. 2020.

FIEB/SENAI. Aprendizagem Industrial Básica. [S.l.], [20--]. Disponible en: http://www.fieb.org.br/senai/pagina/3308/aprendizagem-industrial-basica.aspx. Acceso en: 28 jun. 2020. 
FREIRE, Paulo. Pedagogia do oprimido. 47. a ed. Rio de Janeiro: Paz e Terra, 2005.

HERRERA FLORES, Joaquín. Los derechos humanos como productos culturales. Madrid: Catarata, 2005.

HERRERA FLORES, Joaquín. O nome do riso. Trad. Nilo Kaway Junior. Porto Alegre: Movimento/CESUSC/Bernúncia, 2007.

HERRERA FLORES, Joaquín. La reinvención de los derechos humanos. Andalucia: Atrapasueños, 2008.

IBGE. PNAD Contínua. Disponible en: http://www.oit.org.br/sites/default/files/topic/ipec/pub/caderno1_330.pdf. Acceso en: 28 jun. 2020.

MORIN, Edgar. A cabeça bem feita. Rio de Janeiro: Bertrand Brasil, 2000.

ORGANIZAÇÃO INTERNACIONAL DO TRABALHO. Agenda Nacional de Trabalho Decente para a Juventude. [S.1.], [20--]. Disponible en: https://www.ilo.org/brasilia/temas/emprego/WCMS_301824/lang--pt/index.htm. Acceso en: 28 jun. 2020.

REDE CIDADÃ. O projeto Jovens profissionais do futuro. [S.l.], 2019. Disponible en: http://www.redecidada.org.br/mundo-do-trabalho/jovens-profissionais-do-futuro/. Acceso en: 27 jun. 2020.

SÁNCHEZ RUBIO, David. Repensar derechos humanos: de la anestesia a la sinestesia. Sevilla: MAD, 2007.

WOLKMER, Antonio Carlos. Introdução ao pensamento jurídico crítico. 4. ${ }^{\text {a }}$ ed. São Paulo: Saraiva, 2002. 



\section{TRABAJO INFANTIL DOMÉSTICO, SU REALIDAD, ENFRENTAMIENTO $Y$ PREVENCIÓN}

\section{ELIANE ARAQUE DOS SANTOS}

DOI: $10.51366 / 978-65-89468-10-3-$ coordinfancia-7

Resumen. El trabajo infantil doméstico es aquel desarrollado de forma continuada, con o sin remuneración, por persona con edad inferior a 18 años, sea en casa de terceros, o bien en su propio hogar. Es una realidad que se hace presente en la cultura del país como resquicio de la esclavitud, y también resultante de la pobreza y de la fragilidad económica de las familias. Se trata de una de las peores formas de trabajo infantil, cuya eliminación es prioritaria en virtud del Convenio 182 de la Organización Internacional del Trabajo (OIT), ratificado por el país. Es un trabajo oculto, invisible, ejercido bajo el control y explotación por parte del adulto, lo que, aún, cede espacio al maltrato y demás abusos, incluso sexuales. Para su erradicación, es necesaria la adopción de políticas públicas específicas, que, a la vez, enfrenten las necesidades de los niños y adolescentes involucrados, así como sus familias.

Palabras clave: Trabajo infantil doméstico. Peor forma de trabajo infantil. Trabajo oculto.

\section{INTRODUCCIÓN}

El trabajo infantil es una realidad en Brasil, pese la creciente conciencia social cuanto a sus maleficios y la necesidad de protección integral al niño y adolescente. Además, a ello se suma la actuación constante de entidades públicas y privadas que tienen la temática como objetivo principal. A lo largo de los años, y en especial, a partir de la década de 1990, la lucha por la eliminación de toda forma de trabajo infantil ha sido continuada y, aunque con resultados alentadores en aquellos años, pasó a un ritmo más lento en inicios deste siglo, en especial al inicio de la segunda década. Luego, todavía hay un 
número de niños y adolescentes involucrados en el trabajo precoz e irregular, más de dos millones y cuatrocientos mil, por los últimos datos divulgados por el Instituto Brasileño de Geografía y Estadística (IBGE) ${ }^{1}$.

Después de años de evolución en las acciones de combate y prevención del esa problemática, siendo el país referencia mundial en las acciones desarrolladas y resultados obtenidos, no se consiguió adoptar las políticas públicas necesarias para su prevención y erradicación, habiendo, en ese momento, bloqueo al respecto, vista la extinción de la Comisión Nacional de Prevención y Erradicación del Trabajo Infantil - CONAETI ${ }^{2}$, órgano cuatripartito, vinculado, desde su creación, al entonces Ministerio del Trabajo y Empleo, con perjuicios flagrantes en la articulación y alianzas firmadas y en las acciones previstas en el III Plan Nacional de Prevención y Erradicación del Trabajo Infantil, aprobado en $2018 .^{3}$

A partir del inicio de este siglo, la Comisión, así como demás entes públicos y privados involucrados en la temática, especialmente, el Ministerio Público del Trabajo ${ }^{4}$ y el Foro Nacional de Prevención y Erradicación del Trabajo Infantil (FNPETI) ${ }^{5}$ estuvieron atentos a las acciones contenidas en los planes anteriores, I y II, en su inspección y actualización, con el fin de eliminar toda forma de trabajo infantil, meta establecida por la Agenda 2030 de la Organización de las Naciones Unidas (ONU), a ser alcanzada hasta el año $2025^{6}$.

A pesar de este hito, las dificultades para la realización de la meta puesta están presentes. Y, en ese momento, en que el mundo lidia con la pandemia de la Covid-19, existe la posibilidad del recrudecimiento del trabajo infantil, ante la fragilización de gran parte de la población del país, en especial de los trabajadores, afectados con la pérdida del empleo o con su precarización.

Ahora más que nunca, es necesario traer a la agenda de la cuestión, con la movilización de toda la sociedad en sus actividades, con especial atención a las peores formas de trabajo infantil, cuya erradicación es un compromiso asumido por el país ante la Organización Internacional del Trabajo (OIT), y que, por lo tanto, ante la comunidad internacional, teniendo en cuenta que la ratificación del tratado, en el año 2000 del Convenio n. ${ }^{\circ} 182^{7}$, que se refiere a la eliminación de las peores formas de trabajo infantil, así como, a la vista de dicha Agenda en el año 2030, de la ONU. Las dificultades encontradas se refieren primordialmente a la falta de políticas públicas específicas y al com- 
promiso de las autoridades públicas con esa misión. Y en este contexto se destaca el trabajo infantil doméstico.

\section{TRABAJO INFANTIL DOMÉSTICO, SU REALIDAD Y PERJUICIOS DERIVADOS}

El trabajo doméstico es una realidad que se inserta en la cultura del país, resquicio de la esclavitud, habiéndose naturalizado en el contexto del trabajo, pero sin las garantías debidas a todo trabajador, lo que solamente ocurrió recientemente.

Esto sobresale en la Consolidación de las Leyes del Trabajo ${ }^{8}$, de 1943, de la cual fue excluido (Art. $7^{\circ}$ ) e, mismo en la Constitución Federal, cuyo Art. $7^{\circ}$, al enumerar los derechos del trabajador, también lo excluyó, tratando del tema en su párrafo único, de forma selectiva, por lo tanto, discriminatoria, teniendo en cuenta la designación prevista en su caput. Sin embargo, es cierto que algunos derechos hasta entonces asegurados por la Ley n. ${ }^{\circ} 5.859$, de $11 / 12 / 1972$, fueron significativamente ampliados, aunque permaneciendo, como dicho, sensible diferencia con relación a los previstos para los demás trabajadores.

Aunque nombrada como Constitución Ciudadana, por los fundamentos y principios que consagra, la Carta de 1988 no dio a estos trabajadores, cuando de su promulgación, el debido reconocimiento, con todos los derechos inherentes y derivados del trabajo prestado. Afortunadamente, esa discriminación fue corregida con la promulgación de la Enmienda Constitucional n. ${ }^{\circ}$ 72, de $02 / 03 / 2013$, que equiparó a esos trabajadores con los demás trabajadores, como poseedores de los mismos derechos, y con el advenimiento de la Ley Complementaria n. ${ }^{\circ} 150$, de 1.\%/06/2015, que los disciplina.

Incluso con la corrección legal, la práctica cultural, de devaluación del trabajo doméstico, considerándolo un trabajo menor, una de las consecuencias de la desigualdad existente en el país, se mantiene en una resistencia a su reconocimiento legal como un trabajo como cualquier otro y con derechos iguales.

En ese contexto, y de forma más dañosa, tenemos la realidad del trabajo infantil doméstico, que es toda prestación de servicios continuada, remu- 
nerada o no, realizada por persona con edad inferior a 18 años, para terceros o para su propia familia, y que se naturalizó a lo largo de los años.

Para comprender esta naturalización, uno debe tener en cuenta el régimen esclavista en nuestro país. $\mathrm{Y}$, al respecto, se puede tener como referencia el advenimiento de la Ley del Vientre Libre, Ley n. ${ }^{\circ}$ 2.040, de 28/9/1870, porque ejemplar en cuanto al tratamiento dudoso de liberar y, al mismo tiempo, mantener la tutela de los niños nacidos de esclavas.

Dicha ley decía libres a los hijos de esclavas, nacidos a partir de aquel momento, pero, al mismo tiempo, traía dispositivos que acababan por mantenerlos vinculados al señor $\left(\right.$ Art. $\left.1^{\circ}\right) .{ }^{9}$ Varios son los textos que la analizan y se reportan a las polémicas por ella generadas en la época. Al respecto escribe Marília B. A. Ariza (2018, p. 174-175), en artículo del cual se extrae el siguiente trecho, esclarecedor:

La imagen de la infancia esclava es realmente desoladora. Volviendo al punto de partida, se tiene la pregunta: cha cambiado algo en la vida de estos niños y niñas con la aprobación de la Ley del vientre libre? En la práctica, a pesar de señalar el fin ineludible de la esclavitud que perdía definitivamente sus medios de reproducción, la ley tuvo el efecto de prolongarlo hasta el límite de las posibilidades. Los señores de las madres de los "ingenuos" buscaban a toda costa falsificar los registros de nacimiento obligatorios que demostraban su condición de personas libres, omitiendo o falsificando fechas. Además, la libertad prometida era, por lo menos, dudosa: hasta los ocho años de edad, debían permanecer bajo la tutela de los dueños de sus madres; estos podrían, entonces, optar por ofrecerlos a asilos públicos a cambio de indemnizaciones de 600 mil-réis, o por mantenerlos consigo y disfrutar de sus servicios hasta los 21 años. Raros fueron aquellos que eligieron las indemnizaciones y entregaron a los pequeños al Estado; la mayoría prefirió conservar la mano de obra de niños que en pocos años desempeñarán servicios de adultos. En las décadas de 1870 y 1880, momento en que los índices de manumisión crecían, la ley creaba obstáculos para la emancipación de las familias de los "ingenuos", especialmente para sus madres. Aunque pudieran comprar sus cartas de libertad, estas mujeres se veían obligadas a permanecer bajo el dominio de sus amos si quisieran permanecer cerca de sus hijos.

Después de la abolición, en 1888, antiguos señores intentaron con avidez mantener el control sobre los "ingenuos", comprometiéndolos, con la ayuda de las autoridades judiciales, en contratos de trabajo y vínculos de tutela que tenían siempre la misma falsa justificación: velar por los pobres niños y su futuro, enseñándoles oficios y acogiéndolos en hogares adecuados, protegiéndolos de las nocivas influencias que recibirían de sus madres, padres o semejantes. Era necesario instruir niños y niñas en la disciplina del trabajo y fomentar entre ellos el respeto a las jerarquías sociales que sustituían a la esclavitud, para conservar, en la medida de lo posible, las viejas desigualdades. Rutinas de trabajo extenuantes, violencias variadas y fraccionamientos 
familiares continuaron siendo parte de la vida de estos niños durante años en el período posterior a la abolición.

Lógicamente, existen otras causas para que esa realidad se presente, como, por ejemplo, la pobreza, que también alcanza a la mayoría de la población negra en nuestro país, ciertamente como consecuencia de los largos años de esclavitud y de una abolición hecha sin la debida asistencia a los liberados, una de sus consecuencias más crueles.

Ese contexto de pobreza y carencias dio lugar al surgimiento, en algunas regiones del país, en especial norte y nordeste, de la práctica de familias carentes de entregar a sus hijas a otras familias que las acogían como ahijadas, con la esperanza de tener educación y cuidados, por lo tanto, otra perspectiva de vida. Sin embargo, eso raramente se cumplía, una vez que la realidad era la prestación de servicios no remunerados a la familia como retribución a la acogida, configurando muchas veces su exposición a abusos y violencia. Esa es una práctica aún existente.

El art. 248 del Estatuto del Niño y del Adolescente (ECA), Ley n. ${ }^{\circ}$ 8.069 , de 1990, fue una consecuencia de la práctica cotidiana. Y, a pesar de fundamentado en la doctrina de la protección integral, y teniendo como objetivo regular el art. 227 de la Constitución Federal, instituyendo el sistema de garantía de derechos, esa legislación (BRASIL, 1990) trajo el dispositivo, insertado en su Capítulo II, que trata "de las Infracciones Administrativas", verbis:

Art. 248. Dejar de presentar a la autoridad judicial de su domicilio, en el plazo de cinco días, con el fin de regularizar la guardia, adolescente traído de otra comarca para la prestación de servicio, aunque autorizado por los padres o responsable:

Pena-multa de tres a veinte salarios de referencia, aplicándose el doble en caso de reincidencia, independientemente de los gastos de retorno del adolescente, en su caso.

El dispositivo, aunque tuviera como objetivo disciplinar esa realidad, previendo alguna protección a los adolescentes envueltos a ella, proveniente de la guardia prevista, no enfocaba la cuestión del trabajo implícito a la condición, no enfrentando, por lo tanto, la problemática y, ciertamente, no trayendo la protección pretendida, acabando por consolidar una situación de negación de derechos.

Acerca de ese artículo escribió Oris de Oliveira (2003, p. 106): 
La redacción del artículo 248 fue desafortunada, permitiendo la interpretación, en una lectura apresurada de la aceptación (cuando no una consagración) de la costumbre de, bajo pretexto de guardia, tener al adolescente 'para prestación de servicio doméstico', sin límites y fuera del régimen de empleo. Bajo el manto de esa figura atípica de guardia, ha habido y hay numerosos abusos ocasionalmente detectados, cabiendo su inhibición al Consejo Tutelar, a la Fiscalía Pública y al Juzgado de la infancia y de la adolescencia.

El dispositivo fue finalmente derogado en 2017, por la Ley n. ${ }^{\circ} 13.431$, que establece el sistema de garantía de derechos del niño y del adolescente víctimas o testigos de violencia y altera dispositivos del ECA. Es verdad que, desde la promulgación del Decreto n. ${ }^{\circ}$ 6.481, de 12/6/2008, que aprobó la lista de las peores formas de trabajo infantil como consecuencia de la ratificación del Convenio n. ${ }^{\circ} 182$ de la OIT, el dispositivo era considerado derogado.

Se ve, por lo tanto, que, incluso en un momento de garantía de derechos a los niños y a los adolescentes, el ECA trajo una norma que reflejaba un procedimiento usual de la sociedad, a demostrar su imaginario, de que niños y adolescentes pobres son susceptibles de ser tutelados, a ejemplo de lo que preveía el derogado Código de Menores $^{10}$, no siendo vistos, por lo tanto, como sujetos de todos los derechos enumerados en el citado Art. 227, que integran la protección integral allí dispuesta.

Es importante ese enfoque más amplio para entender la realidad del trabajo infantil doméstico y las condiciones perjudiciales que lo envuelven, como una puerta para abusos, incluso sexuales, malos tratos y violencia.

Esto es potenciado por el hecho de ser ejecutado en domicilios, teniendo, por lo tanto, como característica ser un trabajo oculto, invisible, protegido del conocimiento de terceros, debido a la inviolabilidad que les es inherente, como previsto constitucionalmente (Art. $5^{\circ}$, X y XI, CF). La preservación de la intimidad es, por lo tanto, propiciadora de malos tratos y abusos, incluso sexuales, escondida que está su situación de la mirada del otro, de la sociedad de un modo general.

Es importante señalar que la realidad del trabajo infantil doméstico como situación de trabajo en condiciones perjudiciales e, incluso, de violencia y malos tratos, comenzó a ganar espacio a partir de estudios desarrollados al respecto, que trajeron a la superficie esa realidad, oculta, de explotación, de exposición y de fragilización de los niños y adolescentes en ella envueltos. 
Incluso el Programa de Erradicación del Trabajo Infantil (PETI) ${ }^{11}$, que, en un primer momento, se volvía a algunas situaciones de trabajo infantil consideradas más graves, entre ellas, el trabajo en carbonerías, canteras y casas de harina, delante de esa realidad, y a partir de la reivindicación de las entidades involucradas en la lucha al trabajo infantil, pasó a contemplar a las familias que tenían niños y adolescentes en situación de trabajo doméstico.

En la época, sobresalía la dificultad de la actuación de la fiscalización del trabajo, en razón del principio constitucional de la inviolabilidad del domicilio, lo que fue siendo superado, con procedimientos como el contacto con el empleador o empleadora y sus audiciones para averiguación de la realidad del trabajo, la ida al lugar de trabajo con su autorización y, en casos graves o de negativa de acceso, la obtención de mandato judicial para el acceso al ambiente de trabajo.

Con los estudios y las acciones desarrollados por comisión específica, creada en el marco de la CONAETI, para la elaboración de la Lista de las peores Formas de Trabajo Infantil, de que trata la Convención n. ${ }^{\circ}$ 182, el trabajo infantil doméstico fue así considerado, llegando a formar parte de la lista aprobada por el Decreto n. ${ }^{\circ}$ 6.481/2008.

Conforme referida lista, la actividad compone su ítem 76 , que trae los riesgos ocupacionales envueltos ${ }^{12}$ y las probables repercusiones a la salud ${ }^{13}$. Entre los riesgos ocupacionales, se enumeran esfuerzos físicos intensos, aislamiento, abusos físicos, psicológicos y sexuales. Entre las repercusiones para la salud, contusiones, fractura, heridas, quemaduras, entre otros.

El trabajo doméstico tiene una rutina de actividades repetitivas, penosas, de manipulación de materiales agresivos y tóxicos, siendo susceptibles de provocar accidentes, en especial cuando practicadas por niños y adolescentes, dejándolos a merced del control y de la explotación del adulto, sometidos a largas jornadas de trabajo, además de quedar en confinamiento, lejos de la convivencia social con otros niños y adolescentes y de la familia. Esta realidad es más frecuente en el caso de niños y adolescentes traídos de otros estados y localidades.

Esto es informado por Mauricio Antunes Tavares (2002, p. 37):

Los niños y adolescentes trabajadores domésticos que participaron de esta investigación revelan que el ingreso precoz en el mercado de trabajo, desde el inicio se configura como una relación de explotación, donde los adultos se 
valen de la vulnerabilidad y de la inexperiencia de los más jóvenes ¡desde la "negociación" del "contrato de trabajo!" [...]

El factor edad es la base de muchas discriminaciones y violencias, como la explotación del trabajo infantil, el abuso y la explotación sexual, el abandono y los malos tratos a los niños y adolescentes. Esa "lógica" perversa de abusar y explotar aquellas que deberían ser protegidas también se hace presente en el trabajo infantil doméstico; cuanto menor sea la edad del niño o preadolescente, pero fácil engañarla y maltratarla, sea pagando salarios irrisorios, prohibiendo salidas, descuidando holguras, vacaciones y otros derechos legalmente debidos a las empleadas domésticas, sea agrediendo verbal y físicamente-dando tapas, pellizcos, pudiendo llegar incluso al abuso sexual. Mientras tanto, los violadores siguen protegidos de la inviolabilidad del hogar y la omisión del Estado de la sociedad y de la familia.

Se debe recordar en ese contexto que la Convención n. ${ }^{\circ}$ 182, para efecto de sus disposiciones, considera niño toda persona con edad inferior a 18 años, siguiendo el concepto adoptada por la Convención de los derechos del Niño de la ONU.

La Convención, al enumerar en su art. $3^{\circ}$ las peores formas de trabajo infantil, trae la letra "d" que considera como peor forma de trabajo aquel "que, por su naturaleza o por las condiciones en que es realizado, es susceptible de perjudicar la salud, la seguridad o la moral de los niños" (OIT, 2000).

Por otro lado, la Recomendación n. ${ }^{\circ}$ 190, que complementa la Convención, sirviendo de parámetro para su aplicación, trae en sus ítems I y II indicativos de acciones y de condiciones de trabajo a ser consideradas en el tratamiento del problema. El ítem I aborda los Programas de Acción que tiene entre sus objetivos prestar especial atención, entre otros, a los niños más jóvenes, a las niñas y al problema del trabajo oculto, en el cual las niñas están particularmente expuestas a riesgos. Por otro lado, el ítem II se refiere al trabajo peligroso, enumerando una serie de situaciones para localizar los trabajos en que el niño quede expuesto a abusos de orden físico, psicológico o sexual y aquellos que lo retengan injustificadamente en lugares del empleador (OIT, 1999).

Convención y Recomendación, por lo tanto, conceptualizan las condiciones perjudiciales de trabajo para el concepto de peores formas de trabajo infantil, en las que se inserta el trabajo infantil doméstico.

Una situación aparte, pero también importante para las acciones de combate y prevención de toda forma de trabajo infantil, y que, por lo tanto, 
también debe ser considerada para efecto de las acciones y políticas públicas específicas, es la de los quehaceres domésticos, en que están involucradas niños y adolescentes en el intervalo etario de 5 a 17 años, y que viene siendo enfocada, en especial, en el PNAD continua de 2016 (IBGE, 2017).

Los quehaceres domésticos pueden tener diferentes clasificaciones, con objetivos y consecuencias también diferentes. Existe el desempeño de pequeñas tareas caseras, que se insertan efectivamente en la característica de actividades de cuño educativo y de formación. Serían pequeñas y breves tareas dadas al niño y al adolescente, de acuerdo con su edad y condición, que se insertan en la convivencia familiar y se revelan de integración y socialización, de participación en el día a día de la familia, de asunción gradual de responsabilidad y de solidaridad, de integración a la colectividad familiar.

Estas actividades, especialmente cuando son practicadas por niños, deben ser realizadas en compañía y con la supervisión de los adultos, y constituyen verdadero enseñar a compartir y contribuir. En estas tareas se incluyen, por ejemplo, arreglar la propia cama, guardar la propia ropa, ayudar a lavar y secar la vajilla etc. Son pequeños los momentos del día a día que no interfieren en las actividades escolares, de ocio, de descanso, de juego.

Sin embargo, en muchas situaciones, estos quehaceres domésticos ocurren durante gran parte del día, envolviendo a niños y adolescentes en tareas de cuidados de la casa y de niños, generalmente hermanos y hermanas, tareas que son propias del adulto, de los padres, sus responsables legales. En estas condiciones, asumen la condición de trabajo infantil, con las consecuencias derivadas. Cuando esa realidad es constante, esa continuidad configura trabajo, con repercusiones perjudiciales, por la negación de derechos proveniente.

En tales casos, existe la ocupación de esos niños y adolescentes en tareas de trabajo en la propia casa, porque los están ejecutando en el lugar de sus padres, asumiendo obligaciones inherentes a ellos, propias de los adultos. Se invierte, así, la lógica de la actividad socializadora, integradora, educativa, para la actividad de trabajo, de ejecutar actividades de cuidado y de preservación de la familia.

Esto tiene también valor económico, en la medida en que libera al adulto para el ejercicio de otras actividades, en la búsqueda de condiciones de 
supervivencia, lo que es hecho al costo del sacrificio de esos niños y de esos adolescentes del tiempo necesario para la adquisición de la escolaridad, de la convivencia social con otros niños y adolescentes, del ocio, imprescindible en esa fase de desarrollo, de adquisición de saberes para su maduración, en perjuicio, por lo tanto, de su desarrollo regular y sano. Como se consagra en la Constitución, son personas en desarrollo, sujetas a protección completa.

Por lo tanto, los datos al respecto no pueden ser minimizados y subestimados, bajo pena de distorsión de la realidad, teniendo como consecuencia la no adopción de políticas públicas que traten la cuestión y llegue a todo niño y adolescente en situación de trabajo, cualquiera que sea, por los perjuicios a su integridad como personas.

\section{TRABAJO INFANTIL DOMÉSTICO - PREVENCIÓN Y ENFRENTAMIENTO}

Los datos del IBGE de 2013, analizados por un estudio publicado por el FNPETI (2015) revelan que los niños y adolescentes en el intervalo de edad de 5 a 17 años involucrados en el trabajo infantil doméstico sumaban poco más de 213 mil, de un total de 3,2 millones de niños y adolescentes, en el mismo intervalo de edad, en trabajo. De ese total, 124.682 en el intervalo de edad de 16 a 17 años, con algunos estados presentando un aumento de ese trabajo en el intervalo de 10 a 13 años. Las niñas eran mayoría, alrededor del $96 \%$, y el $73,4 \%$ eran negras.

Ya en el año 2011, eran 258 mil niños y adolescentes en la misma franja etaria en la actividad, conforme datos también del IBGE, permaneciendo porcentaje semejante de niñas y negras referido anteriormente.

Para una breve comparación, existe la cita hecha por Tavares a Schwartzman en su análisis del PNAD/IBGE, que apunta que, en 1998, eran cerca de 559 mil niños y adolescentes, de 10 a 17 años, "en el mercado de trabajo de los servicios domésticos” (TAVARES, 2002, p. 24), aunque, esclarezca que otros estudios traen otros números, por ejemplo, de 375 a 400 mil.

Por estos datos, se observa una disminución en el número de niños y adolescentes involucrados en la actividad, lo que, de hecho, ha estado sucediendo con el tiempo. Sin embargo, ese número todavía es significativo, considerándose estar delante de una de las peores formas de trabajo infantil, 
en un trabajo oculto, en que los menores quedan expuestos a abusos de todos los tipos, además de otros riesgos, como accidentes de trabajo.

Los datos ilustran una composición apremiante de niños y adolescentes provenientes de familias pobres, debilitadas. En ese sentido, como expuesto, las niñas son las más envueltas, además de ser en su mayoría negras, lo que se presenta coherente con lo que fue tratado anteriormente, de ser una actividad con raíces en el régimen esclavista.

Los datos también apuntan que la mayoría está en el intervalo de edad de los 14 a los 17 años, aunque, cuando es trabajo ejercido para la propia familia, sobresale el intervalo de edad de los 9 a los 13 años.

El PNAD continua de 2016 trae datos sobre trabajo infantil en separado de los datos traídos para el trabajo realizado para el propio consumo, lo que resulta en la distorsión del número de niños y adolescentes en situación de trabajo precoz, una vez que indica 1 millón y 700 mil niños y adolescentes en el intervalo de edad de 5 a 17 años en la condición de trabajo infantil y de poco más de 700 mil de niños y adolescentes en el mismo intervalo de edad, envueltos en trabajo para el propio consumo (IBGE, 2017).

Esto necesita ser enfocado, una vez que el trabajo ejercido para el propio consumo trae las mismas consecuencias del trabajo ejercido fuera de ese contexto, como fragilización, vulnerabilidad, negación de derechos, con consecuencias negativas para el desarrollo pleno de esos niños y adolescentes. Por otro lado, es importante el hecho de que el trabajo doméstico involucra a una gran mayoría de niñas negras, mostrando una vulnerabilidad específica, que requiere atención y cuidado en su combate y prevención. Tavares (2002, p. 30) escribe acerca:

Si, como dice Thompson, "para la mayoría de las personas, las relaciones de poder y dominación que las alcanzan más directamente son las caracterizadas por los contextos sociales dentro de los cuales ellas viven sus vidas cotidianas: la casa, el lugar de trabajo, el aula, los compañeros" (1989:18), entonces tenemos que considerar en el trabajo doméstico infanto-juveniles, además de los aspectos relacionados a las condiciones materiales de vida de los trabajadores, las dimensiones vividas por niños y adolescentes en casa, en la escuela y en la comunidad.

Significa decir que la dimensión de trabajadoras domésticas es dividida por las dimensiones de ser niño o adolescente, mujer, negra y mestiza. Son elementos que los unen y los distinguen de los universos de las trabajadoras domésticas adultas y de otros niños y adolescentes trabajadoras. Así, 
es común encontrar niñas pobres siendo iniciadas en el trabajo doméstico desde los primeros años de vida, generalmente comenzando a los siete, ocho años en el trabajo intrafamiliar, siguiendo después para el mercado del trabajo doméstico remunerado como un desdoblamiento "natural" de su condición de mujer, negra y mestiza, niña o adolescente, y pobre (cursiva nuestra).

La prevención y eliminación del trabajo infantil doméstico necesariamente debe abordar esta realidad. La educación, como siempre, es un factor fundamental para disminuir la desigualdad existente en nuestro país y, seguro, para retirar niños y adolescentes de la situación de trabajo. Como se ve, la garantía de sus derechos, como personas en desarrollo, sujetas a la protección completa, no se obtendrá sin la obtención del acceso a la escuela en todos los niveles.

Al mismo tiempo, ésta debe estar acompañada de la garantía de otros derechos, como de convivencia familiar y con otros niños y adolescentes, salud, bienestar, ocio, entre otros, en la forma definida en el ECA, finalmente, del derecho a la libertad, respeto y dignidad como personas humanas.

Para situar mejor la cuestión, se discrimina las recomendaciones traídas por Maria Ignez Moreira y Márcia Stengel (2003, p. 59-60), organizadoras de la obra Narrativas Infanto-juveniles sobre el trabajo Doméstico, a saber:

[...] fortalecimiento de la educación escolar; programas destinados a la familia; programas destinados a la capacitación para el trabajo de las adolescentes; programas de ocio y cultura; programas dirigidos a la salud sexual-reproductiva de las adolescentes; formación de grupos de reflexión para adolescentes que están frecuentando programas específicos; implementación de la red de servicios públicos; campañas publicitarias, y realización de investigación sobre los servicios domésticos hecho por niños y adolescentes en Brasil.

Las recomendaciones presentan legitimidad, porque resultado de la investigación con niños y adolescentes envueltas en el trabajo doméstico, revelan la realidad vivida por ellas y sus necesidades, siendo referencia para pensar la cuestión. Se presentan así como un punto de partida para hablar de prevención y erradicación.

La realización de investigación sobre el tema, una de las recomendaciones hechas, llama la atención porque viene acompañada de reflexión, en el sentido de que "las familias perecen ver esa actividad como estrategia de socialización de las niñas", y de que "las tareas parecen naturalizadas, por ser consideradas como una 'obligación' de las mujeres y teniendo en vista las relaciones de intercambio establecidas en el interior de las casas" (MOREI- 
RA; STENGEL, 2003, p. 59-60). Aunque la reflexión esté situada en el año 2003, se presenta todavía como referencia en estos días, teniendo en cuenta la desigualdad que se mantiene y, lamentablemente, se profundiza, así como las desigualdades de género presentes. Las autoras llaman también la atención sobre el hecho de que "las adolescentes entrevistadas son trabajadoras domésticas no las exime de la obligación del servicio doméstico, lo que significa una exposición a la doble jornada" (MOREIRA; STENGEL, 2003, p. 59-60).

De ahí la necesidad de que las políticas públicas específicas prevean también programas de asistencia y apoyo a las familias, así como visar las cuestiones de género y raza, que hacen más fragilizadas a esos niños y adolescentes. En ese sentido, también destaca la recomendación citada, de programas dirigidos para la salud sexual-reproductiva de las adolescentes.

El fortalecimiento de la educación escolar es algo que impregna esta y otras realidades del trabajo infantil. Aunque los datos del PNAD siguen de 2016 del IBGE revelan que parte de los niños y adolescentes que trabajan asisten a la escuela, la problemática no se resuelve en estar en la escuela, porque, además de que el trabajo trae el desfase escolar, trae también el abandono de la escuela posteriormente.

La educación escolar no implica solamente estar en la escuela, sino especialmente mantenerse en ella en condiciones de aprendizaje, trayendo como inherente a ésta la calidad de la enseñanza y la enseñanza a tiempo completo.

Es inherente a la educación escolar el tiempo de estudio y reflexión, así como las actividades de apoyo y orientación. Y esto, por sí solo, impone la cuestión del tiempo, que deberá estar disponible, lo que aleja el simple estar en la escuela y, al mismo tiempo, el trabajar, sea para terceros, sea para el propio consumo, así como los llamados “quehaceres domésticos”, que, como ya expuesto, vienen escamoteados en trabajo, no configurando, como debía, ocasiones de socialización e integración a la familia.

Por otro lado, asociada a la obtención de la escolaridad existe la formación profesional del adolescente, a partir de los 14 años, como previsto en la Constitución, que debe ocurrir en la forma de la consolidación de las leyes del trabajo (CLT), de "formación técnico-profesional metódica, compatible con su desarrollo físico, moral y psicológico", caracterizándose por "actividades teóricas y prácticas, metódicamente organizadas en tareas de compleji- 
dad progresiva, desarrolladas en el ambiente de trabajo" (BRASIL, 1943, Art. 428). Escolaridad y formación profesional forman un binomio esencial para la preparación del adolescente para la adquisición de condiciones de elección para el ejercicio de cualquier actividad.

De suma importancia las referencias a la convivencia social y al ocio, porque como personas humanas en desarrollo, la convivencia con niños y adolescentes de la misma edad es primordial para verse y comprenderse como tales, compartiendo deseos, anhelos y miedos propios de la edad. La convivencia familiar, a darles seguridad y apoyo en ese crecimiento. El ocio, como momento de relajación y de no hacer nada o hacer lo que apetece, también se muestra primordial para un desarrollo sano.

Todo esto implica el ejercicio de la libertad, el respeto y la preservación de su dignidad. Es lo que deben desear y disfrutar cada niño y adolescente, y es lo que corresponde al estado, a la sociedad y a la familia proporcionar.

\section{NOTAS}

1 Véase el PNAD continuo de 2016 (IBGE, 2017). Aunque el IBGE ya tenga datos actualizados al respecto, aún no se han divulgado, hasta el momento.

2 Creada por la Ordenanza MTE n. ${ }^{\circ} 365$, de 12/09/2002, modificada por la Ordenanza MTE n. ${ }^{\circ} 952$, de 08/07/2003, fue extinguida por la Ordenanza N. ${ }^{\circ}$ 972, de 21/08/19, del Secretario Especial de Previsión y Trabajo, del Ministerio de Economía. El Ministerio Público del Trabajo era uno de sus componentes.

3 Dicho plan prevé acciones para el período 2019-2022. Su texto fue refrendado por el Consejo Nacional de los Derechos del niño y del Adolescente (CONANDA), habiendo sido elaborado a partir de la evaluación del plan previsto para el período 2011-2015, que demostró la ejecución del 60\% de las acciones previstas, conforme muestra la publicación específica del Foro Nacional de Prevención y Erradicación del Trabajo Infantil - FNPETI, disponible en www.fnpeti.org.br.

4 El FNPETI fue creado en (el) 1994.

5 El Ministerio Público del Trabajo tiene como una de sus prioridades activas la erradicación del trabajo infantil y la regularización del trabajo del adolescente. Para tanto, se creó, en el año 2000, la Coordinación Nacional de Combate contra la Explotación del Trabajo de Niñas, Niños y Adolescentes (Coordinfância).

6 Agenda 2030 de la ONU. ODS 8-Promover el crecimiento económico sostenido, inclusivo y sostenible, pleno empleo y productivo, y el trabajo decente para todos. Meta 8.7-Tomar medidas inmediatas y eficaces para erradicar el trabajo forzado y acabar con la esclavitud moderna y la trata de personas. Y asegurar la prohibición y eliminación de las peores formas de trabajo infantil, incluyendo el reclutamiento y uso de niños-soldado, y hasta 2025 poner fin al trabajo infantil en todas sus formas.

7 El Convenio n. ${ }^{\circ} 182$ de la OIT fue aprobado por su Asamblea General en junio de 1999, siendo ratificado por Brasil y promulgado por el Decreto n. ${ }^{\circ} 3.597$, de 12/09/2000. Ella trata de las peores Formas de Trabajo Infantil y la acción inmediata para su Eliminación, siendo complementada por la Recomendación n. ${ }^{\circ} 190$. 
8 Aprobada por el Decreto-Ley n. ${ }^{\circ}$ 5.452, de $1 .^{\circ} / 5 / 1943$.

9 Art. $1^{\circ}$ los hijos de mujer esclava que nazcan en el Imperio desde la fecha de esta ley, serán considerados de condición libre. $\int 1^{\circ}$ los dichos hijos menores quedarán en poder o bajo la Autoridad de los señores de sus madres, los cuales tendrán obligación de criarlos y tratarlos hasta la edad de ocho años completos. Llegando el Hijo de la esclava a esta edad, el Señor de la madre tendrá opción, o de recibir del Estado la indemnización de $600 \$ 000$, o de utilizarse de los servicios del menor hasta la edad de 21 años completos. En el primer caso, el Gobierno recibirá el menor, y le dará destino, de conformidad con la presente Ley. La indemnización pecuniaria arriba fijada será pagada en títulos de renta con el interés anual del $6 \%$, los cuales se considerarán extintos al final de 30 años. La declaración del Señor deberá ser hecha dentro de 30 días, a partir de aquel en que el menor llegue a la edad de ocho años y, si no la hace entonces, quedará entendido que opta por el arbitrio de utilizar los servicios del mismo menor. $\int 2^{\circ}$ cualquiera de esos menores podrá redimirse del peso de servir, mediante previa indemnización pecuniaria, que por sí mismo o por otro oferte al Señor de su madre, procediéndose a la evaluación de los servicios por el tiempo que le quede a llenar, si no hay acuerdo sobre el quantum de la misma indemnización. $\int 3^{\circ}$ corresponde también a los señores criar y tratar a los hijos que las hijas de sus esclavas puedan tener cuando aquellas estén prestando servicios. Sin embargo, esta obligación cesará en cuanto finalice la prestación de los servicios de las madres. Si éstas mueren dentro de ese plazo, sus hijos podrán ser puestos a disposición del Gobierno. $\int 4^{\circ}$ si la Mujer esclava obtiene libertad, los hijos menores de ocho años, que estén en poder del su Señor por virtud del $\int 1^{\circ}$, le serán entregados, excepto si prefiere dejarles, y el Señor estará de acuerdo en quedarse con ellos. $\int 5^{\circ}$ en el caso de alienación de la mujer esclava, sus hijos libres, menores de 12 años, la acompañarán, quedando el nuevo señor de la misma esclava subrogado en los derechos y obligaciones del predecesor. $\int 6^{\circ}$ cesa la prestación de los servicios de los hijos de las esclavas antes del plazo señalado en el $\int 1^{\circ}$, si, por sentencia del juicio penal, se reconoce que los señores de las madres los maltratan, infligiéndoles castigos excesivos. $\int 7^{\circ}$ el derecho conferido a los señores en el $\int 1^{\circ}$ se transfiere en los casos de sucesión necesaria, debiendo el hijo de la esclava prestar servicios a la persona a quien en las acciones pertenezca la misma esclava (BRASIL, 1871).

10 El Código de Menores, Ley n. ${ }^{\circ}$ 6.667, de 10/11/1979, fue derogado por la Constitución de 1988, alejando, por lo tanto, del escenario del tratamiento legal de las cuestiones relativas al niño y al adolescente la doctrina de la situación irregular. Su art. $2^{\circ}$ describe a los niños y adolescentes en situación irregular, como, por ejemplo, aquellos privados de condiciones esenciales de subsistencia, víctimas de malos tratos, en peligro moral, autores de infracción penal (BRASIL, 1979).

11 Programa del gobierno federal, creado en 1996, dirigido a combatir la explotación del trabajo de niños y adolescentes.

12 Esfuerzos físicos intensos; aislamiento; abuso físico, psicológico y sexual; largas jornadas de trabajo; trabajo nocturno; calor; exposición al fuego, posiciones anti ergonómicas y movimientos repetitivos; tracción de la columna vertebral; sobrecarga muscular y caída de nivel.

13 Trastornos musculo esqueléticos (bursitis, tendinitis, dorsalgias, sinovites, tenosinovites); contusiones; fracturas; lesiones; quemaduras; ansiedad; cambios en la vida familiar; trastornos del ciclo vigilia-sueño; DORT/LER; deformidades de la columna vertebral (lumbociatalgias, lumbociatalgias, escoliosis, cifosis, lordosis); síndrome de agotamiento profesional y neurosis profesional; traumatismos; mareos y fobias. 


\section{REFERENCIAS}

AGÊNCIA DE NOTÍCIAS DOS DIREITOS DA INFÂNCIA. Crianças Invisíveis - $\mathrm{O}$ enfoque da Imprensa sobre o Trabalho Infantil Doméstico e outras formas de exploração. Série Mídia e Mobilização Social, v. 6. São Paulo: Cortez Editora, 2003.

ARIZA, Marília B. A. Crianças/Ventre Livre. In: Dicionário da Escravidão e Liberdade, 50 textos críticos. SCHARCZ, Lilia M.; GOMES, Flávio [org.]. São Paulo: Companhia das Letras, 2018.

BRASIL. Lei n. ${ }^{\circ}$ 2.040, de 28 de setembro de 1871. Rio de Janeiro, set. 1871. Declara de condição livre os filhos de mulher escrava que nascerem desde a data desta lei, libertos os escravos da Nação e outros, e providencia sobre a criação e tratamento daqueles filhos menores e sobre a libertação anual dos escravos. Disponible en: http://www.planalto.gov.br/ccivil_03/ leis/LIM/LIM2040.http. Acceso en: 18 ago. 2020.

BRASIL. Decreto-Lei . $^{\circ} \mathbf{5 . 4 5 2}$, de $1 .^{\circ}$ de maio de 1943. Aprova a Consolidação das Leis do Trabalho. Rio de Janeiro, maio de 1943. Disponible en: http://www.planalto.gov.br/ccivil_03/decreto-lei/Del5452compilado.htm. Acceso en: 17 sept. 2020.

BRASIL. Lei n. ${ }^{\circ}$ 6.697, de 10 de outubro de 1979. Institui o Código de Menores. Disponible en: http://www.planalto.gov.br/ccivil_03/leis/19701979/L6697.htm. Acceso en: 18 ago. 2020.

BRASIL. Decreto n. ${ }^{\circ}$ 6481, de 12 de junho de 2008. Regulamenta os artigos 3o, alínea "d", e 4o da Convenção 182 da Organização Internacional do Trabalho (OIT) que trata da proibição das piores formas de trabalho infantil e ação imediata para sua eliminação, aprovada pelo Decreto Legislativo no 178, de 14 de dezembro de 1999, e promulgada pelo Decreto no 3.597, de 12 de setembro de 2000, e dá outras providências. Brasília/DF, jun. 2008. Disponible en: http://www.planalto.gov.br/ccivil_03/_ato2007-2010/2008/ decreto/d6481.htm. Acceso en: jun. 2020.

CONSELHO NACIONAL DOS DIREITOS DA CRIANÇA E DO ADOLESCENTE. Estatuto da Criança e do Adolescente - 12 anos. Edição Especial. [S.l.], [20--]. 
FÓRUM NACIONAL DE PREVENÇÃO E ERRADICAÇÃO DO TRABALHO INFANTIL. Trabalho Infantil Doméstico no Brasil - Avaliação a partir dos Microdados da PNAD-IBGE (2008-2011). Brasília: FNPETI, 2013. Disponible en: www.fnpeti.org.br. Acceso en: jun. 2020.

FÓRUM NACIONAL DE PREVENÇÃO E ERRADICAÇÃO DO TRABALHO INFANTIL. Trabalho Infantil e Trabalho Infantil Doméstico no Brasil - Avaliação a partir dos Microdados da PNADF/IBGE (2012/2013). Brasília: FNPETI, 2015. Disponible en: www.fnpeti.org.br. Acceso en: jun. 2020.

IBGE. PNAD Contínua de 2016 (IBGE). [S.1.], 2017. Disponible en: www. ibge.gov.br. Acceso en: jun. 2020.

LIMA, Andréa. “Onde está Kelly”. In: TAVARES, Maurício Antunes Tavares. Onde está Kelly? O trabalho oculto de crianças e adolescentes explorados nos serviços domésticos na cidade do Recife. Coleção Cadernos Cendhec volume II. Recife: CENDHEC (Centro Dom Hélder Câmara de Estudos e Ação Social), 2002.

MINISTÉRIO DO TRABALHO E EMPREgO. Portaria n..$^{\circ}$ 365, de 12/09/2002. Institui, no âmbito do Ministério do Trabalho e Emprego, a Comissão Nacional de Erradicação do Trabalho Infantil - CONAETI. Disponible en: https://www.legisweb.com.br/legislacao/?id=183758. Acceso en: jun. 2020.

MINISTÉRIO DO TRABALHO E EMPREgO. Portaria n..$^{\circ}$ 952, de 08/07/2003. Dispõe sobre a Comissão Nacional de Erradicação do Trabalho Infantil - CONAETI. Disponible en: https://www.legisweb.com.br/legislacao/?id=185214. Acceso en: jun. 2020.

MINISTÉRIO DO TRABALHO E EMPREgO. Portaria n. 972, de 21/08/2019. Revoga portarias de criação de colegiados e de aprovação dos respectivos regimentos no âmbito do extinto Ministério do Trabalho (Processo n. ${ }^{\circ}$ 19964.103375/2019-89). Disponible en: https://www.legisweb.com. br/legislacao/?id=381718. Acceso en: jun. 2020.

MOREIRA, Maria Ignez; STENGEL, Márcia [org]. Narrativas Infanto-Juvenis sobre o Trabalho Doméstico. Belo Horizonte, MG: Editora PUCMinas/Save The Children, 2003. 
ORGANIZAÇÃO DAS NAÇÕES UNIDAS. Agenda 2030. Disponible en: https://nacoesunidas.org/pos2015/agenda2030/. Acceso en: jun. 2020.

\section{ORGANIZAÇÃO INTERNACIONAL DO TRABALHO. Convenção}

n. ${ }^{\circ}$ 182. Convenção sobre Proibição das Piores Formas de Trabalho Infantil e Ação Imediata para sua Eliminação. [S.l.], 19 nov. 2000. Disponible en: https://www.ilo.org/brasilia/convencoes/WCMS_236696/lang--pt/index. htm. Acceso en: 17 sept. 2020.

ORGANIZAÇÃO INTERNACIONAL DO TRABALHO. Recomendação n. ${ }^{\circ}$ 190. Sobre Proibição das Piores Formas de Trabalho Infantil e Ação imediata para sua Eliminação. [S.1.], jun. 1999. Disponible en: https:// www.ilo.org/brasilia/temas/trabalho-infantil/WCMS_242762/lang--pt/index.htm. Acceso en: 17 sept. 2020.

TAVARES, Maurício Antunes. Onde está Kelly? O trabalho oculto de crianças e adolescentes explorados nos serviços domésticos na cidade do Recife. Coleção Cadernos Cendhec - volume II. Recife: CENDHEC (Centro Dom Hélder Câmara de Estudos e Ação Social), 2002. 


\title{
TRABAJO INFANTIL EN LAS CALLES Y RACISMO ESTRUCTURAL: DESAFÍOS EN LA ACTUACIÓN DEL MINISTERIO PÚBLICO DEL TRABAJO
}

\author{
ELISIANE SANTOS
}

DOI: 10.51366/978-65-89468-10-3-coordinfancia-8

Resumen. El trabajo infantil en las calles de Brasil está relacionado al racismo estructural. Tiene su origen en la post abolición y persiste hasta los días actuales, alcanzando masivamente a los niños negros. Tales análisis vienen de estudios académicos, como de actuación profesional en la temática, que apuntan al racismo como estructurante de las desigualdades sociales productoras y reproductoras del trabajo de niños y adolescentes. Este artículo pretende traer al debate la cuestión racial presente en esa modalidad de trabajo infantil, como también indicar caminos posibles, a partir de políticas de promoción a la igualdad y combate a la discriminación racial, para avanzar en las acciones de enfrentamiento al trabajo infantil en las calles.

Palabras clave: Trabajo Infantil en las Calles. Racismo. Políticas Públicas. Ministerio Público del Trabajo.

\section{INTRODUCCIÓN}

En las últimas décadas, tuvimos una importante reducción del trabajo infantil en Brasil, pasó de más de 9 millones (1996) de niños en situación de trabajo para 2,5 millones (2016). Sin embargo, esos datos, extraídos de PNAD/IBGE, no traen de forma precisa el retrato de las diferentes modalidades de trabajo infantil, notoriamente aquel que ocurre en las calles y está directamente relacionado a la historia de exclusión social de la población negra, vivenciada desde la abolición del sistema esclavista en Brasil y que trae reflejos hasta la actualidad, alcanzando a la población infantil negra. 
En este ensayo, a partir de estudios realizados en investigación académica, como también experiencia en la actuación en el Ministerio Público del trabajo, intercambio de saberes con diferentes actores sociales en espacios de debate como el Fórum Paulista de Prevención y Erradicación al Trabajo Infantil, y otros que actúan en la protección de la infancia y también en foros y comisiones que actúan en la promoción de la igualdad racial, pretendemos demostrar la relación existente entre racismo y trabajo infantil en las calles. Y a partir de eso, apuntar la necesidad de análisis de esta cuestión como estructurante del trabajo infantil, para avanzar en las acciones y políticas sociales para su enfrentamiento.

\section{EL TRABAJO INFANTIL EN LAS CALLES EN LA POST ABOLICIÓN}

Al trabajo infantil en la historia de Brasil normalmente se lo asocia al período industrial, cuando los niños y los adolescentes trabajaban en jornadas extenuantes, condiciones peligrosas, insalubres, en las fábricas, junto con las mujeres, en régimen de superexplotación, sin derechos asegurados, lo que al inicio del siglo XX daría origen a las primeras legislaciones de protección en el trabajo. Hay que remarcar al movimiento obrero, en el período, notoriamente la Huelga General de 1917, que tuvo como pauta principal la abolición del trabajo infantil. En el escenario internacional, la creación de la Organización Internacional del Trabajo (OIT), en 1919, y las primeras normas de protección internacional en el trabajo, direccionadas a la eliminación del trabajo infantil en la industria.

De otro lado, anteriormente a esta situación, en el período colonial, niños negros, junto con los adultos, traídos de África, fueron sometidos a trabajo esclavo, en los servicios domésticos, en la agricultura, en condiciones degradantes y serviles. Muchos ni siquiera tenían 10 años cumplidos (DEL PRIORE, 2013, p. 245 apud SANTOS, 2017) ${ }^{1}$, como revelan los registros históricos, desconocidos u ocultados en los análisis sobre trabajo infantil. Niñas negras además de trabajar en las residencias eran víctimas de violencia sexual ${ }^{2}$ y niños negros adolescentes tenían alto valor de venta en el mercado interno ${ }^{3}$, en razón de la vitalidad que presentaban (LIBERATI; DIAS, 2006, p. 19-20 apud SANTOS, 2017). 
Con la abolición formal de la esclavitud, en 1888, los niños quedaron a su propia suerte en las calles, luchando por la sobrevivencia, escenario que no desentona mucho de la realidad que encontramos en Brasil actualmente.

La infancia en Brasil fue brutalmente violentada, tanto por la explotación del trabajo en la industria, como por la criminalización del trabajo en las calles, este último realizado por los niños negros, hijos de los esclavizados libertos. Esta realidad marca la base de sustentación de la sociedad brasileña, anclada en el no acceso de la población negra a los derechos básicos, especialmente vivienda, trabajo y educación. Penaliza y estigmatiza diferentes generaciones de familias y niños negros, que se quedan sin acceso a esos derechos.

Sobre la situación de los niños negros post abolición, Nepomuceno (2016, apud SANTOS, 2017) afirma:

Los negros libertos no recibieron ningún tipo de apoyo de políticas públicas para esa nueva etapa de su vida. Entonces aumentó la pobreza y la gente pasó a encontrar más niños por las calles. Al iniciarse el siglo XX, encontramos principalmente niños participando en pequeños delitos, y en ese período no vemos respuesta del estado, no había políticas para menores en esa condición social de pobreza. Eso sucedió en todo Brasil. La primera respuesta del estado brasileño solo vino con la policía, cuando la gente pasó a ver a como se llevaban a los niños presos. Se crearon instituciones de internación, con la perspectiva coercitiva y no la de protección. Esas instituciones, en su mayoría, tenían una propuesta de enseñanza regular, pero junto existía una disciplina muy fuerte de trabajo. Ellos trabajaban y desarrollaban alguna formación profesional para atender a las necesidades del mercado en edades que no corresponden a un trabajo adulto. niños de 9, diez años de edad, estaban preparados para trabajar. [...] El trabajo siempre estuvo presente en la vida de un niño pobre brasileño.

Rizzini (2013, pp. 376-7) apud Santos (2017) menciona que el aumento de la marginalidad en el espacio urbano llevó al pensamiento de que el trabajo sería una solución para el problema del abandono y de la delincuencia. En ese sentido, iniciativas de Estado se implementaron con vista a la disciplina y a la corrección de comportamiento socialmente no aceptados, los niños fueron llevados de las calles para trabajar en colonias agrícolas y en industrias, bajo una justificación filantrópica, pero en realidad como política de higienización social, por lo tanto, marcadamente racista.

Tales aspectos históricos nos traen importantes elementos para la comprensión de la división del trabajo y exclusión de la población negra de los puestos formales, perpetuandose formas de esclavización bajo otros ro- 
pajes y la estigmatización de las actividades en las calles como "no trabajo". La propia legislación brasileña criminalizó el comportamiento que llamó "vagancia", así como la práctica de "capoeira", lo que objetivaba marginalizar a la población negra en las calles de Brasil, junto con la política de emblanquecimiento, especialmente con la llegada de los inmigrantes para trabajar en la industria.

Es importante analizar como la propia legislación del trabajo excluye a los niños negros de su protección. La Consolidación de las Leyes de trabajo (1943) en la redacción original de su artículo 403, párrafo $2^{\circ}$ (aún presente en el texto legislativo), permitía expresamente el trabajo de niños en la calles, plazas y espacios públicos, autorizado por los entonces Jueces de "menores", cuando era verificada la necesidad de subsistencia suya o de la familia. Tal disposición, absolutamente incompatible con el texto constitucional de 1988, hasta recientemente se venía aplicando por los Jueces de Derecho, con el fin de justificar el trabajo de adolescentes por necesidad económica, de forma totalmente contraria a las disposiciones constitucionales sobre la edad mínima para el trabajo y la protección integral del niño y del adolescente, como previstos en los artículos $7 .^{\circ}, \mathrm{XXXIII}$, y 227 de la CF.

Es importante, aún, resaltar que el Código Penal de 1890 establecía la edad mínima penal en nueve años (artigo $27, \$ 1 .^{\circ}$ ). Entre nueve y 14 años, la imputabilidad quedaba condicionada a la presencia del discernimiento, determinándose recoger a los niños infractores y llevarlos a establecimientos disciplinarios industriales por el tiempo que el juez creyese conveniente, siempre que no sobrepasase 17 años (artículo 27, \2. ${ }^{\circ}$ c/c artículo 30). Entre 14 y 17 años, el Código preveía una pena más blanda (artículo 65), pudiendo los mayores de 14 ser enviados a establecimientos industriales hasta los 21 años (artículo 399, \$2. ${ }^{\circ}$. Ese sistema hacía posible, en la práctica, la internación (prisión) de un niño de los nueve hasta que cumpliera 21 años de edad en un establecimiento industrial, por tanto, para trabajo forzado.

En ese contexto, la cuestión pertinente al trabajo en la realidad de la vida de los niños negros quedó cubierta por la cuestión penal. En consecuencia, en vez de protección legislativa, recibió tratamiento punitivo. Sin derechos asegurados, los niños negros no solo fueron sometidos al trabajo en las calles, sino también punidos por esa conducta y presas para realizar trabajos forzados para el Estado. 


\section{DATOS ACTUALES SOBRE TRABAJO INFANTIL EN LAS CALLES}

Brasil hasta el día de hoy no tiene una política específica para enfrentar el trabajo infantil en las calles, aunque el Informe Mundial sobre trabajo Infantil, producido por la OIT, en el año 2013, apunte como prioridad en el enfrentamiento al trabajo infantil, en su artículo 6, "Grupos especialmente vulnerables de niños", objetivando que las políticas de protección social alcancen a los niños en mayor riesgo de trabajo infantil, en particular, en las peores formas.

A partir del análisis de los datos de PNAD/IBGE, que mensura el trabajo de niños y adolescentes en Brasil, encontramos lagunas que revelan la imprecisión e incluso inexistencia de datos sobre trabajo en las calles, más específicamente de niños malabaristas, como demostramos en la investigación de la maestría defendida en el Instituto de Estudios Brasileños de la USP, Titulada "Trabalho infantil nas ruas, pobreza e discriminação: crianças invisiveis nos faróis da cidade de São Paulo" (2017).

En el referido estudio, encontramos datos sobre el perfil de niños trabajadores en las calles, a partir de dos investigaciones censitarias, específicamente Encuesta Censitaria Nacional sobre Niños y Adolescentes en Situación de Calle (2011) y el Censo de Niños y Adolescentes en Situación de Calle del Municipio de São Paulo (2006-2007). En estas investigaciones, realizadas a partir de la metodología de verificación in loco, en puntos previamente mapeados como focos de trabajo infantil, bien como en días y horarios determinados, es posible identificar el perfil de los niños en situación de trabajo en las calles.

El referido censo nacional apuntó que: a) la mayoría de los niños está fuera de la escuela (8,8\% nunca estudiaron y 56,3\% estaban fuera de la escuela); b) 70\% son niños negros; c) las principales actividades laborales son la venta de productos (caramelos, chocolates, frutas, gaseosas, helados - 39,4\%), cuidador de vehículos, "flanelinha", lavado y limpieza de vehículos en los semáforos $(19,7 \%)$, separación de material reciclable (16,6\%), malabarismo $(6,1 \%)$, lustrador de zapatos $(4,1 \%)$. También apuntó una categoría expresiva que realiza mendicidad (29,5\%), lo que no está alejado de una concepción de trabajo infantil forzado, cuando es impuesto por un adulto, concepto este traído por la OIT sobre tráfico de personas y trabajo forzado (2013) ${ }^{4}$. 
En la misma estera, en el Manual del Ministerio Público del Trabajo sobre la actuación del Disque 100 (MPT, 2014), consolidamos el entendimiento de que la situación de mendicidad es una forma de trabajo en las calles:

Aunque la denuncia hace referencia a la mendicidad, exclusivamente, la situación que relata, encontrada en grandes centros urbanos, está asociada a la explotación del niño y del adolescente por un adulto (normalmente uno de los padres o ambos), que se aprovecha (y se beneficia) de esta conducta ilícita como verdadera actividad remuneratoria y "ocupación”. En esa misma condición de explotación de trabajo (lato sensu), se encuentran niños lustradores de zapatos, cuidadores de coches, lavadores de vidrios de los autos, vendedores de caramelos y otros productos, malabaristas, distribuidores de panfletos en los semáforos, hurgadores de basura, o incluso trabajo infantil doméstico.

El censo nos dice también que la gran mayoría trabaja para el propio sustento y de sus familias, oriunda de clases sociales muy bajas, en situación de pobreza extrema o absoluta, o aún miseria. Otro dato relevante es con respecto a los programas sociales gubernamentales, la gran mayoría no está alcanzada por estos programas. Según el Censo, 88,5\% afirmaron que no reciben beneficios de órganos gubernamentales. Entre los beneficios recibidos se nombraron la jubilación (3,2\%), el Programa "Bolsa Família" (2,3\%) y el "Benefício de Prestação Continuada - BPC” (1,3\%).

El censo municipal antes referido trae indicadores en la misma línea general del censo nacional: niños y adolescentes negros, del sexo masculino, de clases económicas muy bajas, fuera de la escuela y sin acceso a los programas sociales.

Por tanto, estos niños están invisibles como trabajadores infantiles y, en consecuencia, las familias no tienen acceso a los programas sociales. Este dato revela que las políticas públicas existentes no alcanzan a la población negra más vulnerable, marginalizada en términos de renta, vivienda, educación y de todos los derechos más básicos, y consecuentemente, ciudadanía.

\section{4 ¿CULTURA O IDEOLOGÍA EN EL TRABAJO INFANTIL?}

Durante mucho tiempo entendimos que el problema del trabajo infantil estaba vinculado a cuestiones culturales, presentes en el inconsciente colectivo, sobre todo de las familias al entender este trabajo como benéfico, forma de aprendizaje y forma de combate a la criminalidad, todo fundado en 
mitos, que desconsideran las causas estructurales que permanecen escondidas en lugar de traerlas para hacer una reflexión. De un lado, una ideología que justificó y perpetuó la esclavización moderna de niños - y adultos - en trabajos precarios hasta los días de hoy, además de aquella que defiende el trabajo como algo bueno para el aprendizaje en detrimento del derecho a tener una formación escolar.

Además de eso, no se evidencia efectiva cultura de trabajo precoz en el Brasil actual, pues la edad promedio de ingreso en el mercado de trabajo es 25 años, como nos dice un estudio de IPEA, del año 2015, al traducir, en esa óptica, una cultura de trabajo para la juventud, y un discurso solo selectivo con relación a la cultura del trabajo infantil. Queda evidente que los marcadores de raza, género y clase son determinantes para la comprensión del problema y para necesariamente efectivar políticas de prevención, reparación y rescate de las infancias.

A partir del análisis de la legislación sobre el trabajo infantil y de nuestra historia de explotación de la mano de obra infantil en las fábricas y del trabajo en las calles en la post abolición, podemos identificar dos ideas diseminadas y naturalizadas en la sociedad: (a) el trabajo como formación aprendizaje para la clase trabajadora; y (b) el trabajo como formador del carácter y honestidad en contraposición a vagar y a actividades marginales. Esas dos ideas han sido tratadas como mitos del trabajo infantil o cuestiones culturales que justifican la naturalización de esta práctica en la sociedad.

Se trata, en verdad, de una ideología que compone el sistema social, político y económico, perpetuando su aceptación no solo por la población privilegiada que alcanza a los derechos, sino por la población víctima del trabajo infantil y que no alcanza a los derechos. A través de la ideología, se construyen discursos que ocultan el conflicto social entre clases que disimulan la dominación, dando la apariencia de generalidad y universalidad a mitos, ideas falsas, distorsionadas o que no enfrentan las causas estructurales. Se construye una idea generalizada, sin profundidad de sus causas, sin bases en fuentes en investigación, en ciencia, construyendo falsas verdades, que a pesar de todo disfrutan de amplia adhesión.

Analizando la ideología presente en los discursos que defienden o naturalizan al trabajo de niños y adolescentes podemos identificar dos camuflajes: uno que cubre la dominación histórica de la clase trabajadora, al incor- 
porar el trabajo como valor de aprendizaje desde la infancia en detrimento de la educación; otro que cubre al racismo estructural, al justificar el trabajo de niños negros como alternativa a la criminalidad en detrimento de políticas sociales. El pensamiento dominante hace que esas familias (o la cultura que reproducen) sean entendidas como causas que compiten, principales o determinantes del trabajo infantil, manteniéndose ocultas las causas estructurantes.

Ese discurso no niega la desigualdad entre los segmentos sociales, pero niega que esa diferencia tenga como vector factores histórico-económicos y raciales. Para explicar las diferencias sociales, en Brasil, esa ideología se ha apropiado de la naturalización de las desigualdades y del discurso de la meritocracia. La naturalización es un intento de justificar las desigualdades sociales, atribuyéndose supuestas causas naturales para las diferencias de clase, género y raza. El grupo social que detenta el poder se beneficia del recurso a la naturalización porque, a través de este, se permite establecer y mantener la jerarquización, dándole a la inserción social criterios de esfuerzo y mérito y manteniendo el privilegio de los grupos hegemónicos. Y consecuentemente, entendiendo como natural el trabajo de niños pobres y negros.

Para Whitaker (2007, p. 125) apud SANTOS (2017), es necesario destruir este componente ideológico que confunde al trabajo con educación o como valor de honestidad de forma indiscriminada. Esa ideología persiste en el inconsciente colectivo naturalizando al trabajo infantil y cubriendo al racismo estructural.

\section{EL RACISMO ESTRUCTURAL EL TRABAJO INFANTIL EN LAS CALLES}

La falta de oportunidades de la población negra de usufructuar los derechos, históricamente, alcanzando también a los niños y adolescentes es lo que podemos entender como efectos del racismo que estructura a la sociedad brasileña. Él es sistémico. No depende de que queramos de que exista o no, porque fue la base de sustentación de la sociedad brasileña, del período de esclavización, con la deshumanización de personas negras, para trabajo forzado, penoso, cruel, deshumano y sin remuneración. O sea, las personas negras construyeron la riqueza del país, pero no tuvieron ningún derecho asegurado. Esa situación se refleja en esa desigualdad para acceder a los derechos que hasta hoy no ha sido reparada por el Estado brasileño. 
Es común cuando hablamos de racismo, el pensamiento de que es un acto, una expresión individual de ofensa, e injuria, de degradación de una persona individualmente considerada. Esa es una de las formas como el racismo se manifiesta. En ese caso, a través de la expresión individual, pero que alcanza a toda la sociedad. La Ley n. ${ }^{\circ}$ 7.716/89 establece los crímenes resultantes de la discriminación o prejuicio de raza, color, etnia, religión o procedencia nacional, penalizando conductas como prohibir la entrada a establecimientos comerciales, o el ascensor de un edificio. El crimen no tiene fianza y es imprescriptible, con pena de uno a tres años de prisión, además de una multa.

Ocurre que independientemente de las manifestaciones individuales, el racismo se sumerge en todos los espacios y sectores de la sociedad, como proceso que impide a un grupo étnico racial ejercer plenamente su ciudadanía. Almeida (2018, p. 39) nos enseña que

el racismo, como proceso histórico y político, crea las condiciones sociales para que, directa o indirectamente, grupos racialmente identificados sean discriminados de forma sistemática". Y añade: "aunque los individuos que cometen actos racistas sean responsabilizados, la mirada estructural sobre las relaciones raciales nos lleva a concluir que la responsabilización jurídica no es suficiente para que la sociedad deje de ser una máquina productora de desigualdad racial.

El racismo termina consolidándose también en las instituciones. Si miramos para dentro del Poder Judicial, del Ministerio Público, los cargos de directores de empresas, en el Legislativo, en los cargos del Ejecutivo, tenemos una subrepresentación de la población negra, que hoy representa 55,8\% de las personas que integran la nación, pero que no están presentes en los espacios de toma de decisiones políticas, económicas y sociales.

En esa subrepresentación negra en los espacios de poder en la sociedad brasileña, sobresalen los espacios de la prensa y de la televisión brasileña, conseguimos visualizar cuanto el racismo está introyectado en nuestro país, en nuestro quehacer cotidiano y de forma naturalizada.

En esa misma lógica, es importante entender como el racismo se desvela también en las violaciones de derechos de niños y adolescentes, y específicamente en el trabajo infantil, para que podamos enfrentarlas en sus causas estructurales, con vista a garantizar derechos fundamentales, dando efectividad a la protección integral y prioridad absoluta de todos los niños y adolescentes. 


\section{DESAFÍOS PARA LA ACTUACIÓN DEL MINISTERIO PÚBLICO DEL TRABAJO}

La Coordinación Nacional de Combate contra la Explotación del Trabajo de Niñas, Niños y Adolescentes - Coordinfância, a lo largo de los años, viene actuando firmemente en el enfrentamiento al trabajo infantil, con la realización del proyecto Rescate la Infancia, al cual tuvimos la oportunidad de concebir en su formato actual, cuando en el ejercicio de la Coordinación Nacional (2016), que contempla tres ejes: a) políticas públicas, b) aprendizaje profesional, c) educación.

Los análisis sobre racismo, género y clase social como estructurantes del trabajo infantil pueden indicar nuevos caminos y formas de actuación, tanto en el bies específico del combate al trabajo infantil, a través de Coordinfância, como también en acciones articuladas con la Coordinación Nacional de Promoción de Igualdad de Oportunidades - COORDIGUALDADE.

En el ámbito de la actuación en la Fiscalía Regional del Trabajo de la 2. ${ }^{a}$ Región, ante el Municipio de São Paulo, en la efectuación de políticas públicas para el enfrentamiento del trabajo infantil en las calles, en la Investigación Civil n. ${ }^{\circ}$ 2916/2013, recomendamos, entre otras, a través de propuesta de TAC, en análisis, la implementación de las siguientes acciones:

a) El trabajo infantil en las calles debe estar contemplado en las metas y prioridades de LDO, como acciones direccionadas al proyecto estratégico y metas para su identificación, políticas de protección a los niños y a los adolescentes, profesionalización a los adolescentes y generación de empleo y renta para las familias;

b) Realización de un censo municipal de niños en situación de calle o en la calle, con datos específicos sobre el trabajo INFANTIL EN LAS CALLES, considerados los diferentes tipos de actividades (malabares, lustrador de zapatos, ambulante, otros), franja de edad, género, raza/etnia, composición familiar, locales de residencia, locales de trabajo, renta familiar, renta obtenida con el trabajo infantil, inscripción en programas sociales, escolaridad, discriminación en locales públicos o privados, entre otras cuestiones;

c) Las informaciones obtenidas en el Censo deben orientar la planificación y ejecución de la política para el enfrentamiento del trabajo infantil en las calles, que deberá contemplar acciones intersectoriales abarcando EDUCACIÓN, CULTURA, DEPORTE, SALUD, PROFESIONALIZACIÓN, EMPLEO Y GENERACIÓN DE RENTA, PROGRAMAS DE INCLUSIÓN SOCIAL QUE TENGAN EN CONSIDERACIÓN INTERSECCIONALIDADES DE GÉNERO, RAZA/ETNIA Y TERRITORIOS;

d) Campañas para la prevención al trabajo infantil en las calles, alertando a la población de que no deben contribuir financieramente con trabajos como 
presentaciones artísticas, ventas de productos, lustrado de zapatos u otras actividades;

e) Perfeccionamiento del sistema de registro de las familias del trabajo infantil, de modo que esta no sea revictimizada al pasar por diferentes sectores, buscando un sistema integrado, en que en la primera atención, por la red, ella pueda ser insertada en el Registro Único, con acceso a los programas sociales, priorizando la inserción de los adolescentes en programas de cualificación profesional o vacantes de aprendizaje, como también de las familias en programas de generación de renta, economía solidaria, cursos de capacitación y cualificación;

f) Inclusión en el proyecto pedagógico de las escuelas municipales, en cumplimiento a la Ley n. ${ }^{\circ} 8.069 / 90$, derechos del niño y del adolescente, considerando entre los temas a ser discutidos el trabajo infantil y sus perjuicios;

g) Inclusión en el proyecto pedagógico de las escuelas municipales, en cumplimiento a la Ley n. $.^{\circ} 10.639 / 03$, historia y cultura afrobrasileña y africana, dando especial atención al fortalecimiento de la identidad racial de los niños negros, valorización de la cultura negra y fortalecimiento de la autoestima de los niños negros, más vulnerables al trabajo infantil en las calles y al trabajo doméstico;

h) Priorización de la inserción de las familias identificadas en situación de trabajo infantil en programas de registro para el trabajo, cursos de capacitación, cualificación, generación de renta, directamente o mediante convenios, objetivando profesionalización de las madres y/o responsables por los niños.

Entendemos que se hace necesario pensar en estrategias de actuación, que para más allá del enfrentamiento directo a las violaciones de derechos de niños y adolescentes, entre estas, el trabajo infantil, promuevan acciones que puedan modificar las condiciones desiguales e injustas en el acceso (o no acceso) a los derechos por la población negra. Con relación al trabajo infantil en las calles, un diagnóstico con análisis más precisos por los Municipios, a través de las metodologías de censo se muestra fundamental.

Además de eso, políticas sociales de vivienda, escuela, guarderías, inserción formal en el trabajo de la población negra, y especialmente de mujeres negras, son políticas necesarias para la transformación de las realidades históricamente desiguales, que colocan la mayor parte de la población negra en trabajos precarizados y sus niños trabajando en las calles. El Ministerio Público del Trabajo debe actuar también para la promoción e implementación de estas políticas, de forma articulada con los demás ramos del Ministerio Público, como dispone la Resolución n. ${ }^{\circ} 70$ de CNMP, del 11 de junio de 2019.

Aún, se muestra necesaria una acción articulada entre los Ministerios Públicos, para la implementación de la Ley n. ${ }^{\circ}$ 10.639/2003, que establece la obligatoriedad de la enseñanza afrobrasileña en las escuelas, lo que se suma a 
la obligatoriedad de la inclusión de los derechos del niño y del adolescente en los currículos y programas pedagógicos, prevista en la Ley n. ${ }^{\circ}$ 11.525/2007. Se trata de disposiciones incluidas en la Ley de Directrices y Bases de la Educación, que aún no fue implementada plenamente en la mayoría de los Municipios de los Estados brasileños.

En ese sentido, el proyecto "Rescate la Infancia" puede ser una importante estrategia de actuación, para discutir la cuestión racial en las escuelas, relacionadas a las vulnerabilidades que permean al trabajo infantil, contribuyendo, al mismo tiempo para la implementación de una educación antirracista, emancipatoria y libertaria, en la perspectiva de consciencia de los derechos y ciudadanía.

\section{CONCLUSIONES}

A partir de análisis de datos, estudios e investigaciones realizadas, junto con la experiencia de más de una década de actuación en el enfrentamiento al trabajo infantil, en el Ministerio Público del Trabajo, buscamos sintetizar en este artículo las reflexiones que nos llevaron a concluir por la existencia de una relación directa entre el racismo y el trabajo infantil en las calles en la sociedad brasileña. Tal situación ocurre también con relación a otras formas de trabajo infantil, como el doméstico.

Y esto se debe a la diseminación de la naturalización del trabajo de niños negros en tales actividades a lo largo de décadas. La propia legislación brasileña atribuyó tratamiento diferenciado a estas situaciones, permitiendo, por ejemplo, el trabajo en las calles cuando es autorizado por el poder Judicial o el trabajo en casa de familia, conforme a las disposiciones previstas en la CLT y en el propio Estatuto del Niño y del Adolescente.

A la par de eso, la desigualdad resultante del proceso de no inclusión de la población negra en el trabajo, educación y vivienda en la post abolición, trae consecuencias perversas hasta los días de hoy, afectando también a los niños negros, que son la mayor parte de los niños en situación de trabajo, de forma general, y masivamente en el trabajo en las calles.

Así, entendemos que las políticas de inclusión para la población negra en el trabajo, especialmente mujeres, junto con políticas sociales de vivienda, salud, educación, que tenga en consideración las desigualdades de género y 
raza son fundamentales para el enfrentamiento al trabajo infantil en la sociedad brasileña. Y tales perspectivas de análisis deben ser consideradas también en las estrategias de actuación del Ministerio Público de Trabajo y del conjunto de la red de protección del niño y del adolescente.

Tales acciones son fundamentales para el enfrentamiento al trabajo infantil. Combatir al racismo y a las desigualdades sociales históricas por él producidas en la sociedad brasileña es luchar también por una infancia libre de trabajo para todos los niños.

\section{NOTAS}

1 De los esclavos desembarcados en el mercado de Valongo, en Rio de Janeiro al principio del siglo XIX, 4\% eran niños. De estos, solo $1 / 3$ sobrevivía hasta los 10 años. A partir de los 4 años, muchos de ellos ya trabajaban con los padres o solos, pues perderse de sus genitores era cosa común. A los 12 años, el valor de mercado de los niños ya se había duplicado. ¿Por qué? Se consideraba que su adiestramiento ya estaba concluido y en las listas de los inventarios ya aparecen con su designación establecida: Chico "roça" (campesino), João "pastor", Ana "mucama", transformados en pequeños y precoces máquinas de trabajo (DEL PRIORE, 2012).

2 Las niñas, además de las actividades domésticas o en el campo, eran blanco de los deseos sexuales de los señores. Muchas eran forzadas a entregarse sexualmente a los patrones, sus hijos eran los capataces y, cuando resistían, eran terriblemente golpeadas. Los hijos que nacían de esas relaciones sexuales a veces recibían alguna atención especial de los señores, pero también podían ser abandonados en las instituciones de caridad o en las calles inclusive. (LIBERATI, DIAS, 2006, p. 20).

3 Un negro saludable de 14 años era considerado una mercadería importante y cara, pues tenía toda la fuerza de la juventud para gastar en el trabajo. Por eso, la mayoría de los esclavos jóvenes era llevada para los trabajos pesados. Los que se quedaban en las actividades domésticas, como los pajes, por ejemplo, se podían considerar privilegiados, pues tenían la confianza o la predilección de los patrones. Dourado e Fernandez apud Liberati e Dias (2006, p. 19).

4 El trabajo forzado incluye a trabajadores que están en los hornos de cerámicas, presos en un círculo vicioso de deudas, niños víctimas de tráfico con fines de mendicidad forzada y trabajadores domésticos que son engañados sobre sus condiciones de trabajo.

\section{REFERENCIAS}

ALMEIDA, Silvio. O que é racismo estrutural? Belo Horizonte, MG: Letramento, 2018.

DEL PRIORE, M. A criança negra no Brasil. In: JACÓ-VILELA, AM.; SATO, L. (orgs). Diálogos em Psicologia Social. Rio de Janeiro: Centro 
Edelnstein de Pesquisas Sociais, 2012. ISBN: 978-85-7982-060-1, p. 245. Disponible en: http:books.cielo.org. Acceso en: 14 oct. 2020.

DEL PRIORE, Mary (org). História das crianças no Brasil. 7. a ed. 1. ${ }^{a}$ reimpressão. São Paulo: Contexto: 2013.

FRAGA, Geraldo et al. Infância Castigada, Direitos Negados. In: Leiajá, Especial Infância sem Cor. [S.1], 2017. Disponible en: http://especiais.leiaja. com/infanciasemcor/infanciacastigada/. Acceso en: 22 jun. 2020.

META INSTITUTO DE PESQUISA DE OPINIÃO. Pesquisa Censitária Nacional sobre crianças e Adolescentes em Situação de Rua. [S.1], SDH/IDEST, 2011. Disponible en: http://www.teleios.com.br/ wp-content/uploads/2011/03/Pesquisa-Censitaria-Nacional-sobre-niños-e-Adolescentes-em-Situacao-de-Rua-Mar-2011.pdf. Acceso en: 29 jun. 2020.

MPT - MINISTÉRIO PÚBLICO DO trabajo. Manual de atuação - Denúncias do Disque 100. COORDINFÂNCIA, MPT: Brasília/DF, 2014. Disponible en: https://www.mpba.mp.br/sites/default/files/biblioteca/ crianca-e-adolescente/violencia-sexual/disque-100/artigos/manuais/publicacoes/livro_manualdeatacaodenunciadodisque100_web.pdf. Acceso en: 29 jun. 2020.

OIT - ORGANIZAÇÃO INTERNACIONAL DO trabajo. Relatório mundial sobre trabajo infantil: Vulnerabilidade econômica, proteção social e luta contra o trabajo infantil. Genebra: OIT, 2013. Disponible en: https://www.ilo.org/ipec/Informationresources/WCMS_233016/lang--pt/ index.htm. Acceso en: 29 jun. 2020.

SANTOS, Elisiane dos. A luta antirrracista é também por uma infância livre de trabalho. São Paulo: Estadão, 2020. Disponível em: https:// emais.estadao.com.br/blogs/bruna-ribeiro/a-luta-antirracista-e-tambem-por-uma-infancia-livre-de-trabalho/. Acceso en 29 jun. 2020.

SANTOS, Elisiane dos. Trabalho infantil nas ruas, pobreza e discriminação: criancas invisíveis nos faróis da cidade de São Paulo. 2017. Dissertação (Mestrado em Estudos Brasileiros) - Instituto de Estudos Brasileiros, Universidade de São Paulo, São Paulo, 2017. Disponible en: https:// 
www.teses.usp.br/teses/disponiveis/31/31131/tde-01032018-123114/pt-br. php. Acceso en: 29 jun. 2020.

SÃO PAULO (município). Censo de crianças e Adolescentes em Situação de Rua do Município de São Paulo. São Paulo: SMADS 20062007. Disponible en: https://www.prefeitura.sp.gov.br/cidade/secretarias/ upload/00-publicacao_de_editais/2007_02.pdf. Acceso en: 29 jun. 2020. 



\section{LA PARTICIPACIÓN POLÍTICA Y SOCIAL DE NIÑOS Y ADOLESCENTES EN LA LUCHA CONTRA EL TRABAJO INFANTIL

\author{
FELIPE CAETANO DA CUNHA \\ WILSON GUILHERME DIAS PEREIRA
}

DOI: $10.51366 / 978-65-89468-10-3$-coordinfancia-9

Resumen. Desde siempre, niños y adolescentes fueron considerados como un grupo inferior, menor e incluso sin valor y voz, minimizados por su grupo de edad de vida. La propia etimología de la palabra infancia significa la incapacidad de hablar, es decir, impone el estado humano infanto-juvenil como una forma de incompletitud. A lo largo de la historia, los niños y adolescentes han sido tratados como objetos y explotados de diversas maneras. Sin embargo, también fueron sujetos históricos, a pesar de innumerables veces invisibilizados. Así, esta investigación pondrá en foco la participación social y política de niños y adolescentes en Brasil, y el trabajo infantil como resultado directo de la sujeción infanto-juvenil, articulado con los siglos de esclavitud en el país y la estructuración de un sistema económico capitalista. Esa construcción atraviesa por la auto etnografía y la técnica de investigación del observador participante, comprendiendo a los investigadores como parte de la investigación, y los observados como sujeto del hacer-saber. Se pretende demostrar, por medio de las narrativas que se cruzan, posibilidades de construcción de la participación efectiva que modifique las subjetividades y las comunidades, enfrentando fenómenos sociales, como el trabajo infantil y el adulto-centrismo.

Palabras clave: Niños. Adolescentes. Participación. Trabajo Infantil.

\section{INTRODUCCIÓN}

Brasil tiene una población con más de 60 millones de habitantes entre 0 y 19 años, lo que equivale a casi un tercio de su población. A pesar del gran 
número, todavía hay otro cuantitativo alarmante, el de violaciones diarias que estos individuos sufren. Niños y adolescentes en Brasil son víctimas diarias de abuso intrafamiliar y extrafamiliar, explotación sexual, pornografía infantil, trabajo infantil, hambre, ausencia de acceso a la escolarización, son mano de obra para el tráfico y milicia, además de sufrir la violencia policial y el exterminio gratuito y desmedido de la población negra.

En este artículo, trataremos de una de las mayores violaciones de esos derechos, una herida social que surgió en Brasil colonia, sobrevivió al reinado, ascendió con el Imperio, se explicitó con la república, se solidificó en la dictadura y, desafortunadamente, todavía se sostiene en nuestra democracia: el trabajo infantil que entró en la historia de nuestro país junto con su supuesto "descubrimiento" por los europeos. Es una inhumanidad permitir que parte de la economía se sostenga en las frágiles costas de los niños, que se perpetúe por generaciones, apagadas y silenciadas por esta plaga social. Son voces en todos los rincones del país que han sido y son silenciadas. A pesar de ser tratadas como número, son personas, más específicamente infantes, que se van a cambiar de una lógica comercial barata.

Entrelazada con el combate al trabajo infantil, se pretende abordar la participación infanto-juvenil de niños y adolescentes en Brasil, bajo la perspectiva de un rescate histórico que evidencia y deslegitima discursos como el de subestimación del sujeto no adulto. Las reflexiones y narrativas de este artículo atraviesan directamente la lógica del protagonismo de niños, adolescentes y jóvenes en la garantía de derechos y combate a las violencias.

Mucho más que escribir un artículo científico, pretendemos buscar un posible y necesario camino para el enfrentamiento de violaciones de derechos infanto-juveniles y para pensar políticas públicas, a partir de una construcción democrática y ciudadana desde la infancia y la adolescencia.

\section{METODOLOGÍA}

Fue inspirada en el método de investigación y escritura de la auto etnografía y en la técnica de abordaje de la observación participante, los cuales nos permiten la proximidad con la temática averiguada y rompen las concepciones arcaicas de la academia de investigador y objeto, posibilitando a los investigadores la interacción con la investigación. 
Santos (2017, p. 221) define la auto etnografía como método que permite al investigador el uso de sus experiencias personales para describir y formular críticas, además de reconocer y valorar las relaciones humanas entre investigador y sujetos de la investigación, y cuestiona "[...] las intersecciones entre lo personal y lo político, lo sujeto y lo social, lo micro y lo macro”.

Además de la inspiración en el método auto etnográfico, utilizamos la técnica de la observación participante con un grupo de adolescentes y jóvenes, los cuales representan 14 estados de la federación y poseen participación en las temáticas de participación política y social de niños y adolescentes que, por cuestión de ética, no tendrán sus nombres o estados revelados.

Para Mónico, Alférez, Parreira e Castro (2017), tal técnica posibilita la participación activa del investigador en el escenario social que observa e investiga, tornándose incluso parte de los papeles y hábitos de la investigación, interactuando de forma directa con los sujetos de la investigación. Como técnica y método del campo de investigación cualitativo, es crucial el acompañamiento de un referencial teórico que posibilite la decodificación de las informaciones obtenidas/reflejadas (ANDRÉ, 1992).

Por lo tanto, utilizaremos la revisión bibliográfica de artículos y libros que aborden las temáticas de trabajo infantil y participación política y social de niños y adolescentes.

Por último, se resalta que no pretendemos afirmar en este artículo una supuesta neutralidad, ya que sus investigadores provienen de proyectos políticos y sociales de participación infanto-juvenil; la metodología nos permite caminar en el seno de la investigación/escritura, y la propia academia viene atestiguando la inexistencia de una absoluta impersonalidad en la investigación científica (SANTOS, 2017).

\section{3 "LA HISTORIA NOS HIZO LLEGAR HASTA AQUÍ!" UN BREVE RELATO HISTÓRICO DE LA PARTICIPACIÓN DE NIÑOS Y ADOLESCENTES EN BRASIL}

Boghossian y Minayo (2009, p. 414-415) relatan que, hasta mediados de 1980, la literatura registraba a jóvenes y adolescentes como eminentemente peligrosos, amenazadores y delincuentes, lo que resultó en varios intentos públicos de "adecuación” y "socialización” rígidas. Como resultado tuvimos 
la categorización de la "situación irregular" y el Código de Menores, que se propusieron a "cuidar" para prevenir, tratar y castigar las "condiciones irregulares".

En oposición a las políticas minoristas de la época y como consecuencia de la movilización de los movimientos sociales, nacional e internacional, surge la Convención de las Naciones Unidas para los derechos del niño, la cual cambia radicalmente la forma de pensar y formular políticas públicas infanto-juvenil, removiendo al niño y al adolescente de la categoría de sujetos para convertirse en sujetos de derecho.

Como sujetos, ya no estarían los niños y los adolescentes en situación de hiper subordinación, como defendió otrora, convirtiéndose en sujetos activos, con voz y ejercicio de su ciudadanía.

La Convención creó mecanismos para la efectividad de esa emancipación y cambio paradigmático. Hay cinco artículos que garantizan la libertad de manifestación, expresión y pensamientos: los de los n. os 12, 13, 14, 15 y 16, que, de una forma amplia, determinan las libertades inherentes a la condición del niño y del adolescente, las cuales van desde recibir informaciones hasta incluso organizar grupos, distribuir ideales, a partir de la comprensión de sus potencialidades discursivas.

En Brasil, el cambio de paradigma legal demandó numerosas manifestaciones políticas por parte de los movimientos sociales de niños y adolescentes, juntamente con otros sectores que buscaban el cambio social, jurídico y político de la condición peculiar de desarrollo de aquellos sujetos de derechos.

Como ejemplo, se tiene el Movimiento Nacional de Niños y Niñas de Calle, que fue esencial en dichas articulaciones, y llevó a las calles a varios niños y adolescentes para luchar y defender la creación de una nueva legislación en el país, promoviendo, con ese acto, un marco histórico en la participación política y social de niños y adolescentes, que rompió en la época el velo de la invisibilidad y abrió las puertas de la democracia infanto-juvenil.

Otro momento histórico, según Luiz Dias (2008, p. 1), fue en 1989, cuando, por primera vez, adolescentes entre 16 y 18 años de edad pudieron participar decisivamente del proceso de elección en Brasil, llevando más de $50 \%$ de los adolescentes a las oficinas electorales para obtener sus títulos. 
Es cabal también el reconocimiento de la participación de los adolescentes en el proceso de destitución del expresidente Collor (1990-1992), en el que más de 200 mil adolescentes y jóvenes ocuparon las calles de São Paulo en busca de la salida del entonces presidente. El acto ganó fuerza y una increíble propulsión, extendiéndose rápidamente para las demás regiones del país, siendo posteriormente nombrado movimiento de los Caras Pintadas, uno de los movimientos políticos y sociales más llamativos de la democracia brasileña (DIAS, 2008).

Más recientemente, en 2015, los adolescentes tomaron las calles y las escuelas, una ola de manifestación que se tituló como "la primavera de la escuela secundaria (secundarista) en Brasil". Iniciada en el estado de São Paulo, con razón de los recortes en la educación que resultarían en un proyecto de "reestructuración de las escuelas" que cerraría aproximadamente 94 unidades. La propuesta del Gobierno terminaría en un proceso de alejamiento de la conexión territorial: escuela-alumno-comunidad. Insatisfechos con el proyecto del gobierno, los estudiantes ocuparon las escuelas, en demostración de pertenencia territorial y del deber del Estado de propiciar una educación pública, universal, de calidad y accesible a la comunidad escolar.

Con el apoyo de las redes sociales, el movimiento se extendió de norte a sur, llegando a ocupar innumerables escuelas y universidades, demarcando al poder público la insatisfacción juvenil con los proyectos políticos de educación aplicados en el país. La historia nos permite percibir, así, la creación de un mito, el de que "jóvenes y adolescentes naturalmente no les gusta la política”, cuya finalidad es devaluar a niños, adolescentes y jóvenes como seres políticos

En las rimas poéticas de Charlie Brown Jr.:

Veo en la televisión lo que hablan del joven no es serio

$\mathrm{El}$ joven en Brasil nunca se toma en serio

Veo en la televisión lo que hablan del joven no es serio [...].

\section{4 "CUANDO SUELTE MI VOZ, USTEDES VAN A TENER QUE ESCUCHARME”: ¿QUÉ ES PARTICIPACIÓN?}

En un simple acceso a Google, al escribir la palabra "participación", podemos comprender que la misma proviene del verbo "participar", que trae 
como significado una acción de "quien hace algo", "algo suceda" o, en su uso menos común, "el acto de informar o recibir información”.

Iniciar esta investigación por medio de la significación que es dada a la palabra "participación" es esencial, una vez que diversos autores del campo de las ciencias sociales ya vienen atestiguando el poder y el papel del lenguaje, de lo simbólico sobre lo real y del material sobre lo simbólico.

Para Paulo Freire (2011, p. 33), "las palabras se leen e interpretan a partir de la realidad material”. Por lo tanto, al buscar el signo dado, percibimos que participar es un acto, una práctica, la cual conduce algo/alguna cosa, y que atraviesa por acciones como recibir informaciones e informar.

En la perspectiva de comprender el significado práctico de lo que es participación, durante una actividad con un grupo de adolescentes y jóvenes, cuestionamos sobre lo que sería participación política y social de niños y adolescentes. A continuación, algunas respuestas.

Es tener la oportunidad de saber que ser niño o adolescente es ser sujeto de derecho. Siendo fortalecido al recibir el conocimiento y el poder de hablar sobre lo que sabe. Pero es importante permitirnos la capacitación sobre temáticas diversas (Adolescente A, Región Norte).

Para mí, es incluso con poca edad, puede ser la transformación de nuestra realidad, y la escuela no habla de ello, pero ella tiene un papel fundamental (Joven B, Región Noreste).

Entiendo como un espacio de ejercicio, que debe hacerse a diario, porque no tiene sentido tener los derechos si no hay representación y voz (Adolescente C, Región Noreste).

Estoy de acuerdo con todo lo que otros ya han dicho, pero hay una cosa que es esencial, ¿sabes?, es entender que no somos "el futuro" como muchos insisten en decir, jsomos el presente, el ahora, y tenemos cosas para contribuir con la sociedad hoy! (Adolescente D, Región Noreste).

De ese modo, la participación política y social infanto-juvenil es una acción continua de intercambio, que posee como sujetos activos niños y adolescentes, los cuales reciben informaciones y comunican los datos que poseen a partir de sus experiencias sociales y colectivas, con base en su madurez.

Es crucial la comprensión de la edad y el entendimiento de las fases de la vida, para que no haya su no subestimación, pues, en la participación infanto-juvenil, no hay espacio para adulto-centrismo. Miren la siguiente declaración: 
En particular, comencé a participar muy temprano, a la edad de 9 años, es decir, todavía era un niño, y me doy cuenta de que es solo tener el lenguaje apropiado. Porque los niños tienen mucha curiosidad y están tratando de entender el mundo, y entenderse a sí mismos. Además de eso, ellos son las más silenciadas, y por lo tanto, las que más tienen cosas para hablar, sólo necesitamos todos, aprender a escuchar (Adolescente A, Región Norte).

El niño también puede participar, sólo tiene que pensar las formas, a ver, se puede poner al niño a pensar desde el micro, de sus relaciones con los amigos, la familia, la comunidad, la escuela, su alimentación, reciclaje, son tantos enfoques posibles, simplemente no puede utilizar un enfoque de lenguaje represivo (Adolescente G, Región Norte).

La adolescente "a" de la Región Norte provoca una reflexión, al señalar a todos en el grupo, que los niños son los más silenciados y que no nos estamos preparando metodológicamente de forma adecuada para escucharlos, comprender sus declaraciones, entendiéndolos como ciudadanos en proceso de desarrollo. Después de todo, la participación posee un carácter político-social y subjetivo, ya que participar es una actividad que resulta en cambio y en la formación del individuo, por medio de sus interacciones con el otro, proporcionando instrumentos para la concepción de lo que es el mundo, lo político, cultural y social, colaborando en la perspectiva de construcción de proyectos colectivos (NIRENBERG, 2006; STAMATO, 2009).

El lenguaje es, por lo tanto, uno de los elementos más importantes para una participación y escucha efectiva de niños y adolescentes. Democratizar el lenguaje es también democratizar el conocimiento sobre sus derechos.

Es necesario resaltar, además, que el niño no puede simplemente llegar a un espacio de discusión y de deliberación de política pública y simplemente participar, como si este acto fuera simple y accesible, pues no lo es.

Por obvio que esta afirmación nos parece, en la práctica, no es observada, lo que percibimos en gran escala es que los espacios de política infanto-juvenil, en razón de su postura histórica adulto-céntrica, tienden a encontrar que la participación se limita a tener adolescentes o niños en los espacios para ocupar una silla en sus largas reuniones y registrar la presencia en sus actas.

La participación es un romper con la lógica adultocéntrica, que trata de fijar al adulto como centro de las relaciones humanas, es entender que todos tenemos algo que decir de nuestras realidades. Y los consejos de derecho, foros y redes, sólo avanzarán, cuando estén dispuestos a escuchar de verdad (Joven D, Región Norte). 
La participación de niños y adolescentes presupone su reconocimiento como sujetos, y no asumidos por adultos. Por lo tanto, romper con estructuras como la del adulto-centrismo es esencial para toda la sociedad y fundamental para los espacios de protección, promoción, fiscalización y deliberación de los derechos de niños y adolescentes, que sólo conseguirán avanzar cuando estén dispuestos a escuchar a los sujetos principales de los derechos.

Y escuchar presupone la creación de medios para esa escucha, pues los espacios de discusión, principalmente los que versan sobre derechos de niños y adolescentes, no pueden simplemente pedir que debatan en el mismo nivel de formación técnica.

Boghossian y Minayo (2009) defienden que la participación infantil y juvenil presupone la interacción de niños, adolescentes y adultos en un proceso de estructuración de la autonomía y negación del adulto-centrismo, lo que resulta en la articulación de valores democráticos, colectivos y solidarios.

Se nota, por medio de la articulación conceptual, que la participación infanto-juvenil es un mecanismo de interacción social y política que presupone la autonomía, la escucha, el intercambio y la transformación de estructuras fijas.

Es crucial evidenciar los términos "derecho de hablar y deber de escuchar", organizados por Paulo Freire (2011, p. 38) para el campo de la educación, que se aplica de modo general en las relaciones humanas, en especial en las relaciones adultos y niños:

Derecho de ellos a hablar a lo que corresponde nuestro deber de escucharlos. De escucharlos correctamente, con la convicción de quien cumple un deber y no con la malicia de quien hace un favor para recibir mucho más a cambio. [...] Escuchar en el sentido antes mencionado es en el fondo hablar con ellos, mientras que simplemente hablar con ellos sería una forma de no escucharlos.

Luego, las tentativas metodológicas que no respeten la interacción adulto-niño-adolescente, de forma a reconocerla como una relación entre sujetos de derechos, críticos y pensadores, no deben ser denominadas de participación, pues se restringen a las concepciones paternalistas y asistencialistas, ya superadas desde la derogación del Código de Menores. 
Participar es permitir también la creación de espacios de participación, y esos espacios tienen que tener adolescentes en la construcción, no se puede creer que adolescentes y niños son sólo actores/actrices que van a seguir su guion, no (Joven E, Región Sudeste).

$\mathrm{El}$ joven $\mathrm{C}$ expone al grupo un pensamiento que es de concordancia de todos y, al mismo tiempo, surge una molestia perceptible, el de que todos en la rueda ya habían pasado por situaciones en que en los espacios de garantía de derecho se sentían usados como actores/actrices, en las cuales los adultos intentaban imponer lo que debían hablar o cómo comportarse, incluso nosotros.

En un encuentro con una entidad de gran renombre nacional e internacional en mi ciudad, me llamaron para representar a los adolescentes, pero me dieron un discurso todo listo, y querían que yo hablara exactamente aquello (Joven F, Región Centro-Oeste).

Esto también me ha sucedido mucho, en las reuniones de la escuela, siempre asisto, y varias veces en las actividades como consejo de clase, traté de hablar, y parecía que nadie me escuchaba. A veces era necesario que otro adulto interviniera para decir que estaba tratando de hablar. Cuando la intervención no era para repetir las mismas cosas que yo ya había hablado, sin darme crédito (Adolescente A, Región Norte).

Todo eso que ustedes relatan me toca mucho, porque yo he pasado por eso varias veces, yo vivía lejos de la capital, pero iba a las reuniones del Consejo Estatal con recurso propio, porque yo quería participar. Hubo un día que fui todo el viaje a casa llorando, porque había gastado dinero para ir a la reunión y no me dejaron hablar. La única vez que traté de dar mi opinión sobre la metodología de la Conferencia Estatal, me silenciaron por completo. Resultó que, en la Conferencia los adolescentes decidieron retirarse de la plenaria, porque ella no tenía lenguaje accesible para ellos, ni metodología que los incluyeran. Solamente no se retiraron porque fueron coaccionados por los adultos responsables, con amenazas. Pero todo esto podría haberse evitado si me hubieran permitido participar de verdad en la reunión, tenía varias ideas, incluso había investigado mucho (informe nuestro).

Sirvent (2004) elaboró dos categorías de participación, que resultaría en la forma y método utilizado para la interacción adulto-niño-adolescente. La primera, participación real, sería aquella en que los miembros de un colectivo o grupo interfieren y participan de forma activa en lo social y político, inclusive en las tomas de decisión, dispensando interferencias de terceros para las elecciones; la segunda, nombró de participación simbólica, la cual implicaría una acción de gran interferencia y gestión de otros, y los miembros de aquella comunidad no ejercerían influencia o tendrían poco poder para las tomas de decisión, sin embargo se construye un mito representacional de poder. 
Luego, percibimos que por varias veces la presencia de niños o adolescentes en los espacios puede no significar la existencia de participación efectiva. Definimos como participación efectiva la que se hace sin coacción, miedo, ensayo previo o modelado de discurso, la que genuinamente es del marco lingüístico del niño/adolescente que la pronuncia, y que no posee intervención guiada de práctica o conducta, de modo que haga reverberar los sentimientos y el modo de interpretación del sujeto infanto-juvenil.

Por otra parte, la participación simbólica (SIRVENT, 2004) o la participación regulada (STAMATO, 2009) no es más que una mera concesión, en la que adultos permiten una participación limitada de niños y adolescentes.

No raramente esa pseudo participación es acompañada de la representación única para garantizar que la acción infanto-juvenil no sea real, se garantiza que apenas un adolescente o un niño represente a todos los demás, borrando la multiplicidad de lo que es ser niño y/o adolescente en Brasil.

Con esto, se trata de limitar las posibles acciones y reacciones del sujeto que participa.

En la Conferencia, la representante de la secretaría de estado llamó a los adolescentes que estaban en la conferencia de pura "lacración", porque contestamos (Joven E, Región Sudeste).

Maria Stamato (2009) reconoce en la participación crítica una función esencial para la transformación social y política, y que sólo puede ser realizada mediante la posibilitación de una educación crítica (formación) y de un intercambio de su realidad (información).

En esta perspectiva, las formaciones continuadas del Sistema de Garantía de Derecho deben ser extendidas a los niños y a los adolescentes, con metodología adecuada, comprendiéndolos como esenciales para las políticas públicas.

La formación como medio de garantía de la participación política y social infanto-juvenil está incluso garantizada en el artículo 13 de la Convención de los derechos del niño:

Art. 13. El niño debe tener el derecho de expresarse libremente. Este derecho debe incluir la libertad de buscar, recibir y divulgar información e ideas de todo tipo, independientemente de las fronteras, ya sea verbalmente, por escrito o por medio impreso, por medio de las artes o por cualquier otro medio elegido por el niño. (cursivas nuestras) 
Esto permitirá el empoderamiento infanto-juvenil y, a partir del conocimiento y formación continua acerca de los derechos, el niño y el adolescente podrán plenamente compartir sus conocimientos, incluso con adultos, respecto a la temática.

Al pasar en la práctica y de modo efectivo de objeto del derecho para sujeto de derecho, el cual podrá multiplicar a otros los conocimientos que adquirió, no queda duda de que la educación entre pares es la forma más efectiva del derecho a la participación.

Por último, se resalta que la participación social y política de niños y adolescentes es fundamental en la prevención y erradicación de los males sociales y de las innumerables violaciones de derechos que sufren, las cuales ya fueron incluso citadas en esta investigación, de forma ejemplificada.

Cuando el sujeto conoce sus derechos, los canales de denuncia y atención, ante la mínima posibilidad de violación de sus derechos o de los de alguien a su alrededor, él consigue reaccionar. No estamos suscitando la subcontratación de la responsabilidad de protección infanto-juvenil, sino afirmando la importancia emancipatoria de la autoprotección, como una forma urgente y esencial, cuando existen datos alarmantes demostrando que muchas de las violencias son cometidas por quien tendría el deber de proteger.

\section{5 "FINGE NO VER, PERO ESTOY AQUÍ": LA LUCHA CONTRA EL TRABAJO INFANTIL}

Es muy fácil hablar sobre el trabajo infantil desde una perspectiva teórica, como algo que vemos en los sitios y revistas, o incluso con miradas de extrañeza a la situación explicitada en las calles de nuestro país. Pero, ¿qué tal una percepción de la experiencia? ¿De vivencia? En esa perspectiva niños y adolescentes poseen un papel fundamental.

El trabajo infantil es el hijo de la esclavitud y el padre del trabajo esclavo. No hablamos de ello sólo por el legado de nuestra herencia cultural, sino también por todos los problemas que surgen de ella. Una encuesta realizada por la OIT, en el año 2007, muestra que el 93\% de los trabajadores rescatados del trabajo esclavo eran egresados del trabajo infantil (BRASIL, 2012). 
Son personas que desde el comienzo de su comprensión del mundo siempre han sido descuidadas y completamente exploradas, situación no muy diferente de las que ocurrían en el siglo XIX. El escritor mozambiqueño Mia Couto, en su libro "La confesión de la Leona", trae una reflexión muy importante sobre los niños en situación de trabajo infantil: "¿se puede llamar niño a una criatura que labra la tierra, corta la leña, lleva agua y, al final del día, ya no tiene alma para jugar?” (COUTO, 2016, p. 101).

Es exactamente eso lo que ocurre. El trabajo infantil retira del niño o del adolescente la fase más importante y fundamental en el desarrollo humano, acarreando una maduración precoz; luego se tornan adultos exhaustos y enfermos por no haber disfrutado de fases de la vida tan elementales para la imaginación y discursividad, teniendo que trabajar hasta el resto de sus vidas con innumerables problemas físicos y psicológicos.

Couto (2016) en su reflexión explicita el trabajo infantil en la agricultura, pero esa violación ocurre en los rincones y continentes más diversos, ya los efectos son los mismos: problemas psicológicos, físicos, pérdida o debilitación de partes del cuerpo y muerte. En el lugar de la niñez se tiene un vacío, una fase tan importante que se omitió, a cambio solo de la ganancia. ¿Cuánto vale una niñez o incluso una vida?

Para los adolescentes y jóvenes sujetos del saber hacer de esta investigación, el trabajo infantil es:

Una privación de los derechos del niño y del adolescente, ¿`sabes? Es impedir la vivencia de la infancia. Podríamos incluso hablar qué es una garantía de que sólo algunos niños sean niños, porque mucha gente no quiere eso para sus hijos, pero no le importa que ocurra con el hijo de los otros (Joven $\mathrm{H}$ Región Norte).

Entiendo cómo un mal social, que obstaculiza y perjudica la vida de niños y adolescentes. Y veo mucha gente romantizando eso, diciendo que "el trabajo dignifica al hombre" (Adolescente D, Región Nordeste).

$Y$ esto es cuando no usan el trabajo infantil como única alternativa contra la violencia y la delincuencia (Adolescente G, Región Sureste).

El trabajo Infantil es cualquier trabajo infantil, y también del adolescente que no está como en la ley. Es un problema que debemos resolver (Adolescente J, Región Sur).

Se percibe que el trabajo infantil es una herida social arraigada en el núcleo de nuestra sociedad, siendo incluso justificada con experiencias individuales o como una pseudo dicotomía entre trabajo en la infancia y criminalidad, enturbiando cualquier otra posibilidad. 
Las discusiones sobre trabajo infantil necesitan urgentemente incluir un nuevo público, que siempre estuvo presente, pero nunca fue visto, quizás escuchado, incluso cuando gritaba sus dolores: los niños y los adolescentes.

He estado varias veces en espacios tratando de hablar, explicar lo que en la práctica pasamos, y la gente parecía no escucharme, esto sucede muy principalmente en las reuniones (Joven I, Región Noreste).

Siempre presentes, pero "supuestamente" no vistos, como decía la samba-trama del bloque EURECA, 2016: fingi no ver, pero estoy aqui. En las políticas de lucha contra el trabajo infantil, varias veces no percibimos la presencia real de un sujeto de derecho, sino de un objeto.

Existen tres pilares esenciales para una participación efectiva de niños y adolescentes: el lenguaje, la formación y la divulgación de esos derechos entre sus pares y la sociedad. Sin embargo, cuando estamos hablando de un individuo que está en una situación de violación de sus derechos, creemos que es importante añadir un pilar más, para que además de un divulgador de derechos, tengamos combatientes del trabajo infantil y de otros males sociales.

Cuando hablamos de participación dentro de una violación de derechos, tendremos que incluir la interrupción del ciclo de violaciones, ya que ningún niño/adolescente se sentirá libre y plenamente capaz de hablar sobre derechos, participar e interactuar, mientras esté atado y amordazado por la violación de sus derechos.

Para ello es necesaria la emancipación (término utilizado en este artículo como acto de dar libertad) y la concientización del sujeto, como víctima de una violencia. Este proceso suele ser aún más arduo en el trabajo infantil $y$, en varias ocasiones, nunca llega a suceder.

No en vano, muchos (hoy) adultos naturalizan y defienden el trabajo infantil, a partir de sus experiencias personales, sin reconocer un fenómeno como la violación. Es necesario emancipar a los sujetos víctimas del trabajo infantil para que perciban los perjuicios que sufren, pues a diferencia de otras formas de violación esta es tenida por muchos como natural y buena, y para parte de los propios actores del Sistema de Garantía de Derechos como "un mal menor".

Emancipar niños y adolescentes es comprender que, como sujetos pensantes y críticos, ellos también pueden ser agentes del combate al trabajo 
infantil, denunciando y siendo multiplicadores, a través de la educación entre pares.

No estamos diciendo que ellos/as/us deben garantizar sus propios derechos, ijamás! Este es un deber de los adultos, ya que creemos que donde hay derechos de los niños existe el deber de los adultos.

Como ejemplo de ese cambio tenemos el grupo observado, en el cual más de la mitad ya estuvo en situación de trabajo infantil, comprendió la violencia y hoy actúa en la ruptura del ciclo violaciones de derechos humanos.

La participación, la escucha y el empoderamiento, partiendo de la percepción de los propios adolescentes y jóvenes del grupo, son el mejor camino para erradicar problemas sociales, romper ese ciclo del trabajo y de la explotación infantil.

Si cualquier país quiere erradicar las violaciones de los derechos humanos de niños y adolescentes, debe escuchar a los sujetos principales de la política. Sólo así se concretarán las políticas públicas eficaces constantes de sus objetivos y normas, como el Estatuto del niño y del Adolescente, la Convención de los Derechos de los Niños y las normativas de la Organización Internacional del trabajo.

\section{CONSIDERACIONES FINALES EN ESTA LARGA CAMINATA}

Los niños y adolescentes siempre han estado presentes en la historia, construyendo narrativas y cambios esenciales para su tiempo y espacio. Sin embargo, siempre han sido borrados/invisibilizados de forma intencionada. Para pensar políticas públicas infanto-juveniles es esencial partir del punto de ruptura del velo de la invisibilidad. No es posible pensar en la existencia de quien deliberadamente no se ve.

Además de ver, es necesario escuchar, y aquí hablamos del acto de estar dispuesto a comprender lo que estos sujetos están hablando, en sus más variadas formas de expresarse. Entendemos que los posibles conflictos generacionales pueden dificultar esos diálogos, pero creemos que el acto de escuchar es capaz de transponer esas divergencias. 
Es vital la comprensión de que esos elementos mencionados sólo pueden ser efectivos si existe el interés de transposición de la estructuración adulto-céntrica, pues, mientras las relaciones humanas y sociales estén centradas en adultos, no será posible intercambios entre los sujetos niños-adolescentes-adultos.

Participar es cambiar, transformar algo; la participación que no modifica al sujeto y su entorno probablemente no sea una participación efectiva, sino meramente simbólica. La participación regulada no es la que queremos y proponemos para los espacios de garantía de derechos, y principalmente para la lucha contra las violencias, en especial el trabajo infantil.

Lo que mueve las fases de la infancia y la adolescencia es las ganas de cambiar, de transformar. Los sujetos de derecho sólo se sentirán parte cuando por medio de su lenguaje y su metodología sepan que pueden ser agentes de transformación de sus realidades, cuando comprendan que sus opiniones, pensamientos y creencias pueden y deben ser tenidas en cuenta por los adultos y por toda su comunidad.

Hablamos aquí del poder que identificamos cuando esos sujetos perciben la importancia de sus voces, cuerpos y características, que, durante mucho tiempo, fueron rebajadas y minimizadas por todos aquellos que los rodeaban, inclusive los que deberían defender y fiscalizar sus derechos. El poder y saber que pueden contribuir con un mundo mejor para sí mismos y para los demás.

De hecho, lo que mueve a esta audiencia es el deseo de cambiar una realidad que afecta a tantos otros/as/es como él/a/u. Cuando un niño conoce el poder de su voz, el mundo mejora un poco más, y ejemplos no nos faltan.

\section{REFERENCIAS}

ANDRÉ, M. E. D. A. Quotidiano escolar e práticas sócio-pedagógicas. Brasília: Em Aberto, 1992.

BOGHOSSIAN, Cynthia Ozon; MINAYO, Maria Cecília de Souza. Revisão sistemática sobre juventude e participação nos últimos 10 anos. In: Saude soc. [on-line], 2009, v. 18, n. ${ }^{\circ}$, p. 411-423. ISSN 0104-1290. Disponible en: 
http://dx.doi.org/10.1590/S0104-12902009000300006. Acceso en: 15 abr. 2020.

BRASIL. As relações entre trabalho infantil e trabalho escravo. Portal dos direitos da criança, [S.l], 2012. Disponible en: https://www.direitosdacrianca.gov.br/em-pauta/2012/08/as-relacoes-entre-trabalho-infantil-e-trabalho-escravo. Acceso en: 16 abr. 2020.

COUTO, Mia. A confissão da leoa. São Paulo: Grupo Companhia das Letras, 2016.

CONVENÇÃO sobre os direitos da criança. [S.1.], 20 nov. 1989. Disponible en: https://www.unicef.org/brazil/convencao-sobre-os-direitos-da-crianca. Acceso en: 18 abr. 2020.

DIAS, Luiz Antonio. Política e participação juvenil: os caras-pintadas e o movimento pelo impeachment. In: História Agora, v. 1, p. 4-14, 2008. Disponible en: http://www.educadores.diaadia.pr.gov.br/arquivos/File/2010/ artigos_teses/2010/Historia/artigos/8dias_luiz_artigo.pdf. Acceso en: 17 abr. 2020.

FREIRE, Paulo. A importância do ato de ler: em três artigos que se completam. 51. ${ }^{a}$ ed. São Paulo: Cortez, 2011.

MÓNICO, Lisete; et al. A Observação Participante enquanto metodologia de investigação qualitativa. In: Atas - Investigação Qualitativa em Ciências Sociais. v. 3, p. 724-733, 4 jul. 2017. Disponible en: https://proceedings. ciaiq.org/index.php/ciaiq2017/article/view/1447. Acceso en: 30 mayo 2020.

NIRENBERG, O. Participación de adolescentes en proyectos sociales: aportes conceptuales y pautas para su evaluatión. Buenos Aires: Paidós, 2006.

SANTOS, S. M. O método da autoetnografia na pesquisa sociológica: atores, perspectivas e desafios. In: Plural - Revista de Ciências Sociais, v. 24, n. ${ }^{\circ}$ $1^{\circ}$, p. 214-241, 30 ago. 2017.

SIRVENT, M. T. Cultura popular y participación social: una investigación en el barrio de Mataderos (Buenos Aires). Buenos Aires: Miño y Dávila, 2004. 
STAMATO, Maria Izabel Calil. Protagonismo Juvenil: uma Práxis Sócio-Histórica de Formação para a Cidadania. XV Encontro Nacional da Associação Brasileira de Psicologia Social - 2009. Mesa Redonda ED MR070 - Formação Humana e Profissional, [S. 1.], 2009. Disponible en: http://www.abrapso.org.br/siteprincipal/images/Anais_XVENABRAPSO/389.\%20protagonismo\%20juvenil.pdf. Acceso en: 05 mayo 2020. 



\section{LA PROHIBICIÓN DEL TRABAJO DEL NIÑO Y DEL ADOLESCENTE Y LA DOCTRINA DE LA PROTECCIÓN INTEGRAL EN EL ORDENAMIENTO JURÍDICO BRASILEÑO}

FERNANDA BRITO PEREIRA

DOI: $10.51366 / 978-65-89468-10-3-$ coordinfancia-10

Resumen. El presente artículo propone el análisis de la prohibición del trabajo precoz como forma de materialización de la doctrina internacional de la protección integral de la comunidad infantojuvenil en el ordenamiento jurídico brasileño. Aborda sus elementos constitutivos y principios constitucionales a partir de la revisión de la legislación y del levantamiento bibliográfico, con el objetivo de contribuir, aunque brevemente, para la difusión y la comprensión de la doctrina.

Palabras clave: Trabajo precoz. Doctrina de la protección integral. Elementos. Ordenamiento Jurídico Brasileño. Principios.

\section{INTRODUCCIÓN}

El ordenamiento jurídico brasileño garantiza a los niños y a los adolescentes ${ }^{1}$ el derecho fundamental ${ }^{2}$ a no trabajar. Y lo hace al vedar el trabajo precoz $z^{3}$, así entendido: (a) la prestación de cualquier trabajo por persona con menos de dieciséis años, salvo en la condición de aprendiz, a partir de los catorce años, como (b) el trabajo de cualquier persona con menos de dieciocho años en período nocturno, en locales y/o actividades peligrosos, insalubres, penosos, o que perjudiquen o atenten contra su salud, seguridad, moral, formación y desarrollo, o en las peores formas de trabajo infantil ${ }^{4}$.

Las prohibiciones que recaen sobre el trabajo de la comunidad infanto-juvenil se fundamentan en el valor de la dignidad de la persona humana $\mathrm{y}^{5}$ 
son, en verdad, formas de materialización en el ordenamiento jurídico patrio de la doctrina internacional de las Naciones Unidas de protección integral de la infancia y de la adolescencia, objeto específico del presente ensayo, como se pasará a exponer.

\section{FORMACIÖN Y CONSOLIDACIÓN DE LA DOCTRINA DE LA PROTECCIÓN INTEGRAL}

La doctrina internacional de la protección integral fue constituida en el siglo $\mathrm{XX}^{6}$, a partir de la Declaración Universal de los Derechos Humanos (DUDH), proclamada por la Asamblea General de las Naciones Unidas en París, el 10 de diciembre de 1948.

La revolución industrial de los siglos XVIII y XIX acentuó y expuso la violencia cometida contra los niños y los adolescentes, de modo a no aceptar más que fuese simplemente ignorada ${ }^{7}$. Sumado a eso, al principio del siglo $\mathrm{XX}$, otras áreas del conocimiento humano, como la medicina, la pedagogía y la psicología, contribuyeron para la emergencia de una nueva mentalidad de atención al niño. El amparo normativo en pro de esa comunidad comenzó a formarse, entonces, en ese período histórico. Algunos instrumentos internacionales son adyacentes e, hasta incluso, trataron la temática de la infancia, tales como las Convenciones n. ${ }^{\circ}$ s 5 y 6 , de la OIT, ambas aprobadas en su primera reunión en 1919, y que disponen, respectivamente, sobre la "Edad Mínima de Admisión en los trabajos Industriales" y del "Trabajo Nocturno de los Menores en la Industria”; y la Declaración de Ginebra de 1924 sobre los derechos de los niños ${ }^{8}$. Sin embargo, es la DUDH que asegura que toda persona humana es digna y es titular de derechos, por ser detentora de esa condición (la condición humana). Ya en su primer "considerando", afirma la "dignidad inherente a todos los miembros de la familia humana y de los derechos iguales e inalienables como fundamento de la libertad, de la justicia y de la paz en el mundo". Es, pues, el documento basilar para el reconocimiento internacional de los derechos humanos. Específicamente con relación a la infancia, la Declaración prevé que, junto con la maternidad, "tiene derecho a ayuda y a asistencia especiales. Todos los niños, nacidos dentro o fuera del matrimonio, gozan de la misma protección social”, como está expresado en el art. 25, II. 
Influenciada por la norma en cuestión - donde surgen diversos instrumentos internacionales de derechos humanos -, en provecho de la garantía de los derechos infanto-juveniles, fue adoptada la Declaración Universal de los derechos del niño, por las Naciones Unidas, el 20 de noviembre de 1959. Considerada el marco de fijación de la doctrina de protección integral, ella enuncia diez principios, con acento a la necesidad de protección social y observancia de los mejores intereses del niño, que se refiere al principio 2. ${ }^{\circ}$

La Declaración, también, reconoce a todos los niños como poseedores de los derechos que detenta. Ellos son: igualdad, desarrollo (físico, mental, moral, espiritual y social), libertad, dignidad, nombre, nacionalidad, previsión social, salud, alimentación, recreación, asistencia médica, cuidados especiales, tratamiento y educación para los deficientes, amor, comprensión, permanencia con los padres, en especial con la madre, cuidados especiales por parte de la sociedad y de las autoridades cuando no tienen familia o carecen de medios adecuados de subsistencia, educación, jugar, divertirse, protección y socorro en primer lugar, protección contra negligencia, crueldad y explotación, no ser objeto de tráfico, no estar empleado antes de la edad mínima conveniente, no desempeñar ocupación o empleo que le perjudique la salud y su desarrollo no discriminación, criarse en un ambiente de comprensión, tolerancia, amistad entre los pueblos, de paz y de fraternidad universal.

La consolidación de la doctrina se da con la adopción de la Convención sobre los derechos del niño, por la Organización de las Naciones Unidas, el 20 de noviembre de $1989^{10}$. Además de ratificar instrumentos internacionales que le precedieron, incluso los dos aquí citados anteriormente, la Convención lista los derechos que los niños titularizan - con registro para la garantía de respeto a su opinión (artículo 12) ${ }^{11}$, como su protección contra la explotación económica y realización de cualquier trabajo peligroso, o que interfiera en su educación, o que sea perjudicial para su salud y su desarrollo (artículo 32). Prevé, también, el deber de los Estados a divulgarla a los niños y adultos, y realizar normas para su cumplimiento y análisis de los progresos venideros.

\subsection{Elementos caracterizadores}

Teniendo, pues, como pedestal la Declaración Universal de los Derechos Humanos (1948), la Declaración Universal de los derechos del niño 
(1959), y la Convención sobre los derechos del niño (1989) ${ }^{12}$, la doctrina internacional de las Naciones Unidas de protección integral tiene como sus elementos caracterizadores el reconocimiento de los niños y de los adolescentes como sujetos de derechos y personas en etapa especial de desarrollo ${ }^{13}$.

El primer elemento informa que los miembros de la comunidad infanto-juvenil son titulares de derecho y poseen capacidad para gozar de ellos. Más allá de los derechos atribuidos a todas las personas, incluso a las adultas, ellos poseen derechos específicos, propios de la infancia y de la adolescencia, que les son atribuidos justamente para que puedan disfrutar de una vida digna.

La condición de sujeto rechaza, aún, las ideas que devienen del sentido común de que los niños y adolescentes son meros objetos de intervención estatal o asistencialismo, o son cosas - poseídas por otros (en regla, por los padres), que de ellos pueden usar y/o abusar -. Por eso, incluso, varios derechos consisten en la garantía de protección de los niños y de los adolescentes contra violencias.

Ya el segundo elemento reconoce que esos sujetos están en proceso de madurez (física, psíquica, moral, sexual y social), razón por la cual les deben ser garantizados todos los medios necesarios para su desarrollo pleno y armonioso, y que tenga como objetivo el ejercicio de su ciudadanía y su emancipación ${ }^{14}$. A pesar de contener una perspectiva de futuro, ese elemento reconoce a la comunidad infanto-juvenil en su momento presente - y no como un llegar a ser.

Exactamente por estar en etapa especial de desarrollo, las personas con menos de dieciocho años son vulnerables ${ }^{15} \mathrm{y}$, por tanto, no poseen completa aptitud para la plena consecución y tutela, por sí solos, de los derechos de que son titulares (sujetos). Por ello la necesidad de que otras personas adultas - actúen en su favor, para concretizar sus derechos, protegiéndolos y proveyendo sus necesidades.

\subsection{Incorporación en el ordenamiento jurídico patrio}

La doctrina de protección integral fue incorporada en el caput del art. 227 de la Carta Magna brasileña, "por medio de una interpretación no literal, pero nada contestada” (SANTOS y VERONESE, 2018, p. 113). Se transcribe: 
Art. 227. Es deber de la familia, de la sociedad y del Estado asegurar al niño, al adolescente y al joven, con absoluta prioridad, el derecho a la vida, a la salud, a la alimentación, a la educación, a la diversión, a la profesionalización, a la cultura, a la dignidad, al respeto, a la libertad y a la convivencia familiar y comunitaria, además de colocarlos a salvo de toda forma de negligencia, discriminación, explotación, violencia, crueldad y opresión (BRASIL, 1988) ${ }^{16}$.

Ella fue expresamente adoptada en la Ley n. ${ }^{\circ} 8.069$, del 13 de julio de 1990, que "dispone sobre el Estatuto del niño y del Adolescente", tal como anunciado en su art. $1^{\circ}$ - "Esta Ley dispone sobre la protección integral al niño y al adolescente" - Le cabe no sólo la consolidación de la doctrina en el ordenamiento jurídico patrio, sino también detallarla e instituir el sistema de garantía de derechos.

Además de ir al encuentro de la tendencia normativa internacional, el artículo de la Constitución de la República indicado ${ }^{17}$ y el ECA son frutos del proceso de redemocratización del País vivenciado en las décadas de 1970 y 1980. En particular, de la movilización social en beneficio de los niños pobres y extremadamente pobres - conocidos como 'niños y niñas de la calle', vistos como problema o, hasta incluso amenaza social -, que reivindicaba la adopción de una nueva política de atención a los niños y a los adolescentes.

De hecho, ellos representaron la superación de las particularidades de la doctrina de la situación irregular vigente hasta entonces en Brasil, por medio del Código de Menores de $1979^{18}$, y, hasta mismo, de la legislación especial que lo antecedió, a saber, el Código de Menores de $1927^{19}$. Grosso modo, la referida doctrina criminalizaba la pobreza e institucionalizaba a sus víctimas, ya que volcada para los menores ${ }^{20}$ abandonados y/o infractores ${ }^{21}$, está basada en un modelo asistencialista, segregador, autoritario y punitivo ${ }^{22}$.

Leoberto Narciso Brancher (2000, p. 126) sintetizó las diferencias conceptuales y organizacionales (o de gestión) entre las dos doctrinas en el siguiente cuadro:

\begin{tabular}{|c|c|c|}
\hline ASPECTO & ANTERIOR & ACTUAL \\
\hline Doctrinario & Situación Irregular & Protección Integral \\
\hline Carácter & Filantrópico & Política Pública \\
\hline Fundamento & Asistencialista & Derecho Subjetivo \\
\hline Centralidad Local & Judicial & Municipio \\
\hline
\end{tabular}




\begin{tabular}{|c|c|c|}
\hline Competencia Ejecutoria & Unión/Estados & Municipio \\
\hline Decisorio & Centralizador & Participativo \\
\hline Institucional & Estatal & $\begin{array}{c}\text { Cogestión de la Sociedad } \\
\text { Civil }\end{array}$ \\
\hline Organización & Piramidal Jerárquica & Red \\
\hline Gestión & Monocrática & Democrática \\
\hline
\end{tabular}

Para viabilizar la implementación de los cambios acaecidos tras el nuevo paradigma adoptado, más allá del principio del mejor interés (previsto expresamente en las normas internacionales), a CR/1988 albergó los principios de la responsabilidad compartida, de la prioridad absoluta, de la descentralización político-administrativa y de la participación popular. Ellos fueron previstos en el artículo 227: los dos primeros, expresamente, en el caput, y los dos últimos por remisión, constantes en el párrafo $7 .^{\circ}$, al artículo 204, de la $\mathrm{CR} / 1988$, que trata de las directrices de las acciones gubernamentales en el área de asistencia social. Ellos también fueron previstos y, en algunos casos, detallados en el ECA, y serán puntuados en la secuencia.

\subsection{Principios}

El principio del mejor interés - o de interés superior - informa que, en cualquier situación fáctica o jurídica, habiendo más de una solución consecuente de la aplicación de las reglas incidentes sobre la materia, es imperioso optar por la alternativa existente que, analizada de forma objetiva, mejor salvaguarde los intereses de los niños y de los adolescentes, de modo a realizar los derechos fundamentales de que son titulares. Impone, aún, la preponderancia de los intereses de esos sujetos frente a los intereses de cualesquiera otras personas eventualmente involucradas en una misma situación o con quien están relacionándose.

El ECA prevé, literalmente, la observancia del principio en análisis al tratar del plazo de permanencia del niño y del adolescente en programa de acogida institucional (art. 19, $\ 22^{\circ}$ ), de la aplicación de las medidas específicas de protección (art. 100, \único, IV), de la no observancia del orden cronológico de las habilitaciones para fines de adopción (art. 197-E, \1. $0^{\circ}$ ), entre otras situaciones. De hecho, su observancia es necesaria para solucionar vasta gama de situaciones. Se ejemplifica: en caso de separación de los padres, es mejor 
que el niño sea mantenido con la madre, con el padre o que ellos compartan la guardia (¿aunque esta no sea la voluntad de los padres?)? ¿Es mejor permitir que un niño quede en situación de calle con su familia natural, que acogerla institucionalmente o encaminarla para colocarla con una familia sustituta?

La respuesta para cada caso particular, que no será obtenida fácilmente, dependerá del examen crítico de todos los elementos existentes aspectos financieros, emocionales, prevención de violencias, contexto social etc. Deberá, aún, respetar la opinión del niño o del adolescente involucrado, observados patrones de razonabilidad (tales como su edad, capacidad de discernimiento, madurez para comprender la situación etc.). Así, en el caso concreto, se debe siempre evaluar objetivamente lo que es mejor para el niño o el adolescente en cuestión.

Ya el principio de la responsabilidad compartida - también identificado como responsabilidad tripartita - consecuencia de la previsión de que la comunidad infanto-juvenil debe gozar de protección especial de la familia, de la sociedad y del Estado. Esas tres instituciones poseen responsabilidades propias y solidarias con relación al deber de proveerlos y protegerlos, lo que consiste, al fin y al cabo, en la obligación de dar eficacia a los derechos que les son garantidos.

A la familia - prioritariamente la natural ${ }^{23}$, pero también la ampliada 0 sustituta $^{24}$-, compete la responsabilidad primordial de criar, educar, y garantizar la convivencia familiar y comunitaria ${ }^{25}$. Específicamente a los padres le incumbe el ejercicio del poder familiar y el deber del sustento, guardia y educación. Cuando la familia no tiene recursos materiales suficientes para tanto, el Estado debe incluirla en servicios y programas oficiales de protección, apoyo y promoción, a fin de superar la condición de pobreza y mantener los vínculos familiares, fortaleciéndolos si están fragilizados. De esa forma, la condición de pobreza de la familia, por sí solo no es apta a caracterizar que el niño o el adolescente esté siendo descuidado y, vía de consecuencia, no constituye motivo para la pérdida o suspensión del poder familiar ${ }^{26}$.

La responsabilidad de la sociedad y de la comunidad (esta última especificada en el caput del art. $4 .^{\circ}$, del ECA) asume una perspectiva ético política y otra jurídica, conforme apunta Danielle M. Espezim dos Santos (2017, p. 33-34). La primera indica la existencia de un deber (ético y político) de todos los ciudadanos de asumir la protección integral de niños y adolescentes. La 
segunda informa el deber de, además de no ser omiso frente a las violaciones de derechos - e incurrir en crimen de omisión de socorro (art. 135, del CPB) -, realizar el principio de la participación popular, en la formulación y control de políticas volcadas para la promoción, protección y defensa de los derechos de ese público.

Al Estado, a su vez, le compete ejercer sus funciones típicas - legislativa, judicial y ejecutiva - en pro de los niños y de los adolescentes. Para ello, el legislador debe mantener y perfeccionar el sistema normativo garantista. El juez debe, en los casos concretos de conflictos de intereses llevados a su conocimiento, decidir de acuerdo con las normas, lo que significa, entre otros, promover el mejor interés del sujeto en cuestión. Y el administrador debe elaborar y ejecutar políticas públicas sociales - de educación, de salud, de asistencia social etc. - emancipatorias e inclusivas, de prestar servicios en favor de la comunidad infanto-juvenil. Le compete, necesariamente, ofrecer políticas básicas, programas de atención de protección y programas de atención socioeducativa, conforme dispuesto en el art. 90, del ECA.

La Carta Constitucional también atribuye a los derechos de los niños, de los adolescentes y desde 2000 , de los jóvenes, prioridad absoluta con relación a los derechos de los adultos y de los ancianos, hasta incluso de aquellos que constituyen grupos especiales - como los deficientes, por ejemplo -. Eso comprende, en los términos del párrafo único, del artículo 4. ${ }^{\circ}$, del ECA, de forma no exhaustiva ${ }^{27}$ :

a) primacía de recibir protección y socorro en cualesquiera circunstancias;

b) precedencia de atención en los servicios públicos o de relevancia pública;

c) preferencia en la formulación y en la ejecución de las políticas sociales públicas;

d) destinación privilegiada de recursos públicos en las áreas relacionadas con la protección a la infancia y a la juventud.

El principio constitucional en comento, previsto exclusivamente en favor de los derechos infanto-juveniles, debe ser observado - como criterio de validez que es - cuando de la elaboración, de la interpretación y de la aplicación de las normas, notoriamente de aquellas que se consustancian en políticas públicas $^{28}$. Es que impone la concretización de los derechos garantizados a los niños, a los adolescentes y a los jóvenes, de forma prioritaria y absoluta con relación a los derechos de otros grupos de edad. Su relevancia 
sobresale en un contexto de escasez de recursos públicos, que impone la jerarquización de prioridades.

Ya el principio de la descentralización político-administrativa ajusta que la coordinación y el establecimiento de las normas generales afectas al público ahora enfocado son atribuciones de la esfera federal; al paso que cabe "la coordinación y la ejecución de los respectivos programas a las esferas estadual y municipal, bien como a entidades de caridad y de asistencia social" (art. 204, I, de CR/1988). En el mismo sentido, se encuentra el art. 88, III, del ECA.

El Estatuto prevé, también, de forma más específica, como directriz de la política de atención, a su municipalización (art. 88, I). El municipio asume, pues, protagonismo en la materialización de los derechos y en el ofrecimiento de programas y servicios a los niños y a los adolescentes, debiendo adaptarse para darlos. La descentralización se da, hasta incluso, "horizontalmente, en lo que se refiere al papel de los propios actores de atención en el ámbito local, donde el modelo se concentraba monolíticamente en la autoridad judicial” (BRANCHER, 2000, p. 125).

Finalmente, está el principio de la participación popular, que se traduce en la participación directa de la sociedad en la formulación de las políticas y en el control de las acciones, por medio de organizaciones representativas (conforme previsto en el art. 204, II, de la CR/1988). La participación en esas organizaciones es paritaria (entre la sociedad civil y el Estado), y contempla la "creación de consejos municipales, estaduales y nacional de los derechos del niño y del adolescente, órganos deliberativos y controladores de las acciones en todos los niveles", de acuerdo con el art. 88, II, del ECA.

Así siendo, a los miembros de la sociedad les incumbe componer organizaciones representativas, como los Consejos de Derecho y el Consejo Tutelar, y ocupar otros espacios públicos no estatales, de diálogo y negociación, tales como Fóruns y Conferencias. Este principio posee estrecha relación con la realización del principio de la responsabilidad solidaria, en lo que se refiere a los deberes atribuidos a la sociedad, ya abordado. 


\section{CONCLUSIÓN}

Conforme todo lo dicho, la erradicación del trabajo precoz es una meta establecida en reglas constitucionales, internacionales (ratificadas por el País) y legales garantistas, y está basada en principios que buscan viabilizar, con prioridad, la concretización de la dignidad y de otros derechos fundamentales del público infanto-juvenil. Sin embargo, aún no se vivencia en la dinámica social brasileña la implementación fáctica e irrestricta de la doctrina de protección integral. De hecho,

[...] la realidad todavía es bastante incómoda. Bajo la égida de una nueva norma y una nueva doctrina jurídica, se sigue instrumentalizando a los niños y adolescentes en Brasil. El pasaje del siglo XX para el XXI tiene sus especificidades: la explotación del consumismo precoz acarreando "[...] obesidad infantil, erotización precoz, estrés y conflictos familiares, banalización de la agresividad y violencia, entre otros riesgos" (LIMA; VERONESE, 2015, p. 232); las barreras de color en el ambiente escolar, adonde las relaciones son desiguales en detrimento de negros ante blancos (LIMA; MATTEI, 2015, p. 318). Aún, números relativos la [sic] explotación de la mano de obra [sic] infantil doméstica (CUSTÓDIO; VERONESE, 2009, p. 173), la [sic] situación de calle y la [sic] convivencia familiar de niños y adolescentes en Brasil (RÉ, 2015, p. 443-444) no son nada despreciables en Brasil post Estatuto y su protección Integral. Al contrario, se percibe por estos y otros fenómenos violentos, que los meandros del patrón de funcionamiento de la sociedad brasileña exigen sofisticación estratégica en la interpretación y aplicación de las normas ligadas a la doctrina ahora en aprecio. La invisibilidad, [...] camina al lado del aspecto anterior - "cosificación" -, ambos reduciendo el grado de reconocimiento efectivo de la condición de sujeto de niños y adolescentes. Se piensa aquí en aquellos que no aparecen en las estadísticas, [...] que son violadas en el espacio privado preconcebido como seguro. hecho es que las violaciones como las que más arriba se explicitaron [sic] tienen alto grado de probabilidad de ocurrir en mayor número del que se puede medir exactamente, también en clases más abastadas económicamente, que practican el hábito del silencio y de ocultamiento de sus molestias dolorosas con relación a los vulnerables. (SANTOS, 2017, p. 40-41)

Sumado a las cuestiones sociales y económicas, se puede puntualizar como barreras para la implementación de la protección integral, no exhaustivamente, la falta de conocimiento sobre sus normas y aplicabilidad; a veces la sobreposición, otras la ausencia de actuación de los actores de la red de protección, en consecuencia de la incomprensión del papel de cada uno; la repetición de prácticas y la permanencia de estructuras autoritarias, jerarquizadas y obsoletas; la necesidad de interdisciplinariedad y de actuación sistémica en 
red. En fin, la no aprehensión de la complejidad del modelo adoptado y el no establecimiento de una nueva dinámica social ${ }^{29}$.

Siendo así, para que los niños y los adolescentes sean de hecho beneficiarios de protección integral es necesaria la difusión de la doctrina y el conocimiento acerca de su forma de implementación - vía sistema de garantía de derechos -, el debido funcionamiento de este sistema - en red -, la integración operacional entre los diversos actores y políticas que lo componen, la selección eficaz y la implementación eficiente de políticas públicas de enfrentamiento y erradicación del trabajo precoz, voluntad de articulación política, movilización social, entre otros.

Se buscó con el presente texto contribuir, aunque brevemente, para la difusión y comprensión de la doctrina de protección integral, con el objetivo de enfrentar efectivamente al trabajo precoz y, vía de consecuencia, a la concretización de la protección de la infancia y de la adolescencia. Es que la existencia de leyes garantistas de los derechos fundamentales de los niños y de los adolescentes brasileños, y hasta incluso la asunción de compromisos internacionales por Brasil no son suficientes para materializar el derecho infanto-juvenil al no trabajo, cara de la desprotección social, a la conciencia extendida en el sentido común que favorece al trabajo precoz, e, incluso, a la connivencia de la familia, de la sociedad y del Estado que aceptan ese tipo de trabajo indigno.

\section{NOTAS}

1 En el plano internacional, todas las personas con menos de dieciocho años son consideradas niño (art. 1. ${ }^{\circ}$, de la Convención sobre los derechos del niño, de 1989, que será objeto de mayores digresiones más adelante en este texto). En Brasil, la distinción de edad entre niños y adolescentes se encuentra en el art. 2. ${ }^{\circ}$ del ECA y será observada en el presente estudio por permitir una mejor aproximación del fenómeno del trabajo precoz.

2 A partir de la perspectiva de Robert Alexy (2008. p. 85-144), se entiende por derechos fundamentales los valores y fines considerados de tal relevancia para una sociedad dada, previstos en normas establecidas directamente por la Constitución o en normas atribuidas (destacadas en derechos fundamentales), y que, por tanto, deben ser perseguidos por el respectivo Estado, organizaciones e individuos.

3 Será privilegiado el uso de la expresión "trabajo precoz" en sustitución a la expresión "trabajo infantil". El significado del adjetivo "Infantil" (MICHAELIS, 2019), es "relativo o apropiado a la infancia". Se tiene la convicción que, en razón de la condición de la persona en etapa especial de desarrollo, ningún trabajo sea apropiado a un niño o al adolescente antes de los dieciséis años, salvo en la condición de aprendiz, a partir de los catorce años, y siempre que las condiciones sean apropiadas para su 
realización. Se evita de esa forma, la utilización de una expresión con connotación naturalmente positiva para indicar una práctica nefasta.

4 Las prohibiciones están expresadas en el art. $7 .^{\circ}$, inciso XXXIII y art. 227, \ $3 .^{\circ}$, III, de la Constitución de la República vigente (CR/1988), en los arts. 403, 404 y 405, de la Consolidación de las Leyes del trabajo (CLT), en el art. 67 del Estatuto del niño y del Adolescente (ECA), en la Convención n. 182 de la OIT ("sobre prohibición de las peores formas de trabajo infantil y acción inmediata para su eliminación”), aprobada en Brasil por el Decreto Legislativo n. ${ }^{\circ}$ 246, del 28 de junio de 2001, conforme consolidado en el art. 2. ${ }^{\circ}$, LXVIII, del Decreto n. ${ }^{\circ} 10.088$, del 5 de noviembre de 2019), y reglamentada por el Decreto n. ${ }^{\circ}$ 6.481, del 12 de junio de 2008, que aprueba la lista de las peores formas de trabajo infantil (Lista TIP) y relaciona situaciones que integran esas peores formas.

5 " $[. .$.$] se tiene por dignidad de la persona humana la cualidad intrínseca y distintiva$ reconocida en cada ser humano que lo hace merecedor del mismo respeto y consideración por parte del Estado y de la comunidad, implicando, en este sentido, un complejo de derechos y deberes fundamentales que aseguren a la persona tanto contra todo y cualquier acto de cuño degradante y deshumano, como vengan a garantizar las condiciones existenciales mínimas para una vida saludable [criterio de la Organización Mundial de Salud - OMS], además de propiciar y promover su participación activa y corresponsable en los destinos de la propia existencia y de la vida en comunión con los demás seres humanos" (SARLET, 2009, p. 37). “[...] sea en el ámbito internacional, sea en el ámbito interno (a la luz del derecho constitucional occidental), la dignidad de una persona humana es el principio que unifica y centraliza todo el sistema normativo, asumiendo especial prioridad. La dignidad humana simboliza, de ese modo, verdadero súper principio constitucional, la norma mayor a orientar el constitucionalismo contemporáneo, en las esferas local y global, dotándolo de especial racionalidad, unidad y sentido" (PIOVESAN, 2013, p. 89).

6 Según Sofia Vilela de Moraes e Silva (2017, p. 254), “[...] se infiere que la noción de niño y de adolescente como sujeto de protección no fue contemplada en la Antigüedad, en la Edad Media y tampoco en la Edad Moderna - En este último período no había plena conciencia de la peculiaridad infantil. Tampoco la Declaración de los Derechos del Hombre y del Ciudadano, de 1789, innovó a traer dispositivo específico sobre el niño, aunque haya proclamado la igualdad". A su turno, Fábio Konder Comparato (2006, p. 54) afirma que "la primera fase de internacionalización de los Derechos Humanos [...] tuvo inicio en la segunda mitad del siglo XIX y finalizó con la 2. ${ }^{a}$ Guerra Mundial, manifestándose básicamente en tres sectores: el derecho humanitario, la lucha contra la esclavitud y la regulación de los derechos del trabajador asalariado".

7 "[...] em tal período hubo proliferación de la explotación de la mano de obra infantil, como también del trabajo femenino, visto que eran remuneradas de forma desigual con relación a los adultos de sexo masculino, hecho que hizo que este tipo de contratación un gran atractivo para los dueños de las fábricas". (PAPPENMAURIN; REIS, 2016, p. 71). "La explotación de los grandes industriales hacia los pequeños obreros no tenía límites, porque no había violación a la norma jurídica, o incluso, al precepto moral. En la época, estaba en boga la corriente política del liberalismo clásico, la cual combatía la intervención estatal. Siendo así, el abuso de los patrones era justificado por los propios dictámenes axiológicos enraizados en la sociedad europea. La falta de reglamentación, unida a la busca enloquecida por el lucro, ocasionó una degradación física y mental de los niños" (SILVA, 2017, p. 255). 
8 " "...] en 1924 bajo los auspicios de la Liga de las Naciones se publica la Declaración de Ginebra sobre los derechos del niño; con el objetivo de abarcar la protección y el reconocimiento en cuanto a la alimentación, a la educación, a los cuidados en las situaciones de peligro, sin embargo, esta recibe críticas, pues no teje muchas consideraciones a la familia, no atribuye responsabilidad de los Estados, solo enumera derechos". (VERONESE e FALCÃO, 2017, p. 15).

9 Importa registrar, conforme apuntado por Danielle M. Espezim dos Santos y Josiane Rose Petry Veronese (2018, p. 129), que "Los valores y derechos reconocidos internacionalmente y pactados en la DUDH - Declaración Universal de los Derechos Humanos - en 1948 son representativos de un proceso histórico político que tiene dirección y protagonistas propios: es la marca de la Revolución Francesa que pasa a influenciar directamente el texto del siglo XX. Son, entonces, Europa y el discurso burgués que definen lo que son los derechos humanos en el siglo XX. La opción por una Declaración con pretensión de universalidad tiene influencias directas: el holocausto judío por el nazismo legal alemán y las bombas atómicas tiradas sobre Hiroshima y Nagasaki por EE.UU en la Segunda Guerra Mundial, generaron un gran malestar humanitario".

10 En 1979, 20 años después de la adopción de la Declaración Universal de los derechos del niño, se iniciaron los trabajos que culminaron con la elaboración de la Convención. Para críticas sobre o processo de sua elaboração e seu resultado, ver, por todos, Flávia Rosemberg e Carmem Lúcia Sussel (2010).

11 Sobre esta cuestión, se sugiere la lectura del texto de Esther Maria de Magalhães Arantes (2012), que la aborda de forma crítica.

12 Todos ellos ratificados por Brasil.

13 Hay otros importantes documentos internacionales que tratan de la infancia y de la adolescencia, tales como, la Convención Americana de Derechos Humanos (Pacto de San José de Costa Rica), adoptada por la Organización de los Estados Americanos, el 22 de noviembre de 1969, previendo que "Toda niño tendrá derecho a las medidas de protección que su condición de menor requiere, por parte de la familia, de la sociedad y del Estado" (art. 19); las Reglas Mínimas de las Naciones Unidas para la Administración de Justicia de la Infancia y de la Juventud - Reglas Mínimas de Beijing (Resolución n. ${ }^{\circ} 40.33$ de la Asamblea General de la ONU, del 29 de noviembre de 1985); las Reglas Mínimas de las Naciones Unidas para la Elaboración de Medidas No Privativas de Libertad - Reglas de Tokio (Resolución n. ${ }^{\circ} 45.110$ de la Asamblea General de la ONU, del 14 de diciembre de 1990). Sin embargo, por recorte teórico hecho en este texto, ellos no serán objeto de análisis.

14 Palabra empleada en este texto en su sentido literal, indicativo de "movimiento de liberación; manumisión, independencia” (MICHAELIS, 2019).

15 Vulnerabilidad clasificada como intrínseca por Danielle M. Espezim dos Santos y Josiane Rose Petry Veronese (2018, p. 110; 143 a 145), y que, en sociedades que conviven con la pobreza y desigualdad estructurales, como la brasileña, se suma a la vulnerabilidad social y económica, entre otras, tales como "barreras de color, de género" (p. 112; 146 a 148).

16 La mención al joven deriva de la redacción dada por la enmienda constitucional n. ${ }^{\circ} 65$, de 2010. El texto constitucional original solamente se refería al niño y al adolescente. Conforme previsto no $\int 3^{\circ}$ del artículo 227 , ahora en comento, "El derecho a protección especial abarcará los siguientes aspectos: I - edad mínima de catorce años para admisión al trabajo, observado lo dispuesto en el art. $7^{\circ}$, XXXIII; II - garantía de derechos de previsión social y laborales; III - garantía de acceso del trabajador adolescente y joven a la escuela; IV a VII - Omissis". 
17 Cabe resaltar que la Constitución de la República fue promulgada en 1988, un año antes de la adopción de la Convención sobre los derechos del niño, por la ONU que se dio, como ya indicado, en 1989. No hay duda, sin embargo, que el legislador constituyente fue también influenciado por los trabajos en curso, que llevaron a la adopción de la referida Convención.

18 Ley Federal n. ${ }^{\circ}$ 6.697, de 10 de octubre de 1979.

19 Decreto n. ${ }^{\circ}$ 17.943-A, de 12 de octubre de 1929. Está vinculado a la doctrina del derecho Penal del Menor, que deriva del Código Penal de 1890.

20 "Para efecto de demarcación entre un momento doctrinario y otro, en sede de derecho brasileño, cumple vincular la terminología "menor" y "menorismo" a la vigencia, de interpretación y aplicación de normas relativas a los Códigos de Menores, tanto de 1927 y de 1979, como a aquellas situaciones referentes al período pre estatutario en general'. (SANTOS, 2017, p. 30)

21 Conforme previsto en el art. $1^{\circ}$, del Código, él se volcaba para los menores (personas con hasta dieciocho años de edad) en situación irregular. Ya el art. $2^{\circ}$, consideraba en situación irregular al menor "I - privado de condiciones esenciales a su subsistencia, salud e instrucción obligatoria, aunque eventualmente, en razón de: a) falta, acción u omisión de los padres o responsable; b) manifiesta imposibilidad de los padres o responsable para proveerlas; Il - víctima de malos tratos o castigos inmoderados impuestos por los padres o responsable; III - en peligro moral, debido a: a) encontrarse, de modo habitual, en ambiente contrario a las buenas costumbres; b) explotación en actividad contraria a las buenas costumbres; IV - privado de representación o asistencia legal, por la falta eventual de los padres o responsable; V - Con desvío de conducta, en virtud de grave inadaptación familiar o comunitaria; VI - autor de infracción penal".

22 El historial de la evolución legislativa afecta a los niños y los adolescentes en Brasil puede ser consultado en diversas obras, entre las cuales, se sugiere las de Sueli Teixeira Bessa (2019), Thalissa Corrêa de Oliveira (2017), Sofia Vilela de Moraes e Silva (2009) y Viviane Matos González Perez (2006).

23 Prioridad prevista en el $\$ 1 .^{\circ}$, do art. $1 .^{\circ}$ de la Ley n. ${ }^{\circ} 12.010$, del 03 de agosto de 2009, que, entre otros, "dispone sobre adopción".

24 Previstas, respectivamente, en el art. 25, caput y párrafo único, y en el art. 28 del ECA.

25 A propósito, ver art. 19, ECA.

26 Conforme a lo dispuesto en los artículos 21, 22 y 23 de ECA.

27 "No pretende tal enumeración ser exhaustiva, pues la Ley no podría especificar todas las situaciones en que deberá asegurarse la preferencia a la infancia y a la adolescencia, tampoco todas las formas de garantía" (VERONESE, 2017, p. 6).

28 "El mandato de la prioridad absoluta debe permear las acciones de todos los obligados a la garantía de los derechos fundamentales y debe servir como criterio para los juicios de validez de las Leyes infraconstitucionales - como las presupuestarias -, de los actos de los gestores públicos y de las sentencias judiciales.” (SANTOS, 2017, p. 42).

29 A propósito, se indica la lectura del capítulo VI de la obra de Fernanda da Silva Lima y Josiane Rose Petry Veronese (2012, p. 111 - 141).

\title{
REFERENCIAS
}

\author{
ALEXY, Robert. Teoria dos direitos fundamentais. Trad. Virgílio Afonso \\ da Silva. São Paulo: Malheiros, 2008.
}


ARANTES, Esther Maria de Magalhães. Direitos da criança e do adolescente: um debate necessário. In: Psicol. clín., 2012, vol. 24, n.1, p. 45-56. ISSN 01035665. Disponible en: https://doi.org/10.1590/S0103-56652012000100004. Acceso en: 13 mayo de 2020.

BESSA, Sueli Teixeira. A Atuação Resolutiva do Ministério Público do trabajo e a Promoção do derecho Fundamental à Profissionalização dos Adolescentes em Cumprimento de Medida Liberdade Assistida. Dissertação (Mestrado em Direito). Universidade Católica de Brasília. Brasília, 2019. 154f.

BRANCHER, Leoberto Narciso. Organização e gestão do sistema de garantias de derechos da infancia da juventude. In: Pela Justiça na Educação. Coordenação geral Afonso Armando Konzen ... [et al.]. Brasília: MEC. FUNDESCOLA, 2000. 735p.

BRASIL. Constituição da República Federativa do Brasil. Brasília/DF, 1988. Disponible en: http://www.planalto.gov.br/ccivil_03/constituicao/ ConstituicaoCompilado.htm. Acceso en: 2 oct. 2020.

COMPARATO, Fábio Konder. A afirmação histórica dos direitos humanos. 4. ${ }^{a}$ ed. São Paulo: Saraiva, 2006.

DE OLIVEIRA, Thalissa Corrêa. Evolução histórica dos derechos da niño e do adolescente com ênfase no ordenamento jurídico brasiLeyro. In: Revista Interdisciplinar de Direito, Fundação Educacional D. André Arcoverde. Juiz de Fora, v. 10, n. 2, out. 2013. Disponible en: http://revistas.faa.edu.br/ index.php/FDV/article/view/173. Acceso en: 10 jun. 2019.

EMANCIPAÇÃO. In: DICIONÁRIO Michaelis. Disponible en: http:// michaelis.uol.com.br $/$ busca? $\mathrm{r}=0 \& \mathrm{f}=\& \mathrm{t}=\&$ palavra $=$ emancipa $\% \mathrm{C} 3 \% \mathrm{~A} 7 \%$ C3\%A3o. Acceso en: 22 de mayo 2020.

INFANTIL. In: DICIONÁRIO Michaelis. Disponible en: http://michaelis.uol.com.br/busca?id=EZzGk. Acceso en: 16 sept. 2019.

LIMA, Fernanda da Silva; VERONESE, Josiane Rose Petry (autoras). Os direitos da criança e do adolescente: a necessária efetivação dos derechos fundamentais. Coleção Pensando o derecho no Século XXI; v.5. Florianópolis: Fundação Boiteux, 2012. 243p. 
PAPPENMAURIN, Suellen Karla; REIS, Suzéte da Silva Reis. A explotación do trabajo infantil e suas consequências sociais. In: Direito (Re)Discutido. ADOLFO, Luiz Gonzaga Silva (org.). Águas de São Pedro: Livronovo, 2016, p. 69-85.

PEREZ, Viviane Matos González. Criança e adolescente: o direito de não trabalhar antes da idade mínima constitucional como vertente do princípio da dignidade humana. Dissertação (Mestrado em Direito). Faculdade de Direito de Campos, Rio de Janeiro, 2006. $207 f$.

PIOVESAN, Flávia. Direitos humanos e o Direito constitucional internacional. 14. ${ }^{\mathrm{a}}$ ed., rev. e atual. São Paulo: Saraiva Educação, 2013.

ROSEMBERG, Fúlvia; MARIANO, Carmem Lúcia Sussel. A Convenção Internacional sobre os direitos da criança: debates e tensões. In: Cadernos de Pesquisa. Fundação Carlos Chagas. São Paulo, v. 40, n. 141, p. 693-728, set./ dez. 2010.

SANTOS, Danielle Maria Espezim dos. Proteção Integral e Proteção Social de crianças e adolescentes: Brasil, Políticas Públicas e as Cortes Superiores. Tese (Doutorado em derecho). Universidade Federal de Santa Catarina. Santa Catarina, 2017. $324 \mathrm{f}$.

SANTOS, Danielle Maria Espezim dos. VERONESE, Josiane Rose Petry. A proteção Integral e o Enfrentamento de Vulnerabilidades Infantoadolescentes. Revista de Direito, Viçosa. v. 10, n. 02, 2018, p. 109 - 157.

SARLET, Ingo Wolfgang. Dimensões da dignidade: ensaios de filosofia do direito e direito constitucional. 2. ${ }^{a}$ ed. rev., atualiz. ampl. Porto Alegre: Livraria do Advogado, 2009.

SILVA, Sofia Vilela de Moraes e. Violência sexual contra criancas e adolescentes e eficácia social dos direitos fundamentais infantojuvenis: subsídio à formulação de políticas públicas para o município de Maceió. Dissertação (Mestrado em derecho). Universidade Federal de Alagoas. Maceió, 2009. 160 f.

SILVA, Sofia Vilela de Moraes e. A doutrina da proteção integral às crianças e aos adolescentes e a atuação do Ministério Público do Trabalho. In: KALIL, Renan Bernardi, SILVA, Sofia Vilela de Moraes (org.). Temas Relevantes 
da Atuação do Ministério Público do Trabalho. Brasília: ESMPU, 2017. p. $251-278$.

VERONESE, Josiane Rose Petry (autora e organizadora). Direito da criança e do adolescente: Novo curso-Novos temas. Rio de Janeiro: Lúmen Juris, 2017.

VERONESE, Josiane Rose Petry. FALCÃO, Wanda Helena Mendes Muniz. A Criança e o Adolescente no Marco Internacional. In: VERONESE, Josiane Rose Petry (Autora e Organizadora). Direito da criança e do adolescente. Novo Curso - Novos temas. Rio de Janeiro: Editora Lumen Juris, 2017. p. 11-39. 



\section{INFANCIAS BRASILEÑAS EN COLAPSO: NECESITAMOS RESCATAR LA ÉTICA DEL}

AMOR

\section{GABRIELA LENZ DE LACERDA}

"Al final del día, esos niños están totalmente pagando un precio muy alto por nuestros conflictos, nuestras guerras y nuestros sistemas, y nuestras decisiones estúpidas y gobiernos. Sentí la necesidad de hablar sobre el problema, y estaba pensando: 'si estos niños pudieran conversar o expresarse, ¿qué dirian?' ¿Qué dirian a esta sociedad que los ignora?”

DOI: 10.51366/978-65-89468-10-3-coordinfancia-11

Resumen. El artículo tiene por finalidad compartir algunas reflexiones sobre la problemática de la infancia, a partir de la sociología de la infancia, que analiza los sujetos ocupantes del estatus niño bajo una perspectiva estructural, a ser considerada en cuanto las elecciones políticas. El enfoque del estudio es precisamente el trabajo infantil - remunerado o no - al representar la pérdida del estatus de niño. Al final, se presenta la propuesta de rescate de la ética del amor como uno de los caminos para transformar la realidad social que hoy se presenta.

Palabras-clave: Trabajo infantil. Sociología de la infancia. Estructura social. Ética del amor.

\section{INTRODUCCIÓN}

Capharnaum es una película impactante. Bajo la perspectiva de Zain, un niño sirio de solo 12 años, la película presenta la historia de refugiados que viven en el Líbano. La inmigración se presenta como un problema global, resultado de las elecciones políticas que hemos hecho y con impacto directo 
sobre la vida de las personas, incluso de aquellas que están en desarrollo. La triste circunstancia que hace a la película más real es que Zain actúa un guión inspirado en su propia historia de vida. Fuera de las pantallas de cine, el chico es un refugiado sirio que vive en el Líbano, y nos coloca en el banco de los reos, en litisconsorcio necesario con sus padres, por haberlo dejado venir a este mundo repleto de injusticias sociales.

Zain nos enseña una lección que he aprendido con muchos niños que, por un motivo u otro, se cruzaron por mi camino: infancia es sustantivo que no comporta singular. Delante de las diferentes realidades sociales, existen varias formas de vivir la infancia. En nuestra sociedad moderna, sin embargo, la posibilidad de vivenciar esa importante etapa del desarrollo humano de forma saludable y protegida es cada vez más rara. La estructura social en que vivimos, nuestras guerras y nuestras decisiones políticas afectan a los integrantes de la categoría generacional de la infancia.

La idea del presente artículo es justamente visibilizar algunos de los problemas enfrentados por niños brasileños de las más diversas realidades, víctimas del trabajo infantil - remunerado o no - necesario para el mantenimiento del sistema capitalista.

\section{LA INFANCIA POR LA PERSPECTIVA DE LA SOCIOLO- GÍA DE LA INFANCIA}

En el siglo XVII, el clérigo francés Pierre de Bérrulle clasificó a la infancia como siendo el "más vil y abyecto estado de la naturaleza humana, después de la muerte”. En la era Victoriana, en contrapartida, la infancia estaba vinculada a los sentimientos de pureza e inocencia, propios del romanticismo. Esos extremos muestran que no existe un concepto universal o un marco biológico único para definir quién es y quién no es niño. Al contrario, la historia comprueba que el concepto de infancia ya se alteró numerosas veces, dependiendo del contexto histórico y social (HEYWOOD, 2001, p. 9-10).

Delante de la percepción de que la idea de infancia es una construcción social, el sociólogo danés Jens Qvortrup, al principio de la década de los 80, se dedica a estudiar el status de la infancia dentro de la sociología - línea de investigación, que, en la época, era prácticamente inexistente (BREDA; GOMES, 2012, p. 499). 
A partir del Proyecto internacional "infancia como Fenómeno Social - Implicaciones para Políticas Sociales Futuras (Proyecto infancia)”, realizado entre 1987 y 1992, Qvortrup elabora sus nueve tesis sobre la "infancia como un fenómeno social", presentando a la infancia como una categoría en la estructura social. Coloca, por tanto, la categoría generacional al lado y de forma complementaria a otras categorías clásicas en el campo de análisis de las ciencias sociales, como clase, género y raza. Sus tesis permanecen actuales y sirven de base para analizar la infancia bajo otro ángulo, que aún hoy es poco explorado. Las tesis que él presentó (QVORTRUP, 2011, p. 199-211):

Tesis 1: La infancia es una forma particular y distinta en cualquier estructura social de sociedad: a la infancia no se la define en la sociedad por las características individuales del niño, ni siquiera por su edad - aunque pueda aparecer como una referencia descriptiva. La infancia es una forma estructural particular de organización de un grupo social que posee características propias y distintas de los demás grupos sociales. [negrita nuestra]

Qvortrup (2011, p. 205-206; 210) cita como ejemplo de características definidoras de la categoría en la sociedad moderna la escolarización de los niños (su confinamiento en las instituciones de enseñanza hasta el final de la infancia, o sea, hasta el final de la escolarización obligatoria); y la determinación del lugar del niño como menor (lugar establecido por el grupo dominante de los adultos). Son, por tanto, características abstractas que permiten verificar el lugar en que los niños han sido colocados por los adultos y pueden ser ubicados en la arquitectura social, posibilitando la comparación de niños de diferentes sociedades y culturas y, dentro de un mismo contexto social, permitiendo la comparación con otros grupos en la sociedad.

Tese 2: La infancia no es una fase de transición, sino una categoría social permanente, desde el punto de vista sociológico: la categoría social infancia continúa existiendo como forma estructural independientemente de cuántos niños entran y salen de ella. Las modificaciones cualitativas y cuantitativas no se pueden explicar por las disposiciones individuales, sino por cambios en los propios parámetros sociales. No es, por tanto, una simple fase preparatoria para la vida adulta.

Tese 3: La idea de niño, en sí misma, es problemática, en cuanto la infancia es una categoría variable histórica e intercultural: muchas investigaciones tratan a los niños como un ser "supra histórico". No hay, sin embargo, como separar al niño de la sociedad en la cual vive. Existen diversas concepciones de infancia, construidas a lo largo del tiempo, que reflejan cambios de actitud con relación a los integrantes de esta categoría.

Tese 4: infancia es una parte integrante de la sociedad y de su división de trabajo: los niños son participantes activos de la sociedad no solo porque influencian y son influenciadas por otros grupos sociales (padres, profesores, 
etc), sino también porque (i) ocupan espacio en la división del trabajo (especialmente en lo que se refiere al trabajo escolar, en actividades vinculadas al restante de trabajo de la sociedad y al mercado de trabajo); y (ii) influencian los planes y proyectos de los padres y del mundo social y económico. La infancia, por tanto, interactúa estructuralmente con otros sectores de la sociedad.

Tese 5: Los niños son co constructores de la infancia y de la sociedad: los niños no son meros receptores sin utilidad. Construyen no solo las actividades escolares, sino también a partir de sus relaciones - con los adultos y con otros niños - y con la naturaleza, contribuyendo para la formación de la infancia y de la sociedad. Los niños son participantes en la construcción del mundo y, aunque muchas veces la sociedad niegue ese potencial, presentan acciones propositivas, creativas e innovadoras - no se limitan a reproducir lo que es enseñado.

Tese 6: La infancia es, en principio, expuesta (económica e institucionalmente) a las mismas fuerzas sociales que los adultos, aunque de modo particular: todos los integrantes de los grupos por edad de la sociedad, incluso los niños, sufren la influencia de eventos amplios, de macrofuerzas. La inclusión de la mujer en el mercado de trabajo, desempleo, retracción y expansión del mercado de trabajo, por ejemplo, tiene un impacto directo sobre la vida de los niños. El problema es que, como las fuerzas sociales alcanzan de forma indirecta o mediada por la familia, esa influencia acaba siendo desconsiderada.

Tese 7: La dependencia convencional de los niños tiene consecuencias para su invisibilidad en descripciones históricas y sociales, así como para su autorización a las provisiones de bienestar: históricamente los niños no son retratados en las estadísticas comunes, no son considerados como una unidad de observación distinta de su familia. Eso impide analizar la situación del niño comparada con otros grupos de la sociedad. Atribuir al estatus de los niños la dependencia con relación a los padres se contrapone a la idea de "mejor interés del niño".

Tese 8: No son los padres, sino la ideología de la familia la que constituye una barrera contra los intereses y el bienestar de los niños: a pesar de la falta de información, se han recolectado evidencias suficientes para indicar que los niños, como grupo, más frecuentemente que otros grupos, pertenecen a los más bajos escalones de renta per cápita disponible. El problema es que heredamos la ideología de la familia, al considerar que los niños son una especie de propiedad de los padres - y, consecuentemente, son de responsabilidad exclusiva de los padres. A la sociedad solo le interesa interferir en casos excepcionales, cuando el niño está en una situación de peligro, pero nunca acepta la responsabilidad general de la infancia.

Tese 9: La infancia es una categoría minoritaria clásica, objeto de tendencias tanto marginalizadas como paternalizadoras: el niño es un grupo minoritario, definido con relación al grupo dominante de los adultos, que posee estatus social más alto y más privilegios Por sus características son excluidos de la posibilidad de participación plena de vida en sociedad; y son objeto de una actitud paternalista, que se caracteriza por una "extraña combinación de amor, sentimentalismo, siendo de superioridad en relación 
a la comprensión equivocada de las capacidades infantiles y a la marginalización". [negrita nuestra]

No es por casualidad, que las tesis sobre la infancia fueron publicadas en la década del 90, período de avance de las políticas neoliberales, con medidas tendientes a la desreglamentación de derechos, a la liberalización del mercado y a la privatización de bienes públicos. La teoría presentada por Qvortrup (2011) no es una mera distinción conceptual abstracta. Es de extrema importancia porque rompe con una racionalidad que restringe el análisis de la infancia a una mera cuestión interna de la familia - atribuyendo a los padres la culpa de las dificultades enfrentadas por los hijos. Es agregado un macro parámetro que acentúa los impactos de las políticas públicas y de las decisiones económicas sobre las condiciones de vida de los niños. Busca superar, así, la "indiferencia estructural” que nuestras sociedades tienen con relación a la infancia, al considerar prioritariamente otros numerosos factores de vida y no la infancia. Qvortrup (2011, p. 201) resalta que:

Tales lecciones son importantes, visto que no es común incluir a los niños, científica o políticamente, en el nivel de las políticas mundiales o de las nacionales. ¿Habrá alguien, en cualquier circunstancia, pensando en las consecuencias hacia los niños, por ejemplo, del Tratado de Maastrich o del mecanismo de tasa de cambio o de la crisis de los mercados financieros, etc.? Inmediatamente después de acuerdos de ese tipo, lo que se discute y escribe en primer lugar son los análisis políticos y económicos, que evalúan las consecuencias para Europa; en segundo, los análisis sobre los efectos en el propio país; en tercer lugar, las organizaciones y sus analistas profesionales los exploran intensivamente com vistas a prever las repercusiones para el comercio, la industria, la agricultura, el movimiento trabalhista, etc. Nadie se pregunta, sin embargo, lo que todo eso significa para los niños - para su vida cotidiana, para su bienestar económico, social y cultural.

Más de 20 años después, en que pese a las numerosas normas de protección a la infancia - en el ámbito nacional e internacional - las consideraciones levantadas por Qvortrup (2011) siguen actuales. La infancia sigue siendo desconsiderada como categoría integrante de la estructura social. Las decisiones políticas y económicas tomadas por los adultos continúan ignorando los impactos específicos sobre los niños - tratados como una mera extensión de los padres y, por tanto, de su exclusiva responsabilidad.

El precepto fundador de la sociología de la infancia es justamente que los niños forman parte de la sociedad y del mundo y, por tanto, la infancia debe ser conectada a la macroestructura social, inclusive - y, tal vez, princi- 
palmente - cuando analizamos la economía global. Como será expuesto a continuación, las diferentes circunstancias fácticas enfrentadas por los integrantes de la categoría de la infancia nos indican que los niveles de opresión aumentan cada vez más, lo que nos lleva a reflexionar si la fase del capitalismo que se presenta hoy es compatible con el mantenimiento del estatus de niño.

\section{INFANCIAS BRASILEÑAS EN COLAPSO: ¿EL CAPITALIS- MO ES COMPATIBLE CON EL SER NIÑO?}

Las posibilidades de infancia que están siendo ofrecidas para las generaciones que llegan al mundo parecen que no tienen en consideración un interés real con el desarrollo de los niños. En una sociedad capitalista, centrada en el trabajo humano alienado, los niños no se han salvado de la explotación del trabajo - remunerado o no, dependiendo de su contexto sociocultural. Cada vez más percibimos un verdadero desvío de la finalidad, a transformar la infancia en un mero instrumento de integración de la fase adulta de forma de satisfacer mejor a los intereses del mercado.

Nos cabe a nosotros, por tanto, la reflexión radical ${ }^{1}$ sobre las presiones que recaen - cada vez con mayor violencia - sobre los integrantes de la categoría generacional de la infancia, como efecto de las fuerzas sociales, especialmente de las neoliberales, a poner en riesgo la propia existencia de ese grupo como categoría social diferenciada.

\subsection{El fin de la infancia por el trabajo infantil remunerado: impactos del hambre, del desempleo y de la precarización de las relaciones de trabajo sobre la infancia}

Recorriendo la historia de este país de proporciones continentales que se llama Brasil, podemos percibir que ninguna de las infancias que encontramos en nuestro vasto territorio, en los diferentes tiempos y espacios, ha sido suficiente para permitir el pleno desenvolvimiento físico, mental, moral, espiritual y social del ser humano. Es urgente la reflexión sobre los impactos de las presiones sociales en la realidad de la infancia en las últimas décadas, acarreando la valorización o desvalorización del estatus niño de acuerdo con las elecciones políticas hechas por aquellos que integran la categoría generacional de los adultos. 
En 1988, los legisladores establecieron, en el artículo 227 de la Constitución Federal, el deber del Estado, la sociedad y de la familia de garantizar la prioridad absoluta de los derechos de los niños y de los adolescentes, con su "protección integral". En el mismo sentido y poco tiempo después, el Estatuto del Niño y del Adolescente, de 1990, y el amplio aparato normativo internacional, como la Convención sobre los Derechos del niño en la Organización de las Naciones Unidas, de 1989. Más allá de los textos legales, sin embargo, poco hemos cuestionado los efectos de nuestras elecciones políticas y de nuestro modo de vida sobre la infancia.

Algunos años después de la promulgación de la Constitución, en la década del 90, las políticas neoliberales que preconizaban la desreglamentación de derechos, la privatización de bienes públicos y la liberalización de los mercados resultaron en el desarrollo económico medido por el Producto Bruto Interno Bruto (PBI) ${ }^{2}$, pero no retiraron al país del mapa del hambre.

Como bien recordaba recientemente Fernando Horta (2017), en junio de 2001, en pleno "milagro neoliberal", el Jornal Nacional (noticiero de la red Globo) pasaba una serie de reportajes que revelaba que un niño moría de hambre en Brasil cada cinco minutos. El hambre tiene impacto sobre toda la sociedad, pero, como nos recuerda la sociología de la infancia, aquellos que pertenecen a la categoría generacional de la infancia sufren su impacto de forma particular. Los particulares efectos de las enfermedades relacionadas a la desnutrición infantil resultaron en la multiplicación de los "cementerios de ángeles" por los "sertões" del país, con vidas interrumpidas mucho antes de la expectativa. Las muertes eran efectos colaterales tan previsibles como injustificables de un Estado incapaz de garantizar lo mínimo necesario para una vida con dignidad (JORNAL NACIONAL, 2001).

En 2004, en los primeros años del gobierno de Luiz Inácio Lula da Silva, el entonces Ministerio de Desarrollo Social y Combate al Hambre divulgó la Política Nacional de Asistencia Social - PNAS/2004 -, asumiendo la responsabilidad de erradicar el hambre en Brasil, por medio de la implementación de programas de transferencia de renta, como el "Fome Zero" (al cual se vinculaba el "Bolsa Família”), además de políticas públicas destinadas a garantizar el acceso a bienes básicos como el agua, energía y de generación de renta. 
Una década después, Brasil finalmente saldría del mapa del hambre, conforme datos de las Naciones Unidas para la Alimentación y Agricultura (FAO), divulgados en septiembre de 2014. Según la FAO, algunos factores fueron decisivos para los resultados: aumento de la oferta de alimentos; aumento de la renta de los más pobres con el crecimiento real de $71,5 \%$ del salario mínimo y generación de 21 millones de empleos; Programa del Gobierno Federal de Acceso a la Renta; 43 millones de niños y jóvenes con alimentos; y Gobernanza, transparencia y participación de la sociedad, con la recreación del Consejo Nacional de Seguridad Alimentaria y Nutricional (Consea) (FAO, 2014).

Con la mejora de la calidad de vida de la capa más pobre de la población, no fue solo la mortalidad infantil, que se redujo. Otro grave problema que históricamente recae sobre la infancia brasileña, el trabajo infantil, también presentaba mejora en sus números, en la misma medida en que la renta de los padres mejoraba y las políticas públicas de incentivo a la permanencia en la escuela se multiplicaban. Según datos del Instituto Brasileiro de Geografía y Estadística (IBGE) - Encuesta Nacional por Muestra de Domicilios (PNAD), en 2000 teníamos 6.492 .745 niños y adolescentes, entre 5 y 17 años, ocupados. En 2011, diez años después, el número de niños y adolescentes ocupados caía prácticamente a la mitad - a 3.673.000.

Aún, pese a los compromisos firmados por el gobierno brasileño junto a la Organización Internacional del trabajo (OIT) para la erradicación del trabajo infantil, hoy son más de 2,5 millones de niños y adolescentes que ingresan en el mercado de trabajo antes de los 18 años, según datos del IBGE/ PNAD. Muchos de ellos en actividades encuadradas entre las peores formas de trabajo infantil, enfrentando realidades como las de las niñas do Marajó/ $\mathrm{PA}$, víctimas de explotación sexual en el norte del país, que, conforme retratado en el texto de la jueza Elinay Ferreira (2019), en febrero de 2015:

[...] fueron capturadas diversas "canoas" atracadas a la embarcación - de transporte eminentemente de mercaderías - y varios menores de edad circulando en el local, sin compañía de sus responsables. Sin embargo, antes de la entrada de la policía en la embarcación, la tripulación, percibiendo la aproximación de la lancha de la policía civil comenzó a desatracar las canoas, pero aún así, en el momento del abordaje, fueron encontradas dos niñas escondidas debajo de uno de los camiones transportados, una de ellas tenía solamente 11 (once) años de edad.

Quedó configurado que la presencia de la menor en la embarcación no se limitaba al trabajo infantil de venta de productos de la región, sino a la obten- 
ción de dinero y bienes en general (a ejemplo el diesel), mediante explotación sexual. En el local, además de la tripulación, se encontraron a decenas de camioneros en sus respectivos vehículos, lo que está vedado por las normas de transporte fluvial, esto también generó diversos reportajes en la época.

Cito la situación del trabajo infantil de las niñas de las comunidades ribereñas de Furo do Rio Tajapuru, municipio de Melgaço/Marajó, porque trae indicativos importantes sobre los impactos de la ausencia de políticas de generación de renta sobre la infancia. El Municipio de Melgaço quedó conocido hace algunos años como el municipio con el peor IDH (Índice de Desarrollo Humano) de Brasil. Las niñas víctimas de explotación sexual se aventuran en las balsas que rompen la calma del Río Tajapuru, por donde pasa más de la mitad de los productos electrónicos que consumimos en el país. El cierre de las madereras que ilegalmente funcionaban en la región tuvo impacto sobre la renta de las comunidades ribereñas, lo que, sumado a la más completa omisión estatal, no dejó otra alternativa que la inclusión de los niños en el mercado de trabajo. Extracción de açaí, venta de productos en las balsas y, no es raro, casos como el relatado en la fiscalización, involucrando explotación sexual de niños a cambio de un pollo asado o de diesel para garantizar la energía eléctrica. El acceso a los Derechos Humanos mínimos previstos en la Constitución sale caro - y los niños de Marajó han pagado un precio más alto para garantizarlo.

Esta y muchas otras realidades evidencian que el trabajo infantil en Brasil, de norte a sur, incluye numerosos factores, pero los principales de ellos están relacionados a la pobreza y a la necesidad de complementación de la renta familiar para garantizar la subsistencia. Son, por tanto, reflejo directo del desempleo y de la precarización de las relaciones de trabajo que alcanzan de forma más brutal a las personas negras periferizadas ${ }^{3}$.

$\mathrm{Y}$, frente a los ya alarmantes índices de trabajo infantil en Brasil, la aprobación de la Ley n. ${ }^{\circ}$ 13.467/17 evidencia el abandono político con los sujetos ocupantes de la categoría generacional infancia. Figuras como la tercerización irrestricta, el contrato de trabajo intermitente y del autónomo exclusivo representan la reducción del salario remuneratorio pago justamente a aquellos trabajadores que reciben salarios más bajos. Impactan, por tanto, precisamente sobre las familias de baja renta que históricamente están forzadas a colocar a sus hijos e hijas en el mercado de trabajo antes de la edad mínima permitida. La falta de compromiso con la infancia - manifestado no 
solo por la Reforma Laboral, sino también por otras numerosas medidas tendientes a la reducción o a la ineficacia de los derechos sociales, como la PEC del Techo de los Gastos Públicos y la extinción del Ministerio de Trabajo y Empleo y del Ministerio de Desarrollo Social, implementadas por el gobierno actual - contradiciendo frontalmente con lo dispuesto en el artículo 227 de la Constitución Federal ${ }^{4}$.

La realidad brasileña lamentablemente no se distingue de la realidad de numerosos países. No por casualidad, Qvortrup (2011), al iniciar las nueve tesis de la sociología de la infancia, trae como idea fundante el texto publicado, en 1993, por Bradshaw (et al., 1993, [s.p.] apud QVORTRUP, 2011), en el cual la reflexión se centra precisamente en los efectos del capitalismo financiero sobre los niños del "tercer mundo":

En el artículo sobre la crisis de la deuda internacional y su influencia sobre los niños del Tercer Mundo, los autores demuestran que aquello que el Fondo Monetario Internacional (FMI) llama de "ajustes estructurales" ha impedido, directa o indirectamente, la sobrevivencia de los niños, la libertad de la infancia, el crecimiento económico, el predominio de la atención en la salud, la nutrición adecuada y la urbanización equilibrada. Ellos concluyen que "la inversión en las vidas de los niños parece ser incompatible con la condición impuesta por el capital financiero internacional".

Vivimos en una sociedad adultocéntrica, en la cual poco analizamos los impactos que las políticas económicas adoptadas afectan a la infancia. El status niño está en franca desvalorización, especialmente en Brasil, en la misma medida en que crece la desigualdad social del país ${ }^{5}$ que ya es el más desigual de toda América Latina. La potencialización de la opresión de la categoría generacional ya en condiciones de vulnerabilidad, que tiene su ápice con el ingreso en el mercado de trabajo antes de la edad propia, rompe con los criterios de diferenciación de la categoría adulto y lleva al fin anticipado de la propia infancia.

\subsection{El fin de la infancia a causa del trabajo infantil no remunera- do: actividad escolar como forma de preparación para el mercado de trabajo}

En los contextos socioculturales en que los niños dejaron de ser útiles con sus trabajos manuales por el aumento de la renta de los adultos, la situación de la categoría infancia se alteró. El énfasis pasó a ser dado al conoci- 
miento y a la información, habiéndose convertido la infancia en una etapa de la vida destinada a prepararse para entrar en el mercado de trabajo.

No es un cambio en el sentido que ellos no trabajen más, al contrario, los niños continúan trabajando, pero el cambio está en la naturaleza del trabajo y en la idea acerca del trabajo infantil obligatorio, el cual se vincula al modo de producción, esto es, ellas también deben realizar la producción del conocimiento. En otras palabras, los niños lo hacen a partir de su trabajo en la escuela (BREDA; GOMES, 2012).

Las familias que tienen privilegios de clase - generalmente acompañados de privilegios de raza - ofrecen, con sus condiciones económicas, lo mejor que el dinero puede comprar: escuelas con una "buena" formación para que, en seguida, en el fin de la adolescencia, sea posible la aprobación en el examen de admisión a la Universidad. Para que el plan trazado por los padres sea concretizado, desde muy temprano, las concesiones de tiempo se hacen necesarias. El currículo de las escuelas es cada vez más amplio y el tiempo de cada niño es cada vez menos respetado. "Todos los niños del grupo deben estar alfabetizados hasta septiembre", anunció la profesora de primer año, en una de las mayores escuelas de Porto Alegre/RS, ignorando que niños de 6 o 7 años tienen naturalmente tiempos de desenvolvimiento diferentes.

El fluir del tiempo del niño se ha desnaturalizado como efecto de la subordinación de la existencia infantil a un calendario o agenda. Ser un niño "normal" significa hoy más que nunca mostrar conformidad y ajuste con los criterios definidos institucionalmente. La normalización de la experiencia infantil es medida, por tanto, a partir de los intereses de los adultos. El niño deja de ser el sujeto de su experiencia - transformándose en un mero objeto (PASCUAL, 2007).

La "inadaptación" al tiempo impuesto inaugura una rutina de clases de refuerzo que, sumada a las actividades extracurriculares ya obligatorias - el aprendizaje de una lengua extranjera y la práctica deportiva -, está creando una generación de niños y niñas ansiosos, cansados y, no raro, medicados (RNPI, 2016).

La ausencia de voz de los niños en la mayoría de las decisiones relativas a la organización de su tiempo y de su espacio es contraria a la idea de niños como actores sociales, con derecho de expresar y de que se escuchen sus opiniones. "La escuela y la escolarización es algo 'hecho para' los niños, legitimado por un discurso que prioriza las necesidades y expectativas orien- 
tadas al futuro adulto en superposición a la experiencia actualmente vivida" (GAITAN, 2006, p. 162).

No restan dudas, por tanto, de que las actividades escolares de los niños no están volcadas, como regla, a permitir su pleno desarrollo. Al contrario, la institucionalización de la infancia, con patrones rígidos y universales - desconsiderando la individualidad de cada niño - tiene el claro objetivo de domesticar cuerpos infantiles para el futuro mercado de trabajo.

Podemos hablar sobre la institucionalización de la infancia y, más específicamente, sobre la escolarización de la infancia como un resultado de las demandas provenientes de una economía y de un sistema de gobierno en transformación. Estos movimientos cambiaron dramáticamente la discusión sobre la vida de los niños. Aunque hubo agentes que se esforzaron arduamente para promover la educación escolar de los niños, nos preguntamos si eso hubiera sucedido si esta no hubiese sido entendida como un interés indispensable para el comercio, para el desarrollo de la industria y de la sociedad de forma general. (QVORTRUP, 2010, p. 640).

En una sociedad amenazada por el desempleo, como es la brasileña, pautada por valores cada vez más individualistas y competitivos, son innegables los daños a la salud física y mental de la sociedad en general y, con mayor gravedad aún, en los integrantes de la categoría social infancia. Los médicos epidemiológicos ingleses Richard Wilkinson y Kate Pickett, al reflexionar sobre cómo las sociedades más igualitarias melhoram el bienestar colectivo de la población, traen datos alarmantes sobre el impacto de las desigualdades sociales sobre la salud psíquica de de los jóvenes. Teniendo como base jóvenes ingleses de 15 años, los estudios indican que el 22\% de los adolescentes ya practicaron daños contra sí mismos y, de estos, $43 \%$ lo practica más o menos una vez por mes. Datos de estudios involucrando a jóvenes de EE.UU y de Canadá indican la constancia de porcentuales entre 13 y 24\% de los jóvenes que están en una escuela que se hacen daño voluntariamente. En la investigación aparecen niños de tan solo siete años que se automutilan, haciendo cortes, arañones, quemándose, arrancándose el pelo e, en casos más graves, provocándose heridas y quebrándose los huesos de forma deliberada (WILKINSON; PICKET'T, 2019, p. 108-109).

En la falta de palabras mejores, traduzco las de los propios investigadores - que, al oír las de los niños sobre la realidad por ellas vivenciadas alrededor del mundo, se desahogan: 
Cuesta imaginar que la angustia mental pueda convertir la vida en una experiencia tan dolorosa donde el dolor físico resulte liberador y proporcione una sensación de control, son muchos niños, jóvenes y adultos que afirman auto lesionarse sistemáticamente. Las conductas autolíticas son más comunes entre personas con sentimiento de vergüenza y muy exigentes consigo mismas. Las experiencias de abusos, traumas o abandonos en edades precoces influencian, lógicamente, pero la reciente escalada epidémica de este tipo de conducta apunta que algo cambió en nuestra sociedad para que el problema se agrave de ese modo (WILKINSON; PICKETT, 2019. p. 102).

El dolor practicado por los niños contra ellos mismos es una forma de tratar de aliviar, con el dolor físico, el dolor social de la exclusión. Las imágenes cerebrales de las investigaciones demuestran que el dolor de sentirse excluido por los demás activa las mismas partes del cerebro que el dolor físico. La relación entre los dos dolores es tan profunda que dosis de analgésicos - como paracetamol - reducen no solo el malestar y el dolor físico de los que lo utilizan normalmente, sino también la alteración y la ansiedad emocional derivadas, por ejemplo, de una experiencia de rechazo (WILKINSON; PICKET'T, 2019. p. 102-103).

No tenemos datos suficientes para establecer los índices de automutilación en el contexto social brasileño - que, vale resaltar, es aún más desigual. Noticias vehiculadas en la prensa indican que los episodios efectivamente han aumentado (MARQUES, 2019). Como reacción, fue publicada la Ley n. 13.819 , del 26 de abril de 2019, que "Instituye a la Política Nacional de Prevención de la Automutilación y del Suicidio, a ser implementada por la Unión, en cooperación con los Estados, el Distrito Federal y los Municipios" (BRASIL, 2019). Entre las determinaciones legales, está la necesidad de que las escuelas notifiquen a los consejeros tutelares los casos de automutilación.

Lamentablemente, sin embargo, poco se enfrenta el origen de los problemas, con la falsa esperanza de que resolveremos un problema epidémico con un texto de ley. No cuestionamos el sistema político y económico que se enferma y excluye a una porción cada vez mayor de población, alcanzando no solo a la categoría generacional de la infancia, sino a toda la sociedad. Basta analizar los índices de depresión - ya considerada por la Organización Mundial de la Salud (OMS) como un problema igualmente epidémico (OMS, 2017) - para percibir el impacto de nuestro modo de vida sobre la salud mental de los individuos. 
Los problemas de la infancia en Brasil, por tanto, no se reducen a la necesidad de garantía de una escolarización plena, de la reducción de la mortalidad infantil o de la prohibición del trabajo infantil. La creciente profesionalización e institucionalización de ese período vital que se llama infancia se convierte en una verdadera explotación de los niños. El ofrecimiento de un ambiente cada vez más organizado y estructuralmente jerarquizado, curricularizado, normalizado e instrumentalmente definido, próximo a los propósitos de su socialización para el trabajo del adulto (PASCUAL, 2007, p. 95), indican la pérdida del estatus de niño también para aquellos que no ejercen actividades remuneradas.

Ricos y pobres. Blancos y negros. Niños y niñas. Lo que une a la categoría de la infancia hoy es la lucha contra la opresión de un sistema que cada día se vuelve más incompatible con el ser niño. Entonces cabe la pregunta, ¿por dónde empezar a reconstruir el estatus de niño en nuestra sociedad?

\section{RESCATE DE LA ÉTICA DEL AMOR}

\section{"[...] amar al prójimo como nos amamos a nosotros mismos significa entonces, respetar la singularidad de cada uno - el valor de nuestras diferencias, que enriquecen el mundo que habitamos en conjunto $y$ asi lo transforman en un lugar más fascinante y agrada- ble" $B A U M A N$, Z. El Amor líquido.}

Ante los escenarios de colapso que se presentan, cabe a nosotros, los adultos, reflexionar cómo haremos para reconstruir el estatus de niño en nuestra sociedad. Cómo vamos a reducir las opresiones que han caído, de forma cada vez más violenta, sobre ese grupo social tan vulnerable y del cual depende, incluso, la continuidad de la vida humana.

En un análisis superficial, podríamos caer en el grave error que es atribuir la responsabilidad por el colapso de las infancias a las familias. La sociología de la infancia, sin embargo, rescata un elemento esencial a ser considerado: las fuerzas sociales actúan con gran impacto tanto sobre los adultos como sobre los niños. Igualmente, víctimas de este sistema capitalista volcado para la mercantilización de las relaciones de afecto y para la objetificación y 
jerarquización de los seres humanos, los padres están haciendo lo mejor que pueden, con lo poco que ganan. Ellos también fueron criados en la realidad cultural que naturaliza, en mayor o menor medida, las relaciones que se definen por vínculos de dominación que acarrean las graves situaciones que enfrentan los niños.

Ha llegado el momento, por tanto, de percibir que todos nosotros, los adultos y los niños, estamos pagando precios muy altos por el tipo de política que elegimos. El sistema capitalista nos está enfermando y oprimiendo a todos, incluso a los detentores de privilegios sociales, que destinan su vida a acumular bienes para satisfacer patrones de felicidad vacíos (FROMM, 2015, p. 67-68). Tenemos que empezar a pensar en alternativas, en otros modos de vida, pautados en nuevos valores.

Siguiendo la propuesta de Bell Hooks, creo que el rescate de una ética del amor es la única forma de reconstruir los vínculos sociales ${ }^{6}$, ahí incluido el estatus niño, sin la reproducción de los sistemas de dominación (HOOKS, 2019).

El amor - vale resaltar - no en la concepción inventada por la sociedad moderna, amparada en una idea de amor romántico o de propiedad (FROMM, 2015, p. 11-12; 65). Amor entendido como una preocupación activa con la vida y con el crecimiento físico y psíquico del otro. Es mucho más que un sentimiento, es una actitud, una elección.

Para que el hombre sea capaz de amar, debe ser colocado en su lugar supremo. La máquina económica debe servir, en lugar de servirse de él. Debe quedar capacitado para compartir la experiencia, a compartir el trabajo, en vez de, en el mejor de los casos, compartir los lucros. La sociedad debe ser organizada de modo tal, que la naturaleza social y amorosa del hombre no se separe de su existencia social, sino que se unifique con ella. Si es verdad, como estoy tratando de mostrar, que el amor es la única respuesta sana y satisfactoria al problema de la existencia humana, entonces cualquier sociedad que excluya, relativamente, el desarrollo del amor debe, al fin de cuentas, perecer víctima por su propia contradicción con las necesidades básicas de la naturaleza humana. En verdad, hablar de amor no es "dar un sermón", por la simple razón de que significa hablar de la última y real necesidad de todo ser humano. El oscurecimiento de esa necesidad no significa que ella no exista. Analizar la naturaleza del amor es descubrir su general ausencia hoy en día y criticar las condiciones sociales responsables por esa ausencia. Tener fe en la posibilidad del amor como fenómeno social, y no solo como algo excepcional individual, es una fe racional basada en la penetración de la propia naturaleza del hombre. 
La dificultad se coloca, por tanto, en buscar el amor en una sociedad que desaprendió a amar. El amor presupone el rescate de la importancia del cuidado, con el repensar de una estructura social que valoriza los aspectos productivos en detrimento de las funciones reproductivas. También necesita que tengamos responsabilidad y respeto con las necesidades del otro, sin relaciones de poder o de dominación. Vamos a necesitar reaprender que el amor es, por esencia, libertad. Libertad esa, que solamente puede ser alcanzada colectivamente porque los sistemas de opresión social - no solo los de la infancia, sino también el imperialismo, el sexismo, el racismo y el clasismo están todos interconectados y son interdependientes. Nuestra preocupación tiene que ser expandida más allá de los límites individuales, basando nuestras políticas por un patrón ético que se preocupe también con la opresión y la explotación de los demás. Como bien dice Bell Hooks, nos cabe a nosotros romper con la cultura hegemónica que enseñó a pautar nuestras relaciones sociales con una lógica de dominación.

Una cultura de dominación es anti-amor. Exige violencia para sustentarse. Escoger el amor es ir contra los valores predominantes de esta cultura. Muchas personas se sienten incapaces de amarse a sí mismas o a otras porque no saben lo que es el amor. Músicas contemporáneas como "What's Love Got To Do With It" de Tina Turner defienden un sistema de intercambios en torno al deseo, reflejando la economía del capitalismo: se burlan de la idea de que el amor es importante. En el ensayo "Love and Need: Is Love a Package or a Message?" Thomas Merton argumenta que somos enseñadas/ os, dentro de la estructura de consumo capitalista competitivo, a ver el amor como un negocio: "Ese concepto de amor asume que la maquinaria de compra y venta de las necesidades es lo que hace que todo suceda. Considera la vida como un mercado y el amor como una variación en la libre iniciativa". Aunque muchas personas reconocen y critican la comercialización del amor, ellas no ven otra alternativa. Al no saber amar, o incluso no saber qué es el amor, muchas personas se sienten emocionalmente pérdidas; otras buscan definiciones, formas de sostener una ética del amor en una cultura que niega valores humanos y valorizan lo material. Las ventas de libros que se concentran en la recuperación, libros que buscan maneras de mejorar la autoestima, amor propio y nuestra capacidad de ser íntima/o en los relacionamientos, demuestran que hay conciencia pública de una falta en la vida de la mayoría de las personas (HOOKS, 2019).

Conforme colocado por Erich Fromm (2015), el rescate del concepto de amor significa percibirlo como una actitud, una fuerza activa, con potencia suficiente para romper las paredes de la separación y del aislamiento, para restaurar nuestra integralidad. Presupone la suma del cuidado, responsabilidad, respeto y conocimiento, como elementos interdependientes que son. Aque- 
llos que se preocupan seriamente con el amor como la única respuesta racional al problema de la existencia humana inevitablemente llegan a la "conclusión de que importantes y radicales cambios en nuestra estructura social son necesarias, para que el amor se transforme en un fenómeno social, y no en un fenómeno altamente individualista y marginal" (FROMM, 2015, p. 65-67).

La ética del amor es, por tanto, de tal compromiso político que debe pautar el núcleo de toda la interacción humana, de nuestras relaciones sociales. Es a partir de ese compromiso que es posible la reconstrucción del estatus de la infancia, de modo que la relación entre las categorías generacionales de los adultos y de los niños tenga como finalidad permitir el desarrollo de todas las potencialidades del ser humano, libre de opresiones.

Además de nuestras relaciones familiares, el compromiso ético con el amor es exigido y exigible de los que ocupan cargos públicos - incluidos los miembros del Poder Legislativo, Ejecutivo y Judicial -, imponiendo el análisis de los impactos sobre la infancia de cada una de las decisiones tomadas, para que el ordenamiento jurídico sea interpretado de modo a que confiera la máxima eficacia del artículo 227 de la Constitución Federal.

Como nos enseñó Martin Luther King, el amor es una elección, una voluntad y una acción. "Yo decidí amar", decía al utilizar al amor como fundamento ético de la política, buscando transformar la sociedad para mejorar el bienestar colectivo. Solo así encontraremos

la alegría, la libertad de espíritu traídas por una ética del amor [...] En el momento que elegimos amar, comenzamos a movernos hacia la libertad, a actuar de maneras que nos liberen a nosotras/os mismas/os y a los otros. Esa acción es el testimonio del amor como práctica de la libertad (HOOKS, 2019).

Sé que plantear una ética del amor, en estos tiempos de odio, puede parecer bastante utópico. En mi defensa, digo que el amor a veces brota en medio de una crisis, en medio a un sentimiento de soledad y de falta de esperanza. Brota cuando menos se espera. Pero solo queda si recordamos que el amor es actitud. Es tener cuidado, responsabilidad, respeto y buscar, principalmente, autoconocimiento. Es antes de todo un aceptarse. Y confiar en esa increíble capacidad humana - o tal vez divina, quien sabe - que tenemos de amar. 


\section{NOTAS}

1 Así entendida la que busca la raíz más profunda de problemas que impactan sobre la categoría generacional, para más allá de los aspectos individuales.

2 No será objeto del presente texto las críticas a las mediciones del desarrollo con base en el PBI que lamentablemente aún hoy pautan el imaginario brasileño. Vale enfatizar, sin embargo, que hace décadas que se resalta la importancia de la inclusión de los factores "humano" (SEN., 2000) y "sustentable" (informe de Brundtland, 1987) en el concepto de desarrollo. A propósito, las discusiones más actuales - muchas retomando conceptos de pueblos tradicionales - cuestionan la propia idea de desarrollo. Sobre el tema: TAIBO, Carlos. El decrecimiento explicado con sencillez. Madrid: Los libros de la catarata, 2016, p. 25-28.

3 No es por casualidad que niños negros, de las clases más bajas y periféricas sean las principales víctimas del trabajo infantil en Brasil. No hay como comprender la problemática del trabajo infantil sin considerar la intersección de las diferentes categorías estructurales - edad, raza/color, clase, género y deficiencia - que marcan a la sociedad brasileña.

4 También es esencial el registro de que las cadenas de producción global, propias de a la división internacional de trabajo y necesarias a la sustentación de nuestra sociedad de consumo, están directamente vinculadas al trabajo infantil.

5 En ese sentido, estudio de FGV/IBRE al indicar que Brasil alcanzó el récord de la desigualdad de renta. Disponible en: https://blogdoibre.fgv.br/posts/levantamentodo-fgv-ibre-aponta-desigualdade-recorde-na-renda-do-trabajo. Acceso en: 15 jun. 2020 .

6 En el mismo sentido Bauman, al disertar sobre la liquidez de los lazos de afecto, nos recuerda que el antiguo hombre sin cualidades maduró y se transformó en un hombre sin vínculos (BAUMAN, 2004, p. 42).

\section{REFERENCIAS}

BAUMAN, Zygmunt. O amor líquido: sobre a fragilidade dos laços humanos. Rio de Janeiro: Jorge Zahar Ed., 2004.

BRASIL. Lei n. $^{\circ}$ 13.819, de 26 de abril de 2019. Institui a Política Nacional de Prevenção da Automutilação e do Suicídio, a ser implementada pela União, em cooperação com os Estados, o Distrito Federal e os Municípios; e altera a Lei n. ${ }^{\circ} 9.656$, de 3 de junho de 1998. Brasilia/DF, abr. 2019. Disponible en: http://www.in.gov.br/web/dou/-/lei-n\%C2\%BA-13.819-de-26-de-abrilde-2019-85673796. Acceso en: 15 jun. 2020

BREDA, Bruna; GOMES, Lisandra Ogg. Entre a sociologia, a infância e as crianças: uma conversa com o sociólogo Jens Qvortrup. In: Currículo sem Fronteiras, v. 12, n. ${ }^{\circ}$ 2, p. 499-513, maio/ago. 2012.

FAO, IFAD and WFP. The State of Food Insecurity in the World 2014. Strengthening the enabling environment for food security and nutrition. 
Rome: FAO, 2014. Disponible em: http://www.fao.org/3/a-i4030e.pdf. Acceso en: 15 jun. 2020

FERREIRA, Elinay. O que você quer ser quando crescer? Carta Capital, São Paulo/SP, 14 jun. 2019. Disponible en: https://www.cartacapital.com. br/blogs/sororidade-em-pauta/o-que-voce-quer-ser-quando-crescer/. Acceso en: 15 jun. 2020.

FROMM, Erich. A arte de amar. Trad. Milton Amado. Martins Fontes: São Paulo, 2015.

GAITÁN, Lourdes. Sociología de la infancia: nuevas perspectivas. Editorial Síntesis S.A.: Madrid, 2006.

HEYWOOD, Colin. A History of Childhood: children and childhood in the West from medieval to modern times. 1. ${ }^{a}$ ed. Cambridge: Polity Press, 2001.

HOOKS, Bell. O amor como prática da liberdade. [S.1.], 1999. Disponible en: https://medium.com/enugbarijo/o-amor-como-a-pr\%C3\%A1tica-da-libertad-bell-hooks-bb424f878f8c. Acceso en: 2 jul. 2019.

HORTA, Fernando. Abominável sociedad. Jornal GGN, [S.l.], 10 jul. 2017. Disponible en: https://jornalggn.com.br/artículos/abominavel-sociedad/. Acceso en: 15 jun. 2020

JORNAL NACIONAL. Fome mata 300 niños por dia no Brasil. 2001, 05m01s. Disponible en: https://www.youtube.com/watch?v=UI3yFKVrE4I. Acceso en: 15 jun. 2020

MARQUES, Julia. Cresce alerta para automutilação entre niños e adolescentes no Brasil. Estadão, São Paulo/SP, 4 mai. 2019. Disponible en: https:// saude.estadao.com.br/noticias/geral,cresce-alerta-para-automutilacao-entre-niños-e-adolescentes-no-brasil,70002815855. Acceso en: 15 jun. 2020

ORGANIZAÇÃO MUNDIAL DE SAÚDE (OMS). OMS registra aumento de casos de depressão em todo o mundo; no Brasil são 11,5 milhões de pessoas. [S.1.], 23 fev. de 2017. Disponible en: https:// nacoesunidas.org/oms-registra-aumento-de-casos-de-depressao-em-todo-o-mundono-brasil-sao-115-milhoes-de-pessoas/. Acceso en: 15 jun. 2020. 
PASCUAL, Iván Rodríguez. Para una sociología de la infancia: aspectos teóricos y metodológicos. Madrid: Centro de Investigaciones Sociológicas, Colección Monografías - 245, 2007.

QVORTRUP, Jens. A infancia enquanto categoria estrutural. Trad. Maria Leticia Nascimento. In: Educação e Pesquisa, São Paulo, v. 36, n. ${ }^{\circ}$ 2, p. 631 643, maio/ago. 2010.

QVORTRUP, Jens. Nove teses sobre a "infancia como um fenômeno social". Trad. Maria Leticia Nascimento. In: Pro-Posições, Campinas, v. 22, n. ${ }^{\circ} 1$ (64), p. 199-211, jan./abr. 2011.

REDE NACIONAL PRIMEIRA infancia (RNPI). Recomendações sobre o uso abusivo de medicamentos na infancia. [S.1.], 4 jan. 2016. Disponible en: http://primeirainfancia.org.br/recomendacoes-sobre-o-uso-abusivo-de-medicamentos-na-infancia/. Acceso en: 15 jun. 2020.

WILKINSON, Richard; PICKETT, Kate. Igualdad: cómo las sociedades más igualitarias mejoran el bienestar colectivo. Trad. Catalina Martínez Muños. Madrid: Capitán Swing Libros, 2019. 


\section{LAS TENDENCIAS TRÁGICAS DEL TRABAJO INFANTIL: LA "PROSTITUCIÓN"1 EN LA INFANCIA}

\section{IVAN ROBERTO CAPELATTO}

DOI: 10.51366/978-65-89468-10-3-coordinfancia-12

Resumen. Un fenómeno social en el que la conciencia de las autoridades y de parte de la sociedad civil se mostró más acentuada fue la dinámica del trabajo infantil en el mundo, principalmente en nuestro país, en todas sus formas, especialmente la ocurrencia de los casos de "prostitución" infantil, una realidad histórica, pero que actualmente no puede ser más aceptada y permitida debido a las tragedias que surgen de ella, tanto desde el punto de vista social y familiar como desde el punto de vista psicológico.

Palabras clave: Niños. Trabajo Infantil. "Prostitución” en la infancia.

Ciertamente, es una realidad dura y sin lógica la existencia, en el mundo y, principalmente, en nuestro país de las manifestaciones sociopsicológicas del trabajo infantil. A pesar de la lucha continua de los Tribunales Regionales del Trabajo (TRTs) y del Ministerio Público del Trabajo, de organizaciones no gubernamentales (ONGs) y de las denuncias del ciudadano más consciente, tenemos un número de niños en las calles, involucrados con el trabajo que los saca de casa, de la escuela y de la dignidad con la que deberían ser tratados.

En los vertederos, en el tráfico, en la "prostitución”, en los abordajes de transeúntes y de vehículos en los semáforos, allí están, con edades que varían entre cinco y diez años, ya diferenciadas de sus pares con edades mayores.

De esas trágicas descripciones sobre el trabajo infantil, destaco aquí la cuestión de la "prostitución", quizás la parte más peligrosa y mortal del trabajo infantil, debido a sus consecuencias más nefastas, como la muerte precoz, 
las enfermedades de transmisión sexual, la violencia física y psicológica, y, la más pesada de las tragedias, la pérdida de la identidad personal. Conforme artículo de Ribeiro ([20--]], n. p.) para Brasil-Escuela:

En general, la prostitución infantil se trata de la explotación sexual de un niño que, por varios factores, como la situación de pobreza o la falta de asistencia social y psicológica, se debilita. De esa forma, se convierten en víctimas del atraco por adultos que abusan de menores, los cuales ahora buscan el sexo fácil y barato, ahora intentan lucrar corrompiendo a los menores y conduciéndolos al mercado de la prostitución. Los aspectos facilitadores de esta condición en la que se ve destruida la infancia pasan por alto los derechos y la necesidad de protección del niño. Además de las posibles vulnerabilidades provenientes de la situación socioeconómica - si no la principal causa, ciertamente una de las más importantes - están otros aspectos como el propio género del niño, hecho que explicaría una mayor vulnerabilidad de las niñas, tan expuestas a la violencia contra la mujer incluso en el ambiente familiar. Esto sugiere que son aspectos importantes para la comprensión de la violencia contra el niño y otros más allá de los relacionados únicamente con los problemas de pobreza. La cuestión de género estaría intrínseca a un modelo sociocultural que, a veces, como en el caso brasileño, puede reproducir una naturalización de la discriminación contra la mujer (fruto de valores machistas), vista como objeto desprovisto de valor, de conciencia y libertad.

Así, considerando lo expuesto, estamos frente a una causa extremadamente difícil de combatir, que es la vulnerabilidad de esos niños, niños y niñas, de poca edad, oriundos de hogares deshechos o, muchas veces, de hogares con padres problemáticos (drogadictos, alcohólicos, desempleados y sin recursos financieros para mantener a la familia, sin condiciones psicológicas y sociales para cuidar de sus hijos).

Muchas causas sociales son responsables de este tipo de ocurrencia. No voy a detenerme aquí en describirlas. Ya lo hice en mi artículo para la Revista TST, vol. 81, apartado 1, ene./ mar . 2015, con el título Danos à saúde física e mental, prejuízo irrecuperável.

Quisiera detenerme en las cuestiones referentes a los daños más internos que un niño puede sufrir cuando es sometido precozmente a la condición de una vida sexual, sea por la inmadurez de sus aspectos fisiológicos y anatómicos, sea por la inmadurez de su desarrollo psíquico y de personalidad. Los daños de la vida sexual temprana están asociados con la cuestión de la "prostitución”, de la libertad interrumpida, de la ausencia de la asistencia escolar, de la ausencia del "Jugar" (cuestión extremadamente importante para 
el niño, en su identificación con la realidad externa) y del estereotipo mayor de ser llamada "prostituta" en el medio social.

Las niñas "prostitutas", cuando se les pregunta sobre lo que sienten y sobre lo que hacen, no tienen ningún placer, ni sexual ni corporal (CAPELATTO, 2015, n. p.):

Por cierto, la mayoría de ellas tienen una anestesia, una parestesia en el tracto genital, los niños también. Algunos niños de siete, ocho, nueve años usan estimulantes de la erección del pene para poder relacionarse con adultos. Pero el placer es ser buscado por ese hombre o esa mujer de cuarenta y cinco años, cincuenta años. Esto les da una sensación de poder (un momento único en el que el EGO se siente con algún valor, como si fuera una especie adulterada de autoestima). Así que no es el trabajo, no es el tráfico o la prostitución lo que trae el placer, sino la conexión con el otro.

Los daños más contundentes que aparecen del abuso sexual y psicológico de niños se dividen en daños físicos, daños sociales, daños morales, daños emocionales o psicológicos, daños que interferirán en la propia sexualidad

y daños en el cuerpo (pérdida de la identidad egoica): no consiguen desear más de lo que el día puede ofrecer; no consiguen ningún tipo de autoestima; algunos niños pasan a sufrir de una autocompasión mórbida, lo que, más tarde, les incita al suicidio o a la automutilación; no tienen un imaginario suficiente para crear (en sus mentes, crear salidas para sí mismas); no consiguen sentir afecto, pues confunden afectividad con "pena" y así se degradan más y más, pues esperan recibir del otro la piedad que generan, en forma de dinero, por ejemplo. No consiguen llegar a la vida adulta, por muerte precoz debido a las enfermedades sexualmente transmisibles (ETS) o por asesinato cometido por el abusador o por colegas; no consiguen volver a la familia (a menos que reciban ayuda profesional), pues los lazos de afecto y de cariño se mezclaron con la noción de abandono y la conciencia de que 'todo comenzó dentro de casa', en gran parte de las veces.

Algunas consecuencias del abuso sexual, citadas por Blanchard (1996), son de especial importancia para comprender la gran dimensión de los impactos físicos, emocionales y psicosociales causados por el abuso sexual: ...Haber vivido un trauma físico y psicológico hace que la víctima cuestione su capacidad de defenderse... Ella aprende a odiar su cuerpo porque le recuerda malas experiencias. Ella tiene respuestas disociadas, presenta dificultad para la intimidad y es emocionalmente distante. Ella aprende que no puede controlar su cuerpo y que otra persona puede tocarlo sin su consentimiento. Ella 
no confía en su memoria, sus pensamientos y su sentido de la realidad. Estas consecuencias afectan no solo a la víctima, sino también a la sociedad en general porque un niño traumatizado eventualmente se convierte en un adulto que puede adoptar comportamientos agresivos o pasivos para resolver las situaciones y el estrés (BLANCHARD, 1996).

Según reseña del sitio web Passei Web (2013), en la que se cita la obra del periodista Gilberto Dimenstein denominada Niñas de la noche, uno de los estímulos a la "prostitución" es la propia familia (DIMENSTEIN, [1997] apud PASSEI WEB, 2013):

La niña trabaja, en general, como vendedora de chicles o balas. Pero está obligada a llevar una cierta cantidad a casa, bajo la pena de que le golpeen. Sin dinero, a veces se entrega a los hombres para regresar a casa con la cantidad requerida. El robo es otra alternativa, pero más arriesgada.

Así, percibimos que la miseria, la ausencia de acogida en escuelas o guarderías, la quiebra de la salud mental de la familia, la ausencia de cuidados de la sociedad conducirán, sin duda, a menores a una "trampa de la supervivencia”, calcada en personas sin escrúpulos, verdaderos sociópatas, que facilitarán y promulgarán a esos vulnerables niños un destino cruel e irreversible, centrado en el placer pedofílico de adultos enfermos y en la cuestión económica que garantiza a proxenetas un considerable ingreso financiero proveniente del tráfico de niños y de la prostitución a gran escala.

La "prostitución" infantil es algo que preocupa a todas las ciudades del mundo. Una realidad preocupante y verdadera. En la obra antes mencionada, Dimenstein [1997] pone esto en tesis: "Todas las niñas relatadas en esta obra tienen problemas con los familiares, algunas ni poseen padres o familiares, no teniendo al menos dónde vivir" (DIMENSTEIN, [1997] apud PASSEI WEB, 2013). El libro también muestra que hay una esclavitud en este medio. Las niñas tienen un lugar para vivir y tienen que pagar por todo lo que consumen, desde comida hasta perfumes y ropa. Ellas siempre quedan eternamente endeudadas, sin posibilidades de salir de la "prostitución", muchas veces saliendo por la enfermedad fatal o por el asesinato.

También hay casos de chicas vírgenes subastadas. La virginidad es algo que los hombres quieren como mérito en estos lugares. Hacen subastas para ver quién da más por las chicas vírgenes, y el comprador que da el valor más alto toma la virginidad de la chica (DIMENSTEIN, [1997] apud PASSEI WEB, 2013, en línea). 
Los excesos de maltrato en la infancia, entre ellos el abuso sexual, fenómeno mundial, traen a la superficie un grave problema de salud pública. Los traumas afectan a los menores, a sus familias y se constituyen en una dinámica en la que el horror y la indiferencia se encuentran, llevando a la sociedad a una impotencia sin límites.

La primera experiencia placentera que el niño tiene con el mundo es en la lactancia materna. Los labios y la lengua del bebé se convierten en una zona erógena por la cual, al chupar la leche, el niño siente placer en alimentarse y, por lo tanto, la sensación placentera se asocia con la necesidad de alimento (COSTA; OLIVEIRA, 2011). Freud (2006, n. p.) describe la presencia de este placer:

Quien haya visto a un niño saciado retirarse del pecho y caer en el sueño, con las mejillas sonrojadas y una sonrisa beatificada, se dirá a sí mismo que esa imagen persiste también como norma de la expresión de la satisfacción sexual en épocas posteriores de la vida.

Cuando el placer se hace, sea en la oralidad que hace la lactancia algo sublime, sea en la sexualidad, que, cuando comprendida y vivida, se torna placentera y necesaria como complemento de los otros placeres del cuerpo, ese placer organiza una instancia importante en nuestro desarrollo, que es el EGO, nuestro cuerpo en contacto con el medio externo. El EGO es corporal, y por lo tanto todo lo que sucede con nuestro cuerpo organiza o debilita nuestro EGO.

Los abusos perpetrados por otros al cuerpo del niño, como abusos físicos, sexuales, de aislamiento o abusos morales (como el bullying, por ejemplo), traen, como consecuencias muchas veces irreversibles, la pérdida de la autoestima, la insensibilidad (pérdida de la empatía y la No formación de la compasión) y el aumento de la agresividad hetero y autodirigidas; pueden esos abusos, por el contrario, establecer una relación catatónica con el mundo externo, donde el niño no tiene reacciones o palabras para defenderse o para expresar sentimientos y emociones.

El EGO, así herido, desarticula una noción de realidad (conciencia) del niño victimizado, llevándolo, a veces, a no tener más la noción de sus reales deseos, de sus necesidades verdaderas o una noción de lo que es placentero o doloroso: una confusión de sensaciones corporales que destruyen su condición de ser humano en desarrollo. Sin poder enunciar sus deseos, ese 
niño está condenado a sucumbir frente a las cobranzas de la vida en grupo, sin darse cuenta de que podría desear otro tipo de trabajo, ya que la "prostitución" se ha convertido en una especie de "trabajo" para ella; sin la noción y la conciencia de sus reales necesidades, no sabe distinguir el hambre de las sensaciones de frío o calor, no sabe verbalizar lo que es dolor o lo que es placer, no sabe decir lo que necesita, en un determinado momento, para sentirse perteneciendo a algo o a alguien.

Aquí tenemos lo que significa, de hecho, la acción de la familia (padre, madre, tío, tía, abuela, abuelo...) en la vida de un niño y en la confección de su EGO saludable (relación del cuerpo con la realidad, con los demás y con los objetos externos). La acción de la familia se muestra en lo que llamamos "cuidados", es decir, la preocupación con el niño, con su salud física, con su salud mental, con sus relaciones interpersonales (la importancia de la escuela, de los amigos, de la relación con primos y otros parientes), en fin, el cuidado es la certeza, para el niño, de que ella es querida y amada por las personas que la rodean.

En el libro infantil La Extraña Madame Mizu, escrita por T. Lenain (1998), la soledad de la niña Zoé, que vive sus días en el apartamento, porque los padres están muy ocupados, la hace fantasear con verdaderas locuras sobre la dama que vive arriba. En el texto de Danuza Leão (2001), la cronista habla de una nostalgia que tiene de aquella tía que cuidaba a todos confortando en los cólicos y en las tristezas:

Una tía. Solo que no estoy hablando de una tía cualquiera; estoy hablando de esa tía de antaño, que ni siquiera sé si todavía existe. Ella era así: flaca, ya nacida con cerca de 75 años y con los hombros encorvados; era tan discreta que nunca se enfermaba y, si quedaba, no decía (para no dar gasto); por ser la más vieja de una escalera de 12 o 13 hermanos, quedó combinado que nunca se casaría. En ese momento, era así: el destino de la mayor era ayudar a criar a los más pequeños y cuidar a la madre en la vejez.

Estos dos escritos contemporáneos tienen en común la soledad que vivimos y la nostalgia de un tiempo en que teníamos aquella familia que, con todas las peleas y dificultades, también nos confortaba y nos hacía sentir miembros de un grupo afectivo (CAPELATTO, 2001, n. p.).

Así, como en la literatura, nuestras angustias actuales están también traducidas en las noticias de la prensa, en los relatos de los consultorios médicos y psicológicos, en las escuelas y en los suicidios registrados todos los días. Huérfanos de padre, madre, familia y sociedad, vivimos la crisis de la extin- 
ción de valores, de ética y de cuidados, aquellos que nos mantuvieron vivos hasta aquí. Sin ellos, ¿cómo sentirnos parte integral de un todo? ¿Cómo ser entero? En la soledad del apartamento, como Zoé, terminamos fantaseando la vida, pero necesitamos de nuestros padres y parientes para que nos enseñen a distinguir la realidad de la imaginación, de lo contrario pasamos a creer, como hoy, que la novela es de verdad, que los crímenes son una broma para niños, que Madame Mizu es incluso una bruja; pasamos a creer, también, que el cariño de aquel tío o tía, o incluso padre o madre, en nuestro cuerpo, es un cuidado amoroso y no una invasión, un abuso.

Sin la acogida y la orientación segura y afectiva de los parientes, un niño no conseguirá, por su propia cuenta y responsabilidad, constituir una buena confección egoica, pues la fundamentación de un buen EGO que nos protege y nos da identidad es organizada por el discurso y por el cuidado del otro.

Sin esta consistencia de un EGO suficiente para enfrentar los desafíos y cargos del mundo exterior, un niño sucumbirá a los aparentes "cuidados seductores" de psicópatas y sociópatas que lo perciban frágil, desprotegido y solitario. El cuerpo nos es la forma de percibir el mundo, la realidad y es el medio psíquico que nos hace diferenciar, por la experiencia objetiva, la realidad de la fantasía. Un buen EGO (un cuerpo que permita una buena constitución psíquica) ciertamente podrá diferenciar, en sus contactos sociales, entre aquel que ofrece afecto y aquel que seduce o mente. Un EGO quebrado, sin historias de acogimientos, cuidados y afecto ciertamente no tendrá chances de elegir, de diferenciar el bien del mal, el bueno del mal, el afectivo del abusivo y, así, tendremos esa legión de niños y niñas secuestrados por la maldad, por la codicia de personas sin escrúpulos y sin la posibilidad de medir la extensión del ‘daño’ que harán en pequeñas vidas humanas.

El abuso sexual molesta a la mayoría de las personas. Es triste pensar que los adultos causan dolor físico y psicológico en los niños para satisfacer sus propios deseos, especialmente cuando estos adultos son amigos confiables miembros de la familia (WATSON, 1994, n. p.).

Esta declaración de Watson muestra lo difícil que es para un sujeto humano sano mentalmente no molestarse con el hecho de que hay "monstruos" a menudo dentro del hogar donde viven los niños, lo que les causa, sin duda, la mayor y más pesada pérdida psíquica que un ser humano puede sufrir, que es el abuso perpetrado por un pariente. Esos deseos que necesitan de satisfacción sexual anómala, como la pedofilia, la violación o el abuso, son síntomas y signos de un cuadro alarmante, que se multiplica en la sociedad 
a cada instante: son los signos y síntomas de la perversión, dinámica psíquica que se establece también en sujetos humanos cuya historia familiar está marcada por la ausencia de un buen primer año de vida y por la ausencia de cuidados, afecto y límites del segundo al quinto año de vida.

Según Winnicott (1982), pediatra y psicoanalista del siglo XX, hay una necesidad, para el bebé humano, de un primer año de vida con cuidados y afectos siendo ofrecidos, de preferencia, por la figura materna, que incluye el amamantamiento, la presencia, los cuidados de toda especie, el acogimiento en horas de llanto o cuando ocurran cualesquiera sufrimientos físicos, siendo ideal que la presencia materna sea continua, en una especie de rutina.

Cuando un bebé es separado de su madre precozmente, siendo subcontratado o mantenido bajo los cuidados de diversas personas, hay una pérdida importante que es la no Formación del SELF, estructura única necesaria para un buen desarrollo psíquico y estructura única y necesaria para construir el sentimiento de pertinencia, es decir, aquella sensación de que pertenecemos a algo, alguien o a un lugar. Es el sentimiento de pertinencia que nos traerá la buena relación con la familia, con los otros, con la escuela, con la profesión, con el cortejo, con el matrimonio, con los hijos... sin el sentimiento de pertenencia, nuestra vida se vuelve vaga y estamos sujetos a las elecciones de los demás, a los deseos de los demás y a una dificultad muy grande de constituir nuestros propios deseos.

En ese contexto, la génesis del sentimiento moral, base para la posterior emergencia de valores morales, es atribuida a la actualización de un dinamismo espontáneo de la naturaleza. Así, el sentimiento ético no es el resultado de la introyección de valores impuestos por la sociedad, sino que emerge primariamente del propio movimiento espontáneo del sujeto, cuando tal proceso es favorecido por la actitud del ambiente (la ambientación).

Sin embargo, esta introyección no constituye el momento inaugural de la emergencia del sentimiento moral. En ausencia de la emergencia espontánea de ese sentimiento, cuando el ambiente no favorable inhibe ese proceso, esos contenidos son privados de una base genuina en el sujeto, tornando dominante una tendencia a la sumisión. La aparición espontánea del sentimiento moral exige por parte de la "madre suficientemente buena" una actitud de amorosa receptividad. La transmisión de los códigos culturales es, 
a su vez, una función educativa. Para Winnicott (2011), la educación, siendo imprescindible, no puede reemplazar el amor.

El buen ambiente puede ser traducido como una capacidad del ambiente para aprehender y aceptar la singularidad y diferencia de cada sujeto. Generando la confianza del sujeto emergente en el ambiente, esa actitud posibilita la expansión de las tendencias espontáneas, permitiendo la creación de lo que Winnicott denomina verdadero SELF. Este concepto no designa ninguna esencia metafísica, sino el producto de la actividad autocreativa del sujeto.

El sujeto es considerado verdadero por ser producto de su espontaneidad. Su opuesto, que Winnicott llama falso SELF designa el resultado de un proceso de producción de la subjetividad marcado por un entorno intrusivo que, en lugar de reconocer la singularidad del sujeto, proyecta en él su propio narcisismo. Sintiéndose mal acogido, el sujeto pasa a desarrollarse de manera responsiva, en el angustiado intento de adaptarse a lo que le es exigido. En este caso, la creatividad es sofocada. En el decir de Winnicott, el sujeto pasa a desarrollarse a partir de la corteza, es decir, adaptándose al ambiente, en lugar de hacerlo desde su 'núcleo', es decir, “actualizando las tendencias espontáneas que lo hacen un ser singular” (WINNICOTT, [19 AP] apud PLASTINO, 2006).

Volviendo a nuestros niños sin SELF y con un EGO fragilizado por la ausencia de un buen ambiente, podemos deducir cuántos de ellos se funden en movimientos sociales perversos por la falta de un sentimiento de pertenencia. Se vuelven verdaderas veletas y se pierden en los deseos que no son los suyos, sea por una gran fragilidad psíquica, sea por el dinero que hará diferencia en la vida familiar. En ese momento, el adulto o adolescente perverso, que tampoco se estructuró de una buena manera psíquica, usa y abusa de esos frágiles niños, que, muchas veces, se confunden con ellos mismos en su fragilización como persona, como ser sexualmente saludable (gran parte de esos adultos y adolescentes perversos usa el acto sexual como forma de agredir a la sociedad).

Además, según Plastino (2009), clínicamente, la asfixia del verdadero SELF se verifica en la ausencia o debilidad, en el sujeto, del sentimiento de existir y del sentimiento de que la vida vale la pena ser vivida. La sofocación de las tendencias espontáneas hace que la fusión entre la motilidad y el erotis- 
mo pierda potencia, dejando la motilidad no fusionada expuesta a un proceso en el que la agresividad, entendida como una fuerza que impulsa hacia el otro, se transforme en agresión, que agrega a ese movimiento el odio generado por la frustración. Estos casos, para Winnicott (1982; 2011), se caracterizan por la enfermedad en lugar de la salud. En ellos prevalece el escenario descrito por el psicoanálisis, comandado por impulsos autodestructivos y destructivos y por la fuerte presencia del sentimiento de culpa. Tal estado, sin embargo, no expresa ninguna esencia inmodificable del hombre, la inmodificable pulsión de destrucción, sino que caracteriza una modalidad histórica y, por lo tanto, contingente, de producción de la subjetividad humana. Así, la ausencia del verdadero SELF, adquirida en una tierna infancia en los brazos de la madre o la estructuración del EGO, formada durante la fase anal (de dos a cinco años), son la armadura psíquica suficientes para la protección del sujeto, para su realización como humano y para su consagración como un ser social.

\section{ACCIONES Y PRETENSIONES}

Estos niños se involucran de una manera fácil y se convierten en cómplices de este juego que estamos discutiendo aquí. Un juego que se discute desde 1920, desde entonces discutimos trabajo infantil. Comenzamos a entender por qué es difícil nuestro trabajo, porque tiene que estar centrado, como ustedes están viendo, en el niño; y ese niño tiene que estar vinculado a alguien, a la familia, a un refugio o a alguna tutela, donde alguien pueda hacer que se sientan cuidadas (CAPELATTO, 2015, n. p.).

La Convención n. ${ }^{o} 182$ (OIT, 1999), una de las convenciones firmadas por Brasil ante la Organización Internacional del Trabajo, trata sobre la prohibición y la acción inmediata para eliminación de las peores formas de trabajo infantil, considerando la importancia de la educación fundamental y gratuita, la necesidad de retirar al niño de todos esos trabajos y, al mismo tiempo, atender las necesidades de sus familias. En su artículo $3^{\circ}$, determina que las peores formas de trabajo infantil comprenden:

a) todas las formas de esclavitud o prácticas análogas a la esclavitud, como venta y tráfico de niños, sujeción por deuda y servidumbre, trabajo forzado u obligatorio, inclusive reclutamiento forzado u obligatorio de niños para ser utilizados en conflictos armados;

b) utilización, demanda y oferta de niños con fines de prostitución, producción de material pornográfico o espectáculos pornográficos;

c) utilización, demanda y oferta de niños para actividades ilícitas, en particular para la producción y el tráfico de drogas, tal como se definen en los tratados internacionales pertinentes; 
d) trabajos que, por su naturaleza o por las circunstancias en que son ejecutados, son susceptibles de perjudicar la salud, la seguridad y la moral del niño.

No debe haber forma más terrible, entre las peores, que la esclavitud y la "prostitución" infantil, formas en que el cuerpo y el psiquismo quedan a merced del contraventor, del psicópata, de proxenetas, cuyo mayor deseo es aprovecharse tanto como puedan de esos niños en estado de vulnerabilidad absoluta, sacar de ellos lo que puedan, después, la mayoría de las veces, dejarlos a su propia cuenta, sin la empatía o la compasión posibles, ausencias esas propias de la conducta psicopática.

Es necesario organizar, a través de los TRTs y del TST, eventos en favelas, Escuelas del gobierno, en aldeas, barrios de la periferia, donde se puedan aclarar, de manera simple y clara, la función de la familia y los riesgos que los niños corren al iniciar cualquier tipo de trabajo (principalmente la "prostitución").

De la misma forma, se debe amparar las escuelas y los directores de escuela para que puedan tener atención en relación a aquellos niños que comienzan a faltar las clases, que tienen dificultades de atención, concentración, escritura y lectura; convocar ONGs para esos lugares, principalmente aquellas que trabajan con educación y enseñanza de menores; convocar la actuación del Ministerio Público y de los Consejos Tutelares, tan pronto como se perciba una falla o falta en la conducta de los niños y familiares; organizar eventos y reuniones con los presidentes de asociaciones de barrios; convocar la iglesia que pertenece a esa región, en la figura de los feligreses, de los hermanos de otras iglesias, en fin, movilizar a la sociedad en sus más dignos representantes para intervenir en ese grave e insistente cuadro. Y, aquí también, volver a estimular la acción de los Programas educativos de resistencia a las Drogas (PROERDs), junto a las policías militares de los estados, con el auxilio y la participación de empresarios, asociaciones comerciales e industriales de los municipios.

Finalmente, ante un problema tan serio, el poder público, a través del MPT, de los TRTs y de la sociedad civil, debe establecer prioridad en la atención y en los cuidados con nuestros niños en sufrimiento. 


\section{NOTA}

1 El término "prostitución" se utiliza entre comillas ya que supone una relación comercial entre iguales adultos. En el caso de niños y adolescentes, hay explotación sexual y no "prostitución", ya que involucra personas en condición peculiar de desarrollo y no se reconoce la legitimidad de esa elección o participación.

\section{REFERENCIAS}

BATISTA, M. A vulnerabilidade sexual das crianças prostituídas: o estupro de vulnerável e a sua nova perspectiva frente ao STJ. Monografia (Bacharel em Direito) - Universidade Estadual da Paraíba, 2013.

BLANCHARD,J.SexualExploitationof Children.In:CongresoInternacional Contra a Exploração de Crianças. Brasília, Brasil, 1996.

CAPELATTO, I. Diálogos sobre a afetividade. Edição original. Londrina/ PR: Ed. Papirus, 2001.

CAPELATTO, I. A vida humana: perdas e consequências (um pequeno estudo sobre as depressões, as distimias e o transtorno do estresse pós-traumático). Londrina/PR: Ed. Colégio Universitário de Londrina, 2014.

CAPELLATTO, I. Danos à saúde física e mental: prejuízo irrecuperável. In: Revista do Tribunal Superior do Trabalho, São Paulo, v. 81, n. ${ }^{\circ}$ 1, p. 45-52, jan./mar. 2015.

COSTA, E.; OLIVEIRA, K. A sexualidade segundo a teoria psicanalítica freudiana e o papel dos pais neste processo. In: Itinerarius Reflections. Revista Eletrônica do Curso de Psicologia do Campus JATAÍ - UFG, vol. 7, n. ${ }^{\circ}$ 1, 2011. DOI: https://doi.org/10.5216/rir.v2i11.1239.

FREUD, S. Fragmento da análise de um caso de histeria. Três ensaios sobre a teoria da sexualidade e outros trabalhos. In: Fragmento da análise de um caso de histeria. Três ensaios sobre a teoria da sexualidade e outros trabalhos [1905]. Ed. Standard: Rio de Janeiro, 2006.

LEÃO, D. Una tía. In: Folha de São Paulo, São Paulo, 4 nov. 2001. Seção Cotidiano. Disponible en: http://feeds.folha.uol.com.br/fsp/cotidian/ ff0411200105.htm. Acceso en: 23 mar. 2020. 
LENAIN, T. A estranha Madame Mizu. Rio de Janeiro: Companhia das Letrinhas, 1998.

ORGANIZAÇÃO INTERNACIONAL DO TRABALHO. Convenção n. ${ }^{\mathbf{o}}$ 182. Convenção sobre Proibição das Piores Formas de Trabalho Infantil e Ação Imediata para sua Eliminação. [S.1], 1999. Disponible en: https://www. ilo.org/brasilia/convencoes/WCMS_236696/lang--pt/index.htm. Acceso en: 18 sept. 2020.

PASSEI WEB. Meninas da noite, de Gilberto Dimenstein. [S.1], 6 jun. 2013. Disponible en: https://www.passeiweb.com/estudos/livros/meninas_ da_noite/. Acceso en: 17 ago. 2020.

PLASTINO, C. A. A dimensão constitutiva do cuidar. In: MAIA, M. S. (org.). Por uma ética do cuidado. Rio de Janeiro: Garamond, 2009, p. 53-88.

RIBEIRO, P. S. Prostituição Infantil: uma violência contra a criança. In: Brasil-Escola, [S.1], [20--]. Disponible en: https://brasilescola.uol.com.br/sociologia/prostituicao-infantil.htm. Acceso en: 23 mar. 2020.

WATSON, K. W. Prestadores de cuidados substitutos: ajudando crianças vítimas de abuso e negligência. [S.l], DIANE Publishing, 1994.

WINNICOTT, D. W. A criança e o seu mundo, 6. ${ }^{\mathrm{a}}$ ed. Rio de Janeiro: Zahar Ed., 1982.

WINNICOTT, D. W. Holding e Interpretação. São Paulo: Ed. Martins Fontes, 2010.

WINNICOTT, D. W. Uma nova abordagem. Campinas/SP: Ed. Armazém do Ipê, 2011. 



\title{
¿POR QUÉ LUCHAR CONTRA EL TRABAJO INFANTIL? UN RECORRIDO POR LOS MITOS Y VERDADES EN BUSCA DE LAS RESPUESTAS
}

\author{
KÁTIA MAGALHÃES ARRUDA
}

DOI: 10.51366/978-65-89468-10-3-coordinfancia-13

Resumen. Se pretende discurrir sobre la importancia de combatir el trabajo infantil y sobre los mitos y las mentiras que son creados y entronizados en el sentido común para justificar la existencia de ese tipo de trabajo. El artículo trata de la relación entre pobreza, déficit educacional y trabajo infantil y destaca que la eliminación del trabajo precoz, además de beneficiar la vida de los niños y adolescentes, contribuye indudablemente para la mejoría de toda la sociedad, sea en el aspecto económico, sea en el aspecto social.

Palabras clave: Trabajo infantil. Mitos. Pobreza.

\section{INTRODUCCIÓN}

Creo que aquellos que lucharon por mejores condiciones de vida para los niños en la época de la Revolución Industrial, en el siglo XIX, costarían creer que, en pleno siglo XXI, el mundo todavía tendría un número tan exorbitante de niños y adolescentes en situación similar, de explotación por el trabajo. ${ }^{1}$

¿Cómo explicar tal abuso con la vida y el futuro de estos niños? ¿Falta de conocimiento sobre los daños del trabajo infantil, ignorancia política, desprecio por la vida, acuerdo expresado con este tipo de explotación? Estos cuestionamientos son realizados diariamente por todos los que trabajan con este tema y, obviamente, no hay una respuesta única. Sin embargo, no hay duda de que parte de la sociedad que cierra los ojos ante la realidad del trabajo 
infantil adopta una postura de banalización, que se expresa de las más variadas formas, jsea por la simple omisión, sea por la negación, sea por la aceptación!

Expresiva forma de banalización se expresa en la perpetuación de clichés, de bromas maliciosas, de la utilización o tergiversación de frases populares, que van siendo transformadas en verdades indiscutibles, que aquí llamaremos mitos. Algunos mitos son contados y reproducidos como verdades absolutas, algo que "siempre ha sido asi" y contra el cual poco o nada se puede hacer. Crecimos escuchando que siempre existió pobreza extrema y trabajo infantil y continuamos absorbiendo tales contenidos, incluso cuando varios países del mundo ya demuestran haber superado esos padecimientos.

El presente artículo pretende abordar este tipo de banalización, construida y repetida en frases que, a su vez, justifican comportamientos reprobables. Para ello, pretendemos dividir el trabajo en cuatro tópicos: inicialmente discurrir sobre el sentido de la palabra "mito", que ciertamente nos auxiliará en la percepción de otras concepciones, no restringidas apenas al trabajo infantil. A continuación, pasaremos al análisis de la íntima relación entre pobreza, trabajo infantil y baja calidad en la educación, para, por fin, hablar cuanto la eliminación del trabajo infantil puede repercutir en la mejoría de vida para todas las personas, una vez que implicará en la efectivación de políticas públicas esenciales, como combate a la pobreza, elevación del nivel de educación y mejoría de todos los índices sociales en nuestro país.

\section{EL SENTIDO DE LA EXPRESIÓN "MITO"}

La palabra mito tiene como sinónimo "quimera, absurdo, fabulación, fantasía, invención, desatino y ficción”, por lo tanto, expresa una visión torcida de la realidad o creada como utopía. Tal vez, por esta simbología, se use de manera encubierta, impactando de manera embellecida algunas farsas o mentiras.

Algunos mitos son contados para repasar de forma alegórica conceptos sobre ética, coraje, sabiduría, como ocurre en la mitología griega, estudiada por el psicoanálisis como una expresión simbólica de los sentimientos, intereses y actitudes asumidas por una comunidad, de forma consciente o inconsciente. Al utilizar el concepto utilizado por Roland Barthes (2000)2, Giovanni Gurgel Aciole (2017) reafirma que el mito puede ser "el medio para un fin; la imposición de una ideología, una visión de clase, de una visión 
parcial del mundo que se pretende universalizar. El mito es un sistema de comunicación, un mensaje".

Se aproxima al sustantivo "mentira" teniendo este un concepto más duro y objetivo y tiene semejanza con las expresiones "burla, trola, engaño, estafa, patraña, engaño", aunque el mito también puede presentarse como una farsa o como una distorsión que casi siempre se utiliza de frases de efecto, repetidas y asimiladas no sólo por sus constructores, sino, sobre todo, por las personas más simples que la difundirán como verdades irrefutables, recordando el carácter Chicó de la obra "O auto da Compadecida", el cual siempre aclarando algo, repetía de manera traviesa: “...no lo sé, sólo sé que fue así...”.

Las frases hechas o dichos populares también expresan opiniones, consejos o estímulos pasados de generación en generación y que penetran en el inconsciente de las personas, que, al repetirlas continuamente, desprecian una reflexión más profunda sobre su sentido y alcance, ganando la fuerza y la perpetuación de los mitos. Esto ocurre con algunas frases que se han convertido en un lugar común, pero que son reconstruidas o readaptadas a las circunstancias. Dichas y repetidas, se convierten en "verdades", aunque son mitos construidos con el objetivo de no pensar y, sobre todo, no cambiar la realidad que nos rodea.

Por lo tanto, la palabra desgastada "es mejor trabajar que robar", junto con otros que trataremos de examinar, simbolizan distorsiones de las causas reales que involucran el tema del trabajo infantil y superpone el trabajo temprano como única opción a la vida marginada, anunciada en la expresión "robar". Observen que el dilema es resumido: se dan solamente dos opciones, el trabajo o el robo, como perspectivas en la vida de los niños y adolescentes (pobres).

¿Hasta qué punto se usan estas frases al azar?

O sería mejor preguntar: ¿en qué medida se usan conscientemente como un elemento de dominación? Ese es el sentido que se pretende descortinar: la reproducción de estas palabras de moda expresa una idea convenientemente difundida, como aclara Aciole (2017, pp. 1.158-1.159):

El mito naturaliza la historia y enyesa el mundo, para impedir la transformación. Por lo tanto, se presta a un uso conservador del status quo. Ahí es donde él es esencial: bien alimentado, brillante, expansivo, hablador, se inventa continuamente. Se apodera de todo: justicias, morales, estéticas, diplomacias, 
artes domésticas, literatura, espectáculos. En fin, mito e ideología son parientes cercanos: se entrelazan, se confunden y son categorías ineludibles para desenmascarar el proceso de legitimación de la sociedad burguesa. El mito es producto de una clase social dominante que resulta ser incorporado por los miembros de la clase dominada, incluso cuando se va en contra de sus propios intereses. Producir tal aceptación, por naturalización, es su función. Naturalizar la historia es hacer que las personas acepten los hechos sociales como naturales, para eclipsar el papel de la historia y sus implicaciones sociales. Frases como "es mejor trabajar que robar", "cuanto antes se trabaja, cuanto antes se enriquece", "trabajar temprano educa el carácter" son irreales y contrarias a todos los estudios e investigaciones que demuestran que, cuanto antes el niño comienza a trabajar, mayor es el abandono escolar y los niveles de accidentes de trabajo, menor es su estándar remuneratorio en el futuro y elevadas son las posibilidades de involucrarse en trabajos precarios, perjudiciales a la salud o incluso relacionados directamente a actos infraccionales ${ }^{5}$.

Una investigación realizada en el sistema socioeducativo de Rio de Janeiro, en el período de agosto a diciembre de 2019, y que aplicó cuestionarios a 100 internos e internos de las tres unidades del Degase (Departamento General de Acciones Socioeducativas), muestra los entrelazamientos entre trabajo infantil y tráfico, presentando importantes conclusiones entre los entrevistados: casi 50\% afirmó tener necesidad de contribuir con el sustento de la casa; $86 \%$ no concluyó la enseñanza fundamental; $85 \%$ ya había trabajado en actividades precarias e intermitentes antes de ir para el tráfico, siendo que $41 \%$ comenzó antes de los 14 años y el retorno al tráfico por la mayoría (56\%) ocurrió por motivos económicos, falta de empleo y sustento de la familia (NAPOLIÃO; MENEZES; LIRA, 2020). El documento aún aclara que las unidades no presentan plazas escolares para todos los internos y son pocas las oportunidades de profesionalización.

Ana Lucia Kassouf (2020), de la Universidad de São Paulo, a partir de datos oficiales recolectados por el IBGE en los años 2001 a 2009 y 2011, también demuestra que cuanto antes se trabaja, más bajo es la renta. La comparación se hace con la renta de trabajadores adultos que poseen el mismo nivel de escolaridad, pero ingresaron posteriormente en el mercado de trabajo. Para los trabajadores que comenzaron a trabajar antes de los 9 años, incluso si lograron completar sus estudios, comparándose con los que iniciaron el trabajo después de los 23 años, hay una reducción de ingresos del 43,7\% para los hombres y del $40 \%$ para las mujeres.

En ese aspecto, se reafirma que la reiteración de frases que estimulan el trabajo infantil muestra, en el mejor de los casos, desconocimiento sobre la 
realidad del tema y, en la otra hipótesis, una opción por usarlas como selección ideológica y política, en el sentido de desviar nuevas opciones o de elegir salidas que no efectúen derechos o busquen superación de desigualdades, a pesar de que el texto constitucional brasileño prohíbe el trabajo infantil a personas menores de 16 años de edad, salvo en la condición de aprendiz (que puede ser a partir de los 14 años) y todo tipo de trabajo peligroso, insalubre o en actividades ligadas a sus peores formas, según Art. 7., XXXIII, de la Constitución.

\section{LA RELACIÓN ENTRE POBREZA, TRABAJO INFANTIL Y BAJA EDUCACIÓN}

Una pregunta extremadamente grave sobre el trabajo infantil es el ciclo intergeneracional, es decir, el hijo de una persona que ha sido trabajador infantil tiende a repetir el mismo patrón, sin romper con la perpetuación de la exclusión social. Hay investigaciones sobre esos determinantes del trabajo precoz en Brasil urbano, concluyéndose que el trabajo infantil genera ese comportamiento persistente, sobre todo en estados brasileños con mayor condición de pobreza y por el grado de informalidad de los mercados regionales.

Otro conjunto importante de evidencias se refiere a las persistencias intergeneracional y temporal del trabajo infantil. En el primer caso, los resultados encontrados sugieren que en los estados donde los adultos ingresaron temprano en el mercado laboral, mayor debería ser la tasa de niños que trabajan. Por otro lado, también está bien documentada en la literatura nacional la existencia de una relación inversa entre la edad de entrada en el mercado laboral y el salario actual del trabajador (Ilahi et al. 2000, Emerson \& Portela Souza 2002, Pontili et al. 2008). Por lo tanto, los hallazgos del presente estudio refuerzan la hipótesis de una "trampa de pobreza" en Brasil, es decir, adultos que invierten poco en educación tienden a dirigir precozmente a sus hijos a la actividad laboral. Ya en cuanto a la persistencia temporal, los resultados de los modelos dinámicos indican que aquellos estados con alta tasa de trabajo infantil en años precedentes preservan cerca de $1 / 4$ de esa incidencia en los años siguientes; dado que sugiere posibles efectos desfasados en la aplicación de políticas públicas de combate al referido fenómeno (RAMALHO; MESQUITA, pp. 219-220).

Indudable, también, la relación intrínseca entre el trabajo infantil y bajo rendimiento educativo, lo que ciertamente repercute en la descalificación de la futura mano de obra, ya que la escolaridad y el tiempo de estudio promueven empleos más calificados, con el consecuente aumento en el nivel de 
renta, reduciendo la necesidad de insertar a los niños en el mercado de trabajo (SOUZA; MESQUITA; FIGUEIREDO, 2020). Hay, para ello, un importante análisis realizado por profesores y economistas de la Universidad de Cartagena, en Colombia, que aborda las principales causas y consecuencias del trabajo infantil, incluso referenciando estudios anteriores.

En la literatura existe un creativo cuerpo empírico que trata de analizar la naturaleza de la relación negativa entre la escuela y trabajo infantil, actividades excluyentes debido a que compiten por el tiempo del niño. En especial, los estudios en este sentido se han concentrado en la relación entre el trabajo infantil y las siguientes variables relacionadas con la educación: asistencia a la escuela, rendimiento académico y horas dedicadas al estudio. [...]

En cuanto a los trabajos empíricos que analizan las repercusiones del trabajo infantil sobre el rendimiento académico de los menores se encuentra el de Psacharopoulos (1997) quien argumenta que un niño que trabaja reduce su rendimiento académico por cerca de 2 años de educación comparado con el grupo de control (niños que no trabajan). Asimismo, la repetición de cursos, un fenómeno común en Latinoamérica, está cercanamente asociada al trabajo infantil. Akabayashi \& Psacharopoulos (1999) señalan que la ocupación de los niños esta negativamente relacionada con las destrezas en lectura y matemáticas. Cervini (2005), encuentran evidencia de que el rendimiento promedio en matemáticas de los alumnos de séptimo año en el área urbana en Argentina es un 20\% menor para los niños que trabajan fuera de casa y por cuatro o más horas en contraposición con los no trabajan. Para Binder \& Scrogin (1999) las horas de trabajo no afectan al rendimiento escolar en México (ACEVEDO GONZALEZ; QUEJADA PEREZ; YANEZ CONTRERAS, 2011, p. 118).

Además, la baja calidad en la educación, sea por abandono escolar, sea por bajo desempeño en la escuela, limita las oportunidades de empleos mejores, restringiendo el acceso a los empleos con baja calificación, en condiciones precarias, manteniendo al joven en el mismo ciclo de pobreza ya experimentado por sus padres (KASSOUF, 2007), incluso con repercusión en otros aspectos vitales como el estado de salud, higiene y nutrición de ese joven.

De modo que no se puede negar, en todos los aspectos, las consecuencias nefastas presentadas por el trabajo infantil.

\section{LA ELIMINACIÓN DEL TRABAJO INFANTIL Y LA MEJORA DE LOS ÍNDICES SOCIALES}

Mucho se ha oído sobre los costos de eliminar el trabajo infantil, consustanciado en otro eslogan " ¡el trabajo infantil siempre existió y siempre exis- 
tirá!”, lo que revela el pensamiento no dicho: no vale la pena gastar dinero en este tema. Como si fuera posible conciliar la valorización y priorización de la infancia, prevista en el art. 277 de la Constitución brasileña con la llaga del trabajo infantil, que aplasta, corrompe y destruye la vida de esos niños y niñas.

En impactante investigación sobre los costos y los beneficios económicos provenientes de la eliminación del trabajo infantil en Brasil, ahí incluidos los gastos de proveer escuelas públicas de enseñanza fundamental, el costo de eliminar el valor del trabajo infantil, incluso en actividades peligrosas y que puedan causar daños psicológicos y/o a la salud de los niños y jóvenes, y, haciendo comparación con los beneficios (calculados los beneficios económicos resultantes de una población con más salud y educación), la diferencia fue clara: los costos sumaron 7 mil millones de dólares, mientras que los beneficios fueron de 35 mil millones de dólares, o sea, los beneficios superan exponencialmente los costos.

Por el análisis de la investigación y datos anteriores, así como de los gráficos presentados, los beneficios de la eliminación del trabajo infantil y de la reorientación de estos niños hacia la educación exceden en gran medida los costos. Los autores de la investigación agregan que la fuerza del resultado fue tan grande que es poco probable que cualquier adecuación a la metodología sea capaz de revertir este cálculo. El principal beneficio presentado es, como es lógico, el impulso económico que experimenta un país si todos los niños son educados a través de una educación primaria y secundaria adecuada. Otros beneficios también son relatados, como la calidad de la salud (aunque con resultados subestimados), ya que parte significativa del trabajo infantil en Brasil ocurre en situación insalubre, peligrosa o con comprometimiento físico y psicológico de los jóvenes (KASSOUF; DORMAN; ALMEIDA, 2005).

La política pública de combate al trabajo infantil y estímulo al aprendizaje de los jóvenes, como se ve, camina enlazada con varias otras políticas, como mejora de la educación, disminución de la pobreza, garantía de renta básica, profesionalización, combate al desempleo de jóvenes adultos, lo que confirma la tesis defendida por Amartya Sen ${ }^{6}$ (2010) sobre la intrínseca relación existente entre políticas públicas efectivas y su repercusión para el desarrollo del país. 


\section{CONSIDERACIONES FINALES}

Es necesario romper barreras sociales y culturales para que el camino para la eliminación del trabajo infantil se haga de forma continua y decisiva. Esto pasa por el combate a los clichés creados y difundidos con el objetivo de legitimar la explotación de niños, frases tontas y sin ningún respaldo en estudios e investigaciones.

En sentido contrario, las investigaciones realizadas por instituciones serias y universidades nacionales e internacionales presentan los daños que el trabajo infantil causa en la vida, salud, desarrollo físico y psicológico de los niños y adolescentes, además de proyecciones que desintegran toda la vida adulta de esos jóvenes, reverberando en sus familias y en el cuerpo social en que están inseridos.

Aún más: hay estudios que presentan la repercusión negativa que la explotación de esos niños acarrea en el aspecto económico y cuánto la eliminación del trabajo infantil puede aumentar en calidad de vida para todas las personas, haciendo con que Brasil alcance un nuevo nivel de educación, profesionalización e inserción de los jóvenes en un mundo del trabajo más inclusivo. Como canta Beto Guedes, en "Sol de primavera", "la lección sabemos de memoria, sólo nos queda aprender...".

\section{NOTAS}

1 En 2017, La OIT estimaba que 152 millones de niños seguían sometidos al trabajo infantil, lo que representa a uno de cada diez niños, de 5 a 17 años, y 73 millones estarían en las peores formas de trabajo, es decir, en actividades que ponen en peligro la vida, la salud o la moral de esos niños (MARTINS, 2020).

2 Al principio ya se aclara que para Barthes (2001), aunque el mito es un mensaje y expresa un discurso, "no es un discurso cualquiera", trae un significado y motivación.

3 La obra citada fue escrita por el pernambucano Ariano Suassuna, en 1955, posteriormente transformada en Miniserie, en 1999, y en película, en 2000.

4 Hay estudios que muestran que cerca del $80 \%$ de los presos del Carandiru (casa de detención en São Paulo) fueron trabajadores infantiles, como afirma Leiria (2020).

5 Más del $90 \%$ de los trabajadores rescatados del trabajo forzado y análogo a la condición de esclavo son oriundos del trabajo infantil.

6 La interrelación es defendida, incluso, en el sentido de la elevación del crecimiento económico, visto no apenas como elevación de renta, pero expansión de servicios sociales como salud y educación. 


\section{REFERENCIAS}

ACEVEDO GONZALEZ, KARINA; QUEJADA PEREZ, RAÚL; YANEZ CONTRERAS, MARTHA. Determinantes y consecuencias del trabajo infantil. In: Rev. fac. cienc. econ., Bogotá, v. 19, n. 1, p. 113-124, jun. 2011. Disponible en: http://www.scielo.org.co/scielo.php?script=sci_arttext\&pi$\mathrm{d}=$ S0121-68052011000100007\&lng=en\&nrm=iso. Acceso en: 15 jul. 2020.

ACIOLE, Giovanni Gurgel. O Projeto Mais Médicos para o Brasil e a construção de mitos: uma leitura bartheana. Interface (Botucatu). In: Botucatu, v. 21, supl. 1, p. 1157-1168, 2017. Disponible en: http://www.scielo.org.co/ scielo.php?script $=$ sci_arttext\&pid $=$ S0121-68052011000100007\&lng $=$ en\&nrm=iso. Acceso en: 15 jul. 2020. Epub out. 19, 2017. DOI: https://doi. org/10.1590/1807-57622016.0540.

BARTHES, Roland. Mitologia. Trad. Rira Buongermini e Pedro de Souza. 11. ${ }^{a}$ ed. Rio de Janeiro: Bertrand Brasil, 2001.

BRASIL. Constituição da República Federativa do Brasil. Brasília/DF, 1988. Disponible en: http://www.planalto.gov.br/ccivil_03/constituicao/ ConstituicaoCompilado.htm. Acceso en: 15 jul. 2020.

KASSOUF, Ana Lúcia; DORMAN, Peter; ALMEIDA, Alexandre Nunes de. Costs and benefits of eliminating child labour in Brazil. In: Econ. Apl., Ribeirão Preto, v. 9, n. 3, p. 343-368, set. 2005. Disponible en: www.scielo.br/ scielo.php?script $=$ sci_arttext\&pid $=$ S1413-80502005000300001\&lng=en\&n$\mathrm{rm}=$ iso. Acceso en: 15 jul. 2020.

KASSOUF, Ana Lúcia. O que conhecemos sobre o trabalho infantil? In: Nova econ., Belo Horizonte, v. 17, n. 2, p. 323-350, Aug. 2007. Disponible en: http://www.scielo.br/scielo.php?script=sci_arttext\&pi$\mathrm{d}=$ S0103-63512007000200005\&lng=en\&nrm=iso. Acceso en: 21 jul. 2020. DOI: https://doi.org/10.1590/S0103-63512007000200005.

LEIRIA, Maria de Lourdes. Trabalho infantil - trabalho que ceifa a infância, oportunidades e vidas. In: V/Lex [S.1]. Disponible en: https://app.vlex. com/\#vid/707350605/fromCheckout. Acceso en: 19 jul. 2020.

MARTINS, Helena. OIT: 152 milhões de crianças foram vítimas de trabalho infantil em 2016. In: Agência Brasil, Brasília/DF, 19 set. 2017. Disponible 
en: https://agenciabrasil.ebc.com.br/direitos-humanos/noticia/2017-09/ oit-152-milhoes-de-criancas-trabalho-infantil-2016. Acceso en: 17 jul. 2020.

NAPOLIÃO, Paula; MENEZES, Fernanda; LYRA, Diogo. Ganhar a vida, perder a liberdade: Tráfico, trabalho e sistema socioeducativo. In: CESeC, Rio de Janeiro, jul. 2020. Disponible en: https://cesecseguranca.com.br/textodownload/ganhar-a-vida-perder-a-liberdade-trafico-trabalho-e-sistema-socioeducativo/. Acceso en: 19 jul. 2020.

RAMALHO, Hilton Martins de Brito; MESQUITA, Shirley Pereira de. Determinantes do trabalho infantil no Brasil urbano: uma análise por dados em painel 2001-2009. In: Econ. Apl., Ribeirão Preto, v. 17, n. 2, p. 193-225, jun. 2013. Disponible en: http:/ /www.scielo.br/scielo.php?script=sci_arttext\&pi$\mathrm{d}=$ S1413-80502013000200002\&lng=en\&nrm=iso. Acceso en: 15 jul. 2020.

SEN, Amartya. Desenvolvimento como liberdade. Trad. Laura Teixeira Motta. São Paulo: Companhia das Letras, 2010.

SOUZA, Wallace Patrick Santos de Farias; MESQUITA, Shirley Pereira de; FIGUEIREDO, Erik Alencar de. O Impacto do Investimento Estrangeiro Direto no Trabalho Infantil: Uma Análise Para Países em Desenvolvimento. In: Rev. Bras. Econ., Rio de Janeiro, v. 74, n. 1, p. 75-93, jan. 2020. Disponible en: http://www.scielo.br/scielo.php?script=sci_arttext\&pi$\mathrm{d}=$ S0034-71402020000100075\&lng=en\&nrm=iso. Acceso en: 15 jul. 2020.

TST. Pesquisa revela que quanto mais cedo se começa a trabalhar menor será a remuneração no futuro. Brasília/DF, [20--]. Disponible en: http://www.tst.jus.br/web/trabalho-infantil/programa/-/asset_publisher/ y23X/content/pesquisa-revela-que-quanto-mais-cedo-se-comeca-a-trabalhar-menor-sera-a-remuneracao-no-futuro. Acceso en: 15 jul. 2020. 


\section{LA CONVENCIÓN 182 DE LA OIT, SOBRE LAS PEORES FORMAS DE TRABAJO INFANTIL: UN VIAJE MEMORABLE Y DESAFIANTE}

\section{LELIO BENTES CORRÊA}

DOI: $10.51366 / 978-65-89468-10-3$-coordinfancia-14

En junio de 1998, los Delegados y Delegadas de los más de 170 países presentes en la Conferencia Internacional del trabajo en Ginebra se sorprendieron por la asistencia de 500 niños y adolescentes a la Sesión Plenaria. Por primera vez en la historia, el fuerte aparato de seguridad del Palacio de las Naciones, sede de la ONU, admitió el ingreso de visitantes no sometidos al proceso de acreditación previa. Después de todo, los visitantes eran nada menos que los titulares de los derechos cuya protección motivó esa reunión. Provenientes de las más diversas partes del mundo'(GLOBAL MARCH AGAINST CHILD LABOUR, [20--]), esos niños y adolescentes daban voz al anhelo de toda la infancia (especialmente las casi 246 millones de víctimas del trabajo infantil) por acciones efectivas que pusieran fin a la explotación inhumana, que robaba los sueños y comprometía el futuro de niñas y niños.

Habló en la Conferencia Internacional del Trabajo, el activista por los derechos de la niñez y la adolescencia Kailash Satyarthi ${ }^{2}$ dijo a la junta la adopción de un instrumento por el que se concretaba en el compromiso de la comunidad internacional sobre la protección de la infancia contra la explotación económica y la afirmación de sus derechos, especialmente el derecho a la educación y el pleno desarrollo de sus potencialidades. De la explotación a la educación era el lema repetido al agotamiento, con el fin de marcar el comienzo de una nueva era, en la que todos los niños y adolescentes tendrán derecho a beneficiarse de una educación pública, gratuita y de calidad, capaz de asegurar el desarrollo integral de sus potencialidades y la perspectiva de un futuro feliz. 


\section{El Director General de la Organización Internacional del Trabajo,}

Michel Hansenne ${ }^{3}$, al dirigir sus comentarios finales a la Conferencia, señaló:

[...] el mundo está cambiando, y este cambio sólo puede ser para mejor. Debo agregar: siempre que queramos que sea así.

Los delegados presenciaron una demostración de esta voluntad de actuar cuando la Marcha Global Contra El Trabajo Infantil estalló en este auditorio en una multitud vibrante y colorida. En sus declaraciones plenarias, muchos de ustedes dieron la bienvenida a esta iniciativa lanzada por organizaciones no gubernamentales de países en desarrollo, junto con las del mundo desarrollado. Esto demuestra que las organizaciones no gubernamentales, los sindicatos, las organizaciones de empleadores y las asociaciones de defensa de los derechos del niño pueden trabajar juntos, a pesar de las diferencias nacionales, culturales, religiosas o de otra naturaleza.

Esto debería alentarnos para el futuro. Debemos tener la esperanza de que esta sinergia pueda sostenerse y extenderse a otras actividades prácticas. En un área como el trabajo infantil, y en un contexto de globalización de la economía, el respeto universal por un conjunto de valores requiere cada vez más un esfuerzo conjunto: en el ámbito de las leyes, por aquellos con poder decisorio; cooperación técnica y movilización de la opinión pública.

Más que una invasión pacífica de la Sala de conferencias, el objetivo de la Marcha era hacerse oír, en nombre de decenas de millones de niños trabajando en condiciones extremas, por los delegados a la Conferencia y por los miembros del Comité instalado para examinar las conclusiones concernientes a nuevos instrumentos sobre las peores formas de trabajo infantil. Creo que fueron escuchados (ILO, 1998).

La adopción, en el año siguiente (1999), de la Convención n. ${ }^{\circ} 182$ y de la Recomendación n. ${ }^{\circ} 190$, por el voto unánime de los delegados presentes en la Conferencia Internacional del Trabajo, confirmó la percepción del Director General de la OIT: las voces de los niños y adolescentes se hicieron oír. Como resultado, la comunidad internacional dio un paso significativo hacia la afirmación de los derechos de la infancia, asumiendo el compromiso de eliminar, en carácter de urgencia, las peores formas de trabajo infantil.

Otra observación de Hansenne para el futuro, hoy asume rasgos de vaticinio:

La adopción de estos instrumentos, y especialmente la ratificación universal de la nueva Convención, deberá traer un nuevo impulso a las actividades del Programa Internacional para la Eliminación del Trabajo Infantil (ILO, 1998, cursivas nuestras).

La Convención n. 182 de la OIT fue ratificada a un ritmo jamás visto en aquella organización. En el mismo año de su adopción, cinco países depositaron los respectivos instrumentos de ratificación ante la Oficina del 
Director General de la OIT, incluso los Estados Unidos de América ${ }^{4}$ - país que, a pesar de su importancia económica y política, tiene un historial tímido con relación al número de ratificaciones de normas internacionales en el ámbito de las Naciones Unidas ${ }^{5}$.

Durante la primera década del siglo XXI, otros 166 países ratificaron la Convención n..$^{\circ} 182$ y, en 2020, la centenaria OIT fue testigo de la primera ratificación universal de uno de sus instrumentos ${ }^{6}$.

Tal logro es especialmente notable, considerando que una de las razones para la adopción de un nuevo instrumento sobre trabajo infantil fue exactamente el bajo número de ratificaciones alcanzado por el Convenio n. ${ }^{\circ}$ 138 de 1973. En 1994, 21 años después de su adopción, solo 46 países habían ratificado la Convención (BELEKE; MEYERS, 1995). En la época, era frecuente, entre representantes de gobiernos de países en condición de menor desarrollo económico, la justificación de que la Convención n. ${ }^{\circ}$ 138, si bien relevante, establecía metas ambiciosas, que no podían ser alcanzadas de inmediato. Argumentaban que la ratificación de la Convención podría imponer obligaciones de difícil implementación, acarreando situación de incumplimiento que, a su vez, podría repercutir negativamente en su imagen internacional y en sus relaciones comerciales.

Abstraído el componente voluntad política, ya resaltado por Michel Hansenne en el trecho transcrito alhures, el hecho es que la oportunidad se presentó auspiciosa para los constituyentes de la OIT, que deliberaron por explicitar en el nuevo instrumento las peores formas de trabajo infantil, con relación a las cuales los países que ratificaron se comprometen a adoptar medidas inmediatas y eficaces, que aseguren su probibición y eliminación, en carácter de urgencia.

Las peores formas de trabajo infantil se definen en el artículo 3 de la Convención n. ${ }^{\circ} 182$, que las divide en cuatro tipos:

i) todas las formas de esclavitud o las prácticas análogas a la esclavitud (de ahí, incluidas, entre otras, la venta y el tráfico de niños, la servidumbre por deudas, y el reclutamiento forzoso u obligatorio, para su utilización en los conflictos armados); (ii) el uso, la demanda o la oferta de niños para fines de prostitución, la producción de pornografía o actuaciones pornográficas; (iii) la utilización, reclutamiento y oferta de niños para actividades ilícitas, en particular la producción y el tráfico ilícito de estupefacientes (jife); iv) el trabajo que, por su naturaleza o por las condiciones en que se realizan, es probable que dañe la salud, la seguridad y la moralidad de los niños ${ }^{7}$. 
Es Importante destacar que la Convención n. ${ }^{\circ}$ 182, en su preámbulo, reafirma la centralidad de la Convención n. ${ }^{\circ} 138$ en el sistema normativo de la OIT, en cuanto al trabajo infantil. Los parámetros y objetivos de la Convención n. ${ }^{\circ} 138$ continúan dando norte a la actuación de la OIT en cuanto al tema. La Convención n. ${ }^{\circ} 182$ agregó un criterio de prioridad, destacando la necesidad de una acción eficaz e inmediata para la pronta eliminación de sus peores formas. Resulta entonces que las Convenciones de n. ${ }^{\text {s }} 138$ y 182 no se excluyen, sino que se complementan.

Tal complementariedad fue perfectamente comprendida por la Asamblea General de las Naciones Unidas que, al adoptar la Agenda para el Desarrollo Sostenible 2030, incluyó, en el Objetivo de Desarrollo Sostenible 8 (Trabajo Decente y crecimiento económico), la meta 8.7, de siguiente tenor:

Tomar medidas inmediatas y eficaces para erradicar el trabajo forzado, acabar con la esclavitud moderna y la trata de personas, y asegurar la prohibición y eliminación de las peores formas de trabajo infantil, incluyendo el reclutamiento y uso de niños-soldado, y hasta 2025 poner fin al trabajo infantil en todas sus formas (cursivas nuestras).

Vale decir, la meta a ser perseguida por los países es la efectiva eliminación del trabajo infantil en todas sus formas, mediante acciones y programas con plazo determinado ${ }^{8}$, políticas nacionales y cooperación internacional, entre otras medidas. Como parte de este esfuerzo, deben adoptarse medidas inmediatas y eficaces para prohibir y eliminar, en carácter de urgencia, las peores formas de trabajo infantil.

El acierto de la decisión de la Conferencia Internacional del trabajo al adoptar la Convención n. ${ }^{\circ} 182$ es evidenciado no sólo por su ratificación universal. Se observa que el número de ratificaciones del Convenio n. ${ }^{\circ} 138$ de la OIT también creció exponencialmente, llegando, actualmente, a $173^{9}$.

Es importante recordar que, a partir del depósito del instrumento de ratificación ante la Oficina del Director General, el país miembro pasa a someterse a los mecanismos de control regular del cumplimiento de las obligaciones previstas en el instrumento respectivo, quedando obligado a enviar informes periódicos sobre la situación de los derechos allí previstos en la legislación y en la práctica. Esto ha permitido a la OIT mantener un intercambio bastante fructífero con los países que han ratificado los Convenios de n.os 138 y 182, con repercusiones importantes en la situación del trabajo infantil en todo el mundo. 
El número estimado de víctimas del trabajo infantil en el mundo ha disminuido en casi un $\mathbf{4 0} \%$, en promedio, desde 2000. Según datos de la OIT, en 2000 (OIT, 2013) eran 245,5 millones de niños en el grupo de edad de 5 a 17 años de edad, 170,5 millones de ellos trabajando en condiciones de riesgo para su salud, seguridad y moral. En 2016 (OIT, 2017), se contaban 152 millones de niños víctimas del trabajo infantil, siendo 73 millones en condiciones de riesgo.

En las Américas, en 2016 el número de víctimas del trabajo infantil fue de 10.735.000, de las cuales 6.553 .000 en condiciones de riesgo, una caída del $24 \%$ con respecto a 2008 , cuando las cifras fueron, respectivamente, 14.125 .000 y 9.436 .000 .

Es cierto que tales avances no solo han resultado de la adopción de la nueva Convención. La priorización, en varios países, de políticas públicas dirigidas a la universalización de la enseñanza básica, atención a la salud y alimentación de niños y adolescentes en edad escolar, además de programas de transferencia de renta condicionada a la asistencia escolar tuvieron gran impacto en la reducción global del trabajo infantil.

Igualmente importante fue la implementación de programas de cooperación técnica internacional, capitaneados por la OIT y el UNICEF, orientados al desarrollo de la capacidad nacional de elaborar e implementar estrategias de lucha contra el trabajo infantil, así como monitorear su progreso $^{10}$.

Por otra parte, la exigencia de observancia y efectiva implementación de los convenios fundamentales de la OIT ${ }^{11}$, establecida en varios acuerdos bilaterales de comercio internacional, inclusive en el ámbito del Sistema General de preferencias ${ }^{12}$, como condición para acceso a incentivos especiales, también impactó positivamente el cuadro, tanto bajo la óptica del número de ratificaciones de la Convención n. ${ }^{\circ} 182$ de la OIT, como la adopción de medidas concretas para la eliminación del trabajo infantil, especialmente en los países en busca de una mejor colocación de sus productos en el mercado internacional.

Si bien la evolución favorable del cuadro de ese margen a cierto optimismo, en un informe lanzado en $\mathbf{2 0 1 8}$, la OIT ya alertaba sobre el hecho de que el desafío seguía siendo "formidable" en sus proporciones, y el ritmo 
de la disminución de los indicadores se desaceleraba (OIT, 2018). Entre 2012 y 2016, el número de víctimas del trabajo infantil en el mundo cayó un 1\%, mientras que la reducción en el período de 2008 a 2012 fue del 3\%. El número de niños en el grupo de edad de hasta 12 años se mantuvo prácticamente estable. Si se mantiene ese ritmo, la perspectiva para 2025 (fecha fijada en la meta 8.7 de los Objetivos del Desarrollo Sostenible de la ONU para la eliminación del trabajo infantil en todas sus formas) sería de contar 121 millones de niños y adolescentes víctimas del trabajo infantil.

El cuadro era grave, y requería acción urgente. Según el informe mencionado, “incluso si se mantiene el ritmo alcanzado entre 2008 y 2012, el más rápido registrado hasta ahora, no sería suficiente. Nos estamos moviendo en la dirección correcta, pero tenemos que acelerar mucho el ritmo" (OIT, 2018).

La situación, ya tremendamente desafiante, llegó a degradarse gravemente en 2020, con la crisis sanitaria y económica sin precedentes desencadenada por la Pandemia de COVID-19. Según las estimaciones de la OIT (ILO, 2020b), el número de horas trabajadas en todo el mundo sufrió una reducción del 14\% en el segundo trimestre de 2020, lo que equivale a la extinción de 400 millones de empleos a tiempo completo. El impacto en las Américas es aún mayor, alcanzando el 18,3\%.

Aún mayor es el impacto sufrido por el sector informal - donde se encuentra la mayor parte del trabajo infantil urbano en el mundo (ILO; UNICEF, 2020). En la economía informal, prácticamente no hay reemplazo de ingreso o ahorros. Para la abrumadora mayoría de los más de 2 mil millones de trabajadores informales del mundo, no trabajar debido a lockdown u otras medidas de contención significa perder su medio de subsistencia y la de su familia (ILO, 2020a). Y las familias vulnerables, sin acceso a medidas de protección social, al perder el medio de sustento, tienen más probabilidades de recurrir al trabajo infantil.

A esto se suman los efectos de la Pandemia sobre sistemas educativos en todo el mundo, afectando a casi 1,6 mil millones de estudiantes, en 190 países de todos los continentes, según datos de la Organización de las Naciones Unidas (UN, 2020). Y peor: la recuperación de los sistemas educacionales no está garantizada, ya que la crisis sanitaria y económica presiona los presupuestos públicos, comprometiendo la ya insuficiente inversión en educación 
de calidad en diversos países - especialmente los de baja y media renta (UN, $2020)^{13}$. Con el cierre de escuelas y la falta de mecanismos que permitan la continuidad del proceso educacional, es previsible el incremento de las tasas de evasión escolar, estimándose que otros 23,8 millones de niños y adolescentes en edad escolar vengan a sumarse a los más de 250 millones que se encuentran fuera de la escuela-un incremento del 9,5\% (UN, 2020).

No es difícil constatar, en ese escenario, que niños y adolescentes pertenecientes a familias vulnerables, sin acceso a la educación o protección social, se encuentran bajo mayor riesgo de convertirse en víctimas del trabajo infantil.

Según datos de la OIT y UNICEF, el $\mathbf{5 5 \%}$ de la población mundial no tiene acceso a ningún mecanismo de protección social. Son los más vulnerables a los choques y crisis, como la que ahora se abate sobre la economía mundial, tanto a corto como a largo plazo (ILO, UNICEF; 2020). Para el Banco Mundial (BIRD, 2020b), el número de personas viviendo en condiciones de pobreza extrema (con renta per cápita inferior a 1,90 dólares por día) en 2020, deberá sufrir un incremento con relación a 2019 del orden de 40 a 60 millones, en razón de la Pandemia. Se trata de la reversión de una tendencia a la baja sostenida desde 1990, cuando alrededor del 36\% de la población mundial se encontraba en una situación de pobreza extrema. En 2015, ese porcentaje se encontraba en 10\%, correspondiendo a 734 millones de personas.

La OIT y UNICEF (ILO; UNICEF, 2020) advierten del hecho de que, según evidencias estadísticas, el incremento del $1 \%$ en los índices de pobreza extrema conduce a un aumento de al menos $\mathbf{0 , 7} \%$ en el número de víctimas del trabajo infantil.

Una noción más concreta de la dimensión de la crisis puede ser obtenida mediante la aplicación de esos parámetros de cálculo a la realidad brasileña. Según la PNAD continua del IBGE de 2019 , 13,5 millones de personas (6,5\% de la población) vivían por debajo del límite de la pobreza extrema (NERY, 2019) ${ }^{14}$. Las estimaciones del Banco Mundial (BIRD, 2020A) indican un probable retroceso del $\mathbf{8 \%}$ en el Producto Interno Bruto de Brasil en 2020. Según estudios del King's College London y de la Universidad Nacional de Australia (BARRUCHO, 2020), una retracción de esa magnitud del PIB nacional produciría tamaño impacto en la renta y consumo de los brasileños, 
que entre 700.000 y 3,3 millones de ellos pasarían a la pobreza extrema - es decir, un crecimiento del $23,9 \%$ en el peor escenario, y del $5 \%$ en el mejor escenario.

Aplicada a ratio pobreza extrema vs. trabajo infantil (1 vs. 0,7), el incremento probable en el número de trabajadores infantiles en Brasil en 2020 oscilaría entre $3, \mathbf{5} \%$ y $\mathbf{1 6 , 7 3 \%}$ - un salto que podrá aproximar los números actuales de los 3,2 millones de víctimas del trabajo infantil registrados por la PNAD del IBGE en 2013 (FNPETI, 2014).

El Director General de la OIT, Guy Ryder ${ }^{15}$, al celebrar la ratificación universal de la Convención n. ${ }^{\circ} 182$, se refirió a la trayectoria de este instrumento como "una jornada memorable" (RYDER, 2020). Pero recordó que, a pesar de los éxitos alcanzados, con la reducción de los índices de trabajo infantil en más de 100 millones desde el año 2000, 152 millones de niños siguen siendo víctimas de esa lacra. Y los efectos catastróficos de la crisis sanitaria y económica amenazan con revertir los avances logrados lentamente, a lo largo de décadas. "Vamos a acelerar el ritmo" - propone, en una exhortación a la comunidad internacional para que traduzca en acciones concretas los compromisos asumidos con la ratificación de la Convención n. ${ }^{\circ} 182$ y ponga fin a todas las formas de trabajo infantil.

El viaje es ciertamente memorable. Pero también largo y desafiante, lleno de contratiempos. La ratificación universal de la Convención n. ${ }^{\circ} 182$ de la OIT constituye un objetivo alentador de larga data y merece ser celebrada. Pero el desafío más grande apenas está comenzando. Implementar correctamente las obligaciones consagradas en el texto de la Convención hace 21 años, por el voto unánime de los representantes de trabajadores, empleadores y gobiernos presentes en la Conferencia Internacional del Trabajo, es, más que deber moral, imperativo legal- ya que, en ese momento, todos los países miembros de la OIT tienen en sus ordenamientos jurídicos un instrumento poderoso, claro y preciso sobre el camino a seguir en la lucha contra el trabajo infantil.

El fortalecimiento y la calificación del aparato de control Estatal, así como del sistema de Justicia, es fundamental. La clasificación penal de la explotación de las peores formas de trabajo infantil, con la imposición de sanciones adecuadas y disuasorias, es también necesaria. Pero ningún esfuerzo será exitoso si no va acompañado de la implementación de políticas 
públicas que aseguren a todas y a todos - especialmente a los más vulnerables - acceso a derechos fundamentales, tales como salud, educación, ocio, protección, previsión y asistencia social, entre otros. Obviamente, la concretización de estas medidas dependerá de la asignación de los recursos necesarios - que, en un contexto de crisis, sufren dura competencia con demandas provenientes de otros sectores gubernamentales. Es el momento de demostrar la buena fe en el cumplimiento de las obligaciones asumidas ante la comunidad internacional, así como el aprecio al principio de la prioridad absoluta de los derechos de los niños y adolescentes.

\section{NOTAS}

1 La Marcha Global Contra El Trabajo Infantil reunió a más de 1.400 organizaciones no gubernamentales, cruzando 103 países en cinco continentes, movilizando más de 7 millones de personas contra el trabajo infantil.

2 El indiano Kailash Satyarthi, idealizador de la Marcha Global Contra el Trabajo Infantil, fue galardonado con el Premio Nobel de La Paz 2014.

3 El belga Michel Hansenne fue el $8^{\circ}$ Director General de la OIT entre 1989 y 1999.

4 Los otros cuatro países son: Seychelles (29/09/1999); Malawi (19/11/1999); Irlanda (20/12/1999) y Eslovaquia (20/12/1999).

5 Los Estados Unidos son el único país del mundo que aún no ha ratificado la Convención sobre los derechos del Niño de 1989.

6 El último país en depositar el instrumento de ratificación del Convenio $n^{\circ} 182$ fue Tonga, El 4/8/2020.

7 De acuerdo con el artículo $4^{\circ}$, inciso 1 , de la Convención n. ${ }^{\circ} 182$, tales como los tipos de trabajo que se establecen en la legislación nacional o por la autoridad competente, previa consulta con las organizaciones de empleadores y de trabajadores interesadas y tomando en cuenta las normas internacionales pertinentes, en particular los párrafos 3 y 4 de la Recomendación sobre las Peores Formas de Trabajo Infantil, de 1999”.

8 Sobre Programas con plazo Determinado (Time Bound Programmes), véase la página del Programa Internacional para la Eliminación del Trabajo Infantil de la OIT - IPEC (ILO, [20--]).

9 No han ratificado la convención n. 138 hasta el 13/9/2020: Australia, Bangladesh, Islas Cook, Irán, Liberia, Islas Marshall, Nueva Zelanda, Palau, Santa Lucia, Somalia, Timor-Leste, Tonga, Tuvalu y Estados Unidos de América.

10 El Programa Internacional de la OIT para la Eliminación del Trabajo Infantil IPEC se lanzó en 1992, con seis países signatarios (Brasil, India, Indonesia, Kenia, Turquía y Tailandia). Creció rápidamente, convirtiéndose en el mayor programa mundial exclusivamente centrado en el trabajo infantil, según el Informe Global presentado a la $95^{\mathrm{a}}$ Conferencia Internacional del Trabajo: el fin del trabajo infantil: un objetivo a nuestro alcance. En 2006 estuvo presente en 86 países (OIT, 2006).

11 Son ocho las Convenciones Fundamentales, definidas en la Declaración de la OIT relativa a los Principios y Derechos Fundamentales en el Trabajo, adoptada en 1998, en relación con los cuatro principios de observancia obligatoria por parte de todos los países miembros de la Organización: la Convención n. ${ }^{\circ} 87$ y en el Convención n. ${ }^{\circ}$ 98 de la protección de la libertad sindical y a la negociación colectiva); la Convención 
n. ${ }^{\circ} 29$ y Convención n. 105 (la eliminación del trabajo forzoso u obligatorio); la Convención n..$^{\circ} 138$, y la Convención n. ${ }^{\circ} 182$ (abolición del trabajo infantil; y en la Convención n. ${ }^{\circ} 100$, y la Convención n. 111 (la eliminación de la discriminación en materia de empleo y ocupación) (OIT, 1998).

12 Este es el caso del Sistema General de Preferencias "Plus" de la Unión Europea (EUROPEAN COMMISSION, 2020). Los Estados Unidos de América han introducido exigencias relativas a las normas fundamentales en el trabajo, como en el caso del Acuerdo de Libre Comercio firmado con Jordania, con vigencia a partir de 2001 (artículo 6) (EE.UU., 2000). Disposiciones similares se encuentran en los Acuerdos de Libre Comercio firmados con Chile, con vigencia a partir de 2004 (artículos 18.1 y 18.2); Perú, con vigencia a partir de 2004 (artículos 17.1 a 17.3); Bahrein, con vigencia a partir de 2006 (artículos 15.1 y 15.2); República Dominicana y América Central (CAFTA), con vigencia a partir de 2006 (artículos 16.1 y 16.2); Colombia, con vigencia a 2012 (artículos 17.1 a 17.3); Panamá, con vigencia a partir de 2012 (artículos 16.1 a 16.3) y Corea (KORUS), con vigencia a partir de 2012 (artículos 19.1 a 19.3), entre otros.

13 Según el informe de la ONU, el déficit para la financiación de una educación de calidad en todo el mundo, que giraba alrededor de 148 mil millones de dólares estadounidenses al año, debe sufrir un incremento de hasta un tercio.

14 Instituto Brasileño de Geografía y Estadística-IBGE: Investigación Nacional por Muestra de Domicilios - PNAD continua 2019 (datos referentes a 2018).

15 El británico Guy Ryder es el décimo Director General de la OIT, desde el 1\%/10/2012 hasta la fecha actual.

\section{REFERENCIAS}

BARRUCHO, Luis. Coronavírus: pandemia pode jogar até 14 milhões de brasileiros na pobreza, diz estudo. In: BBC News Brasil, Londres, junho de 2020. Disponible en: https://www.bbc.com/portuguese/brasil-53020785. Acceso en: 14 oct. 2020.

BELEKE, Assefa; MEYERS, William E. First things first in child labour: eliminating word detrimental to children. UNICEF/ILO: Geneva, 1995.

\section{BIRD - THE WORLD BANK. Global economic prospects - Latin Ame- rica and Caribbean. BIRD: Washington, junho, 2020a.}

BIRD - THE WORLD BANK. Understanding poverty. Bird, ago. 2020b. Disponible en: https://www.worldbank.org/en/topic/poverty/overview. Acceso en: 29 sept. 2020.

EUROPEAN COMMISSION. Sustainable development - Labour Rights. 2020. Disponible en: https://ec.europa.eu/trade/policy/policy-making/sustainable-development/\#_labour-rights. Acceso en: 25 sept. 2020. 
FNPETI - FÓRUM NACIONAL DE PREVENÇÃO E ERRADICAÇÃO DO TRABALHO INFANTIL. Dados da PNAD de 2013 revelam tímida redução do trabalho infantil. In: FNPETI: Brasília, 2014. Disponible en: https:/ / fnpeti.org.br/noticias/2014/10/06/dados-da-pnad-de-2013-revelam-timida-reducao-do-trabalho-infantil/. Acceso en: 29 sept. 2020.

GLOBAL MARCH AGAINST CHILD LABOUR. Our story - How we started. [20--]. Disponible en: https://globalmarch.org/about-us/ourstory/. Acceso en: 25 sept. 2020.

ILO - INTERNATIONAL LABOUR ORGANIZATION. Reply by the Directir-General to the discussion of his Report 18 June 1998. In: International Labour Conference, 86th Session, Geneva, June 1998. Disponible en: https://www.ilo.org/public/english/standards/relm/ilc/ilc86/a-dgrep. htm. Acceso en: 25 sept. 2020.

ILO - INTERNATIONAL LABOUR ORGANIZATION. Ending child labour by 2025: A review of policies and programmes. ILO: Geneva, 2018. Disponible en: https://www.ilo.org/wcmsp5/groups/public/---ed_ norm/---ipec/documents/publication/wcms_653987.pdf. Acceso en: 20 sept. 2020.

ILO - INTERNATIONAL LABOUR ORGANIZATION. ILO Brief: COVID-19 crisis and the informal economy - Immediate responses and policy challenges. ILO: Genebra, maio de 2020. Disponible en: https://www.ilo.org/wcmsp5/groups/public/---ed_protect/---protrav/---travail/documents/briefingnote/wcms_743623.pdf. Acceso en: 29 sept. 2020.

ILO - INTERNATIONAL LABOUR ORGANIZATION; UNICEF. COVID-19 and child labour: a time of crisis, a time do act. OIT e UNICEF: Genebra, junho de 2020.

ILO - INTERNATIONAL LABOUR ORGANIZATION. ILO Monitor: COVID-19 and the world of work. 5. ed. ILO: Genebra, junho de 2020b.

ILO - INTERNATIONAL LABOUR ORGANIZATION. Time-bound programmes (TBP). [20--]. Disponible en: https://www.ilo.org/ipec/Action/Time-BoundProgrammes/lang--en/index.htm\#: : text=Time-bound programmes for the, worst forms of child labour. Acceso en: 25 sept. 2020. 
OIT - ORGANIZAÇÃO INTERNACIONAL DO TRABALHO. Declaração da OIT sobre os princípios e direitos fundamentais no trabalho. Disponible en: https://www.ilo.org/public/english/standards/declaration/ declaration_portuguese.pdf. Acceso en: 25 sept. 2020.

OIT - ORGANIZAÇÃO INTERNACIONAL DO TRABALHO. FIUZA, Carlos; COSTA, Alexandra [trad.]. O fim do trabalho infantil: um objetivo ao nosso alcance: Relatório global no quadro do Seguimento da Declaração da OIT sobre os Princípios e Direitos Fundamentais no Trabalho. OIT: Lisboa, 2006.

OIT - ORGANIZAÇÃO INTERNACIONAL DO TRABALHO. Making progress against child labour: global estimates and trends 2000-2012. OIT: Genebra, 2013.

OIT - ORGANIZAÇÃO INTERNACIONAL DO TRABALHO. Global estimates of child labour: results and trends 2012-2016. OIT: Genebra, 2017.

NERY, Carmen. Extrema pobreza atinge 13,5 milhões de pessoas e chega ao maior nível em 7 anos. Agência de Notícias IBGE: Brasília, 06 nov. 2019. Disponible en: https://agenciadenoticias.ibge.gov.br/agencia-noticias/2012-agencia-de-noticias/noticias/25882-extrema-pobreza-atinge-135-milhoes-de-pessoas-e-chega-ao-maior-nivel-em-7-anos. Acceso en: 29 sept. 2020.

RYDER, Guy. A remarkable journey to universal ratification - ILO Director-General. ILO: ago., 2020. Disponible en: https://www.ilo.org/global/about-the-ilo/multimedia/video/institutional-videos/WCMS_751228/ lang--en/index.htm. Acceso en: 29 sept. 2020.

USA - UNITED STATES OF AMERICA. Agreement between the United States of America and the Hashemite Kingdom of Jordan on the establishment of a free trade area. EUA, 2000. Disponible en: https:// ustr.gov/sites/default/files/Jordan\%20FTA.pdf. Acceso en: 25 sept. 2020.

UN - UNITED NATIONS. Policy brief: education during COVID-19 and beyond. UN: EUA, ago. 2020. Disponible en: https://www.un.org/development/desa/dspd/wp-content/uploads/sites/22/2020/08/sg_policy_ brief_covid-19_and_education_august_2020.pdf. Acceso en: 29 sept. 2020. 


\section{EL PROGRAMA DE ERRADICACIÓN DEL TRABAJO INFANTIL $Y$ LA EFECTIVIDAD DE LAS POLÍTICAS PÚBLICAS DEL ESTADO BRASILEÑO EN EL ENFRENTAMIENTO DE LA EXPLOTACIÓN DEL TRABAJO DE NIÑOS Y ADOLESCENTES}

\section{LUCIANA MARQUES COUTINHO}

DOI: 10.51366/978-65-89468-10-3-coordinfancia-15

Resumen. Este artículo aborda el Programa de Erradicación del Trabajo Infantil (PETI), haciendo un análisis retrospectivo sobre los 24 años de implementación de esta política pública, cuyo principal objetivo es el enfrentamiento de la utilización ilícita de mano de obra de niños y adolescentes en Brasil. El artículo también aborda la actuación del Ministerio Público del Trabajo en el combate a la explotación del trabajo infanto-juvenil, que ocurre por medio de la Coordinación Nacional de Combate contra la Explotación del Trabajo de Niñas, Niños y Adolescentes (Coordinfância), y la intersección de la actuación entre esa Coordinación y el PETI.

Palabras clave: Trabajo infantil. Políticas Públicas. PETI.

\section{BREVÍSIMAS CONSIDERACIONES SOBRE LA MOVILI- ZACIÓN SOCIAL EN DEFENSA DE LOS DERECHOS DE LOS NIÑOS Y DE LOS ADOLESCENTES EN BRASIL}

Las décadas de los 80 y 90 del siglo pasado estuvieron marcadas por una intensa movilización de los órganos públicos y de la sociedad civil en defensa de los derechos del niño y del adolescente. Esa movilización contribuyó decisivamente para alterar la situación normativa en Brasil, con la con- 
sagración de nuevos niveles jurídicos de protección a niños y adolescentes y, también, la concepción del niño y del adolescente como sujetos de derechos.

Esos avances jurídicos impactaron de forma decisiva en la lucha contra el trabajo infantil, inserido finalmente en la agenda pública como una llaga social que debía ser enfrentada. Se iniciaba, por lo tanto, una ruptura con un estado social en el que no sólo se concordaba, sino que también se incentivaba el trabajo de niños y adolescentes integrantes de las clases pobres y marginadas en el país.

Hasta la década de los 80, en Brasil, la población iniciaba la vida laboral precozmente, impulsada, principalmente, por la pobreza. Cuanto menor la renta de la familia y la escolaridad de la persona de referencia de la unidad familiar, mayor era el riesgo de ingreso precoz en el mundo del trabajo.

Había, prácticamente, un consenso en la sociedad brasileña en torno al entendimiento del trabajo como un factor positivo para niños y adolescentes. Es bien sabido que esta concepción aún persiste en muchos sectores de la sociedad.

El propio Estado brasileño constituyó un conjunto de políticas de carácter moralizador que dignificaba el trabajo por sobre todas las cosas. El Código de menores, que estuvo en vigor hasta ser derogado por el ECA en 1990, entendía al "menor" que no estudiaba o trabajaba como un potencial "delincuente", que debía ser controlado y reprimido por las estructuras punitivas del poder público.

En relación a la educación, la visión dominante era que la misma debería ser orientada por la utilidad económica. Esa perspectiva legitimaba el trabajo infantil, visto como una forma de hacer al niño "aprovechar el tiempo de forma útil", enseñándole, al mismo tiempo, "una profesión” y "el valor del trabajo" (BRASIL, 2019, p. 9).

A raíz de la movilización social aludida, el artículo 227 de la Constitución Federal surgió como fruto de una enmienda popular organizada por los movimientos Niño y Constituyente y Niño, prioridad nacional durante la Asamblea Constituyente (CÁMARA DE LOS DIPUTADOS, 2018) y dio origen a la norma vector del principio de protección integral, que prevé, en la protección especial garantizada a niños y adolescentes, el derecho a no trabajar antes de la edad y de las condiciones apropiadas. Más tarde, guiado por el principio de protección integral previsto en la Carta Magna, vendría el Estatuto del Niño y del Adolescente, que estatuyó un capítulo dedicado al derecho a la profesionalización y a la protección en el trabajo.

La Convención sobre los Derechos del Niño fue adoptada por la Asamblea General de la ONU el 20 de noviembre de 1989, fue ratificada 
por Brasil en noviembre de 1990, por el Decreto n. ${ }^{\circ}$ 99.710/1990. Entre los preceptos de la Convención, conforme preconiza el art. 32 del referido decreto, está el reconocimiento del derecho del niño" " "contra la explotación económica y contra la realización de cualquier trabajo que pueda ser peligroso o interferir en su educación, o que sea perjudicial para su salud o para su desarrollo físico, mental, espiritual, moral o social" (BRASIL, 1990, p. 10).

La Convención n. ${ }^{\circledR} 182$ de la Organización Internacional del Trabajo, sobre la prohibición de las peores formas de trabajo infantil y acciones inmediatas para erradicación, fue ratificada por Brasil en 2000 (BRASIL, 2000) y la Convención n. ${ }^{\circ} 138$, que trata de la edad mínima de admisión al trabajo, fue adoptada en nuestro país en 2002 (BRASIL, 2002). La serie histórica anual de contaje de la tasa de trabajo infantil fue inaugurada por el IBGE en 1992. El Foro Nacional de prevención y Erradicación del Trabajo Infantil (FNPETI) ${ }^{2}$ se constituyó en 1994 y la Comisión Nacional de Erradicación del Trabajo Infantil (CONAETI) ${ }^{3}$ en 2002.

En el ámbito del Ministerio Público del Trabajo, la Coordinfância fue constituida en 2000 con la importante y desafiante tarea de promover, supervisar y coordinar acciones contra las variadas formas de explotación del trabajo de niños y adolescentes en la esfera de atribución del parquet laboral.

Cuatro años antes de la Constitución de la Coordinfância, en 1996, con la finalidad de combatir el trabajo de niños en carbonerías de la región de Três Lagoas, en Mato Grosso do Sul, nació el Programa de Erradicación del Trabajo Infantil (PETI). En seguida, la iniciativa del Gobierno Federal fue ampliada para otras localidades, dando inicio a una de las más importantes políticas públicas del Estado Brasileño en relación al enfrentamiento del trabajo infantil.

La historia del PETI está, así, estrechamente relacionada a la trayectoria de actuación y constitución de diversas instancias, órganos, estructuras e instituciones dedicadas al combate de la explotación del trabajo de niños y adolescentes. El PETI emerge, así, de la historia del enfrentamiento a la explotación del trabajo infantil en Brasil, siendo un mecanismo construido después de décadas de movilización, reflexión, discusión e interlocución de la red de protección. Es un instrumento que sigue siendo esencial para la efectividad del derecho social al no trabajo asegurado a niños y adolescentes. 


\section{VEINTICUATRO AÑOS DEL PETI}

Los estudios demuestran que la mayoría de los niños que trabajan fueron llevados a esto por sus tutores, por lo que solo una pequeña parte de ellos decide trabajar por su cuenta. Esos mismos estudios indican que las familias inducen a sus niños al trabajo por razones relacionadas a condiciones económicas, escolaridad y vulnerabilidades sociales múltiples, como falta de vivienda, saneamiento básico, salud y acceso a la escuela y a aparatos socio-asistenciales (guarderías y oferta de actividades de contra horario escolar gratuitas, por ejemplo). Son madres, padres y responsables que, movidos y conducidos, generalmente, por sus propias historias personales de explotación y de falta de oportunidades, reproducen con sus hijos e hijas situaciones de trabajo infantil que ellos también experimentaron. Es el famoso moto-continuo de la perpetuación de la miseria.

La ruptura de ese círculo vicioso de pobreza no pasa por la culpabilidad de las familias, sino por la promoción de la inclusión social por medio de programas y políticas públicas que garanticen la posibilidad material y fáctica de evitar el envolvimiento de niños y adolescentes de capas sociales pobres con el trabajo. El PETI parte de esta constatación inevitable y surgió con el objetivo de amparar familias pobres, de modo que ellas puedan proveer mínimamente su subsistencia sin la utilización de la mano de obra infantil.

Como exponen Maria de Fátima Pereira Alberto y Oswaldo Hajime Yamamoto (2017), el PETI fue concebido a partir de una iniciativa desarrollada en la ciudad de Campos dos Goytacazes en Rio de Janeiro en 1992, fomentada por la Organización Internacional del Trabajo (OIT), para el rescate de niños que trabajaban en el corte de la caña de azúcar y en servicios domésticos, con la concesión de una beca y un financiamiento de actividades de contra horario escolar.

Inspirada en una iniciativa de Rio de Janeiro, en el marco del FNPETI, fue constituida una instancia de cooperación de instituciones gubernamentales y no gubernamentales denominada Programa de Acciones Integradas (PAI), creado en 1995. Las discusiones e interlocuciones realizadas en el PAI fueron conducidas al PETI en carácter experimental, siendo seleccionado el estado de Mato Grosso do Sul en razón de las graves denuncias de trabajo de niños en las cosechas de yerba mate y en carbonerías. En el mismo año de su creación, el PETI fue expandido para la región Nordeste y, en 1999, ya estaba 
presente en varios estados brasileños, sobre todo en regiones críticas de explotación de la mano de obra infantil, como la zona cañavera de Pernambuco y de Rio de Janeiro, la región de cultivo de sisal en Bahia, la región citrícola de Sergipe, la región de explotación minera de Rondônia y las regiones urbanas para contemplar niños y adolescentes que trabajaban en los vertederos o basurales.

El PETI nació como un programa de distribución de renta para asegurar condiciones mínimas de supervivencia de las familias, así como para propiciar a los niños y a los adolescentes víctimas del trabajo prohibido actividades de contra horario escolar. El PETI tenía por foco la retirada de niños y adolescentes de 7 a 15 años de las situaciones de trabajo, con concesión de una beca en valor variable, dependiendo del lugar de residencia (zona rural o urbana). El niño o adolescente, a su vez, debería tener una presencia mínima de $75 \%$ en la escuela y en la jornada ampliada del programa (que preveía, entre otras actividades, refuerzo escolar, actividades artísticas, culturales, deportivas y de ocio realizadas en el contra horario escolar) ${ }^{4}$.

El PETI fue también el embrión para la actuación conjunta de diversas instituciones en red. La inserción de los niños y de los adolescentes dependía de la identificación por la Fiscalización del Trabajo, que encaminaba los casos a las Secretarías de Acción Social, objetivando el registro y la inclusión en el PETI. Los trabajos fueron acompañados por comisiones de prevención y erradicación del trabajo infantil, organismos de la sociedad civil que ejercían el control social de la política pública.

En 2005, el PETI fue integrado por el Gobierno Federal al Programa Bolsa Familia (PBF) (BRASIL, 2005). Ese programa federal había sido creado justamente con la finalidad de incorporar y centralizar, en una única política pública, los principales programas sociales ya existentes en Brasil, como el Bolsa Escola, Bolsa alimentação, Auxilio-gás y Fome Zero (BRASIL, 2004).

Con la incorporación del PETI al PBF, las familias marcadas con el trabajo infantil, identificadas por los equipos socio-asistenciales de los municipios, pasaron a recibir los valores previstos para el Bolsa Familia y también a ser sometidas a las condicionantes del programa, que preveían la matrícula y asistencia escolar (mínimo 85\%) de todos los integrantes de la familia con edad de 7 a 15 años, que las gestantes comparezcan a los exámenes prenatales y a actividades educativas relacionadas al embarazo, el cumplimiento del 
calendario de vacunación de los niños y adolescentes, la asistencia periódica a las unidades de salud pública, la participación en actividades educativas relacionadas a la alimentación y a los cuidados generales con salud del niño, entre otras "compensaciones". Se destaca que el PBF prevé como una de las causas de exclusión del beneficio la constatación de trabajo infantil en la familia, condición que no constaba en el PETI anteriormente a la incorporación. ${ }^{5}$

En 2011, el PETI fue introducido en la Ley Orgánica de la Asistencia Social (LOAS) y pasó a integrar el SUAS. Por lo tanto, el PETI fue reconocido como una política pública de Estado ${ }^{6}$.

A partir de 2013, el PETI pasó por una "reformulación" con el objetivo de contribuir a la aceleración del ritmo de erradicación del trabajo infantil. Conforme constó del Plan Nacional de Prevención y Erradicación del Trabajo Infantil y Protección al Adolescente Trabajador elaborado y acompañado por la CONAETI (BRASIL, 2011), a pesar de los avances obtenidos hasta entonces, con reducción numérica significativa de los casos de trabajo infantil, se observó una persistencia de la explotación del trabajo de niños y adolescentes. El plan apuntó, además de la continuación aún elevada de casos, la ocurrencia del trabajo de niños muy pequeños en actividades agrícolas y la no obtención de la erradicación de las "peores formas" de trabajo infantil (narcotráfico, explotación sexual comercial y otras situaciones laborales de gran exposición al riesgo de accidentes y problemas de salud).

La llamada reformulación del PETI vino en 2013, en la $2^{a}$ edición del Plan Nacional, con el desafío de adaptar la política pública a la realidad del trabajo infantil en el país, visando combatir los "nudos críticos", los obstáculos y las dificultades apuntados en el documento.

La propuesta de reformulación del PETI resultó de la evaluación de la nueva configuración del trabajo infantil en Brasil, revelada por el Censo IBGE 2010, y de los avances estructurales de la política de prevención y erradicación del trabajo infantil.

El Censo enseñó la reducción del trabajo infantil en los sectores formalizados, como consecuencia de los avances de la fiscalización y formalización de la economía. De esa forma, las principales incidencias de trabajo infantil actualmente se encuentran en la informalidad, en los ámbitos de la producción familiar, del trabajo doméstico, de la agricultura familiar y en las actividades ilícitas. El desafío consiste en identificar niños y adolescentes inseridos en esas actividades, de difícil visibilidad e identificación e insertarlos en los servicios de la red socio-asistencial y de las demás políticas públicas. 
La reformulación del PETI fortalece el papel de gestión y de articulación de la red de protección al prever la realización de Acciones Estratégicas para enfrentamiento del trabajo infantil y prevé cofinanciación específica para que municipios y estados desarrollen esas acciones que serán detalladas en el transcurso del texto. Las acciones Estratégicas se estructuran en cinco ejes: 1. Información y movilización; 2. Identificación; 3. Protección; 4. Defensa y Responsabilidad; y 5. Monitoreo (MDS, 2014, p. 7).

\section{LA REFORMULACIÓN Y LAS ACCIONES ESTRATÉGI- CAS DEL PETI}

La reformulación y las acciones Estratégicas del PETI fueron pactados a través de la Resolución n. ${ }^{\circ}$ 5, de 12 de abril de 2013, del entonces Ministerio del Desarrollo Social y Combate al Hambre (Secretaría Nacional de Asistencia Social), precisamente con el propósito de dar concreción a la erradicación del trabajo infantil conforme a las Convenciones 138 y 182 de la OIT. Las acciones estratégicas fueron divididas en cinco ejes, que deben ser desarrollados en carácter intersectorial y juntamente con las demás políticas públicas en los estados, municipios y Distrito Federal, con acompañamiento del Gobierno Federal.

La división de las acciones estratégicas en ejes, juntamente con su contenido, demuestra la complejidad del fenómeno del trabajo infantil, exigiendo un conjunto de medidas para su enfrentamiento, obligaciones que no están restringidas apenas a una esfera del Poder Ejecutivo, sino que atraviesan la actuación integrada de todos los sectores de gobierno y del sistema de garantía de derechos. Los ejes de las acciones estratégicas del PETI prevén la indispensable interlocución y cooperación de los actores de la red de protección para asegurar los derechos del niño y del adolescente. Las acciones están encadenadas e interconectadas, con complementación de la actuación de las instancias, órganos e instituciones involucradas, aunque cada una con su atribución específica para la defensa de los derechos e intereses de los niños y adolescentes.

El primer eje denominado "información y movilización” comprende:

I - la sensibilización de los diversos actores y sectores sociales constituidos, que están dispuestos a desenvolver acciones para la erradicación del trabajo infantil; II - la movilización social de los funcionarios públicos, movimientos sociales, centrales sindicales, federaciones, asociaciones y cooperativas de trabajadores y empleadores, para las acciones para la erradicación del trabajo 
infantil; III - la realización de campañas dirigidas, principalmente, para dar a conocer los agravios relacionales y de salud, en el desarrollo de los niños y adolescentes sometidos a trabajo infantil, teniendo en cuenta las principales actividades identificadas; IV - apoyo y acompañamiento en la realización de las audiencias públicas solicitadas por el Ministerio Público, para reafirmar los compromisos para con la finalidad de erradicar el trabajo infantil en los territorios.

El segundo eje prevé la identificación de niños y adolescentes en situación de trabajo infantil con:

I - búsqueda activa e identificación realizadas por los equipos técnicos del SUAS y de forma articulada con las demás políticas públicas; II - registro obligatorio en el Registro Único para Programas Sociales del Gobierno Federal - Registro Único de Niños y Adolescentes y sus familias identificadas en situación de trabajo infantil.

\section{El tercer eje de protección social contempla:}

I - transferencia de renta; II - inserción de los niños y adolescentes en situación de trabajo infantil y sus familias, registradas en el Registro Único, en servicios socio-asistenciales; y III - encaminamiento de los niños y adolescentes en situación de trabajo infantil y sus familias, registradas en el Registro Único para los servicios de salud, educación, cultura, deporte, ocio o trabajo, incluso, en este último caso con acciones intersectoriales para garantizar integralmente la protección social.

El cuarto eje de defensa y rendición de cuentas se ocupa de las siguientes acciones:

I - articulación con las Superintendencias, Gerencias y Agencias Regionales del Trabajo y Empleo para fomento de las acciones de fiscalización; II - acompañamiento de las familias con aplicación de medidas protectoras; III - articulación con el Poder Judicial y Ministerio Público para garantizar la debida aplicación de medida de protección para niños y adolescentes en situación de trabajo infantil; y IV - articulación con los Consejos Tutelares para garantizar aplicación de medida de protección para el niño y el adolescente en situación de trabajo infantil.

Y, por último, el quinto eje prevé el monitoreo de las acciones por medio de:

I - registro de los niños y adolescentes inseridos en servicios de asistencia social, salud, educación, entre otros, en sistema de información pertinente al PETI; II - monitoreo: A) del proceso de identificación y registro de los niños, adolescentes en trabajo infantil y sus familias; b) de la atención de los niños y adolescentes y sus familias en los servicios de asistencia social; c) de las metas pactadas con Estados y Municipios. 
La reformulación del PETI previó, por lo tanto, el establecimiento de nuevas estrategias interdependientes, enfocadas en acciones intersectoriales e interinstitucionales en el proceso de enfrentamiento al trabajo infantil. Son ejes de actuación que se complementan y deben ser ejecutados en su totalidad, aunque es imprescindible que la planificación, la selección y la implementación de las acciones tengan en cuenta las peculiaridades de cada territorio.

Las acciones estratégicas previeron también, a través de la Resolución N. ${ }^{\circ} 08$, de 18 de abril de 2013, del Consejo Nacional de Asistencia Social (CNAS) la cofinanciación por la Unión Federal para desarrollo del PETI en los estados y municipios, encargando a la Unión Federal la promoción de la coordinación nacional del programa. A los estados les correspondió la coordinación del PETI en su territorio y el acompañamiento de las metas de los municipios. Y para los municipios constó el compromiso de definición de equipo o técnico de referencia en la gestión de la Protección Social Especial, la planificación, la ejecución y el desarrollo de acciones en todos los ejes.

La reformulación y el acuerdo de la cofinanciación establecieron los criterios para definición de los municipios con alta incidencia de trabajo infantil, elegibles para recibir los recursos federales, objetivando el desarrollo del PETI. ${ }^{7}$ Fueron fijados los valores mensuales de la cofinanciación federal para apoyo al mantenimiento de las acciones estratégicas vinculadas al PETI, de acuerdo con el porte del municipio y la relación entre el número de registros de trabajo infantil en el Registro Único y la cantidad de niños y adolescentes en situación de trabajo identificados por el Censo Demográfico 2010 del IBGE.

Fue previsto aun que los estados, al aceptar la cofinanciación de las acciones estratégicas del PETI, deberían aportar recursos financieros de las arcas del estado proporcionalmente a los valores recibidos del Gobierno Federal. Inicialmente previsto para los ejercicios 2013/2014, la cofinanciación federal se extendió sucesivamente a través de nuevas resoluciones del Consejo Nacional de Asistencia Social (CNAS). Por último, la Ordenanza n. ${ }^{\circ}$ 627, 04 de abril de 2019, del Ministerio de ciudadanía, estableció la prórroga para el año $2019^{8}$.

La previsión de la cofinanciación del Gobierno Federal y también de los estados para ayudar a los municipios en la implementación del programa de erradicación del trabajo infantil tiene base constitucional y legal, conside- 
rando que política nacional de asistencia social es atribuida a las tres esferas de la Federación. En este contexto, los recursos de la cofinanciación federal para implementación de las acciones estratégicas del PETI son debidos y esenciales, sobre todo para municipios de pequeño y mediano porte, pues propician una colaboración decisiva para ejecución de acciones, posibilitando el soporte material para deflagrar la política pública en el territorio. Los recursos de la cofinanciación pueden ser utilizados en acciones de capacitación, campañas, contratación de personal para constituir los equipos de referencia o coordinación del PETI, entre otros gastos de costeo, conforme delineado en las orientaciones técnicas de gestión del PETI (BRASIL, 2018).

A pesar de las acciones estratégicas del PETI, datos del Sistema de monitoreo del Programa (SIMPETI), principal referencia de monitoreo de las acciones, apuntan que muchos municipios no presentaron planes de ejecución de acciones y tampoco desarrollaron medidas expresivas de enfrentamiento al trabajo infantil. De la misma forma, el seguimiento de los saldos de los recursos de cofinanciación divulgados por el Ministerio de la Ciudadanía apunta que algunos municipios mantienen parados en cuenta recursos recibidos del Gobierno Federal, sin utilización, y muchos devolvieron las parcelas recibidas sin adopción de las acciones estratégicas del PETI.

Pasados casi ocho años del nuevo acuerdo y de la reformulación del PETI, todavía no hay, además, un trabajo de análisis cualitativo y cuantitativo global y consistente, con un balance de la implementación y ejecución de las acciones estratégicas. Esas evidencias apuntan para la necesidad del perfeccionamiento de las acciones de coordinación, monitoreo y control por parte del Gobierno Federal, de los estados y también de los órganos responsables del sistema de Justicia, para exigir efectivamente el cumplimiento por parte de los administradores públicos en relación a la adopción concreta de esa importante política pública.

\section{EL PETI Y LA ACTUACIÓN DEL MINISTERIO PÚBLICO DEL TRABAJO}

Brasil tiene hoy un marco constitucional y legal robusto y sólido de protección de los derechos e intereses de los niños y adolescentes. La Constitución Federal, la consolidación de Las Leyes del Trabajo, el Estatuto del Niño y del Adolescente traen preceptos y marcos normativos que, si fueran 
rigurosamente respetados, garantizarían a todos los niños y a todos los adolescentes los derechos fundamentales básicos para una existencia digna. Sin embargo, como ocurre con relación a otros derechos mínimos y básicos, la protección de los niños y adolescentes en relación al trabajo, sobre todo cuando pobres, negros y residentes de comunidades periféricas, no es respetada.

Se sabe que está prohibido trabajar a cualquier persona menor de 16 años como regla general, excepción permitida solo a partir de los 14 años para la contratación bajo la condición de aprendiz (contrato de trabajo de aprendizaje profesional). También es conocido que está prohibido el trabajo peligroso, insalubre, nocturno, perjudicial a la salud, a la seguridad, a la moralidad o que impida la asistencia escolar a todos aquellos que no hayan alcanzado los 18 años de edad. Es lo que prevé nuestro ordenamiento jurídico, que no puede ser ignorado, y sin embargo lo es, y lo es solemnemente.

La protección integral prevista en el artículo 227 de la Constitución Federal prevé derecho a la vida, salud, alimentación, educación, ocio, profesionalización, respeto, libertad, convivencia familiar y comunitaria, así como establece que los niños y adolescentes deben estar a salvo de toda forma de negligencia, discriminación, explotación, violencia, crueldad y opresión. Sin embargo, cuando nos encontramos con los casos de trabajo infantil, trágicamente aún comunes, se percibe que esa violación de derechos acaba por impedir, casi siempre, la concretización efectiva de los derechos anunciados en la protección integral constitucional y que deberían contemplar sin excepción a todos los niños y los adolescentes brasileños.

El trabajo infantil, en un contexto de vulnerabilidades ${ }^{9}$ diversas y múltiples que marcan a las familias y a las víctimas de esa violencia, no raramente, es considerado como un mal menor ante el argumento de que esas familias, niños y adolescentes son también víctimas de otras violaciones, las que serían más apremiantes, demandando prioridad de los órganos de defensa, control y garantía de los derechos. Ese razonamiento es un gran equívoco, pues el trabajo infantil no es sólo causado por las situaciones de riesgo social a que la familia o la víctima está sujeta, es también causa de esas vulnerabilidades. De esa forma, minimizar el trabajo infantil es consentir la perpetuación y el agravamiento de las fragilidades sociales que sujetan a las víctimas de esa violación de derechos. 
A través del trabajo infantil, muchos niños y adolescentes pierden la vida y la salud, metafórica e incluso, literalmente ${ }^{10}$. El trabajo precoz aleja al niño y al adolescente de la escuela, siendo causa de caída de rendimiento y también de la evasión y del abandono escolar. La profesionalización de la víctima del trabajo infantil es fuertemente perjudicada, ya que el trabajo ejercido por niños y adolescentes, de forma prohibida, no califica y aun compromete la formación escolar. La convivencia familiar y social es impactada con las muchas horas dedicadas al trabajo. Sin mencionar que el trabajo infantil es una violencia que importa en discriminación, explotación, crueldad y opresión, dejando marcas indelebles en las vidas de las víctimas.

El derecho al "no trabajo" es un requisito para alcanzar la protección integral del niño y del adolescente, no sólo porque la protección especial abarca el respeto a la edad mínima y a las condiciones para el ejercicio del trabajo (artículo 227, párrafo $3^{\circ}$ de la Constitución Federal), sino también porque el trabajo infantil es puerta de entrada para innumerables otras violaciones. Sin embargo, el fenómeno trabajo infantil todavía es naturalizado y no es meta de políticas públicas consistentes y perennes de enfrentamiento.

El derecho social al "no trabajo" es una afirmación prevista en nuestra legislación, pero la satisfacción de este derecho, su concreción, no se agota con el no hacer o solo con la retirada de niños eventualmente atrapados en situación de trabajo. Es necesario que haya acciones positivas de la sociedad, de la familia y sobre todo del Estado que garanticen las condiciones materiales necesarias para que se goce de este derecho.

El combate a la explotación del trabajo de niños y adolescentes requiere la prevención, la protección y la atención de las víctimas y sus familias, sin perjuicio del control, de la comprobación, de la fiscalización y de la imposición de sanciones a los explotadores que lucran con el trabajo de los infantes. No basta con acciones puntuales, esporádicas, no estructuradas o planificadas. El combate al trabajo infantil exige la adopción de acciones afirmativas paralelamente a acciones que objetiven la reducción de los casos, todo debidamente elaborado con planificación.

Como ya se ha expuesto, el programa de erradicación del trabajo infantil ha sido elaborado a lo largo de muchos años de enfrentamiento de la explotación del trabajo de niños y adolescentes. Los planes de enfrentamiento Nacionales elaborados por la Comisión Nacional de Erradicación del Tra- 
bajo Infantil (CONAETI), órgano compuesto por representantes del poder público, de los empleadores, de la sociedad civil organizada y organismos internacionales, orientaron las acciones estratégicas del PETI, erigidas como instrumento basilar de enfrentamiento. Entonces, este es el camino que debe pautar las acciones básicas de combate al trabajo infantil ${ }^{11}$.

Se trata de una política pública vital del Estado brasileño para la protección de niños y adolescentes, sin embargo, el programa de erradicación del trabajo infantil y sus acciones estratégicas están todavía distantes de la inserción verdadera en las políticas públicas de los municipios, de los estados y también de la Unión.

La planificación, la implementación, la ejecución y la mejora continua del programa de erradicación del trabajo deberían ser una meta perseguida por el Poder Público, y cabe destacar que el agente político al frente del Poder Ejecutivo no tiene la discrecionalidad en decidir si va a actuar o no contra el trabajo infantil. No existe este margen de elección, porque no hay posibilidad de ejercer un juicio de oportunidad o de convivencia en relación a las políticas públicas esenciales para garantizar los derechos fundamentales y constitucionalmente previstos (MOUSINO, 2015).

La discrecionalidad o el juicio del valor que puede y debe ejercer el Poder Público se limitan a la identificación y selección de las medidas y acciones más eficaces y adecuadas al momento. Aunque el gestor público juzgue o entienda que las políticas públicas de enfrentamiento al trabajo infantil no serían necesarias o adecuadas, la prioridad en la adopción de esas políticas y acciones es absoluta, tiene pilar constitucional y no admite tergiversación.

El Ministerio Público del Trabajo definió como una de sus metas prioritarias de actuación el combate a la explotación del trabajo de niños y adolescentes y la Coordinfância, estructura del parquet laboral constituida con la misión de coordinar las actividades con este propósito, tiene como principal proyecto estratégico de actuación el "Rescate a la Infancia". Esta iniciativa se basa en tres ejes básicos: 1) promoción de políticas públicas para la prevención y erradicación del trabajo infantil; 2) efectivización del aprendizaje profesional; y 3) promoción de acciones de capacitación, orientación, sensibilización de profesionales de educación respecto al trabajo infantil, a través de la inserción de ese tema en currículos escolares, programas pedagógicos, clases, otros eventos y actividades realizados en el territorio escolar. 
Los ejes del principal proyecto estratégico de la Coordinfância tienen intersección con las acciones estratégicas del programa de erradicación del trabajo infantil, especialmente en la promoción de las políticas públicas. En ese eje, el objetivo es justamente fomentar la elaboración e implementación de iniciativas de enfrentamiento, comenzando por la planificación de acciones en un haz interconectado de medidas de carácter intersectorial y en articulación interinstitucional para combatir la explotación del trabajo de niños y adolescentes.

En el desarrollo del eje políticas públicas, el Ministerio Público del Trabajo selecciona municipios con altas tasas de incidencia de trabajo infantil como prioritarios para actuación del parquet y, no por coincidencia, varios de esos municipios son exactamente aquellos elegibles para el recibo de recursos federales de cofinanciación federal del PETI, ya que los criterios de elección consideran los números de casos de trabajo infantil en el territorio, de acuerdo con los datos del IBGE.

Uno de los criterios orientadores que viene siendo utilizado para la selección de los municipios prioritarios para actuación del Ministerio Público del Trabajo es la presentación por el municipio de término de aceptación para recepción de los recursos de la cofinanciación federal y ejecución de las acciones estratégicas del PETI. Tal criterio es uno de los observados, no sólo porque los municipios elegibles para recibir los recursos federales son aquellos con los índices más elevados de incidencia de trabajo infantil, sino también porque son recursos públicos afectados para acciones de erradicación de trabajo infantil, siendo deber del administrador público la utilización de estos fondos en consonancia estricta con la vinculación originaria al PETI.

Elegido el territorio prioritario por el Ministerio Público del Trabajo, por medio de instrucción y recolección de datos y pruebas, incluso visitas y actividades realizadas in loco, son examinadas las acciones eventualmente adoptadas para combate el trabajo infantil por el municipio. La constatación realizada por el Ministerio Público del Trabajo contempla aspectos relevantes, en gran medida, coincidentes con las acciones previstas para los ejes estratégicos del PETI. De esta forma, el examen realizado por el Ministerio Público del Trabajo, verifica, por ejemplo: la constitución de equipos de trabajo y de referencia para la aplicación del programa de erradicación del trabajo infantil; la formación de los profesionales de la red de protección y el sistema de garantías de los derechos de los niños y de los adolescentes 
sobre el trabajo infantil; la estructura humana y material de los equipamientos socio-asistenciales municipales (como CRAS, CREAS y Consejos Tutelares) para el desempeño de sus actividades; la existencia de diagnósticos socio-territoriales para la verificación de los casos de trabajo infantil en la localidad; la existencia de equipos de trabajo de enfoque social, así como la realización de una búsqueda activa en el territorio y la identificación de las situaciones de trabajo infantil; la realización de campañas de sensibilización y concienciación social, la inserción de las víctimas de la explotación infantil y a sus familias, en los aparatos de protección social existentes en el Municipio, mediante la inscripción en el CadÚnico; el fomento de acciones para el incremento de las oportunidades de trabajo protegido y el acceso a la formación profesional para los adolescentes.

Aspecto importante en la verificación de la existencia de las políticas públicas en los territorios municipales es la constatación de la realización de la planificación intersectorial de las acciones estratégicas de erradicación del trabajo infantil, con la creación de líneas estructuradas de actuación, a partir de diagnósticos locales, con establecimiento de metas, de los responsables por la ejecución de las acciones, de mecanismos de verificación y de perfeccionamiento constante de las medidas seleccionadas.

Para planificar las acciones es esencial conocer la realidad local, porque el trabajo infantil no es un fenómeno uniforme en todo el territorio nacional. Aunque presente en la gran mayoría de las localidades brasileñas, de norte a sur, en cada región o municipio hay un tipo de trabajo infantil predominante, lo que exige la identificación para hacer la acción pública más efectiva y eficaz.

La planificación es esencial para optimizar los recursos existentes, financieros y humanos, así como para consolidar como una política pública permanente la lucha contra el trabajo infantil. El plan de enfrentamiento contribuye para evitar paralelismo y superposición de acciones, facilitando, además, el flujo de interacción entre las diversas instancias y estructuras del sistema de garantía de derechos, lo que posibilita la máxima utilización de los recursos disponibles.

La cuestión esencial también es la constatación de la inserción de las acciones de combate al trabajo infantil en el presupuesto municipal, ya que es 
común que esta cuestión sea descuidada en la destinación de fondos públicos, imposibilitándose así la efectividad de la política de enfrentamiento.

Otro punto que merece destaque y es objeto de investigación del Ministerio Público del Trabajo es la existencia de parcelas de la cofinanciación federal para las acciones estratégicas del PETI, en los cofres estatales y municipales, no ejecutadas o, no raramente, devueltas a los cofres federales sin utilización. En caso de que no haya justificación plausible para inercia, la conducta puede configurar grave omisión del administrador público, en la misma medida que la utilización de los recursos en disonancia con lo que es previsto en el programa o para otros fines que el enfrentamiento del trabajo infantil. En el límite, estas conductas pueden incluso configurar la improbidad administrativa del administrador público.

ADMINISTRATIVO Y PROCESAL CIVIL. IMPROBIDAD ADMINISTRATIVA. COMPETENCIA DE LA JUSTICIA FEDERAL. INCONSTITUCIONALIDAD FORMAL Y MATERIAL DE LA LEY N. 8.429/1999. APLICABILIDAD A LOS ANTIGUOS ALCALDES. EJECUCIÓN PARCIAL DEL OBJETO PACTADO. APLICACIÓN IRREGULAR DE FONDOS PÚBLICOS. ART. 10, CAPUT, XI, DA LIA. 1. Las causas relativas a desvío y / o malversación de recursos públicos federales transmitidos a los Estados, Distrito Federal y municipios, y sujetos a la rendición de cuentas ante órgano federal deben ser procesadas y juzgadas ante la Justicia Federal. 2. La presencia del Ministerio Público Federal, órgano de la Unión, en la relación jurídica procesal como autor hace competente la Justicia Federal para el proceso y juicio de la acción (competencia ratione personae), según el art. 109, I, de la Constitución Federal de 1988. (Precedentes del STJ). 3. No hay que hablar de inconstitucionalidad de la Ley N.8.429/1992, teniendo en cuenta que el Supremo Tribunal Federal, en el juicio de la ADI 2.182/ DF, proclamó la constitucionalidad formal del aludido diploma legal. 4. La Ley N. 8.429/1992 encuentra respaldo constitucional en el art. 37, \ $4^{\circ}$, de la CF / 88, siendo, por lo tanto, medio legal para castigar actos de improbidad administrativa practicados por agentes de la administración pública Federal, estadual y municipal. 5. La jurisprudencia del Superior Tribunal de Justicia y de esta Corte Regional ya se encuentra pacificada en el sentido de que las sanciones previstas en la Ley de Improbidad Administrativa se aplican a los alcaldes y antiguos alcaldes, independientemente del hecho de que éstos se sometan también a los dictados del Decreto-Ley 201/1967. 6. Proposición de acción de improbidad administrativa como consecuencia de la aplicación irregular de los fondos federales transmitidos al municipio de Capitán Enéas/MG, en lo que se refiere a la ejecución del Programa de Erradicación del Trabajo Infantil - PETI. 7. La conclusión del informe de fiscalización n. 298/2004, elaborado por la Contraloría General de la Unión, corroborada con los estados bancarios de la cuenta específica del programa y los recibos de pago de las becas mensuales de los beneficiarios, permite inferir que parte de los recursos federa- 
les traspasados fue empleado en finalidad diversa de lo pactado. 8 . Ocurrencia de daño al erario, encuadrándose la conducta en el art. 10, caput, IX, de la Ley n. 8.429/1992. 9. El apelante no tuvo éxito en comprobar la regular aplicación de las sumas públicas transmitidas, por lo que quedaron evidenciadas la materialidad y la autoría del acto de improbidad. 10. Apelación no acepta. (AC 2009.38.07.006198-4, DESEMBARGADORA FEDERAL MONICA SIFUENTES, TRF1-TERCERA CLASE, e-DJF1 fecha: 03/02/2019. [destaque nuestro]

Hechas las debidas constataciones, la inexistencia de políticas públicas o la ausencia de acciones esenciales de combate al trabajo infantil, posibilitan, por parte del Ministerio Público del Trabajo, la adopción de medidas administrativas, extrajudiciales, como las recomendaciones o el ofrecimiento de término de compromiso de ajuste de conducta y eventualmente, incluso judiciales, como acción civil pública, en desfavor de los entes y administradores públicos responsables.

Es sabido que corresponde a la justicia laboral la competencia para juzgar y, por corolario, al Ministerio Público del Trabajo la atribución para actuar en los casos de relaciones de trabajo (aunque espurias e ilegales, como es el caso del trabajo infantil). Si es así, de igual suerte, estos órganos del sistema de garantía de derechos laborales tienen la misión de garantizar el trabajo decente, combatiendo formas degradantes y humillantes de explotación del trabajo humano, a través de todas las herramientas e instrumentos previstos en el ordenamiento jurídico.

Nadie ignora la existencia de un vínculo directo entre la ausencia de políticas públicas, la falta de aplicación del programa de erradicación del trabajo infantil y las relaciones laborales ilegales que victimizan a niños y adolescentes. De esa manera, la misión de asegurar el trabajo decente y combatir la explotación de la mano de obra infantil sólo es posible sin descuidar la necesidad de investigación y exigencia, inclusive judicial, de la implementación de políticas públicas de enfrentamiento.

\section{IMPORTANCIA DEL FORTALECIMIENTO Y CONTINUI- DAD DEL PROGRAMA DE ERRADICACIÓN DEL TRABAJO INFANTIL (PETI). CONCLUSIÓN}

En los últimos veintiocho años, según los datos publicados por el IBGE, se han reducido aproximadamente 7 millones de casos de trabajo in- 
fantil. Sin embargo, la última Encuesta Nacional de Muestra de domicilios (PNAD) divulgada en 2016 apuntó el número expresivo de 2 millones 400 mil casos de trabajo infantil, la mayoría involucrando niños y adolescentes negros y de familias pobres o extremadamente pobres ${ }^{12}$. Las cifras, a pesar de ser alarmantes, están lejos de reflejar la realidad, mucho más dura y cruel, puesto que la mayor parte del trabajo infantil ni siquiera se registra en las estadísticas oficiales, como es el caso del trabajo infantil en el tráfico de drogas, en la explotación sexual comercial, en las calles o incluso en el trabajo doméstico. A este ritmo, Brasil no alcanzará la meta de erradicar completamente el trabajo infantil para $2025^{13}$.

Según el informe mundial sobre el trabajo Infantil de la OIT (2013), la pobreza y las situaciones de choques, como el desempleo, la muerte de los padres o tutores, las calamidades y la recesión económica, contribuyen decisivamente para que haya el trabajo infantil. Las familias pobres, sin acceso a medios de subsistencia, tienen menos probabilidades de retrasar la participación de los niños en el trabajo. Estas familias sacrifican la inversión futura, a largo plazo en la educación y formación de sus niños, por la inversión inmediata y apremiante en supervivencia. El informe señala que cuanto mayor es el número de vulnerabilidades sociales, peor tiende a ser el tipo de trabajo ejercido por el niño y, además, que los niños pertenecientes a algunos grupos sociales y étnicos, sin cuidados parentales, con padres y madres enfermos, desempleados o asignados en trabajos precarios, eventuales, informales o estacionales, tienen una mayor probabilidad de ser víctimas del trabajo infantil.

También de acuerdo con el informe mundial de la OIT, en todo el mundo, el éxito obtenido en la lucha contra el trabajo infantil alió estrategias de rescate de las víctimas a la protección social de las familias para hacerlas menos vulnerables a la pobreza y a los choques.

En Brasil, especialmente en los últimos treinta años, el desarrollo social ganó la centralidad en la pauta pública. Hubo fuerte inversión en políticas de distribución de renta, lo que, aliado al crecimiento económico, a la valorización del salario mínimo, a los récords sucesivos y a los incentivos a la formalización de vínculos laborales, posibilitó la facilitación de acceso al crédito para familias, aun para la formación educacional, lo que trajo ganancias sociales expresivas para reducción de los índices de pobreza y desigualdad social. Así, la lucha contra la pobreza y la desigualdad social ha dado lugar a 
resultados innegables de reducción de los casos de trabajo infantil y de otras violaciones de los derechos del niño y de los adolescentes.

En el análisis de estas últimas décadas y de los beneficios sociales conquistados, imposible no mencionar también la contribución de la actuación fuerte y decisiva de los órganos del sistema de garantía de derechos laborales y de las organizaciones de la sociedad civil en la reducción de los casos de trabajo infantil en Brasil. La propia constitución e implementación del PETI puede atribuirse en buena medida a esta gran movilización pública y social en favor de la defensa del derecho de los niños y adolescentes al no trabajo.

Sin embargo, las pautas sociales, que tuvieron centralidad en las décadas anteriores, están siendo rechazadas con aterrador vigor en los últimos años, con reducción de los gastos públicos en políticas sociales. Se ha producido una disminución de la formalización de los vínculos de trabajo y se observan números crecientes de casos de desempleo, subempleo, trabajo informal y desaliento ${ }^{14}$.

Recientes alteraciones legislativas en las normas de Derecho Laboral posibilitaron la utilización de instrumentos y de formas de contratación expresamente precarias, que privilegian la fragilidad de los vínculos laborales y menor gama de derechos laborales.

Las alteraciones de los rumbos de las inversiones públicas y políticas también afectaron a los órganos de defensa y control, instituciones que fueron protagonistas en la construcción de las condiciones que posibilitaron avances sociales ya citados. Hubo y hay una política de debilitamiento de las estructuras de fiscalización, de defensa del orden jurídico, del control social, del monitoreo y de la construcción de políticas públicas, siendo emblemática de esa situación la reciente incorporación del Ministerio del Trabajo al Ministerio de Economía y la extinción de la Comisión Nacional de Erradicación del Trabajo Infantil (CONAETI).

Esos cambios legislativos y de los rumbos de la pauta pública ciertamente tuvieron y aún tendrán mucho impacto en el aumento de las vulnerabilidades sociales, con aumento de los índices de pobreza e impotencia social. En este contexto, existe una necesidad aún más conmovedora de continuidad e incremento de las políticas públicas de lucha contra el trabajo infantil que tiene en el PETI una absoluta referencia. 


\section{NOTAS}

1 Niño, a efectos de esta Convención, es "todo ser humano menor de 18 años de edad".

2 Constituido con la finalidad de articular y aglutinar actores sociales institucionales involucrados con políticas y programas de prevención y erradicación del trabajo infantil.

3 Constituida por medio de la Ordenanza n. ${ }^{\circ}$ 365, de 12 de septiembre de 2002, era coordinada por el hasta entonces Ministerio de Trabajo y Empleo (MTE), teniendo como una de sus principales atribuciones la elaboración del Plan Nacional de prevención y Erradicación del Trabajo Infantil y Protección al trabajador Adolescente.

4 Según los mismos autores, las actividades de contra horario recibieron diferentes denominaciones: inicialmente como "Jornada Ampliada", nomenclatura de la ordenanza del MDS n. 458 de 2001 del PETI; "Acciones socioeducativas", nomenclatura de la Ordenanza MDS n. 466 de 2005 del PETI; "Servicio Socioeducativo", nomenclatura de la instrucción operacional de la Secretaría Nacional de Asistencia Social del MDS n. ${ }^{\circ} 01$ de 2007 (ALBERTO; YAMAMOTO, 2017).

5 Como resume Maria das Garças Rua (2014), la integración del PETI al PBF se constituyó básicamente en las siguientes acciones: (a) la transferencia, para el PBF, de las acciones del PETI relativas a la transferencia de renta, que se hicieron beneficio financiero del PBF, representando, junto con el registro único, la principal acción de ese Programa; (b) transferencia, del PETI al PBF, de los recursos de los presupuestos destinados a la realización de esas acciones; (c) incorporación de la totalidad de las familias beneficiarias del PETI al CadÚnico, juntamente con las beneficiarias del PBF; (d) la principal acción del PETI pasaron a ser las acciones socioeducativas y de convivencia, que deben ser frecuentadas tanto por los niños/adolescentes de las familias oriundas del PETI , como por las familias beneficiarias del PBF con situación de trabajo infantil. Como programa gubernamental, el PETI quedó restringido a las acciones socioeducativas y de convivencia y a las acciones de fiscalización del trabajo infantil.

6 La Ley n. ${ }^{\circ}$ 12.435/2011 modificó la Ley n. ${ }^{\circ}$ 8.742/1993 (organización de la asistencia Social), introduciendo a la última el artículo $24 \mathrm{C}$.

7 Fueron considerados municipios con alta incidencia de trabajo infantil aquellos que, en el ejercicio de 2013, tenían más de 1.000 casos de trabajo infantil en el Censo Demográfico de 2010 o crecimiento de 200 casos de trabajo infantil entre los Censos Demográficos de 2000 y 2010. En el ejercicio 2014, fueron considerados los municipios con más de 500 casos de trabajo infantil identificados en el Censo Demográfico de 2010.

8 La Resolución n. ${ }^{\circ} 5$ de 16/05/2018 previó que, sobreviniéndose la aprobación del III Plan Nacional de Erradicación del Trabajo Infantil y Protección al Adolescente trabajador por la Comisión Nacional de Erradicación del Trabajo Infantil-CONAETI, sería desencadenado un nuevo proceso de reformulación de las acciones estratégicas del PETI y de su cofinanciación federal, sin embargo, aún no hubo este nuevo acuerdo. El III Plan Nacional de prevención y Erradicación del Trabajo Infantil (20192022) se lanzó en noviembre de 2018.

9 Según el diccionario del desarrollo, "la vulnerabilidad implica una situación de riesgo; significa que personas y/o comunidades están en una situación de fragilidad - sea por motivos sociales, económicos, ambientales u otros - y por eso son más vulnerables a lo que pueda provenir de esa exposición” (Fundación Ciudad de LISBOA, 2020). Además, "muy a menudo la vulnerabilidad está asociada a prácticas de exclusión, de discriminación, de violación de derechos humanos, sociales, económicos, políticos, 
ambientales... todas ellas presuponen una dimensión de riesgo y fragilidad" (Fundación Ciudad de LISBOA, 2020).

10 Según datos del Observatorio de la Prevención y de la Erradicación del Trabajo Infantil, sólo en el período de 2012 a 2018, el sistema CATWEB registró 17 mil accidentes de trabajo con víctimas niños y adolescentes, número alarmante, pero seguramente abajo del real, considerando que la mayoría de los accidentes envolviendo niños y adolescentes no son registrados a través de la CAT-Comunicación de Accidente del Trabajo, porque la mayoría de esas víctimas están en la informalidad. Disponible en: https://smartlabbr.org/trabalhoinfantil/localidade/0?dimensao=acidentes'Trabalho. Acceso en: 15 sept. 2020.

11 La Organización Internacional del Trabajo divulgó los diagnósticos intersectoriales municipales, fruto de una asociación entre el organismo internacional y El Ministerio del Desarrollo Social, que permitió el cruce de datos del IBGE, Ministerio de Educación, Ministerio de la Salud y del entonces Ministerio del Trabajo para presentación de informaciones y análisis sobre el trabajo infantil en todos los municipios brasileños. Se Trata de una importante herramienta que puede auxiliar la planificación y la ejecución de las acciones estratégicas del PETI en Brasil, a partir de los territorios municipales. Para cada municipio existe el registro de Datos Cuantitativos constatados y relativos a cada uno de los ejes de las acciones estratégicas del PETI.

12 Se consideran pobres las familias con Renta domiciliaria per cápita mensual inferior o igual a medio salario mínimo y extremadamente pobres las familias con renta domiciliaria per cápita inferior o igual a un cuarto del salario mínimo.

13 Brasil es signatario de los Objetivos de Desarrollo Sostenible de las Naciones Unidas (Agenda 2030), comprometiéndose a "8.7 tomar medidas inmediatas y eficaces para erradicar el trabajo forzado, acabar con la esclavitud moderna y en tráfico de personas, y asegurar la prohibición y eliminación de las peores formas de trabajo infantil, incluyendo reclutamiento y uso de niños soldado, y para 2025 acabar con el trabajo infantil en todas sus formas" (ONU, 2015, p. 27).

14 Según el IBGE, desalentados son aquellos a quienes "les gustaría trabajar y estarían disponibles, pero no buscaron trabajo por creer que no lo encontrarían. Varios son los motivos que llevan a las personas a desistir de buscar trabajo, entre ellos: no encontrar trabajo en la localidad, no conseguir trabajo adecuado, no conseguir trabajo por ser considerado muy joven o anciano, o no tener experiencia profesional o calificación" (IBGE, 2020).

\section{REFERENCIAS}

ALBERTO, Maria de Fatima Pereira; YAMAMOTO, Oswaldo Hajime. Quando a Educação Não é Solução: Política de Enfrentamento ao Trabalho Infantil. In: Trends in Psychology/Temas em Psicologia. [S.l.], vol. 25, n. 4, p. 1.677-1.691, dez. 2017. Disponible en: https://doi.org/10.9788/ tp2017.4-10pt. Acceso en: 15 jun. 2020.

BRASIL. Decreto n. ${ }^{\circ}$ 99.710, de 21 de novembro de 1990. Promulga a Convenção sobre os Direitos da Criança. Brasília/DF, nov. 1990. Disponible 
en: http://www.planalto.gov.br/ccivil_03/decreto/1990-1994/d99710.htm. Acceso en: 27 jul. 2020.

BRASIL. Lei n. ${ }^{\circ} 8.742$ de 7 de dezembro de 1993. Dispõe sobre a organização da Assistência Social e dá outras providências. Brasília/DF, dez. 1993. Disponible en: http://www.planalto.gov.br/ccivil_03/leis/18069.htm. Acceso en: 27 jun. 2020.

BRASIL. Decreto n. ${ }^{\circ}$ 3.597, de 12 de setembro de 2000. Promulga a Convenção 182 e a Recomendação 190 da Organização Internacional do Trabalho (OIT). Brasília/DF, set. 2000. Disponible en: http://www.planalto.gov. br/ccivil_03/leis/18069.htm. Acceso en: 27 jul. de 2020.

BRASIL. Decreto n..$^{\circ}$ 4.134, de 15 de fevereiro de 2002. Promulga a Convenção 138 e a Recomendação 146 da Organização Internacional do Trabalho (OIT). Brasília/DF, fev. 2002. Disponible en: http://www.planalto.gov. br/ccivil_03/decreto/2002/D4134.htm. Acceso: 27 jul. 2020.

BRASIL. Lei n. ${ }^{\circ}$ 10.836, de 9 de janeiro de 2004. Cria o Programa Bolsa Família, altera a Lei n. 10.689 , de 13 de junho de 2003, e dá outras providências. Brasília/ DF, jan. 2004. Disponible en: http:/ /www.planalto.gov.br/ ccivil_03/_Ato2004-2006/2004/Lei/L10.836.htm. Acceso: 27 jul. 2020.

BRASIL. Observatório da Prevenção e da Erradicação do Trabalho Infantil. Proteção Integral Guiada por Dados. [S.l.]. Iniciativa Smartlab. Disponible en: https://smartlabbr.org/trabalhoinfantil/. Acceso: 14 jun. de 2020.

BRASIL. Plano Nacional de Prevenção e Erradicação do Trabalho Infantil e Proteção ao Adolescente Trabalhador (2011-2015). [S.1], 2. ${ }^{a}$ ed., 2011. Disponible en: https://www.ilo.org/brasilia/publicacoes/ WCMS_233716/lang--pt/index.htm. Acceso: 15 jun. 2020.

BRASIL. Decreto n. ${ }^{\mathbf{1}} \mathbf{1 0 . 0 8 8}$, de 5 de novembro de 2019. Consolida atos normativos editados pelo Poder Executivo Federal. Disponible en: http:// www.planalto.gov.br/ccivil_03/_Ato2019-2022/2019/Decreto/D10088. htm. Acceso: 27 jul. 2020.

BRASIL. III Plano Nacional de Erradicação do Trabalho Infantil e Proteção ao Adolescente Trabalhador (2019-2022). [S.l], 2019. Disponi- 
ble en: https://fnpeti.org.br/media/12dejunho/documentos-de-referencia/ III_plano_nacional.pdf. Acceso: 15 jun. 2020.

CÂMARA DOS DEPUTADOS. As Crianças na Constituinte. Brasília/DF, nov. 2018. Disponible en: https://plenarinho.leg.br/index.php/2018/11/ as-criancas-na-constituinte/. Acceso: 15 jun. 2020.

CONSELHO NACIONAL DE ASSISTÊNCIA SOCIAL. Resolução n. ${ }^{\circ}$ 08, de 18 de abril de 2013. DOU, 30 de abril de 2013, Seção 1 - página 77, abril 2013.

CONSELHO NACIONAL DE ASSISTÊNCIA SOCIAL. Resolução n. ${ }^{\mathbf{o}}$ 10, de 15 de abril de 2014. DOU, 16 de abril de 2014, Seção 1 - página 210, abril 2014.

CONSELHO NACIONAL DE ASSISTÊNCIA SOCIAL. Resolução n. ${ }^{\mathbf{o}}$ 10, de 19 de julho de 2017. Disponible en: http://www.in.gov.br/materia/-/ asset_publisher/Kujrw0TZC2Mb/content/id/19192209/do1-2017-07-24resolucao-n-10-de-19-de-julho-de-2017-19192155. Acceso: 27 jul. 2020.

CONSELHO NACIONAL DE ASSISTÊNCIA SOCIAL. Resolução n. ${ }^{\mathbf{o}}$ 5, de 16 de maio de 2018. Disponible en: http://blog.mds.gov.br/redesuas / resolucao-no-5-de-16-de-maio-de-2018/. Acceso: 27 jul. 2020.

CONSELHO NACIONAL DE ASSISTÊNCIA SOCIAL. Resolução n. ${ }^{\mathbf{o}}$ 12, de 4 de junho de 2018. Disponible en: http://www.in.gov.br/materia/-/ asset_publisher/Kujrw0TZC2Mb/content/id/17500785/do1-2018-06-06resolucao-n-12-de-4-de-junho-de-2018-17500768. Acceso: 27 jul. 2020.

FÓRUM NACIONAL DE PREVENÇÃO E ERRADICAÇÃO DO TRABALHO INFANTIL. FNPETI se manifesta contra a extinção da CONAETI - Comissão Nacional de Erradicação do Trabalho. Brasília, 15 de abril de 2019. Disponible en: https:/ / fnpeti.org.br/noticias/2019/04/15/ fnpeti-se-manifesta-contra-extincao-da-conaeti-comissao-nacional-de-erradicacao-do-trabalho-infantil/. Acceso: 27 jun. 2020.

FUNDAÇÃO CIDADE DE LISBOA. Vulnerabilidade. Dicionário do Desenvolvimento, Lisboa, 2020. Disponible en: https://ddesenvolvimento. com/portfolio/vulnerabilidade/. Acceso: 15 jun. 2020. 
INSTITUTO BRASILEIRO DE GEOGRAFIA E ESTATÍSTICA - IBGE. O que é desemprego. Brasília, 2020. Disponible en: https://www.ibge.gov. br/explica/desemprego.php. Acceso: 15 jun. 2020.

INSTITUTO DE PESQUISA ECONÔMICA APLICADA - IPEA. Comunicado do IPEA n. ${ }^{\circ}$ 75. Gastos com a Política Social: alavanca para o crescimento com distribuição de renda. Brasília, fev. 2011. Disponible en: https:/ / www.ipea.gov.br/portal/index.php?option=com_content\&view $=$ article\&id=7110. Acceso: 15 jun. 2020.

INSTITUTO DE PESQUISA ECONÔMICA APLICADA - IPEA. Uma Década de Bolsa Família. Brasília, 2013. Disponible en: https:/ /www.ipea. gov.br/desafios $/$ index.php?option $=$ com_content\&view $=$ article\&id=2945:catid=28\&Itemid=23. Acceso: 15 jun. 2020.

KEUSEN, Pedro Paulo Guedes. Os Efeitos do Programa Bolsa Família/ PETI sobre o Trabalho Infantil e suas Externalidades. [S.l.], jul. 2014. Disponible en: http://www.econ.puc-rio.br/uploads/adm/trabalhos/files/ Pedro_Paulo_Guedes_Keusen.pdf. Acceso: 15 jul. 2020.

LACERDA, Nara. Extinção do Ministério do Trabalho: o que mudou após um ano? Fenômeno mundial, precarização encontra terreno fértil no enfraquecimento da fiscalização, segundo especialistas. São Paulo: 2020. Disponible en: https://www.brasildefato.com.br/2020/01/14/extincao-do-ministerio-do-trabalho-o-que-mudou-apos-um-ano. Acceso: 27 jun. 2020.

MINISTÉRIO DA CIDADANIA. Portaria n. ${ }^{\mathbf{0}}$ 627, de 4 de abril de 2019. Disponible en: http://www.in.gov.br/materia/-/asset_publisher/Kujrw0TZC2Mb/content/id/70489115. Acceso: 15 jun. 2020.

MINISTÉRIO DO DESENVOLVIMENTO SOCIAL. Benefícios e Condicionalidades do Programa Bolsa Família (PBF). Brasília/DF, 2015. Disponible en: http://www.mds.gov.br/programabolsafamilia/o_programa_bolsa_familia/beneficios-e-contrapartidas. Acceso:15 jun. 2020.

MINISTÉRIO DO DESENVOLVIMENTO SOCIAL. Caderno de Orientações Técnicas para Aperfeiçoamento da Gestão do Programa de Erradicação do Trabalho Infantil - PETI. Brasília/DF, Rede SUAS, jun. 2018. Disponible en: http://blog.mds.gov.br/redesuas/caderno-de-orientacoes-tecnicas-do-peti/. Acceso: 15 jun. 2020. 
MINISTÉRIO DO DESENVOLVIMENTO SOCIAL E COMBATE À FOME. Portaria n. ${ }^{\circ}$ 666, de 28 de dezembro de 2005. Disciplina a integração entre o Programa Bolsa Família e o Programa de Erradicação do Trabalho Infantil. Brasília/DF, dez. 2005. Disponible en: https://www.legisweb. com.br/legislacao/?id=193379. Acceso: 27 jul. 2020.

MINISTÉRIO DO DESENVOLVIMENTO SOCIAL E COMBATE À FOME. Resolução n. 5 de 12 de abril de 2013. Secretaria Nacional de Assistência Social. Brasília, DOU de 08/05/2013, n. 87, Seção 1, p. 116, maio 2013.

MINISTÉRIO DO DESENVOLVIMENTO SOCIAL E COMBATE À FOME. PERGUNTAS E RESPOSTAS: O Redesenho do Programa de Erradicação do Trabalho Infantil. Brasília, 2014. Disponible en: http://www. mds.gov.br/webarquivos/publicacao/assistencia_social/cartilhas/cartilha_ perguntas_respostas_redesenho_peti_2014.pdf. Acceso: 15 jun. 2020.

MOUSINO, Ileana Neiva. Infância, Trabalho e Dignidade. A Atuação Judicial do Ministério Público do Trabalho para implementação da Política Pública de Combate ao trabalho Infantil. Livro Comemorativo aos 15 anos da COORDINFÂNCIA. [S.l.], 2015. Disponible en: https://mpt.mp.br/ pgt/publicacoes/livros/livro-comemorativo-aos-15-anos-da-Coordinfância/@@display-file/arquivo_pdf. Acceso: 27 jun. 2020.

OIT. Bolsa Família contribui com a redução do trabalho infantil. [S.l.], 2013. Disponible en: http://www.ebc.com.br/noticias/brasil/2013/04/oitbolsa-familia-contribui-com-a-reducao-do-trabalho-infantil. Acceso: 14 jun. 2020 .

OIT. Diagnósticos Intersetorial Municipal. Organização Internacional do Trabalho. Promovendo o Trabalho Decente. [S.1.]. Disponible en: http://www.bsb.ilo.org/dimbr/. Acceso: 15 jun. 2020.

OIT. Relatório Mundial sobre Trabalho Infantil. Vulnerabilidade Econômica, Proteção Social e Luta contra Trabalho Infantil. [S.1.], 2013. Disponible en: http://www.ilo.org/ipecinfo/product/download.do?type=document\&id=23795. Acceso: 15 jul. 2020.

ONU. Transformando Nosso Mundo: A Agenda 2030 para o Desenvolvimento Sustentável. Rio de Janeiro: UnicRio, 2015. Disponible en: https:// 
nacoesunidas.org/wp-content/uploads/2015/10/agenda2030-pt-br.pdf. Acceso: 15 sept. 2020.

RUA, Maria das Graças. Avaliação da integração do Programa de Erradicação do Trabalho Infantil (PETI) ao Programa Bolsa-Família (PBF). Revista do Serviço Público. Brasília/DF, v. 58, n. 4, pp. 417-450, fev. 2014. Disponible en: https://doi.org/10.21874/rsp.v58i4.182. Acceso: 11 jul. 2020.

SECRETARIA NACIONAL DE RENDA E CIDADANIA. SENARC n. ${ }^{\circ}$ 334. 10 de setembro de 2012. Disponible en: http:/ / www.mds.gov.br/webarquivos/publicacao/bolsa_familia/Informes/Informe\%20334.pdf. Acceso: 15 jun. 2020.

TRF 1. AC 2009.38.07.006198-4. Relatora: Mônica Sifuentes. e-DJF1: 03/02/2016. Disponible en: http://www.mpf.mp.br/rs/sala-de-imprensa/docs/outros-documentos / acao-civil-publica-nd eg-5002477-22-2016-404.7106. Acceso: 15 sept. 2020.

UNICEF. Convenção sobre os Direitos da Criança. Instrumento de direitos humanos mais aceito na história universal. Foi ratificado por 196 países. [S.l.]. Disponible en: https://www.unicef.org/brazil/convencao-sobre-os-direitos-da-crianca. Acceso: 15 jun. 2020. 


\title{
EL TRABAJO INFANTIL Y LA ACTUACIÓN DE LOS CONSEJOS TUTELARES
}

\author{
LYDIANE MACHADO E SILVA
}

DOI: 10.51366/978-65-89468-10-3-coordinfancia-16

Resumen. El presente artículo tiene como finalidad provocar la reflexión sobre la importancia que los Consejos Tutelares poseen para que el combate a la explotación de niños y adolescentes sea eficaz. Para ello, es imprescindible que los integrantes de esos órganos comprendan el trabajo infantil como una grave violación de derechos y así como la importancia de su propio trabajo dentro del Sistema de Garantías y Derechos. El artículo presenta, además, los fundamentos legales que atribuyen a los consejeros tutelares el deber de fiscalizar y cohibir el trabajo precoz. Por último, sugiere a los miembros del Ministerio Público del Trabajo formas de actuación que tengan como objetivo acercarse y conocer la realidad de los Consejos Tutelares.

Palabras clave: Trabajo infantil. Derechos fundamentales. Consejos Tutelares.

\section{INTRODUCCIÓN}

A lo largo del año 2019, cuando estuve trabajando en el municipio de Palmas/TO, tuve la oportunidad de acercarme a uno de los integrantes del sistema de garantía de derechos de niños y adolescentes, cuyo trabajo reputo como uno de los más imprescindibles en la lucha contra la explotación de la mano de obra infanto-juvenil: los Consejos Tutelares. Constituidos por hombres y mujeres elegidos por la comunidad de la que forman parte, son protagonistas en el sistema de protección previsto en el ordenamiento jurídico interno y externo. Tienen un papel activo para garantizar que niños y adolescentes estén a salvo de toda forma de negligencia y opresión. 
El contacto con los consejeros Tutelares me hizo comprender lo importante que es que el trabajo infantil deje de ser idealizado en el ámbito de la sociedad brasileña. Muchos de esos hombres y de esas mujeres tuvieron sus infancias marcadas por ese tipo de explotación e hicieron de esa realidad su fuerza motriz para el empeño en la protección y niños y adolescentes.

A menudo, apremiados por la pobreza que experimentan cotidianamente en sus comunidades y por la falta de políticas públicas eficientes, muchos(as) consejeros(as) no consideran el trabajo infanto-juvenil como una violación de derechos. Incluso se entiende que los consejos tutelares no tendrían atribuciones para controlar la ocurrencia de violaciones de esa naturaleza.

El presente artículo tiene, por lo tanto, la finalidad de auxiliar miembros del Ministerio Público del Trabajo a vencer la resistencia de algunos integrantes de consejos tutelares, sumándolos de manera permanente en la actuación conjunta al combate del trabajo infantil. Objetiva, también, ser norte para la actuación de Consejeros y Consejeras que, por ventura, duden de su atribución y de su importancia para el éxito de esa empresa.

\section{LA TUTELA JURÍDICA DE NIÑOS Y ADOLESCENTES EN BRASIL}

La Constitución Federal de 1988 inauguró un nuevo ordenamiento jurídico centrado, esencialmente, en el ser humano como destinatario de derechos que son inherentes a la condición humana. Tanto es así que, ya en el artículo primero, la Carta Magna enumera como uno de sus principios fundamentales la dignidad de la persona humana ${ }^{1}$.

Con relación al tratamiento conferido a niños y adolescentes también hubo una ruptura con el paradigma anterior, según el cual a los seres en desarrollo se atribuía el status de objeto y no de sujeto de derechos.

Para tener una idea de cómo los niños y adolescentes eran tratados antes de 1988, basta verificar el régimen de "protección" que estaba vigente en la década del 60 y que perduró durante todo el gobierno militar. El modelo presuponía ser deber del Estado, como forma de garantizar la seguridad nacional, cuidar de los menores de 18 años. 
Fue en ese período que se crearon instituciones como FEBEN - Fundación Educativa del Bienestar del Menor y FUNABEM - Fundación Nacional del Bienestar del Menor. A pesar de existir "bienestar" en sus nombres, en la realidad práctica tales instituciones se asemejaban a lugares de cumplimiento de pena. Los niños y adolescentes, llamados "menores", en situación de vulnerabilidad social eran simplemente llevados a esas fundaciones como forma de evitar su exposición a la delincuencia y a la marginalidad. Era la llamada Doctrina de la Situación Irregular.

Ese modelo fracasó justamente por asemejarse a la aplicación de penalidades. No había una preocupación en atacar de manera efectiva las causas de la vulnerabilidad social. No se planteaba proporcionar a los padres de los niños herramientas y condiciones para ejercer su función parental.

Contraponiéndose a ese modelo, el nuevo ordenamiento jurídico, iniciado a partir de la Constitución de la República de 1988, trajo en el art. 227 un mandamiento que pone a salvo los intereses y derechos de niños y adolescentes del modo más amplio posible, así como extiende la responsabilidad por la garantía de esos derechos la familia y a la sociedad, conocida como Doctrina de la Protección Integral. Este es el contenido del artículo:

Art. 227. Es deber de la familia, de la sociedad y del Estado asegurar al niño, al adolescente y al joven, con absoluta prioridad, el derecho a la vida, a la salud, a la alimentación, a la educación, al ocio, a la profesionalización, a la cultura, a la dignidad, al respeto, a la libertad y a la convivencia familiar y comunitaria, además de ponerlos a salvo de toda forma de negligencia, discriminación, explotación, violencia, crueldad y opresión (BRASIL, 1988).

Nótese que a los niños, a los adolescentes y a los jóvenes les fue garantizada una extensa lista de derechos que abarcan todos los aspectos de su vida en formación. En ese contexto de alteración de la visibilidad de menores de 18 años, de sus demandas y sus derechos, el legislador infra-constitucional editó el Estatuto del Niño y del Adolescente - Ley n. ${ }^{\circ}$ 8.069/90. El conjunto de dispositivos infra-constitucionales consolidados en dicho Estatuto pretendía dar concreción a los derechos garantizados por la Ley Mayor. En este sentido es la lección de Côrrea (2016, p. 17).

Aún más recientemente, en 1990, el Estatuto del Niño y del Adolescente innovó más radicalmente el enfoque del tema, afirmando la condición de niños y adolescentes como sujetos de derechos, resaltando la condición de personas en condición peculiar de desarrollo. 
Hay que señalar que la Constituyente de 1988 también inauguró una nueva forma de gestionar los intereses públicos. La redemocratización del país exigió que la sociedad civil tuviera una mayor participación en las decisiones políticas, especialmente en aquellas relacionadas con la prestación de servicios públicos. La participación popular estaba en plena consonancia con el párrafo único, Art. $1^{\circ}$, de la Ley Fundamental (BRASIL, 1988), in litteris:

Párrafo único. Todo el poder emana del pueblo, que lo ejerce por medio de representantes electos o directamente, en virtud de esta Constitución.

Fue en este escenario que el ECA creó el Consejo Tutelar, atribuyéndole la responsabilidad de ser el puente entre la comunidad, los menores de 18 años, sus familias y el Estado. El legislador ordinario señaló que la Constitución Federal extendió la responsabilidad por las causas de la infancia y la juventud también a la sociedad y creó un órgano que actúa como una longa manus de la voluntad social, otorgándole al ejercicio de sus atribuciones el status de servicio público relevante. En ese sentido la redacción del art. 131 del referido Estatuto (BRASIL, 1990) dice:

Art. 131. El Consejo Tutelar es un órgano permanente y autónomo, no jurisdiccional, encargado por la sociedad de velar por el cumplimiento de los derechos del niño y del adolescente, definidos en esta Ley. (destaque nuestro)

Ya la redacción del art. 132 de ese diploma normativo apunta el carácter democrático de los Consejos Tutelares, al disponer que sus miembros serán elegidos por medio de proceso electoral de la población de base territorial en la que se asienta el respectivo consejo.

Esta previsión, al mismo tiempo que busca evitar la indicación política, permite que los integrantes de determinada comunidad elijan a quienes tienen mejor conocimiento de sus demandas y necesidades.

Pese a que el marco legislativo, sobre el cual se fundamenta la actuación de los Consejos Tutelares, les garantice autonomía, la realidad que impera en el país es la de órganos desestructurados, que funcionan en condiciones materiales y de seguridad absolutamente precarias.

Lo que se percibe es que los(as) consejeros (as) se esfuerzan para cumplir sus deberes legales, superando tanto la falta de los más básicos materiales de trabajo, como la completa ausencia de políticas públicas imprescindibles 
para que niños y adolescentes sean retirados de situaciones de extrema vulnerabilidad.

Bajo estas circunstancias, lo que ocurre es que la realidad, frecuentemente impone que los Consejeros Tutelares tengan que elegir cuáles violaciones de derecho van a combatir. En una sociedad en la que se idealiza el trabajo infantil y en la que son raras las políticas públicas que pretenden frenar la explotación de mano de obra infanto-juvenil, no es difícil percibir que las situaciones relacionadas a ese tipo de violación son las más toleradas $\mathrm{y}$, consecuentemente, las menos combatidas.

Es imperativo, por lo tanto, que el Poder Público, la Sociedad y la Familia pasen a percibir que el trabajo infantil es una grave violación de derecho fundamental y que como tal desafía a la acción a los diversos órganos y entidades que componen el sistema de garantías y derechos de los niños y adolescentes.

\section{EL TRABAJO INFANTIL COMO GRAVE VIOLACIÓN DE DERECHO FUNDAMENTAL}

Los derechos fundamentales poseen un concepto vago y abierto, pero pueden ser definidos como aquellos esenciales para la dignidad de la persona humana e inherentes a esta condición. Mendes (2007) considera que "los derechos y garantías fundamentales, en sentido material, son, pues, pretensiones que, en cada momento histórico, se descubren a partir de la perspectiva del valor de la dignidad humana" (MENDES, 2007, p. 227). Piovesan (1999, p. 82) profundiza esta definición y enseña:

La llamada concepción contemporánea de los derechos humanos se basa en la universalidad y la indivisibilidad de estos derechos. Universalidad porque la condición de persona será el requisito único para la titularidad de derechos, más allá de cualquier otra condición. Indivisibilidad porque los derechos civiles y políticos serán sumados a los derechos sociales, económicos y culturales, ya que no hay verdadera libertad sin igualdad y tampoco hay verdadera igualdad sin libertad. Esta concepción, acogida por la Declaración Universal en 1948, llegó a ser avalada por la Declaración de Viena de 1993, que en su párrafo $5^{\circ}$ consagró que los "derechos humanos son universales, indivisibles, interdependientes e interrelacionados. La comunidad internacional debe tratar los derechos humanos, en su conjunto, de forma justa y equitativa, en pie de igualdad y con el mismo énfasis". 
Inspirada en la Declaración Universal de Derechos Humanos, de 1948, la ONU elaboró la Declaración Universal de los Derechos del Niño, aprobada en 1959, en la cual enumera derechos específicos de los infantes, tales como: derecho a la especial protección para el desarrollo físico, mental y social; a un nombre y una nacionalidad; a la educación y al ocio infantil; a ser protegida contra el abandono y la explotación en el trabajo, entre otros.

El ordenamiento jurídico brasileño, siguiendo estos y otros diplomas internacionales, trajo extenso rol de derechos fundamentales, en él insertando las reglas relativas al trabajo de niños y adolescentes. El inciso XXIII, Art. $7^{\circ}$, de la Constitución de la República (BRASIL, 1988), inserido en el rol de Derechos Sociales es tajante al prohibir cualquier tipo de trabajo para menores de 14:

Art. $7^{\circ}$. Son derechos de los trabajadores urbanos y rurales, además de otros que apunten a la mejora de su condición social:

XXXIII - prohibición de trabajo nocturno, peligroso o insalubre a menores de dieciocho y de cualquier trabajo a menores de dieciséis años, salvo en la condición de aprendiz, a partir de catorce años; (redacción dada por la Enmienda Constitucional n. ${ }^{\circ} 20$, de 1998).

En ese contexto, no hay duda de que, material y formalmente, es derecho fundamental de los niños el no trabajo y de los adolescentes, a partir de 14 años, el derecho al trabajo protegido.

La previsión constitucional está de acuerdo con el ordenamiento internacional, más concretamente con la Convención n. ${ }^{\circ} 138$ de la Organización Internacional del Trabajo (OIT).

1. Todo miembro que ratifique esta Convención especificará, en una declaración anexa a la ratificación, una edad mínima para la admisión a empleo o trabajo en su territorio y en los medios de transporte registrados en su territorio; salvo lo dispuesto en los artículos 4 y 8 de esta Convención, ninguna persona menor de esa edad será admitida a empleo o trabajo en cualquier ocupación.[...]

3. La edad mínima fijada en virtud del párrafo 1 de este artículo no será inferior a la edad de finalización de la escolaridad obligatoria o, en cualquier caso, no inferior a quince años (OIT, 1976).

A partir del análisis de los dispositivos transcritos anteriormente, es posible extraer las reglas que rigen en el País sobre el trabajo de personas menores de 18 años. En resumen:

- $\quad$ Hasta los 14 años el trabajo está PROHIBIDO; 
- A partir de los 14 años, APENAS está permitido en la condición de aprendiz;

- A partir de los 16 años, está permitido, siempre que no sea trabajo nocturno, insalubre, peligroso o considerado peor forma de trabajo infantil.

El Plan Nacional de Erradicación del Trabajo Infantil (BRASIL, 2018) lo define como

toda actividad económica y / o de actividad de supervivencia, con o sin finalidad de lucro, remuneradas o no, realizadas por niños o adolescentes en edad inferior a 16 (dieciséis) años, salvo la condición de aprendiz a partir de los 14 (catorce) años independientemente de su condición ocupacional.

A pesar de la claridad de la legislación nacional y del mandamiento contenido en la Convención n. ${ }^{\circ} 138$ de la OIT, la realidad brasileña camina en dirección opuesta. Se estima que cerca de 2,7 millones de individuos de 5 a 17 años están trabajando en Brasil. Fue lo que apuntó la Investigación Nacional por muestreo de Domicilios - PNAD de 2015.

PNAD de 2016 (IBGE, 2016) contabilizó que 1,8 millones de niños estaban en el mercado laboral. Este número podría ser celebrado dada la sensible reducción en comparación con el número constatado en 2015. Sin embargo, la investigación de 2016 alteró en gran medida la metodología utilizada, excluyendo a los menores de 17 años que trabajan para su propio consumo. Ese proceder impidió que el número real de infantes trabajando llegara al público. Se resalta que la crisis económica por la que viene pasando Brasil hace creer que las cifras relativas al trabajo para la propia subsistencia sean elevadísimas.

Es sabido que el trabajo tiene papel de centralidad en la vida de todo ser humano. Es por medio del trabajo que se adquieren recursos para la subsistencia y se deja un legado social que hace de los hombres y mujeres seres únicos. Sin embargo, muchas veces el trabajo también puede ser medio de explotación y de expropiación de otros derechos igualmente imprescindibles para vivir de forma completa. Hay situaciones en las que, en lugar de dignificar, el trabajo perjudica, dificulta, debilita y fulmina sueños y perspectivas. Es exactamente lo que ocurre con el trabajo precoz. 
La extrema desigualdad existente en el país aliada al aspecto cultural que banaliza e incluso romantiza el trabajo infantil son el fundamento sobre el cual se sustentan las cifras alarmantes que las investigaciones apuntan. Desde la más tierna edad escuchamos el dicho "el trabajo dignifica al hombre". Esa máxima sólo es verdadera cuando el ser humano está delante de un trabajo libre, bien remunerado, que no atenta contra su salud física y mental, y que le permite romper el ciclo de pobreza, propiciando el ascenso social. El concepto de existencia digna es mucho más amplio que el concepto de supervivencia.

El trabajo infantil es, por lo tanto, ejemplo perfecto de labor que roba la dignidad, pues atenta contra los derechos previstos en el art. 227 de la Carta Magna e impide que los seres en formación desarrollen sus plenas potencialidades.

Los perjuicios derivados del trabajo precoz son de las más variadas órdenes. Los niños y adolescentes sometidos desde temprana edad al trabajo son más propensos a la evasión escolar, a ser víctimas de accidentes y de toda clase de explotación. El Observatorio del Trabajo Infantil señala que $17 \mathrm{mil}$ niños y adolescentes sufrieron accidentes de trabajo entre 2012 y 2018, según los datos inseridos en el CATWEB (SMARTLAB, [20--]).

Por si no bastaran todos estos argumentos es imperioso resaltar que la explotación de la mano de obra infanto-juvenil afecta sensiblemente el desarrollo económico de una nación. No por casualidad, los países más pobres del mundo son precisamente los que más utilizan este tipo de mano de obra. En encuesta realizada por la OIT y la Fundación Walk Free, en 2016 se constató que 152 millones de individuos entre 5 y 17 años estaban en situación de trabajo. De ellos, 144 millones son de América Latina, África y Asia (RED PETECA, [20--]). No es difícil verificar que existe una correlación entre el desarrollo humano y económico y el trabajo infantil. Mientras esa fuerza de trabajo es ampliamente utilizada en países subdesarrollados, incluso en Brasil, los países ricos protegen a sus niños y les confieren condiciones de vivir plenamente sus infancias, con fin de que consigan ascender socialmente por medio del estudio.

Ante esto, es necesario introyectar en nuestra sociedad la comprensión de que además de grave violación de derechos humanos, la explotación de niños y adolescentes retroalimenta el ciclo de pobreza e impide el desa- 
rrollo nacional. Para ello, la actuación del Consejo Tutelar es absolutamente imprescindible.

\section{EL CONSEJO TUTELAR Y SU PAPEL EN LA LUCHA CONTRA EL TRABAJO INFANTIL}

Como se ve, la explotación de la mano de obra de niños y adolescentes menores de 14 años y mayores de esa edad, fuera de las hipótesis legales, constituye una grave violación de derechos humanos.

En esta dirección, los Consejos Tutelares tienen una función estratégica en la lucha contra el trabajo infantil. Es lo que se extrae de la Resolución n. ${ }^{\circ} 113$ del CONANDA - Consejo Nacional de los Derechos del Niño y del Adolescente, que instituyó formalmente el Sistema de Garantías y Derechos del Niño y del Adolescente. Según esa normativa, la actuación de ese sistema parte de tres ejes: defensa, promoción y control. Los consejos tutelares se insertan justamente en el primero de ellos, así definido:

Art. $6^{\circ}$. El eje de la defensa de los derechos humanos de niños y adolescentes se caracteriza por la garantía del acceso a la justicia, o sea, por el recurso a las instancias públicas y mecanismos jurídicos de protección legal de los derechos humanos, generales y especiales, de la infancia y de la adolescencia, para asegurar la imposición de ellos y su exigibilidad, en concreto.

Art. $7^{\circ}$. En este eje, se sitúa la actuación de los siguientes órganos públicos:

VII - Consejos Tutelares. (CONANDA, 2006).

Nogueira (2016, p. 104) destaca:

La resolución, por último, hace referencia expresa a los Consejos Tutelares, como órganos, contenciosos no jurisdiccionales, encargados de "velar por el cumplimiento de los derechos de los niños y de los adolescentes", particularmente a través de la aplicación de medidas especiales de protección a niños y adolescentes con derechos amenazados o violados.

El art. $60^{2}$ del ECA repite el art. $7^{\circ}$, XXIII, de la Constitución Federal y prohíbe el trabajo para menores de 16 años, salvo en la condición de aprendiz. Los siguientes artículos garantizan el derecho al trabajo protegido para los adolescentes a partir de 14, a través del contrato de aprendizaje. Ya el art. 136 del Estatuto del Niño y del Adolescente (BRASIL 1990), dispone de forma bastante clara la atribución de los Consejos para fiscalizar la existencia de trabajo infantil:

Art. 136. Son atribuciones del Consejo Tutelar: 
I - atender a los niños y adolescentes en las hipótesis previstas en los arts. 98 y 105, aplicando las medidas previstas en el art. 101, I A VII [...]

Las hipótesis previstas en los arts. 98 (BRASIL, 1990) son las siguientes:

Art. 98. Las medidas de protección del niño y del adolescente son aplicables cuando los derechos reconocidos en esta ley son amenazados o violados:

I - por acción u omisión de la sociedad o del Estado;

II - por falta, omisión o abuso de los padres o del responsable [...]

Como se ve, no hay duda de que el trabajo precoz es una de las hipótesis cubiertas por el art. 98, I, del ECA, ya que se trata de violación al derecho al no trabajo y al trabajo protegido, ambos con previsión expresada en el art. 60 , antes mencionado.

En los términos ya expuestos, no se puede tolerar que los Consejos Tutelares presenten respuestas negativas a las solicitudes de verificación acerca de la existencia de niños o adolescentes en situación de trabajo prohibido. Esa negativa debilita el Sistema de Garantías y Derechos, que deja de ser activado en hipótesis en que solamente una actuación sistémica es capaz de ofrecer resultados prácticos satisfactorios. En ese sentido, los Consejos Tutelares tienen una posición estratégica en esa actuación. Esto se debe a que son estos órganos los que están inmersos en la comunidad en la que actúan y, por lo tanto, son capaces de identificar las causas del trabajo infanto-juvenil dentro de ella. Esta identificación es imprescindible para que las políticas públicas sean definidas y eficientemente implementadas.

Bajo otro enfoque, son los Consejeros Tutelares los que representan el Estado y la posibilidad de auxilio para muchas familias. Es al Consejo Tutelar donde recurren muchas familias cuando se sienten desamparadas por los servicios estatales. A ese órgano cabe, incluso, la inducción de políticas públicas, una vez que conoce de cerca las necesidades y la demanda de cada comunidad que atiende.

De este modo, lo que se espera de los(as) Consejeros(as) Tutelares, así como todos(as) los(as) agentes públicos (as), es que sean capaces de molestarse con todas las violaciones a la infancia, en especial con aquellas que tienen amplia aceptación cultural, como es el caso del trabajo infantil.

Se espera, que su actuación sea marcada por un entendimiento más profundo de las causas y consecuencias del trabajo precoz y que todos sus 
esfuerzos sean destinados a la atención completa al núcleo familiar en el cual el niño y/o el adolescente trabajador se inserte.

Cuando el trabajo infantil se torna imprescindible para el sustento de la familia, ésta debe ser amparada, por ejemplo, con el encaminamiento de los padres para programas de distribución de renta y/o calificación profesional. El niño y/o adolescente en situación de trabajo prohibido debe ser encaminado para programas que le permitan retomar los estudios y/o le garanticen un trabajo protegido, respectivamente.

En la hipótesis de no existir en el municipio política pública y/o programa de acogida para esas familias, la actuación del Consejo Tutelar debe ser articulada con los demás órganos o entidades que componen el Sistema de Garantía y Derechos. Acerca de estas circunstancias, es imperiosa Corrêa (2016, p. 16):

Una visión contemporánea, constitucional y humanista del ordenamiento jurídico impone al agente estatal un cuestionamiento más profundo, con el fin de asegurar tutela efectiva a los derechos de la infancia y de la adolescencia. ¿Cuál es el beneficio real para la formación profesional, cultural y humana de la participación del adolescente en el mercado laboral? ¿Cuáles son las razones de su deseo de trabajar?: ¿falta de acceso a oportunidades de educación? ¿escasez económica? En este caso, ¿cuáles son las alternativas de asistencia social a disposición, y de quién es la responsabilidad de acceso a los más necesitados? ¿No sería más adecuado exigir que los gestores de políticas públicas responsables ofrezcan oportunidades adecuadas - y verdaderamente accesibles - de educación (formal o informal), desarrollo de habilidades intelectuales, sociales - y, si fuera compatible, profesionales - que imponer a niños y adolescentes la carga por la inercia estatal? ¿Es razonable que niños y adolescentes menos favorecidos económicamente se vean obligados a ingresar precozmente en el mercado laboral (con el aval del Estado-Juez), sacrificando sus oportunidades de educación y adquisición de las habilidades necesarias para una vida productiva y digna en la edad adulta?

Son esos cuestionamientos los que, aliados a la certeza de sus atribuciones y a la convicción de la importancia de su trabajo, deben orientar la actuación de los(as) Consejeros(as) Tutelares.

\section{EL MINISTERIO PÚBLICO DEL TRABAJO EN COLABO- RACIÓN CON LOS CONSEJOS TUTELARES}

Los temas anteriores revelan que el derecho al no trabajo y al trabajo protegido se insertan en el rol de derechos fundamentales. Bajo esa perspectiva ambos se encuentran en el espectro de actuación de los Consejos Tutelares 
y más aún del Ministerio Público del Trabajo, cuya esencia constitucional se concretiza con la defensa del ordenamiento jurídico, del régimen democrático y de los intereses sociales e individuales no disponibles (Art. 128, CF).

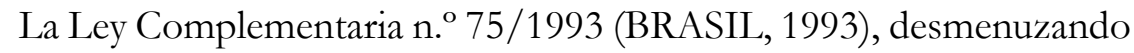
las atribuciones constitucionales del parquet, delega al Ministerio Público del Trabajo la siguiente función:

Art. 83. Corresponde al Ministerio Público del Trabajo el ejercicio de las siguientes atribuciones ante los órganos de Justicia del Trabajo:

V- proponer las acciones necesarias para la defensa de los derechos e intereses de los menores, incapaces e indios, provenientes de las relaciones de trabajo; $[\ldots]$

Es importante resaltar que la expresión "acciones" debe ser interpretada de modo integral y más allá de las medidas judiciales apropiadas para defender el interés de niños y adolescentes provenientes de las relaciones de trabajo. Por lo tanto, es obligación del MPT adoptar todas y cada una de las medidas destinadas, en última instancia, a garantizar que se respete efectivamente el derecho al no trabajo y al trabajo protegido.

Como ya se vio en esa articulación, la actuación de los Consejos Tutelares es fuertemente impactada por la cultura de la idealización del trabajo infanto-juvenil y también por la falta de estructura material. La consecuencia de esto es que, muchas veces, los integrantes de esos órganos se ven obligados a elegir cuál violación de derecho combatir y a menudo, el trabajo infantil no es priorizado.

Ante tales circunstancias, el parquet laboral no puede permanecer inerte, bajo pena de condescender con tal estado de cosas. Es fundamental que Fiscales del Trabajo, inseridos en la comunidad en la que actúan, sean conscientes de las dificultades que los Consejeros y Consejeras encuentran en su actuación. No sólo porque tales dificultades impactan negativamente la tramitación de investigaciones sobre el trabajo infantil, sino porque es deber institucional actuar preventivamente y como inductor de políticas públicas que objetiven combatir ese tipo de explotación.

La Coordinación Nacional de Combate a la Explotación del Trabajo de Niñas, Niños y Adolescentes (Coordinfância), que conmemora 20 años de existencia, ha desarrollado mecanismos para orientar y subsidiar la actuación de los miembros del MPT. El Proyecto Estratégico Rescate la Infancia es uno 
de esos valiosos instrumentos de actuación. El proyecto tiene tres ejes de actuación que tienen como objetivo abarcar todos las frentes de batalla contra el trabajo Infantil, que son: educación, políticas públicas y aprendizaje.

La aproximación de los Consejos Tutelares se puede llevar a cabo, por ejemplo, con la implementación del Eje Políticas Públicas. Por medio de este proyecto es posible conocer la realidad de cada uno de los órganos que componen la red de protección del niño y del adolescente de determinada localidad.

Conocer las dificultades de los Consejos Tutelares posibilita que el Ministerio Público del Trabajo actúe para mejorar las condiciones de trabajo de los(as) consejeros(as), sea por medio de destinación de bienes y realización de capacitaciones o por la exigencia al gestor municipal para que promueva el equipamiento adecuado a los referidos órganos y la elaboración de políticas públicas de acuerdo con la realidad local.

\section{CONCLUSIÓN}

Por todo lo expuesto hasta aquí, resulta que no parece aceptable que, ante todo el marco jurídico citado, el trabajo infantil sea excluido de la lista de graves violaciones de derechos fundamentales. Exponer a niños y adolescentes al trabajo precoz provoca impactos negativos a la salud, a la seguridad, a la educación, así como crea una masa de trabajadores poco cualificados que no son capaces de ascender socialmente ni de robustecer la economía del país.

Actualmente, más de 2,7 millones de personas menores de 18 años tienen sus derechos fundamentales violados diariamente. Bajo tales circunstancias, los Consejos Tutelares tienen una importancia fundamental en la lucha contra el trabajo infantil, pues conocen el contexto social en que los niños y adolescentes trabajadores están inseridos y, por eso, son capaces de apuntar soluciones y políticas públicas más efectivas.

Específicamente para actuación del Ministerio Público del Trabajo, los Consejeros Tutelares realizan fiscalización imprescindible y sin la cual sería muy difícil identificar y responsabilizar a los tomadores de trabajo infantil. 
Sin embargo, esta asociación puede y debe ir más allá. Los Fiscales del Trabajo deben ser conscientes de las dificultades que los Consejeros y Consejeras encuentran en su actuación.

El proyecto Políticas Públicas de la Coordinfância es un instrumento eficaz en la aproximación con los Consejos Tutelares, así como para exigir del Poder Público el equipamiento adecuado de dichos órganos y la elaboración de políticas públicas adecuadas a la realidad local.

Las herramientas necesarias para luchar contra el trabajo infantil se encuentran expuestas. Es una tarea ardua y desafiante que solo podrá ser exitosa si todos los agentes involucrados comprenden que el fortalecimiento mutuo es el camino para que el futuro de niños y adolescentes y, en última instancia, de nuestro país, sea puesto a salvo a partir de ahora.

\section{NOTAS}

1 Art. $1^{\circ}$ La República Federativa de Brasil, formada por la unión indisoluble de los Estados y Municipios y del Distrito Federal, se constituye en Estado Democrático de Derecho y tiene como fundamentos: III - la dignidad de la persona humana (BRASIL, 1988).

2 Está prohibido cualquier trabajo a menores de catorce años, excepto en la condición de aprendiz.

\section{REFERENCIAS}

BRASIL. Constituição da República Federativa do Brasil. Brasília/DF, 1988. Disponible en: http://www.planalto.gov.br/ccivil_03/constituicao/ constituicao.htm. Acceso: 21 jun. 2020.

BRASIL. Lei n. ${ }^{\circ}$ 8.069, de 13 de julho de 1990. Dispõe sobre o Estatuto da Criança e do Adolescente e dá outras providências. Brasília/DF, jul. 1990. Disponible en: http://www.planalto.gov.br/ccivil_03/leis/L8069compilado. htm. Acceso: 21 jun. 2020.

BRASIL. Lei Complementar n. ${ }^{\circ}$ 75, de 20 de maio de 1993. Dispõe sobre a organização, as atribuições e o estatuto do Ministério Público da União. Brasília/DF, maio 1993. Disponible en: http://www.planalto.gov.br/ccivil_03/leis/18069.htm. Acceso: 18 ago. 2020.

BRASIL. Decreto n. ${ }^{\circ}$ 4.134, de 15 de fevereiro de 2002. Promulga Convenção n. ${ }^{\circ} 138$ e a Recomendação n. ${ }^{\circ} 146$ da Organização Internacional do 
Trabalho (OIT) sobre Idade Mínima de Admissão ao Emprego. Brasília, DF: Presidência da República, Casa Civil, 2002.

BRASIL. Ministério Público do Trabalho. Brasília/DF, 2016. Disponible en: https://intranet.mpt.mp.br/pgt/coordenadorias-nacionais/Coordinfância. Acceso: 21 jun. 2020.

BRASIL. Plano Nacional de Prevenção e Erradicação do Trabalho Infantil e Proteção do Adolescente Trabalhador. Comissão Nacional de Erradicação do Trabalho Infantil.[S.I.], nov. 2018. Disponible en: https://www.gov.br/mdh/pt-br/assuntos/noticias/2018/novembro/lancado-3o-plano-nacional-de-prevencao-e-erradicacao-do-trabalho-infantil/ copy_of_PlanoNacionalversosite.pdf. Acceso en: 30 jun. 2020.

CONSELHO NACIONAL DOS DIREITOS DA CRIANÇA E DO ADOLESCENTE (CONANDA). Resolução n. ${ }^{\circ}$ 113, de 19 de abril de 2006. Dispõe sobre os parâmetros para a institucionalização e fortalecimento do Sistema de Garantia dos Direitos da Criança e do Adolescente. Brasília/DF, 2006. Disponible en: https://www.direitosdacrianca.gov.br/conanda/resolucoes/113-resolucao-113-de-19-de-abril-de-2006/view. Acceso: 21 jun. 2020.

CÔRREA, Lélio Bentes. O Trabalho Infantil sob a perspectiva internacional. In: MELO, Guilherme A. Bassi de et al. (orgs.). Trabalho Infantil: mitos, realidade e perspectivas: estudos em homenagem ao professor Oris Oliveira. São Paulo: Ltr, 2016, p. 11-18.

GOMES, Eduardo Biacchi e GONÇALVES, Ana Elise Brandalise. A Proteção ao Trabalho Infantil como Direito Humano e Fundamental: as Convenções n.os 138 e 182 da OIT e o Poder Judiciário Brasileiro. In: FRANCO FILHO, Georgenor de S. et al (orgs). Direito internacional do Trabalho: o estado da arte sobre a aplicação das convenções internacionais da OIT no Brasil. São Paulo: Ltr, 2016, p. 114-125.

IBGE. Pesquisa nacional por amostra de domicílios: síntese de indicadores 2015/IBGE, Coordenação de Trabalho e Rendimento. Rio de Janeiro: IBGE, 2016. Disponible en: https://biblioteca.ibge.gov.br/visualizacao/ livros/liv98887.pdf. Acceso en: 20 jun. 2020.

IBGE. Pesquisa nacional por amostra de domicílios - PNAD Continuada. Brasília/DF, 2016. Disponible en: https://biblioteca.ibge.gov.br/visualizacao/livros/liv101388_informativo.pdf. Acceso en: 20 jun. 2020. 
MENDES, Gilmar Ferreira. Curso de Direito Constitucional. São Paulo: Saraiva, 2007.

NOGUEIRA, Eliana dos Santos Alves. O trabalho em rede como estratégia para a erradicação do trabalho infantil e proteção do adolescente. In: MELO, Guilherme A. Bassi de et al. (orgs.). Trabalho Infantil: mitos, realidade e perspectivas: estudos em homenagem ao professor Oris Oliveira. São Paulo: Ltr, 2016, p. 101-109.

ORGANIZAÇÃO INTERNACIONAL DO TRABALHO. Convenção n. ${ }^{\circ}$ 138. Idade mínima para admissão. [S.1.], junho de 1976. Disponible en: https://www.ilo.org/brasilia/convencoes/WCMS_236696/lang--pt/index. htm. Acceso en: 17 sept. 2020.

PAGANINI, Juliana. Os Impactos do Trabalho Infantil para a Saúde da Criança e do Adolescente. In: SEMINÁRIO INTERNACIONAL DE DEMANDAS SOCIAIS E POLÍTICAS PÚBLICAS NA SOCIEDADE CONTEMPORÂNEA. VII Mostra de Trabalhos Jurídicos Científicos. [S.l], 2014. Disponible en: https://webcache.googleusercontent.com/search?$\mathrm{q}=$ cache:hShxn2Puk8YJ:https://online.unisc.br/acadnet/anais/index.php/ sidspp $/$ article $/$ view $/ 11821+\& c d=3 \& h l=$ pt $-B R \& c t=c \ln \& \& \mathrm{gl}=$ br\&client $=$ firefox-b-e. Acceso: 28 jun. 2020.

PIOVESAN, Flávia. A Proteção dos Direitos Humanos no Sistema Constitucional Brasileiro. In: Revista da Procuradoria Geral do Estado de São Paulo. Disponible en: http://www.pge.sp.gov.br/centrodeestudos/revistaspge/Revista\%20PGE\%2051-52.pdf. Acceso en: 30 jun. 2020.

REDE PETECA. Estatísticas: Trabalho infantil no Brasil e no Mundo. [S.l.], [20--]. Disponible en: https://www.chegadetrabalhoinfantil.org.br/trabalho-infantil/estatisticas/. Acceso: 14 oct. 2020.

SMARTLAB - OBSERVATÓRIO DA PREVENÇÃO E DA ERRADICAÇÃO DO TRABALHO INFANTIL. Acidentes de Trabalho com Crianças e Adolescentes. [S.l.], [20--]. Disponible en: https://smartlabbr. org/trabalhoinfantil/localidade/0?dimensao=acidentesTrabalho. Acceso en: 14 oct. 2020 . 


\section{GARANTÍA DEL DERECHO FUNDAMENTAL A LA PROFESIONALIZACIÓN COMO ESTRATEGIA DE PREVENCIÓN DE LA LETALIDAD Y DEL ENCARCELAMIENTO DE JÓVENES SOCIALMENTE VULNERABLES EN BRASIL}

\section{MÁRCIO ROGÉRIO DE OLIVEIRA}

DOI: 10.51366/978-65-89468-10-3-coordinfancia-17

Resumen. Este artículo aborda las estadísticas sobre letalidad y encarcelamiento juvenil en Brasil, subrayando los factores de violencia y los recortes, social, racial y de edad más afectados. Los índices de violencia y criminalidad muestran que personas jóvenes, negras y que viven en las periferias son las que más sufren con la violencia y el encarcelamiento. La falta de oferta o la oferta insuficiente de buenos programas de políticas sociales y de seguridad en las comunidades urbanas periféricas contribuye para que exista evasión escolar y para que muchos niños, adolescentes y jóvenes sean reclutados por grupos criminosos. Las peores formas de trabajo infantil están presentes con más intensidad en comunidades socialmente vulnerables, especialmente la explotación por el tráfico de drogas. El incremento de mejores políticas de deporte, cultura y ocio para la infancia y juventud periférica, y sobre todo la oferta de oportunidades de profesionalización e ingreso protegido en el mundo del trabajo, son estrategias que pueden reducir la violencia, el encarcelamiento y la explotación del trabajo infantil en esas comunidades.

Palabras-clave: Juventud. Adolescencia. Letalidad. Criminalidad. Encarcelamiento. Seguridad. Profesionalización.

En los años 80, el debate sobre derechos humanos - incluso de niños y adolescentes - se fortalecía por el mundo, mientras que Brasil caminaba 
para acabar la dictadura militar instaurada en 1964 y trataba de consolidar el proceso de redemocratización. Como principal consecuencia, fue promulgada la Constitución Ciudadana de 1988 y, en seguida, la Ley Federal n. ${ }^{\circ} 8.069$, del 13 de julio de 1990 - Estatuto del Niño y del Adolescente (ECA), incorporando relevantes avances de la Normativa Internacional, especialmente las Reglas Mínimas de las Naciones Unidas para la Administración de la Justicia de la Infancia y Juventud (Reglas de Beijing, 1985), la Convención de las Naciones Unidas sobre los Derechos del Niño (1989), las Reglas Mínimas de las Naciones Unidas para la Protección de los Jóvenes Privados de Libertad (1990) y las Directrices de las Naciones Unidas para la Prevención de la Delincuencia Juvenil (Directrices de Riad, 1990).

La promulgación del ECA tradujo el rompimiento con una cultura que, desde las primeras luces del siglo XX y a lo largo de casi 90 años, fundamentó una visión higienista y adulto-céntrica sobre el papel del Estado con relación a niños y adolescentes pobres o abandonados. Esa visión, orientada por la llamada doctrina de la situación irregular, fundamentó una legislación y una política que, a pretexto de "proteger" y/o "corregir" a los menores de 18 años abandonados y/o delincuentes, puso en marcha la acogida institucional y la restricción de la libertad como soluciones para el "problema del menor".

De forma muy clara, el ECA se distanció de las líneas tradicionales de una legislación que, siendo al mismo tiempo paternalista y altamente represiva punitiva, encuadró a las personas menores de 18 años, según Naves (2004, p. 71):

[...] en la categoría jurídica de menores de edad, la cual implicaba, menos que una discriminación etaria, principalmente la ausencia de reconocimiento de sus capacidades, de sus derechos y de sus peculiaridades.

Sí, la llamada legislación especial del menor no fue concebida para todos los niños y adolescentes, sino solamente para aquellos considerados en situación irregular, o sea, al desamparo de la protección familiar o involucrados en actos contrarios a la ley penal: los abandonados, desvalidos o delincuentes.

Con el pretexto de proteger a los menores de la pobreza y de preservarlos de una vida potencialmente volcada hacia el crimen, esa legislación confería poderes casi ilimitados al juez de menores para enviar a todos los que fuesen clasificados en tales categorías para los abrigos y centros correcciona- 
les mantenidos por el Gobierno Federal. No eran sujetos de derechos sino meros objetos de la intervención del Estado y de los adultos.

Con el advenimiento de la Constitución de la República de 1988 (BRASIL, 1988) y del ECA, Brasil abandonó esos paradigmas y abrazó la doctrina de la protección integral, reconociendo a niños y adolescentes como sujetos de derechos fundamentales los que deben ser garantizados por la familia, por la sociedad y por el poder público, con absoluta prioridad: el derecho a la vida, a la salud, a la alimentación, a la educación, al ocio , a la profesionalización, a la cultura, a la dignidad, al respeto, a la libertad y a la convivencia familiar y comunitaria (BRASIL, 1988, artículo 227).

Munir Cury (1990, p. 42), enfatizando la concepción sistémica del ECA, observa que:

No se trata - es siempre bueno resaltar - de mera descripción o explicitación de los derechos listados en el mencionado dispositivo constitucional, lo que podría conducir a un raciocinio escéptico de "más una ley". No. El Estatuto prevé expresamente las acciones de responsabilidad por ofensa a los derechos asegurados al niño y al adolescente, referentes al no ofrecimiento o a la oferta irregular, de la enseñanza obligatoria; de la atención educacional especializada a los portadores de deficiencia; de atención en guarderías, en jardines de infantes y pre escuela a los niños de cero a seis años de edad; de enseñanza nocturna regular, adecuada a las condiciones del educando; de acceso a las acciones y servicios de salud; de escolarización y profesionalización de adolescentes privados de libertad, entre otras hipótesis listadas.

Con ese aplomo, pasadas tres décadas de vigencia de la CR/88 y del ECA, habría que preguntarse si la situación de la infancia y de la juventud de Brasil mejoró tanto como nos gustaría con la aplicación de los principios que rigen la doctrina de la protección integral.

Desafortunadamente, a juzgar por los índices recientes de violencia y criminalidad y sus efectos sobre la juventud brasileña, nos parece que la respuesta a esa pregunta tiende a ser negativa.

Con efecto, visitar las estadísticas de violencia y criminalidad puede ser una experiencia perturbadora, al depararnos con la realidad de 65.602 muertes por homicidio en 2017, de acuerdo con el Atlas de Violencia publicado por el Instituto de Investigación Económica Aplicada y el Fórum Brasileño de Seguridad Pública (IPEA; FBSP, 2019). El estudio destaca que estas muertes equivalen a una tasa de 31,6 por cien mil habitantes, representando más de 
$10 \%$ de los homicidios registrados en el mundo y colocando a Brasil como el país con el mayor número absoluto de homicidios.

En 2017, el 75,5\% de las víctimas de homicidios fueron individuos negros (definidos aquí como la suma de individuos negros o pardos, según la clasificación del IBGE, utilizada también por el Sistema de Informaciones sobre Mortalidad (SIM), con una tasa de 43,1 homicidios para cada grupo de 100 personas negras, al paso que la tasa de no negros (blancos, amarillos e indígenas) fue de 16,0. Eso muestra que para cada individuo no negro que sufrió homicidio en 2017, aproximadamente, 2,7 negros fueron muertos (IPEA; FBSP, 2019).

Pero el recorte más duro es el que nos muestra el impacto de la violencia sobre la población joven, entre 15 y 29 años de edad. En 2017, 35.783 jóvenes fueron asesinados en Brasil. Los homicidios fueron la causa de 51,8\% de los óbitos de jóvenes de 15 a 19 años; de 49,4\% para personas de 20 a 24; y de $38,6 \%$ de las muertes de jóvenes de 25 a 29 años; estos números muestran que los homicidios fueron la principal causa de muertes entre los jóvenes brasileños en 2017 (IPEA; FBSP, 2019).

Además de género, raza y franja etaria, otra característica marcante de las muertes por homicidio en Brasil es la baja escolaridad. Citando Cerqueira e Coelho (2015), el Atlas de la Violencia (IPEA; FBSP, 2016, p. 21) recuerda que

[...] estos autores, al hacer un ejercicio econométrico con base en los microdatos del Censo demográfico del IBGE de 2010 y del SIM, mostraron que, incluso controlando por la Unidad Federativa de residencia, estado civil y edad, las chances de un individuo que tenga hasta siete años de estudio pueda llegar a sufrir homicidio en Brasil son 15,9 veces mayores que las de alguien que haya ingresado en la enseñanza superior, lo que demuestra que la educación es un verdadero escudo contra los homicidios.

Del otro lado de esta moneda están las estadísticas sobre encarcelamiento, según las cuales Brasil alcanzó en 2014 el puesto de la tercera mayor población carcelaria del mundo, con $711.453^{1}$ personas presas, de acuerdo con el Novo Diagnóstico de Pessoas Presas no Brasil (CNJ, 2014). Sumando el total de 373.991 mandatos de prisión pendientes de cumplimiento que había en el mismo período - de acuerdo con el Banco Nacional de Mandatos de Prisión, tendríamos en Brasil la posibilidad de alcanzar la impresionante cifra de 1.089 millones de personas presas (CNJ, 2014). 
Las estadísticas del sistema de prisiones también son dominadas por jóvenes y negros, según el Levantamiento Nacional de Informaciones Penitenciarias (MINISTÉRIO DA JUSTIÇA; DEPEN, 2014): en una población total de 622.202 individuos, equivalente a una tasa de 306,2 presos por cien mil habitantes, 94,2\% eran hombres, $61,67 \%$ eran negros y 55,07\% eran jóvenes de entre 18 y 29 años de edad. Este último es un dato que merece aún más atención si se lo compara con la participación de la misma franja etaria en el conjunto de la población brasileña, que es de apenas 18,9\%.

Considerando todo eso, lo que tenemos en Brasil es una triste combinación de matanza y encarcelamiento de jóvenes, una especie de suicidio generacional que compromete la fuerza de trabajo de la nación y mantiene toda la sociedad en un estado permanente de miedo e inseguridad, sin llegar a hablar de los costos descomunales con el sistema de salud pública y del sistema carcelario y de seguridad pública.

En ese sentido, el Atlas da Violência (IPEA; FBSP, 2016, p. 19) alerta que, en Brasil, la muerte violenta de jóvenes

[...] crece en marcha acelerada desde los años 1980. Según Cerqueira y Moura (2013), el costo de bienestar asociado a la violencia letal que acomete a la juventud alcanza 1,5\% del PBI a cada año. El problema es aún más grave y urgente cuando consideramos que a partir de 2023 el país sufrirá una disminución sustancial en la proporción de jóvenes en la población en general [Camarano et al., 2013]. Esa dinámica demográfica implicará dificultades a las generaciones futuras en varios planos, incluyendo el mercado de trabajo, previsión social y el necesario aumento de la productividad.

Otra característica de esta juventud perdida (IPEA; FBSP, 2016) es que, en su mayor parte, ella nace, vive y circula en las periferias de los grandes centros urbanos, es decir, en las comunidades más vulnerables y sin asistencia de las Regiones Metropolitanas.

Este factor de territorialidad puede ser determinante para que una persona se involucre en situaciones de violencia y criminalidad, conforme reconoce el Ministerio de Justicia de Brasil en su Guía para la Prevención del Crimen y de la Violencia en los Municipios (MINISTÉRIO DA JUSTIÇA; SNASP, 2006, p. 13):

Crímenes violentos son, en primer lugar, mucho más comunes en las periferias de nuestras ciudades que en sus áreas centrales o en sus barrios tradicionales. Las regiones más abandonadas por el Poder Público, donde residen las personas en situación de vulnerabilidad social, serán aquellas donde, tenden- 
cialmente, se encontrarán las mayores tasas de desempleo, la mayor frecuencia de abuso de alcohol y de drogas ilícitas, los indicadores más altos de mal éxito y evasión escolar, la mayor incidencia de casos de embarazos precoces y de negligencia de los padres en el cuidado y monitoreo de sus hijos etc. Suelen ser, también, las regiones con menos presencia policial. [...] Vivir en una región con estas características sociales puede implicar en riesgos significativos para la victimización por homicidio, por ejemplo, o violación sexual. Riesgos que serán aun mayores, en esta misma región, para los habitantes jóvenes y adolescentes.

Si de hecho es así, debemos estar atentos para la circunstancia de que, en la fecha de referencia del Censo Demográfico 2010, Brasil poseía 36 Regiones Metropolitanas y tres Regiones Integradas de desarrollo - RIDE (IBGE, 2013), con cerca de 93 millones de habitantes solo en las capitales y sus entornos. Además, de acuerdo con la publicación Censo Demográfico 2010: aglomerados subnormales: primeros resultados (IBGE, 2011), Brasil tenía en aquella época 11.425.644 personas residentes en aglomerados subnormales (favelas).

El perfil demográfico brasileño es, por tanto, acentuadamente urbano, y son nuestras ciudades que, de algún modo, están comportándose desde hace décadas de forma poco cuidadosa con relación a los niños, adolescentes y jóvenes de las comunidades socialmente vulnerables, como también a sus familias.

Esa falta de cuidado se traduce de forma muy evidente en la insuficiencia $\mathrm{y}$, muchas veces, inexistencia de equipamientos y servicios públicos esenciales en las periferias, tales como buenas escuelas públicas, puestos de salud, servicios de asistencia social, iluminación pública, saneamiento, vigilancia policial comunitaria de calidad, áreas destinadas al deporte, cultura y ocio y, especialmente, guarderías infantiles. Este conjunto de negligencias contribuye fuertemente para el abandono social de estas comunidades y de las familias que en ellas residen, siendo que el segmento más frágil y que acaba sufriendo las consecuencias más intensas es justamente el grupo de los niños, adolescentes y jóvenes, que como personas en especial condición de desarrollo y, por eso, merecedoras de atención prioritaria por parte de la familia, de la sociedad y del poder público (BRASIL, 1988, artículo 227), a quienes no se les respetan los derechos humanos fundamentales.

En ese punto es importante hacer una distinción, para que nadie se imagine que la violencia y la criminalidad son llagas exclusivas de las comunidades pobres y que toda persona solo por ser pobre, negra y residente de 
periferia, estaría condenada al envolvimiento con el crimen. Tanto eso no es verdad que, innegablemente, entre la inmensa mayoría de las personas que viven en comunidades menos favorecidas, los que se envuelven con el crimen y la violencia son proporcionalmente pocos. Por otro lado, incluso siendo una minoría entre las personas de las clases más pobres, no podemos cerrar los ojos para la realidad de que es de esta minoría que salen, en su mayor parte, los 711 mil presos referidos por el Ministerio de Justicia y DEPEN (2014) y los 44.861 muertos por armas de fuego en 2014 (WAISELFINZ, 2016).

En Belo Horizonte, un estudio realizado por el Centro de Estudios de Criminalidad y Seguridad Pública (CRISP) demostró que de los 81 aglomerados urbanos donde están las favelas de la ciudad, solo seis de ellos representaban clusters de violencia. En estas seis áreas marcadamente violentas, se observaron algunas características comunes, como: el acabamiento de las casas ocho veces inferior al existente en las otras regiones, número promedio de años de estudio entre los residentes tres años inferior $(5,53$ contra 8,51), edad promedio de la población más baja que las demás regiones (25 años contra 29), tasa mayor de ocupación informal, peores indicadores de mortalidad infantil y de analfabetismo. De una manera general, los indicadores de protección social eran equivalentes a $1 / 3$ de las otras regiones de la ciudad.

No podemos, entonces, con redobladas excusas, ignorar que algunos factores de violencia y criminalidad se presentan con más intensidad en comunidades pobres de las grandes ciudades que en otras regiones de menor vulnerabilidad. Y, a partir de esa circunstancia, buscar entender las dinámicas de vida que llevan una parcela valiosa de nuestra juventud, en la flor de los 20 años de edad, en su mayoría de sexo masculino, negros, poco instruidos y residentes de las periferias de los grandes centros, a encontrarse en las estadísticas que se mencionaron antes.

Un buen punto de partida sería aceptar la premisa de que, la mayoría de las veces - no como regla absoluta, el ingreso al mundo de la criminalidad ocurre aún en la adolescencia, más acentuadamente entre los 15 y 17 años de edad, situación observada en Brasil y en la mayoría de los países, independientemente del grado de desarrollo. Entonces, estamos hablando de una trayectoria que se inicia y se acentúa entre los 15 y 17 años de edad y, para muchos, termina con la prisión o la muerte violenta en la franja de los 21 años de edad, o antes. 
Otro aspecto que se debe considerar es el hecho de que la criminalidad relevante involucra predominantemente dos tipos de crímenes principales: el robo y el tráfico de drogas. Esto porque, la mayoría de las veces, es la iniciación en esos dos tipos penales - casi siempre guiados por la mano de adultos, que lleva a los adolescentes a una especie de progresión criminal, culminando con el acceso precoz a las armas de fuego y con la práctica de conductas cada vez más graves, hasta el trágico desenlace en la famosa tríada cajón, cárcel o silla de ruedas.

En ese sentido, las estadísticas del sistema de prisión brasileño (MINISTÉRIO DA JUSTIÇA; DEPEN, 2014), afirman que, en 2014, más de la mitad de la población carcelaria brasileña estaba presa por tráfico de drogas $(28 \%)$ o robo $(25 \%)$, siendo razonable pensar que una buena parcela de los que estaban presos por homicidio (13\%) también habían cometido sus crímenes debido a que estaban involucrados con organizaciones criminales especializadas en robos y tráfico de drogas.

Para conocer mejor y tratar ese recorte, más allá de los factores sociales y territoriales, nos parece necesario investigar las razones subjetivas que llevan a los adolescentes a iniciar una trayectoria de infracciones.

Continuaremos esta reflexión hablando un poco más sobre la práctica criminal que, indudablemente, es uno de los mayores flagelos de los días actuales, en todo el mundo y especialmente en América Latina: el tráfico de drogas.

Una buena ilustración sobre ese tema se encuentra en la obra Falcão - Meninos do Tráfico (BILLATHAYDE, 2006), que presenta un vívido relato sobre los bastidores de la producción de un documental sobre el universo de los adolescentes - y hasta niños - que trabajaban para traficantes de drogas en todo el país, entre 1998 y 2006. En ese proyecto, los autores hicieron contacto con traficantes de las mayores ciudades del país y visitaron las bocas de fumo de las principales "favelas", en una inmersión en la que testimoniaron todo tipo de actividad relacionada al tráfico de drogas, desde la preparación de la droga para la venta hasta la ejecución de traficantes rivales. El libro fue dedicado al joven Força, único sobreviviente de los 17 seleccionados para el proyecto, información ésta que, por sí sola, ya dice mucho sobre las estadísticas de muertes por armas de fuego en Brasil. 
En las transcripciones de las entrevistas realizadas con varios adolescentes y jóvenes, podemos identificar factores apuntados por ellos, directa o indirectamente, como "pretextos" para el ingreso en el tráfico de drogas: autoridad parental muy frágil o inexistente; padre muerto o ausente; abandono material e intelectual (evasión escolar); falta de perspectivas; falta de qué hacer; deseo de ser aceptado en determinado grupo con el cual se identifica; deseo de alcanzar estatus y respeto en la comunidad; acceso a dinero y a bienes de consumo.

Moreira, Guerra y Costa (2012), en un trabajo de campo para la investigación cualitativa titulada $A$ construção do laço social de jóvenes moradores de territórios com alto indice de criminalidade violenta (La construcción del lazo social de jóvenes residentes en territorios con alto indice de criminalidad violenta), entrevistaron a 13 jóvenes de un aglomerado en Belo Horizonte, identificaron en los relatos de esos jóvenes el reconocimiento de algunos de los factores ya mencionados: el factor económico, el no tener qué hacer, el consumismo, la falta de oportunidades y el hedonismo (consumo de drogas). Al entender de los autores (MOREIRA; GUERRA; COSTA, 2012, p. 407), estas categorías confieren a los jóvenes una especie de justificativa ideológica para el ingreso a la criminalidad, como podemos percibir en el fragmento transcrito a continuación:

[...] Sin vislumbrar chances de competir por los caminos legales en la carrera supuestamente meritocrática que permite el acceso a los bienes, a la visibilidad y, luego, al reconocimiento social según las exigencias de la sociedad de consumo, nada más seductor que el tráfico de drogas, con sus promesas de lucro rápido y estatus (visibilidad y reconocimiento), aunque por vías oblicuas.

[...] Pero, es por ese mismo proceso que, en un circuito perverso, terminan por ser tomados por el sistema penal, pronto para acogerlos en sus mallas punitivas y, así, confirmar su estatus de marginalizados, de socialmente excluidos.

La cuestión es que el reclutamiento de niños, adolescentes y jóvenes vulnerables por el tráfico de drogas, cuando no los lleva a la muerte o al sistema penal, de cualquier forma acarrea enormes perjuicios al desarrollo saludable de esos individuos, ya que la actividad del tráfico, como también la explotación sexual comercial, el trabajo en las calles y el trabajo infantil doméstico, se insiere entre las peores formas de explotación de trabajo infantil, de acuerdo con la Convención n. ${ }^{\circ} 182$ de la Organización Internacional del trabajo, reglamentada en Brasil por el Decreto Federal n. ${ }^{\circ} 6.481$, del 12 de junio de 2008. 
Alberto, Pessoa, Malaquias y Costa (2020, p. 133) señalan que por causa del trabajo precoz

[...] los niños y adolescentes dejan de frecuentar la escuela, por tener que asumir las responsabilidades del trabajo realizado o por el cansancio de las largas jornadas o de las actividades que exigen un gran esfuerzo físico y son repetitivas. Después, la actividad principal que pasa a guiar el desarrollo de esos sujetos no es la del estudio, responsable por la transmisión de los conocimientos sistematizados y por la formación de los conceptos científicos, que amplía la capacidad de comprensión de la realidad y formación de la consciencia, sino que pasa a ser la del trabajo, realizado en condiciones que obstaculizan el desarrollo integral de los sujetos.

Es una realidad perversa donde, primero, la ausencia de políticas públicas eficaces de protección a la primera infancia contribuye para el solapamiento de varios derechos fundamentales básicos de los niños de las comunidades más vulnerables, y después, cuando al llegar a la adolescencia y juventud deben enfrentar una nueva etapa de negligencia, por falta de políticas adecuadas, no solo de educación regular y apoyo a la familia, sino también de deportes, cultura, ocio, profesionalización e ingreso protegido en el mundo del trabajo. Esa sucesión de negligencias es la que permite, y a veces hasta empuja, a muchos de estos individuos para el trabajo en el tráfico.

En este contexto, asume especial relevancia el esfuerzo realizado en Brasil, en los últimos años, para erradicar al trabajo infantil en todas sus formas y, ahora, con una mirada más atenta al desafío de enfrentar la explotación por el tráfico de drogas, cuya complejidad parece exigir estrategias específicas.

Una posibilidad prometedora, sería ampliar la oferta de programas de aprendizaje y cursos de calificación profesional adaptados para el público juvenil más vulnerable, considerando el desfasaje escolar e, incluso, la necesidad de superación de prejuicios, para que esos adolescentes y jóvenes, incluso aquellos involucrados con el tráfico, tengan acceso a oportunidades que generalmente les son negadas.

No cuesta recordar que la Convención de las Naciones Unidas sobre los Derechos del Niño, adoptada en 1989 por la Organización de las Naciones Unidas (ONU), prevé en su artículo 32 que:

Los Estados Partes reconocen el derecho del niño de estar protegido contra la explotación económica y contra el desempeño de cualquier trabajo que pueda ser peligroso o interferir en su educación, o que sea nocivo para su salud o para su desarrollo físico, mental, espiritual, moral o social. 
En Brasil, la Constitución de la República de 1988 reconoce la profesionalización como uno de los derechos fundamentales de todo adolescente (artículo 227), que debe ser garantizado con absoluta prioridad, observadas las restricciones establecidas en el artículo 7o, inciso XXXIII, en la redacción dada por la Enmienda Constitucional n. ${ }^{\circ} 20$, de 1986, cuales sean la prohibición de cualquier trabajo a personas con edad inferior a 16 (dieciséis) años, salvo en la condición de aprendiz, a partir de los 14 (catorce) años; y prohibición de trabajo nocturno, peligroso o insalubre a personas con edad inferior a 18 (dieciocho) años (BRASIL, 1988).

A su vez, el Estatuto del Niño y del Adolescente (ECA) (BRASIL, 1990) reafirma en su artículo $4^{\circ}$ el Principio de Protección Integral y reitera ser "deber de la familia, de la comunidad, de la sociedad en general y del Poder Público asegurar, con absoluta prioridad, la efectivización de los derechos referentes a la vida, a la salud, a la alimentación, a la educación, al deporte, al ocio, a la profesionalización, a la cultura, a la dignidad, al respeto, a la libertad y la convivencia familiar y comunitaria" (negrita añadida).

La profesionalización es, por lo tanto, un derecho que debe ser asegurado a todo adolescente y joven. Para eso, es imprescindible que la sociedad brasileña se movilice para defender y fortalecer institutos como Aprendizaje Profesional, por el cual los establecimientos de cualquier naturaleza son obligados a emplear y matricular en los cursos de los Servicios Nacionales de Aprendizaje, número de aprendices equivalente a cinco por ciento, como mínimo, y quince por ciento, como máximo, de los trabajadores existentes en cada establecimiento, cuyas funciones demanden formación profesional (BRASIL, 1943; 2000, artículo 429).

Otro mecanismo fundamental para generar oportunidades para el público juvenil más vulnerable es el llamado "medio alternativo de cumplimiento de la cuota”, que prioriza la contratación de adolescentes y jóvenes en situación de vulnerabilidad social, conforme ejemplificado en el $\int 5 .^{\circ}$ del artículo 66 del Decreto n. ${ }^{\circ} 9.579 / 2018$ :

[...] adolescentes distanciados del sistema socioeducativo o en cumplimiento de medidas socioeducativas; jóvenes en cumplimiento de pena en el sistema carcelario; jóvenes y adolescentes cuyas familias sean beneficiarias de programas de transferencia de renta; jóvenes y adolescentes en situación de acogida institucional; jóvenes y adolescentes que salieron del trabajo infantil; jóvenes y adolescentes con deficiencia; jóvenes y adolescentes matriculados en institución de enseñanza de la red pública, en el nivel fundamental, medio regular 
o medio técnico, incluida la modalidad de educación de Jóvenes y Adultos; y jóvenes desempleados y con enseñanza fundamental o media concluida en institución de enseñanza de la red pública.

Entre estos, la Comisión de la Infancia y Juventud del Consejo Nacional del Ministerio Público (CNMP), por medio de un grupo de trabajo instituido para proponer estrategias para la articulación nacional del Ministerio Público con la intención de ampliar el acceso de adolescentes y jóvenes a los programas de aprendizaje y enseñanza profesionalizante, indicó tres situaciones en las que garantizar el derecho a la profesionalización se torna una tarea aún más desafiadora, dichas son los adolescentes en cumplimiento de medidas socioeducativas - gran parte de ellos involucrados con el tráfico de drogas -, los que salieron del trabajo infantil y los adolescentes en situación de acogida institucional.

El referido Grupo de trabajo produjo la publicación "Profesionalización y Trabajo Protegido: Subsidios para la Actuación del Ministerio Público en la Promoción del Acceso de Adolescentes y Jóvenes en Condición de Vulnerabilidad en Programas de Aprendizaje y Cursos de Calificación Profesional" (CNMP, 2019), con el objetivo de incentivar y contribuir para la actuación de las Fiscalías de Justicia de Defensa de los Derechos del Niño y del Adolescente y Fiscalías de Trabajo para promover los derechos a la escolarización y profesionalización de adolescentes y jóvenes que se encuentren en las tres situaciones mencionadas, con la siguiente justificativa:

[...] esta actuación interinstitucional debe contemplar medidas que tengan por objetivo asegurar el derecho a la formación profesional de adolescentes y jóvenes por medio de contratos de aprendizaje, priorizando a los adolescentes y jóvenes en situación de vulnerabilidad y de riesgo social, en especial a los que cumplen medidas socioeducativas, a los que están acogidos y a aquellos en situación de trabajo infantil.

La complejidad de la tarea se potencializa en función del perfil de escolaridad de este público, dada la fuerte correlación entre escolarización y éxito profesional. La situación se agrava con el prejuicio y la representación social que sabemos que existe sobre adolescentes y jóvenes autores de actos de infracción, contribuyendo para hacerlos invisibles y aislarlos socialmente.

Hay necesidad, incluso, de establecer una agenda positiva para sensibilizar al mercado de trabajo, con el objetivo de superar las prácticas selectivas que agudizan la exclusión de esta parte de nuestra juventud, cuando ella se presenta para introducirse en él. (CNMP, 2019, p. 9).

$\mathrm{Al}$ incentivar la actuación conjunta entre los Ministerios Públicos de los Estados y del Distrito Federal y el Ministerio Público del Trabajo (MPT), 
el CNMP reconoce que asegurar el acceso de adolescentes y jóvenes a programas de aprendizaje y cursos profesionalizantes va más allá de la garantía de un derecho a todos reconocido, siendo también una forma de prevenir la cooptación y la explotación de individuos vulnerables por el tráfico de drogas o de tratar de rescatar aquellos que ya han sido cooptados.

Es importante señalar que el MPT ha actuado desde hace más de 20 años contra la explotación del trabajo infantil, continuamente y de forma articulada, especialmente por medio de su Coordinación Nacional de Combate contra la Explotación del Trabajo de Niñas, Niños y Adolescentes (Coordinfância). Ese esfuerzo se articula con la importante actuación de la Inspección del trabajo en Brasil y con otras iniciativas como el Fórum de Erradicación y Combate al Trabajo Infantil y Protección al Adolescente Trabajador (FECTIPA), el Fórum Nacional de Prevención y Erradicación del Trabajo Infantil (FNPETI), la Organización Internacional del Trabajo (OIT), el Programa de Erradicación del Trabajo Infantil (PETI) y el Programa de Promoción del Acceso al Mundo del Trabajo (ACESSUAS trabajo), estos últimos integrantes de la Política Nacional de Asistencia Social.

La articulación en red es fundamental para asegurar oportunidades de educación profesional a adolescentes y a jóvenes en situación de vulnerabilidad y para el enfrentamiento a las peores formas de trabajo infantil, exigiendo la participación de diversos actores públicos y de la sociedad civil, especialmente empresas, Sistema " $\mathrm{S}$ " y demás entidades calificadoras, órganos del Sistema de Justicia y gestores de policías sociales públicas, en todos los niveles.

Y la ampliación de la oferta de tales oportunidades, a lo largo de los años, al mismo tiempo de asegurar el derecho fundamental para esos adolescentes y jóvenes, ciertamente se revelará un importante factor de reducción de los actuales índices de letalidad y aprisionamiento de adolescentes y jóvenes de las periferias brasileñas.

Todo eso considerado, seguimos hacia la conclusión diciendo que Brasil necesita urgentemente hacer más y mejores inversiones en políticas para la infancia y la juventud, con énfasis en las comunidades periféricas más vulnerables socioeconómicamente, de modo de asegurar el desarrollo saludable de todo niño, adolescente y joven que vive en ellas, acceso a la educación de calidad, incluso en la enseñanza infantil, además de buenos programas de 
cultura y deportes, y mecanismos para facilitar el derecho a la profesionalización y al ingreso protegido del joven en el mercado de trabajo.

\section{NOTA}

1 Este número comprendía también 147.937 personas presas en régimen domiciliario.

\section{REFERENCIAS}

ALBERTO, Maria de Fatima Pereira, PESSOA, Manuella Castelo Branco, MALAQUIAS, Thiago Augusto Pereira e COSTA, Cibele Soares da Silva. Trabalho Infantil e Ato Infracional: Análise Histórico-Cultural do desarrollo Infantojuvenil. In: Revista da SPAGESP, vol. 21, n. ${ }^{\circ}$ 1, jan./jun. 2020 Sociedade de Psicoterapias Analíticas Grupais do Estado de São Paulo, São Paulo, 2020.

BILL, MV e ATHAYDE, Celso. Falcão - Meninos do Tráfico. Rio de Janeiro: Objetiva, 2006.

BRASIL. Decreto-Lei n. $^{\circ} \mathbf{5 . 4 5 2}$, de $\mathbf{1}^{\circ}$ de maio de 1943 . Consolidação das Leis do trabalho. Rio de Janeiro, maio 1943. Disponible en: http://www.planalto.gov.br/ccivil_03/decreto-lei/del5452.htm. Acceso: 14 oct. 2020.

BRASIL. Constituição da República Federativa do Brasil. Brasília, DF: Senado, 1998.

BRASIL. Lei Federal n..$^{\circ}$ 8.069, de 13 de julho de 1990. Dispõe sobre o Estatuto da criança e do adolescente. Brasília/DF, jul., 1990. Disponible en: http://www.planalto.gov.br/ccivil_03/leis/18069.htm. Acceso: 14 oct. 2020.

BRASIL. Lei $\mathbf{n} .^{\circ} \mathbf{1 0 . 0 9 7}$, de 19 de dezembro de 2000. Altera dispositivos da Consolidação das Leis do trabajo. Brasília/DF, set., 1990. Disponible en: http://www.planalto.gov.br/ccivil_03/leis/110097.htm. Acceso: 14 oct. 2020.

CNJ - CONSELHO NACIONAL DE JUSTIÇA. Novo Diagnóstico das Pessoas Presas no Brasil. Brasília, 2014. Disponible en: http://www.cnj. jus.br/images/imprensa/pessoas_presas_no_brasil_final.pdf. Acceso: 24 abr. 2020.

CNMP - CONSELHO NACIONAL DO MINISTÉRIO PÚBLICO. Profissionalização e Trabalho Protegido: Subsídios para a Atuação do Mi- 
nistério Público na Promoção do Acesso de Adolescentes e Jovens em Condição de Vulnerabilidade em Programas de Aprendizagem y Cursos de Qualificação Profissional. Brasília, 2019. Disponible en: https:// www.cnmp.mp.br/portal/images/Publicacoes/documentos/2019/PROFISSIONALIZA $\%$ C3\%87\%C3\%83O_E_trabajo_PROTEGIDO_CNMP. pdf. Acceso: 30 jun. 2020.

CURY, Munir. A Mutação Jurídica. In: Brasil Criança Urgente: a Lei 8069/90. São Paulo: Columbus Cultural Editora, 1990. Coleção Pedagogia Social, vol. 3.

GUERRA, Andréa Máris Campos; MARTINS, Aline Souza; CANUTO, Luiz Gustavo Gonçalves. A guerra do tráfico como sistema de vida para adolescentes autores de ato infracional. In: Revue Culture-Kairós - Revue d'Anthropologie des practiques corporelles et des arts vivants. Paris, 2015.

IBGE - INSTITUTO BRASILEIRO DE GEOGRAFIA E ESTATÍSTICA. Censo Demográfico 2010: Aglomerados Subnormais: Informações territoriais. Rio de Janeiro, 2010. Disponible en: http://fw.atarde.uol.com. br/2013/11/1367185.pdf. Acceso: 27 abr. 2020.

INSTITUTO DE PESQUISA ECONÔMICA APLICADA; FÓRUM BRASILEIRO DE SEGURANÇA PÚBLICA (IPEA/FBSP). Atlas da Violência 2016. Brasília, 2016. Disponible en: http://www.ipea.gov.br/atlasviolencia/download/19/atlas-da-violencia-2019. Acceso: 27 abr. 2020.

INSTITUTO DE PESQUISA ECONÔMICA APLICADA; FÓRUM BRASILEIRO DE SEGURANÇA PÚBLICA (IPEA/FBSP) [org.]. Atlas da Violência 2019. Brasília, Rio de Janeiro, São Paulo: IPEA; FBSP, 2019. Disponible en: https://www.ipea.gov.br/portal/index.php?option=com_ content\&view $=$ article\&id=34784.pdf. Acceso: 27 abr. 2020.

MINISTÉRIO DA JUSTIÇA; SNASP. Guia para a Prevenção do Crime da Violência nos Municípios. Brasília, 2006. Disponible en https://www. justica.gov.br/sua-seguranca/seguranca-publica/analise-e-pesquisa/download/outras_publicacoes/pagina-1/9guiaprevencao2005.pdf. Acceso: 25 abr. 2020 .

MINISTÉRIO DO JUSTIÇA; DEPEN. Levantamento Nacional de Informações Penitenciárias - INFOPEN 2014. Brasília, 2015. Disponible en: 
http://www.justica.gov.br/seus-direitos/politica-penal/transparencia-institucional/estatisticas-prisional/levantamento-nacional-de-informacoes-penitenciarias. Acceso: 24 abr. 2020.

MOREIRA, Jacqueline Oliveira; GUERRA, Andréa Máris Campos; COSTA, Domingos Barroso. Pós-Modernidade e Mercado Informal de Drogas Ilegais. O Jovem na Criminalidade. In: Revista Mal-estar e Subjetividade, Fortaleza, vol. XII, n. 1-2, mar./jun. 2012. Disponible en: http://www.redalyc.org/pdf/271/27129925014.pdf. Acceso: 27 abr. 2020.

NAVES, Rubens. Justiça para crianças e jovens. In: PINSKY, Jaime. Práticas de Cidadania. São Paulo: Editora Contexto, 2004.

ORGANIZAÇÃO DAS NAÇÕES UNIDAS. Convenção sobre os direitos da criança Adotada pela Assembleia Geral das Nações Unidas, em 20 de novembro de 1989, e promulgada pelo Brasil através do Decreto n. ${ }^{\circ} 99.710$, de 21 de novembro de 1990. Disponible en: https://www.unicef.org/brazil/ convencao-sobre-os-direitos-da-crianca. Acceso: 28 jun. 2020.

ORGANIZAÇÃO INTERNACIONAL DO TRABALHO. Convenção n. ${ }^{\circ 182}$. Dispõe Sobre a prohibición das Piores Formas de trabajo Infantil e Ação Imediata para sua Eliminação. Disponible en: https://www.ilo.org/ brasilia/convencoes/WCMS_236696/lang--pt/index.htm. Acceso: 28 jun. 2020.

WAISELFISZ, Julio Jacobo. Mapa da Violência 2016. Homicídios por Armas de Fogo no Brasil. Rio de Janeiro: FLACSO, 2016. Disponible en http:/ / www.mapadaviolencia.org.br/. Acceso: 27 abr. 2020. 


\section{LA EXPLOTACIÓN SEXUAL COMERCIAL DE NIÑOS Y ADOLESCENTES COMO UNA DE LAS PEORES FORMAS DE TRABAJO INFANTIL}

\section{MARGARET MATOS DE CARVALHO}

DOI: $10.51366 / 978-65-89468-10-3$-coordinfancia-18

Resumen. Aunque en el pasado las estrategias de lucha contra la violencia sexual se han concentrado en el sistema de Justicia Penal, la explotación sexual comercial de niños y adolescentes, insertada en el concepto de violencia sexual, pasa también a interesar al Sistema de Defensa y Protección de los Derechos Laborales, en virtud de la ratificación por Brasil de la Convención n. ${ }^{\circ} 182$ de la Organización Internacional del Trabajo, que la considera una de las peores formas de explotación de trabajo infantil, atrayendo así la plena atribución del Ministerio Público del Trabajo.

Palabras clave: Trabajo infantil. Explotación Sexual Comercial de Niños y Adolescentes. Atribuciones del Ministerio Público del Trabajo.

\section{INTRODUCCIÓN}

Abordar el tema de la explotación sexual comercial de niños y adolescentes (ESCCA) es una tarea difícil, no sólo por el dolor que causa a las víctimas, que las marca, sino también por la escasez de datos estadísticos, por el tabú que dificulta el necesario diálogo para el debido enfrentamiento de sus causas y consecuencias y por la falta de reconocimiento de que este tipo de violencia sexual es también una de las peores formas de trabajo infantil.

Según UNICEF (2019), la violencia sexual, una de las que más deja marcas psicológicas dañosas, golpea en todo el mundo, alrededor de $15 \mathrm{mi}$ llones de adolescentes de 15 a 19 años. Los datos de 28 países indican que 
nueve de cada diez adolescentes que fueron víctimas informan que el autor de la primera violación fue alguien cercano o conocido. En Brasil, el 70\% de las notificaciones de víctimas de violación se refieren a niños y adolescentes.

En 2019, la ONU lanzó un informe (UNODOC, 2018) que reveló que la trata de personas está avanzando en el mundo, con la explotación sexual de las víctimas como la principal causa detrás del fenómeno. Según este estudio, que analizó datos de 142 países, los niños representan el 30\% de todos los individuos traficados, con el número de niñas afectadas siendo mucho mayor que el de niños. Para niñas y niños, se detectó un patrón diferente. Aunque los niños sean en su mayoría víctimas de la trata de trabajo forzado $(50 \%)$, muchos también son víctimas de explotación sexual $(27 \%)$ y otras formas de explotación, como mendicidad forzada, reclutamiento en tropas y grupos armados y actividades delictivas forzadas. Las niñas fueron víctimas de explotación sexual en el $72 \%$ de los episodios analizados.

También de acuerdo con el mismo informe, la trata de personas en Brasil alcanza cerca de 2,5 millones de víctimas, y anualmente, obtiene un beneficio promedio de 32 mil millones de dólares, del cual 85\% provienen de la explotación sexual. El mismo texto señala que, en un estudio realizado entre los años 2005 y 2011, de las cerca de 475 víctimas del tráfico de personas identificadas por el Ministerio de Relaciones Exteriores, 337 sufrieron explotación sexual.

En Brasil, la principal fuente de informaciones estadísticas sobre violencia sexual es el Disque 100 (MDH, 2018), que es un servicio de cobertura nacional y gratuito. Recibe denuncias de violencia sexual practicadas contra niños y adolescentes y las encamina a las autoridades competentes, preservando el anonimato de la autoría de las conexiones.

Según el Disque 100, si sumamos solamente cuatro años (de 2012 a 2016) de denuncias hechas (53.151), y consideramos las estimativas del canal de denuncia, llegaremos a un promedio aterrador de niños explotados sexualmente en Brasil de 513 víctimas cada 24 horas. Según el Disque 100 sólo 7 de cada 100 casos son notificados, es decir, la sub-notificación es espantosa.

Importante hay que considerar que la explotación sexual comercial de niños y adolescentes es transnacional. Según encuesta realizada con ocasión de la realización de la Copa del Mundo de 2014 en Brasil por la ECPAT Inter- 
nacional (2017), fueron registradas situaciones de explotación sexual comercial de niños y adolescentes en 18 ciudades gemelas, así como en 173 municipios de fronteras, en 46 municipios línea de frontera y en 12 ciudades sede.

Como demuestran los datos anteriores, la explotación sexual comercial de niños y adolescentes es una triste realidad alrededor del mundo y, ante su gravedad y complejidad, los países miembros de las Naciones Unidas promovieron la organización de tres Congresos Mundiales, siendo el último de ellos realizado en Brasil en 2008.

El I Congreso Mundial contra la Explotación Sexual Comercial de niños y Adolescentes fue realizado en 1996, en la ciudad de Estocolmo (declaración, 1998), en el cual fue aprobada la Declaración de Estocolmo, que contempla el concepto de lo que es la Explotación Sexual Comercial de Niños y Adolescentes y establece una Agenda para la acción, con estrategias y planes de acción a ser desarrollados por los Estados. El II Congreso fue realizado en diciembre de 2001, en Yokohama/Japón, donde se firmó el Compromiso Global de Yokohama. Y, finalmente, el III Congreso Mundial se celebró en Río de Janeiro en 2008, cuando se aprobó la Declaración de Río de Janeiro y el llamado a la acción para Prevenir y Eliminar la explotación Sexual de Niños y Adolescentes (DECLARACIÓN, 2008). En este último Congreso, por primera vez, hubo la posibilidad de la participación efectiva de adolescentes, dándoles voz, lo que resultó en la Declaración de los Adolescentes para Eliminar la Explotación Sexual, documento anexo a la Declaración de Río de Janeiro.

La realización de los congresos mundiales arriba referidos trajo el tema de la explotación sexual comercial de niños y adolescentes a la luz, no solo definiendo conceptos, pero principalmente indicando estrategias y políticas públicas de prevención y enfrentamiento. La visibilidad que el tema ganó a partir de los eventos mencionados hizo posible la construcción de un nuevo modo de pensar el problema e indicar soluciones, imponiendo a los países signatarios la incorporación de las declaraciones que fueron elaboradas al final de cada evento, las cuales se equipararon a tratados de derechos humanos y se incorporan al conjunto normativo de cada país, imponiendo la adopción de esos compromisos globales. 


\section{VIOLENCIA SEXUAL CONTRA NIÑOS Y ADOLESCEN- TES Y EVOLUCIÓN HISTÓRICO NORMATIVA}

Como se observa, es a partir de la década de 1990 que el fenómeno de la violencia sexual contra niños y adolescentes pasa a tener mayor visibilidad. $\mathrm{Y}$, en este sentido, las asambleas mundiales celebradas revisten vital importancia, especialmente cuando el último de ellos tuvo lugar en Brasil y en él se permitió a los adolescentes que participaran no sólo como oyentes, sino que también tuvieran voz, principio preconizado en el artículo 16 del Estatuto del Niño y del Adolescente, lo que dio ocasión a la aprobación de la Declaración de los Adolescentes para Eliminar la Explotación Sexual por primera vez en la historia de las asambleas mundiales.

La aprobación del Estatuto del Niño y del Adolescente, a su vez, que se dio por medio de la Ley n. ${ }^{\circ} 8.069 / 1990$, trajo grandes alteraciones en el campo normativo, con considerables avances y conquistas, notablemente en cuanto a un conjunto de normas protectoras contra todo tipo de violencia, incluyendo la violencia sexual (BRASIL, 1990). Los niños y adolescentes pasaron a ser considerados sujetos de derechos, rompiendo con la doctrina de la situación irregular, y protegiendo la condición peculiar de personas en desarrollo, con prioridad absoluta en su atención y destinatarios de la protección integral por parte no sólo de la familia, sino también y principalmente del Estado y de la sociedad.

Es también en esta década que ocurre el proceso de globalización económica, que, al avanzar en Brasil, acentuó la exclusión y las desigualdades sociales, que ya eran extremadamente críticas, alcanzando perversamente los segmentos más vulnerables, especialmente los niños y los adolescentes pertenecientes a las capas más pobres. Son estos niños y adolescentes los que se convertirán en las mayores víctimas de la explotación sexual comercial, aunque la pobreza y la miseria no sean las únicas condicionantes. La globalización económica se caracteriza por la hegemonía capitalista y presenta como características marcantes el desempleo, la pobreza y las desigualdades sociales en elevada escala, lo que hemos comprobado de modo agudo en el año en que el mundo es golpeado por una pandemia que desnuda y desvela la fragilidad de los países subdesarrollados para hacer frente a la gravedad de la enfermedad Covid-19, sea en lo que se refiere a políticas públicas de protección a la salud, sea en relación a políticas públicas de protección de empleos o de ayuda de 
emergencia a las familias empobrecidas por la crisis económica que se profundizó en razón de la pandemia.

A partir de 1993 se instituyen algunos hitos históricos del enfrentamiento del abuso sexual contra los niños y adolescentes en Brasil. En junio de ese mismo año se elabora el informe de la Primera Comisión Parlamentaria Mixta de Investigación (CPMI) para investigar las redes de explotación sexual de niños y adolescentes, trayendo a la superficie numerosos casos de violación de los derechos de niños y adolescentes y evidenciando la falta de políticas sociales básicas y de atención a las víctimas (SENADO, 2005).

Desde el I Congreso Mundial, el movimiento social en defensa de derechos del niño y del adolescente realiza esfuerzos en el sentido de avanzar la discusión de políticas públicas de enfrentamiento al problema. En este sentido, se debe resaltar el encuentro realizado en la ciudad de Natal-RN, en junio de 2000, ocasión en que fue elaborado el Plan Nacional de Enfrentamiento de la Violencia Sexual Contra Niños y Adolescentes. Dicho documento fue analizado por el Consejo Nacional de los Derechos de los Niños y de los Adolescentes $(\text { CONANDA })^{1}$, que deliberó por su adopción como referencia única para las políticas públicas en el tratamiento a la cuestión de la violencia sexual contra niños y adolescentes.

Otro hito relevante es el compromiso por la erradicación de la violencia sexual expresado a partir de la realización de la IV Conferencia Nacional de los Derechos de los Niños y de los Adolescentes, en noviembre de 2001, que ratifica y recomienda la adopción del Plan Nacional de Enfrentamiento a la violencia Sexual Infanto-Juvenil.

Los consejos de derechos son instancias deliberativas de la mayor importancia, inaugurados por la Constitución Federal de 1988 para las áreas de la salud, educación y asistencia social, que descentralizó la formulación, la ejecución y el control social de políticas públicas, permitiendo así la participación de la sociedad civil organizada y el tan deseado control social. A partir de ahí, muchos otros consejos fueron creados para diferentes e importantes áreas, como los Consejos de Derechos de los Niños y de los Adolescentes, en las tres esferas de gobierno, previstos en el Estatuto del Niño y del Adolescente. 
Una de las acciones más importantes de los Consejos de Derechos es la promoción de la participación de la sociedad en la discusión y elaboración de propuestas de políticas públicas. Y es principalmente a través de las conferencias, organizadas por los Consejos, tanto en el ámbito municipal, estatal y federal, que se debaten y establecen las nuevas políticas públicas.

Desde 1995, cada dos años, el CONANDA y los consejos estatales y municipales han convocado sus conferencias, cada una con una temática, de acuerdo con la situación vivida en el período. La I y la II Conferencias Nacionales eligieron tema Niños y Adolescentes - Prioridad Absoluta. La pertinencia de la elección es innegable, considerando que hasta los días actuales todavía es necesario discutir y analizar el alcance de este principio, previsto en el artículo 227 de la Constitución Federal, y regulado por el Estatuto del Niño y del Adolescente, notablemente en su artículo $4^{\circ}$ (BRASIL, 1988; 1990). La III Conferencia Nacional eligió el tema Niños y Adolescentes: una década de historia hacia el tercer milenio. Y la IV Conferencia, considerando los datos alarmantes de violencia contra niños y adolescentes, trató el tema violencia, trayendo como lema Violencia es cobardía y las Marcas permanecen en la sociedad. La IV Conferencia tuvo como objetivo general "promover una amplia reflexión sobre la infancia y la adolescencia y su relación con la violencia, a fin de señalar caminos y definir proposiciones que reviertan la realidad vigente y contribuyan para la mejoría de la calidad de vida infanto-juvenil". En esta conferencia se puso en marcha el Pacto por la Paz (PACTO, 2020).

A pesar de todos los esfuerzos realizados, la organización y la realización de los congresos locales, estatales y nacionales, se puede afirmar que, en la actualidad, aún no logramos el desarrollo de políticas públicas que promuevan la transformación social, comprometida con nuestra Constitución y con el Estatuto del Niño y del Adolescente, en lo que se refiere a la totalidad de los derechos garantizados en el artículo 227 de la Constitución Federal (BRASIL, 1988), pero, muy especialmente, en relación con las cuestiones más complejas y en las que puedan causar daños irreversibles a los niños y a los adolescentes, cuando sean víctimas por ejemplo, de la explotación sexual comercial de niños, niñas y adolescentes.

Esa realidad sigue atormentándonos, porque, en parte, la violencia sexual, como fenómeno social, económico y cultural de naturaleza compleja y multifacética, dificulta cualquier abordaje y exige una mirada crítica basada en las ciencias humanas, capaz de descortinar las contradicciones que envuel- 
ven el fenómeno. La realidad ya no puede seguir siendo ocultada, tampoco ignorada.

En ese sentido, de traer a la superficie y a la discusión el tema de la violencia sexual, asume importancia la publicación de la Secretaría de Estado de Educación de Paraná (2009), la cual sobre el tema dispone que

la violencia y la sexualidad son categorías construidas históricamente. La sexualidad humana está relacionada, sobre todo, con las relaciones culturales y sociales. Siendo la sexualidad una construcción social es también fruto de relaciones contradictorias, donde género, raza y etnia, generaciones, represión y emancipación son categorías también determinantes.

Así, ya en 2004, la Red Estatal de Enseñanza Pública de Paraná buscó tratar de una temática que actualmente se transformó en una gran polémica, dividiendo opiniones, y que se originó de una parte de la sociedad representada por lo que hay de más retrasado y que amenaza introducir en Brasil un oscurantismo que sirve para mantener la dominación patriarcal, subyugando cuerpos y mentes de niños y adolescentes. Hay un movimiento encabezado por fanáticos religiosos y conservadores de varios matices que ha buscado retirar de los currículos escolares temas relacionados a sexualidad y género, a ejemplo del movimiento denominado Escuela sin Partido. ${ }^{2}$

Iniciativas que buscan llevar para la escuela discusión de temas que formen parte de la vida y que necesitan ser debatidos para despertar en las posibles víctimas - niños y adolescentes - mecanismos de protección, deben continuar siendo incentivadas, pues forma parte de la ciudadanía, como también protege niños y adolescentes de la violencia sexual - y por vía de consecuencia, de la explotación sexual comercial, incluida la violencia sexual practicada en el ámbito de la relación familiar.

La violencia es la categoría explicativa de la explotación y del abuso sexual de niños y adolescentes con relación al mercado, a la familia y a las instituciones. Y si nos negamos a establecer este diálogo en la escuela, o en cualquier otro espacio, restaremos de los niños y de los adolescentes la oportunidad de crecer y entender la realidad para, a partir de ahí, transformarla. 


\section{LA EXPLOTACIÓN SEXUAL COMERCIAL DE NIÑOS Y ADOLESCENTES COMO UNA DE LAS PEORES FORMAS DE TRABAJO INFANTIL ATRIBUCIONES DEL MINISTE- RIO PÚBLICO DEL TRABAJO}

La violencia sexual es definida por la Organización Mundial de la Salud (Naciones UNIDAS BRASIL, 2018) como

todo acto sexual, intento de consumar un acto o insinuaciones sexuales no deseadas; o acciones para comercializar o utilizar de cualquier otra manera la sexualidad de una persona a través de la coacción por otra persona, independientemente de la relación de ésta con la víctima, en cualquier ámbito, incluyendo el hogar y el lugar de trabajo.

Aunque en el pasado las estrategias para combatir la violencia sexual se hayan centrado en el sistema de Justicia Penal, actualmente hay un movimiento hacia un enfoque de salud pública que reconoce múltiples factores de riesgo. Estos agravantes interactúan a nivel individual, relacional, comunitario y social. En esta perspectiva, enfrentar la violencia sexual requiere la cooperación de varios sectores, como la salud, la educación, la asistencia social y la justicia penal. La salud pública busca ampliar la atención y la seguridad a toda la población y enfatiza la prevención, garantizando que las víctimas de violencia tengan acceso a servicios y apoyo adecuados.

En el campo de los derechos humanos, la violencia se comprende como toda violación de Derechos Civiles (vida, propiedad, libertad de ir y venir, de conciencia y de culto); políticos (derecho a votar y a ser votado, tener participación política); sociales (vivienda, salud, educación, seguridad); económicos (empleo y sueldo) y culturales (derecho a mantener y manifestar su propia cultura).

Ya la explotación sexual de niños y adolescentes, comprendida en el concepto de violencia sexual, en el ámbito del derecho del trabajo pasó a ser considerada una de las peores formas de explotación de trabajo infantil solamente a partir de la ratificación, por Brasil, del Convenio n. ${ }^{\circ} 182$ de la Organización Internacional del Trabajo. Tal Convención fue incorporada al ordenamiento jurídico interno por el Decreto Legislativo n. ${ }^{\circ}$ 178, de 14/12/1999, ratificado el $02 / 02 / 2000$ y promulgado por el Decreto Presidencial n. ${ }^{\circ} 3.597$, de 12/09/2000, pero con vigencia sólo a partir del 02/02/2001. En resumen: sólo a partir de 2001 Brasil pasa a reconocer que la explotación sexual 
comercial de niños y adolescentes debe ser combatida también como una de las peores formas de trabajo infantil, conforme artículo $3^{\circ}$, letra "b", de la Convención n. ${ }^{\circ}$ 182, atrayendo, así, la atribución del Ministerio Público del Trabajo y la competencia de la Justicia del Trabajo (BRASIL, 2019, Anexo LXVIII).

La violencia sexual de niños y adolescentes provoca graves daños físicos, emocionales y sociales y su entendimiento viene siendo construido a lo largo de los años con diversos actores de la comunidad nacional e internacional de protección, promoción y defensa de derechos de los niños y de los adolescentes, incluidos, también, los operadores del Derecho del Trabajo con relación a la explotación sexual comercial de niños y adolescentes.

Así siendo, la violencia sexual se expresa de dos formas - abuso y explotación sexuales -, es todo acto, de cualquier naturaleza, atentatorio al derecho humano al desarrollo sexual del niño y del adolescente, practicado por agente en situación de poder y de desarrollo sexual desigual en relación a las víctimas, niños y adolescentes.

La gran distinción entre el abuso sexual (y otros delitos sexuales relacionados) y la explotación sexual comercial de niños y adolescentes radica en el carácter mercadológico del crimen. En el abuso sexual y congéneres, no hay el objetivo de lucro, ganancia; ya en la explotación sexual comercial de niños y adolescentes, la relación de mercado, el sexo como moneda, valor de cambio es característica marcada, condición sine qua non. Tal venta puede ser por dinero, favores, regalos, servicios, chantaje, etc.

La explotación sexual comercial es una violencia sexual que se realiza en las relaciones de producción y mercado (consumo, oferta y excedente) mediante la venta de los servicios sexuales de niños y adolescentes por las redes de comercialización del sexo, por los padres o responsables legales, parientes, vecinos etc.

Esta práctica está determinada no sólo por la violencia estructural, que es principal determinante, sino también por la violencia social e interpersonal. Es resultado, además, de las transformaciones ocurridas en los sistemas de valores presentes en las relaciones sociales, como el patriarcalismo, el racismo y las desigualdades sociales, que se contraponen a la idea de emancipación social y económica, de las libertades culturales y de las sexualidades humanas. 
Todas esas transformaciones, especialmente económicas y de gobernanza, han provocado colapsos en el ámbito de las relaciones institucionales, sociales e interpersonales, generando impactos profundos, con el agravamiento de las desigualdades socioeconómicas, provocando exclusión no sólo desde el punto de vista económico, sino también de acceso a políticas públicas sociales; y, por otro, también han promovido el crecimiento de clases, género y orientación sexual; se suma, además, la ausencia de legitimidad del sistema estatal que no se ha dejado de promover la regulación social de la violencia estructural que impregna la sociedad contemporánea.

Se observa que la violencia toma diferentes significados y significantes, es decir, se revela en varios y múltiples espacios sociales, institucionales, de mercado y también en el imaginario social, lo que provoca el vaciamiento de las esferas colectivas de enfrentamiento y resistencia, agudizando las contradicciones y favoreciendo la aparición de nuevas y viejas formas de explotación basadas en la corrupción, en el crimen organizado, mercado clandestino, trata de personas y en la violencia social e interpersonal.

Este escenario de violencia señala para la ruptura de reglas sociales, consensos éticos y de valores y conductas humanas del sentido civilizatorio de la humanidad, sus orígenes, fundamentos y dificultades, tornando niños y adolescentes presas fáciles y desprotegidas.

La explotación sexual revela dos modalidades graves del crimen: la que ocurre en los circuitos en que operan las élites económicas y políticas (corrupción) y que se verifica en los circuitos en que transitan las clases subalternas; y en los circuitos geográficos con fines lucrativos y que tienen como telón de fondo el juego perverso de las relaciones socioeconómicas y culturales, donde la dualidad exclusión e inclusión es fundamental para estudiar este tipo de violencia, que confirma la valorización de poder y de disputa sin límites y una resistencia despolitizada. De esta modalidad, surge como respuesta el mercado violento de las drogas (narcotráfico), del sexo, tráfico (incluso el de niños y adolescentes), de las armas (contrabando), etc. La explotación del trabajo desaparece en este contexto de violaciones complejas y graves.

La explotación sexual comercial de niños y adolescentes se define en la Declaración de Estocolmo (declaración, 1998) como:

la explotación sexual comercial de niños y adolescentes es una violación fundamental de los derechos infanto-juveniles. Esta comprende el abuso sexual 
por parte de adultos y la remuneración en especie al niño, al adolescente, a una tercera persona o varias. El niño y el adolescente son tratados como un objeto sexual y una mercancía. La explotación sexual comercial de niños y adolescentes constituye una forma de coerción y violencia, que puede implicar el trabajo forzado y formas contemporáneas de esclavitud.

La explotación sexual perjudica los derechos fundamentales, desde el momento en que estos no están siendo respetados y garantizados. Además, la explotación sexual se coloca en el campo de la negación de un derecho inalienable: el de la soberanía y autonomía sobre la vida y sobre el propio cuerpo, que debe ser, por encima de cualquier hecho, protegido para el pleno desarrollo. Además, la sexualidad, en cuanto actividad sexual debe ser ejercida de forma igualitaria y simétrica, como una libre opción y no como una mercancía valorada por las órdenes económico-sociales (SANTOS, 2004).

En este sentido, la explotación sexual comercial se manifiesta en diferentes modalidades:

Prostitución: es una forma de explotación sexual comercial, aunque sea una opción voluntaria de la persona que está en esta situación. La prostitución femenina, en el mundo adulto, abre un campo para el debate sobre su naturaleza, donde intervienen diversas disciplinas (filosofía, ética, psicología, sociología y ciencias jurídicas). Los niños y los adolescentes, por su condición peculiar de desarrollo, y, por estar sometidos a las condiciones de vulnerabilidades y riesgo social, son considerados prostituidos (os) y no prostitutas (os). La prostitución consiste en una relación de sexo y mercantilización y en un proceso de transgresión, según el informe elaborado por el ECPAT (2017).

También es considerada una forma de esclavitud moderna y socialmente aceptada y hay quienes sostienen que esta profesión sufre de las mismas condiciones de subordinación y dependencia que cualquier otro trabajo, como así defendía Gabriela Leite, que presidió la Asociación Nacional de Prostitutas de Brasil, en entrevista concedida a la Revista Viração y publicado en el sitio otras palabras (REVISTA VIRAÇÃO, 2013).

Turismo sexual: es la explotación de adultos, niños y adolescentes por visitantes, en general, procedentes de países desarrollados, pero también de visitantes turistas del propio país, involucrando la complicidad, por acción directa u omisión de agencias de viajes, guías turísticos, hoteles, bares, restaurantes, botes, cafeterías, barracas de playa, camareros, porteros, Gasolinera, 
taxistas, prostíbulos, casas nocturnas y de masaje, además de la tradicional cafetería (ECPAT, 2017).

Tráfico con fines sexuales: de acuerdo con el Decreto n. ${ }^{\circ}$ 5.017/ 2004, que promulga en suelo nacional el Protocolo de Palermo, Art. $2^{\circ}$, letra "a",

[...] es el reclutamiento, el transporte, el traslado, el alojamiento o la recopilación de las personas, a través de la amenaza de las características de la fuerza u otras formas de coacción, al rapto, al fraude, engaño, abuso de autoridad o de una situación de vulnerabilidad o a través de la oferta o la aceptación de pagos o ventajas para obtener el consentimiento de una persona que tenga autoridad sobre otra, con fines de explotación (BRASIL, 2004).

Pornografía Infanto-Juvenil: se define como todo material audiovisual en el que se utilizan niños y adolescentes en un contexto sexual o, según Interpol (apud NASCIMENTO; SILVA, 2014), la "representación visual de la explotación sexual de un niño o adolescente, concentrada en la actividad sexual y en las partes genitales de ese niño o adolescente". Para los expertos que actualmente estudian la pornografía infantil y juvenil en internet, se trata de "una exposición sexual de imágenes de niños y adolescentes que incluyen fotografías implícitas, negativas, proyecciones, revistas, películas, videos y discos de computadora" (GOMES, 2004).

En este contexto, la cuestión de la explotación sexual de niños y adolescentes exige un análisis de la represión de la delincuencia organizada y de la lucha contra la delincuencia como relaciones de fuerza, poder y conflicto que ocupan puestos privilegiados en la sociedad.

Pero no es solo eso. Para el Ministerio Público del Trabajo, la explotación sexual comercial de niños y adolescentes es también una de las formas más degradantes de la explotación del trabajo infantil, conforme lo demás ya en los referidos anteriormente y que figura en la Convención n. ${ }^{\circ} 182$ de la Organización Internacional del Trabajo (BRASIL, 2019, Anexo LXVIII).

El artículo 3 de la Convención n. ${ }^{\circ} 182$ de la OIT (BRASIL, 2019, Anexo LXVIII), deja claro que, entre las peores formas de trabajo infantil, se encuentra el trabajo esclavo y la explotación sexual comercial de niños y adolescentes (habla en utilización u oferta de niños para la prostitución y la producción pornográfica). 
De esa manera, la configuración legal de la explotación sexual comercial de niños y adolescentes como relación de trabajo ilícita, degradante y violadora de la dignidad de la persona humana y del patrimonio ético-moral de la sociedad genera al Ministerio Público del Trabajo la obligación institucional de promover la responsabilidad civil de los agresores por todos los daños, materiales y morales, individuales y/o colectivos, y de cualesquiera personas que vengan a favorecer tales prácticas, incluso, a través de la omisión.

También compete al Ministerio Público del Trabajo la búsqueda de estrategias de actuación preventivas, lo que exige la formulación y la ejecución de políticas públicas de enfrentamiento a ese tipo de violación, considerándose toda la complejidad que envuelve el tema. La actuación estratégica comprenderá también la identificación de la red de explotación, de la cual deberá exigirse el cumplimiento de obligaciones que eviten la continuidad o la permanencia de la violación.

\section{CONCLUSIÓN}

Importante tomar en cuenta que la explotación sexual comercial de niños y adolescentes es crimen. Sin embargo, está comprobado que tratar la explotación sexual infanto-juvenil apenas desde el punto de vista criminal no resuelve el problema delante de su complejidad, habiendo implicaciones económicas, políticas y sociales.

El Ministerio Público del Trabajo tiene por misión resguardar el respeto a los derechos fundamentales de los seres humanos en el mundo del trabajo y, en especial, de los niños y de los adolescentes, razón por la cual consideramos la explotación sexual comercial de niños y adolescentes primero como violación de derechos humanos y, por lo tanto, de derechos fundamentales y, por último, como apropiación degradante de la fuerza de trabajo.

Según la Ley Orgánica del Ministerio Público del Trabajo (Ley Complementaria n. ${ }^{\circ} 75 / 1993$, arts. 83 y 84, inciso V y II), sus atribuciones son las siguientes:

[...] a) instaurar una investigación civil y otros procedimientos administrativos, siempre que sean apropiados, para garantizar el respeto de los derechos sociales de los trabajadores; b) proponer las acciones necesarias para la defensa de los derechos e intereses de los menores, incapaces e indios, derivados de las relaciones de trabajo (BRASIL, 1993). 
Luego, la participación del Ministerio Público del Trabajo con la temática de la explotación sexual comercial de niños y adolescentes se da en razón no del enfoque criminal, que es un componente importante, pero también bajo el enfoque laboral, o sea, posibilita la búsqueda por la responsabilización de la explotación de la mano de obra de niños y adolescentes en actividad reconocida como una de las peores formas de explotación del trabajo infantil, lo que atrae la atribución de instituciones importantes, antes desconsideradas de este contexto, como el Ministerio Público del Trabajo y la Inspección del Trabajo.

El combate a la explotación del trabajo infantil es - y debe seguir siendo - prioridad para el Ministerio Público del Trabajo, y no podría ser diferente con razón del principio de la prioridad absoluta consagrado en el artículo 227 de la Constitución Federal y de sus atribuciones constitucionales y legales (BRASIL, 1988).

Por ser un tema y una actuación de gran complejidad, los Fiscales del Trabajo tienen, a lo largo del tiempo, desarrollado estrategias de actuación en varias líneas diferentes, abarcando especialmente estrategias de prevención, enfrentamiento y responsabilización.

No podemos dejar de reconocer las dificultades enfrentadas, pero ya tenemos un largo camino recorrido que nos ha traído una experiencia práctica singular que merece reconocimiento y, más que eso, replicabilidad, o sea, todavía carecemos de una propuesta de acción nacional que involucre al conjunto de miembros del Ministerio Público del Trabajo para que podamos, en cada rincón de este país, actuar de modo a no sólo prevenir, sino también retirar niños y adolescentes de tan gravísima realidad, manteniéndolos en programas que garanticen el no retorno a esa situación.

Además de eso, forzoso mencionar la hipocresía que rodea el tema, pues la explotación sexual es ampliamente tolerada por nuestra sociedad, aunque el prejuicio contra las trabajadoras de esta actividad demuestra una terrible paradoja, o sea, mientras se naturaliza el "consumo" de esas mujeres, que son incluso libremente anunciadas en folletos, internet, books distribuidos en hoteles e incluso en outdoors gigantescos esparcidos en las grandes ciudades, de otro las profesionales del sexo son vistas como criminales, de bajísima moral y condenadas a vivir segregadas. 
Si la explotación sexual comercial de niños y adolescentes no debe ser admitida de ninguna manera, sino firmemente combatida y erradicada, ¿cómo debemos mirar a las mujeres, trabajadoras sexuales, que alguna vez fueron adolescentes y posiblemente niños víctimas de esta explotación, y que siguen siendo víctimas?

En nuestra legislación no está prohibido que la mujer elija esta profesión. Ella puede ser profesional del sexo. Decir que, con el reconocimiento de la profesión, se estaría afrentando la dignidad de la persona humana, tal vez las condiciones de trabajo que se les imponen es que sean indignas, no la profesión ya reconocida por legal y que consta de la Clasificación Brasileña de Ocupaciones ${ }^{3}$.

Las profesionales del sexo son brutalmente explotadas diariamente, sin ningún derecho garantizado, expuestas a la violencia, al consumo excesivo de drogas y alcohol, al tráfico interno y externo, a la desaparición, a la pérdida de referencia, a enfermedades sexuales contagiosas, a la ruptura de la convivencia familiar, al alejamiento de sus hijos, en fin, son mujeres que todos los días tienen sus derechos humanos violados. Pero no queremos "tocar el tema”, porque eso implica reconocer que, como cualquier otra persona, también son destinatarias de todos los derechos, los cuales deben ser protegidos, como, por ejemplo, con garantía de un ambiente de trabajo saludable.

Considerando la ineficiencia de las acciones desarrolladas, es momento de preguntarnos dónde nos equivocamos, qué debemos hacer y a dónde queremos llegar. ¿Hemos sido negligentes o complacientes con esta violación de los derechos humanos? Si no es posible combatir la prostitución, o más bien la explotación sexual comercial de mujeres, que está institucionalizada y va a seguir existiendo, ¿por qué no se reconocen los derechos de las mujeres que son explotadas y que - considerando las condiciones actuales de trabajo - son víctimas, en condiciones análogas a las de esclavas? La explicación tal vez sea muy simple: porque para la mayoría de la población, en esta cultura machista, no son seres humanos, sino objetos sexuales. Y los objetos no tienen derechos.

Así, la atribución del Ministerio Público del Trabajo, además de prevenir, combatir y promover la responsabilización de los que practican la explotación sexual comercial de niños y adolescentes, debe ser más amplia, a 
fin de alcanzar la protección de los derechos de las profesionales del sexo, degradados cotidiana e históricamente.

\section{NOTAS}

1 El Consejo Nacional de los Derechos del Niño y del Adolescente - CONANDA es un órgano colegiado permanente de carácter deliberativo y composición paritaria, previsto en el artículo 88 de la Ley n. ${ }^{\circ} 8.069 / 90$ - Estatuto del Niño y del Adolescente (ECA).

2 El Programa Escuela sin Partido, o apenas escuela sin Partido, es un movimiento político creado en 2004 en Brasil y divulgado en todo el país por el abogado Miguel Nagib. Él y los defensores del movimiento afirman representar a padres y estudiantes contrarios a lo que llaman "adoctrinamiento ideológico" en las escuelas.

3 CBO - Clasificación Brasileña de Ocupaciones. La Clasificación Brasileña de Ocupaciones (CBO) es un documento que retrata la realidad de las profesiones del mercado de trabajo brasileño. Fue instituida por la Orden n ${ }^{\circ} 397$, de 10/10/2002.

\section{REFERENCIAS}

BRASIL. Constituição da República Federativa do Brasil. Brasília/DF, 1988. Disponível em: http://www.planalto.gov.br/ccivil_03/constituicao/ ConstituicaoCompilado.htm. Acceso en: 11 set. 2020.

BRASIL. Lei n. ${ }^{\circ}$ 8.069, de 13 de julho de 1990. Dispõe sobre o Estatuto da Criança e do Adolescente e dá outras providências. Brasilia/DF, 1990. Disponível em: http://www.planalto.gov.br/ccivil_03/leis/18069.htm. Acceso en: 18 out. 2020.

BRASIL. Lei Complementar n. ${ }^{\circ}$ 75, de 20 de maio de 1993. Dispõe sobre a organização, as atribuições e o estatuto do Ministério Público da União. Brasilia/DF, 1993. Disponível em: http://www.planalto.gov.br/ccivil_03/ leis/18069.htm. Acceso en: 11 set. 2020.

BRASIL. Decreto n. 5.017, de 12 de março de 2004. Promulga o Protocolo Adicional à Convenção das Nações Unidas contra o Crime Organizado Transnacional Relativo à Prevenção, Repressão e Punição do Tráfico de Pessoas, em Especial Mulheres e Crianças. Disponível em: http://www.planalto. gov.br/ccivil_03/_ato2004-2006/2004/decreto/d5017.htm. Acceso en: 11 set. 2020.

BRASIL. Decreto n. ${ }^{\mathbf{1}} \mathbf{1 0 . 0 8 8}$, de 5 de novembro de 2019. Consolida atos normativos editados pelo Poder Executivo Federal que dispõem sobre a pro- 
mulgação de convenções e recomendações da Organização Internacional do Trabalho - OIT ratificadas pela República Federativa do Brasil. Disponível em: http://www.planalto.gov.br/ccivil_03/_Ato2019-2022/2019/Decreto/ D10088.htm. Acceso en: 11 sept. 2020.

DECLARAÇÃO de Estocolmo. [S.l.], 1998. Disponível em: http://pfdc.pgr. mpf.mp.br/pfdc/atuacao-e-conteudos-de-apoio/legislacao/crianca-e-adolescente/decl_estocolmo. Acceso en: 16 jul. 2020.

DECLARAÇÃO do Rio de Janeiro e Chamada para Ação para Prevenir e Eliminar a Exploração Sexual de Crianças e Adolescentes. Rio de Janeiro/RJ, 2008. Disponível em: http://www.crpsp.org.br/portal/comunicacao/diversos/mini_cd/pdfs/declaracao_rj.pdf. Acceso en: 17 jul. 2020.

ECPAT BRASIL. Relatório de monitoramento do país sobre a exploração sexual comercial de crianças e adolescentes. [S.1.], 2017. Disponível em: http://ecpatbrasil.org.br/site/wp-content/uploads/2019/06/Monitoramento-de-Pa\%C3\%ADs-ECPAT-2017.pdf. Acceso en: 13 jul. 2020.

GOMES, Patrícia Saboya. Esperança para as crianças do Brasil: a CPMI da Exploração Sexual apresenta seus resultados. Brasília: Senado Federal, 2004.

MINISTÉRIO DA FAMÍLIA, DA MULHER E DOS DIREITOS HUMANOS - MDH. Disque 100. Brasília, 7 maio 2018. Disponível em: https:// www.gov.br/mdh/pt-br/acesso-a-informacao/disque-100-1. Acceso en: 9 jul. 2020.

NAÇÕES UNIDAS BRASIL. OMS Aborda Consequências da Violência Sexual para Saúde das Mulheres. [S.1.], 25 jul. 2018. Disponível em: https://nacoesunidas.org/oms-aborda-consequencias-da-violencia-sexual-para-saude-das-mulheres/. Acceso en: 9 jul. 2020.

NASCIMENTO, Laura Pereira; SILVA, Rosane Leal. Crianças e adolescentes internautas como alvo da criminalidade online: pedofilia e pornografia na internet. In: XI SEMINÁRIO INTERNACIONAL DE DEMANDAS SOCIAIS E POLÍTICAS PÚBLICAS NA SOCIEDADE CONTEMPORÂNEA. VII Mostra de trabalhos jurídicos científicos. [S.l.], 2014. Disponível em: https://online.unisc.br/acadnet/anais/index.php/sidspp/article/ view/11741/1541. Acceso en: 18 out. 2020. 
PACTO pela Paz. Disponível em: http://mj.gov.br/sedh/ct/conanda/pacto. pdf. Acceso en: 17 jul. 2020.

REVISTA VIRAÇÃO. Gabriela Leite: contra preconceitos, a força da ironia. In: Outras palavras, sem categoria, [S.l.], 11 out. 2013. Disponível em: https://outraspalavras.net/sem-categoria/gabriela-leite-contra-preconceitos-a-forca-corrosiva-da-ironia. Acceso en: 13 set. 2020.

SANTOS, Benedito Rodriguez dos. Contribuições para um balanço das campanhas de combate ao abuso e exploração sexual de crianças e adolescentes no Brasil. In: LIBÓRIO, Renata Maria Coimbra; SOUSA, Sônia M. Gomes (org..). A exploração sexual de crianças e adolescentes no Brasil: reflexões teóricas, relatos de pesquisas e intervenções psicossociais. São Paulo: Casa do Psicólogo; Goiânia: Universidade Católica de Goiás, 2004.

SENADO. Relatório final da Comissão Parlamentar Mista de Inquérito da exploração sexual de crianças e adolescentes. Brasilia/DF, 2005. Disponível em: https://www2.senado.leg.br/bdsf/item/id/84599. Acceso en: 17 jul. 2020 .

SECRETARIA DE ESTADO DA EDUCAÇÃO DO PARANÁ. A Sexualidade na Rede Estadual de Ensino. Paraná: Superintendência da Educação-Departamento da Diversidade- Núcleo de Gênero e Diversidade Sexual, 2009.

UNICEF BRASIL; CIDADE APRENDIZ. A Educação que protege contra a violência. [S.l], jun. 2019. Disponível em: https://www.unicef.org/brazil/relatorios/educacao-que-protege-contra-violencia. Acceso en: 9 jul. 2020.

UNODOC - UNITED NATIONS OFFICE ON DRUGS AND CRIMES. Global Report on Trafficking in Persons - in the context of armed conflict 2018. New York, 2018. Disponible en: https://www.unodc.org/documents/lpo-brazil//Topics_TIP/Publicacoes/GloTIP2018_BOOKLET_2_ Conflict.pdf. Acceso en: 9 jul. 2020. 


\section{LA INSTITUCIONALIZACIÓN Y CASTIGO COMO POLÍTICA DE ENFRENTAMIENTO AL TRABAJO INFANTIL EN EL TRÁFICO DE DROGAS

\author{
MARIA DE FATIMA PEREIRA ALBERTO \\ RAFAELA ROCHA DA COSTA \\ MANUELLA CASTELO BRANCO PESSOA \\ THIAGO AUGUSTO PEREIRA MALAQUIAS
}

DOI: $10.51366 / 978-65-89468-10-3-$ coordinfancia-19

Resumen. El objetivo de este artículo es discutir el trabajo infantil que ocurre en la venta y en el tráfico de drogas, así como presentar reflexiones alrededor de la política de enfrentamiento en Brasil a ese tipo de trabajo, que figura entre las peores formas. Fue realizada una investigación entre los años 2017 y 2020, en el estado de Paraíba, en unidades de medidas socioeducativas de privación y restricción de libertad. Se han aplicado 137 cuestionarios, de los cuales $86,1 \%$ fueron respondidos por personas en el intervalo de edad correspondiente a la infancia y adolescencia. Fueron invitados a una entrevista más profunda 110 jóvenes y, entre ellos, fue constatado que 37,2\% trabajaron en el tráfico. Los resultados demostraron que, en la práctica, aunque haya legislaciones dirigidas a la protección de los niños y adolescentes, Brasil no comprende el trabajo en la venta y en el tráfico de drogas como trabajo infantil. Así, la política de enfrentamiento al trabajo infantil relacionada a la actividad de venta y tráfico de drogas consiste en medidas punitivas de institucionalización y de criminalización.

Palabras clave: Trabajo infantil. Tráfico de drogas. Medidas socioeducativas. 


\section{INTRODUCCIÓN}

Este artículo tiene como objetivo discutir el trabajo infantil en la venta y en el tráfico de drogas, así como presentar reflexiones sobre cómo ha estado sucediendo la política de enfrentamiento en Brasil a ese tipo de trabajo. Las discusiones se basaron en datos empíricos discutidos a la luz de la literatura sobre el tema. Se tiene como presupuesto la política de enfrentamiento al trabajo infantil en la venta y en el tráfico de drogas, que consiste en medidas punitivas, de institucionalización y criminalización.

La legislación nacional, el Decreto n. ${ }^{\circ}$ 6.481/2008, la legislación internacional alrededor de la Convención n. ${ }^{\circ} 182$ de la Organización Internacional del Trabajo (OIT), y la literatura académica reconocen el tráfico como trabajo infantil (FNPETI, 2018). A partir de esas perspectivas, un estudio empírico realizado a lo largo de tres años en Brasil, más específicamente en el estado de Paraíba ${ }^{1}$, ha investigado el trabajo infantil en la trayectoria de vida de adolescentes y jóvenes que cumplen medidas socioeducativas de privación y restricción de libertad. Entre los datos provenientes de la investigación, se identificó, en la trayectoria de vida de adolescentes y jóvenes, niños y niñas, la tierna presencia del trabajo infantil. Entre las actividades de trabajo desempeñadas emerge el trabajo en el tráfico y la medida socioeducativa como un factor punitivo en la trayectoria de esos trabajadores precoces.

Si la Sociedad Brasileña reproduce el mito de que "es mejor trabajar...", se supone que el trabajo infantil sería un "antídoto contra la criminalidad". Si hay 2,5 millones (siendo 1,8 millones ocupadas +716 mil que trabajan para propio consumo) de niños y adolescentes trabajando (IBGE, 2017/2018), no debería haber adolescentes cumpliendo medidas socioeducativas por trabajo. Según el Consejo Nacional del Ministerio Público (BRASIL, 2019), 18.086 adolescentes cumplen medidas de internación; 2.065 cumplen medidas de semilibertad; y 3.947, de internación provisional. De ese modo, ¿cómo explicar que 150 mil adolescentes entre 12 y 18 años están cumpliendo medidas socioeducativas y por lo menos 24 mil están en privación de libertad?

La literatura del área todavía apunta una serie de contradicciones relacionadas a la forma como esa problemática es entendida en Brasil. En la investigación de Bortolozzi (2014), fue posible analizar el sentido del trabajo en el tráfico de drogas experimentado por niños y adolescentes, tanto los que estaban trabajando como los que habían trabajado en ese mercado que, de 
acuerdo con dicho autor, representa la segunda mayor economía del mercado global. Los resultados apuntan a una construcción - no siempre inmediata del tráfico como una empresa organizada jerárquicamente con patrones, distintas ocupaciones y planes de carrera, como también fue destacado por Coscione et al. (2019), Silva y Simão (2005) y Cruz Neto, Moreira y Sucena (2001).

Pero ¿por qué no es esa la concepción inicial? Porque los participantes hicieron una distinción entre trabajo (digno), como una actividad lícita que no perjudica a otras personas, y el tráfico, más conectado a la criminalidad que exactamente al mundo del trabajo, aunque reconocieron que eran explotados (BORTOLOZZI, 2014; Cruz NETO; MOREIRA; SUCENA, 2001). Costa y Barros (2019) y Barros y Vilela (2016) explican que el tráfico de drogas viene siendo estudiado y considerado apenas a partir de comparaciones con otros tipos de actividades laborales, lo que va produciendo esa dicotomía del lícito e ilícito, distanciando el trabajo en el tráfico de la dimensión del trabajo y aproximando, sólo, la dimensión del crimen.

Se destaca el carácter organizativo de esa actividad, la variabilidad, las infidelidades del medio, los debates de normas que inciden (SCHWARTZ; DURRIVE, 2010). Se trata de una actividad laboral que ocupa parte (o gran parte) del tiempo de los adolescentes y jóvenes, dependiendo de la función, incluido el horario nocturno. De acuerdo con Bortolozzi (2014), en la jerarquía en que se organiza el trabajo en el tráfico, los niños y adolescentes son los que van a la calle, con el objetivo de pasar/vender la droga, por lo tanto, son los que quedan en mayor riesgo de ser atribuido a ellos un acto de infracción, una medida socioeducativa o incluso la muerte. Como dicen Silva y Simão (2005), los más jóvenes son los que están “en primera línea”, luego, los primeros en ser golpeados. Además de eso, se destaca el propio abordaje policial revestido de prácticas de violencia y violaciones (CRUZ NETO; MOREIRA; SUCENA, 2001).

Analizando los motivos para inserción en el trabajo en el tráfico, la literatura apunta para ese tipo de actividad como forma de supervivencia personal y de la familia y, del mismo modo, como forma de alcanzar bienes de consumo, que pueden parecer superfluos. Sin embargo, como señalan Coscione et al. (2019), Bortolozzi (2014), Silva y Simão (2005) y Cruz Neto, Moreira y Sucena (2001), obtener estos bienes es lo que permitía el acceso y la visibilidad de estos adolescentes y jóvenes por parte de la sociedad. Tal visibilidad aparece en dos momentos: 1) cuando utilizan el dinero para conseguir 
los bienes/servicios y se convierten en consumidores; 2) después, en cuanto a las actividades realizadas para recibir dinero y acceder a dichos servicios se asignan actos infractores.

Ese sistema socioeducativo es considerado ineficiente, pues no transforma la trayectoria de los jóvenes y, al no posibilitar otras elecciones, acaba reforzando la permanencia en el tráfico (BORTOLOZZI, 2014; CRUZ NETO; MOREIRA; SUCENA, 2001). Cruz Neto, Moreira y Sucena (2001), ya apuntaban para algo en ese sentido, de que los servicios socioeducativos generaban el miedo de construcción de nuevos proyectos, en vez de promover los proyectos fuera del tráfico de drogas.

La inserción de niños y adolescentes en la actividad de venta y tráfico de drogas tiene como motivos tanto el hecho de tener como modelos de acción a los adultos que también trabajaban en el tráfico, como las vivencias anteriores en actividades laborales consideradas lícitas. Pero, se destaca que incluso estos trabajos, por sí solos, son ilícitos, ya que son ejecutados por niños y adolescentes y tal práctica también está prohibida en la ley (BORTOLOZZI, 2014). El análisis de la literatura sobre el tema va delineando reflexiones sobre el tipo de actividad ilícita considerada peligrosa para los demás, para la propia clase media y alta; pero el trabajo infantil, también ilícito, perjudica solo a los más empobrecidos, además de ser las principales víctimas de asesinato, como identificado por Guedes (2020). Hay mitos que justifican una actividad ilegal (el trabajo infantil) en función de otra (acto de infracción). Luego, se cuestiona: ¿el acto de infracción no estaría siendo atribuido como forma de penalizar trayectorias marcadas por violaciones?

Estos trabajos, considerados lícitos por la sociedad, son percibidos de forma negativa, pues el pago en el tráfico es mayor. Esto se debe a que, frente a la baja escolaridad y al histórico de evasión escolar de los niños y adolescentes que se insertaron precozmente en actividades laborales, los trabajos lícitos para aquellos que no tuvieron una formación escolar/profesional se configuran en actividades descalificadas, no dignas y mal remuneradas. Marcon y Furukawa (2008), por ejemplo, al realizar una investigación con internos de una penitenciaria, constataron que la trayectoria de estos fue marcada por la salida de la red de enseñanza y que tal salida se debió a la necesidad de trabajar para ayudar a la familia. 
Prevalece el posicionamiento de que la escuela no tenía sentido, no respondía a sus necesidades básicas y, por lo tanto, buscaban otras formas (ilícitas) de hacerlo (BORTOLOZZI, 2014). Marcon y Furukawa (2008) señalan aún que las condiciones objetivas de vida de la infancia y de la adolescencia de los internos de la penitenciaria tuvieron relación con la inserción en el trabajo infantil, la salida de la red de enseñanza y con el encarcelamiento. Como destacan Silva y Simão (2005), ante los bajos salarios y las dificultades de los familiares, las actividades de trabajo ilícitas se van constituyendo en estrategias concretas de supervivencia; el trabajo precoz en el tráfico y el dinero resultante se van revelando como la vía de satisfacer a sus necesidades (CRUZ NETO; MOREIRA; SUCENA, 2001).

Ante lo presentado, se pregunta: ¿una medida socioeducativa de internación, que puede llegar hasta tres años, es una medida protectora para el trabajo infantil en las peores formas en el caso de venta y tráfico de drogas? Seguramente no. Se concluye que la política pública del Estado brasileño en el enfrentamiento al trabajo infantil en las peores formas consiste en medidas punitivas de institucionalización y de criminalización.

\section{LOS ITINERARIOS DE LAS BÚSQUEDAS}

Los datos empíricos presentados en este artículo constituyen el resultado de tres años de investigación, realizada entre los años 2017 y 2020, en el estado de Paraíba, en unidades de medidas socioeducativas de privación y restricción de libertad. La referida investigación siguió los preceptos éticos de la investigación con seres humanos y ha objetivado analizar la relación entre el trabajo infantil y las medidas socioeducativas. Participaron de la investigación adolescentes y jóvenes, niños. Se aplicaron 137 cuestionarios: 86,1\% afirmaron que trabajaron en la infancia o en la adolescencia y 10,2\%, que no trabajaron, pero ayudaron; luego, si se suma trabajo y ayuda, se obtiene que $96,3 \%$ de la muestra fueron trabajadores infantiles.

Los que informaron que trabajan o ayudan, fueron invitados a una entrevista más profunda, en la que participaron 110 adolescentes y jóvenes y, entre ellos, 41 participantes, o 37,2\%, trabajaron en el tráfico. Sin embargo, no todos los 41 cumplían directamente medidas por tráfico, porque, a veces, la medida socioeducativa es, por otro lado, acto de infracción que tiene una relación indirecta con el tráfico, por ejemplo, un robo efectuado para remediar una deuda contraída en la venta de drogas. 
El análisis de los datos para efecto de este artículo ha sido hecho mediante la lectura de cada una de las 110 entrevistas. La construcción de categorías a partir de la lectura tuvo como objetivo identificar cuantos informaron que trabajaron, cómo y por qué comenzaron a trabajar, cómo migraron de las demás actividades para el tráfico, el proceso de actividad laboral en el tráfico de drogas y las consecuencias para su vida. El tráfico de drogas como una actividad de trabajo comporta todo un proceso que comprende tareas, rutina, relación de trabajo, autónomo o empleado, formas de pago (como era pagado), lo que conseguían, uso de drogas, consecuencias en el tráfico (atribución de la autoría del acto de infracción y medida socioeducativa), consecuencias de las medidas (castigo y criminalización).

\section{EL TRABAJO INFANTIL EN EL TRÁFICO DE DROGAS: ACTIVIDAD, INSTITUCIONALIZACIÓN Y CASTIGO}

\subsection{La inserción temprana en el trabajo infantil en el narcotráfico}

Entre los 110 que participaron de la entrevista más profunda, 89 adolescentes y jóvenes se identificaron como siendo del sexo masculino y 21 se identificaron como siendo del sexo femenino, con edades variando de los 14 a los 20 años. En cuanto a la etnia, a través de una cuestión de auto declaración, se reveló que la mayoría se autoidentificó como moreno (40), seguido de blanco (27), marrón (24), negro (6), amarillo (2), gallego (2), moreno claro (2), indígena (1), pelirrojo (1) y café con leche (1). Cabe la reflexión por la presencia del colorismo al abordar la identidad racial. Sin embargo, observándose la definición del Estatuto de la Igualdad Racial (BRASIL, 2010), se percibe que, aunque no se hayan identificado como tal, los datos revelan que la mayoría es negra, resultado de la suma de moreno, pardo, negro, moreno claro y café con leche, que da exactamente $70 \%$.

Las edades en que comenzaron a trabajar fueron variadas, abarcaron entre 5 y 17 años, en que $70 \%$ comenzaron en el intervalo de 10 a 14 años; $9 \%$, en el intervalo de 5 a 9 años; y 18,18\%, en el intervalo de 15 a 17 años. Ya el inicio del trabajo infantil en el tráfico de drogas hubo quien comenzara con 5 años, como afirmó uno de los participantes: “empecé a traficar con 5 años", pero la mayoría comenzó en otras actividades de trabajo infantil y migró para el tráfico de drogas. 
La principal causa de la inserción precoz en el trabajo apuntada por los participantes fue la necesidad financiera de la familia, pero hubo quien uniera la necesidad financiera y el deseo de autonomía o el trabajo como antídoto a la marginalidad; esta última causa, representada por la expresión "para no hacer cosa equivocada". Aún hubo quienes atribuyeron como causas el uso de drogas, el dolor y la venganza, cuando un miembro de la familia los obligaba. En el caso del tráfico de drogas, los motivos son los mismos, pero hubo quienes alegaron el cambio motivado por el valor de las ganancias que eran mayores en el tráfico de drogas que en las actividades consideradas lícitas.

Otro aspecto señalado como causa, posibilita prever una imagen glamorosa de la actividad y la introyección de un sentimiento de poder: "porque yo creía ser bonito lo que hacía, me creía bien cuando yo vendía, pero después de un buen tiempo yo me puse a pensar que aquello no era para mí”. Se percibe, entonces, que, poco a poco, ese sentimiento de poder se fue disipando y dando lugar al significado de una actividad fácil, que propicia muchas ganancias, pero contradictoriamente también pérdidas rápidas. Por otra parte, esa idea de la ganancia fácil estuvo presente en el discurso de todos y todas, a ejemplo: "y en el tráfico yo ganaba también dinero, mucho dinero..., porque en el tráfico lo que viene fácil se va fácil”.

Tales hallazgos corroboran los estudios emprendidos por Coscione et al. (2019), Bortolozzi (2014), Silva y Simão (2005) y Cruz Neto, Moreira y Sucena (2001), destacando la entrada en el tráfico como forma de supervivencia y de acceso a bienes de consumo. Luego, esa forma de organización del trabajo se configura como una forma prototipo de la sociedad de consumo, como señalan Barros y Vilela (2016), una vez que se pone como informal, como ilegal, agregando toda la violencia que rodea esa actividad. Vale la pena señalar que cuando se presentó la droga como causa, no siempre la trayectoria fue del uso al trabajo. Por el contrario, hubo varios participantes que informaron el proceso inverso, por comenzar a trabajar en el tráfico de drogas, la terminó usando: "comencé a traficar con 5 años, usar drogas; las comencé con 6 años", "solo comencé a usar drogas después de involucrarme con la facción y comencé a trabajar en el tráfico también”.

Tales declaraciones elucidan las condiciones objetivas de vida de esos sujetos, en cuales formas ilícitas son caminos posibles a sus ojos (BORTOLOZZI, 2014; MARCON; FURUKAWA, 2008). Parece que hay un camino 
en esa trayectoria, que pasa por el trabajo infantil: la salida de la red de enseñanza y, como consecuencia final, el encarcelamiento, lo que, como señalan Barros y Vilela (2016), legitima una concepción moralista que resulta en una guerra sanguinaria, en la cual lo poco que se hace lo es por la vía de la violencia, funcionando como recurso, código normativo de comportamiento y como punto final para la resolución de los conflictos inherentes a la vida.

\subsection{El tráfico de drogas como actividad laboral infantil}

$\mathrm{Ni}$ todos los participantes, adolescentes y jóvenes, niños y niñas reconocieron de inmediato que las actividades desempeñadas en el tráfico de drogas consistían en trabajo. Aunque relataran las tareas que desempeñaban, sea parte de ellas o la participación en todo el proceso, las tareas recibían sentidos variados, provenientes de la alienación que se inscribía en el proceso, pues, no participando del todo, acababan no reconociéndose en la parte que hacía el producto. Otro aspecto que invisibilizaba la actividad se refería al carácter moral de que se revestía la actividad, dicotomizada entre "correcto" y "incorrecto", "leve" y "honesto", como puede ser observado en el diálogo abajo entre un Participante (P) y un Investigador (I):

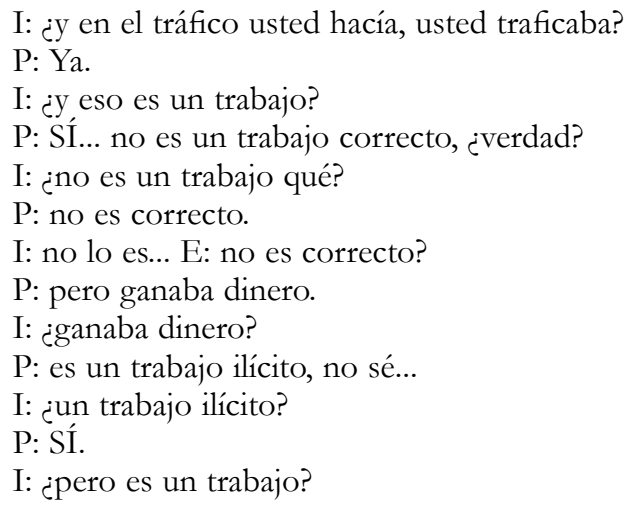

Otro ejemplo se puede ver en el discurso de otro (a) participante: “y: es. Yo, en mi infancia, traficaba. No, eso es todo. No recuerdo nada demás que traficar. Empecé a traficar a la edad de 13 años. Fue, trabajé en el tráfico”.

El diálogo que se procesaba con los investigadores llevaba a la confrontación con lo que hacían, lo que resultaba, frecuentemente, en la descripción de detalles de las rutinas con la descripción de la carga de trabajo. En los diálogos y en el estudio de la literatura, se percibió una actividad que 
comporta un proceso de producción y de organización con la división de trabajo (COSCIONE et al., 2019), proceso que presenta similitudes y diferencias a depender de la diversidad de contextos de los estados brasileños. En el caso de los participantes de esa investigación, el proceso y la división del trabajo incluyen niños, adolescentes y jóvenes que participan, ocupan y realizan diversas funciones y actividades, ya sea como autónomo o vinculado a un patrón, tales como "el corre", "avión”, "envasador", “intermediario", "vendedor", "carguero", "gerente” y "jefe”.

Como afirma Schwartz y Durrive (2010), es necesario tener en cuenta lo que supera los resultados de la actividad, para que las dramáticas de la actividad no se oculten. El cumplimiento de cada una de estas tareas resulta en dramas que a menudo son invisibilizados por el otro y por el propio trabajador. De ese modo, los investigadores, en el momento de la entrevista, confrontaron a esos jóvenes, siendo posible acceder a los aspectos relacionados a la tarea ejecutada, así como al sentido atribuido a cada tarea. Tal composición permitió comprender esta actividad laboral para los trabajadores de los niños.

La descripción de la realización de un conjunto de tareas demarca cómo se dio la inserción de algunos en la actividad, las funciones cumplidas y lo que demandaba física y psíquicamente. Los relatos y diálogos entre investigador y participante revelaron la gestión de la actividad por esos adolescentes y jóvenes: el gasto de energía, de fuerza física, de actividades prolongadas por jornadas que comportaban varias horas de trabajo, en situaciones de guardia de los territorios de comercialización, bajo situaciones de riesgos, al acecho de posibles invasiones por parte de grupos competidores y rivales o de embestida de la policía, como puede ser observado en el trecho: "en una semana yo pasaba todo el día, y por la noche a veces ni iba a casa. Salía a las 6 de la mañana de casa, iba a la playa y me quedaba hasta las 10, 11 de la noche", y al día siguiente también: "mi rutina en el tráfico era 24 por 48. así que todo el día en el tráfico y por la noche también. me iba a casa muy poco”.

El "corre", terminología utilizada por ellos para referirse a la realización de pequeños servicios o boquillas dentro del comercio de drogas, es realizado algunas veces por niños, que significa el inicio del proceso de reclutamiento para esa actividad, como demuestra el siguiente discurso: "en el corre, en el momento del corre, la persona hace el corre, sabes? Toma la droga, manda, a veces trae unos chicos, unos chicos pequeños aun, como, 9 años, 10 años". La actividad de envasador se refiere a las tareas de preparar, 
separar, enrollar o embolsar las drogas en pequeñas porciones para la actividad minorista o, en el lenguaje de los participantes, "hacer la pasta", definida por algunos como una tarea repetitiva, interminable, realizada sin descanso durante todo el día:

¡Vaya! Eso es triste. Fui a (cita la ciudad) favela que hay allí hacer este negocio de... pasaba todo el día en el fumadero con el cigarrillo. Y entonces me tocaba un "corre", empaqueta, entonces llegaba otro "corre" y empaqueta. ¡Es triste! ¡Es todo el día! Todo el día. Solo cuando se hace noche la persona descansa.

El vendedor es el encargado del comercio minorista, puede permanecer en un lugar fijo o moverse, una especie de vendedor ambulante, como revela el siguiente discurso:

Sólo trabajé en el tráfico. Yo empecé a vender en las esquinas, las chozas, las casas, alquilaba la casa y entonces comenzaba a adelantar drogas, ahí llegaban los drogadictos, ¿sabes? Como se dice. Llegaba los drogados y empezaba a preguntar si tenía piedra, marihuana; entonces yo empezaba a despachar y tomaba el dinero. No, no hice nada más que tráfico.

Hubo el relato de otra tarea para la cual los participantes no asignaron un nombre, pero que consiste en una función de intermediario, cuya acción no se da directamente con el cliente, pero con un portador, el avión, que va a adquirir la droga para otra persona, pero que es parte de la rutina del comercio del narcotráfico: "mi rutina en el tráfico era así, usted se queda allí sentado con el 'balón de polvo', parado allí en una esquina, me quedo en un bar, me quedo sentado, y entonces, aquí vienen los aviones y las toman".

Y también está la función del carguero, que es la denominación utilizada por los adolescentes y jóvenes para referirse a quien busca la droga y hace la distribución. Es una persona de confianza del jefe, como le describen los participantes:

[...] yo cogía una carga que venía, no era para mí, era para mi jefe. Llegué a recoger una carga de 30 kilos. 30 kilos cuestan qué, cuesta medio millón. Así se distribuía en los barrios. Dejaba 5 kilos aquí, 5 allí. El carguero para la facción es el que sale distribuyendo la droga.

La mayoría se refirió a la figura de un jefe para quien trabajaba, "que es el jefe que manda”. Pero hubo quien afirmó ser autónomo y tener incluso personas trabajando para sí, como revelan las declaraciones de algunos participantes: "yo vendía para mí mismo y no pasaba todo el día. Había alguien allí trabajando también", "me vendía a mí mismo en dola. Tomaba media pieza 
y me la vendía a mí mismo". Las formas de pagos pueden ser en drogas, en efectivo u otras monedas. "Cada trabajo yo ganaba una parte, pero cuando yo estaba trabajando para mí mismo yo ganaba mi dinero duramente”.

En el caso de los participantes de la investigación que origina este capítulo, el pago no siempre está vinculado a las características de las tareas realizadas, a las demandas físicas y psíquicas, ni a la jornada o a la carga de trabajo, se refiere a la droga vendida, al producto comercializado, cuyo acuerdo de pago puede ser en una forma de división, o sea, a cada $\mathrm{X}$ vendido una cierta fracción o porcentaje del dinero o de la droga es del vendedor, o el pago se efectúa mediante la venta de la droga.

E: ¿alguna vez has trabajado en algo?

A: solo en tráfico.

E: ¿solo en el tráfico? ¿Y cómo te pagaban por el trabajo?

A: bueno, eh, yo tenía que dar el dinero del cabrón y me quedaba con el mío. E: ¿y tú solo recibías dinero o recibías algo más?

A: no, yo recibía dinero, pero después me detuve, no quería más eso para mí. $\mathrm{E}:$ ¿Y cómo te pagaban por el trabajo, por ese trabajo?

A: por lo que vendía, ¿no? Que yo cogía de mucho.

Los kilos... cada kilo es 1000 de pasta, 500 era mío. Cada kilo que cogía 500 era mío. Cuando fui a trabajar para "Dola", de cada 5 que vendía 1 era mía. Que ya no vale la pena por ahí. Por eso me estresé. Porque de 5 dola solo se gana 1. Una Dola es lo que, 5 de pasta, ¿entiendes?

Yo vendía, ahí conseguía un dinero allí, iba a pagar al jefe y el jefe me daba el mío. Me pagaban en efectivo. Además del dinero, recibía drogas como pago.

Luego, quedan visibilizadas esas leyes del tráfico, su contexto laboral como una economía de experiencias (BARROS; VILELA, 2016). La confianza se coloca como uno de los valores que organizan las relaciones interpersonales y comerciales en el tráfico, a partir de lo que es dicho por esos adolescentes y jóvenes. Las anticipaciones se encuentran en el camino de la prescripción de esa actividad, y ellos están todo el tiempo gestionando la actividad, el uso que hacen de su cuerpo y que los otros, sobretodo el jefe, lo hace también. Se destaca el cuestionamiento planteado también por Barros y Vilela (2016, p. 177): “¿qué sociedad, estamos produciendo diariamente, es capaz de hacer posible la existencia de organizaciones de trabajo en que el humano es elevado a la condición de instrumento?’. Sobretodo cuando hablamos de niños, adolescentes y jóvenes, cuando existe una legislación que debería protegerlos.

Por el contrario, como apuntado en el material publicado por el FNPETI (2018) y por Silva y Simão (2005), los niños acaban ocupando la 
línea de frente, son los primeros a ser alcanzados, son los que quedan en mayor riesgo de haberles atribuido un acto de infracción, una medida socioeducativa, o incluso la muerte. Como afirman Costa y Barros (2019), el sentido conferido al tráfico se establece a través de ese vínculo entre actividad y violencia, distanciándolos del sinónimo de un trabajo que implicaría una relación apoyada socialmente.

\subsection{Las consecuencias, infracción y medidas socioeducativas de internación}

No todos reconocieron los aspectos negativos de la inserción temprana en el trabajo, en particular el trabajo en las peores formas (tráfico de drogas). Algunos señalaron que el trabajo en el tráfico evitó morir de hambre, posibilitó ayudar a las familias, obtener la ganancia de mucho dinero y el acceso a bienes, aparatos electro electrónicos y objetos de consumo que componen la vida moderna, como moto, coche, ordenador, notebook, móvil. Pero incluso entre los que ensalzaron aspectos positivos, hubo quienes llamaron la atención sobre los aspectos negativos del trabajo en el tráfico de drogas. Así, fueron apuntados también aspectos negativos: el sufrimiento causado a la familia, lo que nominaron como el envolvimiento con el acto de infracción y haber recibido una medida socioeducativa de internación, la cual, a su vez, también tenía una serie de consecuencias, como ilustra el siguiente tramo de entrevista: "haber trabajado fue malo, ¿verdad? No tuvo nada bueno porque estoy aquí, no dio nada bueno para mí, solo algo malo”.

A pesar de la dicotomía expresada en la concepción de los participantes al usar la expresión "trabajo fácil" para referirse a las actividades en el tráfico de drogas, la realidad es muy diferente, es decir, no hay nada fácil. Hay una serie de consecuencias o implicaciones derivadas del desempeño de las tareas, principalmente el riesgo de muerte derivado de los enfrentamientos con los grupos rivales competidores o con la policía. No se puede olvidar que, además de los riesgos de la actividad en sí, estos trabajadores son niños y adolescentes. Entra en cuestión cómo la cultura aprehende más allá de los mecanismos de defensa, para conseguir realizar la actividad de trabajo, una vez que reconocen las diversas dificultades, los riesgos, pero, aun así, necesitan hacer, es decir, lo que refleja las dramáticas en las que están involucrados (SCHWARTZ; DURRIVE, 2010). Son sujetos en proceso de desarrollo que 
internalizaron solo la concepción del crimen, fueron alienados del proceso y no se perciben a sí mismos como trabajadores.

De hecho, parece que no son sólo ellos los que no entienden como trabajo. El propio Estado brasileño, signatario de la Convención no 182 de la OIT (OIT, 1999), el Estatuto del niño y del Adolescente (ECA, 1990) y el Decreto $\mathrm{n}^{\circ}$ 6.481/2008 (BRASIL, 2008), tampoco reconocen esa práctica como trabajo. Aunque otrora ese trabajador infantil en el tráfico haya trabajado en otras actividades, solo cuando migra para el tráfico es visto y penalizado con la atribución de una autoría de acto de infracción y, consecuentemente, con una medida socioeducativa de internación. De ese modo, el acto de infracción es otra consecuencia de la trayectoria de trabajador infantil desde tierna edad, con 5, 11 o 14 años. El acto infractor es una consecuencia del trabajo infantil. El adolescente o joven que no internalizó que él o ella es un trabajador explotado por el tráfico, internaliza que se involucró con el acto de infracción. Usan el término participación para significar sus trayectorias, como lo demuestran las siguientes líneas:

Trabajar temprano me ayudó a involucrarme porque veía a la gente en el medio de la calle mientras se quedaban allí, haciéndolo así. Ahí yo ponía atención, solo quedaba poniendo todo en cada rincón de los otros y 'tal'...

Tenía 15 años cuando me envolví por primera vez. Traficaba a los 14 años. No me involucré antes del tráfico. Tenía 15 años cuando me envolví por primera vez. Conseguía dinero, vendía piedra, cocaína, solo. Sólo conseguía dinero. Sólo dinero.

Esta participación también tiene consecuencias o implicaciones. En el caso de la participación en el trabajo infantil en el tráfico de drogas, los adolescentes y jóvenes son responsabilizados, criminalizados y castigados con una medida socioeducativa de internación o en la expresión de ellos: "rodaron" - “ahí después rodé fue la primera vez, tenía 12 años”. Tal vez el término "rodar" sea realmente un significado representativo de la situación, ya que "rodar" significa "hacer girar alrededor". Es lo que les sucede; comienzan con una violencia, trabajan precozmente, el Estado no los protege, conforme medida protectora definida en el ECA, pero los criminaliza, llevándolos a cumplir medida socioeducativa en institución donde es víctima de otra serie de violencias y violaciones que son cometidas por el propio Estado (desde la no Garantía de los derechos preconizados en el ECA y regulados en el SINA$\mathrm{SE}$, hasta otras violencias institucionales). Entonces cierra el giro con otras violaciones y violencias. Como afirman Costa y Barros (2019), esa dicotomía 
entre lo lícito y lo ilícito produce y legitima el distanciamiento del trabajo en el tráfico de la dimensión del trabajo y la aproximación apenas de la dimensión del crimen.

Aunque los participantes de la investigación justifican el trabajo en el tráfico por la necesidad de supervivencia, de sostener a la propia familia, del deseo de acceso a bienes de consumo, de ser obligados porque fueron amenazados por otras personas, incluyendo familiares o integrantes de facciones, e incluso que enaltezcan los aspectos positivos de conseguir dinero, fama y conquistar mujeres, hay una serie de consecuencias negativas, como pérdida de la infancia, "adultización" precoz, desistencia y alejamiento de la escuela y medidas socioeducativas. En el caso de las medidas socioeducativas de internación, sufren encarcelamiento, aislamiento social, violencia institucional, violencia entre pares, miedo, añoranza, imagen negativa de sí, nostalgia, alejamiento y sufrimiento de la familia, incertidumbre en cuanto al futuro, intento de suicidio y riesgo de muerte (PEREIRA et al., 2020), que se transforma en genocidio, a tal punto de identificarse, en las investigaciones del Estado, adolescentes que cumplieron medidas, se convirtieron en trabajadores, pero fueron víctimas de asesinato (GUEDES, 2020), llevando Paraíba a presentar, en algunos años, altos índices de homicidio de adolescentes y jóvenes, pasando del 19. ${ }^{\circ}$ lugar en el ranking de los estados en 1997 para el 6. ${ }^{\circ}$ lugar en 2014 (WAISELFISZ, 2016).

\section{CONCLUSIÓN}

El análisis y discusión de los datos permitieron acercarse al presupuesto de que la política de enfrentamiento al trabajo infantil, en la venta y en el tráfico de drogas, consiste en medidas punitivas, de institucionalización y de criminalización.

Esta reflexión pasa por el ámbito legislativo, considerándose el Decreto n. ${ }^{\circ} 6.481$ / 2008 y el Convenio n. ${ }^{\circ} 182$ de la OIT, ya ubicados en el presente texto. Ambos definen el tráfico de drogas como una de las peores formas de trabajo infantil. Sin embargo, si hay adolescentes cumpliendo medidas por trabajo infantil en las peores formas en el tráfico de drogas, entonces, se concluye que Brasil no cumple la Convención citada, la recomendación n. 190 y el Estatuto del niño y del Adolescente (ECA), o que Brasil no comprende el trabajo en la venta y en el tráfico de drogas como trabajo infantil. 
El trabajo en el tráfico se convirtió en una extensión de la explotación del trabajo infantil, esta vez en la venta y en el tráfico de drogas, siendo la respuesta del Estado a esa problemática proveniente a través de una medida socioeducativa de internación. Esas medidas acaban potenciando la problemática de encarcelamiento, aislamiento social y diversos tipos de violencia; además del miedo, la añoranza, formación de una imagen negativa de sí mismo y el alejamiento de la familia, lo que lleva a un cuestionamiento: "¿qué es ser traficante?”, tocando la indefinición de la propia ley en la caracterización de porciones de droga que definen lo que es el tráfico.

Existen varios retos y posibilidades, entre los cuales se destacan la necesidad de repensar la política de socio educación y de distanciarse el trabajo infantil en el tráfico del análisis puramente de criminalización, acercándolo al proceso de trabajo y a las dramáticas que lo envuelven. Se hace necesaria la construcción de un proyecto de sociedad solidaria, que respete derechos humanos, proceda a la redistribución de renta, efective políticas sociales, garantice la participación de niños, adolescentes y jóvenes, se crea identidades de pertenencia, procesos educativos críticos y políticas de protección de la vida y de enfrentamiento al trabajo infantil.

\section{NOTA}

1 El referido estudio viene siendo realizado por el Núcleo de Investigaciones y estudios sobre el desarrollo de la infancia y Adolescencia (NUPEDIA), en la Universidad Federal de Paraíba (UFPB), con recursos del CNPq a través de beca productiva y Beca PIBIC.

\section{REFERENCIAS}

BARROS, Vanessa Andrade de; VILELA, Thaisa. O acerto de contas no trabalho do tráfico de drogas varejista. In: Gerais - Revista Interinstitucional de Psicologia, v. 9, n. 2, p. 162-181, 2016.

BORTOLOZZI, Remon Matheus. O sentido do trabalho para jovens trabalhadores da economia da droga: Exame retrospectivo. 2014. Dissertação (Mestrado em Educação), Universidade de Brasília, Brasília, 2014.

BRASIL. Lei n. ${ }^{\mathbf{0}} \mathbf{8 . 0 6 9}$, de 13 de julho de 1990. Institui o Estatuto da Criança e do Adolescente (ECA). Brasília/DF, 1990. Disponible en: http://www.planalto.gov.br/CCIVIL_03/leis/L8069.htm. Acceso en: 12 dez. de 2019. 
BRASIL. Decreto n. ${ }^{\circ}$ 6.481, de 12 de junho de 2008. Regulamenta os artigos 3. ', alínea “d”, e 4. ${ }^{\circ}$ da Convenção n. ${ }^{\circ} 182$ da Organização Internacional do Trabalho (OIT) que trata da proibição das piores formas de trabalho infantil e ação imediata para sua eliminação. Brasília/DF, 2008. Disponible en: http://www.planalto.gov.br/ccivil_03/_ato2007-2010/2008/decreto/ d6481.htm. Acceso en: 12 dez. de 2019.

BRASIL. Lei n. ${ }^{\circ}$ 12.288, de 20 de julho de 2010. Estatuto da Igualdade Racial. Brasília/DF: Congresso Nacional, 2010. Disponible en: http://www. planalto.gov.br/ccivil_03/_ato2007-2010/2008/decreto/d6481.htm. Acceso en: 12 dez. de 2019.

BRASIL. Conselho Nacional do Ministério Público. Panorama da execução dos programas socioeducativos de internação e semiliberdade nos estados brasileiros. Brasília: CNMP, 2019.

COSCIONI, Vinicius et al. Significados do mundo do crime para adolescentes em medida socioeducativa de internação. In: Rev.latinoam.cienc. soc.niñez. [S.1.], juv., v. 17, n. 2, p. 318-338, 2019. DOI: http://dx.doi.org/10.11600/1692715x.17214.

COSTA, Ana Paula Mota; BARROS, Betina Warmling. Traficante não é vagabundo: trabalho e tráfico de drogas na perspectiva de adolescentes internados. In: Rev. Direito Práx. Rio de Janeiro, v. 10, n. 4, p. 2.399-2.427, 2019. DOI: 10.1590/2179-8966/2019/36727.

CRUZ NETO, Otávio; MOREIRA, Marcelo Rasga; SUCENA, Luiz Fernando Mazzei. A vida no tráfico: cotidianos de uma sociedade que não se reconhece. In: Nem soldados nem inocentes: juventude e tráfico de drogas no Rio de Janeiro. Rio de Janeiro: Editora FIOCRUZ, 2001, p. 123150. DOI: $10.7476 / 9788575415191$.

FÓRUM NACIONAL DE PREVENÇÃO E ERRADICAÇÃO DO TRABALHO INFANTIL (FNPETI). Trabalho infantil no tráfico drogas: $\mathrm{O}$ que diz a produção acadêmica? Coordenado por Maria de Fatima Pereira Alberto e Manuella Castelo Branco Pessoa. Brasília: FNPETI, 2018.

GUEDES, Italo Oliveira. As Condições Objetivas de Vida da Juventude Vítima de Homicídio na Cidade de João Pessoa. 2020. Dissertação (Mes- 
trado em Psicologia Social), Universidade Federal da Paraíba, Paraíba, 2020, [não publicada].

IBGE. Pesquisa Nacional por Amostra de Domicílios Contínua - Trabalho Infantil 2016. Rio de Janeiro, RJ: IBGE, 2017/2018. Disponible en: https://biblioteca.ibge.gov.br/visualizacao/livros/liv101388_informativo. pdf. Acceso en: 03 ago. 2020.

MARCON, Sonia Silva; FURUKAWA, Tatiane Sano. Família, infância e adolescência: rememoração de internos da Penitenciária Estadual de Maringá, Paraná, Brasil. In: Rev Gaúcha Enferm., v. 29, n. 1, p. 60-67, 2008.

ORGANIZAÇÃO INTERNACIONAL DO TRABALHO (OIT). Convenção n. ${ }^{\circ}$ 182. Piores formas de trabalho infantil, [S.l.], 1999. Disponible en: https://www.ilo.org/brasilia/convencoes/WCMS_236696/lang--pt/index.htm. Acceso en: 15 jul. 2020.

PEREIRA, Letícia Bianca Aquino et al. Medidas socioeducativas como consequência do trabalho infantil: penalização, encarceramento e sofrimento infanto-juvenil. In: ALBERTO, Maria de Fatima Pereira; COSTA, Rafaela Rocha. Trabalho infantil: trajetórias de vida punidas e encarceradas com medidas socioeducativas. [S.1.], 2020 [no prelo].

SCHWARTZ, Yves; DURRIVE, Louis (org.). Trabalho e ergologia: conversas sobre a atividade humana. 2. ${ }^{\text {e }}$ d. Trad.: J. Brito e M. Athayde. Niterói: Universidade Federal Fluminense, Editora da UFF, 2010.

SILVA, Jaílson de Souza; SIMÃO, Mário Pires. A Vida no "Movimento": Crianças e Adolescentes no Tráfico de Drogas. In: Anais do X Encontro de Geógrafos da América Latina. São Paulo: Universidade de São Paulo, p. 14.496-14.508, 2005.

WAISELFISZ, Julio Jacobo. Mapa da violência de 2016: homicídios por arma de fogo. Rio de Janeiro: Flacso, 2016. Disponible en: http:/ / flacso.org. br/files/2016/08/Mapa2016_armas_web-1.pdf. Acceso en: 3 ago. 2020. 



\title{
LOS JÓVENES EN CONFLICTO CON LA LEY Y EL DERECHO AL TRABAJO: LA CUOTA ALTERNATIVA COMO CONCRECIÓN DEL ACCESO AL
} TRABAJO

\author{
MARIANE JOSVIAK
}

DOI: 10.51366/978-65-89468-10-3-coordinfancia-20

Resumen. El aprendizaje profesional se constituye en importante Instituto del Derecho del Trabajo brasileño, a través del cual actualmente, alrededor de 500 mil adolescentes y jóvenes de 14 a 24 años (CAGED, julio de 2019) están inseridos en el mundo del trabajo. Este contrato especial de trabajo con duración máxima de dos años posee un papel transformador en las vidas de los adolescentes y jóvenes brasileños que, como aprendices, tienen obligatoriedad de asistir a la escuela, participar de curso de formación ofrecido por las entidades calificadoras y comparecer al trabajo. Se constituye en política pública esencial para concretar derechos constitucionales fundamentales de adolescentes y jóvenes, en particular el derecho de profesionalización, con énfasis en dar prioridad a los, social y económicamente, vulnerables. La creación de la cuota alternativa o más comúnmente conocida como cuota social posibilita que más y más aprendices sean contratados por empresas que tengan actividades insalubres, peligrosas o penosas para ejercer la parte práctica del aprendizaje en organismos públicos, instituciones sin fines lucrativos y en el propio sistema socioeducativo. Así, para el fortalecimiento de ese instituto, se revela esencial que la administración pública también contrate aprendices y que, en general, utilice el instituto para resocializar adolescentes y jóvenes que cumplen medidas socioeducativas en el Sistema de Infracciones o penas en el Sistema Penal brasileño, promoviendo de esta forma, un diálogo entre el derecho del trabajo, el derecho "infraccional" y el derecho penal.

Palabras clave: Instituto de aprendizaje profesional. Cuota alternativa. Contratación de aprendices por la Administración Pública. 


\section{INTRODUCCIÓN}

Este estudio tiene como objetivo iluminar el aprendizaje profesional como una de las principales formas de inclusión en el primer empleo, con lo que se legitima la prioridad absoluta como práctica de una sociedad y no apenas como un precepto fundamental constitucional ${ }^{1}$. Ese derecho humano fundamental expresado por la profesionalización se concreta cuando prioriza la vulnerabilidad inherente a la juventud, de aquellos aún más vulnerables, como lo son: los egresados del trabajo infantil, los beneficiarios de programas de renta mínima, las personas con discapacidad, aquí sin límite de edad máxima, los adolescentes de casas de acogida y del sistema socioeducativo, los jóvenes del sistema penitenciario hasta 24 años, los estudiantes de escuela pública, sin olvidar la posibilidad de contratación de los demás en porcentaje remanente, dado que, además de las prioridades, la vulnerabilidad es condición que también forma parte de toda la juventud.

Se busca a través de este artículo también hablar de la cuota alternativa del aprendizaje profesional, que posibilita que empresas consideradas penosas, insalubres o peligrosas puedan contratar aprendices para trabajar en instituciones sin fines lucrativos, en la administración pública, así como también en el propio sistema cerrado de aprendices que cumplen medidas socioeducativas.

Este artículo busca, además, generar la sensibilización sobre la necesidad de que haya legislación en el ámbito municipal, estadual, distrital o federal para la contratación de jóvenes aprendices en el sector público, así considerada la administración pública directa, autárquica y fundacional en las diversas esferas federativas.

Al final, se pretende plantear la cuestión de la importancia de acciones efectivas construidas a través de la red de protección, para que los adolescentes que cometieron infracciones penales o jóvenes del sistema penitenciario hasta los 24 años, puedan ser alijados de la práctica de infracción o criminal, por medio de la resocialización promovida con el aprendizaje profesional, que les posibilita la escolarización y profesionalización, entre otros derechos humanos y fundamentales expresados en la legislación brasileña. 


\section{EL APRENDIZAJE COMO DERECHO HUMANO}

El aprendizaje profesional es un instituto existente en Brasil desde 1942/1943 con la creación del Servicio Nacional de la Industria y Servicio Nacional del Comercio, siendo actualizado desde entonces por la Carta Magna Brasileña y legislaciones relacionadas. El aprendizaje es un derecho a la profesionalización del joven brasileño, conforme a lo dispuesto en la Constitución Federal $^{2}$ y ha sido un instrumento poderoso para disminuir la vulnerabilidad social de los jóvenes, tanto desde el punto de vista social como económicamente, ya que es deber de la familia, de la sociedad y del Estado, entre otros derechos, promover la profesionalización del joven.

El aprendizaje profesional, por lo tanto, promueve junto a la profesionalización el acceso al ocio, salud, escuela, cultura, dignidad, respeto, libertad y convivencia familiar y comunitaria, existiendo la posibilidad de que, a través de sus vidas profesionales, los jóvenes en Brasil puedan tener acceso a los derechos expresados, como suyos, de forma taxativa en la Carta Magna, pero que, en un país aún con grandes distorsiones económicas, en crecimiento y desarrollo, resulta en el hecho de que muchos de esos derechos les sean negados o posibilitados pero con limitaciones temporales y cuantitativas.

En el año 2000, la legislación del aprendizaje sufrió amplia reformulación, con refuerzo en los aspectos social, laboral y educacional, posibilitando que entidades no estrictamente educacionales, por su carácter social y con énfasis en la inserción en el mundo del trabajo, vinieran también a ser entidades calificadoras de adolescentes a partir de 14 años hasta 18 años, como también de personas con discapacidad sin límite etario. ${ }^{3}$

Cabe afirmar que el aprendizaje profesional se instaura a través de un contrato especial, por escrito, por plazo determinado de hasta dos años, en que el aprendiz tiene acceso a la formación técnico-profesional metódica y será este contrato debidamente registrado en la CTPS, siendo el aprendiz necesariamente inscrito en programa de Aprendizaje Profesional, en el que existe la previsión de las actividades teóricas y prácticas a ser desarrolladas por él.

La legislación brasileña dispone que cabe a los empleadores contratar aprendices en el porcentaje de $5 \%$ a $15 \%$ de las funciones que demanden formación profesional, excluidas algunas funciones específicas. El análisis de cuáles son las funciones que demandan formación profesional se realiza a 
través de la Consulta del Registro Brasileño de Ocupaciones (CBO), en el sentido de que apenas las funciones que no demanden formación profesional serán excluidas inicialmente del cálculo.

Dispone respecto de las funciones que deban ser excluidas del cálculo, además de aquellas que no demandan formación profesional, la actualización que consta en la instrucción Normativa n. ${ }^{\circ}$ 146, de 25 de julio de 2018, que excluye de la base de cálculo, las siguientes funciones:

las funciones que, en virtud de ley, requieran habilitación profesional de nivel técnico o superior; - las funciones caracterizadas como cargos de dirección, de gerencia o de confianza, en los términos del inciso II del art. 62 y $\int 2^{\circ}$ del art. 224 de la CLT; los trabajadores contratados bajo el régimen de trabajo temporal instituido por el art. $2^{\circ}$ de la Ley n. ${ }^{\circ}$ 6.019, del 3 de enero de 1974; IV - los aprendices ya contratados (MTE, 2018).

Se afirma que las empresas de mediano y gran porte con más de siete empleados están obligadas a contratar aprendices conforme las directrices arriba detalladas. Para las empresas de pequeño porte, existe la facultad de contratación y se hace necesario el surgimiento de leyes incentivadoras de esta contratación, para empresas micro o pequeñas.

Pueden ser entidades calificadoras del aprendizaje, además del Sistema S, así entendido el Servicio Nacional del Comercio y Servicio Nacional de la Industria e incluso otros integrantes de esa categoría como: el Servicio Nacional del Cooperativismo, el Servicio Nacional de la Agricultura y el Servicio Nacional del Transporte, con prioridad en la contratación; así como innovó posibilitando a las entidades sin fines lucrativos, a las escuelas de educación técnica y tecnológica y por último a las entidades deportivas, como aptas a ser entidades calificadoras ${ }^{4}$.

Se observa el fortalecimiento del aprendizaje profesional al crear el Registro Nacional del aprendizaje profesional, estableciendo las normas para inscripción en el programa de las entidades formadoras de aprendices, entre otras medidas adoptadas. ${ }^{5}$

Para el instituto del Aprendizaje Profesional, son entidades aptas para proporcionar el aprendizaje los entes del Sistema Nacional de Aprendizaje; las escuelas técnicas de educación; las organizaciones sin fines de lucro que tengan por objetivo la asistencia al adolescente y a la educación profesional, debidamente inscritas en el Registro Nacional de Aprendizaje y registradas en 
el Consejo Municipal de los Derechos del Niño y del Adolescente - CMDCA; las entidades de práctica deportiva, en las diferentes disciplinas, asociadas al Sistema Nacional del Deporte y a los Sistemas de Deportes de los Estados, del Distrito Federal y de los Municipios.

Según el CAGED ${ }^{6}$, Brasil posee cerca de 484 mil aprendices, pero posee un potencial de aproximadamente 977 mil vacantes si todas las empresas cumplieran el mínimo de $5 \%$ de la cuota, pudiendo este número triplicar para casi 3 millones, caso adoptasen el 15\% que la Ley permite y aún más si la administración pública directa, autárquica y fundacional en las esferas municipal, estadual o distrital y federal implantasen legislaciones para el cumplimiento de la legislación del aprendizaje profesional. Las causas de la rescisión contractual de ese contrato de aprendizaje profesional están enumeradas en la ley, arriba nominada, añadiendo las justas causas. Y al respecto, dispone el artículo 13 de la Instrucción Normativa 146/2018:

[...] en su término final; cuando el aprendiz cumpla veinticuatro años, observado lo dispuesto en el párrafo único del art. $6^{\circ}$; III - anticipadamente, en las siguientes hipótesis: desempeño insuficiente o inadaptación del aprendiz, que deben ser comprobados mediante laudo de evaluación elaborado por la entidad ejecutora del aprendizaje, a quien corresponde su supervisión y evaluación, previa consulta al establecimiento donde se realiza el aprendizaje; falta disciplinaria grave prevista en el art. 482 de la CLT; ausencia injustificada a la escuela que implique pérdida del año escolar, comprobada por medio de declaración del establecimiento de enseñanza; a petición del aprendiz; cuando del cierre del establecimiento, cuando no existe la posibilidad de transferencia del aprendiz sin que eso genere perjuicio al propio aprendiz; ante la muerte del empleador constituido en empresa individual; en el caso de rescisión indirecta.

El aprendizaje profesional se transformó en un importante medio de acceso al primer empleo, a través del cual adolescentes y jóvenes de 14 a 24 años han garantizado su iniciación profesional, recibiendo: salario-mínimo-hora, registro en la CTPS, contrato de trabajo con duración máxima de 2 años, sin derecho a multa ni aviso previo, ya que es un contrato a plazo determinado; derechos previsionales debidos a los demás empleados en condiciones similares; el FGTS de $\%$ y el vale-transporte.

La obligatoriedad de frecuencia escolar posibilitó que el aprendizaje profesional se convirtiera en un poderoso instrumento que produce el retorno a las salas de aula, ya que el joven debe estar cursando la enseñanza fun- 
damental o media para ser aprendiz, siendo innecesaria la obligatoriedad si, el adolescente o joven, ya hubiera concluido la enseñanza media.

En lo que se refiere a incentivos financieros para la contratación del aprendiz, se observa que, en la actual coyuntura política, no se prevé un cambio en la legislación y no se vislumbra la actuación estatal legislativa para incentivar la contratación de aprendices. La financiación de los cursos de aprendizaje profesional, entendemos que requiere, imprescindiblemente, de un cambio legislativo que pueda efectivamente contribuir para la contratación de más jóvenes vulnerables o personas con discapacidad reduciendo la incidencia de desigualdades sociales efectivamente.

Para la persona con discapacidad no hay límite máximo de edad para ser aprendiz y esa contratación se transformó en una poderosa forma de inclusión, ya que la persona con discapacidad preserva el beneficio de prestación continuada por hasta dos años.

Las cuotas de aprendizaje y las de persona con discapacidad no son las mismas, pero se admite mediante acuerdos de compromiso con el Ministerio de Economía, a través de los auditores fiscales y del Ministerio Público del Trabajo, la posibilidad de contratar temporalmente personas con discapacidad como aprendices por hasta dos años, esperándose que la persona con discapacidad deje de ser aprendiz y que desee ocupar la vacante de persona con discapacidad, si no fuera así, se rompe el acuerdo y la empresa deberá demostrar la contratación de PCD, superado el período de hasta dos años.

La persona con discapacidad que recibe el Beneficio de la Prestación Continuada puede celebrar contrato de aprendizaje, por período de hasta dos años, siendo posible continuar recibiendo el BPC concomitantemente, conforme autoriza el párrafo $2^{\circ}$ del art. 21-A de la Ley n. ${ }^{\circ} 8.742 / 93$, incluido por la Ley n. ${ }^{\circ} 12.470 / 2011$, recordando que no hay límite de edad para celebración de contrato de aprendiz para persona con discapacidad.

\section{LA CUOTA SOCIAL O EL MEDIO ALTERNATIVO DE CUMPLIMIENTO DE CUOTAS}

En 2016, se creó en el ámbito "infralegal” una legislación de suma importancia, con la participación de auditores del trabajo del entonces Ministerio de Trabajo y Empleo y de la Gerencia del Aprendizaje en la Coor- 
dinfância del Ministerio Público del Trabajo. Esa legislación posibilitó que empresas que aducían no tener forma de inserir al aprendiz con menos de 18 años en sus instalaciones por caracterizarse como insalubres, peligrosas y penosas pudiesen, cuando no llenasen sus plazas con mayores de 18 años, utilizar la posibilidad de contratar aprendices adolescentes y socio-educandos del régimen cerrado en áreas administrativas, para trabajar en órganos públicos y entidades sin fines lucrativos.

Acerca de la Cuota Alternativa, la instrucción Normativa n. ${ }^{\circ}$ 146/2018, dispone:

Art. 23-A. El establecimiento de un contratante, cuyas peculiaridades de la actividad o en los lugares de trabajo que constituyan una molestia para la realización de las clases prácticas, además de poder ministrarlas exclusivamente en las entidades calificadas en formación técnico profesional, podrán solicitar ante la respectiva unidad descentralizada del Ministerio de Trabajo y Seguridad Social la firma de un acta de compromiso para el cumplimiento de la cuota a la entidad concedente de la experiencia práctica del aprendiz. $\int 1^{\circ}$ corresponderá al Ministerio de Trabajo y Previsión Social definir:

I - Los sectores de la economía en que la clase práctica podrá darse en las entidades otorgantes; $y$

II $-\mathrm{El}$ procesamiento de la solicitud de firma de acuerdo de compromiso.

$\int 2^{\circ}$ se consideran entidades otorgantes de la experiencia práctica del aprendiz:

I - Organismos públicos;

II - Organizaciones de la sociedad civil, en virtud del art. $2^{\circ}$ de la Ley n. ${ }^{\circ}$ 13.019, de 31 de julio de 2014; y

III - Unidades del Sistema Nacional de Atención Socioeducativa - Sinase.

$\int 3^{\circ}$ Firmado el acuerdo de compromiso con el Ministerio de Trabajo y Previsión Social, el establecimiento contratante y la entidad calificada por él ya contratada deberán firmar conjuntamente alianza con una de las entidades concedentes para la realización de las clases prácticas.

$\int 4^{\circ}$ Corresponderá a la entidad calificada el acompañamiento pedagógico de la etapa práctica. (Incluido por el Decreto n. ${ }^{\circ} 8.740$, de 2016)

$\int 5^{\circ}$ La selección de aprendices será realizada a partir del registro público de empleo, disponible en el portal electrónico Más Empleo y deberá priorizar la inclusión de jóvenes y adolescentes en situación de vulnerabilidad o riesgo social, tales como: (Incluido por el Decreto n. ${ }^{\circ}$ 8.740, de 2016)

I - Adolescentes egresados del sistema socioeducativo o en cumplimiento de medidas socioeducativas; (incluido por el Decreto n. ${ }^{\circ}$ 8.740, de 2016)

II - Jóvenes en cumplimiento de pena en el sistema penitenciario; (incluido por el Decreto n. ${ }^{\circ} 8.740$, de 2016)

III - Jóvenes y adolescentes cuyas familias sean beneficiarias de programas de transferencia de renta; (incluido por el Decreto n. ${ }^{\circ}$ 8.740, de 2016) IV - Jóvenes y adolescentes en situación de acogida institucional; (incluido por el Decreto n. ${ }^{\circ} 8.740$, de 2016) 
$\mathrm{V}$ - Jóvenes y adolescentes egresados del trabajo infantil; (incluido por el Decreto n. ${ }^{\circ} 8.740$, de 2016)

VI - Jóvenes y adolescentes con discapacidad; (incluido por el Decreto n. ${ }^{\circ}$ 8.740, de 2016)

VII - Jóvenes y adolescentes matriculados en la red pública de enseñanza, a nivel fundamental, medio regular o medio técnico, inclusive en la modalidad de Educación de jóvenes y Adultos; y, (Incluido por el Decreto n. ${ }^{\circ} 8.740$, de 2016)

VIII - Jóvenes desempleados y con educación primaria o secundaria completada en la red pública. (Incluido por el Decreto n. ${ }^{\circ} 8.740$, de 2016)

$\int 6^{\circ}$ los porcentajes que serán cumplidos en la forma alternativa y en el sistema regular deberán constar del término de compromiso firmado con el Ministerio de trabajo y Previsión Social, con mira al cumplimiento integral de la cuota de aprendizaje, observados, en todos los casos, los límites previstos en la sección IV del Capítulo IV del Título III del Decreto-Ley n. ${ }^{\circ} 5.452$, de $1^{\circ}$ de mayo de 1943 - Consolidación de las Leyes del Trabajo y la contratación del porcentaje mínimo en el sistema regular, (incluido por el Decreto n. ${ }^{\circ}$ 8.740, de 2016).

Este modelo fue creado a partir de experiencias concretas y teorización inicial de la gerencia del aprendizaje en el ámbito del Ministerio Público del Trabajo, que fue acogido por el Ministerio de Trabajo y Empleo, actual Ministerio de Economía. Son estas las experiencias prácticas aducidas: Guardia Mirim de Foz do Iguaçu en Foz do Iguaçu - Paraná; Uniflor en la ciudad de Londrina - Paraná; Ministerio Público del Estado, Ministerio Público del Trabajo y Defensoría Pública de Bahia; así como la experiencia de Rio Grande do Sul de la contratación de los adolescentes de la FASE.

Después, advino la Ordenanza n 693, del 23 de mayo de 2017, del Ministerio de Trabajo y Empleo, según la cual:

Art. $1^{\circ}$ - Los establecimientos que desarrollan actividades relacionadas a los sectores económicos enumerados abajo podrán requerir junto a la respectiva unidad descentralizada del Ministerio de Trabajo la firma del Acuerdo de Compromiso para el cumplimiento de la cuota en entidad otorgante de la experiencia práctica del aprendiz, en los términos del $\int 1^{\circ}$ del artículo $23-\mathrm{A}$ del Decreto 5.598 / 2005:

I - Limpieza y conservación;

II - Seguridad privada;

III - Transporte de carga;

IV - Transporte de valores;

V - Transporte colectivo, urbano, intermunicipal, interestatal;

VI - Construcción pesada;

VII - Limpieza urbana;

VIII - Transporte marítimo y marítimo;

IX - Actividades agropecuarias; 
$\mathrm{X}$ - Empresas de tercerización de servicios;

XI - Actividades de Telemarketing;

XII - Comercialización de combustibles, y

XII - Empresas cuyas actividades desarrolladas preponderantemente estén previstas en la lista TIP (Decreto n⿳6.481 / 2008).

$\int 1^{\circ}$ - El Ministerio de Trabajo podrá acatar la solicitud de otros sectores que se encuadren en la hipótesis descrita en el artículo 23-A, a criterio de la auditoría fiscal del trabajo.

Art. $2^{\circ}$ - el procesamiento de la solicitud de firma del Acuerdo de Compromiso se dará junto a la Superintendencia Regional del Trabajo y Empleo de la unidad de la Federación en que el establecimiento se encuentre situado, en los términos del Art. 28 del Decreto n. ${ }^{\circ}$ 4.552, del 27 de diciembre de 2002, Reglamento de Inspección del Trabajo.

$\int 1^{\circ}$ Los porcentajes que serán cumplidos en la forma alternativa y en el sistema regular deberán constar en el acuerdo de compromiso firmado con el Ministerio de Trabajo y Previsión Social, con miras al complemento integral de la cuota de aprendizaje, observados, en todos los casos, los límites previstos en la sección IV del Capítulo IV del Título III del Decreto-Ley n. ${ }^{\circ}$ 5.452, del $1^{\circ}$ de mayo de 1943 - Consolidación de las Leyes del Trabajo y la contratación del porcentaje mínimo en el sistema regular (MTE, de 2017).

Así, la argumentación que algunas empresas utilizaban ante el Ministerio de Economía, Ministerio Público del Trabajo o Justicia del Trabajo fue sustituida con la edición de esa legislación. Se argumentaba que no podían simplemente contratar aprendices, porque el objeto no era permitido para adolescentes en razón del ambiente ser insalubre, peligroso o penoso o que no había función específica para adolescentes o jóvenes y no se buscaba ninguna otra alternativa, de ahí la excelencia de la denominación cuota alternativa. La conocida cuota social o alternativa nació teniendo en cuenta los valores de la prioridad absoluta y el derecho a la profesionalización con prioridad de los adolescentes de 14 a 18 años en la contratación, o sea, si la empresa es considerada insalubre, peligrosa o penosa y se practican actividades vedadas a menores de 18 años, según la Lista de las peores formas del trabajo infantil, Lista TIP, editada por el Decreto n ${ }^{\circ}$ 6.481/2012, la empresa puede valerse de la contratación de adolescentes para funciones en sectores en que los elementos arriba descritos no estén presentes, de la contratación de mayores de 18 años o, también, de la utilización de la cuota social o alternativa.

Se observa que una empresa de construcción civil, de vigilancia o portadora así como una que tenga funciones prohibidas para adolescentes, conforme la Lista de las peores formas de trabajo infantil, no puede automáticamente ser excluida de cumplir su papel social de concretar derechos, ya que también cabe a la sociedad la prioridad absoluta, además de a la familia 
y al Estado, conforme previsión del art. 227 de la Constitución Federal. El aprendizaje profesional no pretende sustraer funciones que puedan ser cumplidas por mayores, pero no olvida el gran índice de desempleo entre los jóvenes y la exigibilidad de experiencia cuando están apenas iniciando sus vidas profesionales, de ahí la previsión de la obligatoriedad, excluidas determinadas funciones, de contratar de 5\% a 15\% de los empleados como aprendices.

Luego, la experiencia de la actuación solidaria trajo situaciones arriba relatadas y ejemplificadas como el origen social de referida legislación, o sea, si una empresa dice que no puede contratar menores de 24 años en sus funciones por inimaginables motivos, le es posibilitado contratar jóvenes aprendices que necesitan trabajar e incluirlos en organismos públicos, instituciones sin fines lucrativos o aún ofrecer a los adolescentes del sistema socioeducativo o penitenciario, o egresados del trabajo infantil, o beneficiarios de programas de renta mínima, o social y/o económicamente vulnerables o personas con discapacidad o incluso a otros, la posibilidad de también tener acceso al primer empleo o a veces el segundo empleo, aunque no con tanta experiencia profesionalmente en su mayor parte, a través de la modalidad aprendizaje profesional.

La Instrucción Normativa n. ${ }^{\circ}$ 146/2018 del Ministerio de Trabajo y Empleo dispone, además:

CAPÍTULO VIII - CUMPLIMIENTO ALTERNATIVO DE LA CUOTA DE APRENDICES

Art. 39. El establecimiento contratante cuyas peculiaridades de la actividad o de los lugares de trabajo constituyan obstáculo a la realización de las clases prácticas, en los Términos de reglamento específico del Ministerio de Trabajo, podrán requerir junto a la respectiva unidad descentralizada del MTB la firma del Acuerdo de Compromiso para el cumplimiento de la cuota en entidad otorgante de la experiencia práctica del aprendiz.

$\int 1^{\circ} \mathrm{El}$ acuerdo de compromiso previsto en el caput debe ser firmado por el Auditor-Fiscal del Trabajo responsable de la acción fiscal, así como por la jefatura inmediata y por el establecimiento contratante.

$\int 2^{\circ}$ Se considera entidad otorgante de la parte práctica a órganos públicos, organizaciones de la sociedad civil, en los términos del art. $2^{\circ}$ de la Ley $n^{\circ}$ 13.019/14 y unidades del Sistema Nacional de Atención Socioeducativa. $\int 3^{\circ}$ El término de compromiso debe prever la obligatoriedad de contratación de adolescentes en situación de vulnerabilidad o riesgo social, tales como:

a) adolescentes egresados del sistema socioeducativo o en cumplimiento de medidas socioeducativas;

b) jóvenes en cumplimiento de pena en el sistema penitenciario; 
c) jóvenes y adolescentes cuyas familias se beneficien de programas de transferencia de ingresos;

d) jóvenes y adolescentes en situación de acogida institucional;

e) jóvenes y adolescentes egresados del trabajo infantil;

f) jóvenes y adolescentes con discapacidad;

g) Jóvenes y adolescentes matriculados en la red pública de enseñanza, a nivel fundamental, medio regular o medio técnico, inclusive en la modalidad de Educación de Jóvenes y Adultos; y,

h) jóvenes desempleados y con educación primaria o secundaria completada en la red pública.

$\int 4^{\circ}$ Las partes podrán elegir, al término del compromiso, el perfil prioritario de los jóvenes y adolescentes a ser contemplados.

$\int 5^{\circ}$ Los porcentajes a ser cumplidos en la forma alternativa y en el sistema regular deberán constar del acuerdo de compromiso firmado con el Auditor-Fiscal del trabajo, para conferencia del cumplimiento integral de la cuota de aprendizaje.

$\int 6^{\circ}$ Firmado el acuerdo de compromiso con el Auditor-Fiscal del Trabajo, el establecimiento contratante y la entidad calificada ya contratada deberán firmar conjuntamente asociación con una de las entidades concedentes para la realización de las clases prácticas.

$\int 7^{\circ}$ Corresponderá a la entidad calificada el acompañamiento pedagógico de la etapa práctica.

$\int 8^{\circ} \operatorname{Los}$ párrafos $1^{\circ}, 2^{\circ}, 3^{\circ}$ y $4^{\circ}$ del art. 38 de esta Instrucción Normativa se aplican al acuerdo de compromiso previsto en el caput (MTE, 2018).

De esta forma, cada vez se fortalece más la cuota social en nuestro país, tanto en ambiente simulado como en la práctica en empresas, en instituciones sin fines lucrativos y también en talleres de música, deportes y en el régimen cerrado, entre otros.

A través de acuerdos de compromiso firmados por el Ministerio de Economía y obligaciones inseridas en acciones civiles públicas el sistema de la cuota alternativa se ha tornado poco a poco más popular y encantado a las unidades otorgantes y empresas que de otra forma no conseguirían inserir la totalidad de aprendices que necesitarían, logrando también que dirijan la mirada sobre la responsabilidad social en la comprensión de este proceso. Aquí nos corresponde hacer un paréntesis para la posibilidad de que las empresas que paguen sus tributos según el Lucro Real destinen para este tipo de contratación con la aquiescencia del respectivo fondo de la infancia y adolescencia. O también, se hace imprescindible que el administrador público venga a ofrecer al empresario contratante exenciones fiscales o incentivos financieros para fortalecer el mecanismo de la cuota alternativa. 


\section{EL PODER PÚBLICO Y LA CONTRACCIÓN DE APREN- DICES}

La prioridad absoluta como precepto fundamental constitucional se materializa adecuadamente en lo que se refiere al Derecho a profesionalización cuando el Poder Público se dispone a efectivamente preceptuar legislativamente acerca de la contratación de aprendices en su ámbito de administración pública directa, autárquica y fundacional.

Para esto en 2009 se inició esta proposición ante el Foro Nacional de Aprendizaje, o sea, la Administración Pública en general tiene el deber de contratar aprendices y priorizar al adolescente de 14 a 18 años y al adolescente vulnerable social y económicamente.

Posteriormente, surgieron nuevas proposiciones y el anteproyecto de contratación de aprendices en la Administración Pública no avanzó, aunque haya sido aprobado por la sociedad y el poder público que componía el Foro Nacional, con numerosas nuevas inserciones de texto legislativo.

En síntesis, sería obligatorio que la administración pública federal, directa, autárquica y fundacional contratase el porcentaje 5\% de la totalidad de sus servidores públicos como aprendices, con énfasis en la contratación de adolescentes vulnerables social y económicamente, de casas de acogida, del socioeducativo, del sistema penitenciario, oriundos de programa de renta mínima del gobierno federal, de personas con discapacidad, de egresados del trabajo infantil y de escuelas públicas y juventud que se auto declarara negra o parda.

La primera ley acerca del asunto fue la Ley n¹5.200/2006 del Estado de Paraná, objeto de Acción Civil Pública promovida por el Ministerio Público del Trabajo, en la cual obtuvo éxito en primer y segundo grado ante la Justicia Laboral paranaense, para que las 700 vacantes destinadas al socioeducativo fuesen atendidas en el Estado, habiendo sido firmado acuerdo para que fueran también incluidos adolescentes vulnerables social y económicamente, entre otros, siendo que el recurso inicial vino del Consejo Estatal de los Derechos del Niño y del Banco Interamericano de Desarrollo, cabiendo al Ejecutivo Estatal sugerir la inclusión en el presupuesto al Legislativo Estatal para que en el futuro sea una política pública estatal. 
Como Ley municipal, a continuación, citaremos dos construidas después de la convocatoria a los Municipios en el Ministerio Público del Trabajo para su realización en el Estado de Paraná, siendo que el municipio de Pinhais fue el primero en adherir y posteriormente el municipio de Araucária, con el empeño especial para tal realización del Promotor de Justicia David Querer Aguiar y con verificación y sugerencia de redacción realizada con nuestro apoyo. A seguir, nos atendremos a la del municipio de Araucária en Paraná, transcrita a continuación, Ley $n^{\circ} 3.360 / 2018$, que dispone sobre la inclusión de adolescentes aprendices en la Administración Pública Municipal, Autárquica y Fundacional en Araucária y da otras providencias, viniendo a establecer:

Art. $1^{\circ}$ Queda el Poder Público Municipal autorizado a instituir, en el ámbito de la Administración Pública Directa, Autárquica y Fundacional, el Programa Joven Aprendiz, conforme disponibilidad presupuestaria, según las normas generales constantes de la presente Ley. Párrafo único. El programa tiene por objetivo proporcionar a los aprendices inscritos formación técnico-profesional que posibilite la oportunidad de ingreso en el mercado de trabajo, mediante actividades teóricas y prácticas desarrolladas en el ambiente de trabajo; ofrecer a los aprendices condiciones favorables para recibir el aprendizaje profesional y estimular la inserción, reinserción y mantenimiento de los aprendices en el sistema educacional, a fin de garantizar su proceso de escolarización. Art. $2^{\circ}$ Podrán ser admitidos en el Programa, adolescentes de 14 a 18 años que serán inscritos en cursos de aprendizaje dirigidos a la formación técnica profesional metódica, promovidos por los Servicios Nacionales de aprendizaje o por entidades sin fines lucrativos, que tengan por objetivo la asistencia al adolescente y a su formación y que estén inscritas en el Registro Nacional de aprendizaje, del Ministerio del Trabajo y Empleo. Art. $3^{\circ} \mathrm{El}$ público objeto de este programa es formado, preferencialmente, por jóvenes de las clases sociales desfavorecidas y/o en situación de riesgo social, y serán atendidos de manera prioritaria, aquellos que cumplan con los siguientes criterios: I - Haber completado o estar cursando, en la red pública a nivel municipal y estatal, la Enseñanza básica (regular, complementaria o especial) o recibir beca integral en la red privada de Enseñanza Primaria y/o Secundaria; II - Recibir un ingreso familiar de hasta 02 (dos) veces el salario mínimo, o comprobar el estado de carencia mediante inscripción propia o la de algún miembro de la familia de la misma residencia en el Registro Único para Programas Sociales del Gobierno Federal; III- No mantener ningún tipo de vínculo laboral o de prestación servicio formal;

IV - Ser residente en el Municipio de Araucária.

V - Ser portador de discapacidad.

Párrafo único. La selección de aprendices por las entidades cualificadas en formación técnico-profesional metódica será realizada mediante un proceso 
selectivo simplificado, que considerará los conocimientos mínimos necesarios para el desempeño de las ocupaciones definidas en los programas de aprendizaje, además de adoptar criterios, previstos en este artículo, basados en los aspectos socioeconómicos y culturales, a través de mecanismos que garantan la participación mayoritaria de adolescentes y jóvenes en situación de vulnerabilidad social y económica. (PARANÁ, 2018).

La contratación de hasta 70 aprendices en Araucária posibilitó que los jóvenes que se hacían algún curso en el Senai, en aquel momento, con prioridad socioeducativa y vulnerables, pudiesen ser aprendices en el Municipio de Araucária, después de la realización de diversas acciones conjuntas entre el Ministerio Público del Trabajo, Ministerio Público Estatal, Ministerio de Economía, Municipio de Araucária y el Senai -Servicio Nacional de la Industria- es decir, los empresarios se comprometieron a contratar a los aprendices después de que el Ministerio Público de Trabajo llamara a audiencia pública a más de 100 empresas y posterior llamada del Ministerio Público Estatal a las mismas para que demostrasen que, al menos, un aprendiz pertenecía al sistema socioeducativo.

Una empresa del área de la limpieza, la Empresa Emparseg Ltda., contrató aprendices en la modalidad cuota alternativa y fue editada la ley municipal que garantizó que el poder público municipal también contratara aprendices. Una serie de acciones que pueden hacer gran diferencia en la vida de muchos adolescentes de esta ciudad de la región metropolitana de Curitiba. Se observa la actuación del municipio con la oferta de merienda y vale transporte inicial, así como actuación para viabilizar la escolarización próxima al local de trabajo y del curso, como agentes de éxito también en este proceso. Así es que se observa a través de esa modalidad de contratación el comienzo de un nuevo futuro para innúmeros adolescentes y el distanciamiento de la reincidencia en infracciones, con la simple oportunidad de un empleo justo y adecuado a la edad, con la oferta de escuela obligatoria y profesionalización siendo la parte teórica en la entidad formadora y la práctica en la empresa, así como es el instituto del aprendizaje profesional. 


\section{EL APRENDIZAJE PROFESIONAL DEL ADOLESCENTE DEL SOCIOEDUCATIVO O DEL JOVEN DEL SISTEMA PE- NITENCIARIO}

La ley que instituyó el Sistema Nacional Socioeducativo en Brasil para los jóvenes que cometieron infracciones, prevé la necesidad de que exista la preparación de los jóvenes, que están cubiertos por la ley, para el mundo del trabajo. Luego, corresponde actuar al Sistema $S$, Senai, Senac, así como al Senar, Senat, Sescoop, para que los jóvenes sean profesionalizados.

De este modo, la Ley n. ${ }^{\circ} 12.594 / 2012$ dispone:

Art. 76. El art. $2^{\circ}$ del Decreto-Ley n. ${ }^{\circ} 4.048$, del 22 de enero de 1942, pasa a ser vigente sumado el siguiente $\int 1^{\circ}$, renumerándose el actual párrafo único para $\int 2^{\circ}$ :

Art. $2^{\circ}$

$\int 1^{\circ}$ Las Escuelas del Senai podrán ofrecer plazas a los usuarios del Sistema Nacional de Atención Socioeducativa (Sinase) en las condiciones a ser dispuestas en instrumentos de cooperación celebrados entre los operadores del Senai y los gestores de los Sistemas de Atención Socioeducativa locales. $\int 2^{\circ}$

(NR) (BRASIL, 2012).

Los arts. 77, 78 y 79 disponen de forma similar para el sistema Senac, Senar y Senat, no habiéndose pronunciado la legislación sobre el Sescoop, pero entendemos que esto no aleja la obligación similar de todos los "S".

Se observa que, en la práctica, esta ley ya está dando sus frutos, como es el caso de la Araucária-Paraná, donde, después de la actuación conjunta entre el Ministerio Público del Trabajo, Ministerio Público Estatal y el Senai (Servicio Nacional de la Industria), se estableció un proyecto consistente en las siguientes y sucesivas, etapas desde 2014: convocatoria de las empresas en el Municipio de Araucária para cumplir con la cuota de aprendizaje con la inclusión de, al menos, un adolescente del socioeducativo; realización de curso de capacitación para los jóvenes del socioeducativo, siendo primero uno exclusivo y un segundo junto a los demás, para evitar de esta forma cualquier posibilidad de discriminación en el trabajo y en la vida; el Ministerio Público del Trabajo realizó investigaciones y acciones civiles públicas de empresas no contratantes en la Justicia del Trabajo; investigaciones y acciones civiles públicas en la Justicia Común, o tribunales ordinarios, también en relación a empresas no contratantes de adolescentes que cumplen medidas socioeducativas en Araucária-Paraná; adopción de la ley municipal para la contratación 
en el municipio de aprendices que se encuentren cumpliendo medidas socioeducativas; celebración de acuerdos de compromiso para que las empresas actúen contratando aprendices de forma alternativa o en la modalidad de la cuota social para trabajar en la prefectura o en entidad sin ánimo de lucro, como es el caso de la Empresa Empaserg.

No se debe olvidar la actuación realizada en la Fase do Rio Grande do Sul, institución del Estado de Rio Grande do Sul, responsable por los adolescentes en semilibertad o en régimen cerrado que, en colaboración con el Centro de Integración Empresa y Escuela de ese estado, bajo la reparación del Ministerio de Público del Trabajo, a través de la auditora Denise Brambilla, produjo la observancia efectiva Prioridad Absoluta que prevé la Constitución Brasileña.

Se trata de una realidad social modificada por la unión de colaboradores y por la idealización de proyectos que produjeron diferencias en las vidas de innúmeros jóvenes que pudieron como integrantes del Sistema Sinase tener acceso a este Sistema de protección. Los adolescentes que, por haber cometido cualquier infracción penal fueron o están siendo profesionalizados como aprendices dentro de los moldes de la legislación del aprendizaje, pasaron a, obligatoriamente, ir a la escuela, a aprender una profesión en ambiente simulado y a tener acceso a la debida remuneración de las empresas para las cuales prestan servicios, quedando parte de esa remuneración depositada en libreta de ahorros para que, posteriormente, cuando hayan egresado del sistema se beneficien de ese acceso remuneratorio bajo las normas laborales y puedan proseguir como aprendices en régimen abierto o encaminados a una empresa asociada, pudiendo, en ese momento retirar estos recursos para establecer una nueva vivienda con sus recursos propios.

De esa forma, entendemos que corresponde al Sistema " $S$ ", de forma obligatoria y no facultativamente, aplicar recursos para que jóvenes que están cumpliendo medidas socioeducativas sean atendidos en la modalidad aprendizaje profesional, interpretación esta fundamentada en el hecho de que los referidos servicios nacionales son costeados con el 1\% de las nóminas de la industria, comercio, transporte y del medio rural, por lo tanto entendemos que ese recurso es recolectado impositivamente, configurándose una dotación de naturaleza tributaria y consistiendo en un deber y no apenas un poder. 
Además, ante los principios de la prioridad absoluta, del interés superior y de la protección del niño y del adolescente, esa ley merece ser interpretada como un deber, conjugada aún con la progresiva gratuidad en la oferta de los cursos concedidos por Senai y Senac, a reforzar aún más que tal oferta de cursos a los adolescentes del Sinase debe ser interpretada como obligatoria.

Las medidas socioeducativas corresponden a sentencias judiciales dictadas por jueces de las varas de la infancia y adolescencia y en algunos casos comprenden jóvenes de hasta 21 años. Según el Estatuto del Niño y del Adolescente, esas medidas pueden ser de seis tipos: advertencia, obligación de reparar el daño, prestación de servicios a la comunidad, libertad asistida, semilibertad e internación. Entre las directrices del Sinase, conforme al Plan Nacional de Atención Socioeducativa están:

j) Garantizar la oferta y acceso a la educación de calidad, a la profesionalización, a las actividades deportivas, de ocio y de cultura en el centro de internación y en la articulación de la red, en medio abierto y semilibertad" (BRASIL, 1990).

La socio-educación consiste en una política pública específica para los jóvenes en conflicto con la ley. Así, entendemos que, en cualquiera de los casos de medidas adoptadas, los adolescentes pueden y deben ser encaminados a la profesionalización mediante aprendizaje profesional, configurándose un rescate de la sociedad brasileña de los jóvenes excluidos que, muchas veces victimizados, cometieron actos de infracción. La adopción de cualquier medida tiene que tener carácter pedagógico, y el aprendizaje profesional garantiza la escolaridad y la profesionalización.

El Sistema Integrado Nacional de atención socioeducativa prevé la necesidad de políticas públicas efectivas para hacer con que recursos públicos sean destinados al área de la infancia y adolescencia. Así, dispone acerca del Sistema $S$ y también de las políticas presupuestarias. Esas disposiciones deben ser valoradas conforme los principios constitucionales del interés superior, primacía del niño y del adolescente y protección integral para interpretar y aplicar normas de la ley del Sinase, en el sentido de que son coercitivas y obligatorias, cabiendo a los administradores públicos actuar para objetivar la profesionalización, calificación profesional y talleres temáticos dirigidos para esos adolescentes. 
Como ejemplo de política pública adoptada para contratación de aprendices podemos mencionar el proyecto ejecutado en el municipio de Campo Mourão, Paraná, durante los años 2017 a 2020, conforme, Aguiar, Passari y Wood (artículo en prensa):

Por medio de la actuación del Ministerio Público del Trabajo, en los procedimientos administrativos 000036.2018.09.009/6 y 000025.2019.09.009/4, El Municipio de Campo Mourão celebró término de convenio con la entidad Centro de Educación Santa Maria (CEDUS) y realizó la contratación de aprendices en cumplimiento de medidas socioeducativas de prestación de servicios a la comunidad y libertad asistida, en programa de acogida institucional y en situación de trabajo infantil. La contratación de los aprendices ocurrió de forma indirecta, con el registro del contrato de trabajo por el CEDUS, de conformidad con el artículo 431 de la CLT y ley municipal $3.711 / 2016$, siendo las clases teóricas ofertadas por el CEDUS y actividades prácticas en órganos públicos de la Prefectura de Campo Mourão (PARANÁ, 2018, 2019b). Los aprendices fueron seleccionados por medio de un proceso selectivo ejecutado por el Centro de Referencia Especializado de Asistencia Social (CREAS) y CEDUS. Durante sus actividades, el CEDUS promueve, además de las actividades teóricas, medidas de acompañamiento del desempeño de los aprendices, por medio de un equipo formado por trabajadores sociales y psicóloga, con atención individualizada a los aprendices, incluso con visitas domiciliares para constatación de las necesidades socioeconómicas y de salud de los jóvenes, siendo que los recursos para ejecución del proyecto son provenientes de destinación decurrente de la actuación del Ministerio Público del Trabajo.

Excelente trabajo desarrollado con el objetivo de posibilitar que los adolescentes que cometieron infracciones penales o egresados del Trabajo Infantil pudieran ser contratados como aprendices para laborar en el Municipio de Campo Mourão, frente a la edición de la Ley n. ${ }^{\circ} .711$ / 2016, apoyada e incentivada por el Ministerio Público del Trabajo.

Y aún, no debemos olvidar la Ley de Contratación de Aprendices del Estado de Paraná ${ }^{7}$ que estableció contratación de 700 aprendices de adolescentes en conflicto con la Ley y ante el incumplimiento por el estado, fue objeto de Acción Civil Pública por el Ministerio Público del Trabajo, habiendo sido celebrado acuerdo en segundo grado de jurisdicción para que en 2020 y 2021 sean contratados los 700 aprendices bajo pena de multa a ser arbitrada por el Juzgado del Trabajo. ${ }^{8}$ 


\section{CONCLUSIÓN}

El Instituto del aprendizaje profesional y sus innumerables posibilidades para introducir al joven brasileño en el mundo del trabajo ha provocado sustanciales cambios en el acceso y en la percepción de la Sociedad en este proceso. El discurso dirigido solo para el otro, como "por qué no trabaja, yo no entiendo", se encuentra aclarado y objetivado para demostrar que el acceso depende de un cambio de comportamiento para que los individuos, la familia, la sociedad y el Estado se dediquen a efectivamente cumplir el mandamiento Constitucional de la prioridad absoluta y actúen con base en la solidaridad social.

La pregunta pasa a ser: ¿cómo puedo colaborar individual, colectivamente o de forma pública para que este proceso se modifique? Con seguridad es mediante el establecer formas de colaboración como se demuestra en este artículo, empezando por el propio Ministerio Público, en dos de sus facetas, Ministerio Público Estatal y el Ministerio Público del Trabajo, en la construcción de políticas en los distintos ámbitos de la Federación brasileña, para posibilitar que ciudades, pequeñas, grandes, estados y la Unión prestigien el acceso de aprendices en sus unidades federativas, principalmente adolescentes o jóvenes con vulnerabilidad social y económica, siendo $80 \%$ de ellos, para garantizar el acceso prioritario a los más vulnerables de entre la juventud esencialmente vulnerable y, dentro de esta, sí, no olvidar a los jóvenes que se encuentran excluidos de la sociedad por haber cometido infracciones penales habiendo sido aprehendidos o, incluso, todos aquellos que se encuentran en los sistemas penitenciarios, ocasión en la que la ley debería abrir excepción para no existir límite de edad para tornarse un aprendiz, permitiendo que todos pudieran serlo dentro de las unidades socioeducativas o de las prisiones. Y, además, que los entes públicos se dispongan a ser unidades otorgadoras del aprendizaje profesional para posibilitar el acceso a través de la cuota social.

Estamos hablando de oportunidades expresadas en derecho previamente prescrito y, para eso, el cambio debe ser de toda la sociedad y solo se concreta en el actuar y el pensar jurídico y social ha ayudado a fundamentar e incluso a indicar caminos para este actuar colectivo de acceso al joven del sistema educacional o penitenciario al aprendizaje profesional como efectiva forma de reconstrucción individual y de rehabilitación del joven alijado por la práctica de infracción o criminal verificada. 
Esto, para que no piensen los más individualistas: ¿Para qué darle oportunidad a quien cometió un error? Simplemente porque la vida está hecha de oportunidades esta vez amparadas en la Constitución y en la legislación, utilizando el razonamiento lógico jurídico para la construcción de soluciones que propicien una sociedad centrada en la cura individual para que el individuo pueda reconstruirse y sumar, transformando de esta forma su historia y también contribuyendo para su sociedad en el futuro.

\section{NOTAS}

1 Art. 227 de la Constitución Federal.

2 Inciso XXXIII del art. 7 de la Constitución Federal.

3 Ley n. ${ }^{\circ}$ 10.097/00, que modificó los artículos 428 a 433 de la Consolidación de las Leyes del Trabajo.

4 Art. 430 de la Consolidación de las Leyes del Trabajo.

5 Ordenanza n. ${ }^{\circ}$ 723/12 del Ministerio de Trabajo y Empleo.

6 CAGED-Ministerio de Economía-julio de 2019.

7 Ley n. 15.200/2005 del Estado de Paraná.

8 ACP 000107-36.2015.5.09.0004.

\section{REFERENCIAS}

AGUIAR, Raquel; PASSARI, Fábio; WOOD, Edineia. A promoção de Políticas Públicas de Aprendizagem pelos Municípios para Adolescentes em Situação de vulnerabilidade Social. [S.l], [20--]. Apresentado no Curso de Direitos Humanos e Trabalho da ESMPU. Artículo aún no publicado.

BESSA, Suely; JOSVIAK, Mariane; MARQUES, Geny Helena. Aprendizagem no Sistema Socioeducativo. In: Manual de atuação da Coordenadoria Nacional de Combate à Exploração do Trabalho da Criança e do Adolescente. Brasília/DF: 2015.

BRASIL. Decreto-lei n. ${ }^{\mathbf{5}} \mathbf{5 . 4 5 2}$, de 1 de maio de 1943. Aprova a consolidação das leis do trabalho. Brasília-DF, maio 1943. Disponible en: http:// www.planalto.gov.br/ccivil_03/decreto-lei/Del5452compilado.htm. Acceso: 23 jun. 2020.

BRASIL. Constituição da República Federativa do Brasil. Brasília/DF, 1988. Disponible en: https://www.senado.leg.br/atividade/const/con1988/ CON1988_05.10.1988/CON1988. Acceso: 22 jun. 2020. 
BRASIL. Decreto n. 5.598 de $\mathbf{1}^{\mathrm{o}}$ de dezembro de 2005. Regulamenta a contratação de aprendizes e dá outras providências. Brasília-DF, dez. 2005. Disponible en: https://presrepublica.jusbrasil.com.br/legislacao/96246/decreto-5598-05. Acceso: 24 jun. 2020.

BRASIL. Lei n. $^{\mathbf{0}} \mathbf{1 2 . 5 4 1}$, de 18/01/2012. Institui o Sistema Nacional de Atendimento Socioeducativo (Sinase). Brasília-DF, jan. 2012. Disponible en: http://www.planalto.gov.br/ccivil_03/_Ato2011-2014/2012/Lei/L12594. htm. Acceso: 20 jun. 2020.

CARTA de Curitiba da Aprendizagem. Produzida pelo Fórum de Aprendizagem do Paraná com o fito de sensibilização política acerca do tema. Curitiba/ PR, out. 2019. Audiência Pública realizada na Assembleia Legislativa do Paraná em 23 out. 2019.

CNJ. Programa justiça jovem. Panorama Nacional: a execução das medidas socioeducativas de internação. Brasília/DF: 2012. Disponible en: https:// www.cnj.jus.br/wp-content/uploads/2011/02/panorama_nacional_doj_ web.pdf. Acceso: 27 mar. 2020.

JOSVIAK: Mariane; BLEY, Regina Bergamaschi (orgs.). Políticas públicas e aprendizagem: a participação do Ministério Público na construção de políticas públicas para profissionalizar jovens no Paraná. In: Ser aprendiz: aprendizagem profissional e políticas públicas - aspectos jurídicos, teóricos e práticos. São Paulo: LTr, 2009.

JOSVIAK, Mariane. O Sinase e as políticas públicas para o jovem em conflito com a Lei: a aprendizagem profissional e os direitos fundamentais e humanos. In: Boletim científico ESMPU. Brasília/DF, a. 14, n. ${ }^{\circ}$ 44, p. 131-149, jan./jun. 2015.

MINISTÉRIO DO TRABALHO E EMPREGO. Instrução Normativa MTE n. ${ }^{\circ}$ 146, de 25 de julho de 2018. Brasília-DF, jul. 2018. Disponible en: https://www.in.gov.br/materia/-/asset_publisher/Kujrw0TZC2Mb/ content/id/34730621/do1-2018-07-31-instrucao-normativa-n-146-de-25de-julho-de-2018-34730599. Acceso: 24 jun. 2020.

MINISTÉRIO DO TRABALHO E EMPREGO. Portaria MTE n. ${ }^{\mathbf{0}} \mathbf{7 2 3}$ de 23/04/2020, alterada pela Portaria n. ${ }^{\circ}$ 634/2012. Brasília DF. Disponible en: https://www.legisweb.com.br/legislacao/?id=381718. Acceso: 20 jun. 2020. 
PARANÁ. Lei n. $^{\mathbf{0}} \mathbf{1 5 . 2 0 0}$, de 10 de julho de 2006. Institui o programa estadual de aprendizagem para o adolescente em conflito com a lei. Curitiba/ PR, jul. 2006. Disponible en: https://leisestaduais.com.br/pr/lei-ordinaria-n-15200-2006-parana-institui-o-programa-estadual-de-aprendizagem-para-o-adolescente-em-conflito-com-a-lei-conforme-especifica-e-adota-outras-providencias. Acceso: 13 jun. 2020.

SINDICATO NACIONAL DOS AUDITORES FISCAIS DO TRABALHO. Manual da Aprendizagem Profissional: o que é preciso saber para contratar o aprendiz. Brasília: SINAIT, 2019. 65 p. Disponible en: https:// enit.trabalho.gov.br/portal/images/manuais/Manual_de_Aprendizagem_ versao_para_download.pdf. Acceso: 30 jun. 2020. 


\title{
TRABAJO INFANTIL EN CADENAS PRODUCTIVAS DE GRANDES EMPRESAS: VIOLENCIA SISTÉMICA Y FALACIA DISCURSIVA
}

\author{
MARQUES CASARA
}

DOI: $10.51366 / 978-65-89468-10-3-$ coordinfancia-21

Resumen. Este artículo analiza la ocurrencia del trabajo infantil en cadenas productivas de grandes empresas, así como las prácticas de ocultación usadas para evitar la identificación de los enlaces que conectan el problema con los reales beneficiarios, las corporaciones que utilizan, en la obtención de sus materias primas, la explotación de niños y adolescentes. También se menciona aquí ejemplos de investigaciones de cadenas productivas realizadas por este autor, en asociación con el Ministerio Público del Trabajo.

Palabras clave: Trabajo infantil. Cadenas productivas. Dilema civilizatorio.

En las cadenas productivas, establecer responsabilidades para el trabajo infantil es una misión compleja. En general, hay numerosos e intrincados enlaces entre la materia prima y el producto final. Esta complejidad dificulta el rastreo de todas las etapas del negocio, principalmente cuando entran en escena mecanismos de ocultación, estratagemas que objetivan ocultar el vínculo entre grandes empresas y la explotación del trabajo infantil, fenómeno que ocurre, con más frecuencia, en la base de la cadena productiva. Todo esto sucede, en general, lejos de los ojos del consumidor y, en algunos casos, también al margen del escrutinio de las estructuras gubernamentales de fiscalización.

Los mecanismos de ocultación tienen el propósito de obliterar el controlador del capital, ocultándolo en un laberinto formado por atravesadores, empresas de fachada, fraudes tributarios, falsificación de informes de sostenibilidad, frentes de hierro, contratos de fachada, publicidad engañosa y toda 
una gama de simulaciones y disimulaciones, objetivando preservar las grandes marcas de eventuales daños a la reputación, al ser acusadas de explotar trabajo infantil o esclavo o alguna otra forma de violencia contra los derechos humanos.

El cuidado de la reputación está directamente vinculado a la imagen de la empresa. Las grandes marcas multinacionales suelen, en general, asociar sus actividades al discurso de la "sostenibilidad" y del respeto a los derechos humanos. Pero en la práctica no es así. Su comportamiento varía según el país en el que operan. En muchos casos, las violaciones contra niños y adolescentes, intolerables en sus países sede, se incorporan a la gestión del negocio, dependiendo de dónde ocurre la actividad.

Esta elasticidad ética y legal es visible principalmente en países con un control deficiente sobre la garantía de los derechos humanos y el cumplimiento de la legislación ambiental. Es el caso de Brasil, con el agravante de que las estructuras de fiscalización padecen de sucesivos y crecientes recortes presupuestarios, lo que favorece, en algunos casos, la impunidad.

Aún así, en nombre de la preservación de la imagen, las empresas ponen en acción las estructuras de ocultación. Buscan, en esencia, evitar que se establezcan vínculos concretos entre ellas y la explotación de niños y adolescentes, usadas como mano de obra barata y desechable en diversos sectores de la economía. El objetivo es uno: obtener materia prima barata, sin importar los derechos humanos, sin importar el medio ambiente.

En el siglo XXI, en cadenas productivas que operan globalmente, en tiempo real, intrínsecamente conectadas a aparatos tecnológicos de comunicación y rastreo, explorar niños y adolescentes no es algo que se haga por casualidad o sin saberlo. Todo lo contrario. Las empresas saben lo que hacen y lo hacen movidas por la lógica esencial de un capitalismo anticuado y depredador, pero aún en boga en los países periféricos: reducción de costos, sin tener en cuenta el valor de la vida.

Debido a esto, se hace necesaria, más que nunca, investigar y rastrear cadenas productivas. Desentrañar los mecanismos de ocultación e identificar los vínculos entre la parte superior y la base del proceso. No es más que reunir información y pruebas materiales que establezcan vínculos entre las 
víctimas y los exploradores que tienen el control de la estructura, la parte superior de la pirámide.

El objetivo de investigar la cadena productiva es identificar y responsabilizar a las empresas que controlan el flujo de capitales y la comercialización de la mercancía final. Esto se debe a que se ha consolidado el entendimiento de que, en las redes de negocios, los responsables del trabajo infantil o esclavo no son solo las personas o empresas que están vinculadas a la actividad en el lugar donde ocurre la violación. También son responsables aquellos que financian la producción y comercializan el producto terminado.

En una cadena productiva, quien gana dinero con la mercancía que tuvo trabajo infantil, en cualquier etapa de la producción, es responsable del problema. No importa cuán lejos esté la compañía del lugar de ocurrencia. No importa cuán oculta esté, a menudo protegida por proveedores, intermediarios o fraudes que tengan como objetivo ocultar el origen de la materia prima.

Una empresa que compra insumos sin monitorear el origen tiene plena responsabilidad por lo que sucede en la base de la cadena. Cabe recordar aquí una antigua y conocida frase, atribuida al fiscal Earl J. Silbert, que en el siglo pasado actuó en el distrito estadounidense de Columbia. Conocido por la brillante conducción de la investigación del caso Watergate ${ }^{1}$, Silber dijo a sus colegas, durante la fase de levantamiento de pruebas: follow the money - "sigue el dinero". Esa frase es una jerga usada, alrededor del mundo, por investigadores de diferentes tipos de crímenes. Es una frase aparentemente simple, pero que guarda mucha complejidad.

Es necesario seguir el dinero, identificar la red de proveedores, establecer los vínculos económicos, detectar el origen de las materias primas, rastrear a los atravesadores informales, observar si existen fraudes tributarios o falsificación de documentos que objetivan ocultar o maquillar el origen de los insumos. Es en esta etapa inicial de la cadena, la obtención y manipulación de la materia prima, donde se encuentran los trabajadores más vulnerables.

\section{MULTINACIONALES}

Brasil todavía tiene un lucrativo mercado de vidas humanas baratas. Niños y adolescentes disponibles para actividades prohibidas, arriesgadas e 
insalubres. Una parte de esta red de explotación está al servicio de las empresas más grandes del mundo, multinacionales que operan en decenas de países y que están radicadas, muchas veces, en regiones que han erradicado el trabajo infantil, pero que son conniventes con violaciones fuera de sus fronteras.

Es el caso, por ejemplo, de Suiza. El país es conocido por fabricar uno de los mejores chocolates del mundo. Hace una amplia propaganda de esta hazaña. Pero oculta que la compañía más grande instalada en su territorio, Nestlé, explota a miles de niños y adolescentes en granjas de cacao en Brasil (CASARA, 2019) y África (WHORISKEY; SIEGEL, 2019).

Niños descalzos y mal alimentados, que faltan a la escuela para trabajar en la cosecha del cacao en el interior de Brasil, no están apenas al servicio de sus familias o de los negociantes que recorren la región comprando cacao de miles de pequeños productores (OIT, 2018). Estos niños están al servicio del mercado global de chocolate, una cadena productiva que mueve US 1100 mil millones al año (CARVALHO; NETO, 2019) y que es controlada por grandes multinacionales del sector de alimentos.

Casos como este se repiten en otras grandes cadenas productivas, en las cuales los reales beneficiarios están ocultos o instalados a miles de kilómetros de los lugares de la violencia, muchas veces perpetrada por negociantes, propuestos o títeres, todos al servicio de grandes marcas.

En un taller de costura que explota a niños y adolescentes, por ejemplo, la responsabilidad no será solo del propietario del establecimiento, sino también de la marca de ropa que contrató el servicio y que debería monitorear todos los enlaces de la cadena productiva, a fin de evitar la explotación ilegal de la mano de obra, de la cual es la real beneficiaria. Esta lógica sirve para toda y cualquier actividad económica: quien tiene el control económico de la cadena productiva es responsable de lo que sucede en todas las etapas, desde la base hasta la parte superior.

En este contexto, recientemente se ha dado una importante contribución para ayudar a comprender los sectores económicos que se benefician del trabajo infantil. A finales de 2016, se lanzó un estudio que sirvió como punto de partida para una serie de investigaciones de cadenas productivas, entre ellas el cacao y la confección, mencionadas anteriormente. 
Ese estudio, titulado El Trabajo Infantil en las principales agrupaciones de actividades económicas de Brasil (DIAS, 2016), fue producido mediante el análisis de los microdatos de la investigación Nacional por muestra de domicilios (PNAD), en un trabajo solicitado por el Foro Nacional de Prevención y Erradicación del Trabajo Infantil (FNPETI). Ofrece una amplia gama de información sobre la explotación de niños y adolescentes en distintos sectores de la economía.

En el cacao, señala la existencia de 7.990 niños y adolescentes en situación de trabajo infantil, en áreas de producción localizadas, principalmente, en los estados de Pará y de Bahía. Ese dato fue el punto de partida de una investigación que duró un año y medio, coordinada por este autor, en asociación con el Ministerio Público del Trabajo (MPT) y la Organización Internacional del Trabajo (OIT, 2018). El objetivo era establecer todos los enlaces de la cadena, desde la base hasta la parte superior.

La investigación identificó a seis multinacionales del sector de alimentos como las principales beneficiarias de la explotación del trabajo infantil en los cultivos de cacao: Nestlé, Mondelez, Garoto, Barry Callebaut, Cargill y Olam Brasil (CASARA, 2019). Los datos fueron puestos a disposición del MPT y de la OIT, que iniciaron una serie de tratativas con el objetivo de cambiar el modelo del negocio y erradicar el trabajo infantil de esa cadena productiva.

El problema del trabajo infantil, sin embargo, no se limita sólo a esa violencia. En las cadenas productivas, la explotación de niños y adolescentes nunca es un fenómeno aislado. En general, está acompañado de otros crímenes. En el caso del cacao, también hay trabajo esclavo, fraudes fiscales y violación del Estatuto de la Tierra, con el fin de maquillar la sobreexplotación de la mano de obra de familias en régimen de división igual.

La cadena del sector textil y de confección, otro ejemplo citado anteriormente, también sufre de violaciones diversas, las cuales agravan aún más el problema del trabajo infantil. De los más de 170 mil niños y adolescentes en actividad en esa cadena productiva (DIAS, 2016), la mayoría trabaja en talleres domésticos administrados por un pariente que, en general, también se encuentra en situación de vulnerabilidad. En este y otros sectores, las familias empleadas de manera informal se ven obligadas a llevar a sus hijos a la condición de explotación. 
En el vestuario, al menos 800 mil mujeres costureras actúan en la informalidad (CNTV, 2015). La mayoría son madres que han convertido sus propias casas en talleres de costura, al servicio de grandes tiendas de ropa y accesorios. Es en este ambiente donde prospera gran parte del trabajo infantil. En el vestuario, asociada a la explotación de la mano de obra de niños y adolescentes, la violencia de género representa un grave y aún poco enfrentado fenómeno de violación de los derechos fundamentales.

Es un sector que emplea a 1,7 millones de Trabajadores en Brasil. De eso, el $76 \%$ son mujeres. Una cadena productiva mayoritariamente femenina, de las cuales 800 mil actúan en condiciones precarias (ibidem). Es una vida marcada por jornadas excesivas, violaciones de derechos humanos, discriminación de género, enfermedades causadas por el exceso de trabajo. Todo esto en talleres informales o ilegales, lo que agrava, en gran medida, el problema del trabajo infantil.

Los casos mencionados anteriormente, el cacao y la ropa, no son una excepción. Otras cadenas productivas padecen el mismo problema, tales como: humo, yeso, yuca, castaña, minería y muchas otras.

En un extremo aún más grave, se observa el fenómeno de la explotación sexual comercial de niños y adolescentes, orquestada por redes altamente especializadas y que mueven un lucrativo mercado, aún oculto por un brutal manto de silencio. En ese escenario, cabe mencionar el trabajo desarrollado por Childhood Brasil, que busca sensibilizar empresas para capacitar a sus camioneros, de modo que se conviertan en agentes de protección de la infancia y de la adolescencia en las carreteras.

\section{DRAMA EDUCATIVO Y SOCIAL}

Trabajo infantil es "trabajo realizado por niños o adolescentes que los priva de la infancia, compromete su potencial y su dignidad y que puede ser perjudicial para su salud, su desarrollo físico o mental" (OIT, [201-]). En Brasil, la Constitución prohíbe el trabajo para menores de 16 años, excepto como aprendiz, a partir de los 14 años. También está prohibido el trabajo de menores de 18 años en actividades clasificadas en la llamada Lista de las Peores Formas de Trabajo Infantil, que abarca cualquier actividad ilícita o perjudicial para la salud o la integridad moral (OIT, 2000). 
La gran mayoría de las actividades de trabajo infantil que tienen lugar sobre la base de grandes cadenas productivas están fuera de los límites de lo permitido. Implican actividades insalubres, peligrosas y que a menudo privan a los niños y adolescentes del derecho a ir a la escuela. Mirar el escenario educativo, de los niños y adolescentes sometidos al trabajo infantil, es un recorte sombrío y que da el verdadero significado de lo que es tener una vida impedida de desarrollarse en su plenitud.

Desde un punto de vista legal, el fenómeno está debidamente tipificado. Para escapar de la acusación de explotar a niños y adolescentes en sus cadenas productivas, las empresas que se benefician de esta práctica adoptan, en diferentes sectores de la economía, una estructura discursiva muy parecida: informes de sostenibilidad genérico, ricamente ilustrados pero imposibles de comprobar en relación al origen de las materias primas o la garantía de los derechos humanos. Las empresas que se benefician económicamente del trabajo infantil simplemente pasan por alto el daño causado en la vida de los trabajadores jóvenes

La cadena de producción del tabaco es uno de muchos ejemplos. En Brasil, la producción de cigarrillos es controlada por dos empresas, la British American Tobacco - dueña de Souza Cruz-y Philip Morris. Según lo demostrado por la investigación de cadena productiva publicada en 2019 por Papel Social, en colaboración con el Ministerio Público del Trabajo, estas dos empresas son las principales beneficiarias de una amplia red de trabajo infantil en cultivos de tabaco en los estados de Rio Grande do Sul, Santa Catarina y Paraná (CASARA; DALLABRIDA, 2019).

Según la publicación, en algunas ciudades de Rio Grande do Sul, más de la mitad de los niños y adolescentes en edad escolar están en situación de trabajo infantil. Al mismo tiempo que explotan niños en cientos de ciudades en la región sur, esas mismas empresas publican extensos informes de sostenibilidad genéricos y sin comprobación de las informaciones allí mencionadas, al menos en lo que se refiere al enfrentamiento del trabajo infantil.

Son 150 mil familias que plantan humo en 619 municipios de la región sur de Brasil, configurando la mayor área exportadora del mundo (AFUBRA, 2018). También es la región con uno de los impactos más significativos en la vida de los jóvenes estudiantes. En Rio Grande do Sul, mayor productor 
nacional, el 90\% de los cultivadores de tabaco no consiguen terminar la enseñanza fundamental. Solo el $2.1 \%$ termina la escuela secundaria.

Desde el sur hasta el norte del país, cuando hay trabajo infantil, el escenario es muy similar. En Pará, con motivo de la investigación que identificó los vínculos del trabajo infantil con las grandes empresas de cacao y chocolate, este autor conversó con decenas de profesoras, padres y gestores escolares. Las declaraciones siempre son muy parecidas: cansancio durante las clases, imposibilidad de cumplir las tareas escolares, evasión.

La gran empresa que tiene trabajo infantil en su cadena productiva es responsable directa de la perpetuación de la miseria en las regiones productoras de materias primas. Un niño sin escuela será un adulto vulnerable al trabajo degradante y la miseria.

\section{DILEMA CIVILIZATORIO}

En lo que se refiere a las empresas que explotan niños y adolescentes en sus cadenas productivas, el discurso de la sostenibilidad y del respeto a los derechos humanos se presenta como una falacia, un juego de escena que objetiva, sobre todo, ocultar las reales prácticas adoptadas por esas corporaciones.

La sostenibilidad, en su valor de causa, es un dispositivo conservador a dar la cara humana a una estructura económica insostenible, en que el discurso de la sostenibilidad equivale de hecho, "a una mayor dosis de artificialismo técnico-científico y a más negocios, más Industria y a más mercado” (LIPOVETSKY, 2009, p. 197).

Creer en la sostenibilidad como instrumento de transformación, según Zizek, es como la creencia supersticiosa del aficionado frente a la televisión, gritando y saltando en el sofá, con la expectativa de que su gesto influirá en el resultado del partido (ZIZEK, 2012, p. 310).

Latouche (2009, p. XII) dice que la sociedad actual fue fagocitada por una economía cuya única finalidad es el crecimiento por el crecimiento, que abarca todo, incluso los movimientos contrarios a ella. Para el autor:

Es significativa la ausencia de una verdadera crítica de la sociedad de crecimiento en la mayoría de los discursos ambientalistas, que sólo hacen rodar en sus colocaciones sinuosas sobre el desarrollo sostenible. 
El hecho es que nos enfrentamos a un brutal dilema civilizatorio. El advenimiento de lo que llamamos "globalización", asociado con las nuevas tecnologías de comunicación, nos dio la sensación de que finalmente habíamos logrado un lugar mejor. Dulce ilusión. Las violaciones continúan. En Brasil, hasta el momento, poco avanzamos en el entendimiento de la importancia del valor de la vida en la fabricación de una mercancía. Este elemento no entra en las hojas de cálculo corporativas con el mismo énfasis que otros elementos, como la rentabilidad.

Además, los recortes en las áreas de supervisión del gobierno federal garantizan que nada demasiado significativo, desde el punto de vista de la represión, deba ocurrir por un tiempo. Las empresas que explotan a niños y adolescentes se ven protegidas por un manto de silencio e invisibilidad.

Para tener efectividad, el enfrentamiento al trabajo infantil requiere el cumplimiento de cinco etapas iniciales, fáciles de ser descritas, pero difíciles de ser aplicadas:

- El consumidor debe boicotear a las empresas que explotan a niños y adolescentes;

- Las empresas necesitan dar, a los derechos humanos, el mismo valor que dan a los resultados del trimestre. $\mathrm{O}$ a la bonificación que los ejecutivos reciben al final del año;

- El gobierno debe dejar de sabotear sus propios mecanismos de supervisión e invertir en capacitación técnica, equipos y diligencias de campo;

- Los sindicatos de trabajadores necesitan reinventarse y volver a tener protagonismo en la defensa de los derechos humanos;

- Los medios de comunicación deben dejar de tener miedo de perder anunciantes y pasar a denunciar explícitamente las marcas que violan los derechos humanos.

En Brasil, el enfrentamiento del trabajo infantil en cadenas productivas no ha presentado la efectividad esperada. Lo que se observa es el agravamiento de la cuestión. No hay, en el corto plazo, ninguna señalización de mejora en este escenario. 


\section{NOTA}

1 El caso Watergate fue un escándalo político que planteó pruebas de la participación de la Casa Blanca con un asalto a la sede del Comité Nacional Demócrata, con el objetivo de fotografiar documentos y instalar escuchas clandestinas. El caso culminó en renúncia del entonces presidente norte-americano, Richard Nixon, en 1974.

\section{REFERENCIAS}

AFUBRA - ASSOCIAÇÃO DOS FUMICULTORES DO BRASIL. Dados sobre a fumicultura brasileira. Santa Cruz do Sul, 2018. Disponible en: https://bit.ly/3h4r8dn. Acceso en: 16 ago. 2020.

CARVALHO, Cleide; NETO, João Sorima. Chocolate: com pequenos produtores, cacau vem renascendo na Bahia. In: O Globo, 21 abril 2019. Disponible en: https://glo.bo/3gupdP3. Acceso en: 13 ago. 2020.

CASARA, Marques; DALLABRIDA, Poliana. Vidas Tragadas: os danos sociais da produção de fumo no Brasil. São Paulo: Papel Social, 2019.

CASARA, Marques. Trabalho infantil na produção de chocolate. In: Brasil de Fato, 26 nov. 2019. Disponible en: https://bit.ly/3h4r8dn. Acceso en: 13 ago. 2020 .

CNTV - CONFEDERAÇÃO NACIONAL DOS TRABALHADORES DO VESTUÁRIO. O raio x do vestuário. CNTV, abril 2015. Disponible en: https://bit.ly/3h4r8dn. Acceso en: 15 ago. 2020.

DIAS, Júnior César. O trabalho infantil nos principais grupamentos de atividades econômicas do Brasil. In: Fórum Nacional de Prevenção e Erradicação do Trabalho Infantil, dez. 2016. Disponible en: https://bit. ly/3h4r8dn. Acceso en: 15 ago. 2020.

LATOUCHE, Serge. Pequeno tratado do decrescimento sereno. São Paulo: Martins Fontes, 2009.

LIPOVETSKY, Gilles. A sociedade pós-moralista. São Paulo: Manole, 2009.

OIT - ORGANIZAÇÃO INTERNACIONAL DO TRABALHO. C182 Convenção sobre Proibição das Piores Formas de Trabalho Infantil. 
Brasília, 2000. Disponible en: https://bit.ly/312Q6oc. Acceso en: 15 ago. 2020.

OIT - ORGANIZAÇÃO INTERNACIONAL DO TRABALHO. Cadeia Produtiva do Cacau: Avanços e Desafios Rumo à Promoção do Trabalho Decente. Brasília, nov. 2018. Disponible en: https://bit.ly/39TPjJ1. Acceso en: 4 ago. 2020.

OIT - ORGANIZAÇÃO INTERNACIONAL DO TRABALHO. OIT e MPT: Projeto para melhoria das condições de trabalho no polo gesseiro de Pernambuco conquista 2. ${ }^{\circ}$ lugar no Prêmio CNMP. Organização Internacional do Trabalho, 22 ago. 2019. Disponible en: https://bit.ly/39TPjJ1. Acceso en: 10 ago. 2020.

OIT - ORGANIZAÇÃO INTERNACIONAL DO TRABALHO. O que é trabalho infantil. Brasília, [201-]. Disponible en: https://goo.gl/A6duMU. Acceso en: 15 ago. 2020.

TERAZONO, Emiko. Welcome to the world of Big Chocolate (paywall). In: Financial Times, dez. 2014. Disponible en: https://goo.gl/9h9QpD. Acceso en: 4 ago. 2020.

WHORISKEY, Peter e SIEGEL, Rachel. Cocoa's child laborers. In: The Washington Post, 5 jun. 2019. Disponible en: https://wapo.st/3i5jwHO. Acceso en: 4 ago. 2020.

ZIZEK, Slavoj. O ano em que sonhamos perigosamente. São Paulo: Boitempo, 2012. 



\section{PROTECCIÓN AL NIÑO Y AL ADOLESCENTE EN SITUACIÓN DE TRABAJO: LA POLÉMICA PRESENTE EN LA (IN)COMPRENSIÓN DE LA COMPETENCIA MATERIAL DE LA JUSTICIA ESPECIALIZADA}

NOEMIA PORTO

DOI: $10.51366 / 978-65-89468-10-3-$ coordinfancia-22

Resumen. El presente artículo trata sobre el trabajo infantil artístico, cultural y/o deportivo en la perspectiva de que es un trabajo, aunque en situación excepcionalmente autorizada por la norma internacional, representado por la Convención n. ${ }^{o} 138$ de la OIT. De ese modo, la protección integral y prioritaria que debe estar dirigida a niños y adolescentes no se circunscribe a una cuestión de derecho de familia, involucrando, esto sí, protecciones jurídicas típicas del campo laboral. Siendo relación de trabajo, aunque no se configure la hipótesis de contrato de empleo, la competencia para la concesión de autorizaciones es de la Justicia del Trabajo, por fuerza del art. 114 de la Constitución. Ese dispositivo constitucional no puede ser interpretado a la luz de la norma infra constitucional, como es el caso del art. 149 del Estatuto del Niño y del Adolescente (ECA). De la misma forma, esto designa la pertinencia de la actuación del Ministerio Público del Trabajo. La experiencia internacional también indica el consenso de que es un trabajo y que los marcos regulatorios protectores deben ser pertinentes al campo laboral.

Palabras claves: Trabajo Artístico Infantil. Convención n. ${ }^{\circ} 138$ de la OIT. Competencia material de la Justicia Laboral. 


\section{INTRODUCCIÓN}

¿Existe diferencia entre presentaciones artísticas y situaciones de trabajo cuando se refiere a la protección jurídica dirigida a niños y adolescentes? ¿Debe esta diferencia constitucionalmente guiar la definición de la competencia material en el ámbito del Poder Judicial? ¿La definición de la competencia se relaciona con el incremento del sistema de garantía para la protección de niños y adolescentes? Las indagaciones pueden estar en el centro de los debates que envuelven las reflexiones sobre el trabajo infantil artístico y la competencia material de la Justicia del trabajo.

Decisión reciente en sede de conflicto de competencia en el ámbito del Superior Tribunal de Justicia (STJ) permite observar algunos aspectos interesantes sobre la competencia material de la Justicia del Trabajo, en la medida en que se reafirma la pertinencia de la evaluación de la causa de pedir para fines de definición de la competencia material; se aleja la consideración, lamentablemente recurrente, sobre la hipótesis de que la actuación especializada esté definida apenas cuando se considere la existencia de vínculos de empleo consolidados "a priori”; y se revela la actuación del Ministerio Público del Trabajo, en cooperación con el Ministerio Público Estatal, en la defensa de los intereses de adolescentes en situaciones de trabajo.

En abril de 2020, decisión del ministro Herman Benjamin del STJ, en sede de conflicto de competencia (CC $\mathrm{n}^{\circ}$ 171408), definió la competencia de la Justicia del trabajo para ejecutar cláusula incumplida de Término de Ajuste de Conducta (TAC), firmado entre el Ministerio Público del Trabajo y determinada entidad educacional, versando sobre el trabajo de adolescentes entre 16 y 18 años de edad, incluso delante de la concesión de licencia, por la justicia común, que autorizaba la actuación como "guardias infantiles".

Observando su poder-deber constitucional (BRASIL, 1988, Art. 129, III) El Ministerio Público del trabajo firmó TAC con el Centro de Educación Infantil y formación pequeños de Jesús para vedar la disponibilidad de menores de dieciocho años en actividades externas de control de tránsito en calles, avenidas, plazas, estacionamientos privados o públicos y locales de eventos. Tal término, a pesar del intento del centro educativo, no fue anulado por decisión judicial. Aun habiendo firmado el referido acuerdo, la entidad privada, posteriormente, solicitó en la justicia común Estatal licencia judicial para autorizar a los adolescentes con edad entre 16 y 18 años a trabajar en 
el aparcamiento público rotatorio, conocido como "Área Azul”, en determinado municipio. El Juicio Estadual de la Vara de la infancia y Juventud de la respectiva Comarca decidió por la concesión del permiso, a pesar de la existencia del aludido TAC. El Ministerio Público Estatal presentó un recurso frente a la decisión, sin embargo, sin éxito en la instancia de apelación. El Tribunal de Justicia alejó la pertinencia de la actuación del Ministerio Público del Trabajo, mismo con recurso del Ministerio Público Estadual, por no considerar la existencia de relación de trabajo en sentido estricto, lo que equivale a considerar que sólo sería imprescindible la referida actuación ministerial especializada en hipótesis de contrato de empleo. La causa de pedir no ha sido valorada, sino más bien un juicio sobre la competencia institucional si se vincula a situaciones de contratos de empleo.

Por lo tanto, el punto muerto estuvo presente delante del permiso que fue concedido por la justicia común, por un lado, y la ejecución requerida por el Ministerio Público del Trabajo de cláusula incumplida del TAC, todo involucrando la posibilidad o no de adolescentes activarse en determinada situación de trabajo. El Ministerio Público Federal opinó por el conocimiento del conflicto, para que fuera declarada la competencia de la Justicia Laboral. Así, otra rama del Ministerio Público también comprendió que la definición de la atribución institucional no dependería de la definición, "a priori”, de la existencia de vinculación contractual laboral.

Para el ministro Herman, la concesión de licencia por la justicia común no puede impedir el cumplimiento de cláusula constante en TAC firmado con el Ministerio Público del Trabajo. La causa de pedir en la acción de ejecución laboral, prevista en el art. 876 de la CLT (BRASIL, 1943), que contiene diversas cláusulas, y no solo la del trabajo como "guardias infantiles", indica desdoblamientos del TAC ante la justicia del trabajo y, por lo tanto, la demanda conexa debería, necesariamente, tramitar en el mismo juicio. Hay en ese razonamiento la lógica de la "vis atractiva". De hecho, el juicio sobre la competencia, que se vincula a la causa de pedir, precede necesariamente al juicio sobre el mérito de la causa (es decir, si sería relación de trabajo en sentido estricto o no).

La actuación del Ministerio Público del Trabajo en el tema del trabajo, independientemente de la situación de empleo, involucrando niños y adolescentes, que puede, incluso, redundar en la consolidación de TACs, sin embargo, no ha sido suficiente para dirimir controversias sobre la competen- 
cia material de la justicia del trabajo, que tiene sede constitucional (BRASIL, 1988, Art. 114).

Evidencia de esto es la decisión liminar del Supremo Tribunal Federal (STF), en control de constitucionalidad concentrado (ADI 5326), en cuanto a la competencia de la justicia del trabajo para la autorización del trabajo infantil artístico, cultural y/o deportivo, en la medida de la desconsideración de que se refiere a la protección a niños y adolescentes en situación de trabajo en que hay desarrollo y explotación de actividad económica. La decisión liminar perdura con posibilidad, desde 2019, conforme el respectivo progreso procesal, de que el mérito de la discusión en el control concentrado sea llevado a la apreciación plenaria del STF.

El presente artículo pretende reflexionar críticamente sobre ese impasse partiendo, en un primer momento, de la estructura normativa constitucional y de la previsión en norma internacional para situar el tema de la protección integral y prioritaria a los niños y a los adolescentes también en el marco de la inserción en situaciones de trabajo. A continuación, serán abordados aspectos de la decisión del STF y la dificultad presentada por la Corte en divisar manifestaciones artísticas y culturales, e incluso de participación en eventos, de la típica y ocurrida inserción en ambiente laboral, aunque con finalidad de expresión artística, con explotación económica, de los llamados artistas infantiles. Después, serán referidos marcos regulatorios del Derecho comparado, específicamente en el caso de Portugal, de California (EE. UU.) y de Argentina, para considerar como la experiencia extranjera comprende el trabajo infantil artístico como trabajo, a atraer la actuación de órganos, de control y de garantía, especializados en la temática laboral.

\section{LA EXCEPCIONALIDAD DEL TRABAJO INFANTIL AR- TÍSTICO (TIA) Y LA PROTECCIÓN JURÍDICA PARA NIÑOS Y ADOLESCENTES EN SITUACIÓN DE TRABAJO}

La Constitución de 1988, con la redacción conferida por la Enmienda Constitucional n. ${ }^{\circ}$ 20/1998, prohíbe cualquier trabajo a los menores de dieciséis años, salvo en la condición de aprendiz, a partir de los catorce años. Además, se encuentra vedado el desarrollo de trabajo en el periodo nocturno o en condiciones peligrosas y/o insalubres a los menores de dieciocho años (BRASIL, 1988, Art. $7^{\circ}$, XXXIII) ${ }^{1}$. 
La Constitución (BRASIL, 1988, Art. 227) también prevé la responsabilidad compartida de la familia, de la sociedad y del Estado en lo que se refiere al deber de asegurar

al niño y al adolescente, con absoluta prioridad, el derecho a la vida, a la salud, a la alimentación, a la educación, al ocio, a la profesionalización, a la cultura, a la dignidad, al respeto, a la libertad y a la convivencia familiar y comunitaria, además de ponerlos a salvo de toda forma de negligencia, discriminación, explotación, violencia, crueldad y opresión.

Constituye, además, deber estatal el de promover "programas de asistencia integral a la salud del niño, del adolescente y del joven, admitida la participación de entidades no gubernamentales" (BRASIL, 1988, Art. 227, \ $1^{\circ}$ ).

El carácter imperativo de tales normas, la superioridad de la Constitución sobre el resto del ordenamiento jurídico y su centralidad en el sistema normativo, como fuente irradiadora para las demás normas y ramos jurídicos, que deben ser comprendidos e interpretados a partir de sus previsiones, son características que marcan el paradigma del Estado Democrático de Derecho, asumido en 1988 (BRASIL, 1988, Art. $1^{\circ}$, caput). ${ }^{2}$

La Organización Internacional del Trabajo (OIT), la Conferencia de Ginebra, en la que se produjo el 18 de junio de 1998, estableció los principios fundamentales sobre los que se sirven del norte, en la práctica, a saber: la libertad sindical y el efectivo reconocimiento del derecho a la negociación colectiva; la eliminación de todas las formas de trabajo forzoso u obligatorio; la efectiva abolición del trabajo infantil; y la eliminación de la discriminación en materia de empleo y ocupación (ILO, 1998). En el marco de las normas laborales internacionales, el tema del trabajo infantil es una prioridad.

Importante subrayar el Convenio n. ${ }^{\circ} 138$ de la Organización Internacional del Trabajo (OIT), que versa sobre la edad mínima de admisión al empleo, ratificado por Brasil, en los términos del Decreto n. ${ }^{\circ} 4.134$, de 15 de febrero de 2002, y que se contempla en el Decreto n. ${ }^{\circ} 10.088$, del 05 de noviembre de 2019, que se ha consolidado en los actos normativos del Poder Ejecutivo que ver con la adopción de convenios y recomendaciones de la OIT. En los términos del artículo 8, ítems 1 y 2, se tiene lo siguiente (BRASIL, 2019, anexo LXX):

1. La autoridad competente podrá conceder, previa consulta con las organizaciones interesadas de empleadores y trabajadores, cuando tales organizaciones existan, por medio de permisos individuales, excepciones a la prohi- 
bición de ser admitido al empleo o de trabajar que prevé el artículo 2 de la presente Convención y, en su caso, de los propósitos, tales como participar en representaciones artísticas.

2. Los permisos así concedidos limitarán el número de horas del empleo o trabajo autorizadas y prescribirán las condiciones en que éste se podrá realizar.

El trabajo infantil artístico forma parte de la excepción a la regla de prohibición del trabajo infantil, o de la edad mínima para admisión en el empleo, pero sin nunca dejar de considerarse que es trabajo, tanto que hay exigencia de autorización por la autoridad, con limitación de horas del empleo o trabajo y prescripción de las condiciones en que deberá ser realizado. La prohibición relativizada en los casos de actividades artísticas no significa necesariamente que esta forma de actividad sea más beneficiosa para niños y adolescentes o exenta de la construcción de marcos regulatorios de protección. Su carácter esporádico, de desarrollo de la expresión artística y de talentos, puede indicar su posibilidad de realización, que ocurre en beneficio de otros, pero también del niño y del adolescente y de sus familias. Sin embargo, eso no es suficiente para inmunizar esa forma de trabajo de eventuales daños o perjuicios para niños y adolescentes.

El trabajo infantil artístico, por lo tanto, fue admitido por la Convención n. ${ }^{\circ} 138$ de la OIT, que permite la actividad artística infantil siempre que esté debidamente autorizada por la autoridad competente, que fijará las garantías para el desarrollo de un trabajo protegido y acorde con la primacía de la protección integral (BRASIL, 2019, Anexo LXX). Esa es una cuestión interesante, en la medida en que, hasta el momento, Brasil no cuenta con un marco regulatorio legislativo para el tema. De este modo, la regulación, caso por caso, sobreviene del contenido de los permisos judiciales, para que, al mismo tiempo, se permita la actividad, pero, aún, su desarrollo en condiciones de seguridad y de protección.

En el caso del trabajo artístico en Brasil, por diversas razones, incluso culturales, el imaginario popular vincula el arte al glamur, al ocio y a la diversión, como si cualquier trabajo artístico fuera excluyente de la idea de trabajo vinculado a la producción de bienes o servicios destinados al mercado.

En lo que se refiere a las autorizaciones, en realidad, sólo se proveen, como se observa en la experiencia del Poder Judicial, en las grandes producciones y para niños y adolescentes que tengan un papel fijo, como personaje 
de telenovelas, películas u obras de teatro y musicales. En la actuación de extras, en cualquier producción (cine, televisión, teatro), o en participación en el mercado publicitario (fotos o video), esto normalmente no ocurre. Esto revela que la protección jurídica no ha tenido el alcance propugnado por la normativa internacional.

En la práctica, niños y adolescentes son regimentados para esas modalidades de trabajo, con o sin autorización. La cuestión se entrelaza, por lo tanto, con la omisión estructural del Poder Público, eso porque es necesario reconocer que apenas el sistema de permisos no es suficiente y, aún, no se construyó en Brasil un marco regulatorio legislativo capaz de orientar o sistematizar la demanda por la participación, pero con reglas protectoras. De hecho, es difícil en este marco atestiguar la eficiencia del Estado para situaciones que pueden llamarse exploratorias, pero socialmente diluidas, y que a menudo cuentan con el deslumbramiento y la complicidad de los propios padres o tutores. De todos modos, en este marco de ausencia de un marco regulatorio legislativo sistematizado, el Poder Judicial tiene un papel extremadamente relevante de actuar, en cada situación concreta, como verdadero garante, o sea, de modo a permitir el desarrollo de la actividad, pero condicionarla a aspectos que puedan también representar la protección integral para el niño y el adolescente, en la forma prevista por la Constitución de 1988.

El trabajo artístico es trabajo, aunque no sea trabajo. Trabajo, por cierto, que, para ser desarrollado, requiere entrenamiento, dedicación, disciplina y sacrificios, que pasan desapercibidos por la mayoría de las personas que aprecian el arte. En el trabajo artístico de niños esto ocurre, en mayor grado, ya que el sujeto es más frágil y susceptible a cansarse e irritarse con facilidad, estando aún en fase de desarrollo físico y emocional. Esta convivencia con el mundo adulto y la sujeción a las reglas propias del ambiente traen varias influencias a aquella infancia, como la maduración precoz.

En realidad, diferentemente de las manifestaciones artísticas libres, vale decir, en centros culturales, en las escuelas u otros ambientes similares, el trabajo infantil artístico es trabajo y, como tal, impacta la vida de los niños y de los adolescentes generando consecuencias que no pueden ser consideradas solo positivas. Ciertamente, uno de los aspectos que dificultan el desarrollo de un sistema protector adecuado para los niños y los jóvenes en esta peculiar situación es ignorar que el trabajo infantil artístico es trabajo, aunque no sea trabajo desarrollado dentro de un marco contractual de empleo. 
El permiso excepcional y, por lo tanto, por plazo determinado, para el trabajo representado por el desarrollo de una actividad artística, cultural, deportiva o publicitaria necesitaría considerar, como mínimo, el análisis de aptitud física y psíquica del niño y del adolescente, la seguridad del medio ambiente laboral, incluyendo limitación de jornada y tiempos de descanso, el acompañamiento por los responsables y la garantía de una remuneración justa y adecuada.

Como, fuera del campo de las llamadas manifestaciones artísticas libres, existe el ejercicio de un trabajo que, en los Términos de la OIT, no se encuentra insertado en la previsión prohibitiva para niños y adolescentes, las controversias en torno a él, notablemente en cuanto a los aspectos protectores, se insertan en la competencia de la Justicia Especializada, en la forma del art. 114 de la Constitución Federal (BRASIL, 1988). La Justicia del Trabajo no es la justicia del empleo o del desempleo, sino la justicia que actúa en todas las cuestiones del mundo del trabajo. Esta consideración indica que la causa de pedir relacionada al trabajo (o a la autorización para el trabajo) y la "vis atractiva" de los debates que lo rodean, ambos elementos indicados en la decisión del ministro Herman Benjamin, son relevantes para dar al art. 114 de la Constitución la extensión que le es adecuada.

No siempre, sin embargo, esa constatación ha prevalecido.

\section{EL STF Y LA (IN)COMPRENSIÓN SOBRE LA MATRIZ NORMATIVA DE LA COMPETENCIA MATERIAL DE LA JUSTICIA DEL TRABAJO}

La cuestión de la competencia de la Justicia del trabajo para procesar y juzgar demandas, lo que incluye las solicitudes de autorización, relacionadas al trabajo infantil artístico, tiene matriz constitucional, por la incidencia del art. 114 de la Constitución (BRASIL, 1988), y revela, como telón de fondo, la prevalencia o no de un sistema formal de garantías que esté dirigido a la comprensión del fenómeno insertado en el trabajo infantil y en la protección jurídica al trabajo. Sin embargo, el STF, en decisión liminar, confirmada por mayoría en el plenario, ha indicado una comprensión diversa, interpretando el tema a partir del Reglamento infra constitucional (del ECA), cuando la expectativa sería que el comando constitucional es que orientara la lectura de las demás normas del ordenamiento jurídico, tal como advierte la doctrina y 
la propia jurisprudencia de la Corte en los demás casos. Es de la lógica de la supremacía material y formal de la Constitución que sus normas orienten la interpretación de las demás del sistema infra constitucional, y no lo contrario.

En mayo de 2015, la Asociación Brasileña de Emisoras de Radio y Televisión (ABERT) juzgó en el STF la acción directa de inconstitucionalidad (ADI) n. ${ }^{\circ}$ 5326, que todavía depende de decisión en el mérito.

Sin embargo, la provisión liminar requerida fue atendida por el ministro relator, Marco Aurelio, que suspendió la eficacia de la expresión "incluso artístico”, constante del inciso II de la Recomendación Conjunta n. ${ }^{\circ} 1 / 14$ y del art. $1^{\circ}$, inc. II, de la Recomendación Conjunta n. ${ }^{\circ} 1 / 14$, así como apartó la atribución, definida en el Acto GP n..$^{\circ}$ 19/2013 y en la provisión GP/CR n. ${ }^{\circ} 07 / 2014$, en cuanto a la apreciación de solicitudes de licencia dirigidas a la participación de niños y adolescentes en representaciones artísticas y, también, la creación del Juzgado Especial en la Justicia del Trabajo. En definitiva, los preceptos fueron suspendidos y se asentó, al menos en sede liminar, la competencia de la justicia común para analizar las solicitudes de permisos.

La medida cautelar requerida, y reiterada por la entidad autora, estuvo fundamentada en la hipótesis de grave inseguridad jurídica si tales actos continuaran en vigor. Sin embargo, se trataba, en realidad, del deseo de la autora de retirar de la Justicia del trabajo la competencia para avanzar en este tema. Al contrario de lo defendido, fue justamente el primado de la seguridad jurídica que motivó la construcción cooperativa de actos a partir de los debates entre la justicia común Estadual, la Justicia del trabajo, el Ministerio Público Estadual y el Ministerio Público del Trabajo.

Específicamente en cuanto a la Recomendación Conjunta n. ${ }^{\circ}$ 01/2014, a la vista de la importancia del Estado de São Paulo y de la cantidad de situaciones de trabajo infantil, incluyendo el artístico, fue celebrada como verdadero avance en la articulación institucional para el combate al trabajo infantil y dispuso sobre la competencia de la Justicia del trabajo y de la justicia Estadual de la infancia y de la Juventud en el caso de solicitud de autorización para trabajo - incluso artístico y deportivo - de niños y adolescentes.

En el marco de la comunicación del Tribunal Superior del trabajo, el acto normativo se reflejó de la siguiente manera:

La Recomendación Conjunta n. ${ }^{\circ}$ 01/2014, fue firmada por la Controladoría General de Justicia del Tribunal de Justicia en el Estado de São Paulo; Controladoría Regional del consejo Regional de Trabajo de la $2^{a}$ Región, la 
Controladoría Regional del consejo Regional de Trabajo de la $15^{\text {a }}$ Región; y la Coordinación de la Niñez y de la Juventud, el Tribunal de Justicia en el Estado de São Paulo; el Ministerio Público del Estado de São Paulo; el Ministerio Público del Trabajo de la $2^{\mathrm{a}}$ Región, y el Ministerio Público del Trabajo de la $15^{\text {a }}$ Región.

Con la celebración del acto, queda recomendado a los jueces de derecho de la infancia y de la juventud, a los jueces del trabajo de la $2^{\mathrm{a}}$ y $15^{\mathrm{a}}$ región, y a los miembros del Ministerio Público Estatal y del Ministerio Público del Trabajo de la $2^{\mathrm{a}}$ y $15^{\mathrm{a}}$ región que tomen como directriz, para efecto de competencia:

- las causas que tengan como base los derechos fundamentales del niño y del adolescente y su protección integral, en virtud de la Ley n. ${ }^{\circ} 8.069 / 90$, se insertan en el ámbito de la competencia de los jueces de derecho de la infancia y juventud;

- las causas que tengan como base la autorización para trabajo de niños y adolescentes, inclusive artístico y deportivo, y otras cuestiones conexas derivadas de esas relaciones de trabajo, debatidas en acciones individuales y colectivas, se insertan en el ámbito de la competencia de los jueces del trabajo, en los términos del art. 114, incisos I y IX de la Constitución Federal.

Con eso, los órganos involucrados entienden que las causas cuyo objeto sea la autorización para el trabajo de niños y adolescentes, incluso artístico y deportivo, y otras cuestiones conexas derivadas de esas relaciones de trabajo son de competencia exclusiva de los jueces del trabajo. Los jueces de la infancia y juventud deben juzgar solamente causas que tengan como objeto los derechos fundamentales del niño y del adolescente y su protección integral, en virtud de la Ley n. ${ }^{\circ} 8.069 / 90 .^{3}$

Por lo tanto, la actuación conjunta institucional no atendió a la expectativa de la ABERT, que pretende que la competencia, a pesar de lo previsto en el art. 114 de la Constitución, no fuese de la Justicia del trabajo porque no pretendía y no pretende que alguna situación típica de trabajo sea considerada como existente, así como los derechos protectores que de eso puedan transcurrir. La liminar desprestigió ese esfuerzo institucional, y los diálogos que lo precedieron, indicativos del compromiso judicial con la protección integral de niños y adolescentes, incluyendo las situaciones de trabajo a las cuales estén sometidos.

El ponente, en la decisión liminar, mantenida, por mayoría, en el plenario, contextualiza las autorizaciones para que niños y adolescentes comparezcan a programas de radio y televisión, así como figuren en obras de teatro, lo que indica la sustancial disminución del alcance de lo que, en realidad, implica el trabajo infantil artístico, cultural y/o deportivo. Al prestar ese contexto diminuto de las actividades involucradas, consideró la competencia de la justicia común en un argumento de tradición, y no de constitución, es decir, 
la lógica expresada fue la de que las autorizaciones "siempre fueron formalizadas por el Juzgado Especial - de la infancia y de la juventud - de la Justicia Común". Es cierto, sin embargo, que el argumento de tradición tampoco expresaba la realidad, tanto que la Justicia del Trabajo, como mínimo desde la Enmienda Constitucional n. 45 de 2004 ("Reforma del Poder Judicial"), venía concediendo las citadas autorizaciones, a la raíz de la Convención n. ${ }^{\circ}$ 138 de la OIT, y de otras normativas nacionales e internacionales protectoras. Además, en la fundamentación del voto que prevaleció no se tejen Consideraciones sobre el hecho de que la excepción permisiva para el trabajo infantil artístico viene justamente de una norma laboral internacional, y de un organismo especializado en la temática del trabajo humano (OIT).

El ministro Marco Aurelio desestimó el ingreso como amigos de la corte de la Asociación Nacional de los Fiscales del Trabajo - ANPT - y de la Asociación Nacional de los Magistrados de la Justicia del Trabajo ANAMATRA. Si, por un lado, el ministro relator no consideró pertinente la contribución técnica de las entidades representativas del Ministerio Público del Trabajo y de la magistratura laboral, por otro, utilizó como base teórica de la decisión el contenido de dictamen elaborado, a petición de la entidad autora, por la profesora Ada Pellegrini Grinover que, a pesar de todas las credenciales académicas, no poseía trayectoria de investigación, de estudios y/o experiencia de actuación en el campo específico del derecho del trabajo. La profesora, reportando a la tradición civilista, trató el tema como de tutela "diferenciada de los seres humanos en desarrollo", sin conseguir establecer el vínculo indisociable del niño y del adolescente como sujetos de derechos, incluso en el campo del trabajo, en las situaciones excepcionales en que eso es permitido. Siguiendo una línea de tradición, y no de constitución, la profesora hizo referencia a la Jurisdicción Voluntaria del revocado Código de Menores. Ocurre, sin embargo, que la tutela presente en tales permisos no se refiere a la defensa de Derechos Fundamentales de los niños y de los adolescentes exclusivamente en esta condición, sino, sí, en el ámbito de una ciudadanía en el campo del trabajo.

Los dispositivos atacados en la ADI, y suspendidos en sede liminar, no pretenden innovar el orden jurídico en el tema de la competencia jurisdiccional, y, sí, traducen la reglamentación concreta de precepto constitucional, en la medida en que el art. 114 de la Constitución Federal dirige a la Justicia del Trabajo la competencia material para procesar y juzgar las demandas rela- 
cionadas a las relaciones de trabajo, y no solo a las relaciones de empleo, siendo cierto que el rol de incisos allí presentes es meramente ejemplificativo, y no exhaustivo. Aunque la relación versada sea de trabajo infantil, en la excepcional situación artística, cultural y / o deportiva, a la ocasión de la Convención n. ${ }^{\circ} 138$ de la OIT, el ponente insistió sobre la necesidad de ley ordinaria federal que versara expresamente sobre el asunto. Sin embargo, la referida Convención, ratificada por Brasil, tiene estatura de norma supralegal, estando por encima, jerárquicamente, de las demás normas infra constitucionales. ${ }^{4}$

La tutela integral en cuestión se refiere a una tutela cuando el niño y el adolescente son sometidos a una situación de trabajo, por eso, la lectura del art. 227 de la Constitución debería ser hecha de forma sistemática y conjugada con los arts. $114,6^{\circ}$ y $7^{\circ}$ del mismo Texto (BRASIL, 1988). El aislamiento del art. 227 hizo prevalecer una perspectiva de ausencia de trabajo y de una tutela exclusiva de derechos del niño y del adolescente.

La decisión, por cierto, no pudo distinguir entre la participación de niños y adolescentes en eventos artísticos y la presencia en eventos como trabajadores. Sin esa importante distinción, la referencia normativa utilizada fue la del art. 149 del Estatuto del niño y del Adolescente (ECA), que versa sobre la primera hipótesis, y no sobre la segunda. De ese modo, la Constitución, al menos en su perspectiva sistémica (arts. $6^{\circ}, 7^{\circ}, 114,227$ ), y su relación con la normativa internacional (Convenio n..$^{\circ} 138$ de la OIT), fue analizada a partir de la norma infra constitucional, y no al revés, como debería.

El voto divergente de la ministra Rosa Weber contempló ese marco diferencial, eso porque refirió que los actos normativos, construidos de forma cooperativa por el Poder Judicial estatal y del trabajo y por el Ministerio Público Estatal y del trabajo, se referían a la autorización para el trabajo infantil, y no a la autorización para la participación de niños y adolescentes en eventos o representaciones artísticas. En típica situación de trabajo, las empresas contratantes (o intermediadoras) solicitan el permiso para el trabajo infantil, lo que atrae la competencia material de la Justicia del trabajo.

El voto conductor, además, revela la comprensión, al menos en el marco de la orden judicial, de que la competencia de la justicia del trabajo dependería de la norma jurídica incidente (si de Derecho civil, de Derecho administrativo, etc.), cuando, en realidad, el propio STF ya definió, antes incluso de la EC 45/2004, que la mencionada competencia se define por la 
naturaleza de la relación versada (laboral) y no por el diploma normativo que deba ser aplicado. ${ }^{5}$ La decisión revela, además, una lógica que no corresponde a lo dispuesto en el art. 114 de la Constitución de que la competencia material de la justicia del trabajo se resumiría a los contratos de empleo, y no a las relaciones de trabajo ("lato sensu"). ${ }^{6} \mathrm{Y}$, por último, siguiendo el guión de esas incomprensiones, con típica inserción de elemento no jurídico en el debate, hay una pre comprensión distorsionada sobre la magistratura del trabajo o sobre su capacidad para actuación en esas cuestiones, eso porque al referir el juicio de la infancia y de la juventud (en el ámbito de la justicia común y no de la justicia del trabajo), el relator afirma ser esta última la autoridad que reúne los predicados y las capacidades institucionales necesarias para la realización de examen de tal relevancia y responsabilidad. En este último aspecto, es cierto que la distribución de competencia material que deriva del Texto Constitucional no podría ser comprendida a partir del criterio de elección de la rama del Poder Judicial que el STF indicara como más competente o con predicados mejores, debido a la responsabilidad que la temática requiere. En resumen, no es el caso de una elección subjetiva.

La decisión liminar, ratificada por la mayoría del plenario, se aleja de lo que ha sido construido en la experiencia internacional, en la consideración de que el trabajo infantil artístico es trabajo y, como tal, merece especial protección del campo especializado.

\section{TIA Y LA EXPERIENCIA DE MARCOS REGULATORIOS INTERNACIONALES QUE CONSIDERAN EL CAMPO DE COBERTURA LABORAL}

Aunque esta puede no ser una respuesta definitiva, es posible considerar que las dificultades en el reconocimiento de la competencia de la justicia del trabajo para las demandas que envuelvan el trabajo infantil artístico se derivan de la errónea comprensión de que el campo de cobertura del art. 114 de la Constitución Federal, incluso después de la Enmienda Constitucional n. 45 de 2004, continuaría siendo la existencia de un contrato de empleo.

Cuando se afirma el sistema normativo internacional, en cuanto a la necesidad de autorización por la autoridad competente, y, además, se indica la pertinencia de futuro marco regulatorio legislativo, ante la omisión que persiste, hay la convicción de que la mediación estatal es necesaria considerando 
las previsiones constitucionales. Los padres o tutores no poseen acumulación de conocimiento necesario a fin de analizar si el ambiente de trabajo es propicio al niño o al adolescente. Efectivamente, necesidades diversas pueden dejar a la familia vulnerable, permitiendo que cualesquiera condiciones de trabajo sean impuestas, pasando a lo largo de la protección integral definida como prioritaria para niños y adolescentes.

En Portugal, la cuestión se encuentra disciplinada, al menos con reglas generales, en el Código del Trabajo (Ley n. ${ }^{\circ} 7 / 2009$, de 12 de febrero), o sea, no hay duda de que las manifestaciones artísticas no voluntarias constituyen una forma de trabajo y deben ser protegidas observando los principios y los parámetros construidos en este campo especializado. En la forma del art. $3^{\circ}$, "el menor con edad inferior a 16 años no puede ser contratado para realizar una actividad remunerada prestada con autonomía", a menos que haya "concluido la escolaridad obligatoria y se trate de trabajos ligeros" (PORTUGAL, 2009). En este sentido, se permite, por ejemplo, siempre que, con motivos objetivamente justificados, el trabajo nocturno para "el menor con edad igual o superior a 16 años" en actividad de naturaleza cultural, artística, deportiva o publicitaria, siempre que se garantice un periodo equivalente de descanso compensatorio al día siguiente o en fecha más próxima posible (Art. 76, 3, "b"). En virtud del art. 81 del mismo Código, "la participación de menor en espectáculo u otra actividad de naturaleza cultural, artística o publicitaria está regulada en legislación específica” (PORTUGAL, 2009).

En los Estados Unidos de América, y más específicamente en el Estado de California, que alberga uno de los centros productores de entretenimiento más grandes del mundo (Hollywood), hay predicciones que buscan guiar esta situación laboral especial. En la sesión 1700.37 del California Labor Code, hay previsión de que el niño o el adolescente no podrán anular lo establecido en contrato firmado con una agencia de talentos acreditada, aunque eso haya ocurrido cuando aún menores de edad, debiendo, por lo tanto, prestar los servicios artísticos avenidos en películas, televisión, registros fonográficos, etc. incluyendo, según rol no exhaustivo, los servicios como actor, actriz, danzarina, músico, comediante, cantante, escritor, especialista, actor de voz, entre otros. Para ello, está el llenado de formulario aprobado por el Comisionado del trabajo (Labor Commissioner), siendo el contrato aprobado por el tribunal superior del condado donde ese menor reside o es empleado (USA, 2020a). 
El tema también se trata en el California Family Code, Sección 6750, que regula los contratos celebrados entre el niño o el adolescente y un tercero. Las hipótesis enumeradas revelan contratos de los más variados tipos, y para los muchos servicios artísticos o creativos y deportivos, contratados directamente o a través de terceros (empresa de préstamo, agencias, etc.), siempre con la preocupación de definir qué persona o entidad debe ser considerada el empleador (EE. UU., 2020a). Definido que es contrato y las diversas situaciones de intermediación, con definición de quién es el empleador, la regulación define el concepto de ganancias brutas. La definición es relevante porque la sesión 6752 establece, por regla general, que el 15\% de los ingresos se mantendrán en confianza, en una cuenta u otro plan de ahorro y se conservarán en beneficio del niño y el adolescente (EE. UU, 2020c).

Por lo tanto, se observa, en el caso de la legislación del Estado de California, que el trabajo de niños y adolescentes en actividades culturales, artísticas, deportivas y similares no se circunscribe a una cuestión del derecho de familia. Se trata, en realidad, de la participación de los responsables legales en la protección de los intereses de los niños y de los adolescentes en esta excepcional situación de trabajo y de forma a, por un lado, garantizar aquellos (empresarios) que pactan las actividades, pero también, el futuro de esos niños y adolescentes en términos de ingresos, definiéndose, incluso, quiénes son considerados empleadores en las más diversas modalidades de intermediaciones contractuales.

Importante observar que la ABERT, autora de la ADI en el STF (5326), no posee legitimidad universal para la proposición de ADIs, debiendo, en realidad, comprobar objetivamente la ocurrencia de pertinencia temática entre los intereses que defiende y la cuestión constitucional planteada para apreciación de la Corte. Ocurre que, defendiendo intereses de emisoras de radio y televisión, incluso consigue abarcar el rol de situaciones, de beneficiarios y de interesados, directa o indirectamente, en el tema del trabajo infantil artístico. Como se nota de la regulación normativa del Derecho comparado, radio y televisión no representan o sintetizan la gama de actividades que pueden traducir una situación de trabajo infantil artístico, cultural y/o deportivo.

El trabajo infantil artístico no puede ser tratado como un evento que se circunscribe a la relación familiar y/o de autorización de los responsables. Habiendo una situación de trabajo, aunque no siempre de empleo, la cuestión trasciende el ámbito familiar y atrae la necesidad de protección que es típica 
a la siembra del derecho del trabajo, que, destacándose, no es exclusivamente un derecho dirigido a las relaciones contractuales de empleo.

Argentina ratificó el Convenio n. ${ }^{\circ} 138$ de la OIT y, mediante la Ley n. ${ }^{\circ} 26.390 / 2008$, estableció la edad mínima de admisión al empleo, que pasó a ser de 16 años, prohibiéndose, en todas sus formas, el trabajo de menores, independientemente de que haya una relación contractual, con o sin remuneración (ARGENTINA, 2008a). Específicamente en cuanto al trabajo infantil artístico, el Ministro de Trabajo editó resolución (44/2008) para regular el trabajo de menores en el ámbito de la Provincia de Buenos Aires. Interesante indicar, aunque de forma resumida, las motivaciones del acto de reglamentación, las cuales justamente revelan la consideración de que el trabajo infantil artístico es una forma de trabajo infantil y, evidentemente, una forma de trabajo que merece la atención estatal para que garantías y protecciones sean definidas en favor de los niños y de los adolescentes.

Estas son algunas de las razones utilizadas para tal efecto: i) que las preocupaciones de los cuales provienen de la Comisión Provincial para la Erradicación del Trabajo Infantil y, en particular, en el desarrollo integral de los niños, niñas y adolescentes; ii) el reconocimiento y la promoción de la Convención sobre los Derechos del Niño, el derecho a la participación en la vida cultural y artística, pero teniendo siempre en cuenta como una prioridad para su protección frente a cualquier tipo de trabajo que pueda entorpecer su educación, o ser nocivo para su desarrollo; y iii) en los mismos términos del Convenio n. ${ }^{\circ} 138$ de la OIT sobre la necesidad de que la autoridad competente para otorgar, por medio de permisos individuales, con la posibilidad de que el arte es el único de la edad mínima establecida por la ley, lo que se debe hacer con la previsión de que el límite en el número de horas y las condiciones en las que se establecen para que se produzca de forma segura; iv) la existencia, en el ámbito internacional, y de la Recomendación Relativa a la Condición del Artista, que fue aprobada en la Conferencia General de las Naciones Unidas para la Educación, la Ciencia y la Cultura (UNESCO), en el año 1980, y que fue ratificado por la Argentina, en la cual se considera que los artistas y los trabajadores de la cultura, y que, como tales, a los beneficiarios de los derechos laborales; (v) el hecho de que la participación de los niños y de las niñas en las actividades artísticas, excepto cuando esto se produzca, con el fin de, exclusivamente, de la educación o la cultura o el ocio, se configura el trabajo, y como consecuencia de ello, se constituye en una de las tantas for- 
mas de trabajo infantil; vi) la la necesidad de una herramienta con la normativa de la regulación detallada de la tramitación de los permisos individuales restrictivos, a ser otorgados por la Autoridad de Aplicación, para el Trabajo de las Niñas y de los Niños menores de 14 años de edad, en Actividades Artísticas, de tal forma que se garantice el derecho a la educación, al desarrollo, a la recreación y al esparcimiento, ARGENTINA, 2008b).

Coherente con la idea de que la regulación está dirigida a una forma de trabajo infantil, aunque artístico, hay previsión de que la fiscalización está a cargo de la Subsecretaría de Trabajo (Art. $1^{\circ}$ ). Cualquier persona física o jurídica con la pretensión de emplear niños o niñas debe solicitar la autorización con antelación, cuyo trámite se dará en la respectiva Comisaría Regional del trabajo y Empleo (Art. $3^{\circ}$ ). La solicitud por escrito debe contemplar la firma de los padres o del responsable legal y, además, incluir explícitamente el detalle de los términos del contrato, incluyendo la cantidad de días y horas de trabajo, los detalles de la obra artística y el responsable que acompañará el desarrollo de las actividades del niño o del adolescente (Art. $4^{\circ}$ ). Para la autorización, si es necesario, el Subsecretario de Trabajo podrá solicitar la manifestación de organismo público o privado que considere pertinente (Art. $7^{\circ}$ ). Otras exigencias como aptitud física del artista y la certificación de la escolaridad también están expresamente previstas (Art. $5^{\circ}$ ) (ARGENTINA, 2008b).

Por lo tanto, en Argentina, el trabajo infantil artístico recibe Regulación pública en el contexto de que es un trabajo infantil y, además, de que es una forma de trabajo, debiendo ser resguardados los derechos, incluso laborales, de los niños y de los adolescentes.

Los ejemplos arriba mencionados revelan, primero, la consideración de que el trabajo infantil artístico es trabajo; que niños y adolescentes deben ser destinatarios de la protección estatal en temas como jornada, soporte y análisis psicológico y físico, medio ambiente laboral, resguardo de sus ganancias y existencia de órganos de fiscalización; el tema envuelve la actuación, por su especialidad, de las instituciones laborales. Así, ni de lejos se imagina que sólo el análisis de padres o de los responsables y la comprobación de la asistencia escolar puedan definir suficientemente niveles jurídicos de protección para niños y adolescentes.

Brasil, sin embargo, marca una distancia considerable en el tratamiento adecuado del tema, sea en términos de protección jurídica para esas situa- 
ciones de trabajo, sea en la definición adecuada del sistema formal que deberá actuar como garante de los derechos correspondientes.

\section{CONCLUSIÓN}

La participación de niños y de adolescentes en el mundo de las artes, del espectáculo, del deporte, de la moda y de la publicidad, en situaciones de trabajo, que implican en el desarrollo de actividad económica, demanda el establecimiento de protección jurídica que considere los beneficios de esa inserción, pero, también, eventuales perjuicios para tales sujetos de derechos.

La participación infanto-juvenil en esas actividades, que implican en atribuciones, posee naturaleza de trabajo y demanda protecciones específicas considerando la peculiar condición de niños y de adolescentes. La protección jurídica debe involucrar diversos temas, tales como jornada, asistencia y rendimiento escolar, condiciones ambientales laborales, protección del ingreso, que esté definido en condiciones de igualdad, entre otros.

La Convención n. ${ }^{\circ} 138$ de la OIT es marco normativo internacional, con carácter supralegal en Brasil, que establece excepción a la prohibición del trabajo infantil, admitiendo el empleo y el trabajo de niños y de adolescentes en el caso de finalidades dirigidas a la participación en representaciones artísticas. Por lo tanto, el trabajo infantil artístico es parte de la excepción a la regla de prohibición del trabajo infantil, o de la edad mínima para la admisión al empleo, pero sin dejar de considerarse que es trabajo. Enfáticamente, el trabajo artístico infantil es trabajo, aunque pueda no estar caracterizada la hipótesis de empleo.

Aunque la excepción esté establecida por reconocerse que, especialmente en vista de la finalidad artística, cultural y/o deportiva, hay beneficios para los niños, los adolescentes y sus familias, eso no es suficiente para inmunizar esa forma de trabajo de eventuales daños o perjuicios.

Decisión reciente del STJ (CC 171408 MG) recoloca en la discusión aspectos importantes en la temática de la autorización para el trabajo, pertinentes al hecho de que la causa de pedir, relacionada al trabajo, sin prejuicio sobre la existencia de vínculo de empleo, y la "vis atractiva" de los debates 
que rodean esa cuestión, deben ser considerados en la interpretación del alcance de la competencia material de la justicia del trabajo. El propio STF, en otros precedentes, también considera que no importa el derecho a ser aplicado para estar definida la competencia de la Justicia del trabajo y, sí, la naturaleza de las cuestiones debatidas (pertinentes a la relación de trabajo y a los temas circundantes).

La cuestión de la competencia de la Justicia del trabajo para procesar y juzgar demandas, lo que incluye las solicitudes de autorización, relacionadas al trabajo infantil artístico, tiene matriz constitucional, por la incidencia del art. 114 de la Constitución, y revela, como telón de fondo, la prevalencia o no de un sistema formal de garantías que esté dirigido a la comprensión del fenómeno insertado en el trabajo infantil y en la protección jurídica al trabajo.

Sin embargo, en el marco de la ADI 5326, es necesario volver a plantear la cuestión de que es una autorización para el trabajo infantil, en circunstancias excepcionales, y no de autorización para la participación de niños y adolescentes en eventos o representaciones artísticas. En típica situación de trabajo, las empresas contratantes (o intermediadoras) deben solicitar la autorización para el trabajo infantil, observando la directriz de la norma laboral internacional, inserta en Convención ratificada por Brasil, lo que atrae tanto la competencia funcional e institucional para la actuación del Ministerio Público del Trabajo como la competencia material de la Justicia del trabajo. Efectivamente, las manifestaciones artísticas no voluntarias constituyen una forma de trabajo y deben ser protegidas observando los principios y los parámetros construidos en este campo especializado.

La experiencia internacional, en realidades diversas, posee algo en común, o sea, la consideración de que el trabajo infantil artístico, cultural y/o deportivo no se inserta exclusivamente en un contexto del derecho de familia, al contrario, se trata de manifestación de trabajo y, por eso mismo, la legislación regente, cuando existente, es la legislación específica laboral, con designación de órganos y/o entidades de tal siembra para actuar en la autorización y fiscalización en cuanto al cumplimiento de normas jurídicas de protección. En Brasil, sin embargo, todavía no se tiene un marco regulatorio legislativo suficiente y coherente para esa especial situación de trabajo y la cuestión de la competencia de los órganos de actuación ha sido impregnada 
de incomprensiones sobre el hecho de que es trabajo; la competencia de la justicia del trabajo no se resume a situaciones de empleo; y la protección al trabajo en el caso de niños y adolescentes, cuando excepcionalmente eso es permitido, debe observar normas que son y fueron construidas en el campo laboral, envolviendo limitación de jornada, protección a la remuneración, medio ambiente laboral, entre otras.

Hay, sin duda, un largo camino a recorrer nacionalmente para que, desmitificado el deslumbramiento que forja ciertos sentidos comunes, se pueda considerar jurídicamente relevante la protección integral y prioritaria para niños y adolescentes en situaciones de trabajo debido a las manifestaciones artísticas, culturales y/o deportivas.

\section{NOTAS}

1 En la redacción original del Texto de 1988, había prohibición de cualquier trabajo a los menores de 14 años, salvo en la condición de aprendiz.

2 Ana Paula de Barcellos (2007, p. 2-3) lista las premisas fundamentales del constitucionalismo contemporáneo de Occidente, desde el punto de vista metodológico-formal.

3 Disponível em: http://www.tst.jus.br/web/trabalho-infantil/noticias/-/asset_ publisher/ry7Y/content/ato-conjunto-promove-avanco-no-combate-ao-trabalhoinfantil. Acceso en: 7 jun. 2020.

4 De hecho, el STF decidió (RE n. 466.343-1 / SP) que las Convenciones sobre Derechos Humanos ratificadas por Brasil, sin observancia del procedimiento previsto para las enmiendas constitucionales, poseen estatura supralegal, o sea, superior a las leyes ordinarias. Sobre dicho juicio, según Daniela Muradas (MURADAS, 2010, p. 152): “[...] la nueva teoría acogida permitirá el control de convencionalidad de la legislación nacional, verificando la conformidad de los dispositivos de legislación nacional con estos diplomas internacionales, retirando la eficacia de aquellos preceptos que se demuestren incompatibles con estos documentos internacionales, en la línea de la aplicación del criterio lex superiori derogat inferior".

5 Se trata del conflicto de jurisdicción n. ${ }^{\circ}$ 6.959-6, juzgado por el Plenario del STF el 23 de mayo de 1990, teniendo como ponente para la sentencia el ministro Sepúlveda Pertenece. La decisión tiene el siguiente extracto: "menú-justicia del trabajo: competencia: Const., artículo 114: acción de empleado contra el empleador objetivando la observación de las condiciones negociales de la promesa de contratar formulada por la empresa en consecuencia de la relación de trabajo. 1 - Compete a la justicia del trabajo juzgar demanda de servidores del Banco de Brasil para obligar a la empresa al cumplimiento de la promesa de venderles, en dadas condiciones de precio y modo de pago, apartamentos que, asintiendo en transferirse a Brasilia, aquí vinieran a ocupar, por más de cinco años, permaneciendo a su servicio exclusivo y directo. 2 - a la determinación de la competencia de la Justicia del Trabajo no importa que dependa la solución de la demanda de cuestiones de Derecho civil, pero sí, en el caso, que la promesa de contratar, cuyo alegado contenido es el fundamento de la solicitud, haya sido hecha debido a la relación de empleo, insertándose en el contrato de trabajo". 
6 En tema con repercusión general, relacionado al Enunciado Vinculante n. ${ }^{\circ}$ 22, el STF definió la competencia de la justicia del trabajo para las acciones por pérdidas y daños, propuestas por los herederos y/o sucesores de los trabajadores fallecidos, en casos de accidente del trabajo.

\section{REFERENCIAS}

ARGENTINA. Ley 26.390, de 4 de junio de 2008. Prohibición del trabajo infantil y protección del trabajo adolescente. Buenos Aires, jun. 2008a. Disponible en: http://servicios.infoleg.gob.ar/infolegInternet/anexos/140000-144999/141792/norma.htm. Acceso en: 10 sept. 2020.

ARGENTINA. Resolución del Ministerio de Trabajo n. 44/2008. Buenos Aires, 2008b. Disponible en: https://normas.gba.gob.ar/ar-b/resolucion/2008/44/200332. Acceso en: 6 jul. 2020.

BARCELLOS, Ana Paula de. Neoconstitucionalismo, direitos fundamentais e controle das políticas públicas. In: Revista Diálogo Jurídico, n. ${ }^{\circ}$ 15, 2007, Salvador, p. 1-31.

BRASIL. Decreto-lei n. 5.452, de $\mathbf{1}^{\mathrm{o}}$ de maio de 1943. Aprova a Consolidação das Leis do Trabalho. Disponível em: http://www.planalto.gov.br/ ccivil_03/decreto-lei/Del5452compilado.htm. Acceso en: 10 set. 2020.

BRASIL. Constituição da República Federativa do Brasil. Brasília/DF, 1988. Disponível em: http://www.planalto.gov.br/ccivil_03/constituicao/ constituicao.htm. Acceso en: 10 sept. 2020.

BRASIL. Decreto n. ${ }^{\circ} \mathbf{1 0 . 0 8 8}$, de 5 de novembro de 2019. Consolida atos normativos editados pelo Poder Executivo Federal que dispõem sobre a promulgação de convenções e recomendações da Organização Internacional do Trabalho - OIT ratificadas pela República Federativa do Brasil. Brasília/DF, nov. 2019. Disponível em: http://www.planalto.gov.br/ccivil_03/_Ato20192022/2019/Decreto/D10088.htm\#art6. Acceso en: 15 jun. 2020.

ESTADOS UNIDOS DA AMÉRICA (EUA). California Legislative Information. Code Labor. Section 1700.37. Washington D.C., 2020a. Disponible en: https://leginfo.legislature.ca.gov/faces/codes_displaySection.xhtml?sectionNum=1700.37.\&lawCode=LAB. Acceso en: 6 jul. 2020. 
ESTADOS UNIDOS DA AMÉRICA(EUA). California Legislative Information. Family Code. Section 6750. Washington D.C., 2020b. Disponible en: https://leginfo.legislature.ca.gov/faces/codes_displaySection.xhtml?sectionNum=1700.37.\&lawCode=LAB. Acceso en: 6 jul. 2020.

ESTADOS UNIDOS DA AMÉRICA(EUA). California Legislative Information. Family Code. Section 6752. Washington D.C., 2020c. Disponible en: https://leginfo.legislature.ca.gov/faces/codes_displaySection.xhtml?sectionNum=1700.37.\&lawCode=LAB. Acceso en: 6 jul. 2020 .

ORGANIZAÇÃO INTERNACIONAL DO TRABALHO (OIT). Declaração da OIT sobre princípios e direitos fundamentais no trabalho. [S.1], [20--]. Disponível em: https://www.ilo.org/public/english/standards/ declaration/declaration_portuguese.pdf. Acceso en: 7 jul. 2020.

PORTUGAL. Lei n. ${ }^{\mathbf{7}}$ 7/2009 (Código do Trabalho). Lisboa, 2009. Disponível em: https://dre.pt/pesquisa/-/search/602073/details/maximized. Acceso en: 6 jul. 2020.

REIS, Daniela Muradas. O princípio da vedação do retrocesso no Direito do Trabalho. São Paulo: Ltr, 2010.

SUPREMO TRIBUNAL FEDERAL (STF). ADI 5326. Disponível em: http://portal.stf.jus.br/processos/detalhe.asp?incidente $=4781750$. Acceso en: 7 jul. 2020.

SUPREMO TRIBUNAL FEDERAL (STF). Conflito de Jurisdição n. 6.959-6. Relator designado ministro Sepúlveda Pertence. Disponível em: http://redir.stf.jus.br/paginadorpub/paginador.jsp?docTP=AC\&docID=30431. Acceso en: 7 jul. 2020.

SUPREMO TRIBUNAL FEDERAL (STF). Repercussão Geral. Tema 242. Disponível em: http://www.stf.jus.br/portal/jurisprudenciaRepercussao $/$ verAndamentoProcesso.asp?incidente $=2678966$ \&numeroProces so $=600091 \&$ classeProcesso $=$ RE\&numeroTema $=242$. Acceso en: 7 jul. 2020 .

SUPERIOR TRIBUNAL DE JUSTIÇA (STJ). Processo CC 171408 MG 2020/0073818-5., Rel. ministro Herman Benjamin, DJ 04/05/2020. Disponível em: https://scon.stj.jus.br/SCON/decisoes $/$ toc.jsp?livre $=\% 28 \mathrm{C}$ $\mathrm{C}+171408 \% 29+\mathrm{E}+\% 28 \% 22$ HERMAN+BENJAMIN $\% 22 \% 29$. MIN.\&b=DTXT\&thesaurus=JURIDICO\&p=true. Acceso en: 10 jul. 2020. 
TRIBUNAL SUPERIOR DO TRABALHO (TST). Trabalho Infantil. CSJT. Notícias. Ato conjunto promove avanço no combate ao trabalho infantil. Brasília/DF, [20--]. Disponível em: http://www.tst.jus.br/web/trabalho-infantil/noticias/-/asset_publisher/ry7Y/content/ato-conjunto-promove-avanco-no-combate-ao-trabalho-infantil. Acceso en: 7 jul. 2020. 



\section{LA HISTORIA DE LA LUCHA CONTRA EL TRABAJO INFANTIL EN REINO UNIDO'

\author{
OSCAR GUARDIOLA-RIVERA \\ FERNANDA PEREIRA BARBOSA
}

DOI: 10.51366/978-65-89468-10-3-coordinfancia-23

Resumen. Introducción; 1. Industria y trabajo infantil; 2. La cronología de la lucha contra el trabajo infantil en Reino Unido; 3. Trabajo infantil en el momento actual y datos estadísticos: ¿Qué significa ser niño?; Conclusión; Referencias.

Palabras clave: Trabajo infantil. Reino Unido. Combate.

"bis Gottes Febl bilft' Hölderlin. Dichterberuf.

\section{INTRODUCCIÓN}

Cualquier intento de historización de la lucha contra el trabajo infantil en el mundo anglófono, especialmente en Reino Unido, debe lidiar con el hecho de que estamos lidiando con la relación entre las categorías político económicas de la modernidad y la siempre recurrente cuestión de la subjetividad. Es decir, subjetividad, dotada de conciencia (tal vez afectada por la inconsciencia, la (in)división sexual, el ver y ser visto) y derechos o deberes.

Debemos examinar esta relación no solo en el nivel de la moral, o incluso de las relaciones socioeconómicas, sino, además, articularla como una unidad conceptual que puede ayudar a aclarar ciertos problemas institucionales, y si tales problemas son cosas del pasado o aún mucho nuestro. Además, dado que esta relación (o subjetividad como tal) depende de si los cuerpos naturales en cuestión (niños) están viendo y siendo vistos, y por lo tanto definidos por dicha dinámica (si la subjetividad de uno es el resultado de que 
uno se ve a sí mismo siendo visto por otros y potenciados por ese vínculo múltiple, o simplemente definidos por lo que ven los demás) se trata también de la ley en el campo de la visión y la existencia: la visualidad, la visualización, el ser invisible y cómo hacerse ver y oír.

Esto plantea un reto inmediato a la ley y nuestras concepciones de la ley. Durante demasiado tiempo, la ley se ha concebido como una cuestión de palabras. De hacer las cosas con palabras, o peor aún un asunto de La Palabra. Pero, por supuesto, como los niños saben muy bien, ver es antes que palabras. El niño reconoce y mira antes de que pueda hablar. Otro sentido en el que el ver viene antes que las palabras, no menos existencial pero quizás más político, es este: ver establece nuestro lugar en el mundo circundante. Es tanto una cuestión de diferencia como de orientación. Poco después de ver, nos damos cuenta del hecho de que también podemos ser vistos, o no.

El ojo del otro se combina con el nuestro para que sea plenamente creíble, no solo un hecho, sino también un hecho real, que somos parte del mundo visible. Esta naturaleza recíproca de la visión es más fundamental que la de la palabra escrita e incluso el diálogo hablado. Esta inmediatez, por así decirlo, desafía la vigencia de ciertos medios en los medios escritos por ley, o la reducción de la retórica legal a los medios de percepción dialógica y mediatizada. En este sentido, todas las imágenes, incluidas las de los niños, son creadas por el hombre. Lo mismo ocurre con no solo un hecho, o nada en absoluto, sino un hecho real. El hecho real que nos preocupa es la casi invisibilidad de los niños en la larga historia de las instituciones - jurídicas y políticas - y su evidente irrupción (en el panorama) en algún momento entre los siglos XVII y XIX, y con especial intensidad en este último.

\section{INDUSTRIA Y TRABAJO INFANTIL}

Los niños aparecen (o parecen desaparecer) para el ojo occidental a raíz de la expansión europea, el despojo global y el desplazamiento forzado o la desaparición de innumerables pueblos, especialmente en lo que se convertiría en el comercio transatlántico. Como tales, parecen investidos con la apariencia de una renovación de las categorías más antiguas del Derecho Romano reinventado para adaptarse a las necesidades de expansión, despojo y desplazamiento. En otras palabras, como parte de la relación histórica y social que hemos llegado a conocer con el nombre de "propiedad", tan familiar para 
nosotros. Lo que puede resultar menos familiar es el hecho de que en una relación tan dramática el papel desempeñado por los niños implica, en el mejor de los casos, formar parte de la fuerza laboral que produce el bien en los bienes comercializados globalmente (propiedad) y, en el peor, como la parte que en tal relación se define la no parte. La parte del no-parte, como dirían los filósofos. Es decir, la parte invisible, la parte que desaparece.

En las etapas constitutivas pero contemporáneas de esa no relación, los niños llegan a definirse legalmente no solo a sí mismos sino a casi todos los demás pueblos del mundo como niños: mujeres en todas partes, nativos americanos y desplazados por la fuerza de lo que ahora se conoce como África. todos ellos se ven a través del prisma de las prescripciones del derecho romano para los niños. Es decir, ya sea como no personas o, en el mejor de los casos, solo en camino a convertirse en personas o, para hablar en términos legales, en ciudadanos. Nuestra hipótesis de trabajo aquí, mejor articulada en el trabajo de personas como Frantz Fanon, Etienne Balibar, Silvia Federici, Manuela Carneiro da Cunha y Eduardo Viveiros de Castro, es que la modernidad político jurídica comprende dos movimientos antitéticos con respecto a las diferencias antropológicas, lineales demarcaciones o divisiones que producen mujeres, indígenas, esclavos y niños como hechos (legales).

El proyecto de modernidad sigue siendo, en este sentido, relevante e no completo en su misma culminación y globalización, como dice Balibar. Por un lado, la modernidad inventó una noción de ciudadano que no solo implica pertenecer a una comunidad orgánica creada a partir del conjunto inorgánico de relaciones "impersonales" que producen los bienes y el bien en ellos para satisfacer una dieta cada vez mayor de necesidades. Pero también, que tiene acceso "a un sistema de derechos del que ningún ser humano puede ser legítimamente excluido”. Este universalismo reprime las diferencias y los modos de orientación en la esfera de la particularidad que tanto la política como el derecho buscan neutralizar - la domesticación de los cuerpos naturales.

Por otra parte, la modernidad amplía como nunca el proyecto de clasificar a los seres humanos precisamente en función de sus diferencias particulares, generalizando así el concepto de diferencia y transformándolo para designar no tanto un estatus jerárquico sino más bien posibilidades de actualización humana entre las que se encuentra el individuo. Hay que elegir y que vienen a representar, a hacer visible, poder, capacidad, valor y precio. Estos 
movimientos chocan entre sí cuando la variación humana se convierte en el medio "lógicamente consistente" de privar a individuos, colectivos, grupos o clases de sus derechos naturales (el derecho a tener derechos de Arendt), esclavizando así la naturaleza y obligándola a anularse produciendo no personas. Los niños se encuentran entre esas "no personas" o cuerpos naturales en camino de convertirse en personas cuyo mismo "potencial" (para madurar) tiene que anular su relacionalidad natural para ser producidos como tales. Además, deben elegir este destino o ser visto para elegirlo. En resumen, para que se les niegue el acceso a la ciudadanía, ellos (como las mujeres, los nativos y negros) también deben ser "eliminados de la humanidad"2

Continuando con Balibar y más allá, el proyecto de modernidad no es solo relevante, aunque incompleto en su realización. Asimismo, en la medida en que debe escindir de la humanidad los cuerpos naturales sumergidos en la oscura morada del proceso de producción del bien en los bienes, se atraviesa, de cabo a rabo, con la negación (más precisamente, la desautorización) de las alianzas. que los humanos deben hacer con los no humanos para proyectar el universo común de derechos. Tal negación del nexo humano/no humano produce lo que llamaremos lo inhumano. Esto es un oscurecimiento del universo de la naturaleza, o la domesticación de los cuerpos naturales, que ocurre cuando una parte (los niños, por ejemplo) se convierte en la no parte del nexo relacional mientras que otra parte (el hombre blanco adulto) se hace. para representar el todo.

Este es un truco imaginario: la denigración de un cuerpo natural, como cuando los niños negros parecen desaparecer en el fondo oscuro del retrato "Dutch Golden Age". Están ahí, pero como la no parte de una no relación. En términos fanonianos, viven en la zona del no ser. O simplemente como seres potenciales no realizados. Fundamentalmente, ese potencial que no se realiza se transmite a los bienes que producen, prestándoles su vida. El tropo del que hablamos es una combinación entre sinécdoque (la sustitución de una parte por el todo) y fetichismo (la visión voyerista que objetiva un cuerpo, convirtiéndolo en una cuasi mercancía o fuerza de trabajo y fuerza, así como en un sujeto larvario). Este truco, este movimiento convierte al hombre en todo el hombre, por un lado, y por el otro hombre (como mujer, negro, nativo, niño o infantil) es la mitad o un tercio del hombre. No es un individuo, sino un dividuo, las partes pueden agruparse, comprarse y venderse. 
No es de extrañar, por lo tanto, que la historia de la lucha contra el trabajo infantil encaje tan clara y concretamente con el despojo del cuerpo de las mujeres y los indígenas como lo historiaron personas como Silvia Rivera Cusicanqui y Silvia Federici, así como con el desplazamiento forzado y el comercio. en trabajo esclavo. La "oleada" del trabajo infantil es parte integral de la domesticación y la mercantilización, la fetichización de algunos cuerpos (convertidos en nadie) en las moradas de la producción vistos solo como los ven otros (como en la fórmula "la imaginación del adulto de la imaginación de los niños”). Pero también, más adelante en la secuencia, la potenciación de esa doble visión (verse uno mismo solo como lo ven los demás) en una subjetividad larvaria capaz no solo de resistir a los embates más violentos sino también de convertirse en algo o alguien más sin necesidad de destrucción.

En este sentido, tampoco es de extrañar que la lucha contra el trabajo infantil aparezca primero en la visualización de otros mundos en éste en la literatura utópica. Es en el libro elaborado por el jurista británico Thomas More, en su oposición a la economía mercantil emergente, Utopia, donde se atestigua y denuncia por primera vez la situación de las mujeres y los niños en Inglaterra. Queda a la sociedad mejor, que siempre está en el pasado en el futuro, y en el presente como anti-futuro (o el futuro en las posibilidades latentes del pasado) imaginar una situación en la que los niños y los jóvenes no son ni meros proletarios ni condenados al endeudamiento y la existencia de un precariado.

Por supuesto, tales imaginaciones siempre les parecen tonterías a quienes se encuentran en la situación actual. Si podemos creer el boceto que Erasmo dejó de su amigo en una carta a Ulrich van Hutten en 1519, el genio del sinsentido y la sátira fue el "daemon ... desde la infancia" de Thomas More. Esta caracterización de la imaginación de los niños como la de la subjetividad larvaria rebelde es la clave para comprender la historia jurídica del combate al trabajo infantil. El narrador de Utopía es como un niño, su mismo nombre, Raphael Hythloday, un juego de traducciones del griego que significa "bablante de tonterías”. Decir que la historia de la lucha legal contra el trabajo infantil es una historia de disparates es, por lo tanto, el mayor cumplido. Encomia el papel crucial de la imaginación en el cambio legal.

Significa tanto la elección necesaria de medios de comunicación "indirectos" cuando aquellos en una situación de ser excluidos de la humanidad luchan por convertirse en plenamente humanos, por una humanidad más in- 
tegral (con otros no humanos) y las limitaciones de tales métodos indirectos. Porque, como Raphael Hythloday reconoce en Utopía, los métodos de transformación legal y justicia particular son imperfectos en el sentido de que solo producirían reformas parciales en lugar de la reforma más radical, parecida a una raíz (no solo rizomática) que propone la novela. El punto aquí es que la esfera de la imaginación (tanto estética como política) es más extensa que los límites de la jurisdicción civil y la constitución (narrativa).

Este último se crea de manera conversacional, permitiendo la construcción de los diversos aspectos de la subjetividad - identidad, identificación y reconocimiento - a través de las descripciones narrativas que empleamos en conversación con nuestra comunidad histórica inmediata, como teóricos del derecho mainstream y algunos críticos como HLA Hart, Jürgen Habermas y Charles Taylor lo dirían. Pero si la idea de identidad es central para cualquier comprensión de una constitución narrativa y para procesos de transformación legal como los que en Gran Bretaña y otros lugares proporcionaron un mínimo de agencia a los niños en el trabajo y en el mercado, es importante considerar que tales identidades del yo y la comunidad, siendo narrativas o incluso construcciones literarias, son, a la vez, imaginarias (en el sentido crítico Kantiano de que la imaginación enmarca nuestra política y reglas legales) y en la secuencia histórica concreta que estamos intentando trazar. Aquí también el resultado de la instrumentalización y estandarización, en el sentido que le da a tales términos la literatura crítica de los años sesenta en adelante por gente como Adrono, Benjamín y Enrique Dussel.

En otras palabras, la lucha contra el trabajo infantil en la historia jurídica de Gran Bretaña tiene lugar en el contexto de lo que el historiador jurídico Alain Supiot ha denominado correctamente "el sueño de la armonía a través del cálculo", y está enmarcado por él. Supiot habla así de la gobernanza de los números que en las condiciones de la modernidad (Estado-mercado) subordina el contenido (nos atrevemos a decir el "espíritu") de las leyes, o su semejanza con el verdadero valor (en el sentido Rousseauniano del término, que Hegel tradujo al término alemán Tapferkeit en su ensayo de 1802 sobre la ley natural), al cálculo de la utilidad, el precio y el valor para poner las leyes "al servicio de los patrones económicos armoniosos que supuestamente regirían el funcionamiento de las sociedades humanas". ${ }^{3}$

El punto aquí es que nuestra visión del campo legal en la época del colonialismo y el capital como si fuera la etapa de progreso liberal o lineal 
hacia lo mejor, una trama, a través de la enumeración legal y las estadísticas, no debe en modo alguno oscurecer el hecho de que los cuerpos de los niños (junto con las mujeres y los esclavizados) son el escenario de un combate, un campo de batalla, una lucha librada mayoritariamente por aquellos que han sido separados de la humanidad o arrojados al lado de los objetos y la naturaleza. Los matices políticos y militantes del término "coraje" (Tapferkeit, en alemán) están ahí para recordarnos que la subjetividad (incluida la subjetividad de los niños) viene a significar la concreción de la conducta que es libre y deliberadamente diseñada para expresar ese aspecto de la humanidad, personalidad que estaba más allá del ámbito de la necesidad física. Es decir, lejos tanto de la "naturaleza" (concebida como mera reserva, espacio-tiempo vacío o la legalidad numérica del sueño del orden espontáneo de la naturaleza) como de la esfera de la necesidad física, la "esfera inorgánica”, o la esfera de la mera agregación en la que la cohesión, si existiera momentáneamente, sólo puede tener una cualidad limitada y accidental.

En cambio, la lucha por la subjetividad (como en la lucha contra el trabajo infantil) es una cuestión de praxis, la esfera de lo orgánico o el ámbito de la verdadera asociación. Ya sea que los pioneros de la comprensión del derecho en las condiciones de la modernidad entendieran que esto incluye a los jóvenes o no, lo cierto es que el combate contra la mera objetivación del cuerpo natural de los niños como no completamente humano o mera fuerza de trabajo (como el de las mujeres y los pueblos negros o nativos) abre el territorio de aquello que enraizado en la alianza entre humanos y no humanos (naturaleza) conlleva el desarrollo de personalidades más allá de lo que ha sido dado (a hombres y mujeres) tanto por la naturaleza como por condiciones sociales naturalizadas, i.e. es decir un espacio-tiempo diferente, una creación. En definitivo, la creación inventiva y combativa de un espacio-tiempo basado en el repudio sistemático de la ideología de la eficiencia.

Si es así, distingamos (dentro del movimiento de transformación jurídica) entre las reformas legales relativas al papel de los niños que apuntaban a fundamentar más firmemente la ideología de la eficiencia (así como la esclavitud africana fue justificada por algunos juristas y pensadores de la Neoescolástica en vista de la ineficacia de los nativos americanos, y luego la esclavitud de los africanos reemplazada por la compensación y la personalización de las corporaciones como en el caso de 3 \& 4 Will. 4 c. 73 en Gran Bretaña o la 14a Enmienda a la Constitución de los EE. UU) por un lado, y por otro, aque- 
llas reformas que apuntan a llevar la idea misma de eficiencia más allá de su aplicación unilateral en el ámbito inorgánico (agregación económica, moral y psicología) y en el propiamente político.

Entre estas últimas se incluyen aquellas medidas en las que la práctica y la imaginación de los niños ya no se postula al servicio de la imaginación del adulto sino como parte del acto militante de desmantelar los regímenes de austeridad, financiarización y destrucción del medio ambiente, en los que, al poder repudiar la eficiencia, esta se hace en nombre de otros valores más progresivos. Podemos ver eso en el tratamiento dado por Thomas More de la difícil situación de los niños y las mujeres hacia una vis utópica en el siglo XVI, y en el siglo XXI en las acciones de los niños que protestan en combate con la imaginación adulta de su imaginación sobre el medio ambiente y la naturaleza, así como su salida a las calles en las Américas y en otros lugares hacia una vida diferente (incluido el acceso a la educación gratuita en Chile o los EE. UU. y el Reino Unido, o a las urnas a una edad más temprana, o simplemente existir como niños negros o nativos y así sucesivamente).

En este último caso hablamos de transformación jurídica no sólo en términos de "soluciones" (política, reforma parcial) sino de "principios" cuando de Utopía, una visión moderna en el sentido de una sociedad que reflexiona sobre haber enfrentado el trabajo y la guerra, representan una comunidad de trabajo movilizada por la lucha contra la naturaleza (domesticada) y la pobreza. En la medida en que tiende hacia el modelo jurídico-político del siglo XVI, más democrático que autoritario, no se puede ver en Utopía un proyecto constitucional o un plan dogmático para la sociedad del futuro, sino sólo una invitación a sus lectores a mirar en el tema de "la mejor forma de gobierno". Es decir, invitarlos a explorar la cuestión de cómo sería la humanidad si estuviéramos comprometidos en la búsqueda interminable e incompleta de un orden político más justo o bueno (no considerar su orden como el orden justo de una vez por todas). El punto es la liberación de una vis utópica, ni una dieta de soluciones mágicas ni la convicción de que tales soluciones están bien fundamentadas, sino el impulso detrás del combate contra las injusticias y la excelencia del pensamiento sobre la diferencia de lo que hay actualmente, para ejemplo de trabajo infantil o condición precaria, y, por lo tanto, una cuestión de principios.

Los dos principios que regresan sin cesar en el movimiento hacia la alteridad social ("principio" significa aquí la idea de un comienzo diferente que 
sea capaz de conducir ese comienzo desde el pasado hacia el futuro y contra la futurificación de lo actual) son "la eliminación del hambre del otro" y "otro objetivo de las instituciones sociales que la mera limitación de los efectos de la guerra". Estos son los mismos principios que se encuentran en la reinvención de Charles Dickens de la lucha contra el trabajo infantil en el siglo XIX.

Si bien que el trabajo infantil no fue, estrictamente hablando, una invención de la era de la Revolución Industrial, solo la raíz de la triangulación entre las plantaciones de esclavos, el expansionismo europeo y la red mundial de comerciantes de fábricas se convirtió en el empleo de niños muy pequeños. extendido. Formaba parte del conjunto de fenómenos históricos que, al marcar ciertos cuerpos, marcó una ruptura histórica decisiva con la práctica más tradicional. El cuerpo joven que denuncia la ropa nueva del emperador se suma a las demás figuras del canon literario sobre los orígenes y desarrollo del capitalismo, Caliban y la bruja. Deben estudiarse juntos, ensamblando el cuerpo proletario y precario que es a la vez el terreno y el arma de resistencia contra las lógicas emergentes de la esfera inorgánica de la sociedad (global), lo que se ha denominado "acumulación primitiva" en el canon académico sobre la relación entre derecho y economía.

Este análisis debe realizarse no solo desde el punto de vista del trabajo masculino asalariado y la producción de bienes, sino también desde la perspectiva de los cambios introducidos en el lugar social de las mujeres y los niños por la producción de la fuerza de trabajo, como, entre otros, ha observado Silvia Federici ${ }^{4}$. En Reino Unido, la intensificación del empleo infantil a la raíz de la industrialización provocó una serie de investigaciones parlamentarias sobre las condiciones laborales de los niños en las fábricas y minas. Sus informes sorprendieron a personas como Elizabeth Barrett Browing y Charles Dickens, inspirando tales hazañas de la imaginación basadas en la dura realidad de que los cuerpos jóvenes y otros cuerpos marcados se convierten en el lugar de conflictos sociales como "The Cry of the Children", "Hard Times" y "David Copperfield".

En "Tiempos difíciles", el antagonismo social se vuelve a imaginar como una agitación existencial en el pequeño corazón de la "niña número veinte", Sissy Jupe. De hecho, de esto se tratan los personajes de circo "fantásticos" del libro: un retrato ficticio pero realista del reemplazo y la corrupción de valores valientes por parte de la sociedad de mercados emergentes en los altares del valor monetario, el precio y el riesgo en el comercio de 
contratos y mercados futuros (como en la doctrina caveat emptor adoptada en el mundo angloparlante, a ambos lados del Atlántico a raíz de casos como el Laidlaw v. Organ). El punto aquí no es solo la representación de una sociedad en la que una "persona racional", idealmente, no confiaría en nadie porque nadie debería ser responsable ante nadie por nada, sino también, una sociedad en la que el contraste entre personajes como los jóvenes Sissy y la clase emergente de propietarios de fábricas y sus llorosos sátrapas llegan a los límites del superrealismo y del absurdo. ${ }^{5}$

El más grande novelista del siglo XIX en lengua inglesa, creador de personajes indelebles que representan a los comerciantes, banqueros, gerentes y abogados helados de la burguesía en ascenso, no habría tenido problemas para escribir e interpretar en los argumentos del abogado del acusado en Laidlaw el nefasto entrelazamiento entre romance y fantasía en una sociedad en la que los demandantes por error, las mujeres, los negros y los niños deben depender en su detrimento de la veracidad de los empresarios comerciales, banqueros, dueños de fábricas, administradores de plantaciones y otros beneficiarios de los oficios triangulares. Los niños trabajadores aparecen en varias otras novelas de Dickens, la más memorable en "Oliver Twist", con su escape por los pelos como aprendiz del señor Gamfield, el deshollinador, y en David Copperfield. David Copperfield, por supuesto, se basó vagamente en las propias experiencias de Dickens al comenzar a trabajar en la fábrica de Warren en Blacking a la edad de 12 años, luego del encarcelamiento de su padre por deudas. "Water Babies" de Charles Kingsley presenta la difícil situación de los deshollinadores de la nación junto con una serie de novelas más efímeras, como "The Life and Adventures of Michael Armstrong, Factory Boy" de Frances Trollope y Helen Fleetwood de Charlotte Elizabeth.

Todos ellos expusieron el sufrimiento de los niños trabajadores al lector de clase media. Con tales escritos, muchos de los comentaristas más vocales y prolíficos del período dirigieron su atención a los niños trabajadores. El panorama de Dickens puede leerse como ficción, caricatura o exageración, pero si es así, entonces es una caricatura del más alto nivel, "que delinea las líneas esenciales de la verdad", como dijo E. P. Thompson. "El señor Bounderby, el tosco y avaro dueño de una fábrica de Hard Times, el tipo del inicio de la Revolución Industrial estaba cediendo el paso a su primo más sofisticado, el señor Gradgrind. Gradgrind no solo tiene poder y riqueza: también tiene una teoría para justificar y perpetuar la explotación. La burguesía vic- 
toriana [inglesa] había construido a partir de fragmentos de Adam Smith y Ricardo, Bentham y Malthus un sistema teórico de hierro, que ahora estaba asegurando con la autoridad del Estado y la ley, y santificando con las bendiciones de la religión. Las leyes de la oferta y la demanda eran "leyes de Dios" y en todos los asuntos importantes de la sociedad todos los demás valores [como el coraje o la Voluntad General] deben ceder ante los valores básicos. ${ }^{6}$

Esto incluye, por supuesto, los valores asociados con la humanidad de los pueblos negros, mujeres y niños. La situación de los niños trabajadores comenzó a entrar en el corazón más liberal de la nación cuando reformadores como John Fielden y Lord Ashley, el Séptimo Earl de Shaftesbury, asumieron su causa en el Parlamento. Como veremos en la siguiente sección, la campaña contra el trabajo infantil culminaría en dos leyes fundamentales: la Ley de fábricas (1833) y la Ley de minas (1842). La Ley de fábricas prohibiría el empleo de niños menores de nueve años y las horas de trabajo de los niños de entre nueve y 13 años. La Ley de Minas, a su vez, aumentaría la edad de inicio de los trabajadores de las minas de carbón a 10 años. En efecto, estas dos leyes alinearon los distritos industriales con el resto del país y buscaron mejorar la situación creada por el empleo sistemático de niños pequeños.

Aumentar la edad en la que los niños comienzan a trabajar fue un importante paso adelante para el bienestar infantil, pero de hecho hizo muy poco para mejorar las condiciones laborales de los muchos niños que seguían trabajando. Los niños en el lugar de trabajo seguían estando en gran parte desprotegidos del maltrato a manos de empleadores y compañeros de trabajo. Así, en la década de 1850, el futuro diputado liberal, George Edwards, trabajaba como granjero con un hombre que "nunca perdió la oportunidad de golpearme". Esto, concluyó, "no era una excepción a la regla, todos los niños pobres en esos días eran maltratados'. E “incluso cuando los padres estaban al tanto del abuso de sus hijos, la pobreza a menudo significaba que no podían tomar ninguna acción efectiva. Roger Langdon, por ejemplo, describió cómo casi lo mata el labrador borracho para quien había trabajado. Informó a sus padres, pero como "todos los demás lugares de la parroquia estaban llenos y mis padres no podían permitirse el lujo de mantenerme en la inactividad", siguió trabajando para el hombre. "Abordar el abuso sistemático de trabajadores jóvenes y vulnerables resultó ser una tarea más difícil problema que sacar a los niños pequeños de las fábricas".7 


\section{LA CRONOLOGÍA DE LA LUCHA CONTRA EL TRABAJO INFANTIL EN REINO UNIDO}

Los cambios en la forma en que la sociedad, las instituciones y el gobierno ven la infancia no se produjeron en forma de revolución. Más bien, la búsqueda de cambios sociales a través del derecho escrito se llevó a cabo de manera gradual, lenta y durante más de tres siglos. Esto significa que la historia de la lucha contra el trabajo infantil se ha venido desarrollando de forma lógica, lineal y continua, sin interrupciones en el tiempo y el espacio. La evolución legislativa, por lo tanto, no trajo un nuevo principio (y debemos repetir que "principio" aquí significa la idea de un comienzo diferente), sino la continuación de una historia de objetivación y domesticación de los cuerpos humanos. En las siguientes líneas, presentamos de forma sencilla y sucinta los cambios legislativos que se han producido en Reino Unido para limitar la explotación del trabajo infantil.

Habiendo sido la primera gran potencia industrial, Gran Bretaña también fue pionera en el amplio uso del trabajo infantil en varios segmentos de la actividad económica. Sin embargo, también fue el primer país en albergar movimientos para la extinción de la explotación laboral infantil. Se puede argumentar que los movimientos sociales y las Organizaciones No Gubernamentales $(\mathrm{ONG})$ fueron clave para cambiar el pensamiento social sobre el trabajo infantil, así como para el surgimiento de reglas y regulaciones para proteger a los niños, niñas y adolescentes. ${ }^{8}$ En el siglo XIX, cuando algunas personas comenzaron a ver a la infancia de manera diferente y reclamaron regulaciones laborales, la explotación del trabajo infantil poco a poco comenzó a ser repelida y condenada por parte de la sociedad. ${ }^{9}$ En este contexto, surgió una serie de regulaciones en Inglaterra y Gales como un medio para limitar el trabajo infantil.

Es importante resaltar que, en ese momento, el patrocinio estaba en gran parte en contra de la regulación y prohibición del trabajo infantil. Los fabricantes, propietarios de fábricas y pensadores conservadores y liberales se opusieron firmemente a estas reglas por varias razones. En primer lugar, consideraban que el uso de mano de obra barata (niños y mujeres) era esencial para el funcionamiento de la economía. En segundo lugar, también se alegó que la intervención legislativa a través de la regulación laboral perjudicaría considerablemente la competitividad de los productos británicos en el mer- 
cado. En tercer lugar, las opiniones conservadoras también defendieron que la intervención estatal en esta dirección sería una amenaza para las libertades individuales, derechos que estaban sobrevalorados en su momento. ${ }^{10}$ En resumen, los empleadores y los pensadores liberales buscaban mantener el orden social tal como era: una sociedad en la que un pequeño porcentaje de individuos fuera efectivamente considerado ciudadanos; una sociedad en la que la defensa de los derechos y libertades individuales de estos ciudadanos (que, no por casualidad, iban de la mano de los intereses económicos y de mercado) se dio por objetivar a otros seres humanos (niños, por ejemplo).

A pesar de la resistencia, se votaron diferentes Leyes de Fábricas y, más tarde, se convirtieron en leyes que regulan el trabajo infantil y que poco a poco eliminan los peores casos de trabajo infantil. De hecho, las primeras iniciativas legislativas tuvieron lugar relativamente temprano, en el siglo XVIII. En 1788, el parlamento aprobó una ley que prohibía el empleo de niños menores de 8 años como deshollinadores. ${ }^{11}$ Sin embargo, la explotación del trabajo infantil continuó ocurriendo en Reino Unido. Las investigaciones han demostrado que, a pesar de la prohibición legal, en el siglo XIX todavía se empleaba en gran medida a los niños como limpiadores de chimeneas. Además de recibir sueldos más bajos que los adultos, los niños también fueron considerados más ágiles debido a su menor tamaño. ${ }^{12}$ Sin embargo, el empleo de niños se utilizó ampliamente en muchos campos diferentes durante la mayor parte del siglo XIX, hasta tal punto que, en las zonas rurales, por ejemplo, los niños solían empezar a trabajar en el campo a la edad muy temprana de cinco o seis años. ${ }^{13}$

El caso de Martha Appleton es un triste ejemplo de las espantosas condiciones laborales a las que fueron sometidos miles de niños en el siglo XIX. Martha era una niña de 13 años que trabajaba en el sector textil en Wigan como "basurera", recogiendo trozos de algodón sueltos debajo de las máquinas. Durante su jornada laboral, Martha se desmayó y su mano izquierda se atascó en una máquina en funcionamiento sin protección contra accidentes. Como consecuencia, Martha se vio afectada por lesiones irreversibles. Sus dedos resultaron gravemente heridos y, como ya no podía trabajar de manera eficiente, Martha también perdió su trabajo. ${ }^{14}$

En la primera mitad del siglo XIX, muchos militantes contra el trabajo infantil surgieron de clases sociales privilegiadas. Estos militantes actuaron influyendo en personas y grupos de personas, haciéndoles conscientes del 
daño que causa, en la infancia y la sociedad, la explotación del trabajo infantil. También abogaron por la abolición del trabajo infantil ante la prensa y el parlamento, contribuyendo así de manera decisiva a la aprobación de la primera legislación que regula el uso del trabajo infantil en la producción industrial. ${ }^{15}$

La aprobación de la Ley de Fábricas en 1833 hizo ilegal que las fábricas textiles emplearan a niños menores de 9 años. Además, la ley ordenaba a las fábricas textiles que ofrecieran al menos dos horas diarias de educación a los niños de entre 9 y 13 años. En cuanto a la jornada laboral, la Ley de Fábricas establece que los niños de 9 a 13 años no deben trabajar más de nueve horas diarias, mientras que los niños de 13 a 18 años no deben trabajar más de doce horas diarias. Se prohibió el empleo de niños para el trabajo nocturno. La Ley de Fábricas también es de gran importancia porque creó el puesto de inspector de fábrica, fortaleciendo la aplicación de las reglas. Sin embargo, no siempre se observaron las normas de protección. En primer lugar, porque muy a menudo los inspectores no podían especificar la edad exacta de los niños trabajadores. En segundo lugar, los propietarios de fábricas comúnmente no ofrecían las horas semanales de educación que eran obligatorias. ${ }^{16}$

Cabe mencionar que la Ley de Fábricas de 1833 surgió en un momento en que los reformadores dieron a conocer las terribles condiciones laborales a las que estaban expuestos los niños, condiciones que podrían compararse con la esclavitud. De hecho, la Ley se aprobó al mismo tiempo que se abolió la esclavitud en el Imperio Británico, lo que sucedió en 1833-1834. ${ }^{17}$

El trabajo en las minas y bajo tierra también fue objeto de duras críticas. Las degradantes condiciones laborales a las que fueron sometidas las mujeres y los niños en este campo salieron a la luz con la publicación de un informe de una Comisión Real en 1842. El informe, ilustrado con imágenes de niños y mujeres en su trabajo, describía un terrible escenario en el que niños menores de 8 años fueron empleados y trabajaron en condiciones degradantes y peligrosas. ${ }^{18}$ La situación presentada fue tan impactante que, en el mismo año, el Parlamento aprobó rápidamente el Proyecto de Ley de Minas y Minas de carbón (Ley de Minas). La Ley de Minas prohíbe el empleo de mujeres y niñas de todas las edades en cualquier actividad clandestina y de niños menores de 10 años. La Ley de Regulación de Minas de Carbón elevó la edad mínima para los niños, de 10 a 12 años, y también mejoró las reglas de seguridad en el ambiente laboral. 
En 1870, la Ley de Educación introdujo cambios profundos en la educación de los niños, ya que sentó las primeras bases para la creación de la educación gratuita y obligatoria. Como consecuencia, los niños del Reino Unido fueron introducidos gradualmente a la escuela y, por lo tanto, se retiraron de la situación del trabajo infantil. Además, los niños comenzaron a ser tratados ya no como "pequeños adultos", sino que ahora eran vistos como niños que merecían un trato especial de acuerdo con su estado y necesidades. ${ }^{19}$

Sin embargo, la existencia de legislación escrita no fue suficiente para cambiar la realidad y el pensamiento social. Los resultados prácticos derivados de estas legislaciones se mantuvieron por debajo de las expectativas. A principios del siglo XX, los ciudadanos británicos se sorprendieron por el abuso y la explotación de los niños en el trabajo que seguía siendo una realidad. Quedó claro que las medidas legislativas por sí solas no serían suficientes para cambiar la realidad social. ${ }^{20}$ Por ejemplo, los niños todavía eran empleados como "niños trepadores" (actividad que también incluía a las niñas) y realizaban tareas peligrosas como limpiar chimeneas o extinguir fuego en su interior. Las condiciones de trabajo también seguían siendo terribles: los empleadores a menudo maltrataban a los niños; sin condiciones de seguridad, los niños suelen sufrir accidentes laborales con las consiguientes lesiones o la muerte; los salarios siguieron siendo extremadamente bajos.

A pesar de la existencia de una legislación protectora durante medio siglo, los niños siguieron trabajando en las minas, fábricas y textiles, en las mismas condiciones degradantes. Quedó claro que una amplia movilización social era clave para fortalecer las leyes existentes, así como para el establecimiento de un estándar más protector. Por lo tanto, se establecieron varias organizaciones que lucharon contra el trabajo infantil en todo el Reino Unido, cuyos miembros pertenecían a varios sectores y clases sociales. ${ }^{21}$

En 1889 se fundó la Sociedad Nacional para la Prevención de la Crueldad contra los Niños (NSPCC). La NSPCC desempeñó un papel destacado en la historia de la lucha contra el trabajo infantil en Reino Unido al fortalecer el sistema legal de protección infantil y contribuir al fin de las peores formas de trabajo infantil. Inicialmente, la NSPCC tenía como objetivo principal la abolición del abuso del trabajo infantil, especialmente en condiciones peligrosas. La organización benéfica lideró la lucha contra la explotación infantil en Reino Unido proporcionando información pública sobre problemas de abuso infantil, defendiendo reglas de protección más estrictas, monitoreando el 
cumplimiento de las leyes por parte de la sociedad y el gobierno, y brindando directamente protección y refugio a los niños abandonados y desamparados. ${ }^{22}$ Hoy en día, la NSPCC es "la única organización benéfica para niños del Reino Unido con poderes legales que le permiten tomar medidas para proteger a los niños en riesgo de abuso". ${ }^{23}$ Con el objetivo de hacer que 5 millones de niños estén más seguros para 2021, la NSPCC ha establecido cinco objetivos, que son: prevenir el abuso infantil en familias que enfrentan adversidades; prevenir el abuso sexual infantil; ayudar a los niños a hablar y a los adultos a actuar sobre el abuso; ayudar a los niños que han sufrido abusos a volver a la normalidad; y proteger a los niños del abuso en línea. ${ }^{24}$

En Reino Unido se siguieron produciendo varios avances legislativos en materia de protección infantil, no solo a nivel nacional sino también a nivel internacional. El Reino Unido ha firmado numerosos tratados internacionales sobre los derechos del niño, i.e. es decir, la Convención de las Naciones Unidas sobre los Derechos del Niño, la Declaración de los Derechos del Niño de las Naciones Unidas, así como algunas convenciones europeas. ${ }^{25}$ Con respecto a las normas internacionales que prohíben el trabajo infantil, el Reino Unido ha firmado las Convenciones 138 (Convención sobre la Edad Mínima) y 182 (Convención sobre las Peores Formas de Trabajo Infantil) de la Organización Internacional del Trabajo - OIT. ${ }^{26}$

Es posible notar que la historia de la lucha contra el trabajo infantil, irónicamente, está escrita y contada bajo los lentes de un hombre adulto. Mientras que los niños son vistos como meras víctimas de la Revolución Industrial, el hombre adulto es retratado como el personaje principal. Los historiadores y académicos identifican muy a menudo la historia de la lucha contra el trabajo infantil con la historia del desarrollo de las instituciones sociales y los actos legislativos como respuesta al problema de la explotación del trabajo infantil. Por lo tanto, mientras que los niños son representados como "objetos históricos para los que los adultos idean estrategias adecuadas"27, el personaje principal es el hombre adulto, el que exploró el trabajo infantil; el que, después, liberó a los niños; y el que hoy protege a los niños. 


\section{TRABAJO INFANTIL EN LA ACTUALIDAD Y DATOS ES- TADÍSTICOS - ¿QUÉ SIGNIFICA SER NIÑO?}

Con el conocimiento de la extensa legislación nacional e internacional, así como el trabajo de las organizaciones benéficas que luchan contra el trabajo infantil en Reino Unido, ahora discutiremos la efectividad de esta red de seguridad. En otras palabras, esta tercera sección tiene la intención de analizar datos y estadísticas en todo el Reino Unido para considerar el estado actual del trabajo infantil.

En investigaciones realizadas a través de fuentes de prensa y sitios web oficiales británicos y europeos, algunos temas específicos han llamado nuestra atención. En primer lugar, los datos estadísticos sobre trabajo infantil en Reino Unido (y otros países europeos) son bastante escasos y difíciles de encontrar.

En segundo lugar, las estadísticas sobre la esclavitud moderna y la trata de personas de niños migrantes son alarmantes. Los datos muestran un aumento del 63\% en las denuncias por explotación del trabajo infantil en Reino Unido en 2016. Según un artículo publicado en 2017 por el periódico Independent, este aumento comprende principalmente a niños migrantes y está directamente relacionado con las débiles medidas de protección actualmente adoptadas. por el gobierno británico. Las víctimas potenciales eran principalmente de Vietnam, Albania y Polonia. El artículo también establece que, a pesar de la existencia del Mecanismo Nacional de Remisión (NRM), un marco para identificar a las víctimas de la trata de personas y la esclavitud moderna, y para prevenir la reincidencia de la víctima, después de ser identificadas, muchas víctimas son abandonadas y no reciben cualquier tipo de apoyo, lo que hace que terminen volviendo a una situación de esclavitud. ${ }^{28}$

En tercer lugar, la investigación ha demostrado que el trabajo infantil no es un problema que se haya resuelto en el pasado. Debido a la crisis económica de 2008, el trabajo infantil en condiciones irregulares se ha convertido una vez más en un problema entre muchos países europeos. En 2013, el Alto Comisionado de las Naciones Unidas para los Derechos Humanos informó que, en Reino Unido, los niños trabajaban de manera irregular durante muchas horas. Además, en 2015, en un seminario celebrado en Liverpool, muchos niños en edad escolar secundaria denunciaron prácticas irregulares en el trabajo, como sueldo inferior al mínimo, falta de condiciones de seguridad, 
trabajo informal, discriminación de género y el evidente daño a su educación escolar. Esto sucedió entre familias en situación de pobreza que, ante la crisis y el desempleo, no tuvieron más remedio que enviar a sus hijos a trabajar como forma de complementar los ingresos familiares. ${ }^{29}$

A la vista de los datos anteriores, nos preguntamos: ¿es el trabajo infantil y los problemas institucionales que lo rodean una cosa del pasado? ¿O estos problemas todavía nos persiguen? En la sociedad moderna, ¿se considera realmente a los niños como sujetos de derechos o simplemente como objetos de protección?

Nuestra tesis aquí es: si bien, a lo largo de la historia, algunos niños (como los de familias económicamente favorecidas) se han convertido en objeto de preocupación y protección, por otro lado, una parte considerable de los niños (como los niños migrantes y los niños de familias pobres) permanece en el estatus quo ante, es decir, permanecen invisibles, abstractas y, como tales, una abstracción realizada u objetivada como potenciales trabajadores precarios. Es decir, los niños permanecen invisibles como tales y solo pueden volverse visibles como consumidores potenciales (si nacen en familias económicamente favorecidas) o como trabajadores precarios potenciales (si no). Nuestro argumento aquí es que la ley escrita no ha cambiado el estatus de objeto que tienen todos los niños (ricos, pobres, migrantes, ciudadanos, niñas y niños). Aún hoy en día, los niños no tienen su propia historia, sino solo un camino histórico en el que los hombres adultos han dado pasos para "mejorar" la situación de los niños mientras capturan (y aprisionan) su imaginación; el bienestar de los niños, así como su miseria, son objeto de los esfuerzos de los demás. ${ }^{30}$

\section{CONCLUSIÓN}

Hablamos a este respecto de "la imaginación de los adultos o la imaginación de los niños". Tomamos prestado este término de uno de nuestros maestros, el antropólogo Michael Taussig quien, a su vez, ha sido enseñado por sus interlocutores amerindios en el Pacífico y la Amazonía, entre Brasil, Venezuela y Colombia, durante sus muchos años de "trabajo de campo" y notas de campo/diario. Como él dice, "hablar de la imaginación del adulto o de la imaginación del niño es inevitablemente entrar en la estética no menos que en la naturaleza política del secreto". En última instancia, este es el tipo 
de problema ético y político que conecta las leyes de derechos humanos y de los niños no solo con lo estético sino también, de manera crucial, con el goce del que el capitalismo se beneficia y prolifera.

Para ser precisos, este es un tipo de goce sociohistórico específico. No estamos hablando de trauma individual, sino del fenómeno que el surrealista negro Pierre Yoyotte llamó "la miseria del deseo". Se ejemplifica en lo que sucede cuando los adultos hablan de cosas "serias" o majestuosas, incluidos los niños, en el oído del niño, como si el niño no pudiera oír "o cuando cambian entre dirigirse al niño sentado frente a ellos un minuto como objeto y en otro minuto siguiente como sujeto". ${ }^{31}$

Se trata de una "epistemología absurda", el niño puesto en la posición de estar y no estar ahí. O bien, cuando toda una población es considerada afeminada e infantilizada o denigrada por "los adultos en la sala", es decir, los políticos señoriales y sus ricos propietarios, que les imponen todo tipo de prohibiciones (más o menos legales y morales) mientras están al mismo tiempo burlándose de ellos con dinero. El ejemplo principal aquí es la intersección entre las prohibiciones moralizantes cristianas evangélicas/calvinistas (a menudo dirigidas contra el deseo, la fantasía y el "materialismo"), el "carácter sagrado" de la ley y el orden y la colonización de la totalidad del espacio social por el dinero.

Las prohibiciones evangélicas/Ccalvinistas tratan a la población como si un niño, en el oído del niño, que no puede ver ni oír, se pone en la posición de estar y no estar allí. Si la gente se da cuenta de su potencial como consumidores, está bien. Pero si se rebelan contra sus "padres fundadores", como deben hacer todos los niños en su camino hacia la madurez, entonces eso está prohibido. ¿El resultado? Tan pronto como los más pobres ganan algo de poder adquisitivo - como lo hicieron en Brasil durante las administraciones del Partido de los Trabajadores del siglo XXI - se les pide que admiren a los más ricos entre las personas que pueden usar su dinero para eludir la prohibiciones moral-legales impuestas a la mayoría. Y la gente responde a esa interpelación. Por un lado, les gustaría obtener el tipo de satisfacción que parecen tener las clases más adineradas (lo que les permite eludir todas las prohibiciones legales y morales) y así identificarse con ellos, con "el padre". Por otro lado, están cargados de culpa moral, reforzados contra el deseo por la estricta moral conservadora del evangelismo/calvinismo y burlados por el dinero. Se unen a las llamadas clases medias que están absolutamente maduras para una 
contrarrevolución de las emociones y los ideales. La única salida para este pueblo infantilizado es la satisfacción, pero como ninguna satisfacción material vendrá después de que gane la contrarrevolución, deben conformarse con las emocionales o místicas. "Son victorias infantiles", advierte Yoyotte. ${ }^{32}$

¿Por qué? Porque, sí, pueden tener apariencia de paraíso. Pero el paraíso es, por supuesto, un lugar para los muertos en el que adquieren una intensidad hiperbólica. "Paraíso" es la zona gris de la policía, en la que violencia también significa autoridad (patriarcal). Como dicen antropólogos como Taussig a propósito de Venezuela, Colombia o Brasil, esta zona gris es donde emerge el espectro en medio de la ley, que, al ser administrada por la policía, de hecho, deja de existir, "pero es este pantano el que sostiene el majestuoso" o formas graves. Ante nosotros, ahora, un joven negro, un niño, esposado, apretado contra el pavimento en Brixton o Harlem, con una rodilla en el cuello; o contra el muro a punto de ser baleado por la policía o la milicia paramilitar en el sur de Bogotá o en la favela Maré, Río de Janeiro. Esto es lo sagrado en la vida cotidiana: dejar morir (en una pandemia, por ejemplo, en la guerra, etc.) o "mejorar", corregir y convertir en seriedad - o lo señorial - la falta de seriedad y la capacidad de fantasía de los niños. La ley y el lawfare en manos del padre arma la fantasía de los niños, la convierten en secreto o "secreto público" como dice Taussig. La policía (y la figura del "padre") le dicen al niño esposado: "Todo lo que hagas, paso a paso, tienes que pedirme permiso". ${ }^{33}$

No será suficiente categorizar esto como estúpido (aunque la estupidez es palpable), o malvado (aunque es monstruosamente malvado) o como irracional. Al igual que Taussig, encontramos aquí una resonancia entre la larga historia de lucha contra el trabajo infantil y ser tratados como niños, por un lado, y el continuo devenir de la imaginación adulta del niño, por el otro. Lo que está más en juego aquí es el funcionamiento de las reglas por las que se rigen las relaciones sociales, incluidas las reglas para relacionarse con los niños y, por supuesto, con los niños dentro y fuera del trabajo. Si hay tales leyes, su ser es esa informalidad vinculante o burla y fantasía con formalidad, seriedad y majestuosidad. En otras palabras, esto quiere decir que la raíz del colonialismo aquí y en extranjero o de la llamada Revolución Industrial, en Gran Bretaña como en otros lugares, no hay relación (y, por lo tanto, no hay relación de reconocimiento) entre adultos y niños. Lo único posible en tal situación, que es nuestra situación, es la no relación en la que los niños son 
"sagrados" o "desechables". Como mujeres, multitudes o "personas" para el caso.

¿Qué sigue en la historia de la lucha contra el trabajo infantil y la infantilización? Tenemos dos futuros por delante: el primero es que el niño, en su inmadurez ética, ve y habla directamente (revelando a la gente que el emperador no usa ropa) porque es inocente, sagrado (y, por la misma razón, desechable). "Escucha al inocente", dice el padre cuando la policía del padre está a punto de estrangularlo o dispararle. En segundo lugar, otra forma de ver el acto del niño es considerarlo cualquier cosa menos inocente. Más bien, como un jugador sofisticado, que se aprovecha del posicionamiento adulto del niño como inocente, sagrado o desechable, para desenredar o darle un giro más al secreto público de que los emperadores no visten ropa. En su papel actual como consumidores potenciales o futuros trabajadores precarios, nos recuerdan que en nuestras sociedades depredadoras el sacrificio sagrado de un número cada vez mayor de niños, jóvenes y personas no es un regalo de la carne, sino más bien, la toma del regalo de vida. Esta sería la verdad (de nuestra condición) que los niños implican: todo trabajo y nada de juego.

En la imaginación adulta del niño, éste encarna la pasión por el acertijo y el secreto, y el juego o jugueteo con acertijos y secretos como alternativa al sacrificio para escapar y salir de la economía del goce, de la sed de la carencia. el in-goce, o la miseria del deseo que es propia del discurso y la condición capitalista, así como la que caracterizó a los países llamados "socialistas reales”. Salir significa aquí “dejar ir” y "dejar ser”: dejar ir a los niños y dejarlos ser. Un sentido diferente de la educación (gratuita, universal, no patriarcal) en el que lo infinito en el otro puede empezar a morar en la aparente finitud de la "pasividad absoluta" de los niños. Si y cuando los niños están "autorizados" por medios más o menos legales para no ir a la escuela (como sucedió en Gran Bretaña durante la pandemia de 2020), se les permitirá, al menos parcialmente, sustraerse a la ley. En esta nueva y diferente situación, los padres se han descubierto dando a sus hijos el regalo de su amor, que es el regalo del tiempo, que por supuesto es el regalo de la vida. Dar, es decir, lo que no tienen a su disposición.

Esto puede parecer demasiado poco, una conclusión humilde. Dar a los niños un pequeño margen de maniobra con la capacidad de no tomar la norma por ley. Pero esto también puede resultar crucial. Pues este acto separa la inscripción o morada del otro en mí del tipo de consentimiento contractual 
que define en la actualidad tanto la ley como su más allá. Del otro lado no se encuentran ni el desorden, ni el caos puro y simple, ni su aparente opuesto, la "law (fare)" y el (decisiva, posfascista) orden. Más simplemente, este es un énfasis en dos requisitos: primero, no hay ley sin interpretación. No solo en el sentido de fijación o indeterminación de su significado, sino también, o, mejor dicho, en el sentido de sentido como orientación: lo que es y lo que no es la ley, y el sacrificio no es la ley. En segundo lugar, más allá de la ley, existe un espacio-tiempo para una experiencia vivida que no cae dentro de la jurisdicción de ninguna ley actual. Aquí restamos plenitud, lo que es la justicia, pero todavía no, de lo que se considera justo en los órdenes jurídico-normativos de hoy. En este nivel, como muchos han señalado antes que nosotros, el viejo debate entre nomos y nomina no tiene ningún objeto. Esto nos devuelve al tema del tipo de "experiencia oceánica" que caracteriza el juego y la imaginación de los niños (en la imaginación de los adultos). Tal es la experiencia de la posibilidad, desenfrenada, utópica en el sentido del mar de posibilidades que envuelve el desierto de lo real aquí y ahora, o eutópico y eunomiano. No es necesario nombrar a un padre aquí, ni los orígenes de la legislación, incluidas las leyes que combaten el trabajo infantil. Después de todo, no hay orígenes, solo fragmentos. Y lo que importa es cómo jugamos con esos fragmentos, o qué hacemos después de darnos cuenta de que es la imperfección la que funda la vida o la multiplica. Aquí, los niños toman la iniciativa. Que nuestras hijas e hijos sigan rebelándose.

\section{NOTAS}

1 Documento escrito originalmente en inglés, utilizando el sistema de referencia de Harvard, completamente conservado en las traducciones. Traducción realizada por Antonio Dari Antunes Zhbanova de la Agencia H3 Traduções.

2 Etienne Balibar, Citizen Subject. Foundations for Philosophical Anthropology (New York: Fordham University Press, 2017) 275-276, para todas las paráfrasis y citas en este párrafo y en el anterior.

3 Alain Supiot, "El sueño de la armonía mediante el cálculo" in Le Monde Diplomatique en Español, Feb. 2015, 3. Ver también, G. W. F. Hegel, The Scientific Ways of Treating Natural Law, Its Place in Moral Philosophy, and its Relation to the Positive Science of Law, trad. por T. Knox (Philadelphia, 1975) 104, vía Rousseau, Montesquieu and Christian Garve.

4 Silvia Federici, Caliban y la Bruja (Madrid: Traficante de Sueños, 2004/7) 27.

5 Laidlaw v. Organ, 15 US (2 Wheat.) 178, 193 (1817).

6 E. P. Thompson, William Morris: Romantic to Revolutionary (London: Merlin Press, 1977) 8-9.

7 Emma Griffin, Trabajo infantil, en la Biblioteca Británica, Discovering Literature: Romantics \& Victorians, artículo publicado en el sitio web de la Biblioteca Británica 
el 15 de mayo de 2014, disponible en https://www.bl.uk/romantics-and-victorians/ articles/child-labour\#footnote1. Ella cita a Roger Landon, The Life of Roger Landon, Told By Himself (London: Elliot Stock, 1909) 31-33, Y George Edwards, From Crow-Scaring to Westminster: Una autobiografía con un prefacio del Reverendísimo Lord Ailwyn de Honingham, con una introducción de W. R. Smith (Londres: Labor Publishing, 1922) 19-19.

8 A. Bequele, and W. Myers, First things first in child labour: Eliminating work detrimental to children (Ginebra, Oficina Internacional del Trabajo, 1995) 52.

9 Nuno Ferreira, 'Working Children om England and Wales: Waking up From Inertia' (2017) 28(3) King's Law Journal, 381.

10 Ibidem.

11 Parlamento del Reino Unido, 'Children and chimneys'. Disponible en: https://www.parliament.uk/about/living-heritage/transformingsociety/ livinglearning/19thcentury/overview/childrenchimneys/. Acceso en: 02 junio 2020.

12 Los Archivos Nacionales, 'Child Labour'. Disponible en: http://www.nationalarchives. gov.uk/pathways/citizenship/struggle_democracy/childlabour.htm. Acceso en: 15 mayo 2020.

13 Ibidem.

14 Ibidem.

15 A. Bequele, y W. Myers, First things first in child labour: Eliminating work detrimental to children (Ginebra, Oficina Internacional del Trabajo, 1995) 52.

16 Los Archivos Nacionales, 'Child Labour'. Disponible en: http://www.nationalarchives. gov.uk/pathways/citizenship/struggle_democracy/childlabour.htm. Acceso en: 15 mayo 2020.

17 Ibidem.

18 Parlamento del Reino Unido, 'Living Heritage: Reforming Society in the 19th Century - Coal Mines'. Disponible en: https://www.parliament.uk/about/living-heritage/ transformingsociety/livinglearning/19thcentury/overview/coalmines/. Acceso en: 23 junio 2020.

19 Los Archivos Nacionales, 'Child Labour'. Disponible en: http://www.nationalarchives. gov.uk/pathways/citizenship/struggle_democracy/childlabour.htm. Acceso en: 15 mayo 2020.

20 A. Bequele, y W. Myers, First things first in child labour: Eliminating work detrimental to children (Ginebra, Oficina Internacional del Trabajo, 1995)52.

21 A. Bequele, y W. Myers, First things first in child labour: Eliminating work detrimental to children (Ginebra, Oficina Internacional del Trabajo, 1995) 52-53.

22 Ibidem, 53.

23 Comisión Europea, NSPCC - National Society for the Prevention of Cruelty to Children'. Disponible en: https://ec.europa.eu/justice/grants/results/daphne-toolkit/ content/nspcc-national-society-prevention-cruelty-children_en. Acceso en: 23 junio 2020 .

24 Sociedad Nacional para la Prevención de la Crueldad contra los Niños, 'Our Strategy'. Disponible en: https://www.nspcc.org.uk/about-us/performance-plans-strategy/. Acceso en: 23 junio 2020.

25 Por ejemplo, la Convención Europea sobre la adopción de niños, la Convención Europea sobre la Condición Jurídica de los niños nacidos fuera del Matrimonio, la Convención Europea sobre el Reconocimiento y la Ejecución de decisiones relativas a la custodia de niños, entre otros.

26 Organización Internacional del Trabajo, 'Ratifications for United Kingdom of Great Britain and Northern Ireland'. Disponible en https://www.ilo.org/dyn/normlex/en/ 
f?p=1000:11200:0::NO:11200:P11200_COUNTRY_ID:102651. Acceso en: 18 Mayo 2020.

27 Robert McIntosh, Boys in the Pits: Child Labour in Coal Mines (McGill-Queen's University, 2000) 10 .

28 Independent, 'Child Labour Exploitation Referrals Surge 63\%, Figures Show' (2016). Disponible en: https://www.independent.co.uk/news/uk/home-news/child-labourexploitations-referrals-rise-figures-latest-a7752116.html. Acceso en: 23 junio 2020.

29 Nils Muižnieks y Alto Comisionado de las Naciones Unidas para los Derechos Humanos, 'Child Labour in Europe: A Persisting Challenge' (2013). Disponible en: https://www.coe.int/en/web/commissioner/-/child-labour-in-europe-a-persistingchallen-1. Acceso en: 23 junio 2020.

30 Robert McIntosh, Boys in the Pits: Child Labour in Coal Mines (McGill-Queen's University, 2000) 10 .

31 Michael Taussig, "The Adult's Imagination of the Child's Imagination", in Aesthetic Subjects, ed. by P. R. Matthews \& D. McWhirter (Minneapolis: University of Minnesota Press, 2003) 454.

32 Pierre Yoyotte, "Antifascist Significance of Surrealism", in Black, Beige \& Brown. Surrealist Writings from Africa and the Diaspora, ed. by F. Rosemont \& R. D. G. Kelley (Austin: University of Texas Press, 2009) 42-3.

33 Michael Taussing, "The Adult's Imagination of the Child's Imagination", 455.

\section{REFERENCIAS}

Bequele, y W. Myers, First things first in child labour: Eliminating work detrimental to children (Ginebra, Oficina Internacional del Trabajo, 1995)

Comisión Europea, 'NSPCC - National Society for the Prevention of Cruelty to Children'. Disponible en: https://ec.europa.eu/justice/grants/results / daphne-toolkit/content/nspcc-national-society-prevention-cruelty-children_en. Consultado el 23 de junio de 2020

Federici S, Caliban y la Bruja (Madrid: Traficante de Sueños, 2004/7)

Ferreira N, 'Working Children on England and Wales: Waking up From Inertia’ (2017) 28(3) King's Law Journal, 381

Griffin E, y Biblioteca Británica, 'Child Labour'. Disponible en: https:// www.bl.uk/romantics-and-victorians/articles/child-labour. Published on 15 May 2014. Consultado el 18 de mayo de 2020.

Humphries J, 'Childhood and child labour in the British industrial revolution' (2013) 66(2) Economic History Review, 395

Independent, 'Child Labour Exploitation Referrals Surge 63\%, Figures Show' (2016). Disponible en: https://www.independent.co.uk/news/uk/ 
home-news/child-labour-exploitations-referrals-rise-figures-latest-a 7752116. html. Consultado el 23 de junio de 2020.

Organización Internacional del Trabajo, 'Ratifications for United Kingdom of Great Britain and Northern Ireland'. Disponible en: https://www.ilo. org/dyn/normlex/en/f?p=1000:11200:0::NO:11200:P11200_COUNTRY_ ID:102651. Accessed on 18 May 2020

International Labour Organisation, 'ILO says global number of child labourers down by a third since 2000' (23 September 2013). Disponible en: https://www.ilo.org/global/about-the-ilo/newsroom/news/WCMS_221568/ lang--en/index.htm. Consultado el 03 de junio de 2020.

McIntosh R, Boys in the Pits: Child Labour in Coal Mines (McGill-Queen's University, 2000)

Muižnieks N, y Alto Comisionado de las Naciones Unidas para los Derechos Humanos, 'Child Labour in Europe: A Persisting Challenge' (2013). Disponible en: https://www.coe.int/en/web/commissioner/-/child-labour-in-europe-a-persisting-challen-1. Consultado el 23 de junio de 2020

Sociedad Nacional para la Prevención de la Crueldad contra los Niños, 'Our Strategy'. Disponible en: https://www.nspcc.org.uk/about-us/performance-plans-strategy/. Consultado el 23 de junio de 2020

Parlamento del Reino Unido, 'Children and chimneys'. Disponible en: https://www.parliament.uk/about/living-heritage/transformingsociety/livinglearning/19thcentury/overview/childrenchimneys/. Consultado el 02 de junio de 2020.

Parlamento del Reino Unido, 'Living Heritage: Reforming Society in the 19th Century - Coal Mines'. Disponible en: https://www.parliament.uk/about/ living-heritage/transformingsociety/livinglearning/19thcentury/overview/ coalmines/. Consultado el 23 de junio de 2020

Supiot A, "El sueño de la armonía mediante el cálculo" in Le Monde Diplomatique en Español, Feb. 2015

Taussig M, "The Adult's Imagination of the Child's Imagination", in Aesthetic Subjects, ed. by P. R. Matthews \& D. McWhirter (Minneapolis: University of Minnesota Press, 2003) 
The Guardian, 'Banksy Slave Labour mural row re-erupts over new sale in London'. Disponible en: https://www.theguardian.com/artanddesign/2013/ may/11/banksy-slave-labour-mural-row-sale. Consultado el 30 de junio de 2020

Los Archivos Nacionales, '1833 Factory Act: Did it solve the problems of children in factories?'. Disponible en: https://www.nationalarchives.gov.uk/ education/resources/1833-factory-act/. Consultado el 02 de junio de 2020.

Los Archivos Nacionales, 'Child Labour'. Disponible en: http://www.nationalarchives.gov.uk/pathways/citizenship/struggle_democracy/childlabour. htm. Consultado el 15 de mayo de 2020

Yoyotte P, "Antifascist Significance of Surrealism”, en Black, Beige \& Brown. Surrealist Writings from Africa and the Diaspora, ed. por F. Rosemont \& R. D. G. Kelley (Austin: University of Texas Press, 2009) 


\title{
EL MINISTERIO PÚBLICO DEL TRABAJO EN LA LUCHA CONTRA EL TRABAJO INFANTIL - PROYECTO RESCATE LA INFANCIA
}

\author{
PATRICIA DE MELLO SANFELICI
}

FLEISCHMANN

DOI: $10.51366 / 978-65-89468-10-3$-coordinfancia-24

Resumen. El presente artículo pretende presentar el instrumento utilizado por el Ministerio Público del Trabajo para colaborar con la erradicación del trabajo infantil, especialmente a partir de la experiencia práctica de la autora como Coordinadora Nacional de la Coordinfância ${ }^{1}$. Para ello, aborda el Proyecto Rescate la Infancia en sus tres ejes: profesionalización, políticas públicas y educación, presentando algunos resultados ya obtenidos, especialmente en el trienio 2017/2019. Concluye con un rápido análisis acerca de la efectividad de este instrumento para la finalidad del parquet laboral, cual sea, la protección integral, absoluta y prioritaria del niño y del adolescente, conforme el artículo 227 de la Constitución Federal.

Palabras clave: Ministerio Público del Trabajo. Coordinfância. Proyecto Rescate de la Infancia. Trabajo Infantil. Políticas Públicas.

\section{EL MINISTERIO PÚBLICO DE TRABAJO (MPT)}

El MPT está definido en los artículos 127, 128 y 129 de la Constitución Federal (BRASIL, 1988) como una 'institución permanente, esencial para la función jurisdiccional del Estado, que le encarga la defensa del orden jurídico, del régimen democrático y de los intereses sociales e individuales no disponibles", en relación con las relaciones de trabajo, siendo una de las ramas del Ministerio Público de la Unión. Está dirigido a la defensa de la legislación vigente en lo que respecta a las relaciones de trabajo, actuando, por lo 
tanto, al servicio de la sociedad y del interés público, con existencia autónoma de los Poderes del Estado.

Para realizar mejor sus funciones, el MPT estableció metas prioritarias, así como creó coordinaciones temáticas estratégicas para el tratamiento isonómico, articulado y coordinado de las cuestiones más caras a la institución, que son las siguientes:

- erradicación del trabajo esclavo (CONAETE - Coordinación Nacional de Erradicación del Trabajo Esclavo);

- defensa de la salud del trabajador y del medio ambiente del trabajo sano (CODEMAT - Coordinación Nacional de Defensa del Medioambiente Laboral);

- lucha contra el fraude en las relaciones laborales (CONAFRET - Coordinación Nacional de Combate a los Fraudes de las Relaciones Laborales);

- lucha contra las irregularidades en la administración pública (CONAP - Coordinación Nacional de Promoción de la Regularidad del Trabajo en la Administración Pública);

- defensa de la libertad sindical (Conalis - Coordinación Nacional de Promoción de la Libertad Sindical);

- regularidad del trabajo en los puertos (Conatpa - Coordinación Nacional del Trabajo Portuario y Acuaviario);

- lucha contra la discriminación en las relaciones laborales (Coordinación Nacional de Promoción de la Igualdad de Oportunidades);

- erradicación del trabajo infantil y protección del trabajador adolescente (Coordinfância - Coordinación Nacional de Combate contra la Explotación del Trabajo de Niñas, Niños y Adolescentes).

La observación de las metas institucionales demuestra que el MPT se destina, esencialmente, a la garantía del trabajo decente, concepto acuñado por la Organización Internacional del Trabajo (OIT) en 1999, y que se logra cuando el trabajo, tanto de hombres como de mujeres, además de ser productivo y de calidad, ocurre en condiciones de libertad, equidad, seguridad 
y dignidad. El trabajo decente es condición básica para la superación de la pobreza, la reducción de las desigualdades sociales, la garantía de la gobernabilidad democrática y el desarrollo sostenible, y que se apoya en cuatro pilares estratégicos: de los derechos y principios fundamentales en el trabajo, la promoción del empleo de calidad y la extensión de la protección social y del diálogo social (OIT, [201-]).

En tal contexto, el MPT se presenta como institución de gran relevancia social, actuando directamente en la garantía de derechos relacionados al mundo del trabajo, valorando, así, para que las relaciones laborales se establezcan con respeto a la dignidad de la persona del trabajador. Este trabajo se realiza con la importante participación de la sociedad, a quien corresponde, precipitadamente, informar al MPT las irregularidades que puedan estar ocurriendo y violando, por consecuencia, los derechos establecidos en la legislación brasileña. Esa noticia, una vez llevada al conocimiento del órgano ministerial, podrá determinar la instauración de procedimiento de investigación, por el cual se buscará la confirmación o no del hecho informado y, una vez confirmado el hecho, la persecución del cese de la conducta, por vía administrativa o judicial.

Además de esta acción investigativa, de suma relevancia cuando noticiadas irregularidades que afrontan la legislación y los derechos laborales, tiene el MPT un importante papel proactivo con miras al alcance de sus metas prioritarias. Esa actuación se da, generalmente, por medio de procedimientos promocionales que objetivan, entre otras acciones, aproximar el MPT de otras instituciones y de la sociedad, fomentar audiencias públicas, implantar proyectos estratégicos y establecer canales de diálogo que permitan fortalecer la actuación institucional, a fin de alcanzar, con mayor eficacia, las metas arriba mencionadas. Es en este cuadrante de la actuación promocional que surge el proyecto rescata la infancia, a ser analizado a continuación. Antes, sin embargo, importante tejer algunas palabras tanto sobre el concepto de trabajo infantil en Brasil, como sobre la actuación específica del MPT en el combate a esta práctica, ya que es en ese contexto que el referido proyecto encontrará guarida. 


\section{EL TRABAJO INFANTIL EN BRASIL}

La definición del trabajo infantil en la legislación brasileña es bastante objetiva y deriva del Texto Constitucional, que en su artículo 7..$^{\circ}$ inciso XXXIII, garantiza la "prohibición de trabajo nocturno, peligroso o insalubre a menores de dieciocho y de cualquier trabajo a menores de dieciséis años, salvo en la condición de aprendiz, a partir de catorce años" (BRASIL, 1988).

Luego, no hay espacio para interpretación: está probibido el trabajo de niños y adolescentes antes de los 16 años, salvo la especial condición de aprendiz, que se admite solo a partir de los 14 años. A partir de los 16 años, el trabajo está permitido, pero con advertencias: siempre que no ocurra en actividades insalubres, peligrosas y nocturnas.

La legislación infraconstitucional todavía impone la prohibición del trabajo antes de los 18 años en locales que sean perjudiciales a la formación y al desarrollo físico, psíquico, moral y social del adolescente, y en locales que no permitan la asistencia a la escuela conforme especificado en los artículos 403 y 405 del Decreto-Ley n. ${ }^{\circ}$ 5.452/1943 (BRASIL, 1943). También el Estatuto del niño y del Adolescente se vuelve a la protección contra el trabajo infantil, especialmente en sus artículos 60 a 69, los cuales, además de reiterar los sellos sobre-enfatizados, garantizan el derecho a la profesionalización y a la protección en el trabajo para los adolescentes, debiendo ser respetada la condición peculiar de persona en desarrollo que el adolescente ostenta, así como su profesionalización estar relacionada a la capacitación adecuada al mercado de trabajo (BRASIL, 1990).

Como se observa, la legislación es bastante protectora contra el trabajo infantil, lo que deriva del principio que informa el compromiso del Estado brasileño con la infancia: su protección integral, absoluta y prioritaria, conforme el artículo 227 de la Constitución Federal (BRASIL, 1988). Y no podría ser diferente, ya que el trabajo es un ambiente de diversos y complejos riesgos que, a menudo, causan la enfermedad y la muerte de adultos - ¡cuánto más de niños y adolescentes!

Por ser personas en desarrollo, aún en formación, tales individuos no están preparados, sea física, psicológicamente, para enfrentar la dinámica del trabajo, para encontrarse y conseguir tratar adecuadamente con riesgos tan impactantes que pueden ser encontrados incluso en el más simple de los 
ambientes laborales. Así, la protección conferida por nuestra legislación contra el trabajo infantil es fundamental para garantizar el derecho a la vida, a la educación, al ocio, en fin, a todos los derechos que son atribuidos a los niños y a los adolescentes por la legislación vigente. El trabajo infantil roba y mata a la infancia, y debe ser extirpado del territorio nacional también como una forma de protección a toda la sociedad, ya que un país que no tiene la infancia protegida no tendrá condiciones de progresar y evolucionar verdaderamente, con justicia y paz sociales, condiciones necesarias para que la violencia cese de difundir tan absurdamente en nuestro territorio.

\section{EL MINISTERIO PÚBLICO DEL TRABAJO Y LA LUCHA CONTRA EL TRABAJO INFANTIL}

Como ya se ha visto, el MPT tiene, en el combate al trabajo infantil, una de sus metas prioritarias, lo que se suma al compromiso asumido por el Estado brasileño en la Agenda 2030 de la organización de las Naciones Unidas $^{2}$, en el sentido de erradicarlo del territorio nacional hasta el año 2025. Para el enfrentamiento de ese importante problema, el MPT actúa ante toda y cualquier noticia de irregularidad envolviendo el trabajo de niños y adolescentes - recordando que tales prácticas ilegales pueden ser de los más diversos tipos, desde la explotación del trabajo infantil en el propio núcleo familiar (lo que, probablemente, determinará actuación coordinada con el Ministerio Público Estatal) hasta el trabajo en el tráfico de estupefacientes - una de las peores formas de trabajo infantil, según la lista TIP $^{3}$ - pasando, también, por la explotación sexual comercial de niños y adolescentes, trabajo en la agricultura, trabajo en las calles, entre tantas otras hipótesis que, desafortunadamente, son constatadas.

Además de la actividad investigadora, teniendo en vista que el trabajo infantil posee naturaleza compleja, muchas veces no siendo denunciado por fuerza de la tolerancia social que todavía lo envuelve, entendió el parquet laboral en tratar el tema de forma más proactiva, sin la necesidad de noticias de algún hecho específico, y de modo nacionalmente articulado. Para ello, fue creada, en el año 2000, la Coordinación Nacional de Combate contra la Explotación del Trabajo de Niñas, Niños y Adolescentes (Coordinfância), volcada a la promoción, a la supervisión y a la coordinación de acciones contra las variadas formas de explotación del trabajo de niños y adolescentes, buscando el tratamiento uniforme del problema en el ámbito del parquet laboral. 
Aunque desde 2000 importantes acciones vienen siendo implantadas, es en el año de 2016, después de experiencias previas que permitieron analizar las mejores acciones para efectividad de la actuación institucional, que nace el proyecto estratégico objeto de este artículo: El "Rescate la infancia". A él se dedican las próximas líneas, orientadas a la comprensión de las estratégicas que lo orientan.

\section{EL PROYECTO RESCATE LA INFANCIA}

El proyecto Rescate la Infancia nace a partir de la reunión de tres iniciativas que ya venían siendo implantadas por el MPT, cada una orientada a un objetivo específico (los proyectos MPT en la escuela, aprendizaje profesional y Políticas Públicas de Combate al trabajo Infantil). Esta iniciativa se hizo necesaria para consolidar esas estrategias y obtener mejores resultados en el desempeño del mister institucional de combate al trabajo infantil. En ese sentido, es importante destacar algunos fragmentos del propio texto que consolida el nacimiento del proyecto en referencia, a saber:

El análisis de los datos de la investigación Nacional por muestra de domicilio - PNAD/IBGE, en su serie histórica, demuestra que el vector de disminución del trabajo prohibido de niños y adolescentes sufrió reducción expresiva, más lenta en los últimos años, y, aún, la última información de la serie histórica presentó elevación en los números de trabajo de niños y adolescentes entre 5 y 17 años, de 3.1 millones para 3.3 millones, exigiendo mayor efectividad en la actuación del combate al trabajo infantil, especialmente en el campo del trabajo informal, doméstico y cadenas productivas, normalmente invisible. Se observa que el número de trabajadores infantiles prevalece en las actividades urbanas informales, la agricultura familiar y el trabajo doméstico.

En efecto, en estos campos, la actuación de los órganos de fiscalización es limitada, siendo más eficaces acciones preventivas en el campo de políticas públicas, educación y profesionalización.

Uno de los factores que dificultan la reducción del trabajo infantil en Brasil es que la proporción de la población aún no lo concibe como un problema social. Algunos mitos impregnan hasta hoy el imaginario popular, actuando como verdaderas barreras culturales que dificultan la efectividad de los derechos del niño y del adolescente. Por lo tanto, se entiende que invertir en la formación de futuros ciudadanos, comprometidos con una sociedad sin explotación, es una de las mejores estrategias para reducir el trabajo infantil. Se Busca, así, una forma de actuación institucional concentrada, orientada a resultados, proactiva y capaz de dirigir estratégicamente los esfuerzos del MPT, con acciones dirigidas a la deconstrucción de los mitos del trabajo infantil, por medio de discusión de la temática y actuación por proyectos 
estratégicos, orientados a la educación, a la profesionalización y a políticas públicas (MPT, 2016).

Como se observa, el nacimiento del Proyecto Rescate la Infancia está pautado en la necesidad de incrementar aún más el esfuerzo para la erradicación del trabajo infantil, que ya venía en caída, pero todavía acometía un número muy expresivo de niños y adolescentes en Brasil a la época del surgimiento del proyecto - y que aún hoy, desafortunadamente, alcanza por lo menos 2 millones y 400 mil personas con menos de 18 años. El objetivo general del proyecto, aún según la misma fuente suplida, es prevenir y combatir el trabajo infantil, concientizar a la sociedad, fomentar políticas públicas, promover la formación profesional y proteger al trabajador adolescente (MPT, 2016).

Por lo tanto, se percibe que, de la misma manera que el problema en cuestión es complejo, también la solución debe ser polifacética. Por esta razón, el proyecto se basa en tres ejes fundamentales: Profesionalización, Educación y Políticas Públicas. Dichos ejes se enfrentan a los bordes principales que deben recortarse para que exista la posibilidad de erradicar efectivamente el trabajo infantil en el lugar donde se aplica dicha iniciativa. Las estrategias en referencia pretenden, en definitiva, responder a las siguientes preguntas: ¿cómo sensibilizar a la sociedad sobre los profundos daños que el trabajo infantil provoca al niño y al adolescente que son, de esta práctica, víctimas? Además, ¿cuál es la alternativa que puede ser presentada para las personas encontradas en situación de trabajo infantil o para aquellas que pueden ser víctimas de esa ilegalidad?

Al tiempo en que se busca la respuesta a tales preguntas, el Proyecto Rescate la Infancia se presenta como medida fundamental para la mayor protección de la infancia, ya que el trabajo infantil, además de configurar, en sí, una profunda violación, se encuentra en la base de varias otras lesiones a los derechos del niño y del adolescente. Realizar el Rescate de la Infancia es implementar y hacer efectivo el principio de la protección integral, absoluta y prioritaria de la infancia, garantizado en el ya referido artículo 227 de la Constitución Federal (BRASIL, 1988). Pasemos, pues, a analizar cada uno de los ejes fundamentales en referencia. 


\subsection{Eje Profesionalización}

El eje profesionalización tiene su fundamento en el artículo 428 y siguientes de la Consolidación de las Leyes del Trabajo (BRASIL, 1943), que establecen la obligatoriedad de que las empresas contraten como aprendices, de 5 a 15\% del número de empleados. Se trata de una cuota legalmente establecida para inserción de adolescentes y jóvenes en el mundo del trabajo por medio de un contrato particular y específico, que trae consigo todas las garantías del contrato de empleo, pero sin configurar mera explotación de la mano de obra - por el contrario, el foco, en ese especial contrato, es el aprendizaje de un oficio en sus aspectos teóricos y prácticos, aliada necesariamente a la permanencia en la escuela, preparando, así, al adolescente para el ingreso en el mundo del trabajo.

Sin lugar a dudas, el contrato de aprendizaje profesional es una de las más importantes políticas de atención al derecho a la profesionalización que los adolescentes poseen, conforme preconiza el ECA (BRASIL, 1990). Es una forma segura de ingreso en el mercado de trabajo, con respecto a la condición del adolescente de persona en desarrollo, y que, en última instancia, colabora sobremanera para la formación de futura mano de obra calificada, ya que, al final del contrato, el aprendiz estará plenamente apto al ejercicio del oficio para el cual fue formado.

Diversos efectos extremadamente positivos han sido percibidos a partir de la concreción del aprendizaje profesional, especialmente cuando dirigida al público en mayor vulnerabilidad (cual sea, los adolescentes en cumplimiento de medida socioeducativa y en acogimiento institucional, así como los egresados del trabajo infantil). Además de garantizar los derechos del adolescente aprendiz, también la sociedad es profundamente beneficiada, por un lado por la mayor oferta de mano de obra calificada, pero también porque existe una evidente relación entre la profesionalización y la generación de oportunidades con la reducción de vulnerabilidades y también, por consecuencia, con la disminución de los índices de violencia social.

Sin embargo, a pesar de ser un instituto ampliamente beneficioso, y a pesar de que la ley es bastante clara al imponer esta obligación a los empleadores en general - en plena aplicación del principio de Responsabilidad social de la empresa y de la función social de la propiedad - todavía hay mucha resistencia al pleno cumplimiento de ese mandamiento normativo. Un enorme 
porcentaje de las cuotas de aprendizaje debidas por las empresas permanece, anualmente, inactivo, muchas veces siendo presentados argumentos absolutamente refutables o fácilmente transponibles para el incumplimiento de la legislación vigente. Tales hechos hacen que el cumplimiento de las cuotas de aprendizaje sea uno de los principales focos de actuación investigativa del MPT, siendo objeto de muchos procedimientos de investigación en todo Brasil.

Además de la actuación investigativa, considerando la evidente relevancia del instituto del aprendizaje profesional tanto para el público adolescente y joven, como para la sociedad en general, la actuación promocional se muestra necesaria y se realiza por el eje profesionalización, que busca la conciencia y sensibilización de las empresas para la importancia de las cuotas determinadas en ley, destacando la relevancia de ser dada prioridad en la contratación de los adolescentes en situación de mayor vulnerabilidad social - lo que es garantizado por el Decreto n. ${ }^{\circ}$ 9.759/2018 (BRASIL, 2018).

Esta conciencia se da a partir de audiencias públicas o colectivas que involucren a las empresas locales, el sistema S, las entidades formadoras y la red de protección de la infancia. En esas audiencias, además de que el MPT destaca las ventajas del aprendizaje profesional, se busca hacer un vínculo entre las empresas, las entidades formadoras y la red de protección, que muchas veces no poseen mucho contacto, lo que hace que oportunidades no surjan o no sean de conocimiento del público prioritario.

Las experiencias ya realizadas demuestran que, a partir de la acción del MPT, las cuotas abiertas tienden a disminuir, haciendo así que el aprendizaje profesional se vuelva más efectivo. Es ejemplo de esa situación la implantación del Proyecto en el municipio de Luziânia/GO, que ocurrió en junio de 2018. Antes de la actuación del MPT en la ciudad, el municipio contaba con 25 aprendices contratados. Después de 6 meses de la realización de la audiencia pública involucrando a la Procuraduría del Trabajo local, con la participación activa de la Fiscal del Trabajo Geny Helena Fernandes Barroso, que fue la responsable por la convocatoria de las empresas locales con cuotas abiertas y posterior mantenimiento del diálogo con ellas, el número de aprendices contratados subió para 139, lo que representa un aumento de $456 \%$ en el número de contrataciones. 
Tales datos demuestran el acierto de la estrategia de sensibilización, que también promovió la aproximación de todos los actores que necesitan estar involucrados para que ocurra, de hecho, la plena implementación de las cuotas de aprendizaje profesional previstas en ley, con priorización de los adolescentes más vulnerables, que son aquellos que más necesitan esa oportunidad. Esa aproximación se dio con la importante participación, en la audiencia colectiva, no apenas de las empresas convocadas, sino también de las entidades formadoras y del sistema S presentes en la ciudad de Luziânia, así como de los órganos componentes de la red de protección local, que pudieron llevar a los adolescentes más vulnerables las oportunidades existentes.

Aún con relación a la necesidad de priorizar la atención donde la vulnerabilidad es mayor, vale destacar el importante papel que el MPT ha desempeñado en perfeccionar las oportunidades de acceso al aprendizaje profesional tanto para los adolescentes en cumplimiento de medida socioeducativa, como para los adolescentes en acogimiento institucional. Con la precursora experiencia de la Fiscal Regional del Trabajo Mariane Josviak, que dio inicio a tratativas de esa naturaleza en Paraná ya en 2006, con aprobación de ley estadual en ese sentido, son ejemplos actuales de esas iniciativas los siguientes proyectos: Medida de Aprendizaje, llevado a efecto por las Fiscales del Trabajo Simone Beatriz Assis de Rezende y Cândice Gabriela Arosio en Mato Grosso do Sul; Creando Juicio, que creó consorcio de entidades del Sistema de Justicia de Rio de Janeiro con esta finalidad, estando el MPT representado por la Fiscal del Trabajo Dulce Martini Torzecki ${ }^{4}$; Medida de Aprendizaje en el Distrito Federal, capitaneado por la actual Coordinadora Nacional de la Coordinfância, Fiscal del Trabajo Ana Maria Villa Real Ferreira Ramos; y el Aprendizando, en Rio Grande do Sul, en una asociación entre MPT, MP/RS y OIT, entidades representadas, respectivamente, por esta autora, por la fiscal Cinara Vianna Dutra Braga y por la oficial de la OIT Thais Dumet.

Además de los proyectos nominados, muchas otras iniciativas han surgido en el territorio nacional, como en Espírito Santo (por la Fiscal del Trabajo Sueli Teixeira Bessa) y en Paraíba (por el Fiscal del Trabajo Raulino Maracajá Coutinho Filho), en razón de la percepción de la importancia de esas acciones para conferir a los adolescentes más vulnerables las oportunidades que les faltan para que puedan superar las dificultades y los traumas hasta entonces enfrentados, y obtener un espacio (con el debido preparación 
y protección) en el mundo del trabajo - que oportuniza, en última instancia, construcción de efectiva ciudadanía.

\subsection{Eje Educación}

El eje Educación, conocido como MP'T en la escuela, tuvo origen en 2008, bajo el formato del Programa de Educación contra la explotación del trabajo del niño y del Adolescente (PETECA) ${ }^{5}$, idealizado por el Fiscal del Trabajo Antônio de Oliveira Lima - que hasta hoy sigue implantando este programa con gran éxito en el Estado de Ceará, siendo el colega una referencia nacional en el combate al trabajo infantil.

La lógica de este eje es la aproximación con la comunidad por medio de la escuela, con formación de los profesores sobre el tema trabajo infantil, para poder debatir y dialogar con los alumnos sobre tan impactante problema. El foco son las escuelas municipales, y actualmente el eje se vuelve especialmente para los alumnos de $\operatorname{los} 4^{\circ}$ y $5 .^{\circ}$ años de la escuela primaria.

Se observa que la realización del MPT en la escuela permite el derrocamiento de muchos mitos que envuelven la temática del trabajo infantil, por medio de la reflexión dialógica, y no de la imposición del pensamiento. Se ve, por ejemplo, la famosa jerga "niño que está en la escuela puede trabajar, basta continuar estudiando": a partir de las reflexiones en las capacitaciones que el MPT ministra a los educadores, éstos son capaces de observar lo que, efectivamente, está detrás de una frase aparentemente sencilla.

En verdad, el trabajo infantil retira del niño y del adolescente el derecho y la condición de estudiar de hecho, de asimilar los contenidos que se les ofrecen, ya que impone una carga muy pesada de actividades. No por otra razón, el trabajo infantil se encuentra en la raíz de la evasión escolar-y muchas veces es en la capacitación que el profesor va a percibir que aquel su alumno que ha faltado a las clases, o que no las consigue acompañar de hecho, está, en la verdad, en situación de trabajo (muchas veces, incluso, se puede estar delante del trabajo infantil doméstico, que aunque sea una de las peores formas de trabajo infantil de acuerdo con la lista TIP, permanece invisible para la sociedad, pero produciendo máculas indelebles en la formación del sujeto).

Los mitos son muy controlados, por lo tanto, en el diálogo como en las actividades de ocio, para demostrar que el trabajo infantil afecta el desa- 
rrollo físico, psicológico y/o moral del niño y del adolescente, y robarles las oportunidades y maculando, a veces de forma irreversible, en su infancia, y que, en ocasiones, sus propios intereses Con los de los análisis realizados en la clase de la escuela, se ha conseguido un alcance inimaginable, el tema en el seno de la comunidad, por lo que no sería posible de otro modo, dada la imposibilidad de promover esa integración social, si no en la escuela. La estrategia de capacitar a los educadores para que puedan ejercer el papel de multiplicadores de conocimiento también se muestra acertada, ya que, si el MPT mantuviera para sí ese conocimiento y esa posibilidad de abordaje, no lograría éxito en alcanzar el importe de escuelas, profesores y alumnos que ha logrado alcanzar.

Después del proceso de reflexión realizado en aula, el eje culmina con el premio MPT en la escuela, por el cual los trabajos realizados por los alumnos, a partir de las discusiones hechas en aula, podrán ser premiados a nivel municipal (que queda bajo responsabilidad del municipio que adhirió al proyecto), estatal (organizado por la Coordinfância Regional) y nacional (que ocurre en Brasilia, llevando a la capital federal los alumnos y profesores ganadores).

Como ejemplo del éxito de esta estrategia, en el año 2018 fue posible implementar el MPT en la escuela en 389 municipios de 9 unidades de la Federación, alcanzando 4.835 escuelas, capacitando a más de 32.000 profesores, lo que benefició al menos a 873.000 alumnos.

Se tiene, así, en el MPT en la escuela, además de una estrategia de amplio éxito, un instrumento de dignificación de la educación, atribuyéndose a la escuela el papel fundamental que ejerce (o debe ejercer) en la vida de cada alumno - un espacio de ciudadanía, de formación y de reflexión. Al mismo tiempo, confiere al profesor el reconocimiento de su fundamental interacción con el alumnado, siendo el responsable directo por la formación de cada niño y adolescente con que convive. Es, pues, esencialmente, un instrumento de reconocimiento de la importancia de la escuela y del profesor, así como de la relación del alumno con esa institución y ese sujeto formador de ciudadanía.

\subsection{Eje Políticas Públicas}

Por último, el eje Políticas Públicas busca articular la red de protección, el sistema de Justicia y las autoridades municipales en torno al problema del 
trabajo infantil, fomentando una mejor identificación de los casos presentes en la localidad, así como el debido enfrentamiento del problema conforme a las particularidades locales. Se trata de una acción de suma relevancia, siendo nítido que, después del paso del MPT por el municipio, la articulación en torno a la protección de la infancia contra el trabajo infantil tiende a fortalecerse - pues, si eso no ocurre espontáneamente, podrán ser adoptadas las medidas apropiadas para remediar los problemas encontrados, desde la presentación de término de ajuste de conducta hasta la proposición de acción civil pública.

En pocas palabras, el eje se desarrolla de la siguiente manera: se realizan visitas del MPT a diversos organismos locales, comenzando por los pertenecientes al sistema de justicia local, pasando por toda la estructura de la red de protección municipal. Así, inicialmente, los Fiscales del Trabajo responsables por la implantación del proyecto suelen hacer contacto con la Fiscalía de Justicia responsable por la localidad, con la Justicia Estadual (buscando, en su caso, el contacto con los jueces de la infancia y adolescencia) y la Justicia del Trabajo. Ese diálogo inicial pretende presentar el proyecto y hacer una importante aproximación con esos órganos públicos, que desempeñan funciones de alto relieve en diversas materias, y también en la defensa de los derechos de los niños y de los adolescentes, incluso en lo que se refiere a la protección contra el trabajo infantil.

Después de ese diálogo inicial con el sistema de justicia, son hechas visitas, con finalidad de reconocimiento, en los equipamientos de la red de protección asistencial del municipio, destacándose: consejo tutelar, CRAS (Centro de Referencia de Asistencia Social), CREAS (Centro de Referencia Especializada de Asistencia Social), CMDCA (Consejo Municipal de los Derechos del niño y del Adolescente) y otros, que, eventualmente, puedan existir. Es importante recordar que la red, aunque posea esa estructura básica, puede cambiar de un local para el otro, siendo más o menos estratificada conforme a las particularidades locales (tamaño del municipio, número de familias a ser atendidas, mayor o menor incidencia de alguna actividad).

Por último, alcanzado el diagnóstico de la red, se realizan visitas a las secretarías municipales que pueden colaborar para la solución de los problemas eventualmente encontrados. En general, se visitan la Secretaría de Asistencia Social (o su corresponsal), la Secretaría de Salud, la Secretaría de Educación y la Secretaría de Trabajo. También aquí la estructura es cambiante de ciudad a ciudad, de acuerdo con variaciones que van desde la economía 
local prevaleciente hasta las elecciones políticas que compiten con la Administración Pública municipal.

Al final, se realiza una reunión con el alcalde, en la que se presenta el resultado de la acción, buscando el compromiso del municipio en resolver los problemas que, eventualmente, hayan sido identificados en la localidad objeto de la implantación del proyecto. De un modo general, es posible afirmar que generalmente hay pendientes a ser resueltas, ya que el trabajo infantil es un problema de alta complejidad y, por más comprometida que sea la municipalidad con el tema, difícilmente habrá sido totalmente erradicado el problema (no se tiene noticia de una ciudad brasileña en que no ocurra ninguna forma de trabajo infantil). Así, el eje Políticas Públicas ejerce un importante papel de destacar y evidenciar al gestor las cuestiones a ser objeto de atención, siempre teniendo en vista el interés prioritario del niño y del adolescente, que deben recibir protección absoluta e integral.

El eje Políticas Públicas llegó a un menor número de municipios, dada la mayor complejidad de su implantación, ya que requiere el desplazamiento de miembros y servidores del Ministerio Público del Trabajo hasta el local, con permanencia de, por lo menos, dos o tres días. Sin embargo, incluso con tales dificultades, ya fue posible implantar tal eje en por lo menos 25 locales, siendo cierto que, después del paso del MPT, el municipio pasa a observar el problema con más cuidado y comprometimiento ${ }^{6}$.

A título de ejemplo, una vez más, el municipio de Luziânia merece destaque: antes de la implantación del proyecto, se identificaron los siguientes factores: falta de recursos humanos e infraestructura en la red de protección, notablemente en los consejos tutelares; CMDCA sin noción plena de sus atribuciones y competencias; problemas en la comunicación entre los equipamientos. Pasado seis meses de la implantación, ya era visible el cambio. El Consejo Tutelar que estaba en peor condición había recibido nueva sede, adecuada a las necesidades del trabajo, habiendo mejorado el diálogo y la aproximación entre los órganos de la red de protección ${ }^{7}$.

Es importante destacar que, como el eje Políticas Públicas tiene un trabajo muy específico delante de la red de protección local, la presencia de un servidor trabajador de asistencia social califica mucho, las intervenciones ministeriales. El MPT posee una servidora que asesora técnicamente el proyecto en este aspecto, la trabajadora social Vitória Raskin, que ha participado 
en diversas etapas nacionales relativas a la implantación de ese eje, con excelentes resultados en la aproximación del MPT a la red de protección.

Por último, merece destaque también la actuación de la Fiscal Regional del Trabajo Margaret Matos de Carvalho, que, durante su larga historia en el MPT, produjo algunos de los mejores resultados en diversas searas, notablemente en la colaboración para la construcción de políticas públicas eficaces de combate al trabajo infantil, y también el Fiscal del Trabajo Tiago Ranieri de Oliveira, que idealizó esa iniciativa todavía como proyecto autónomo, el cual también quedó laureado en el Premio $\mathrm{CNMP}^{8}$.

\section{CONCLUSIONES}

La digresión ahora realizada permite concluir que el Ministerio Público del Trabajo ejerce fundamental papel en la lucha al trabajo infantil, herida que todavía asola por lo menos 2 millones y 400 mil niños y adolescentes en Brasil. Ese papel es desempeñado tanto en su función investigativa, actuando delante de las noticias que llegan a su conocimiento, relativas a la explotación del trabajo de niños y adolescentes, como también en su función promocional, por la cual realiza, en esencia, el Proyecto Rescate la Infancia.

Este proyecto, por medio de sus 3 (tres) ejes fundamentales, permite el enfrentamiento de las principales aristas que necesitan ser recortadas para que haya efectiva erradicación del trabajo infantil. Esto se debe a que un problema complejo como el trabajo infantil sólo podrá ser debidamente enfrentado si se tiene en cuenta esa complejidad - lo que determina, evidentemente, una pléyade de acciones que deben ser articuladas conjuntamente, con el esfuerzo de miembros, servidoras y servidores del MPT'

Promover el Rescate la Infancia es una medida fundamental para la mayor protección de la infancia, ya que el trabajo infantil se encuentra en la base de varias otras violaciones de los derechos del niño y del adolescente. Realizar el proyecto permite colaborar para la efectividad del principio de protección integral, garantizado en el artículo 227 de la Constitución Federal. Con tal instrumento, el MPT ha actuado fuertemente para que el Estado Brasileño pueda cumplir la meta asumida ante las Naciones Unidas, relativa a la erradicación del trabajo infantil hasta el año de 2025. Es un desafío bastante difícil, con pocas posibilidades de pleno éxito (aunque Brasil haya logrado una importante disminución en el número de niños y adolescentes en situa- 
ción de trabajo infantil, especialmente desde los años 1990 hasta 2015). Sin embargo, las dificultades no pueden configurar el estancamiento de la acción. Por el contrario: deben impulsar a todas las instituciones para lograr mejores resultados, ya que se está tratando del sujeto de derechos prioritariamente protegido por nuestra Constitución Federal, y sin cuya protección integral no se obtendrá, en ninguna medida, efectivo avance social y económico. Porque, como dijo el sociólogo y activista Herbert De Souza (1992), el añorado Betinho:

\begin{abstract}
Si no veo en el niño a un niño, es porque alguien lo violó antes, y lo que veo es lo que queda de todo lo que le fue quitado. Ese que veo en la calle sin padre, sin madre, sin casa, cama y comida, ese que vive la soledad de las noches sin gente cerca, es un grito, es un asombro. Ante él, el mundo debería detenerse para comenzar un nuevo encuentro, porque el niño es el principio sin fin, y su fin es el fin de todos nosotros.
\end{abstract}

\title{
NOTAS
}

1 Durante la gestión de la autora, fue Vice-Coordinador Nacional el Fiscal Regional del Trabajo Ronaldo José de Lira, y gerentes del proyecto Rescate la Infancia las siguientes colegas: Fiscal Regional del Trabajo Margaret Matos de Carvalho y Fiscales del Trabajo Cândice Gabriela Arosio, Jailda Eulidia da Silva Pinto, Dulce Martini Torzecki y Ana Maria Villa Real Ferreira Ramos, las cuales colaboraron sobremanera para que la Coordinación pudiese alcanzar los resultados obtenidos, los cuales se encuentran registrados en el PGEA 20.02.0001.0008862/2019-37.

2 La Agenda 2030, según sus idealizadores, es un plan de acción para las personas, el planeta y la prosperidad, que busca fortalecer la paz universal. El plan indica 17 Objetivos de Desarrollo Sostenible, los ODS, y 169 objetivos para erradicar la pobreza y promover una vida digna para todos, dentro de los límites del planeta. Son objetivos y metas claras, para que todos los países adopten de acuerdo con sus propias prioridades y actúen en el espíritu de una asociación global que oriente las elecciones necesarias para mejorar la vida de las personas, ahora y en el futuro (ONU, [2020]).

3 La Lista TIP fue aprobada por el Decreto n. ${ }^{\circ} 6.481$ / 2008 y representa el reconocimiento por el Estado brasileño de las peores formas de trabajo infantil enumeradas en la Convención n. ${ }^{\circ} 182$ de la OIT.

4 El proyecto Creando juicio - una red de apoyo a la ciudadanía por el aprendizaje estuvo entre los finalistas del 14. Premio Innovare en el año 2017.

5 El Proyecto PETECA fue galardonado con el $1 .^{\circ}$ lugar en el premio CNMP inducción de Políticas Públicas, en el año 2018.

6 En el momento en el que el autora ha estado delante de la Coordinfância Nacional, ha sido posible la implementación de un proyecto, en 10 municipios (Boa Vista/ RR, Luziânia/GO, Medicilândia/PA, Feira de Santana/BA, Ipatinga/MG, Toritama/ PE, Santa Cruz do Capibaribe/PE, Rio Brilhante/MS, Santana do Livramento/MS e Juína/MT), y con la imprescindible colaboración de los compañeros: la Fiscal Regional del Trabajo Margaret Matos de Carvalho y de los Fiscales del Trabajo Ronaldo José de Lira, Safira Nila de Araújo Campos, Priscipla Moreto de Paula, Geny Helena Fernandes Barroso, José Carlos Souza Azevedo, Mariana Lâmego de Magalhães Pinto, 
Jailda Eulídia da Silva Pinto, Ana Carolina Lima Vieira Ribemboim, Annelise Fonseca Leal Pereira, Luciana Marques Coutinho, Adolfo Silva Jacob, Túlio Mota Alvarenga, Cândice Gabriela Arósio, Simone Beatriz Assis Resende, Ana Lúcia Stumpf Gonzáles y Ludmila Pereira Araújo.

7 Los datos integrales de la implementación se pueden consultar en el PA-PROMO 000168.2018.18.002 / 5.

8 El eje, aún como Proyecto Políticas Públicas de Combate al trabajo Infantil, obtuvo el 2. ${ }^{\circ}$ lugar en la edición de 2013 del premio del Consejo Nacional del Ministerio Público.

9 En ese particular, es necesario registrar un agradecimiento especial a la analista procesal Bruna Rossol, que desempeñó el cargo de Asesora de la Coordinfância durante el período en que la autora estuvo frente a la Coordinación Nacional. Su apoyo técnico fue imprescindible tanto para la realización de las acciones, como para la consolidación de los datos obtenidos. En su persona, se extiende el agradecimiento a todos los servidores y servidoras del MPT que apoyan y colaboran activamente para la implantación del Proyecto Rescate la Infancia en Brasil.

\section{REFERENCIAS}

BRASIL. Decreto-lei n. ${ }^{\circ}$ 5.452, de 1 de maio de 1943. Aprova a Consolidação das Leis do Trabalho. Rio de Janeiro, maio de 1943. Disponible en: http://www.planalto.gov.br/ccivil_03/leis/18069.htm. Acceso en: 18 ago. 2020 .

BRASIL. Constituição da República Federativa do Brasil. Brasília/DF, 1988. Disponible en: http://www.planalto.gov.br/ccivil_03/constituicao/ ConstituicaoCompilado.htm. Acceso en: 18 ago. 2020.

BRASIL. Lei n. ${ }^{\circ}$ 8.069, de 13 de julho de 1990. Dispõe sobre o Estatuto da Criança e do Adolescente e dá outras providências. Brasília/DF, jul. 1990. Disponible en: http://www.planalto.gov.br/ccivil_03/leis/L8069compilado. htm. Acceso en: 18 ago. 2020.

BRASIL. Decreto n. ${ }^{\circ}$ 9.579, de 22 de novembro de 2018. Consolida atos normativos editados pelo Poder Executivo federal que dispõem sobre a temática do lactante, da criança e do adolescente e do aprendiz, e sobre o Conselho Nacional dos Direitos da Criança e do Adolescente, o Fundo Nacional para a Criança e o Adolescente e os programas federais da criança e do adolescente, e dá outras providências. Brasília/DF, nov. 2018. Disponible en: http:// www.planalto.gov.br/ccivil_03/_Ato2015-2018/2018/Decreto/D9579.htm. Acceso en: 18 ago. 2020. 
MINISTÉRIO PÚBLICO DO TRABALHO. Projeto Resgate a Infância. Brasília: Coordinfância, 2016. Disponible en: https://intranet.mpt.mp.br/ pgt/coordenadorias-nacionais/Coordinfância/projeto-estrategico/resgate-a-infancia-vs-final_atualizado-com-novos-indicadores.pdf. Acceso en: 25 jun. 2020.

OIT. Trabalho Decente. [S.l], [201-]. Disponible en: https://www.ilo.org/ brasilia/temas/trabalho-decente/lang--pt/index.htm. Acceso en: 14 mayo 2020.

ONU. Agenda 2030. [S.1]. Disponible en: www.agenda2030.org.br. Acceso en: 22 mayo 2020.

SOUZA, Herbert José de (BETINHO). A criança é coisa séria. Rio de Janeiro: AMAIS, 1992. 


\title{
COORDINFÂNCIA EN ACUARELA: HISTORIAS Y TRAYECTORIAS DE VIDA'
}

\author{
RAFAEL DIAS MARQUES
}

"En una boja cualquiera dibujo un sol amarillo.

$Y$ con cinco o seis rectas es fácil hacer un castillo. Deslizo el lápiz alrededor de la mano y me doy un guante. $Y$ si bago llover, con dos rayas tengo un paraguas"

DOI: 10.51366/978-65-89468-10-3-coordinfancia-25

Fue así, como con la canción Acuarela de Toquinho y Vinicius de Moraes que, hace más o menos 20 años, un grupo de miembros del Ministerio Público del Trabajo, en la soleada ciudad de Fortaleza, ensimismados con sus nuevas funciones, diseñadas en 1988, ensayaron, entre muchas pinceladas, sobre una tela blanca, desafiadora y enigmática, las primeras cuatro o cinco rectas, los primeros bosquejos de la Coordinación Nacional de Combate contra la Explotación del Trabajo de Niñas, Niños y Adolescentes.

En aquel momento, todo estaba todavía muy enmarañado, los colores pálidos y desteñidos, las rectas, las curvas, la imagen, la tibia, la obra en construcción. El MPT ya actuaba - ¡cómo actuaba! - en asuntos que involucraban niños y adolescentes en el mundo del trabajo, dando pareceres en casos individuales, participando en audiencias, juzgando reclamos laborales. Así, se venían implantando en las Procuradurías Regionales las Coordinación de Defensa de los Incapaces, después denominadas como Coordinación de Defensa de los Intereses de Menores e Incapaces.

En efecto, desde 1994, el MPT participaba del Fórum Nacional de Prevención y Erradicación del Trabajo Infantil y en las acciones embrionarias del Programa de Erradicación del Trabajo Infantil (PETI), en Mato Grosso do Sul, cuyo modelo se transformaría en la principal política del Estado brasileño con respecto al enfrentamiento del trabajo infantil. 
Pero, allí, en aquel momento, ya se preveía, entre los Procuradores del Trabajo, un vacío, una incompletitud, un espacio por donde se resbalaba la necesidad de crear una estructura que significase un avance para las cuestiones colectivas y difusas; para una actuación coordinada, armónica, proactiva y articulada con las demás instituciones del Sistema de Garantía de los Derechos de los Niños y de los Adolescentes; para una actuación nacional.

Realmente, había mucha tinta para pintar, mucho papel para dibujar, mucho campo para soñar y osar, al final, ya habían pasado más de diez años desde la promulgación de la CF/88 y de la edición de la Convención de los Derechos del Niño de la ONU, balizas inéditas de un novel sistema de normas de protección a la infancia, basado en los principios de protección integral y prioridad absoluta.

Aún se estaba en un rico proceso de discusión a respecto de la ratificación de las Convenciones n 138 y 182 de la OIT, que contienen normas sobre cuestiones que afectan a la edad mínima, al trabajo y a la eliminación urgente de las peores formas de trabajo infantil. Al lado de eso, millones de niños y adolescentes en situación de trabajo, como en los cañaverales y plantaciones de sisal, en Alagoas, Paraíba y en Bahia, o en las carbonerías de Mato Grosso, Pará y Minas Gerais o, también, en el sector del calzado en el interior de São Paulo. Así que era preciso hacer de todo eso, de toda esta materia prima, un nuevo diseño de actuación institucional, los trazos de una nueva acuarela. Era necesario reinventarse, desteñir para colorear de nuevo. Y el cambio estructural, por lo menos en el MPT, estaba muy próximo, urgente.

Era septiembre de 2000, época del Seminario Combate contra la Explotación del Trabajo de Niñas, Niños y Adolescentes - Avances y Estrategias - Perspectivas para el Futuro - 10 años de ECA, realizado en Fortaleza. En aquel momento y lugar, varios miembros del Ministerio Público del Trabajo, de todo Brasil, todos en comunión de deseos y sueños, hermanados, mirando hacia adelante, osando, ya anunciando como el MPT debería organizarse en su misión, aprendices de un nuevo arrebol, diseñaron, con muchas rectas, rayas y curvas, corriendo el lápiz aquí, allí y más allá, una acuarela multicolor, repleta de desafíos y osadía, que empezó a ser pintada en un documento histórico, que marcaría al Ministerio Público del Trabajo en el porvenir de los tiempos: la Carta de Fortaleza - Por el Rescate de la Ciudadanía de los Niños y de los Adolescentes que Trabajan, que ya indicaba un cambio de ruta y de rutina de trabajo. Co- 
mienza una historia de muchos hechos, inquietudes, creatividad y dedicación visceral. Allí, la idea de la Coordinfância fue esbozada.

Ese fue, el telón de fondo, la tela, la moldura, que llevaría al, entonces Procurador General del Trabajo, Guilherme Mastrichi Basso, a dar la pincelada inaugural, aquel mismo año. Vino en la forma de Ordenanza PGT n. 299 , de 10/11/2000, que selló, definitivamente, el nacimiento de la Coordinación Nacional de Combate contra la Explotación del Trabajo de Niñas, Niños y Adolescentes, usando tintas, colores, trazos y marcos en pro de una bella acuarela de defensa de los derechos fundamentales de niños y adolescentes, en las relaciones de trabajo. Los trazos principales fueron definidos así: A) promover, supervisar y coordinar acciones contra las diferentes formas de explotación del trabajo de niños y adolescentes; B) promover estudios y uniformizar entendimientos; C) representar el MPT en compromisos variados.

Compusieron la obra pintores representantes de todas las regiones nacionales, de norte a sur, de este a oeste, bajo la batuta inicial de maestros rectores, destacándose, por estar allí, en el origen, Eliane Araque dos Santos y Lelio Bentes Corrêa, a quienes siguieron tantos otros, hoy recordados en esta obra de homenaje a los 20 veinte años de la Coordinfância. La Coordinación nació, pues, bajo el signo del espíritu pionero, de vanguardia, ella que fue y es la madre de todas las Coordinaciones Nacionales Temáticas del Ministerio Público del Trabajo.

Pero, como toda acuarela recién pintada, aún con la pintura fresca, necesitaba afirmar sus colores, que corrían el riesgo de desvanecerse entre las ataduras de la burocracia institucional; de parar, ante los diques sociales de la permisibilidad del trabajo infantil, ante el correr de las aguas del tiempo.

Era, entonces, ocasión de afirmación de sus matices conceptuales. Así, las pinceladas siguientes fueron de consolidación de conceptos, anclaje de parámetros y directrices de acción, así como de afirmación de un nuevo enfoque de actuación institucional, menos individual y más colectivo, menos reactivo y más proactivo, más planeado y armónico, más integral y más integrado a las demás instituciones del sistema de garantía de derechos de niños y adolescentes.

$\mathrm{Y}$, entonces, vinieron las primeras reuniones de los Procuradores-pintores que, dos veces al año, ajustando las pinceladas, la nitidez de las imágenes 
y los propósitos, la forma y el volumen, después de largas discusiones, mucho convencimiento, mucha paciencia y mucha pasión, consolidaron premisas importantes, como el trabajo infantil doméstico como una de las peores formas de trabajo infantil; los primeros análisis de fondo sobre trabajo deportivo y trabajo artístico; las primeras discusiones sobre la tesis de la competencia de la Justicia del Trabajo para el procesamiento y juicio de las autorizaciones judiciales para; los primeros embates contra las autorizaciones judiciales para trabajo antes de la edad mínima, concedidas por Juez de Derecho, de la infancia y/o del trabajo, posibilitando la labor antes de la edad mínima prevista, una franca, abierta y activa violación de derecho fundamental por parte del Estado-juez.

En este sentido, se acertaron los primeros entendimientos en materia de grupos móviles, estudios de temas polémicos y uniformización de procedimientos. Se firmaron, después de muchos borrones, los trazos de la articulación social e interinstitucional, las líneas de la sensibilización de la sociedad con respecto a la perversidad y a los daños del trabajo infantil.

Se diseñaron, con volumen cada vez mayor, la participación en comisiones externas, audiencias públicas y foros de discusión, cuyo ejemplo mayor es el Fórum Nacional de Prevención y Erradicación del Trabajo Infantil. Se crearon varias campañas publicitarias, inclinadas a apagar los mitos de aceptabilidad del trabajo infantil.

Estos trazados iniciales respondían, sí, a la necesidad de integrar acciones e instituciones, al final, redes necesitaban ser tejidas; corazones necesitaban ser seducidos; manos necesitaban - y necesitan - ser dadas, tal es la complejidad de factores que yacen en la problemática del trabajo infantil.

La paleta de colores de esa Coordinfância en acuarela, de perenne formación, se expandió aún más y, en aquel momento, creyente en una actuación que precisaba extrapolar las relaciones de empleo para alcanzar todo el universo de las relaciones de trabajo, especialmente el sector informal de la economía, se esbozaron algunos campos prioritarios de actuación urgente:

1) protección del adolescente sometido al régimen de aprendizaje, prácticas y trabajo educativo, como alternativas a las famosas guardias-mirins;

2) combate al trabajo infantil en los "basurales"; 
3) combate al trabajo de niños y adolescentes en actividades ilícitas (explotación sexual y tráfico de drogas);

4) combate a la explotación del trabajo infantil en régimen de economía familiar;

5) combate al trabajo infantil doméstico.

Coordinfância tenía y tiene prisa, pues la protección de la infancia requiere inmediatez y prioridad. En esta fase de la vida, el tiempo corre más rápido y la necesidad de protección es grande. Cualquier daño perpetrado en la infancia - entre los cuales, los daños provenientes del trabajo infantil - se extrapolan fuertemente para las demás etapas de la vida, causando traumas y sustentando proyectos de adultos problemáticos.

El tiempo fue pasando y, tras muchos estudios y pruebas, nuevas formas de disposición se fueron pensando, nuevos artífices fueron envolviéndose fielmente en la obra, de los cuales son ejemplos los abnegados servidores del Ministerio Público del Trabajo.

La acuarela, antes bañada de un determinado color, con determinado volumen, bajo una forma definida, se fue transfigurando, destiñéndose para colorearse en seguida, como si una nueva tendencia de actuación se fuera depurando entre los tantos borrones del tiempo, de los aciertos y errores, de los avances y retrocesos, probados, vividos, experimentados, en la punta, por solícitos, creativos y osados miembros y servidores del MPT, siempre en busca de nuevos tonos para una acuarela que ya se desmenuzaba en el tiempo.

Entonces una travesía se completaba: la era de los estudios, de la consolidación de conceptos, de la definición de campos de actuación, de la construcción de enunciados y manuales de actuación, se agregaba la era de la ejecución, de la definición de objetivos, acciones, metas, plazos, recursos y responsables, en pro de un Ministerio Público apto a entregar excelencia y resultados palpables a una sociedad más consciente del papel del poder público; en pro de un Ministerio Público del Trabajo proactivo y resolutivo.

Coordinfância, ya en 2009/2010, siguiendo su veta de pionerismo y vanguardia, se iniciaba en las tintas de la Gestión Estratégica y las pincelaba, con más y más perfección, por medio de los pinceles de la gestión por proyectos. 
Y, así, una gran parte de los esfuerzos fueron canalizados para ejecutar Proyectos Estratégicos, que cumplen el papel de posibilitar el cumplimiento de la misión del Ministerio Público del Trabajo como institución defensora del orden jurídico, del régimen democrático y de los intereses sociales e individuales indisponibles, en las relaciones de trabajo.

La acuarela, en permanente construcción, trazaba sus cuadrantes en los siguientes Proyectos, a saber:

A) el Proyecto MPT en la Escuela: de manos dadas contra el trabajo infantil, centrándose en la sensibilización de alumnos, padres, profesores y comunidad escolar, en cuanto a los daños del trabajo infantil, por medio del arte-educación;

B) el Proyecto Políticas Públicas que, al fortalecer el sistema de garantía de los derechos fundamentales de niños y adolescentes, entre los cuales el derecho fundamental a no trabajar, por medio de la articulación y eventual responsabilización del propio Poder Público omiso, osó agregar al Estado como deudor de acciones mínimas, en el contexto de abastecedor de políticas públicas indispensables para lo mínimo existencial e instrumental para la creación de las condiciones materiales que alejan a niños y adolescentes del trabajo precoz, sea en el campo de la educación, profesionalización, asistencia social, trabajo, renta, etc; y, finalmente,

C) el Proyecto Aprendizaje Profesional, como medio de garantizar el usufructo del derecho fundamental a la profesionalización, a partir de premisas como la universalización de acceso a la formación profesional, interiorización de las oportunidades y alternativa concreta, protegida y garantizadora de derechos laborales y previsionales, a públicos vulnerables, como los retirados del trabajo infantil, la población de baja renta, adolescentes autores de actos delictivos y cumplidores de medidas socioeducativas, bien como aquellos acogidos institucionalmente.

Con efecto, y porque osó, creyó y contó con sus Procuradores y servidores artífices, la Coordinfância conquistó y presenta un lugar relevante en el contexto de la Gestión Estratégica del Ministerio Público del Trabajo, pues definió su estrategia y alineó su diseño entre sus colaboradores, fijando acciones, metas, objetivos, plan director e indicadores de desempeño, así haciendo, evaluando y monitoreando su actuación, supo medir sus resultados y sus en- 
tregas a la sociedad brasileña. Son los matices del pionerismo, los colores de la vanguardia, los trazos de la dedicación, de la fe y de la devoción que una vez más se dejan transparentar en acuarela.

Coordinfância en acuarela sigue, pues, su camino y, por donde pasa, exponiéndose en hechos e intenciones, testeándose en nuevas composiciones, ha arrancado aplausos y elogios, nacionales e internacionales, como ejemplo tenemos el Premio CNMP Gestión Estratégica, edición 2013, que destacó el Proyecto Políticas Públicas, como buena práctica institucional, en el área de la infancia y de la adolescencia, agraciándolo con el segundo lugar en todo el Ministerio Público brasileño. Reconocimientos más allá de las fronteras nacionales también han sido dedicados a la obra de la Coordinfância, como las invitaciones para la presentación de buenas prácticas en Mozambique, México y Cabo Verde. Y más aun, el Proyecto Políticas Púbicas fue una de las tres buenas prácticas nacionales de combate al trabajo infantil, seleccionadas para presentar en la III Conferencia Global sobre Trabajo Infantil.

En los últimos años, en el perenne movimiento de desteñir para volver a colorear, se percibió una necesidad de integración entre los tres Proyectos que distinguieron la Gestión Estratégica de Coordinfância. Así, ellos pasarían a ser uno solo, en una simbiosis tan eficaz como efectiva para combatir la compleja problemática del trabajo infantil y del trabajo del adolescente. Nacía el proficuo Proyecto Rescate la Infancia, que pasó a condensar técnicas integradas para promover la concientización sobre la temática, la formación profesional de adolescentes y la promoción de políticas públicas amarradas al conjunto de los derechos fundamentales de los niños y adolescentes. Y se pasó a sumar contundentes acciones estratégicas contra el trabajo infantil en cadenas económicas.

Sus tesis de actuación, muchas de vanguardia, también han obtenido reconocimiento junto a los Tribunales brasileños, incluso en el Tribunal Superior del Trabajo. Con efecto, son varias las decisiones que declaran la competencia de la Justicia del Trabajo para apreciar causas ministeriales en las cuales se pretende la condenación del Estado a la prestación de políticas públicas de prevención y erradicación del trabajo infantil. Otras tantas son las que reconocen la competencia de la Justicia del Trabajo, para procesar y juzgar los hechos en que se discuten tutelas inhibitorias y condenatorias, resultantes de ilícito referente a la explotación sexual comercial de niños y adolescentes; o, aun, aquellas que proclaman la competencia de la Justicia 
obrera para activar parámetros de protección a los adolescentes en formación profesional deportiva, en los casos de los atletas menores.

Pero es necesario hacer el cierre, bajo pena de cansar demasiado, a quienes se dispusieron a leer esta ingenua oda a la Coordinfância en el año en que la Coordinación cumple 20 primaveras, contadas desde aquellas primeras pinceladas de los años 2000.

Realmente, mucho ya se pintó y sería imposible relatar toda esta trayectoria, creada y trazada con tanta devoción, hoy tan bien conducida por las manos dedicadas y talentosas de las Procuradoras del Trabajo Ana Maria Villa Real Ferreira Ramos y Luciana Marques Coutinho.

De hecho, mucho aún habrá que pintar. Nuevos y viejos desafíos, en matices y perspectivas diferentes, se confrontan en esa acuarela sin fin: el trabajo informal en las grandes ciudades; el trabajo en la agricultura familiar; el trabajo infantil doméstico, invisible y todavía aceptado; el trabajo infantil en el narcotráfico; el trabajo infantil artístico, en el cual glamour y fama esconden trabajo, cegando a los padres, familias e incluso a los jueces de los más altos escalones; la ausencia de formación profesional para adolescentes autores de acto de infracción o bajo acogida institucional.

En todos estos frentes, está la Coordinfância, inventando y reinventando, pintando y repintando, borrando aquí, esbozando más allá, coloreando y destiñendo, y volviendo a colorear, el cuadro de protección de la infancia en las relaciones de trabajo.

Muchos, sin embargo, intrigados, no entienden la vivacidad, la acción resolutiva y la proactividad de la Coordinación en acuarela, el sentimiento de pertenencia que de ella se desparrama. Se sorprenden al ver la fragilidad típica de una acuarela, pintada con agua y tinta, ante la fortaleza y actuación vanguardista de la Coordinación. Cuestionan por qué las cosas tienen éxito en la Coordinfância, por qué ellas se expanden ocupando espacios en blanco y ensanchando fronteras de actuación. Otros, miembros del MPT y servidores, simplemente, se dejan contagiar y engruesan devotamente la corriente, sin vergüenza, sin pudor, sin parsimonia.

Es que aquella acuarela en profusión fue ganando cada vez más ímpetu, deslizando su pintura más allá de la tela del Ministerio Público de Trabajo, en cuanto institución. La pintura se integró para dentro de la vida de los 
miembros y servidores del MPT y, mezclados en su piel, en su sangre, en sus fluidos, en sus almas y sus deseos, cuerpo y mente, ganaron sustancia, fuerza y coraje. Contribuyó a un sentimiento repleto de energía.

Y, ahora, no están hechas solamente de pigmentos y agua, resisten a la fuerza del tiempo y no pueden borrarse o rasgarse. Son el arranque, la esperanza, la fe, la creencia, la convicción, la certeza de que es posible un Brasil y un mundo sin trabajo infantil.

Ah, Coordinfância, son tantos sus trazos, tantos sus colores, tantos sus matices, tantos los espacios por donde corren hechos, deseos y sueños, que no puede ser entendida solamente así, en la medida del tiempo. Es estado de espíritu, profesión de fe, vida misionera, mantra, fiebre, fuerza visceral, entraña, iparto!

Definitivamente, no cabe en una línea temporal. Podría ser uno, dos, diez, veinte, cincuenta años. Es que, simplemente, cabe solamente en nuestros corazones y en nuestras mentes, donde no hay tiempo ni espacio, donde no hay límites, ni bordes, ni diques, ni fronteras, ni censuras; donde todo es infinito, amplio y abismal como el universo; donde todo es posible y bello, especialmente posible y bello, cuando, en la punta, está el principio de todo: la infancia y la adolescencia, tan frágiles e ingenuos, tan fértiles y proficuos, tan mágicos y creativos, donde osadía combina con imaginación, base donde se edifica la mayor obra de la vida: la persona humana en su dignidad y ciudadanía, iplenas, repletas, colmadas!

Hay un futuro entero para colorear, desteñir y volver a pintar otra vez, a borrar, a hacer y deshacer y rehacer, al final, como dicen Toquinho y Vinicius, en la canción acuarela que te encarna en vida: "Un niño camina y caminando llega a un muro. Y allí en seguida adelante esperando a la gente el futuro está. Y el futuro es una astronave que intentamos pilotar. No tiene tiempo ni piedad, ni tiene hora de llegar. Sin pedir licencia cambia nuestra vida. Después convida a reír o a llorar. En esa estrada no nos cabe conocer o ver lo que vendrá. El fin de ella nadie sabe bien, en realidad, adónde va a dar. Vamos todos en una linda pasarela."

Larga vida a ii Coordinfância!!

Por mí, Rafael Dias Marques, un pintor-artífice-aprendiz de las causas de la infancia. 


\section{NOTA}

1 Texto basado en el Discurso de Homenaje a la Coordinación Nacional de Combate contra la Explotación del Trabajo de Niñas, Niños y Adolescentes, proferido en ocasión de la solemnidad conmemorativa de sus 15 años. 


\section{INFORMALIDAD Y TRABAJO INFANTIL: LA COMPLEJIDAD DE LOS DESAFÍOS A LA REGULACIÓN SOCIAL DEL TRABAJO

\author{
RENATA QUEIROZ DUTRA \\ VALDEMIRO XAVIER DOS SANTOS JÚNIOR
}

DOI: $10.51366 / 978-65-89468-10-3-c o o r d i n f a n c i a-26$

Resumen: Este artículo tiene por objetivo discutir en qué medida el trabajo infantil se relaciona con la informalidad, arrojando luz sobre la importancia de que las políticas públicas dirigidas a la erradicación del trabajo infantil dialoguen con la expansión del mercado de trabajo formal, priorizando la regularización de los puestos de trabajo y el acceso a los derechos de ciudadanía, con Asociación complementaria a las políticas de transferencia de renta, de generación de renta y de acceso al crédito. A partir de un levantamiento de datos y estudios sobre el concepto y la composición de la informalidad, su exclusión en relación a las políticas sociales de Protección al trabajo y las complejidades generadas para nuestro mercado de trabajo, notablemente a la luz de marcadores raciales y de género, se revisita la producción científica que vincula la incidencia del trabajo infantil a los contextos de informalidad, cuestionando la simplificación consistente en atribuir la causalidad del trabajo infantil exclusivamente a la pobreza. Por último, el artículo conecta los debates sobre la disputa por una regulación social del trabajo centrada en la idea de protección, a partir de los parámetros internacionales y constitucionales, y la lucha por la implementación de la doctrina de la protección integral a la infancia.

Palabras clave: Trabajo infantil. Informalidad. Regulación del trabajo. Protección completa.

Para Elis. 


\section{INTRODUCCIÓN}

La explotación del trabajo infantil es una herida histórica de las sociedades capitalistas. Desde sus inicios, se ha presentado con mayor intensidad en contextos de pobreza, subdesarrollo y sobreexplotación. Si el derecho del trabajo se afirma en el devenir histórico como tecnología fundamental para la preservación de la vida y de niveles civilizadores mínimos de cohesión social, la erradicación del trabajo infantil se coloca como una de las premisas del cumplimiento de esa misión.

El desarrollo de la idea de protección a la infancia, con el sofisticado perfeccionamiento de la doctrina de la protección integral, consolida, además del sellado del trabajo precoz, el deber público de asegurar a los niños y a los adolescentes desarrollo sano y pleno, por medio de la urgencia de políticas públicas que dialoguen con las complejidades de los riesgos a que están expuestos.

A partir de ese sesgo, el presente artículo tiene por objetivo discutir en qué medida el trabajo infantil se relaciona con otro problema estructural del mercado de trabajo brasileño: la informalidad, arrojando luz sobre la necesidad de que las políticas públicas dirigidas a la erradicación del trabajo infantil dialoguen con la expansión del mercado de trabajo formal y, sobre todo, con la priorización de la afirmación de derechos de ciudadanía y de la regularización de los puestos de trabajo, correlacionadas, de modo complementario, con las políticas de crédito y de generación de renta ${ }^{1}$. Este artículo se compone de esta introducción y cuatro partes más.

En el primer ítem, será realizado un levantamiento de datos y estudios sobre el concepto y la composición de la informalidad, su exclusión con relación a las políticas sociales de protección al trabajo, y las complejidades generadas para nuestro mercado de trabajo, notablemente a la luz de marcadores raciales y de género.

En el segundo ítem, revisaremos la producción científica que vincula la incidencia del trabajo infantil a los contextos de informalidad, cuestionando la simplificación consistente en atribuir la causalidad del trabajo infantil exclusivamente a contextos de pobreza, en ausencia de otros marcadores de exclusión relevantes. 
En el tercer ítem, procuraremos conectar los debates sobre la disputa por una regulación social del trabajo centrada en la idea de protección, a partir de los parámetros internacionales y Constitucionales de tutela de los trabajadores en sentido amplio, y la lucha por la concretización de la protección integral a la infancia.

Por último, presentaremos las consideraciones finales.

La elaboración del artículo proviene de una investigación teórica interdisciplinaria, proveniente del diálogo de saberes económicos, sociológicos, jurídicos y del campo del Servicio social, siempre desde una perspectiva interseccional, en la cual se considera la inseparabilidad estructural de las opresiones de raza, género y clase (AKOTIRENE, 2018).

\section{INFORMALIDAD Y DESPROTECCIÓN SOCIAL}

Hay una serie de cuestionamientos respecto a la categoría "informalidad", que se refieren a su potencial de explicación de los fenómenos recientes de reestructuración del mercado capitalista (nueva informalidad) y de las antiguas formas de trabajo precarias (vieja Informalidad), especialmente por la significativa gama de fenómenos que abarca y por las diferentes concepciones que circulan en el sentido común, en la academia y en la formulación de políticas públicas (KREIN; PRONI, 2010). En ese tópico, se objetiva extraer de los conceptos abordados instrumentos útiles para la contextualización del trabajo infantil con relación a la informalidad.

\subsection{La evolución del concepto de informalidad}

Como señalan Krein y Proni, a principios de los años 70, la Organización Internacional del Trabajo (OIT) dirigía su alcance de comprensión a la parte significativa de la población de los países periféricos no incorporados al avance de las relaciones mercantiles modernas (KREIN; PRONI, 2010). El concepto de "sector informal urbano" fue fundado delante de la creencia que el estándar asalariado formal y provisto de protección social era un destino inexorable a la marcha capitalista, existiendo sectores atrasados y que aún no se habían incorporado a su dinámica, engendrando otras estrategias de supervivencia. Las "actividades informales" serían aspectos residuales de una sociedad en proceso de modernización y el papel del Estado sería incorporar 
ese contingente humano al mercado de trabajo formal (KREIN; PRONI, 2010, p. 8).

La denominación "sector informal" hacía referencia a las actividades al margen del estándar fordista de asalariado formal en el contexto urbano (acuñado de sector tradicional), ambiente en el que florecía el "desarrollo", la introducción al progreso técnico y la expansión urbana. Por lo tanto, el sector informal tendría una "funcionalidad": absorber el exceso de fuerza de trabajo en los momentos de desaceleración de la economía y proporcionar fuerza de trabajo en un escenario de crecimiento - puerta de entrada al mercado formal. Esas actividades serían marcadas por su carácter inherente "a la supervivencia del individuo o su grupo familiar, baja productividad, desprotección desde el punto de vista social y de los derechos fundamentales, además de ser encampadas por 'cuenta propia' o por 'emprendimientos muy pequeños"” (KREIN; PRONI, 2010, p. 8).

La identificación de la existencia del sector informal con la no absorción de la población económicamente activa en puestos de trabajo formales y asalariados, en virtud de la insuficiencia del crecimiento económico, dirigió las investigaciones sobre el tema a analizar los problemas relacionados a la generación de empleo y a formular acciones de combate a la pobreza. Se creía que la tendencia del sector informal era la desaparición a partir de la expansión económica y de la formalización de algunas actividades, por medio de una postura selectiva del Estado frente al fomento de actividades informales que deberían prosperar y otras que deberían desaparecer como resultado de la competencia inter capitalista (KREIN; PRONI, 2010).

Iniciada la década de los $90^{2}$, nuevos procesos sociales fueron incorporados a la dinámica capitalista, notablemente relacionados a la adaptación de las empresas modernas frente a la inestabilidad de la demanda y a la incorporación de medidas de descentralización productiva asociadas a la subcontratación de empresas y de fuerza de trabajo (KREIN; PRONI, 2010).

El crecimiento del desempleo y la reaparición de formas precarias de trabajo dirigieron el debate hacia dos caminos distintos: eliminar el conjunto heterogéneo de actividades que constituían el sector informal de la economía; o aprovechar el potencial de generación de ingresos y ocupaciones para la mayor parte de la población desprovista. La OIT optó por el punto medio de 
la época, que consistía en apoyar al sector informal rechazando las situaciones de extrema explotación y condiciones de trabajo inhumanas.

En 2002, la OIT pasó a utilizar el término “economía informal”, con el reconocimiento de la importancia social y política de esas actividades, otrora condenadas a la desaparición con el crecimiento económico. Se presupone la existencia de distintos grados de formalización en la estructura económica, que van desde la informalidad absoluta hasta la formalidad total (una especie de escala de protección). Esta concepción también permitía una importante distinción dentro del fenómeno de la informalidad: las situaciones relacionadas a los sectores no estructurados de la economía y aquellas relacionadas a la ejecución de manera informal en los sectores organizados de la economía capitalista.

La intervención estatal imaginada, delante del cuadro arriba citado, debería tener carácter gradual, objetivando la reducción del hiato entre el estándar de empleo definido para las actividades formales y las condiciones relacionadas al trabajo informal. El reconocimiento legal de las actividades informales sería necesario, así como el acceso a un conjunto de derechos y protecciones sociales, además de la representación de sus derechos ante los Estados (KREIN; PRONI, 2010).

En el contexto nacional, los debates se vuelven más sistemáticos también en la década de los 70, con interés investigativo en el sector informal urbano. De ese marco, surgieron y predominan tres tipos de abordaje más delimitados (THEODORO, 2000).

Inicialmente se utilizó el enfoque técnico, para el cual el desarrollo económico es un fin que justifica los medios. La informalidad sería una anomalía transitoria, fruto de las rápidas y violentas transformaciones de los países en vías de desarrollo. Se reservaba al Estado el papel de formalización de esas actividades, una vez que la informalidad sería automáticamente extinguida con el alcance del status de país desarrollado (THEODORO, 2000, p. 10).

Por otra vía, el abordaje político (gestado en el período de la nueva República, en medio del aumento del desempleo, de la informalidad y de un proceso inflacionario creciente) considera la informalidad como un problema no solamente económico, sino social, con perspectiva en el rescate de la ciudadanía (THEODORO, 2000, p. 12). Esta no sería una anomalía también transi- 
toria del funcionamiento del mercado de trabajo, pero una posible solución al desempleo contextual y una estrategia de supervivencia debido a las ausencias de empleo y de un sistema de seguridad universalizado. Las políticas públicas deberían ser dirigidas al aspecto de la formalización de las actividades laborales en paralelo a una política social de carácter fragmentado y asistencialista.

Por último, el último abordaje sería la subsidiaria, que tiene su guarida en la reestructuración productiva y en la redefinición del papel del Estado, siendo una reinterpretación "a la brasileña" del discurso neoliberal (THEODORO, 2000, p. 14). Se considera en esta perspectiva que cada trabajador informal sería un pequeño emprendedor potencial, que debería ser apoyado por medio de políticas crediticias, y regulado por el mercado en sus demandas prioritarias. En este enfoque, hay una pérdida sustancial en el carácter "transformador" de la política pública en la realidad social. En ese sentido, las políticas públicas dirigidas al apoyo del sector informal padecieron esas deficiencias de concepción, así como fueron marcadas por el clientelismo, por acciones corporativas y por injunciones políticas. ${ }^{34}$

En la búsqueda del perfeccionamiento teórico del concepto de informalidad, es importante destacar la delimitación de tipos conceptuales que retratan sus diferentes formas. La vieja Informalidad estaría consustanciada en la insuficiencia en la generación de empleos y absorción de la población económicamente activa, lo que tendría como consecuencia la concretización de estrategias de supervivencia. La informalidad neoclásica está relacionada a la racionalidad de las empresas en la búsqueda por reducción en el costo derivado de la legislación laboral. Por último, la nueva Informalidad o Informalidad post-fordista resulta de la introducción del progreso técnico y nuevas formas de organización del trabajo (KREIN; PRONI, 2010, p. 20). La concepción de Nueva Informalidad, atribuida a los cambios estructurales del capitalismo y a la precariedad del trabajo, ganó fuerza en la primera década del siglo XXI, acoplando actividades formales e informales, y distinguiéndose de la vieja informalidad, que remite al carácter inherente a la supervivencia.

En otra perspectiva, Cacciamali (2000) añade al debate el concepto de proceso de informalidad, que se refiere a los cambios estructurales en curso en la sociedad y en la economía, que inciden en la redefinición de las relaciones de producción, de las formas de inserción de los trabajadores en la producción, de los procesos de trabajo y de instituciones. En el contorno del proceso de informalidad, se estaría aprehendiendo tanto determinadas 
formas de organización de la producción que envuelven el trabajo por cuenta propia y el trabajo para microempresas, con baja organización y productividad, en el cual las figuras de empleado y empleador se confunden en la búsqueda por la supervivencia, como las diferentes formas de asalariado ilegal.

Este segundo grupo estaría compuesto por empleos sin registro o sin derecho a la protección social, así como por una expansión de los contratos atípicos, como el trabajo temporal, las cooperativas de trabajo y los contratistas de mano de obra. Cacciamali (2000) considera este concepto relevante para examinar los cambios en la relación de producción y en la inserción en el mercado de trabajo contemporáneamente, una vez que no habría una dicotomía estanca entre mercado formal e informal, sino un continum de situaciones que pueden ser observadas tanto del lado de la demanda como de la oferta de trabajo. Lo que definiría esta Informalidad sería la precariedad del trabajo, desprovisto de la protección de las leyes laborales y previsionales establecidas en normas públicas estatales y negociaciones colectivas.

\subsection{Informalidad, raza y género}

Sumado a este proceso, hay un estructural componente racial en el fenómeno de la informalidad, que afecta desigualmente a la población e indica la construcción social del lugar del negro en el mercado laboral ${ }^{5}$. La narrativa preponderante construida sobre el trabajo (y sobre el propio derecho del trabajo) en Brasil fue conducida en dirección diversa a este reconocimiento, identificando la historia del trabajo en el territorio nacional con la historia del trabajo libre, asalariado, marcado por la exclusión de trabajadoras y trabajadores negros, a pesar de su papel fundamental para la producción y generación de riquezas (ALVES, 2019).

Los estudios elaborados-considerándose las particularidades de la formación del mercado de trabajo libre en Brasil después de la abolición-indican que es fundamental atentar que, mientras el mercado de trabajo formal (posteriormente protegido por la legislación laboral) fue resguardado al trabajador blanco inmigrante, a partir de una política deliberada e incisiva del gobierno brasileño de blanqueo de la población, al negro liberado fueron relegadas las posiciones mal remuneradas y comprendidas como relacionadas a la "economía de subsistencia", en especial en el sector de servicios. Más tarde, es este 
conjunto el que va a dar origen al "sector informal" en Brasil (THEODORO, 2005), en un proceso que se ha reproducido históricamente.

No es posible comprender la informalidad de modo apartado de la segregación racial en Brasil ${ }^{6}$ porque el significado de la abolición en el país fue multifacético. Hubo pérdida de espacios de trabajo por los ex esclavizados, que fueron empujados en un proceso de urbanización pauperizada y precarización del trabajo, especialmente en el sector informal. En otra perspectiva, la incorporación del negro al mercado de trabajo "libre" fue aliada de una integración a las esferas política y de ciudadanía, elementos que significaban, en la realidad concreta, el acceso a la tierra, al trabajo y a la movilidad para pensar y actuar (ALVES, 2019, p. 21). Para Theodoro, no es posible pensar pobreza y exclusión en Brasil de forma apartada de los destinos de los ex esclavizados y de su reproducción (2005), en los cuales el trabajo informal jugó (y juega) un papel central.

Se trata, en gran medida, de los desdoblamientos generacionales de los "ganadores" (REIS, 2019): personas, predominantemente negras, que persistieron, desde el post esclavitud, comprometidas en el trabajo informal por medio de la actividad de ganancia, porque no fueron absorbidas por las formas jurídicamente tuteladas de trabajo ni fueron insertadas socialmente de forma satisfactoria para que pudieran a ellas habilitarse. Ese segmento estructural de nuestro mercado de trabajo ha sido estudiado por la literatura reciente, sobre todo por los estudios centrados en la cuestión racial (ALVES, 2019), no como figura ACCIDENTAL en los momentos de crisis, sino como marcador central de nuestro mercado de trabajo que, en momentos de crisis y en función del discurso neoliberal, tiende a crecer, "tragando" rebanadas del mercado de trabajo formal.

El escenario presenta especial vulnerabilidad a la fuerza de trabajo femenina, y notablemente a las mujeres negras, cuyas ocupaciones históricas en el trabajo doméstico y de cuidado remunerado ${ }^{7}$, en el comercio de calle y en las relaciones de asalariado ilegal determinadas por la intensa precariedad o por el ocultamiento de vínculos (trabajadoras tercerizadas de limpieza en situación de desprecio a los derechos laborales, vendedoras de cosméticos, trabajadoras “autónomas" en salones de belleza, entre otras) tienden a encontrar rendimientos más bajos que los masculinos y protección social incompatibles con las cargas familiares asumidas por ese conjunto, acumulando las condi- 
ciones de subyugación y abuso de la fuerza física, que Angela Davis (2016, p. 19) y Patricia Hill Collins explicitan en sus obras (2019, P. 107-108).

Delante de ese cuadro, en que subsisten actividades ejercidas como "una estrategia de supervivencia o de complementación de la renta" (vieja informalidad) y situaciones creadas que "tienden a burlar el arquetipo protector que posibilita el acceso de los obreros a la previsión social y a los derechos laborales" (nueva informalidad), en continuo proceso intercambiable, profundizadas por los marcadores de género y raza, es que se inscribe este análisis sobre la regulación social de la informalidad relacionada al trabajo infantil. ${ }^{8}$

\section{TRABAJO INFORMAL Y TRABAJO INFANTIL: CONE- XIONES MÁS ALLÁ DE LA POBREZA}

La vasta literatura disponible respecto a la explotación del trabajo infantil es unísona en el sentido de que el reclutamiento del trabajo infantil por parte de las familias no proviene de decisiones autónomas o de contexto individuales: se trata de problemática que integra la cuestión social y forma parte de la propia constitución del sistema capitalista de producción (LOURENÇO, 2014). Las actividades empresariales a escala global producidas en el capitalismo contemporáneo interconectan multinacionales a empresas de menor porte o a individuos que trabajan por cuenta propia al gusto de su propio riesgo, originando una especie de inframundo laboral, en virtud de la búsqueda de menores costos de producción. Existe así un proceso de construcción de realidades distintas de producción, las cuales forman parte de la misma dinámica económica de precariedad (ANTUNES, 2018).

Al mismo paso, como observa Edvânia Lourenço (2014), el contexto de precariedad de las familias se alía a un discurso ideológico ratificador del trabajo infantil, que se basa en la premisa de que el trabajo precoz sería una forma eficiente de prevención a lo que se designa marginalidad, inclusive con carácter educacional. Tal perspectiva criminal evidentemente parte de una percepción limitada de la problemática, porque acentúa y privilegia - entre las múltiples causalidades de la criminalidad reprimida por el Estado - la intencionalidad del sujeto y no los mecanismos perversos de selectividad y exclusión social que la informan. Para ella, el acoplamiento de esos dos elementos - precariedad familiar y discurso ideológico - conduciría a una perpetuación de la situación de los padres por los hijos: el trabajo informal se ligaría a esa 
cadena en la medida en que es él el responsable por los menores ingresos familiares, que, a su vez, inducen a la demanda de los padres por el trabajo de sus hijos (LOURENÇO, 2014).

El denominado "trabajo de supervivencia", marcador de la antigua Informalidad, cuya ejecución tiende a suceder, en gran medida, en el espacio privado de los domicilios de los trabajadores, con baja productividad y desprovisto de protección social, sería un facilitador de inserción de los niños en la dinámica de vida y trabajo de sus respectivas familias, sea porque esas dos esferas acaban por confundirse, sea por tornar el ambiente laboral sumiso a la fiscalización estatal (LOURENÇO, 2014).

De forma análoga, Souza, Bidarra y Staduto (2012) comprenden la relación entre trabajo infantil e informalidad, considerando que los sujetos que componen el conjunto de los trabajadores informales se caracterizan, además de la baja renta proveniente de su labor, por la baja calificación. Para los autores, el trabajo en la infancia y el perjuicio derivado de él para la escolarización implican la limitación de las oportunidades de inserción en el mercado de trabajo, siendo definidor también de una relación inversa entre trabajo infantil e informalidad, que engendraría la transmisión intergeneracional del trabajo infantil.

Investigación realizada en Paraná que cruza los datos sobre informalidad y escolarización identifica la presencia mayor de originarios del trabajo infantil en la informalidad que en la formalidad y permite dibujar con mucha claridad un ciclo que envuelve "trabajo informal - baja renta-baja renta familiar-trabajo infantil - no escolarización-trabajo informal-renta baja y nuevamente trabajo infantil" (SOUZA; BIDARRA; STADUTO, 2012, p. 17).

Además de esas conexiones, vale cosechar la contribución más específica de Cacciamali, Batista y Tatei (2011) en cuanto a la causalidad entre la forma de inserción del cabeza de familia y la propensión al trabajo infantil. Las autoras puntúan, a partir de amplio levantamiento empírico, que la comprensión de las dinámicas que engendran el trabajo infantil no puede limitarse a la cuestión de la renta y, por lo tanto, al escenario de pobreza. De acuerdo con la teoría económica, la demanda de trabajo infantil proviene de al menos cuatro factores: sustitución en alguna escala del trabajo del adulto por el del niño, menor costo del trabajador en este grupo de edad, poca capacidad de 
organización de ese grupo y legislación apropiada y su aplicación (CACCIAMALI; BATISTA; TATEI, 2011, p. 13).

Evidentemente, no hay margen empírico para entender que el trabajo informal, por regla general, permite el alcance de ingresos superiores al del trabajo formal. Sin embargo, durante el trato metodológico e investigación de datos, las autoras evidencian puntos para comprensión de la situación. Cacciamali et al. Se separaron dos grupos de análisis de acuerdo con la referencia de sustento familiar: aquellas familias que poseen renta oriunda de trabajo asalariado formal y aquellas que poseen renta oriunda del trabajo por cuenta propia. Excepto en la situación de profesionales liberales, el trabajo infantil es utilizado de forma más intensa en las familias con Renta oriunda del trabajo por cuenta propia, una vez que se considera la participación del niño o adolescente como una estrategia de reducción de costos, además de un elemento de confianza y de garantía para operar y mantener el pequeño negocio (CACCIAMALI; BATISTA; TATEI, 2011).

Es interesante notar, por ejemplo, que, aunque la renta familiar de las familias que poseen trabajo relacionado al empleo doméstico (asalariado formal) sea menor, la intensidad de utilización del trabajo infantil en ese grupo es inferior a la encontrada en las familias cuya renta proviene de actividades por cuenta propia (CACCIAMALI; BATISTA; TATEI, 2011, p. 14), evidenciando la complejidad del fenómeno, no explicado solamente por la pobreza o rebaja de la renta.

Otro aspecto relevante que suplanta el criterio unidimensional del ingreso y de la pobreza es que el trabajador por cuenta propia, por asumir lo que llaman "riesgo gerencial de la renta", tiene más incentivo para reclutar el trabajo de la familia y de los niños, una vez que ese recurso impacta directamente en su ingreso y también en su capacidad de enfrentar las adversidades (CACCIAMALI; BATISTA; TATEI, 2011).

Por regla general, las familias menos acomodadas, por no poseer ahoroos o activos líquidos o, aún, por no poseer acceso a créditos, acaban haciendo uso del trabajo infantil como forma de garantía de enfrentamiento a la inconstancia de los ingresos. El proceso de informalidad, al señalar la interrelación de las formas de trabajo ligadas a la nueva y a la vieja Informalidad, también explicita que su predominancia como precariedad impacta en la intensificación del trabajo infantil. 
El patrón asalariado formal socialmente protegido inhibe la necesidad de utilización de la fuerza de trabajo infantil, como forma de administración de riesgos, una vez que existe para esos adultos la posibilidad de recurrir a las garantías instituidas en la pantalla pública de protección social. Una vez que el proceso de informalidad aleja las relaciones laborales de ese estándar, el vínculo entre las violaciones y vulnerabilidades mencionadas se presenta.

En ese sentido, estudios producidos en Brasil demuestran que el status ocupacional de los padres repercute en la propensión al trabajo infantil de modo más relevante que la renta familiar o que la propia asistencia escolar que suele ser muy apuntada, inclusive en el sentido común. Cacciamali et al. explican que los trabajadores formales administran los riesgos y las posibilidades de pérdida del ingreso por medio de la pantalla de Protección social (seguro-desempleo, indemnizaciones rescisorias, saqueo del FGTS, inserción previsional), mientras que los trabajadores informales tienden a encontrar como única alternativa para riesgos y pérdidas de ingreso la propia base familiar, lo que incluye niños y adolescentes (CACCIAMALI; BATISTA; TATEI, 2011, p. 17).

La contundencia de esa conclusión tiende a ser nublada por el hecho de que, salvo raras excepciones, la renta del trabajo formal suele ser superior a la del informal, pero el aislamiento de las variables permite observar que hay mayor propensión al uso del trabajo infantil entre los trabajadores por cuenta propia que entre los empleados, así como determinadas peculiaridades geográficas (mayor propensión al uso del trabajo infantil en el campo que en la ciudad y mayor incidencia en las regiones Sur y Sudeste que en el Nordeste).

Por lo tanto, es posible admitir que Empleo e renta familiar son variables significativas para prevenir el trabajo infantil (CACCIAMALI; BATISTA; TATEI, 2011), lo que invita a un importante direccionamiento de las políticas públicas dirigidas a la erradicación del trabajo infantil al enfrentamiento del ya citado contexto de informalización del mercado de trabajo, que es tendencia global de la actual cuadra del capitalista (ANTUNES, 2018) y se intensifica en Brasil después de la Reforma Laboral (leyes n. 13.429 y N. ${ }^{\circ} 13.467 / 2017$ ).

Esa elucidación es significativa para pensar políticas públicas dirigidas a la prevención del trabajo infantil en áreas asoladas por la pobreza. Poner crédito a la generación de renta de los adultos, por sí solo, a el combate al trabajo infantil, puede significar la construcción de políticas públicas pautadas 
en diagnósticos incompletos, que no capturan la complejidad de esa realidad y que nublan el relevante papel de la regulación protectora del trabajo para una actuación concertada contra el trabajo infantil (CACCIAMALI; BATISTA; TATEI, 2011).

El discurso de incentivo al emprendimiento funda una perspectiva de la racionalidad neoliberal para el trabajo y para la formación de sujetos-empresas (DARDOT; LAVAL, 2016), desconectados de sus trayectorias de clase, género y raza. Su fomento por medio del microcrédito, oriundo de una perspectiva de Estado irresponsable frente a la informalidad (abordaje subsidiario), puede resultar en estímulo a arreglos empresariales cuya rentabilidad se pauta en la estafa a la regulación protectora del trabajo y que se asocia, indirectamente, a formas de facilitación del trabajo infantil.

También en ese sentido, las políticas de transferencia de renta, como el Programa Bolsa Familia ${ }^{9}$, en las cuales se destacan el impacto en la escolarización y en la inhibición del trabajo infantil en virtud del aumento de la renta de las familias, no tiene evaluación positiva consensual por parte de los investigadores del área. Algunos señalan que programas en este formato no han tenido impactos idénticos - tampoco persistentes-sobre todo en regiones rurales, con amplia tradición de agricultura familiar y en algunos Domicilios pobres. Aunque actúan para reducir el trabajo infantil, en algunas regiones, como consecuencia de la reducción de la pobreza, estas políticas no tienen capacidad de eliminar focos de persistencia del trabajo infantil en lapsos temporales más amplios. Por lo tanto, se señala que las políticas de lucha contra el trabajo infantil tampoco pueden centrarse exclusivamente en la transferencia de ingresos e ignorar variables como la escolarización y la formalización del mercado laboral (RAMALHO; MESQUITA, 2013).

Por otro lado, pero en el mismo diapasón, la comprobación de que Familias bajo responsabilidad de un trabajador por cuenta propia tiene mayor probabilidad de insertarse precozmente en el mercado de trabajo, gracias a la posibilidad de que sus responsables puedan hacer uso productivo del trabajo infantil, señala una inconveniencia en los patrones de fomento solamente basados en el microcrédito (CACCIAMALI; BATISTA; TATEI, 2011).

Evidenciado el enlace delicado entre el status ocupacional de los padres y la propensión al trabajo infantil, se profundizan otros marcadores relevantes en la reproducción de la cadena entre informalidad y trabajo infantil: 
si hay una reproducción histórica del trabajo informal entre personas negras y si, dentro de ese seguimiento, actividades de menor rendimiento y estereotipadas son ejercidas por mujeres, se considera la especial victimización, por el trabajo infantil, de los niños negros, con acentuación de la explotación para aquellas del género femenino, en una reproducción de trayectorias familiares y de caracteres étnico-raciales y de género que concretizan la reproducción de ciclos de pobreza, racismo y opresión femenina ${ }^{10}$.

\section{LA DOCTRINA DE LA PROTECCIÓN INTEGRAL Y LA REGULACIÓN SOCIAL DEL TRABAJO: UNA INTERSEC- CIÓN COMPLEJA}

Demarcado conceptualmente el grupo heterogéneo y las diferentes situaciones cubiertas cuando se trata de informalidad, así como explicitada su composición racializada y estructural desde el punto de vista económico, en el contexto brasileño, el denominador común al que se llega es que la informalidad se presenta como producto de omisiones significativas de la regulación protectora del trabajo, así comprendida aquella amparada en el constructo normativo constitucional en su promesa de efectividad.

La ausencia de protección social derivada de dichas omisiones de la regulación protectora es multifacética y profunda. En el sentido de una omisión histórica, se concreta cuando nos referimos, por ejemplo, a las trabajadoras domésticas sin cartera firmada y a los vendedores ambulantes - pues son de sujetos presentes en el funcionamiento de la reproducción social del país, desde la esclavitud, y cuyas formas de trabajo y existencia no fueron absorbidas por una pantalla pública de Protección al trabajo y de concretización de la ciudadanía. En el sentido de una exclusión derivada de las disputas en torno al proceso dialéctico de regulación social del trabajo (DUTRA, 2018), ella se afirma cuando la prescripción protectora no alcanza la dimensión de la efectividad, porque el incumplimiento legal por parte de los empleadores encuentra en la indulgencia, o incluso en la velocidad de la actuación de las instituciones y actores de Protección, una importante guarida para la persistencia de situaciones de informalidad que resultan de la ilicitud (FILGUEIRAS, 2012; CARDOSO; LAGE, 2007), concretizando lo que Antonio Casimiro Ferreira denomina de derecho subversivo del trabajo (2012). Vale destacar que las fallas de la regulación institucional inciden con mayor frecuencia entre grupos vulnerables, como mujeres y personas negras, incluso cuando se trata 
de trabajo formal, como apuntan investigaciones sobre la temática (DUTRA, 2018).

Por otro lado, la construcción de la doctrina de la protección integral de la niñez, en el marco de los instrumentos internacionales de protección que han sido ratificados por la Argentina, y de las normas internas, se diseñó en el año 1924, con la Declaración de Ginebra, a través de la Declaración de los Derechos del Niño de 1959, de la Constitución Federal de 1988, la Convención de las Naciones Unidas sobre los Derechos del Niño (1989) y en el Estatuto del Niño y del Adolescente - ECA (Ley n. ${ }^{\circ}$ 8.069/90).

Este complejo de desarrollo que se está produciendo en torno a las diez afirmaciones de protección que garanticen a los niños y a los adolescentes el derecho a un trato igualitario y la no discriminación, el derecho a la protección especial de las oportunidades y los recursos que les apoyen el desarrollo de todas las potencialidades de las diferentes dimensiones del derecho a un nombre y a una nacionalidad; el derecho a las prestaciones de la seguridad social ${ }^{11}$; el derecho a un trato especial, en vista de su condición de discapacidad; el derecho a un desarrollo completo de su personalidad; el derecho a la educación; el derecho a la atención prioritaria; y, el derecho a no ser tratados de diferentes formas crueles o perversas, de los que no estén en situación de trabajo infantil (RIBEIRO, 2014).

En este conjunto se destacan las protecciones especiales laborales, que, en el ámbito de la Organización Internacional del Trabajo, fueron transmitidas por medio de las primeras Convenciones de la OIT (Convenios n. ${ }^{\circ}$, n. 6 y n. ${ }^{\circ} 7$ ), consolidadas por medio de las Convenciones n. ${ }^{\circ} 138$ y n. ${ }^{\circ} 182$, además de inseridas de forma difusa en diversos convenios especiales de la OIT y, también, en su reciente Agenda para el Trabajo Decente. Los desafíos a la concretización de una protección amplia y multidimensional a los niños y adolescentes, traducida en el principio del mejor o mayor interés del niño (RIBEIRO, 2014), tienen su amplitud acentuada en función de la dimensión de la desigualdad social y de la existencia de discriminaciones de género y raza en una nación.

En la efectividad de ese estándar universal en países en desarrollo, violentados por profundos procesos de pauperización y exclusión, hay que considerar las diversidades y las cuestiones político-económicas que asolan la realidad de esos países. La formación específica y singular de los mercados de trabajo, la calidad de la regulación del trabajo y la naturaleza de la ocupación 
de los adultos, así como los procesos de exclusión a los que éstos se encuentran sometidos son elementos fundamentales en la política de lucha contra el trabajo infantil, en la medida en que considera ese riesgo social - además de una elección ética o individual de las familias - como resultado de procesos estructurales. Los escenarios de profundo aligeramiento de derechos sociales operan según modos de vida incompatibles con el desarrollo pleno y seguro de niños.

En la articulación de esas estructuras, pensar la informalidad como indicador y como cuestión social a ser tratada en conjunto - y como premisa - para el combate al trabajo infantil dialoga con los datos de la OIT que evidencian que en las economías emergentes y pobres es común que más de la mitad de la fuerza de trabajo esté comprometida en las franjas de la informalidad. Algunos de ellos, con destaque para los países latinoamericanos, africanos y asiáticos, poseen el $70 \%$ de la fuerza de trabajo en la informalidad (v. g. Bolivia, Perú, Indonesia, Pakistán, Tanzania, Malî), alcanzando el 90\% en la India (NICOLI, 2016). Estos datos, no por casualidad, coinciden con aquellos indicadores de concentración del trabajo infantil, que revelan la mayor incidencia del trabajo infantil en Asia y el Pacífico, seguida por las regiones del África subsahariana y de América Latina y el Caribe (ILO, 2011 apud RIBEIRO, 2014, p. 25).

Como observa Pedro Augusto Gravatá Nicoli, el trabajo en condición de absoluta precariedad siempre convivió con el empleo regulado (2016), siendo pertinente considerar la composición heterogénea de la "clase-que-vive-del-trabajo" (ANTUNES, 1999), incluyendo todos aquellos que viven de su trabajo, inclusive en la condición de desempleados e informales. En las últimas décadas del siglo $\mathrm{XX}$, sin embargo, con el advenimiento de la reestructuración productiva y las transformaciones por las que ha pasado el sistema capitalista de producción, lo que antes eran los márgenes del sistema se expande de tal forma que pasa a ocupar su centro, desafiando los sistemas instituidos de protección laboral a recolocar sus criterios (NICOLI, 2016).

De ahí porque el desafío, para el derecho del trabajo, de dejar de tratar la informalidad como externalidad indeseable y provisional, y pasar a utilizar sus tecnologías y arreglos jurídicos para pensar formas de alcance de ese grupo, como por otra parte ya se encaminan las perspectivas de protección a nivel internacional, en una recomposición de cuadros protectores que recupera 
la vocación original de la regulación laboral y promueve un ajuste de cuentas con los márgenes históricos de segregación (NICOLI, 2016, p. 74).

En ese sentido, Nicoli explica que, desde 1999, la OIT firma la necesidad de preocuparse por todos los trabajadores-asalariados, no regulados, por cuenta propia y domésticos - haciéndolo por medio de la agenda del trabajo decente (NICOLI, 2016, p. 115). A partir de entonces, la OIT define su misión institucional con base en una concepción de global de protección que implicó reconocer que todos los que trabajan y necesitan de protección tengan derechos, lo que implica decir de la aplicabilidad de todas sus convenciones a las relaciones de trabajo en sentido amplio, así como de un deber general establecido para los Estados, de Protección al trabajo en amplitud similar, con compromiso de medidas ejecutivas, legislativas y judiciales para tanto (NICOLI, 2016, p. 117-121).

Se percibe, al articular informalidad y labor infantil, que el cuello de botella de las políticas públicas para las mencionadas cuestiones se encuentra, sobre todo, cuando identificado el trabajo infantil exclusivamente con la pobreza y no con los arreglos productivos que la determinan. Al reportar, además de la pobreza, el status ocupacional como elemento relevante, se revela imprescindible para la lucha al trabajo infantil el fortalecimiento para la lucha a las relaciones de trabajo fraudulentas e ilegales, así como el acampamiento de políticas públicas prioritarias enfocadas en derechos a la ciudadanía y a la inserción formal, las cuales pueden asociarse, apenas en adición al crédito y al emprendimiento, que ha sido capitaneados por la razón neoliberal (DARDOT; LAVAL, 2016).

El refuerzo de políticas de inclusión que dialoguen con la titularidad de derechos, dignidad y participación política evidencia un camino palpable de intervención en las trayectorias de familias que enfrentan el riesgo del trabajo infantil. El abordaje subsidiario de la informalidad, el matrimonio de sus pautas prioritarias con la agenda neoliberal, la exacerbación de la violencia del Estado Penal - inclusive de aquella oriunda del funcionamiento normal de la máquina pública - la selectividad y foco en las políticas públicas puramente asistenciales y la fragilización de la pantalla de protección social, por medio de reformas en el sistema laboral y previsional, son agravantes de las violaciones de los postulados de protección al niño y al adolescente, que se enredan en el todo complejo de la regulación social del trabajo. 


\section{CONSIDERACIONES FINALES}

De acuerdo con las conclusiones de la amplia investigación emprendida por Cacciamali (2010), la regulación de la nueva Informalidad presupone la disputa por la regulación y la efectividad de las disposiciones concernientes al asalariado y a la protección social. El envoltorio laboral asegura, además de la renta y subsistencia, dimensiones relevantes de construcción de la ciudadanía a nivel individual y colectivo, con amplitud de las familias y comunidades. Por otro lado, la comprensión de la vieja informalidad y de sus raíces históricas es esencial para la construcción de políticas públicas compatibles con ese sector, que objetiven el crecimiento económico y el reflejo crecimiento de las posibilidades de ganancia de los informales, asegurando sus derechos de ciudadanía y la reducción de su vulnerabilidad (CACCIAMALI, 2000).

Estas políticas de enfrentamiento a la problemática del trabajo informal se alinean al combate al trabajo infantil, en la medida en que esa llaga es atravesada, según importantes estudios (CACCIAMALI; BATISTA; TATEI, 2011; RAMALHO; MESQUITA, 2013), no sólo por situaciones de pobreza, sino por los arreglos productivos y ocupacionales que definen un determinado status de ciudadanía o de "subcidadanía" a los familiares de los niños que son colocados delante de ese riesgo.

La articulación e integración necesaria entre la doctrina de la protección integral y agenda del trabajo decente implican un fortalecimiento de la regulación social del trabajo, en cuanto política afecta al Poderes Públicos - al Ejecutivo, al Legislativo y al judicial - así como la priorización de políticas públicas que aseguren procesos de Ciudadanía e inclusión sólidos, no asegurados por políticas exclusivamente estructuradas en la transferencia de renta o en la adhesión a la tendencia neoliberal del microemprendimiento y del microcrédito.

\section{NOTAS}

1 Cabe destacar que "desde hace dos años, Brasil no sabe cuántos niños y adolescentes están trabajando en Brasil. La última información divulgada por el IBGE, responsable por el levantamiento de uno de los peores males brasileños, fue de 2016, divulgada al año siguiente. Eran 2,3 millones ese año. La divulgación de los datos de 2017 y 2018 estaba programada para junio del año pasado, pasó para noviembre, después marzo de este año y ahora, según el instituto, debe ocurrir en junio, ya trayendo los datos de 2019” (O GLOBO, 2020). Añádase a la información del reportaje que la divulgación de los datos arriba mencionados tampoco ocurrió en el mes de junio de 2020. 
2 La OIT redescutió la cuestión de la informalidad en 1993 en 15. ${ }^{a}$ International Conference of Labour Statisticians (KREIN; PRONI, 2010, p. 11).

3 Sin embargo, algunas características distintivas merecen prudencia en la discusión y conceptualización de la "informalidad brasileña". Inicialmente, se debe tener en cuenta que las desigualdades regionales producen diferentes escenarios de "informalidad", no siendo aplicable un concepto o interpretación única a las diversas situaciones surgidas en un país de dimensiones continentales y realidades distintas. Además, la preconcepción de que el trabajo informal actúa en áreas intersticiales es considerada equivocada, una vez que no corresponde a la realidad vivida en el país. En varias metrópolis, la oferta de productos por el comercio Callejero compite directamente con el comercio formal, a veces incluso compartiendo espacios contiguos.

4 Es necesario resaltar que el rechazo al concepto también debe ser considerado en las manifestaciones académicas. En primer plano, se argumenta su indeterminación (y menor especificidad) conceptual con el transcurso de la historia de su desarrollo, llevando a una ambigüedad infértil para tratar la realidad del mercado de trabajo nacional. Otra perspectiva crítica es la que considera que la nueva Informalidad no tiene carácter intersticial, proliferando con la lógica del sistema capitalista. La reestructuración productiva y la flexibilización transforman las relaciones formales en informales, y estas nuevas estrategias no estaban alterando el contenido de la subordinación, sino intensificando la explotación del trabajo. Por último, una tercera perspectiva crítica sostiene que, con la disipación del consenso sobre "estándares mínimos de legalidad", el concepto de informalidad pasa a ser problemático. La polisemia del término puede conducir a confusión en la interpretación de la situación diversa y completa.

5 Esa aproximación llama la atención sobre el hecho de que el prejuicio racial en Brasil acabó definiendo "el lugar" del negro en el mercado de trabajo, o sea, el negro pasa a ser visto preponderantemente en la desocupación, en la informalidad y en las ocupaciones con precarias relaciones de trabajo (MARTINS, 2012, p. 457).

6 Negros y pardos que componen la población negra del país son mayoría entre trabajadores desocupados $(64,2 \%)$ o subutilizados $(66,1 \%)$, según informativo Desigualdades sociales por color o raza en Brasil, divulgado hoy (13) por el Instituto Brasileño de Geografía y Estadística (IBGE). El levantamiento presentado en el mes en que se conmemora el día de la conciencia Negra (20/11) reúne datos de diversas investigaciones, como la síntesis de los Indicadores sociales, el Censo y, principalmente, la investigación Nacional por muestra de domicilio - continua (PNAD continua) de 2018. Actualmente, los negros representan el 55,8\% de la población brasileña y el $54,9 \%$ de la fuerza de trabajo. La informalidad también afecta más a este contingente. Mientras 34,6\% de personas blancas se encuentran en condiciones informales de trabajo, la informalidad alcanza 47,3\% de negros y pardos (Agencia BRASIL, 2019A).

7 "Un estudio realizado en asociación entre el Instituto de Investigación Económica Aplicada (Ipea), vinculado al Ministerio de planificación, y la ONU Mujeres, brazo de las Naciones Unidas que promueve la igualdad entre los sexos, compiló datos históricos del sector de 1995 a 2015 y construyó un retrato evolutivo de las nociones de raza y género asociadas con el trabajo doméstico. Los resultados demuestran el predominio de las mujeres negras a lo largo del tiempo. En 1995, había 5,3 millones de trabajadores domésticos en Brasil. De esos, 4,7 millones eran mujeres, siendo 2,6 millones de negras y pardas y 2,1 millones de blancas. La escolaridad promedio de las blancas era de 4,2 años de estudio, mientras que la de los afrodescendientes era de 3,8 años. Veinte años después, en 2015, la población general de esos profesionales creció, llegando a 6,2 millones, siendo 5,7 millones de mujeres. De esas, 3,7 millones eran 
negras y pardo y 2 millones eran blancas. El nivel escolar de las blancas evolucionó a 6,9 años de estudio, mientras que, en el caso de las afrodescendientes, llegó a 6,6 años" (WENTZEL, 2018).

8 La Investigación Nacional por Muestra de Domicilio (PNAD), encuesta más reciente del Instituto Brasileño de Geografía y Estadística (IBGE) que trata el asunto, muestra que hay 2,7 millones de niños y adolescentes entre 5 y 17 años en esa situación. En general, el número tiene tendencia a la baja, pero sigue siendo preocupante, principalmente en cuanto al grupo de edad de 5 a 9 años. Antes de cumplir 10 años de edad, 79 mil brasileños ya están trabajando - aumento del 13\% entre 2014 y 2015, en la comparación más reciente del IBGE (AZEVEDO, 2017).

9 No se trata aquí de desmerecer los resultados de tales políticas, que son incuestionables en la atenuación de las desigualdades sociales brasileñas, sino de problematizar, con base en resultados de investigaciones, sus límites específicamente con relación a la problemática abordada en este artículo.

10 Los datos del Instituto Brasileño de Geografía y Estadística (IBGE) de 2016 muestran que Brasil tiene 2,4 millones de niños y adolescentes entre 5 y 17 años trabajando. Los adolescentes negros y pardos corresponden a 66,2\% del total del grupo identificado en situación de trabajo infantil (AGENGIA BRASIL, 2019b).

11 En este campo, se resalta la decisión dictada en la acción Civil Pública n. ${ }^{\circ}$ 501726734.2013.4.04.7100, al admitir al menor de dieciséis años, como tiempo de contribución, el trabajo comprobadamente ejercido como ASEGURADO obligatorio, además de aceptar para la comprobación del ejercicio laboral los mismos medios probatorios puestos a disposición de los demás asegurados obligatorios mayores de dieciséis años, a excepción de aquellos asegurados al asegurado facultativo, en ámbito nacional.

\section{REFERENCIAS}

AGÊNCIA BRASIL. Negros são maioria entre desocupados e trabalhadores informais no país. [S.1], 2019a. Disponible en: https://agenciabrasil. ebc.com.br/economia/noticia/2019-11/negros-sao-maioria-entre-desocupados-e-trabalhadores-informais-no-pais. Acceso en: 17 mayo 2020.

AGÊNCIA BRASIL. Trabalho infantil ainda é preocupante no Brasil, diz fórum. [S.l], 2019b. Disponible en: https://agenciabrasil.ebc.com.br/ direitos-humanos/noticia/2019-06/trabalho-infantil-ainda-e-preocupante-no-brasil-diz-secretaria. Acceso en: 17 mayo 2020.

AKOTIRENE, Carla. O que é interseccionalidade? Coordenação: Djamila Ribeiro. Belo Horizonte: Letramento/Justificando, 2018.

ALVES, Raíssa Roussenq. Entre o silêncio e a negação: trabalho escravo contemporâneo sob a ótica da população negra. São Paulo: Ed. Letramento, 2019. 
ANTUNES, Ricardo. Os sentidos do trabalho: Ensaio sobre a afirmação e a negação do trabalho. 2. ${ }^{a}$ ed. São Paulo: Boitempo Editorial, 1999.

ANTUNES, Ricardo. O privilégio da servidão: o novo proletariado de serviço na era digital. São Paulo: Boitempo, 2018.

AZEVEDO, Alessandra. Trabalho infantil atinge 2,7 milhões de crianças e adolescentes no Brasil. In: Correio Braziliense, Brasília/DF, 11 jun. 2017. Disponible en: https://www.correiobraziliense.com.br/app/noticia/economia/2017/06/11/internas_economia,601710/trabalho-infantil-atinge-2-7-milhoes-no-brasil.shtml. Acceso en: 17 mayo 2020.

CACCIAMALI, Maria Cristina. Globalização e processo de informalidade. In: Economia e Sociedade, Campinas: Unicamp. I.E., n. ${ }^{\circ}$ 14, jun. 2000.

CACCIAMALI, Maria Cristina; BATISTA, Natália Nunes Ferreira; TATEI, Fábio. Padrões familiares de utilização do trabalho infantil. In: Revista da ABET, vol. X, n. ${ }^{\circ} 1^{\circ}$, jan./jun. 2011.

CARDOSO, Adalberto M; LAGE, Telma. As normas e os fatos. Rio de Janeiro: FGV, 2007.

COLLINS, Patrícia Hill. Pensamento Feminista Negro. São Paulo: Boitempo, 2019.

DARDOT, Pierre; LAVAL, Christian. A nova razão do mundo: ensaio sobre a sociedade neoliberal. São Paulo: Boitempo, 2016.

DAVIS, Angela. Mulheres, raça e classe. São Paulo: Boitempo, 2016.

DURÃES, Bruno José Rodrigues. Trabalho de rua, perseguições e resistências: Salvador no final do século XIX. In: Revista Brasileira de História \& Ciências Sociais, v. 4, n. ${ }^{\circ}$ 7, 2012.

DUTRA, Renata Queiroz. Trabalho, regulação e cidadania: a dialética de regulação social do trabalho. São Paulo: LTr, 2018.

FERREIRA, António Casimiro. Sociedade da Austeridade e direito do trabalho de exceção. Porto: Vida Económica, 2012. 
FILGUEIRAS, Vitor. Estado e direito do trabalho no Brasil: regulação do emprego entre 1988 e 2008. (Tese de Doutorado). Faculdade de Filosofia e Ciências Humanas da UFBA. 2012.

KREIN; José Dari; PRONI, Marcelo W. Economia informal: aspectos conceituais e teóricos. Brasília: OIT, 2010.

LOURENÇO, Edivânia Ângela de Souza. Reestruturação produtiva, trabalho informal e invisibilidade do trabalho de crianças e adolescentes. Serv. Soc. Soc. São Paulo, n. ${ }^{\circ}$ 118, p. 294-317, abr/jun 2014.

NICOLI, Pedro Augusto Gravatá. Fundamentos de Direito internacional social: sujeito trabalhador, precariedade e proteção global às relações de trabalho. São Paulo: LTr, 2016.

O GLOBO. Há dois anos, o Brasil não sabe quantas crianças trabalham no país. [S.1], [20--]. Disponible en: https://oglobo.globo.com/economia/ ha-dois-anos-brasil-nao-sabe-quantas-criancas-trabalham-no-pais-24188446. Acceso en: 17 mayo 2020.

RAMALHO; H. M. de B.; MESQUITA, S. P. de. Determinantes do trabalho infantil no Brasil Urbano: uma análise por dados em painel 2001-2009. In: Economia Aplicada. v. 17, n. ${ }^{\circ} 2,2013$.

REIS, João José. Ganhadores: a greve negra de 1857 na Bahia. São Paulo: Companhia das Letras, 2019.

RIBEIRO, Ana Carolina Paranhos de Campos. A doutrina da proteção integral nas dinâmicas internacional e brasileira: uma proposta quadrangular a partir do estudo da erradicação das piores formas de trabalho infantil. 262 p. Dissertação (Mestrado em Direito) - Universidade de Brasília, Brasília, 2014.

SOUZA, E. L. da C.; BIDARRA, Z. S.; STADUTO, J. A. R. A relação entre trabalho na infância e inserção do trabalhador adulto na informalidade. In: Revista da ABET, v. XI, n. ${ }^{\circ}$ 1, jan/jun 2012.

THEODORO, M. L. As bases da política de apoio ao setor informal no Brasil. Brasília: Ipea, 2000. (Texto para Discussão, n. ${ }^{\circ}$ 762). 
THEODORO, M. L. O estado e os diferentes enfoques sobre o informal. Brasília: Ipea, 2002. (Texto para Discussão, n.o 919).

THEODORO, M. L. As características do mercado de trabalho e as origens do informal no Brasil. In: JACCOUD, Luciana. (org.). Questão Social e Políticas Sociais no Brasil Contemporâneo. Brasilia: IPEA, 2005.

WENTZEL, Marina. O que faz o Brasil ter a maior população de domésticas do mundo. In: BBC Brasil, Suíça, 26 fev. 2018. Disponible en: https:/ /www. bbc.com/portuguese/brasil-43120953. Acceso en: 17 mayo 2020. 



\section{LA AUDITORÍA FISCAL DEL TRABAJO EN LA LUCHA CONTRA EL TRABAJO INFANTIL: EVOLUCIÓN E INSTRUMENTOS DE ACTUACIÓN}

\section{ROBERTO PADILHA GUIMARÃES}

DOI: $10.51366 / 978-65-89468-10-3-$ coordinfancia-27

Resumen. El presente trabajo tiene por objetivo el estudio evolutivo de la actuación de la inspección del trabajo en el combate al trabajo infantil. La inspección del trabajo surgió y se desarrolló junto con el derecho del trabajo, inicialmente dirigido a la protección de los niños y adolescentes trabajadores. La actuación de la inspección del trabajo en el combate al trabajo infantil en Brasil, a lo largo de su existencia, fue fuertemente marcada por una actuación de carácter represivo. A partir de la Constitución Federal de 1988, la inspección empezó a preocuparse con la necesidad de mayor eficacia y eficiencia de sus acciones, y con la implementación de alternativas para la resolución del problema. Por medio de experiencias acumuladas en su trayectoria, la inspección viene buscando superar los estándares que atribuyen a la actividad de fiscalización funciones tan solamente punitivas, para actuar también en la promoción y garantía de los derechos fundamentales del niño y del adolescente. En ese contexto, viene desarrollando nuevas bases de actuación dirigidas a la implementación de soluciones definitivas y sostenibles para el enfrentamiento al trabajo infantil.

Palabras clave: Trabajo infantil. Inspección del trabajo. Legislación laboral.

\section{INTRODUCCIÓN}

Desde su creación, la inspección del trabajo tiene su actuación orientada para la reducción de los índices del trabajo infantil en Brasil, inicialmente con una acción dirigida solamente para la represión frente al incumplimiento 
de normas legales. Sin embargo, a partir de la Constitución Federal de 1988 (BRASIL, 1988), con la evolución de la postura de la sociedad en relación a los derechos del niño y del adolescente y de la adopción por el ordenamiento jurídico brasileño de la doctrina de la protección integral, la inspección del trabajo también inició un proceso de transformación en su forma de actuación en búsqueda de mayor eficiencia en sus acciones y de alternativas más amplias para cambiar la realidad del trabajo infantil en el país.

Este periodo de desarrollo permitió la acumulación de conocimiento y experiencias sobre la realidad, las causas y las consecuencias del trabajo temprano. Además, los Auditores Fiscales del Trabajo (AFTs), sensibilizados con las varias situaciones de trabajo infantil encontradas en su día a día de trabajo pasaron a preocuparse con la necesidad de implementar soluciones permanentes y sostenibles para la resolución del problema.

El resultado es que, a lo largo de su trayectoria de actuación en el combate al trabajo infantil, la inspección del trabajo viene buscando superar los estándares que atribuyen a la actividad de fiscalización funciones tan solamente punitivas, a través del establecimiento de nuevas bases de actuación, con el objetivo de promover la garantía de los derechos fundamentales del niño y del adolescente.

Para el abordaje del tema, inicialmente trataremos del histórico de la creación de la inspección del trabajo como institución que nace con vocación inicialmente para las cuestiones relacionadas al trabajo de niños y adolescentes, siendo coetánea al propio origen del derecho del trabajo (BIGNAMI, 2007).

Enseguida, presentaremos las nuevas bases de actuación de la inspección del trabajo que apuntan para una acción más amplia, sobrepasando las fiscalizaciones meramente represivas, con el objetivo de garantizar la protección integral de niños y adolescentes en el trabajo.

Y, por último, presentaremos los instrumentos de que dispone la auditoría fiscal del trabajo en la lucha al trabajo infantil dentro de los nuevos estándares de actuación de la inspección del trabajo. 


\section{EVOLUCIÓN HISTÓRICA DE LA ACTUACIÓN DE LA INSPECCIÓN DEL TRABAJO EN LA LUCHA CONTRA EL TRABAJO INFANTIL}

Históricamente, la ley identificada en Inglaterra como Lord's Althorp Act se considera como el hito inicial de la inspección del trabajo en el mundo como organismo estatal (BIGNAMI, 2007).

La referida norma, promulgada en 1833, trajo importantes disposiciones sobre el trabajo de niños y adolescentes, entre las cuales destacamos: la prohibición al empleo de menores de 9 años; la limitación de la jornada de trabajadores menores de 13 años en 9 horas; el veto al trabajo nocturno; y la escolaridad obligatoria (OLIVA, 2006, p. 48). Para garantizar el cumplimiento de las normas, designó a cuatro inspectores, que tenían el poder de ingresar a las fábricas, resolver conflictos derivados de la aplicación de las leyes e imponer sanciones a los infractores (SUSSEKIND et al, 2000, p. 1.262).

Posteriormente, otros países también instituyeron servicios de inspección para velar por el cumplimiento de normas relacionadas con menores de edad, como fue el caso de Francia, en 1841, que instituyó un servicio de fiscalización compuesto por 15 funcionarios "a fin de frenar el trabajo de menores de ocho años” (BIGNAMI, 2007, p. 26).

En ese contexto, según estudio de la Organización Internacional del trabajo (2003, p. 1):

El origen de la inspección del trabajo está vinculada históricamente con la necesidad de vigilar y combatir eficazmente los peores abusos practicados contra los niños en el mundo laboral y proteger su salud.

En Brasil, la inspección del trabajo tiene una contribución histórica en la reducción del trabajo infantil y permanece como una de las acciones gubernamentales más importantes para el enfrentamiento del problema, siendo considerada por la OIT referencia de buenas prácticas a ser compartidas con otros servicios de inspección (OIT, 2010).

Se trata de una institución cuyo registro de creación más antiguo en el país es el 17 de enero de 1891. Igual que el primer registro de la inspección de trabajo en el mundo, la creación en Brasil también se relacionó con el trabajo de niños. En el caso, el Decreto n. ${ }^{\circ} 1.313$, en su artículo 1. ${ }^{\circ}$, disponía sobre la creación de la inspección laboral para el fin específico de "[...] fiscalización 
permanente de todos los establecimientos en que trabajen menores" (BRASIL, 1891). El citado decreto nunca fue ejecutado, sirviendo solamente como instrumento de la diplomacia brasileña para demostrar el compromiso del País con las normas de carácter social (BIGNAMI, 2007).

En 1931, a partir de la enmienda constitucional que pasó a la Unión la competencia para legislar sobre materia laboral, fue promulgado el Decreto n. ${ }^{\circ}$ 19.671-A, que estableció la organización del Departamento Nacional del Trabajo, cuya atribución incluía la organización, higiene, seguridad e inspección del trabajo (MATTJE; MATTJE, 2017).

En el año 1943, la Consolidación de las Leyes del Trabajo (CLT) entró en vigor por medio del Decreto-Ley n. ${ }^{\circ}$ 5.452/1943. La CLT reunió los derechos del trabajador en un solo documento y reservó el Capítulo I, del Título VII, para tratar específicamente de la fiscalización del trabajo, bajo la nomenclatura "Acerca del Proceso de Multas Administrativas". Dicho título subrayó el carácter entonces represor de la actuación de la inspección del trabajo (SUSSEKIND et al, 2000).

La Constitución Federal de 1988, en su artículo 21, inciso XXIV, fijó expresamente la competencia de la Unión de "organizar, mantener y ejecutar la inspección del trabajo" (BRASIL, 1988). Según Sussekind (2000), "los textos constitucionales anteriores no registraban un dispositivo similar" (SUSSEKIND et al, 2000, p. 1.265).

A partir de la evolución de la postura de la sociedad en relación con los derechos del niño y del adolescente y de la adopción por el ordenamiento jurídico brasileño de la doctrina de la protección integral, la actuación de la inspección del trabajo en el combate al trabajo infantil en Brasil fue intensificada en la década de 1990, considerando la gran cantidad de niños y adolescentes con edad entre 5 y 17 años trabajando en Brasil, cuyo número era superior a 10 millones (OIT, 2010).

Para el enfrentamiento de ese problema, la primera medida adoptada en el ámbito de la inspección del trabajo fue la creación de grupos de Auditores-fiscales del Trabajo (AFTs), en cada unidad de la Federación, dedicados exclusivamente al tema del trabajo infantil. Esos grupos fueron responsables por la elaboración de diagnósticos de focos de trabajo de niños y adolescentes por medio de la realización del mapeo de las principales actividades que, en 
la época, utilizaban mano de obra infantil en el país. Ese trabajo evolucionó, resultando en la publicación del Mapa de Indicativos del Trabajo del niño y del Adolescente, en el periodo desde 1999 hasta 2005, a partir de las informaciones recolectadas por AFTs (OIT, 2010).

Con base en los diagnósticos realizados, la inspección del trabajo pasó a planear y ejecutar acciones fiscales en actividades económicas que más utilizaban la mano de obra de niños y adolescentes, buscando también la articulación y la integración con otras instancias dedicadas a la prevención y a la erradicación del trabajo infantil.

En el año 2000, fueron creados los Grupos Especiales de Enfrentamiento al Trabajo Infantil y de Protección al Trabajador Adolescente (GECTIPA). Estos grupos "funcionaban como una célula especial para generar competencia y capacidad institucional que pudo ser transversalizada en toda la estructura de la inspección del Trabajo" (OIT, 2010, p. 27).

El trabajo de los GECTIPA resultó en "una gran mejora de la inspección del trabajo infantil, incluido un desarrollo significativo en la padronización de las técnicas y los procedimientos”. Además de eso, los miembros del GECTIPA desempeñaron un importante papel como agentes de articulación para el desarrollo de los Foros Estaduales de Prevención y Erradicación al Trabajo Infantil y de toda la red de Protección al niño y al adolescente, contribuyendo también en el desarrollo de los programas sociales dirigidos a la erradicación del trabajo infantil (OIT, 2010).

En 2004, para adecuarse a la nueva legislación que regulaba la carrera de los AFTs, los GECTIPAs fueron extintos y las acciones de combate al trabajo infantil, en el ámbito de las Comisarías Regionales del trabajo, pasaron a ser responsabilidad de todos los AFTs (OIT, 2010).

Posteriormente, fueron editadas instrucciones normativas (n. ${ }^{\circ} 54$, n. $^{\circ}$ 66 y n. $\left.{ }^{\circ} 77\right)$ con el objetivo de uniformizar los procedimientos y documentos fiscales relacionados con la fiscalización para enfrentamiento al trabajo infantil.

Actualmente, la Instrucción Normativa n. ${ }^{\circ}$ 102, de 28 de marzo de 2013, establece los procedimientos de la fiscalización para el combate al trabajo infantil. 


\section{DESARROLLO DE LAS NUEVAS BASES DE LA ACTUA- CIÓN DE LA AUDITORÍA FISCAL DEL TRABAJO EN LA LUCHA CONTRA EL TRABAJO INFANTIL}

A lo largo de la trayectoria de actuación de la inspección del trabajo en Brasil, se constató que el trabajo infantil, por ser un fenómeno complejo, con multiplicidad de causas y consecuencias, y que se presenta de diferentes formas, debería ser mejor comprendido con el objetivo de planificar y desarrollar las acciones para su enfrentamiento.

Otra cuestión también percibida fue la necesidad de actuación de Auditores Fiscales del trabajo especializados en la materia, así como la adopción de procedimientos e instrumentos adecuados para ese tipo de fiscalización.

Además de eso, se observó que la acción aislada de la fiscalización para el combate al trabajo infantil enfocada solamente en la determinación del alejamiento del niño o del adolescente del trabajo irregular, aliada a la imposición de sanciones administrativas delante de la empresa infractora, no tendría la posibilidad de producir, por sí mismo, resultados efectivos en cuanto a la garantía de la protección integral al niño y al adolescente y del no regreso al trabajo.

En ese contexto, a partir del aprendizaje adquirido durante estos años de actuación, fueron establecidas las bases que guían actualmente la actuación de la inspección del trabajo en el combate al trabajo infantil. A continuación, abordaremos cada uno de estos aspectos, destacando sus especificidades.

\subsection{Conocimiento del fenómeno trabajo infantil}

La apropiación del conocimiento acerca del fenómeno trabajo infantil es imprescindible para el diseño y la implantación de acciones eficaces para su enfrentamiento y para la garantía de los derechos de los niños y de los adolescentes.

En ese contexto, la inspección del trabajo viene realizando, desde la década de 1990, estudios y diagnósticos sobre focos de trabajo infantil en Brasil, identificando las actividades económicas que representan mayor riesgo para niños y adolescentes (OIT, 2010). 
La evolución de este trabajo resultó en la edición del primer Mapa de Indicativos del Trabajo Infantil, en 1997, conteniendo informaciones detalladas sobre los focos de trabajo infantil y los perjuicios a la salud de los niños y de los adolescentes como consecuencia del trabajo precoz. La última publicación del Mapa tuvo lugar en 2005 (OIT, 2010).

El aprendizaje adquirido en este periodo apuntó para la necesidad del conocimiento de la dimensión, de las causas y consecuencias del problema, a fin de viabilizar la planificación de acciones, estrategias y definición de metas frente a un fenómeno complejo como es el trabajo infantil.

\subsection{Especialización de auditores fiscales del trabajo y desarrollo de procedimientos e instrumentos de actuación}

El combate al trabajo infantil exige del AFT capacidades y acciones diferenciadas, teniendo en cuenta las peculiaridades y la complejidad de la materia. Por ese motivo, en el desarrollo de la inspección del trabajo infantil en Brasil, se adoptó, en un primer momento, una política de formación de grupos de AFTs especializados, que sirvieron como polo de aglutinación y difusión de conocimiento sobre el tema (OIT, 2010).

Posteriormente, el combate al trabajo infantil pasó a formar parte del rol de las competencias institucionales de todos los AFT y cada unidad de la Federación pasó a contar con una coordinación responsable por la actividad especializada de combate al trabajo infantil.

Para la realización de las acciones fiscales, otro punto a ser destacado está relacionado al desarrollo de procedimientos e instrumentos de actuación que consideran las peculiaridades que envuelven el enfrentamiento al trabajo infantil. Luego, a partir de los años 90, fueron editadas diversas instrucciones normativas estableciendo protocolos y acciones específicas para ser observadas en las acciones fiscales de combate al trabajo infantil. Cada instrucción normativa que venía a sustituir a la anterior traía más elementos para las acciones de combate al trabajo infantil, a partir del aprendizaje adquirido a lo largo de los años.

Actualmente, la Instrucción Normativa n. ${ }^{\circ} 102$, de 28 de marzo de 2013, establece los procedimientos de la fiscalización para el combate al trabajo infantil, considerando las peculiaridades de ese tipo de acción, así como 
proporciona el instrumental técnico, incluyendo documentos estandarizados a ser utilizados en las acciones fiscales.

\subsection{La articulación como acción indispensable para el combate al trabajo infantil}

El trabajo infantil, como ha sido referido ya, es un fenómeno social multicausal complejo que transita en las dimensiones sociales, económicas y culturales. Por eso, su enfrentamiento de forma adecuada solo se puede alcanzar por medio de la acción integrada del gobierno con la sociedad y de la articulación de los distuintos niveles (federal, estatal y municipal) y sectores de gobierno (trabajo, educación, asistencia social, salud, entre otros).

Dentro de ese contexto, los AFT, a partir de la Constitución Federal de 1988, pasaron a actuar en el fomento a la articulación de acciones para la erradicación del trabajo infantil, sea en la participación de la creación y coordinación de espacios de articulación, como el Foro Nacional y los Foros Estatales de Prevención y Erradicación del Trabajo Infantil, sea en la promoción de acciones conjuntas con otros órganos y entidades (OIT, 2010). Además, AFTs pasaron a realizar la coordinación de la Comisión Nacional de Erradicación del Trabajo Infantil (Conaeti) y a participar de las comisiones estatales y municipales de erradicación del trabajo infantil.

La experiencia acumulada en la coordinación y articulación de acciones contra el trabajo infantil viene trayendo las siguientes lecciones:

a) genera claridad con relación al papel de cada institución, teniendo en cuenta que, muchas veces, las competencias de cada órgano se presentan de forma concurrente o superpuesta;

b) asegura la intervención en situaciones de trabajo infantil por órganos dotados de instrumentos de actuación específicos, aplicables y eficientes para determinado caso concreto;

c) proporciona la combinación de esfuerzos para hacer más eficientes y efectivas las acciones de cada actor social;

d) implica la disminución de la reincidencia de niños y adolescentes retirados del trabajo infantil, a través de la inclusión en políticas públicas sectoriales, en el aprendizaje profesional, entre otras; y 
e) asegura la coherencia y sostenibilidad de las acciones.

En el día a día de la inspección del trabajo, podemos sistematizar la actividad de articulación de acciones para la erradicación del trabajo infantil en tres momentos distintos: en la planificación de acciones; en la ejecución de acciones de fiscalización; y después de las acciones de la fiscalización.

La primera objetiva el intercambio de informaciones entre órganos y entidades sobre la ocurrencia de trabajo infantil y de trabajo adolescente prohibido, con la finalidad de subsidiar y orientar la planificación de las acciones de combate al trabajo infantil. Las mejores experiencias en ese tipo de articulación apuntaron para el establecimiento de protocolos (flujos) de información entre los diferentes órganos, con el objetivo de agilizar el intercambio de datos e informaciones.

La segunda tiene por objetivo la combinación de esfuerzos para garantizar la intervención más eficiente para el enfrentamiento de los diferentes tipos de trabajo infantil. Podemos citar las siguientes acciones relacionadas con este tipo de articulación:

a) realización de acciones de combate al trabajo infantil en conjunto entre órganos y entidades en la búsqueda de una mayor eficiencia y efectividad;

b) creación de grupo de trabajo para casos de trabajo infantil más complejos, con participación coordinada de varios órganos con competencias y atribuciones diversas, permitiendo así un abordaje más completo y eficiente; $y$

c) establecimiento previo de protocolos de actuación con el objetivo de agilizar la articulación de acciones para el enfrentamiento de los diferentes tipos de trabajo infantil.

Por último, la tercera objetiva la combinación de esfuerzos con el objetivo de asegurar la sostenibilidad de las acciones fiscales realizadas, previniendo la reincidencia de niños y adolescentes en situación de trabajo prohibido, mediante la inclusión de jóvenes egresados del trabajo infantil en políticas públicas que aseguren la protección social, la inclusión en la escuela, la protección a la salud, el acceso a la cultura y al deporte, la formación profesional etc. 
En esa articulación, la inspección del trabajo realiza el encaminamiento de los egresados del trabajo infantil a los órganos responsables por la ejecución de las políticas públicas de protección al niño y al adolescente. Además de eso, la inspección del trabajo actúa en el fomento de servicios y acciones para implementación de soluciones definitivas y sostenibles para la erradicación del trabajo infantil.

\section{INSTRUMENTOS DE LA AUDITORÍA FISCAL DEL TRABAJO EN LA ACTIVIDAD DE LUCHA CONTRA EL TRABAJO INFANTIL}

La actuación de la inspección del trabajo en el combate al trabajo infantil y Protección al adolescente trabajador es regulada por la Instrucción Normativa (IN) n. ${ }^{\circ}$ 102/2013. Este normativo, elaborado dentro de las nuevas bases de actuación de la inspección del trabajo, trae instrumentos importantes para el enfrentamiento al trabajo infantil, así como los procedimientos que deben ser observados durante las acciones de fiscalización.

La IN n. ${ }^{\circ}$ 102/2013 es complementada por la IN n. ${ }^{\circ} 112$, de 22 de octubre de 2014, que dispone sobre la constitución y actuación del Grupo Móvil de Fiscalización de Combate al Trabajo Infantil (GMTI).

A continuación, presentamos las principales disposiciones de la instrucción normativa, así como los instrumentos de actuación de la inspección del trabajo en la lucha contra el trabajo infantil.

\subsection{Planeamiento de acciones fiscales}

Según la IN n. ${ }^{\circ}$ 102/2013, en el art. 3º las fiscalizaciones relacionadas al combate del trabajo infantil y aquellas que objetivan a la protección del adolescente trabajador tienen prioridad absoluta en el ámbito de las Superintendencias Regionales del Trabajo (SIT, 2013).

La planificación de las acciones se lleva a cabo sobre la base de los objetivos establecidos por la Subsecretaría de Inspección del Trabajo, que se elaboran a partir del Plan Plurianual (PPA). Las acciones de fiscalización son planificadas con fundamento en diagnósticos elaborados con datos del IBGE, especialmente los relacionados al Censo, Censo Rural y PNAD, estu- 
dios sectoriales, así como denuncias e informaciones recibidas sobre la ocurencia de trabajo infantil y de trabajo irregular de adolescentes.

\subsection{Coordinación de acciones}

Actualmente, cada unidad de la Federación cuenta con una coordinación responsable de la actividad de combate al trabajo infantil, así como con AFTs especializados y dedicados a la materia distribuidos en las distintas unidades de la fiscalización (Superintendencias y Gerencias Regionales). En el ámbito nacional, las acciones son coordinadas por la División de Trabajo Infantil e Igualdad de Oportunidades (DTIOP).

\subsection{Articulación de acciones con la red de Protección al niño y al adolescente}

La importancia dada a la articulación interinstitucional se puede observar en la IN n. ${ }^{\circ}$ 102/2013 (SIT, 2013), que trae diversas disposiciones sobre la materia.

Según el art. 4. ${ }^{\circ}$, la actividad de combate al trabajo infantil debe contemplar la promoción de articulación e integración con los órganos y entidades que componen la red de protección a niños y adolescentes, en el ámbito de cada unidad de la Federación, buscando la elaboración de diagnósticos y la elección de prioridades que irán a componer la planificación anual, con la indicación de sectores de actividad económica a ser fiscalizados.

Ya en el artículo 5. ${ }^{\circ}$, es preconizada la actuación junto a los foros estatales y municipales de combate al trabajo infantil y Protección al adolescente trabajador, así como la integración y el fortalecimiento de la red de protección a niños y adolescentes.

Por último, el artículo 12 trata de los encaminamientos que deben ocurrir después de la acción fiscal para la red de Protección al niño y al adolescente. Además de eso, también refiere que el coordinador de la actividad deberá realizar el seguimiento de los encaminamientos y de las providencias solicitadas, así como establecer flujo de informaciones con los órganos o entidades pertenecientes a la red de Protección al niño y al adolescente. 


\subsection{Capacitación y especialización de auditores fiscales del trabajo}

Con el objetivo de preparar los AFT para la actividad de combate al trabajo infantil, está siendo promovida, en el ámbito de la Escuela Nacional de Inspección del trabajo (ENIT), un curso de capacitación continuada, organizado en cuatro módulos, totalizando 160 horas de estudio.

Uno de los objetivos de la capacitación es dotar al cuerpo de AFTs de conocimientos necesarios para actuación frente a los diferentes tipos de trabajo infantil, incluyendo los del sector informal, aplicando nuevas formas de abordaje y protocolos de fiscalización, especialmente frente a las peores formas de trabajo infantil.

Otra acción importante para la calificación de las acciones de enfrentamiento al trabajo infantil fue la creación del Grupo Móvil de Combate al trabajo Infantil (GMTI), por medio de la Instrucción Normativa n. ${ }^{\circ}$ 112/2014 (SIT, 2014).

El GMTI, con actuación en todo el territorio nacional, diferentemente de otros grupos móviles de fiscalización en el ámbito de la Subsecretaría de Inspección del Trabajo, fue idealizado a partir de la combinación de la actuación represiva con la articulación intersectorial, con el objetivo de alcanzar efectividad y sostenibilidad de las acciones de la fiscalización, de modo que los resultados alcanzados sean mantenidos y potenciados.

Sus acciones son planificadas con foco en las siguientes prioridades: a) actividades económicas clasificadas entre las peores formas de trabajo infantil; b) los focos de trabajo infantil más significativos, con base en estudios y diagnósticos; y c) las denuncias sobre trabajo infantil que presenten indicativos de mayor riesgo o complejidad (SIT, 2014).

\subsection{Procedimiento de control}

A continuación, enumeramos las principales acciones realizadas por los AFTs en el curso de una acción de Fiscalización para el combate al trabajo infantil y Protección al adolescente trabajador. 


\subsubsection{Identificación de trabajadores menores de 18 (dieciocho) años en situación de trabajo prohibido}

Esta acción figura entre las más importantes en la actividad de combate al trabajo infantil, teniendo en vista que es esencial tanto para la aplicación de sanciones administrativas, como para la promoción de los derechos fundamentales de niños y adolescentes.

Para la realización de esta actividad, el AFT realiza el llenado de documento, titulado "Ficha de Verificación Física", cuyo modelo es previsto en el anexo I, de la IN n. ${ }^{\circ}$ 102/2013, para cada niño y/o adolescente encontrado en situación irregular de trabajo, independientemente del tipo de relación laboral. Los datos registrados en dicho formulario serán enviados a la red de protección al niño y al adolescente.

Importante hay que subrayar que los datos constantes en la ficha van a permitir la identificación de los niños y/o adolescentes encontrados en situación irregular de trabajo, así como su localización, sea en su residencia, sea en su escuela, con el objetivo de viabilizar la adopción de medidas de protección, integración en programas sociales e inclusión en el aprendizaje profesional.

\subsubsection{Determinación del cambio de función}

Se trata de una medida que tiene por objetivo la regularización del trabajo del adolescente con edad entre 16 y 17 años que esté trabajando en actividades o condiciones prohibidas por la legislación.

Para la "Determinación de Cambio de Función", el AFT efectúa la labranza y entrega al empleador de un término, cuyo modelo es previsto en la IN n. ${ }^{\circ}$ 102/2013, relacionando a los trabajadores en situación irregular y determinando la alteración de función. Importante resaltar que solo habrá la determinación de cambio de función en el caso de que haya en el local condiciones y actividades permitidas por la legislación para el trabajo de adolescentes con edad entre 16 y 17 años.

En caso de que el responsable del establecimiento o lugar de trabajo no atienda a la determinación de cambio de función, o no sea posible la adecuación de la función del adolescente, queda configurada la rescisión indirec- 
ta del contrato de trabajo, en los términos del párrafo único del art. 407 de la CLT (BRASIL, 1943).

\subsubsection{Determinación del alejamiento del trabajo}

Esta providencia será adoptada cuando verificada la ocurrencia de niños o adolescentes trabajando sin la edad mínima para el trabajo, o en la hipótesis de no ser posible el cambio de función o adecuación de las condiciones de trabajo de adolescentes con edad entre 16 y 17 años flagrados en actividades o condiciones prohibidas por la legislación.

Por esta medida, está determinado al empleador, a través de la labranza y entrega de un término, cuyo modelo se encuentra previsto en la Instrucción Normativa n. ${ }^{\circ}$ 102/2013, para que, de forma inmediata, providencie la interrupción de las actividades del trabajador en condición irregular, así como proceda a la extinción de la relación laboral, incluyendo el pago de sumas laborales debidas.

El pago de los fondos laborales ocurrirá en presencia del AFT. En la oportunidad, los niños y adolescentes deben estar acompañados por su tutor legal o autoridad competente.

\subsubsection{Actuación}

Constatada la irregularidad relacionada al trabajo infantil o al trabajo de adolescentes en condiciones prohibidas por la legislación, el AFT deberá labrar auto de infracción, con la identificación del infractor, la cita de la norma que fue incumplida, la descripción de los hechos constatados durante la acción fiscal, y los elementos que llevaron a la conclusión de la existencia de irregularidad, asegurada la amplia defensa y el contradictorio.

Importante observar que con relación a las infracciones relacionadas al trabajo de niños y adolescentes no se observará la doble visita, teniendo en vista el entendimiento consolidado en la Nota Técnica n. ${ }^{\circ}$ 62/2010/DMSC/ SIT, que aleja la adopción de este criterio en las hipótesis de infracciones caracterizadas como insanables. Tal entendimiento radica en el hecho de que, en las infracciones relacionadas con el trabajo infantil, la doble visita no podría acarrear ninguna alteración con relación a la infracción ya consumada, que, 
una vez ocurrida, acarrea daños a los trabajadores precoces, especialmente en el caso de las peores formas de trabajo infantil.

\subsubsection{Comunicación de trabajo infantil y solicitud de providen- cias, informe de fiscalización e inclusión en el aprendizaje pro- fesional}

Con el objetivo de asegurar eficacia y eficiencia en la actuación fiscal, a través de la promoción de soluciones definitivas para la erradicación del trabajo infantil, incluyendo la prevención del retorno de niños y adolescentes al trabajo irregular, fueron establecidos en los protocolos de la fiscalización una serie de acciones que deben ser realizadas después de las fiscalizaciones.

En este contexto, al final de la acción fiscal, la Jefatura de fiscalización del trabajo provee el encaminamiento de la ficha de verificación física, acompañada de un documento titulado "Término de Comunicación de Trabajo Infantil y Solicitud de Providencias”, previsto en la IN n. ${ }^{\circ}$ 102/2013, para el consejo tutelar, asistencia social y Ministerio Público Estatal. Dichos encaminamientos tienen por objetivo el accionamiento de órganos que puedan viabilizar la garantía de derechos, la inclusión en programas sociales, y la protección a los niños y adolescentes egresados del trabajo infantil (SIT, 2013).

Además, hay también el envío de informe de fiscalización detallado al Ministerio Público del Trabajo acompañado de los documentos resultantes de la fiscalización (término de alejamiento del trabajo, término de cambio de función y Autos de infracción etc.). Esta medida tiene por objetivo dar conocimiento al Ministerio Público de informaciones y documentos pertinentes al incumplimiento de normas relacionadas con la protección del niño y del adolescente en el trabajo.

Con relación a los adolescentes alejados del trabajo, especialmente aquellos oriundos de familias en situación de vulnerabilidad, la fiscalización del trabajo ha promovido, cuando posible, la inclusión en el aprendizaje profesional. Esta acción ha proporcionado la generación de oportunidades de calificación para adolescentes, asegurando, al mismo tiempo, la formación profesional protegida, la garantía de derechos laborales y sociales, y la prevención de la reincidencia de situaciones de trabajo desprotegido o irregular. 


\section{CONSIDERACIONES FINALES}

La actuación de la inspección del trabajo en el combate al trabajo infantil pautada solamente en las acciones represivas y punitivas se mostró insuficiente para el enfrentamiento del problema, considerando que no llevaba en cuenta las especificidades del fenómeno, el cual debería ser mejor estudiado y comprendido; no se preocupaba con la promoción de los derechos del niño y del adolescente, necesarios para dar sostenibilidad a las acciones fiscales; no se preocupaba con la prevención del regreso de niños y adolescentes al trabajo infantil; y no actuaba de forma coordinada con otros actores sociales.

El proceso de desarrollo de las nuevas bases de actuación fue realizado a lo largo de muchos años, a partir de la acumulación de experiencias proporcionadas por el cotidiano de la actividad de los Auditores Fiscales del Trabajo.

Como resultado de todo este proceso de transformación, se desarrollaron nuevas bases de actuación de la inspección del trabajo en la lucha contra el trabajo infantil, a partir de las siguientes premisas:

a) el conocimiento de la dimensión y de la realidad del trabajo infantil es condición sine qua non para garantizar la eficiencia y efectividad de las acciones de enfrentamiento al trabajo infantil;

b) la acción de combate al trabajo infantil, considerando su complejidad, exige una actuación especializada, incluyendo la capacitación de agentes y el desarrollo de procedimientos y de instrumentos de actuación;

c) la eficiencia y la sostenibilidad de las acciones de combate al trabajo infantil dependen de la existencia de un trabajo articulado con la red de protección y de la promoción de las políticas públicas que viabilicen la garantía de la protección integral a los niños y a los adolescentes.

Por último, es importante subrayar que este proceso de cambio no se trata de un sistema cerrado. A pesar de los avances observados en las últimas décadas, la inspección viene constantemente buscando innovaciones y desarrollando nuevos métodos de trabajo con el objetivo de promover mejoras en su forma de actuación, y orientando su trabajo dentro de las nuevas realidades del trabajo infantil en Brasil. 


\section{REFERENCIAS}

BIGNAMI, Renato. A inspeção do trabalho no Brasil: procedimentos especiais para a ação fiscal. São Paulo: LTr, 2007.

BRASIL. Decreto n. ${ }^{\circ}$ 1313, de 17 de janeiro de 1891. Rio de Janeiro/ RJ, jan. 1891. Estabelece providencias para regularizar o trabalho dos menores empregados nas fábricas da Capital Federal. Disponível em: https:/ / www2.camara.leg.br/legin/fed/decret/1824-1899/decreto-1313-17-janeiro-1891-498588-publicacaooriginal-1-pe.html. Acceso en: 11 de maio de 2020.

BRASIL. Decreto-lei n. ${ }^{\circ}$ 5.452, de 1 de maio de 1943. Brasília/DF, maio 1943. Aprova a Consolidação das Leis do Trabalho. Disponível em: http:// www.planalto.gov.br/ccivil_03/decreto-lei/Del5452compilado.htm. Acceso en: 18 ago. 2020.

BRASIL. Constituição da República Federativa. Brasília/DF, 1988. Disponível em: http://www.planalto.gov.br/ccivil_03/constituicao/constituicao.htm. Acceso en: 18 ago. 2020.

MATTJE, Emerson Tyrone; MATTJE, Diane de Figueiredo. Auditoria Fiscal do Trabalho no Brasil em Perspectiva Histórica. Revista da Escola Nacional da Inspeção do Trabalho (ENIT), Brasília/DF, v. 1, n. 1, p. 128-147, jan-dez, 2017.

OFICINA INTERNACIONAL DO TRABALHO. Manual para Inspectores: Combatiendo las peores formas de trabajo infantil. San José: Oficina Internacional del Trabajo, 2003.

OLIVA, José Roberto Dantas. O princípio da proteção integral e o trabalho da criança e do adolescente no Brasil: com as alterações promovidas pela Lei n. ${ }^{\circ} 11.180$, de 23 de setembro de 2005, que ampliou o limite de idade nos contratos de aprendizagem para 24 anos. São Paulo: LTr, 2006.

ORGANIZAÇÃO INTERNACIONAL DO TRABALHO. As boas práticas da inspeção do trabalho no Brasil: a prevenção e erradicação do trabalho infantil. Brasília: OIT, 2010.

SECRETARIA DE INSPEÇÃO DO TRABALHO. Nota técnica n. ${ }^{\mathbf{o}}$ 62/2010/DMSC/SIT. Brasília/DF, 2010. Critério da Dupla Vista. Conside- 
rações Gerais. Disponível em: http://www.sinpait.com.br/download/notatecnica622010duplavisita.5.pdf. Acceso en: 16 de setembro de 2020.

SECRETARIA DE INSPEÇÃO DO TRABALHO. Instrução Normativa n. ${ }^{\circ}$ 102, de 28 de março de 2013. Brasília/DF, 2013. Dispõe sobre a fiscalização do trabalho infantil e proteção ao adolescente trabalhador. Disponível em: http:/ / www.normaslegais.com.br/legislacao/instrucao-normativa-sit-102-2013.htm . Acceso en: 16 de setembro de 2020.

SECRETARIA DE INSPEÇÃO DO TRABALHO. Instrução Normativa n. ${ }^{\circ}$ 112, de 22 de outubro de 2014. Brasília/DF, 2014. Dispõe sobre a constituição e atuação do Grupo Móvel de Fiscalização de Combate ao Trabalho Infantil - GMTI. Disponible en: http://www.fiepr.org.br/para-sindicatos/assistencia-sindical/uploadAddress/INSTRUCAO_NORMATIVA_N_112_ DE_22_DE_OUTUBRO_DE_2014[58086].pdf. Acceso en: 16 sept. 2020.

SUSSEKIND, Arnaldo et al. Instituições de Direito do Trabalho. 19. ${ }^{a}$ ed. atual. São Paulo: LTr, 2000. 


\section{ADOLESCENTES EN MEDIDA SOCIOEDUCATIVA: ¿QUÉ EL TRABAJO INFANTIL TIENE QUE VER CON ESTO?}

\section{SIMONE BEATRIZ ASSIS DE REZENDE}

DOI: $10.51366 / 978-65-89468-10-3-$ coordinfancia-28

Resumen. Se trata de un artículo con presentación de parte de los resultados de investigación sobre aprendizaje profesional empleado para promover el Desarrollo Humano y auxiliar en la reintegración social de adolescentes en cumplimiento de medidas socioeducativas con restricción de libertad. Delante de su proceso de desarrollo, el adolescente posee vulnerabilidades singulares, dejándolo más susceptible a los factores de riesgos, que potencien las consecuencias negativas si no hay factores de protección adecuados, pudiendo llevar a la comisión del acto de infracción. Entre esos factores de riesgos están la explotación del trabajo infantil, inclusive para actividades ilícitas, por lo tanto ahora se presenta la percepción de los adolescentes entrevistados sobre ese factor. Como fuente primaria, se utilizaron entrevistas realizadas con adolescentes en los estados de Mato Grosso do Sul, Rio Grande do Sul y Rio de Janeiro. Como fuentes secundarias, se consultó la bibliografía específica sobre las temáticas abordadas y, como investigación documental, se analizaron autos judiciales de ejecución de medidas socioeducativas de los sujetos de la investigación. Como resultado, se constató que 87,17\% de los adolescentes entrevistados, 10 de ellos egresados y 29 aún cumpliendo medida socioeducativa, poseían histórico de trabajo infantil.

Palabras clave: Adolescentes. Medidas socioeducativas. Trabajo Infantil.

\section{INTRODUCCIÓN}

¿El trabajo infantil puede ser considerado factor de riesgo y estímulo para la comisión de acto de infracción? ¿Puede el trabajo infantil considerarse un factor de prevención del acto infractor? Reflexiones que provienen del 
mito, propalado aún hoy, en pleno siglo XXI, de que "es mejor que el niño esté trabajando que robando" y que pueden generar respuestas diametralmente opuestas y de aparente carácter obvio para sus interlocutores.

Saber si el adolescente que cumple medida socioeducativa posee histórico de trabajo infantil puede arrojar luz a la realidad. Vale la tentativa de una inmersión en el universo de esos adolescentes en cumplimiento de medida socioeducativa, cuya peculiar situación afecta ordinariamente a la población hiposuficiente, negra/parda y del sexo masculino, para extraer de la fuente cuál es su percepción sobre el trabajo infantil.

El presente artículo tiene por objetivo traer parte de los resultados de la investigación de campo realizada para la confección de la tesis de doctorado en Desarrollo Local, por ${ }^{1}$ la Universidad Católica Don Bosco (UCDB), titulada "Aprendizaje Profesional para adolescentes en cumplimiento de medida socioeducativa con restricción de libertad: desarrollo humano y reintegración social”, defendida en junio de 2019 (REZENDE, 2019).

La investigación de campo fue realizada por intermedio de entrevistas semiestructuradas, cuyo guión, compuesto de 46 preguntas, posibilitó la recolección de datos para las tres categorías de análisis elegidas. Una de esas categorías, Territorio vivido/reintegración social, quedó subdividida en "Vínculo con el territorio de origen" y "Relación con familiares/comunidad". En la categoría Curso de Aprendizaje Profesional se investigó la "escolarización/escolarización", "contratación por la empresa" y "Resultados del curso en términos de competencia, valores y perspectivas personalmente construidas". La categoría de análisis denominada trabajo fue subdividida en "Mercado de trabajo" y "Trabajo infantil" y son los resultados de esa última que ahora se presenta.

Las indagaciones formuladas acerca de la subcategoría Trabajo infantil tuvieron, a su vez, un núcleo objetivo y otro más subjetivo. Se preguntó, por ejemplo, si el entrevistado trabajó de pequeño; cuántos años tenía; qué actividades emprendidas; si dejó de estudiar; si hubo incentivo de los padres o responsables para el trabajo; si hubo perjuicio a los estudios; si estaba trabajando cuando cometió el acto de infracción; cuáles sus percepciones sobre el trabajo en sí; y, se cree que el trabajo infantil contribuyó para la práctica del acto de infracción. 
Se pretendió, así, con la escucha, dar voz a los 39 adolescentes entrevistados en los estados de Mato Grosso do Sul, Rio de Janeiro y Rio Grande do Sul, en el período de noviembre de 2018 a febrero de 2019, acerca de las cuestiones arriba expuestas.

\section{ELECCIÓN Y PERFIL SOCIODEMOGRÁFICO DE LOS SUJETOS DE LA INVESTIGACIÓN}

Los sujetos de la investigación se dividieron en dos grupos. El Grupo 1, con 29 adolescentes que, en el momento de la entrevista, estaban cumpliendo medida socioeducativa con restricción de libertad, y que habían sido incluidos en programa de aprendizaje profesional, siendo cierto que varios de ellos ya habían concluido el curso. Los 10 adolescentes del Grupo 2, en el momento de la entrevista, ya habían cumplido la medida socioeducativa con restricción de libertad y, en la época del cumplimiento, participaron del programa de aprendizaje profesional.

La investigación fue hecha por medio de muestreo no probabilístico, o sea, la selección de los sujetos de la muestra no fue aleatoria y, sí, dependiente de la identificación y localización de la población estudiada, en consideración a la posibilidad del joven que ya cumplió la medida socioeducativa no estar accesible, lo que se confirmó en parte. Luego, delante de la condición de internos en unidad socioeducativa, con estándares de seguridad bastante rígidos, los adolescentes entrevistados del Grupo 1 fueron elegidos por el equipo técnico y la identificación y contacto de los adolescentes del Grupo 2 ocurrió con la ayuda de los equipos del CIEE/RS en Rio Grande do Sul y de la Escuela de gestión Socioeducativa Paulo Freire/RJ en Rio de Janeiro y, a pesar de los esfuerzos y el emprendimiento de arduo trabajo de búsqueda y de tentativas de contacto, pocos adolescentes comparecieron a los locales de las entrevistas.

Todos los nombres de los sujetos entrevistados son ficticios, elegidos por ellos en el momento de la entrevista, para preservar el secreto de sus identidades. Un hecho inusual ocurrió y merece registro. Al ser instado a elegir un nombre ficticio, uno de los adolescentes respondió que podría ser “cualquiera” y, preguntado, reafirmó su opción. La única respuesta posible en la ocasión, y que fue dada por la autora, sería que él no era cualquiera, siendo 
importante saber qué nombre o apodo le gustaría que constara en el trabajo de investigación. Finalmente, el adolescente tomó su decisión.

Esa manifestación, de sinceridad cortante, es el retrato perfecto de la invisibilidad de los adolescentes, que cumplen o cumplieron medida socioeducativa, además de otros en situación de vulnerabilidad y riesgo social. Se Justifica, así, el destaque de los nombres de todos los adolescentes entrevistados, cuyas declaraciones ilustran los resultados de la investigación.

Conocer la trayectoria de vida y condición personal de los sujetos de la investigación fue una actividad ardua e impactante, pero imprescindible para acechar a sus percepciones sobre los temas bajo análisis. Después de la consulta a 52 procesos judiciales de ejecución de la medida socioeducativa de los 39 entrevistados, con manejo de aproximadamente 9.500 páginas, fue posible elaborar una síntesis del contexto de vida de cada uno de los entrevistados.

Se registra que el acceso a los autos judiciales sólo ocurrió después de las entrevistas para prevenir posible direccionamiento, aunque involuntario, de las preguntas hechas. Ninguna indagación fue hecha en el sentido de conocer la naturaleza del acto de infracción cometido, pues no era el foco de la investigación.

Con el mismo propósito, se recolectó algunas informaciones personales de los adolescentes antes de la entrevista, por autodeclaración, con la finalidad de identificar la población investigada en cuanto a la edad, color, escolaridad, renta familiar, estado civil, la existencia o no de hijos y, aún, género. Se constató que de los 39 adolescentes:

- en el día de la entrevista, 97,44\% estaban en el intervalo de edad de los 16 a los 19 años y 43,58\% de los entrevistados tenían entre 16 a 17 años;

- 66,66\% de los entrevistados se declararon del color parda o negro, $30,76 \%$ del color blanco ${ }^{2}$; y 1 entrevistado no respondió (2,56\%);

- a pesar de la mayoría de los adolescentes estar en la franja de los 16 a los 18 años (74,2\%), apenas 38,43\% de ellos estaban cursando o habían terminado la enseñanza secundaria; y los demás, 58,96\%, frecuentaban el $4^{\circ}$ al $9^{\circ}$ año (2,56\%, o sea, 1 adolescente no declaró la escolaridad);

- 53,84\% poseían renta familiar de hasta 3 salarios mínimos y apenas $7,69 \%$ de 3 a 5 salarios mínimos, considerando todos los ingresos de los 
que trabajan, divididos por el número de habitantes de la misma residencia; ninguno de los entrevistados declaró renta mayor que 5 salarios mínimos y $38,46 \%$ no supieron o no quisieron declarar;

- 32 de ellos se declararon solteros, 5 casados y 1 separado;

- 6 de ellos declararon tener un hijo, incluso Yara, y,

- 98,44\% de los entrevistados se auto declaran del sexo masculino, siendo cierto que apenas Yara, del Grupo 2, apareció para la entrevista, o sea, apenas $2,56 \%$ del total era del sexo femenino.

De acuerdo con el levantamiento Anual SINASE 2014 (Brasilia, 2017, p. 32), 56\% de los adolescentes que estaban en cumplimiento de medida socioeducativa estaban en el intervalo de edad de los 16 a los 17 años; "56\% de los adolescentes y jóvenes en restricción y privación de libertad fueron considerados pardos/negros, a $21 \%$ fueron atribuidos al color blanco y al $1 \%$ al color amarillo" y $22 \%$ no tuvieron registro en cuanto a su color (Brasilia, 2017, p. 33).

Se percibe, así, que el universo de los adolescentes investigados guarda cierta semejanza con la población en cumplimiento de medida socioeducativa, de acuerdo con el levantamiento Anual SINASE 2014 (BRASÍLIA, 2017).

\section{CON LA PALABRA, LOS ADOLESCENTES ENTREVISTA- DOS}

Lo ideal sería abordar los resultados extraídos de la investigación teniendo en cuenta todos los aspectos consustanciados en las tres categorías de análisis elegidas y cotejados por el referencial teórico de la tesis.

Sin embargo, las declaraciones de los 39 adolescentes sobre el trabajo infantil, que traen relatos contundentes de su vivencia, autorizan la extracción de fragmentos que posibilitan la presentación objetiva de los datos.

Como arriba expuesto, se indagó a los sujetos de la investigación, la edad de inicio y la actividad laboral desarrollada, las condiciones deflagradoras del trabajo infantil, el papel de los padres para la inserción precoz en el trabajo y, si estaba trabajando o estudiando en el momento de la comisión del acto de infracción. 


\subsection{La voz de los adolescentes del Grupo 1}

Parte de los adolescentes negaron que habían trabajado de niño, pero lo revelan al responder con cuántos años iniciaron la actividad laboral. Ilson, por ejemplo, dijo que no trabajaba cuando era niño, pero "cuando tenía unos 12, 13 años movía el auto, hacía el trabajo de taller de carrocería”.

La impresión de que no ejercían actividad laboral, pero apenas "ayudaban" a familiares es compartida por algunos adolescentes, como Simi que auxiliaba al Padre que tenía problemas físicos y, también, por Adriano que afirmó que le gustaba trabajar y ayudar al Padre. Thales refuerza la misma situación:

Oradora A: ¿usted trabajó de pequeño?

Thales: mi padre siempre me enseñó lo que es correcto desde pequeño. Yo trabajaba.

Oradora A: ¿usted trabajaba? ¿Con cuántos años comenzó a trabajar?

Thales: con unos doce, once allí. No trabajar. Cómo ayudar. Auxiliar de mecánica para que yo aprenda para después no pasar trabajo. ¿Sabe señora? Aprender. Entonces estaba aprendiendo auxiliar. ¿Sabe? Coge esa llave. ¿Qué llave? Esta es la llave Philips. Ese de aquí se llama destornillador.

De los 29 entrevistados que estaban cumpliendo medida socioeducativa de internación, 23 afirmaron haber comenzado a trabajar en actividades lícitas en edades entre 7 y 16 años, siendo que de esos 23 adolescentes, 7 (siete) afirmaron que iniciaron el trabajo antes o hasta los 11 años (Adriano, Josué, Magrão, Paraguaio, Davi, Balança y Bocão). De los 29 adolescentes, tres afirmaron que iniciaron el trabajo con el aprendizaje profesional (JC a los 16 años; Leandro y Tam no informaron la edad) y uno de ellos, Yuri, dijo que no trabajó. 
Gráfico 1. Edad de inicio del trabajo infantil-Grupo 1

Não trabalharam ou não respoderam

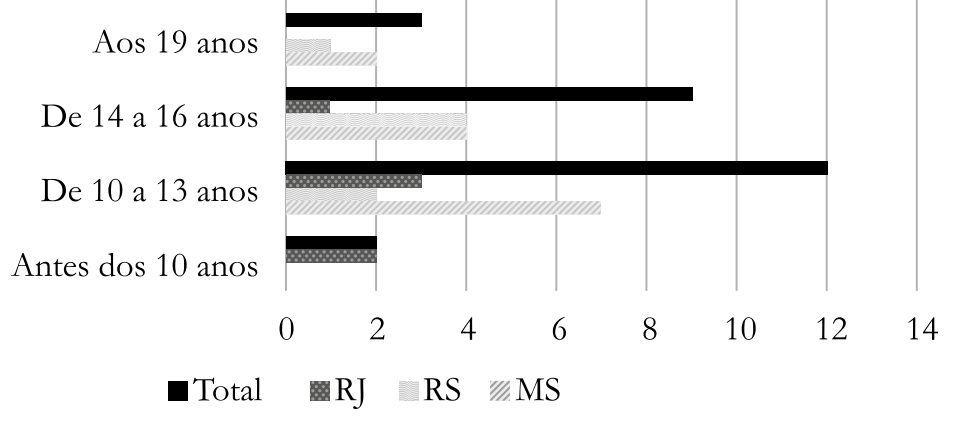

Fuente: la autora (2020).

Inicialmente, Gui dijo haber comenzado el trabajo a los 18 años, con el aprendizaje profesional y en la unidad educativa de internación. Sin embargo, en otro momento de la entrevista reveló que, a los 14 años estudiaba por la mañana y "traficaba por la noche". Se dice en los autos judiciales que, a los 16 años, fue incautado por estar conduciendo un vehículo robado. Del mismo modo, Yuri que, a los 15 años, fue incautado por acto de infracción análogo al tráfico de drogas.

Otros adolescentes, también ignorando la explotación laboral para el tráfico de drogas o para otros fines ilícitos, relataron apenas la edad en que iniciaron el trabajo en actividad lícita. Jean afirmó que a los 15 o 16 años ayudaba en la obra de construcción civil de su hermano, pero los autos judiciales revelaron que a los 12 años ya estaba involucrado con la producción y tráfico de drogas, cuando ocurrió su primera internación. Mateus dice que a los 17 años comenzó a trabajar en un mercado "para dar un tiempo incluso de lo que yo estaba haciendo aquí", o sea, ya estaba comprometido con el tráfico de drogas, constando en los autos judiciales que a los 12 años fue incautado por guardia y porte ilegal de droga, porte de arma de fuego y de munición.

Las declaraciones reflejan el sentido común de que el envolvimiento del adolescente con el tráfico de drogas y otras actividades ilícitas, no es visto como explotación de su mano de obra, como consta expresamente en la Convención n. ${ }^{\circ} 182$ de la Organización Internacional del trabajo, ratificada por Brasil $^{3}$, que describe las peores formas de trabajo infantil, cuya La letra "c" del en el art. $3^{4}$ tiene la siguiente redacción: 
Artículo 3 A los efectos de esta Convención, la expresión las peores formas de trabajo infantil comprende: [...]

c) utilización, reclutamiento u oferta de niños para la realización de actividades ilícitas, en particular la producción y el tráfico de estupefacientes;

Otras actividades consideradas como peores formas de trabajo infantil están enunciadas en las demás letras del Art. 3 arriba mencionado, cual sea, todas las formas de esclavitud o prácticas análogas a la esclavitud (letra "A"); la utilización, el reclutamiento o la oferta de niños para la prostitución, la producción de pornografía o actuaciones pornográficas son encartadas como explotación (letra “b”); y, por último, el trabajo que, por su naturaleza o por las condiciones en que es realizado, es susceptible de perjudicar la salud, la seguridad o la moral de los niños (letra “d”).

Frente a este instrumento internacional, Brasil aprobó la lista de las peores Formas de Trabajo Infantil, la llamada Lista TIP, por el Decreto n. ${ }^{\circ}$ 6.481, de 12 de junio de 2008, y al cotejar las innumerables actividades laborales emprendidas por los entrevistados, cuando niño o adolescente, se constata que están incluidas entre ellas.

Guerreiro, Josué, Juliano, Davi, Tony y Robson trabajaron en lavado a chorro, lo cual está prohibido, como se desprende del ítem 77 de la Lista TIP, ante el uso de solventes orgánicos o inorgánicos, aceite diesel y otros productos, cuya exposición puede causar "dermatosis ocupacionales; encefalopatías; quemaduras; leucocitosis; elaiconiosis; episodios depresivos; temblores; trastornos de personalidad y neurastenia". También Ilson trabajó en actividades descritas como peores formas de trabajo infantil, cuáles son, en cerrajería (ítem 52) y taller de coche (ítem 24).

A los siete años, Bocão pasó a vender balas y dulces en las calles, cuya actividad está descrita en el ítem 73 de la Lista TIP, o sea, estuvo expuesto "a la violencia, drogas, acoso sexual y tráfico de personas” además de atropello ("probables riesgos ocupacionales"). Como "probables repercusiones para la salud", esa actividad puede causar, entre otras, comprometimiento afectivo, dependencia química, enfermedades sexualmente transmisibles y actividad sexual precoz. Del perfil y contexto del adolescente, construido a partir de las informaciones constantes en los autos judiciales analizados, Bocão, a los 11 años, era dependiente químico. Y, a los 15 años, se concretó el riesgo de acoso sexual, lo que llevó al adolescente al acto de infracción análogo al de homicidio, pues mató, por asfixia mecánica, a un hombre que conoció cuan- 
do vendía bala y dulces en una señal de tráfico. Relató, en los autos judiciales, que la víctima ofreció $\mathrm{R} \$ 150,00$ para hacer sexo oral en el adolescente y, después, se negó a pagar.

Trabajos en construcción civil, incluyendo restauración, reforma, demolición se enumeran en el ítem 58 de la Lista TIP por los riesgos ocupacionales existentes, como esfuerzo físico intenso, accidente por caída o con maquinaria y equipo, exposición al polvo de pinturas, cemento y otros materiales. Estas actividades están listadas entre las emprendidas por Luan, Paraguayo, Simi, Yago, Davi, Jean, Robson, Tony, Balança y Bocão.

En cuanto a las condiciones desencadenantes del Trabajo infantil, 14 de los adolescentes no respondieron o no fueron preguntados ${ }^{5}, 8$ de ellos afirman que necesitaban dinero y los otros 7 se justifican diciendo que sólo ayudan, o que les gustaba trabajar, entre otras. El siguiente gráfico identifica los motivos del inicio del trabajo infantil por Estado investigado.

Gráfico 2. Condiciones desencadenantes del trabajo infantil-Grupo 1

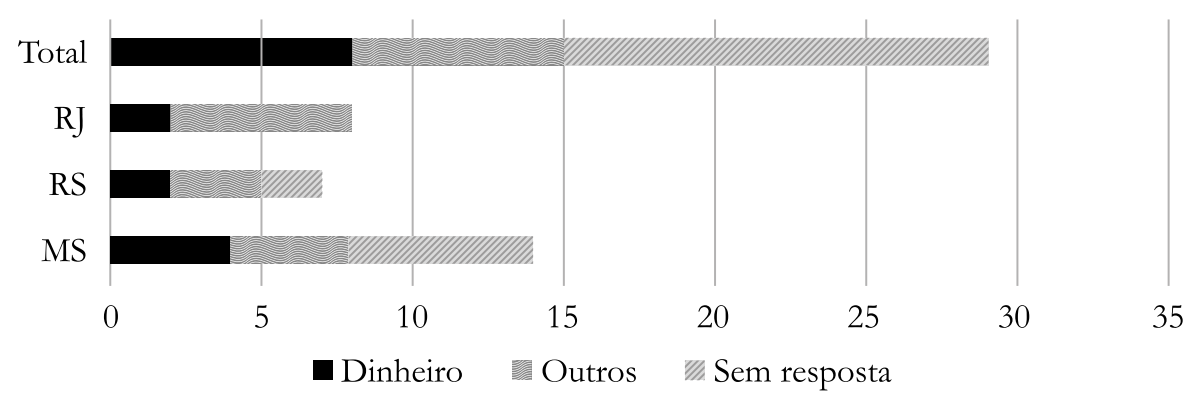

Fuente: la autora (2020).

El papel de los padres o tutores en el inicio del trabajo infantil es descrito como una cuestión positiva, considerado como incentivo e inspiración por diez adolescentes ( 8 de MS, 8 de RS y 2 del RJ). Algunos mencionaron que el comienzo del trabajo infantil se dio por su propia voluntad. Once adolescentes no respondieron o no se los preguntó.

En cuanto a la pregunta acerca de la relación entre el trabajo precoz y el abandono de la escuela, se percibe que la gran mayoría de los entrevistados no cree que haya causa y efecto. Bocão, por ejemplo, afirma que fue "broma mismo" y que fue en la ola de amigos. Robson dice que nunca dejó de es- 
tudiar, pero a los 18 años está asistiendo al $9^{\circ}$ grado de la Escuela Primaria. Artur, a los 16 años, todavía está en el séptimo grado de la Escuela Primaria. El retraso escolar es indicativo de que el trabajo infantil puede no ser la causa única, pero contribuyó a la desmotivación y la desorganización del adolescente para asistir a la escuela. La distorsión edad/escolaridad quedó evidenciada en la investigación.

Ninguno de los entrevistados mencionó la deficiencia de la enseñanza formal y del sistema educacional como motivo para su alejamiento y justificaron la evasión escolar por cambio de residencia, uso de drogas, envolvimiento con el mundo del crimen, entre otros. Leandro Y Artur no supieron responder, pero Magrão, Guerreiro, Davi, Simi y Bocão dejaron claro que necesitaron priorizar el trabajo y no consiguieron conciliar las dos actividades:

Magrão: dejé de estudiar y fui a trabajar, ¿verdad?

Guerreiro: en la carpintería. Entonces yo estudiaba por la mañana, ¿sabe? Entonces mi jefe dijo que si yo trabajara todo el día, yo podría ganar más y me pasó para Noche y yo fui, pasé por la noche y dejé de estudiar. Por eso estoy en el noveno. Ya era para terminar de estudiar.

Oradora A: ¿has estado trabajando todo el día y estudiando por la noche?

Guerreiro: sí

Oradora A: ¿y entonces no funcionó?

Guerreiro: No. ¿Por qué tenía trabajo pesado en la carpintería? A veces tenía carga de banco y todo para mandar fuera y yo llegaba cansado a casa y ni siquiera iba a estudiar...

$[\ldots]$

Oradora A: ¿y crees que dejaste de estudiar porque estabas trabajando demasiado?

Guerreiro: Verdad...

Oradora A: ¿usted en el momento en que comenzó a trabajar dejó de estudiar?

Davi: no dejé de estudiar...Cuando estaba en el octavo grado dejé de estudiar. Oradora A: ¿pero estaba trabajando? ¿Dejó de estudiar por qué estaba trabajando?

David: sí

Oradora A: ¿en serio? ¿Por qué? ¿No había tiempo?

Davi: No. Trabajaba todo el día, pero después, me metí en un lío allá.

La gente del Consejo Tutelar fue allá para hablar con mi abuelo, con mi tía, para resolver esto.

Oradora A: ¿Sobre el trabajo?

Davi: entonces empecé a trabajar medio turno. Trabajaba solo por la mañana.

Oradora A: el Consejo Tutelar fue allí porque solo estaba trabajando, no estaba estudiando, ¿verdad? 
Davi: ya no iba a la escuela.

[...] Oradora A: En ese momento, ¿qué pensaba de trabajar?

Davi: en el caso, yo creía lo bueno que era estar allí, estar aprendiendo, pero es malo también porque yo estaba saliendo de la escuela, que la escuela era lo más importante. Pero podía ayudar a mi abuelo.

Oradora A: ¿y no ha dejado de estudiar, aun trabajando?

Simi: No. Después de que me hundí en las drogas y comencé a robar, entonces, yo dejé los estudios, mientras yo estaba trabajando mi padre no me dejaba faltar en la escuela, él decía, "tú quieres trabajar para los otros, vas a tener que estudiar". Pasado un tiempo comencé a fumar marihuana, a involucrarme más con los demás, con el robo, luego, prácticamente abandoné los estudios.

Bocão: Tenía. Trabajo, trabajo puente, deshierbe, lo que me llame estoy listo. Quiero trabajar, lo que me llame voy.

Oradora A: Entonces, perjudicó la escuela, un poquito, ¿no?

Bocão: Sí, lo único que me perjudicó fue la escuela.

No se puede negar que la educación formal, en Brasil, necesita de urgente reforma de sus directrices, pues sólo la universalización e igualdad de trato será posible dar cumplimiento a los principios constitucionales de ciudadanía y de dignidad de la persona humana. En una investigación realizada en el Centro de Socio educación de Ponta Grossa/PR constató que, la mayoría de los adolescentes atendidos habían sido liberados de sus derechos fundamentales desde que nacieron y no concluían la enseñanza fundamental, por haber sido expulsados de la escuela por el "contenido oculto", expresiones fuertes, pero que definen la situación. Jesús (2013, p. 133) constata:

Los adolescentes, generalmente, tienen baja escolaridad, abandonan la escuela, o bien, fueron "expulsados" de ella (a pesar de ser prohibida oficialmente la expulsión, el currículo oculto los expulsa). La escuela a través del currículo oculto, entendido por Giroux "como siendo las normas, valores y creencias imbuidas y transmitidas a los alumnos a través de reglas subyacentes que estructuran las rutinas y relaciones en la escuela y en la vida del aula" (GIROUX, 1986, p. 71); expulsa sutilmente de su interior a todos aquellos que no se constituyen como alumnos ideales (sin dificultades de aprendizaje, con buenos hábitos de higiene, respeto e adecuación a las normas escolares, sin distorsión edad/grado).

Los adolescentes entrevistados tampoco veían la relación entre el trabajo infantil y la comisión del acto de infracción y al utilizar, como justificación la "ausencia de trabajo", se colocan en la posición de proveedores de su propia subsistencia. Las dificultades de mantenerse en la escuela son inmen- 
sas y se ven con una naturalidad impresionante, como se ve en los pasajes transcritos a continuación:

Oradora A: ¿cree que el trabajo de niño puede haber contribuido de alguna manera a la práctica del acto de infracción?

Davi: la falta de... Contribuyó, ¿ंverdad?

Oradora A: ¿en serio?

Davi: la falta de trabajo contribuyó.

Oradora A: Ah, es al revés. Usted piensa que el hecho de no está trabajando... ¿Lo es?

Davi: Sí

Oradora A: ¿Por qué piensa eso?

David: porque cuando salí de mi trabajo...Vivía solo mi abuelo y yo. Por lo tanto, mi abuelo tenía un problema, estaba dirigiendo los papeles, que él tenía un problema en la rodilla y ya no podía trabajar. Y nosotros sólo recibimos una ayuda del gobierno, que era de la Bolsa Familia, que era ciento y pocos. Entonces tuve que ayudar a mi abuelo, y entonces siempre estaba trabajando. Entonces, en mi caso, el mercadillo que yo trabajaba, el dueño se involucró con unos cabrones, dio un lío. Le dispararon, tuve que dejar de trabajar en el mercado porque los hombres fueron allá para disparar allá.

Guerreiro: sí...Eu sacaba 1.000, 1.200 al mes. Pero le debía mucho a él también. Como su padre tenía un bar y yo gastaba en el bar y tomaba mucho dinero por adelantado con él, llegaba el final del mes y no tenía nada. Dejé de trabajar después y me quedé sin dinero, sin nada y mi madre siempre decía que nos faltaban las cosas. Entonces mucha gente me llamó para hacer algo malo y yo no pensé y fui.

Yago: Ah, sí que hay una conexión sí, a causa... Yo no encontraba trabajo, si no encontraba trabajo no tenía forma de conseguir dinero. Ahí como yo veía a la gente siendo del crimen ganando dinero fácil, rápido allí, iba allí cogía el dinero allí ya pasaba allí, quedaba con bastante dinero, luego dije así "ah, voy a entrar para ver cómo es". Ahí lo cogí, ahí es donde entré y estaba hasta ahora, cuando antes de estar preso.

Robson: no sé si lo entendí, pero si estuviera trabajando no habría hecho el acto infractor.

Balança: No, No. Que una cosa es trabajar, otra cosa es robar. Más sólo que tú ves allí que no estás arreglando nada en el trabajo. Así que robó, ¿qué hace? [inint] [00:17:41] dinero, cada uno [inint] [00:17:44] está necesitando.

Esas son, en rápidas líneas, la percepción acerca del trabajo infantil y su influencia en la escolaridad y en la comisión del acto de infracción de los adolescentes que, en el momento de la entrevista, se encontraban internos, en cumplimiento de su medida socioeducativa. 


\subsection{La voz de los adolescentes del Grupo 2}

Los adolescentes egresados relatan actividades laborales a los 8 años (Pirata y Nabo), de los 11 a los 12 (Thales y Yara) y de los 13 a los 14 años (Jonatas, Naor, Brain). Dos de ellos no informaron la edad (Japinha y Cauan). Se percibe que, tal cual los sujetos del Grupo 1, Los adolescentes egresados no poseen conocimiento acerca de la edad mínima para el inicio del trabajo, como se desprende de las declaraciones de Jonatas y Naor:
Oradora A: ¿usted trabajó de pequeño?
Jonatas: No. do albañil, en obra y en hostelería. vez?
Jonatas: no recuerdo, pero no era un niño.
Oradora A: no, ¿era Que, unos 12 años, 13?
Jonatas: sí, unos 13 años.
Oradora A: ¿usted trabajó de pequeño?
Naor: he trabajado. Pero cuando era niño, no.
Oradora A: ¿con cuántos años comenzó a trabajar?
Naor: con unos 14 años por ahí.

Oradora A: ¿No? ¿Comenzó a trabajar cuando tenía cuántos años?

Jonatas: cuando era niño, no. Pero antes de entrar a la FASE, trabajé ayudan-

Oradora A: ¿y tenía cuántos años cuando comenzó a trabajar por primera

El trabajo precoz mencionado por los adolescentes abarca actividades en establecimientos comerciales (tienda, hotel, bar, taller mecánico y "lancheria”), en el comercio (confección de helado y de trufas, montaje de "pula-pula", reparación de lavadora), en lugar público (venta de trufas, venta de bala y dulces, venta de frutas y verduras), En construcción civil, en Hacienda, además de trabajo infantil doméstico (cuidadora de niño). Varias de las actividades mencionadas por los adolescentes están incluidas en la Lista TIP, como trabajo en obras (ítem 58) y en lugares públicos (ítem 73). Sólo Cauan dijo que no había trabajado nunca, pero se verificó que a los 16 años estaba involucrado en el tráfico de drogas.

También Cabelo y Japinha afirmaron haber comenzado a trabajar en el aprendizaje profesional. Sin embargo, el primero fue incautado por un acto de infracción análogo al tráfico de drogas a la edad de 17 años. No hay, en los autos, indicación o mención de participación de Japinha con el tráfico.

La necesidad de dinero constó como condición desencadenante del inicio del trabajo en el habla de la mayoría de los adolescentes (Cabelo, Jona- 
tas, Naor, Pirata, Yara y Brain). Yara relata que no trabajaba y, sí, ayudaba a la madre, mientras que Thales dijo que ayudaba para "aprender", percepción distorsionada, pero muy común:

Thales: con unos doce, once allí. No trabajar. Cómo ayudar. Auxiliar de mecánica para que yo aprenda para después no pasar trabajo. ¿Sabe señora? Aprender. Entonces estaba aprendiendo auxiliar. ¿Sabe? Coge esa llave. ¿Qué llave? Esta es la llave Philips. Ese de aquí se llama destornillador. [...] Ganaba un beneficio todos los viernes. Me daban dinero allí. [...] Solo aprendía. Venga. Ese es un destornillador. Esta es una pinza. Esta es la llave torque. Así se aprieta un tornillo. Enseñándome así. Y yo me quedaba mirando.

Yara: yo comencé a trabajar no era por así por necesidad, es que yo era una persona muy imperativa, ahí como mi madre, yo la ayudaba a vender también ella hacía un dulce "cueca volcada" también para vender, ahí yo ayudaba, yo salía a vender con ella y a veces yo salía a vender sola pero no por necesidad sino para tener una renta más

El papel de los padres o responsables en la deflagración del trabajo infantil no quedó totalmente esclarecido en el Grupo 2, pues cinco entrevistados nada dijeron al respecto, uno de ellos afirmó que se inspiró en la madre y fue a trabajar, otro que la abuela lo incentivó, dos otros o tuvo el incentivo de la madre o no fue impedida por ella. Nabo, huérfano de madre, vivía con los tíos y contó que, a los 8 años, el tío enseñaba “a hacer las cosas (sic), no le gustaba cuando yo quedaba sólo viendo televisión, me gustaba ver los dibujos de antiguamente". Pirata relata que a los ocho años "ya iba a la (sic) obra ayudar a mi padre". La impresión de Pirata, de que "solo ayudaba".

En cuanto a la indagación se detuvo de estudiar delante del trabajo, cinco de ellos dijeron que sí, pero presentaron otras justificaciones, excluyendo la correlación con el trabajo precoz. Se destaca que, Nabo afirmó que no estudiaba cuando comenzó a trabajar a los ocho años de edad y que sólo comenzó a asistir a la escuela a los diez años.

Se constató que la mitad de los adolescentes estaba fuera de la escuela y no trabajaba en el momento de la comisión del acto de infracción que los llevó al cumplimiento de medida socioeducativa. Cabello y Japinha afirmaron que estudiaban cuando cometieron el acto de infracción, Thales dijo que estudiaba y trabajaba y Yara afirmó que no estudiaba. Brain no se manifestó sobre el tema. 
Los adolescentes del Grupo 2 se mostraron menos dispuestos a responder algunas de las preguntas formuladas en las entrevistas, dejando prever un cierto constreñimiento o timidez.

\section{MSE Y TRABAJO INFANTIL: RESULTADOS DE LA BÚSQUEDA}

El trabajo infantil es culturalmente aceptado por la sociedad brasileña y el discurso de los adolescentes refleja eso, pues algunos de ellos negaron que habían trabajado como niño y, en respuestas posteriores respondieron que iniciaron el trabajo a los 12 años o 13.

Ninguno de ellos se percibía como sujetos de derecho al no trabajo y no hubo, ni siquiera indicios, de cuestionamiento acerca de la necesidad de trabajar por ausencia de condiciones financieras de su familia o incluso de políticas públicas.

Los adolescentes tampoco visualizan la relación entre el trabajo infantil y la comisión del acto de infracción, justificándolo por la ausencia de trabajo, o sea, se colocan en la posición de proveedores de su propia subsistencia, pues necesitan actuar como si fueran adultos cuando todavía son niños, intercambian los juegos de la infancia por la responsabilidad de su supervivencia y, a veces, de su familia (BARQUERO, 2011).

Se constató que $76,92 \%$ del total, o sea, 30 adolescentes declararon, en la entrevista, que ejercieron actividades laborales antes de los 16 años y siempre de forma precaria, teniendo en cuenta que, con excepción de Pirata, todos los demás dijeron que el primer registro en la cartera de trabajo ocurrió con la contratación para el curso de aprendizaje.

De los 9 adolescentes que afirmaron no haber trabajado antes de los 16 años, se verificó que 4 de ellos, a temprana edad, pasaron a ser explotados por el tráfico, como por ejemplo Gui, que a los 14 años estudiaba por la mañana y "traficaba por la noche", Yuri, incautado a los 15 años por acto de infracción análogo al tráfico de drogas y Jean, que a los 12 años ya estaba involucrado en la producción y tráfico de drogas. También Mateus, a los 12 años, fue incautado por guardia y porte de droga, porte de arma de fuego y de munición. No fue posible extraer de los autos judiciales informaciones precisas acerca de los otros adolescentes no citados. 
De esta forma, considerando los 30 adolescentes que afirmaron haber iniciado el trabajo antes de los 16 años, sumándose a los 4 mencionados en el párrafo anterior con histórico de explotación para actividad ilícita antes de los 16 años, el porcentaje de los adolescentes entrevistados que fueron sometidos al trabajo precoz se eleva para $87,17 \%$.

Si la constatación del porcentaje de $76,92 \%$ de trabajo infantil auto declarado ya sería suficiente para superar el mito de que niños y adolescentes que trabajan no "roban" o no cometen otros actos infractores y de que el trabajo precoz protege y enseña, cuanto más el porcentaje de $87,17 \%{ }^{6}$.

\section{CONCLUSIÓN}

El universo de los adolescentes entrevistados se reveló más denso de lo que se había supuesto al inicio de la investigación y los momentos vivenciados en las entrevistas dejan prever los perjuicios a su desarrollo integral proveniente de la dura realidad vivenciada por ellos. Algunos gestos e intervenciones, como, por ejemplo, para la toma de medicamentos psiquiátricos, pueden ser una pequeña muestra.

Cada rostro y cada mirada fueron rememorados en la lectura de los autos judiciales de ejecución de la medida socioeducativa de cada uno y trajeron y traen reflexiones acerca del futuro de las próximas generaciones.

Nada justifica la violación de derechos de otros por la práctica de acto de infracción. Pero es forzoso concluir que, delante de los relatos, se constata que el trabajo infantil contribuyó para su alejamiento de la escuela y les trajo otras perjudiciales consecuencias físicas y psicológicas.

Es necesario repensar las políticas públicas y construir oportunidades a los adolescentes que tuvieron la infancia segada por la explotación de su mano de obra, sin derecho a una gestión protectora de un responsable para ayudarles a construir un camino.

Los verdaderos factores de protección, que pueden impactar positivamente en la vida del niño y del adolescente, son aquellos que, además de garantizar su integridad física y psíquica, promueven su desarrollo integral, articulando las diversas dimensiones de la naturaleza humana, como social, intelectual, emocional y física. 
La constatación de que $87,17 \%$ de los adolescentes entrevistados posee histórico de trabajo infantil autoriza a responder a las preguntas del inicio. Sí, el trabajo infantil es un hecho de riesgo y estímulo para la comisión del acto de infracción. No, el trabajo infantil no es un factor de prevención del acto infractor.

La triste trayectoria de vida de Bocão, que comenzó a trabajar a los 7 años, a los 11 era dependiente químico y, a los 15 años, mató por asfixia mecánica a un hombre que conoció en una esquina cuando vendía bombones, pues ese le ofreció el valor de $\mathrm{R} \$ 150,00$ para hacer sexo oral y después se negó a pagar, refuerzan los resultados de la investigación de que el trabajo infantil puede contribuir con la comisión de acto de infracción.

\section{NOTAS}

1 Desarrollo Local es entendido, por el programa de postgrado, "como el protagonismo de los actores de un determinado territorio, con apoyo de organizaciones públicas y privadas, en la reflexión de la realidad vivida para agenciar y coordinar, por medio de procesos interactivos y cooperativos, los recursos tangibles e intangibles originarios del local o de áreas externas, en la búsqueda de soluciones sostenibles para los problemas, necesidades y aspiraciones colectivas, de orden social, económico, cultural, político y del ambiente natural". Disponible en: https://site.ucdb.br/cursos/4/mestrado-edoutorado/32/mestrado-e-doutorado-em-desenvolvimento-local/13242/sobre-oprograma/13243/. Acceso en: 19 jun. 2020.

2 De acuerdo con el IBGE, el color sólo puede ser auto declarado y, por la PNAD de 2014, la mayor parte de la población brasileña residente es blanca, o sea 45,5\% del total, $45 \%$ son de color parda y otros $8,6 \%$ se declararon de color negro.

3 El Decreto n. ${ }^{\circ} 3.597$, de 12 de septiembre de 2000, promulgó el Convenio n. ${ }^{\circ} 182$ y la Recomendación n. ${ }^{\circ}$ 190, ambas de la Organización Internacional del Trabajo (OIT) sobre la prohibición de las peores Formas de Trabajo Infantil y la acción inmediata para su eliminación, concluidas en Ginebra el 17 de junio de 1999. Y el Decreto n. ${ }^{\circ}$ 10.088, de 5 de noviembre de 2019 derogó dicho decreto, sustituyéndolo.

4 Consta de esta forma los artículos en la Convención, o sea, sin el símbolo “o”, lo que difiere de las leyes brasileñas.

5 En algunos momentos, no fue posible hacer todas las preguntas programadas, sea por el momento de la entrevista, por el contexto, por el cambio de asunto por el adolescente o algún detalle percibido por la investigadora.

6 En una investigación realizada en 2002, en las unidades educacionales del Estado de Mato Grosso do Sul, se constató que 98,43\% de los adolescentes habían comenzado a trabajar precozmente. El informe fue publicado por primera vez, en 2018, por la Revista n. ${ }^{\circ} 11$ del Ministerio Público del Trabajo de Mato Grosso do Sul, por iniciativa de la autora con las debidas autorizaciones (CATARINO; SARAVI, 2018). 


\section{REFERENCIAS}

BARQUERO, Rute Vivian Ângelo et al.. Histórias de vida de jovens egressos de medidas socioeducativas: entre a margem e a superação. In: Educação. Porto Alegre, v. 34, n. ${ }^{\circ}$ 3, p. 341-350, set./dez. 2011.

BRASIL. Levantamento Anual SINASE 2014. Brasília: Ministério de Direitos Humanos, 2017.

BRASIL. Decreto . $^{\circ}$ 3.597, de 12 de setembro de 2000. Promulga a Convenção 182 e a Recomendação 190 da Organização Internacional do Trabalho (OIT) sobre a proibição das Piores Formas de Trabalho Infantil e a Ação Imediata para sua Eliminação, concluídas em Genebra, em 17 de junho de 1999. Disponible en: https://www2.camara.leg.br/legin/fed/decret/2000/ decreto-3597-12-setembro-2000-371954-norma-pe.html. Acceso en: 08 oct. 2020 .

BRASIL. Decreto n. ${ }^{\circ}$ 6.481, de 12 de junho de 2008. Regulamenta os artigos $3^{\circ}$, alínea “d”, e $4^{\circ}$ da Convenção 182 da Organização Internacional do Trabalho (OIT) que trata da proibição das piores formas de trabalho infantil e ação imediata para sua eliminação, aprovada pelo Decreto Legislativo $\mathrm{n}^{\mathrm{o}} 178$, de 14 de dezembro de 1999, e promulgada pelo Decreto $\mathrm{n}^{\mathrm{o}}$ 3.597 , de 12 de setembro de 2000, e dá outras providências. Disponible en: https://www2.camara.leg.br/legin/fed/decret/2008/decreto-6481-12-junho-2008-576432-publicacaooriginal-99613-pe.html. Acceso en: 08 oct. 2020.

BRASIL. Decreto n. $^{\mathbf{1}} \mathbf{1 0 . 0 8 8}$, de 05 de novembro de 2019. Consolida atos normativos editados pelo Poder Executivo Federal que dispõem sobre a promulgação de convenções e recomendações da Organização Internacional do Trabalho - OIT ratificadas pela República Federativa do Brasil. Disponible en: https://www.in.gov.br/en/web/dou/-/decreto-n-10.088-de-5-de-novembro-de-2019-231356812. Acceso en: 08 oct. 2020.

CATARINO, Regina Rupp; SARAVI, Maristela Borges de Souza et al.. Trabalho Infanto-Juvenil. Mito e Realidade. In: Revista do Ministério Público do Trabalho do Mato Grosso do Sul, n. ${ }^{\circ}$ 11, 2018, p. 215-273.

JESUS, Vania Cristina Pauluk de. Condições escolares e laborais de adolescentes autores de atos infracionais: um desafio à socioeducação. In: Revista Eletrônica de Educação, v. 7, n.3, p. 129-142. 2013. Disponible en: http:// 
www.reveduc.ufscar.br/index.php/reveduc/issue/view/14. Acceso en: 04 abr. 2020 .

\section{ORGANIZAÇÃO INTERNACIONAL DO TRABALHO. Convenção n. ${ }^{\mathbf{o}}$} 182. Disponible en: http://www.planalto.gov.br/ccivil_03/leis/18069.htm. Acceso en: 19 mayo 2019.

REZENDE, Simone Beatriz Assis de. Aprendizagem profissional para adolescentes em cumprimento de medida socioeducativa com restrição de liberdade: desenvolvimento humano e reintegração social. 2019. 367 p. Tese (Doutorado em Desenvolvimento Local). Universidade Católica Dom Bosco, Campo Grande, MS. Disponible en: https://site.ucdb. $\mathrm{br} / /$ public/md-dissertacoes/1031152-tese-simone-beatriz-assis-de-rezende-compressed.pdf. Acceso en: 19 jun. 2020. 



\section{LOS 20 AÑOS DE LA COORDINFÂNCIA: RESISTENCIA Y LUCHA EN EL COMBATE AL TRABAJO INFANTIL}

\section{VALESCA DE MORAIS DO MONTE}

DOI: 10.51366/978-65-89468-10-3-coordinfancia-29

Resumen. En el presente artículo se describen las acciones realizadas en el período de ejercicio de la coordinación nacional de Coordinfância, destacando el contexto político experimentado por el país en aquel período. La democracia brasileña, en proceso continuo y acelerado de erosión tras el golpe de 2016, pasó a experimentar el aniquilamiento de conquistas fundamentales, con el debilitamiento de las políticas públicas inclusivas que redujeron las desigualdades sociales. En este sentido, los severos impactos sufridos en el área de protección de la infancia pasaron a exigir actuación aún más resolutiva, proactiva y eficiente de los integrantes de Coordinfância del Ministerio Público del Trabajo.

Palabras clave: Coordinfância. Coordinación nacional. Protección integral a la infancia. Rescato la infancia.

\section{INTRODUCCIÓN}

El aniversario de 20 años de Coordinfância merece ser celebrado con intensidad, pues es una fecha conmemorativa de extrema relevancia para el Ministerio Público del Trabajo. Creada el 10 de noviembre de 2000, la Coordinación Nacional de Combate contra la Explotación del Trabajo de Niñas, Niños y Adolescentes es símbolo de resistencia y lucha desde el inicio de sus trabajos. La combativa colega Eliane Araque dos Santos fue su primera coordinadora nacional, la responsable de imprimir la identidad inicial rumbo a la actuación concertada y armónica de los coordinadores regionales de cada una de las Fiscalías del Trabajo del País. 
Integre Coordinfância durante casi 20 años. Hoy tengo convicción en decir que la más rica experiencia profesional no fue haber sido su coordinadora nacional entre los años 2016 y 2017, sino, haber sido testigo, a lo largo de los años, de las luchas diarias de las Fiscales y de los Fiscales del Trabajo que actúan en la protección a la infancia y a la juventud. Ser integrante de Coordinfância es defender la concretización de la Constitución Federal diariamente, es saber que el texto constitucional no opera milagros si no hay una verdadera apropiación de las directrices constitucionales de protección a la infancia.

Cuando asumí la coordinación nacional, al lado del amigo y competente Fiscal del Trabajo Tiago Ranieri, Brasil acababa de sufrir el duro golpe de 2016, episodio inicial de un proceso devastador que resultó en una grave calamidad económica, política y social para el país. La democracia brasileña, en proceso continuo y acelerado de erosión, pasó a experimentar el aniquilamiento de conquistas fundamentales, como el debilitamiento de las políticas públicas inclusivas que reducían las desigualdades sociales.

Crisis política, polarización social e ideológica, prensa partidista alineada con el sector económico, activismo judicial, crisis fiscal, privatizaciones, extinción de carteras ministeriales como la de Derechos Humanos, este escenario tan adverso verificado en aquel año de 2016 exigió que Coordinfância potenciase su actuación resolutiva, con el fin de reconstruir la agenda positiva en el campo de los derechos fundamentales, evitando, así, aún más retrocesos sociales.

El presente artículo tiene por principal objetivo colaborar en la construcción de la memoria de Coordinfância. Para ello, aquí serán consolidadas las principales acciones realizadas en el período en que ejercí el cargo de coordinadora nacional. Regístrese que ellas solo pudieron ser concretizadas en razón de la competencia y entrega de cada uno de los dos Fiscales del trabajo que la integran.

Las principales iniciativas adoptadas durante mi gestión como coordinadora nacional, en síntesis, fueron: a) implantación simultánea de los 3 ejes estructurales de actuación de Coordinfância (educación, aprendizaje y políticas públicas) por el proyecto estratégico Rescate la Infancia ${ }^{1}$; b) creación del curso de enseñanza a distancia para capacitación de los consejeros tutelares por plataforma do MPT; c) unificación en el ámbito nacional de la 
campaña \#chegadetrabalhoinfantil (\#bastadetrabajoinfantil); d) elaboración de nuevo material didáctico para el eje educación y para el eje aprendizaje; e) conmemoración del día mundial de combate al trabajo infantil con la presencia inédita en el MPT de Kailash Satyarthi, agraciado con el Premio Nobel de la $\mathrm{Paz}$.

Es hora, por tanto, de discursar sobre cada una de esas iniciativas, no sin antes contextualizar la lucha por la erradicación del trabajo infantil a la luz de las normas constitucionales y del golpe de 2016.

\section{LA CONSTITUCIÓN, EL TRABAJO INFANTIL Y LA EROSIÓN DEMOCRÁTICA A PARTIR DE 2016}

Una de las más expresivas contribuciones de la Constitución de 1988 para el desarrollo de la democracia en Brasil fue la opción consciente de la defensa de los derechos fundamentales. La intensa actuación en el área de protección a la infancia y adolescencia revela la importancia de la constitucionalización del derecho fundamental al no trabajo antes de los 16 años, como a la protección de los adolescentes en la franja de los 16 a los 18 años, conforme expresado en el art. $7^{\circ}$, inciso XXXIII.

El art. 227 de la Constitución Federal, antes de la Convención sobre los Derechos del niño, exige que Estado, familia y sociedad asuman su misión de tutelar, con absoluta prioridad, los derechos de las niñas, los niños y de los adolescentes, responsabilizándolos solidariamente en esta tarea indispensable. La teoría de la protección integral asume centralidad en el ordenamiento jurídico brasileño por ser niños y adolescentes titulares de derechos que demandan atención especial, por no poseer todos los mecanismos hábiles para la plena consecución de sus derechos.

Además de las normas constitucionales protectoras a la infancia, existen las Convenciones internacionales n. ${ }^{\text {os }} 182$ (eliminación de las peores formas de trabajo infantil) y 132 (edad mínima al trabajo), ambas de la Organización Internacional del Trabajo y ratificadas por Brasil, que deben ser respetadas, promovidas y respetadas hasta por los Estados que no la ratificaron. Regístrese también, por importante, la Agenda $2030^{3}$ para el Desarrollo Sustentable, de la Organización de las Naciones Unidas (ONU), que reconoce la erradicación de la pobreza como el mayor desafío del siglo. 
En Brasil, a pesar del marco legal y constitucional de protección de la infancia, aún hay cerca de 2,4 millones de niños y adolescentes en la faja de los 5 a los 17 años en situación de trabajo ${ }^{4}$. En un contexto de creciente pobreza, la mayor dificultad encontrada en el proceso de erradicación del trabajo infantil es el enfrentamiento de la falsa creencia de que el trabajo, independientemente de la edad en que es ejercido, siempre ennoblece y dignifica. La mayor parte de la población brasileña acepta el trabajo infantil y lo identifica como un mal de menor impacto social, lo que importa reiterar que el mayor obstáculo en la lucha por la erradicación del trabajo infantil es el mito de que trabajar en la infancia no trae graves perjuicios.

El trabajo infantil es una llaga social incompatible con los cambios paradigmáticos que trajo la Constitución de 1988, siendo una de las más graves violaciones de derechos humanos por perjudicar el presente y el futuro de sus víctimas. El desafío de erradicar el trabajo infantil es la lucha a ser combatida en diversas arenas, exigiendo que el MPT asuma postura mucho más resolutiva y proactiva en su actuación.

En la mayor parte de las denuncias llevadas a conocimiento del MPT con relación al trabajo infantil, aprendizaje o no cumplimiento de política pública, no es suficiente la actuación limitada a la instauración de investigaciones civiles y el consecuente juicio de acciones civiles públicas, o incluso celebración de términos compromiso de ajustamiento de conducta. La defensa intransigente de la protección integral de la infancia y adolescencia exige, aún que dentro de la esfera tradicional de actuación por el MPT, la discusión más amplia y exhaustiva del tema, con profundización de la interlocución horizontal con actores sociales en busca de soluciones creativas y sustentables junto a los actores que se encuentran en la base.

Es necesario que el MPT profundice, también en la esfera extrajudicial, su actuación en defensa del orden jurídico y de los intereses sociales indisponibles. Eso significa afirmar que existen muchas experiencias exitosas de la participación del MPT en foros, en colectivos y en órganos públicos destinados a la formulación y ejecución de medidas destinadas a la concretización de las normas y de los principios constitucionales. A título ejemplificativo, cito el Fórum Nacional de Prevención y Erradicación del trabajo Infantil (FNPETI) y sus ramificaciones en los estados. En esos ambientes, el Ministerio Público es uno más entre varios actores sociales públicos o privados, cuyo objetivo es el mismo, a saber: postular la realización de principios 
constitucionales inherentes al Estado Democrático de Derecho. Innegablemente la lucha por la protección integral de niños y adolescentes conduce a la eficacia del principio de la dignidad de la persona humana, colocado como uno de los dos centros gravitacionales de la Constitución de la República de 1988, conforme listado en el art. 227.

Los Fiscales y las Fiscales del Trabajo que integran Coordinfância son testigos diariamente de las potencialidades de la actuación colectiva, de los movimientos sociales y la necesidad de que la concretización del derecho fundamental al no trabajo antes de los 16 años y la protección integral de la infancia y adolescencia debe ser operada por toda la sociedad, por la familia y por el Estado, bajo el riesgo de hacer letra muerta a las importantes e inéditas directrices previstas en la Constitución.

Los severos impactos sufridos en el área de protección de la infancia, tras el golpe de 2016, exigieron actuación aún más resolutiva, proactiva y eficiente de los integrantes de Coordinfância. El desmonte de las políticas públicas existentes, el debilitamiento de las acciones gubernamentales que estaban en curso durante los años anteriores, la ruptura de la agenda positiva de la infancia, la duda en cuanto a la concreción de las normas y principios constitucionales hicieron que fuera imperiosa la actuación estructurada del MP'T bajo varias formas, cuales sean, la preventiva, la represiva, en actuación concertada y dialógica con la sociedad civil organizada y el poder público en sus diferentes esferas. Comprender las consecuencias del debilitamiento de la democracia y resistir a las medidas que causan precariedad, derivadas de un gobierno ilegítimo, fueron los mayores desafíos vivenciados por los integrantes de Coordinfância en aquel período.

El combate al trabajo infantil es tema que necesita ser pautado en los más diversos frentes de discusión con el objetivo de construir soluciones posibles, proponer y exigir la implementación de las políticas públicas, cobrar el cumplimiento del cupo de aprendizaje, sensibilizar a la sociedad en cuanto a los perjuicios derivados del trabajo antes de los 16 años y de la protección necesaria en la franja de los 16 a los 18 años.

En una breve síntesis, paso a listar las principales acciones específicas de Coordinfância en el período comprendido entre julio de 2016 y agosto de 2017, cuando ejercía el cargo de coordinadora nacional. 


\section{a) El proyecto Rescate la Infancia y la implantación de los 3 ejes estructurantes de actuación de Coordinfância: educación, políticas pú- blicas y aprendizaje}

El proyecto Rescate la Infancia fue oficialmente instituido como un proyecto estratégico del MPT en octubre de 2016, a partir de la necesidad de implantación simultánea de los 3 ejes estructurantes de actuación de Coordinfância: educación, aprendizaje y políticas públicas.

El nombre del proyecto (Rescate la Infancia) fue elegido de forma democrática entre todos los integrantes de Coordinfância, en una de las primeras reuniones de nuestra gestión en agosto de 2016. Lo que pesó de forma decisiva para la elección de ese nombre fue el hecho de que el verbo "rescatar" evoca el sentido de urgencia que la protección a la infancia exige, conectándose a otras acciones igualmente fundamentales, como salvar, recuperar, retomar.

Rescatar la infancia es imperativo en el universo de la coordinación y su transitividad directa con la infancia hizo que, por unanimidad, eligiéramos ese nombre para nuestro proyecto estratégico. Su principal objetivo es prevenir y combatir el trabajo infantil, concientizar a la sociedad, fomentar políticas públicas, promover la formación profesional y proteger al trabajador adolescente.

Para ello, la implantación pasó a hacerse inicialmente en aquellos municipios que habían sido beneficiados por el cofinanciamiento presupuestal del gobierno federal, pero que aún no habían adoptado en sus territorios las providencias necesarias para la prevención y erradicación del trabajo infantil.

De forma simultánea, los ejes educación, políticas públicas y aprendizaje pasaron a ser implantados en aquellos municipios previamente identificados y con alto índice de trabajo infantil. Es importante resaltar que Coordinfância siempre tuvo como centro gravitacional de su actuación tales ejes estructurantes, siendo los factores espacial y temporal el gran diferencial del proyecto estratégico Rescate la Infancia.

Es necesario tejer breves y sintéticas consideraciones relativamente a cada uno de los ejes de actuación del proyecto, de modo de exponer la forma como fue implantado en su nuevo formato. 


\section{Eje educación}

En lo que respecta al eje educación (antiguo MPT en la Escuela), es importante reiterar que su mayor propósito es la sensibilización de los profesores y alumnos con relación al tema. Es innegable que muchos docentes aún replican los mitos sobre el trabajo infantil, contribuyendo para que la sociedad acepte y haga invisible esta grave violación a las normas constitucionales. Desarrollar el tema en sala de clase, espacio privilegiado de promoción de conocimiento, no solo es propiciar la estandarización de información esencial para el pleno dominio de la temática, sino también capacitar a la comunidad escolar para que sus integrantes sean actores sociales en la identificación de las posibles víctimas.

El primer paso para el desarrollo de este eje es el acto público que involucra el esclarecimiento y la sensibilización de directores escolares, de coordinadores pedagógicos y de profesores de la red pública de educación municipal y estatal. Este es el momento en que el MPT presenta su material didáctico y pedagógico, haciéndolo disponible sin costo al gestor municipal, como resalta que su contenido deberá ser dado preservando el método pedagógico de cada profesor.

Hay que resaltar que el presente eje, además de la preeminencia del papel del profesor, destaca al aluno como otro gran protagonista en el proceso que involucra la erradicación del trabajo infantil. Como es de conocimiento general, casi el 97\% de las niñas y los niños en el país están matriculados en las escuelas, lo que importa decir es que la comunidad escolar es absolutamente fundamental en el proceso de concientización y sensibilización en cuanto a los perjuicios causados por el trabajo infantil.

El momento culminante del proyecto educación ocurre con la presentación y premiación de los trabajos desarrollados por los alumnos en la sala de clase. El proceso, hasta llegar a su etapa conclusiva, garantiza que los conocimientos adquiridos por los alumnos puedan llegar a sus casas, a los barrios y a otros espacios de convivencia, diseminando las informaciones necesarias para que los perjuicios surgidos del trabajo infantil sean conocidos por todos.

\section{Eje Aprendizaje}

El inciso XXXIII del art. $7^{\circ}$ de la Constitución de la República expresamente consigna la prohibición del trabajo antes de los 16 años, salvo en la 
condición de aprendiz a partir de los 14 años. Al lado del derecho fundamental de no trabajar antes de la edad mínima está el derecho fundamental de la profesionalización, previsto en el art. 227 de la Constitución de 1988.

Desde la Ley n. ${ }^{\circ}$ 10.097/2000, el MPT actúa en la concientización de las empresas en cuanto a los beneficios de aprendizaje para la vida del aprendiz, como para la propia empresa. Audiencias públicas, seminarios, procedimientos promocionales, participación en foros regionales de aprendizaje son ejemplos de actuaciones extrajudiciales del MPT, cuyo objetivo es la sensibilización de las empresas para el cumplimiento de una obligación legal: el cupo aprendiz previsto en el art. 429 de la CLT.

En el segundo semestre de 2016, continuamos las articulaciones ya iniciadas para la actuación integrada y conjunta del MPT, "Magistratura del Trabajo" y el entonces Ministerio del Trabajo y Previsión Social. La idea era la realización anual, en los meses de mayo, de audiencias públicas con el propósito de exigir el cumplimiento del cupo legal de aprendizaje en las empresas. Nacían, de esa forma, las Semanas Nacionales de aprendizaje, eventos en los cuales las instituciones mencionadas avanzaban más allá de la perspectiva de mera sensibilización y pasaban a priorizar el efectivo cumplimiento del cupo legal previsto desde el año 2000.

A partir de esa iniciativa nacional, el proyecto Rescate la Infancia potenció la promoción del aprendizaje en los municipios brasileños que recibieron cofinanciamiento gubernamental para la erradicación del trabajo infantil, pero que persistían en el incumplimiento de la legislación. Al mapear los segmentos económicos preponderantes en el respectivo territorio, como en los municipios circunvecinos, el MPT tenía por objetivo dar concreción al derecho fundamental a la profesionalización por medio del aprendizaje.

Regístrese que la actuación del MPT daba prioridad, además del cumplimiento del cupo legal aprendiz, a la implementación de los programas de profesionalización, con la cualificación de los cursos profesionales compatibles con la región; la realización de diagnósticos de las entidades de formación profesional; la verificación de la regularidad de los cursos de aprendizaje ya ofrecidos; la sensibilización de la comunidad para la obligatoriedad del cumplimiento legal de contratación de aprendices en las empresas, como la identificación de los jóvenes y adolescentes insertados en los programas de aprendizaje. 


\section{Eje Políticas Públicas}

En la aplicación del eje políticas públicas por el Rescate la Infancia, el municipio elegido para implantar el proyecto fue analizado bajo tres perspectivas: la previsión presupuestaria de rúbrica específica en el presupuesto municipal para el área de la infancia; la estructuración y articulación intersectorial de la red de protección; las alternativas existentes ofrecidas para la población en situación de vulnerabilidad.

El principal objetivo del eje políticas públicas es verificar la existencia de rúbrica específica dentro del presupuesto municipal destinado al costeo de acciones para el combate a las vulnerabilidades en el área de la infancia y adolescencia. La real institucionalización de la referida rúbrica es la primera evidencia de la concretización del principio constitucional de la protección integral. En la práctica, se verifica que los municipios siquiera tienen conocimiento de la obligatoriedad de la existencia de presupuesto propio para la infancia, distinto de las rúbricas destinadas a la educación, a la salud y a la asistencia social.

La última finalidad del proyecto es la de viabilizar alternativas a la familia, al niño y al adolescente, de modo de integrar, en una zona de ciudadanía ampliada, la víctima oriunda del trabajo infantil. Así, se hace fundamental la verificación de la estructuración y articulación intersectorial en la red de protección del municipio, a saber, los consejos tutelares, el Centro de Referencia en Asistencia Social (CRAS) y el Centro de Referencia Especial en Asistencia Social (CREAS). Dada la realidad encontrada en los municipios, con frecuencia es necesaria la capacitación de los actores integrantes de la red de protección en cuanto al tema trabajo infantil.

Los miembros del MPT, al implantarse el referido eje en los respectivos municipios, con frecuencia necesitan realizar audiencias individuales con cada secretaría para, de modo articulado, verificar si están funcionando los servicios de convivencia y fortalecimiento de vínculos en el horario opuesto al escolar, si hay proyectos de cultura, ocio, deporte, si existen escuelas de tiempo integral etc. De nada serviría retirar al niño del trabajo precoz y no dar alternativas para que él ejerza sus derechos previstos en la Constitución de 1988. Así, se vuelve fundamental estructurar la red de protección, crear flujos de atención a los grupos en vulnerabilidades y viabilizar alternativas para eliminar y cohibir la reincidencia de victimización. 
La misión del MPT, por tanto, es analizar las principales características del municipio en cuanto al combate al trabajo infantil y, a partir de ahí, proponer al intendente la firma del término de compromiso de ajuste de conducta después de construidas, discutidas y presentadas las cláusulas de acuerdo con las necesidades locales. Caso no sea posible el ajuste extrajudicial, otra alternativa no habrá sino el juicio de acción civil pública.

\section{b) Creación Curso EAD (enseñanza a distancia) de capacita- ción de consejeros tutelares por plataforma do MPT}

El premiado curso de capacitación de consejeros tutelares promovido por ESMPU, ideado por la Fiscal del Trabajo y excoordinadora nacional Elisiane Santos, sirvió como inspiración para el primer curso EAD creado por Coordinfância en la plataforma del propio MPT.

El objetivo de nuestra gestión en la coordinación nacional fue viabilizar la autonomía de un curso de enseñanza a distancia para la sensibilización de los consejeros tutelares sin la necesidad de someterse al calendario estacional de ESMPU. Por estar el eje políticas públicas centrado en la capacitación de la red de protección a la infancia, Coordinfância, junto con CODEP/ MPT, apostó todos los esfuerzos posibles para la creación de un curso objetivo, resolutivo y que pudiese medir y certificar la regularidad presencial y cualitativa de los participantes.

El curso producido por la Coordinfância tuvo la participación de integrantes de la Coordinación, como de los principales representantes del sistema de garantías de derechos de la infancia, actores y activistas de derechos humanos.

\section{c) Unificación nacional de la campaña \#chegadetrabalhoinfan- til (\#bastadetrabajoinfantil)}

Una iniciativa importante de nuestro período de coordinación involucra el uso del hashtag "chega de trabalho infantil" ("basta de trabajo infantil"). Ese lema fue creado por la PRT-15. Región, que fue pionera en la creación de una campaña moderna, actualizada, con potencial para la diseminación entre las demás PRTs. Así, optamos por sugerir a los integrantes de Coordinfância la unificación de sus respectivas campañas institucionales con el objetivo de conferir una identidad más marcante a la propia Coordinfância. La sugeren- 
cia fue muy bien recibida por los coordinadores regionales, que manifestaron su concordancia y posibilitaron que el hashtag \#chegadetrabalhoinfantil (\#bastadetrabajoinfantil) fuera adoptado en el ámbito nacional, incluso con la confección de camisetas con el tema de la campaña, bien como el banner colocado en la fachada frontal de la sede de la Fiscalía General del trabajo en Brasilia.

\section{d) Elaboración de nuevo material didáctico para los ejes Educa- ción Aprendizaje}

El material pedagógico utilizado por Coordinfância hasta el año de 2016, ideado para el proyecto entonces denominado MPT en la Escuela, era el librillo "Jugar, estudiar, vivir... Trabajar, solo cuando crezca", en el cual los personajes Rafael, Clara, Ana, Dudu y Julio vivenciaban en la comunidad escolar las consecuencias del trabajo infantil. Los principales daños que sufre un niño que trabaja están retratados de manera objetiva, creativa y muy bien ilustrada. Al final del librillo, constaban palabras cruzadas, sopa de letras, laberinto y juegos para colorear. Un material de excelente calidad que cumplió y cumple su papel de concientizar a la sociedad y a la comunidad escolar de los perjuicios causados por el trabajo infantil.

Al asumir la coordinación nacional, sin embargo, surgió la necesidad de actualizar y perfeccionar el material pedagógico a ser utilizado en la implantación de los ejes educación y aprendizaje. La difícil misión de elaborar un nuevo material pedagógico también contó con ayuda directa e incansable de los gerentes de los ejes estructurantes de Rescate la Infancia (Antonio Lima, Cândice Arosio, Dulce Torzecki, Margaret Matos y Tiago Ranieri). Así, los cuadernos de orientación pedagógica pasaron a contar con información relacionada al concepto de trabajo infantil, cómo denunciar el trabajo infantil, cuales son los mitos y las verdades sobre el tema, las principales formas de trabajo infantil, material de soporte constituido por nuevas publicaciones, juegos de mesa, pósteres para fijar en las salas de clase, historietas.

Asimismo, todo ese importante material podrá ser utilizado en la capacitación de la red de protección, o sea, estará apto para emplearse también en ambientes fuera de la escuela, como en los cursos para sensibilizaciones de los consejeros tutelares y del sistema de garantía de derechos en general (secretarías, consejos municipales, organizaciones de la sociedad civil etc.). 


\section{e) La cadena productiva del cacao}

Importante iniciativa de Coordinfância fue la de realizar un estudio acerca de la cadena productiva del cacao con el objetivo de mapear a sus actores, entender la dinámica de todo el proceso productivo, determinar las condiciones de trabajo existentes, como viabilizar la adopción de estrategias de actuación para la erradicación del trabajo infantil.

El año 2017 comenzó con la contratación, por la Organización Internacional del Trabajo (OIT), por medio de una alianza con el MPT, de investigadores que pasaron a recorrer los principales productores brasileños de cacao para obtener la información necesaria. A partir de julio de 2017, se iniciaron las visitas de los investigadores a los principales polos productores de cacao en el país, con la conclusión de los trabajos en junio de 2018.

\section{f) Presencia del ganador del Premio Nobel de la Paz Kailash Satyarthi en el auditorio de PGT}

La celebración del día mundial del combate al trabajo infantil, en junio de 2017, contó con la presencia inédita del activista indio Kailash Satyarthi en el auditorio de la Fiscalía General del Trabajo. Coordinfância Nacional y el Fórum Nacional de Prevención y Erradicación del trabajo Infantil realizaron el evento con la participación de todos los gerentes de los ejes estructurantes de Rescate la Infancia, niñas y niños, adolescentes, las y los Fiscales del trabajo, Ministros del TST, Jueces del TRT de la $10^{a}$ Región, como diversos representantes del sistema de garantía de derechos.

En la ocasión, Kailash Satyarthi resaltó que negar el derecho a la educación es negar todos los derechos constitucionales, destacando que el trabajo infantil se figura el mayor crimen contra la humanidad porque impide la oportunidad de educación y reproduce la pobreza.

\section{CONCLUSIÓN}

En la parte final de este testimonio del período en que estuve en la coordinación nacional de Coordinfância, me gustaría enfatizar un aspecto: todo lo que fue realizado sería imposible sin la inestimable colaboración del entonces vicecoordinador nacional, Tiago Ranieri, de los gerentes de los ejes de Rescate la Infancia y, evidentemente, todas y todos los Fiscales que estuvie- 
ron juntos en el combate al trabajo infantil, manteniendo encendida la llama de la protección integral a la infancia y adolescencia. Estoy segura de que el legado de la gestión que estuvo frente a Coordinfância fue el de aprendizaje y madurez propiciados por la convivencia con colegas tan valiosos y actuantes.

En el momento en que escribo estas líneas, vislumbro esta publicación como una oportunidad única de celebrar 20 años de luchas y conquistas en esta área que es fundamental para la sociedad brasileña. Reitero la importancia de la movilización de tantas y tantos colegas, en la interlocución con la sociedad civil y con instituciones del poder público, en la búsqueda por educación, por salud y por una vida digna para las niñas, los niños y los adolescentes en el presente y en el futuro.

Felicitaciones por los 20 años de esta Coordinación única y fantástica, nuestra Coordinfância.

\section{NOTAS}

1 El proyecto Rescate la Infancia fue creado por la Ordenanza PGT n. ${ }^{\circ}$ 659, del 26 de octubre de 2016, cuyo objetivo es prevenir y combatir el trabajo infantil, concientizar la sociedad, fomentar políticas públicas, promover la formación profesional y proteger al trabajador adolescente.

2 El día 13 de junio de 2017, Coordinfância, junto con el Fórum Nacional de Prevención y Erradicación del Trabajo Infantil, celebró el día mundial de combate al trabajo infantil en el auditorio de la Fiscalía General del Trabajo, con la presencia del activista indio Kailash Satyarthi.

3 Objetivo 8: Promover el crecimiento económico sustentado, inclusivo y sustentable, empleo pleno y productivo y trabajo decente para todos. [...] Meta 8.7: Tomar medidas inmediatas y eficaces para erradicar el trabajo forzado, acabar con la esclavitud moderna y el tráfico de personas, y asegurar la prohibición y eliminación de las peores formas de trabajo infantil, incluyendo reclutamiento y utilización de niños soldado, y hasta 2025 acabar con el trabajo infantil en todas sus formas.

4 Según datos extraídos del sitio del Fórum Nacional de Prevención y Erradicación del Trabajo Infantil, la Encuesta Nacional por Muestra de Domicilios (PNAD), en 2016, atestó la existencia de 2,4 millones de niños y adolescentes de 5 a 17 años en situación de trabajo infantil, lo que representa $6 \%$ de la población (40,1 millones) en esta franja de edad. 



\title{
TRABAJO, INFANCIA Y MODERNIDAD: ¿CINCO SIGLOS DE SUBALTERNIDAD?
}

\author{
WALTER UDE
}

DOI: $10.51366 / 978-65-89468-10-3$-coordinfancia-30

Resumen. Este texto discute aspectos del trabajo infantil explotado en el contexto de la modernidad occidental, con foco en las relaciones coloniales que constituyen la práctica cultural de esa actividad, las que están ocultadas por gran parte de la literatura académica dedicada al tema, considerando que adoptan modelos epistemológicos eurocéntricos para el análisis de ese fenómeno secular. En contrapunto a esos referenciales teóricos occidental-céntricos, se propone una otra epistemología, fundamentada en el pensamiento decolonial, que dialoga con los saberes tradicionales de matriz afro-diaspórica e indígena, y por medio de una lectura intercultural crítica, con objetivo de evidenciar otros modos de entender procesos educativos dirigidos a los niños, y formas distintas de comprender el mundo del trabajo. La educación escolar infantil, dentro del modelo occidental colonial, enfatizó el trabajo capitalista como proyecto pedagógico de la agenda mercantil instituida por la modernidad, a través de una arquitectura lineal, disciplinada y uniformada. La pedagogía afro-diaspórica e indígena se fundamenta en los saberes ancestrales enseñados por los maestros y maestras de su cultura, en el quehacer de sus prácticas comunitarias, en contacto respetuoso con la naturaleza, y en el culto a la espiritualidad. Para enfrentar esas contradicciones, el texto nos invita a un giro decolonial de ruptura con la subalternidad impuesta por el colonialismo patriarcal y capitalista.

Palabras claves: Trabajo infantil explotado. Modernidad. Decolonialidad. Pedagogía afro-pindorámica. 
Este artículo se propone discutir cómo la noción de Trabajo e Infancia fue construida a través del proceso de colonización impuesto al territorio pindorámico $^{1}$ (SANTOS, 2015), el cual fue nombrado como Brasil por los colonizadores europeos. La visión eurocéntrica de comprender el trabajo y la educación infantil se formuló en el interior de los presupuestos de la matriz colonial que, hasta hoy, fundamenta las principales prácticas pedagógicas dirigidas a los niños de ese escenario, tanto en las instituciones escolares y formativas, como en las familias y demás relaciones sociales más amplias. La idea de un supuesto saber superior y noble, originado en una cultura tenida como civilizada, impuso de modo violento, en términos simbólicos y físicos, una hegemonía cultural que pasó a constituir la subjetividad de los brasileños, y los demás pueblos latinos.

Sin embargo, en Pindorama, como se refiere el quilombola Nego Bispo (SANTOS, 2015), ya se encontraban modos de ver al niño y, a su vez, de educarlo, los cuales eran muy distintos de la visión occidental-céntrica, considerándose las distintas etnias indígenas que habitaban ese vasto territorio situado en el Hemisferio Sur del planeta. La pluriversidad educativa de esas prácticas se acomplejaron, aún más, con la llegada de las variadas etnias africanas que han sido esclavizadas por los portugueses, desde el inicio del siglo XVI. Dentro de ese contexto, se articuló la construcción de pedagogías afro-pindorámicas y afro-diaspóricas (SANTOS, 2015; COSTA; UDE, 2019), que se consolidaron a través de epistemologías diferenciadas con relación al modelo colonial de educarse, aunque algunas aldeas indígenas mantuvieron sus formas singulares de educar. Sin embargo, esas pedagogías fueron ignoradas o descuidadas por nuestra sociedad e, incluso, por el mundo académico que prefirió seguir, de forma hegemónica, los cánones eurocéntricos, entendidos como forma superior de filosofar.

Es más, la única filosofía admitida como legítima, dentro del modelo eurocéntrico y colonial, se convirtió en aquella que está en consonancia con las directrices de la matriz griega y sus clásicos. Como si las matrices pindorámicas y africanas no fueran constituidas por principios filosóficos de pensarse y comprender la vida, dentro de sus complejidades. Frente a eso, cabe indagar: ¿cómo se estableció ese modo jerárquico y dominante de entender esas diferentes visiones culturales? El análisis de aspectos históricos del pensamiento occidental indica que esa jerarquía se constituyó por la dicotomía cuerpo/ mente fundamentada en el pensamiento griego, que fue sistematizado por 
Platón al instituir que el cuerpo es el lugar de las pasiones, del desequilibrio, de lo sucio, de la inferioridad y de lo primitivo; en contrapunto con la razón que representa un lugar superior, noble, limpio y disciplinado (TAYLOR, 2013; SODRÉ, 2017; SANTOS, 2019). Además de eso, en esa perspectiva, la razón y el cuerpo fueron concebidos como situados en el individuo, y, de ese modo, si alguien lleva una vida controlada y de éxito, fue porque siguió la razón de forma individualizada; y si alguien vive de modo descontrolado es porque siguió las pasiones primitivas del cuerpo. Esa creencia se convirtió en el gran mote de la modernidad, en su versión liberal, es decir, el fracaso resulta de una elección individual y el éxito es una conquista resultante del esfuerzo y de la disciplina individual. Esa configuración individualizante se estableció como telón de fondo para la institución de la meritocracia, con el objetivo de ocultar las desigualdades sociales, al depositar en el individuo la única responsabilidad por su propio fracaso (SOUZA, 2012).

Sin embargo, las epistemologías afro-pindorámicas conciben la vida de forma pluriversa, pues no operan con esas separaciones entre cuerpo/ mente, subjetivo/objetivo, razón/emoción, naturaleza/cultura, profano/sagrado, entre otras dicotomías producidas por la matriz occidental-céntrica. $\mathrm{Al}$ contrario, esas dimensiones se conciben de forma articulada en las matrices africanas e indígenas. Es decir, en un ritual indígena o africano, lo sagrado, lo profano, lo lúdico, la corporeidad, la danza, la música, la naturaleza, lo personal, lo social, la alegría, la tristeza, la maldad, los secretos, entre otras manifestaciones, son expresadas de forma conjunta, en sus tensiones y en sus entrelazamientos. Ese modo de comprender la vida nos convoca a producir un giro decolonial que rompa con ese modo jerárquico y dicotómico de ser, pensar y establecer relaciones de poder, impuesto por los colonizadores (MOTA NETO, 2016).

En ese sentido, este artículo se fundamenta en la matriz decolonial, una propuesta defendida por distintos autores del Hemisferio Sur, principalmente de América Latina, como Anibal Quijano, Walter Mignolo, Nelson Maldonado-Torres, Ramón Grosfoquel, Enrique Dussel, Orlando Fals Borda, y de Brasil, como Paulo Freire, Muniz Sodré, José Jorge de Carvalho, Antônio Bispo dos Santos, Nilma Lino Gomes, João Colares da Mota Neto, entre otros, a partir de un movimiento que emergió de la perspectiva poscolonial inaugurada por Franz Fanon (2008), en la década de 1960. En realidad, se trata de la defensa de otro paradigma, fundamentado en los saberes ancestra- 
les afro-pindorámicos, en los movimientos sociales, en las prácticas sociales de nuestro territorio, en una reflexión epistemológica que articula esos saberes y sus prácticas, con metodologías singulares emergidas de las diferentes experiencias socioculturales de nuestra matriz intercultural, en una "ecología de saberes", con carácter liberador (SANTOS, 2019).

Sin embargo, otras formas de lucha y resistencia son anteriores a ese proceso afirmativo constituido en el medio académico que ha sido construido a través de rupturas epistemológicas con modelos eurocéntricos, como las luchas por liberación desencadenadas por los pueblos indígenas y quilombolas que, en su gran mayoría, no están registradas en la bibliografía de los estudios nacionales. En ese aspecto, cabe destacar que solo recientemente este tipo de contenido se volvió obligatorio en las escuelas brasileñas, tras reivindicaciones de los movimientos afirmativos de la comunidad afrobrasileña.

Aun en el marco de la matriz colonial eurocéntrica, la razón fue concebida como propiedad masculina, perteneciente a un hombre blanco, heterosexual y rico. En esa perspectiva, la razón superior es posesión del hombre; y la mujer, los esclavos y el niño son solamente dotados de cuerpos, que necesitan la disciplina de su patriarca. Como se observa, se trata de un núcleo marcante del patriarcalismo, fundador de prácticas machistas, feminicidas, homofóbicas, transfóbicas, y autoritarias, bien como de la constitución de un predador que intenta imponer su supuesta superioridad a la naturaleza, por medio de la depredación del ecosistema. En esa configuración, es posible situar la separación entre naturaleza y cultura producida por la matriz occidental-céntrica y colonial.

Para lo que nos interesa aquí, en esta breve reflexión, tomando el modelo colonial como matriz hegemónica que estableció al niño como objeto de un adulto propietario de una razón absoluta, patriarcal y superior, dentro de un sistema capitalista, queda evidente el sentido del trabajo infantil explotado en la historia de nuestra sociedad. En ese presupuesto, la razón se ha hecho un sinónimo de disciplina y orden y éstos, a su vez, se transformaron en los marcadores del trabajo y de la educación capitalistas. Incluso, la modernidad construyó una relación directa entre trabajo y educación escolar, con foco en el individualismo y en la competencia, que son marcas de la modernidad. El modelo hegemónico de la familia patriarcal burguesa, de origen europeo, nuclear y heteronormativo también compone esa construcción de la subalternidad de la mujer y de los niños. Basta consultar los estudios iconográficos de 
Ariès (1981), los cuales muestran como las ideas de trabajo, familia, infancia y escuela se produjeron de forma simultánea, para atender al modelo mercantil y jerárquico que tuvo sus cimientos en la modernidad, tal como fue transmitido a través de la colonización occidental.

Como destaca Mota Neto (2016), inspirado en Fanon, "la colinealidad, es el lado oscuro de la modernidad". Las prácticas racistas, machistas y predatorias a la naturaleza, observadas en la modernidad, están basadas en la colinealidad. Del mismo modo, la explotación del trabajo infantil está inclusa en el mismo contexto. Así siendo, la lucha contra formas de trabajo explotado, dirigidas a los niños, necesita una mirada decolonial, para que se rompa con prácticas colonizadoras que aún habitan nuestro imaginario y nuestras prácticas sociales. Ese tipo de postura epistemológica y política frente a tantas violencias, "[...] significa decir que la perspectiva decolonial procura revelar el terror, la muerte, la discriminación y el epistemicidio escondidos por detrás de la retórica de salvación de la modernidad" (MOTA NETO, 2016, p. 44-45).

Cuando se observan niños explotados en el trabajo en zonas rurales, como en el corte de la caña, en la cosecha de naranja y café, en las carbonerías, y otras formas envilecedoras de trabajo esclavo, se nota que nuestra historia colonial está presente en esas prácticas sociales. Varios argumentos se presentan para justificar ese tipo de actividad, como: "Es mejor trabajar que robar"; "Es para ayudar a la familia", "Trabajo es disciplina”, y otras narrativas. Esa misma representación del trabajo infantil explotado se encuentra en el medio urbano. Inclusive, en un estudio que he realizado sobre niños trabajando en las calles de Belo Horizonte, en horarios nocturnos, quedó evidenciado que hay una relación muy cercana entre el trabajo infantil rural y el trabajo infantil urbano, en tanto constituye una práctica transgeneracional de familias vulnerables que migraron del área rural a la ciudad y no encontraron formas de sobrevivencia que fueran capaces de romper con el trabajo de los niños en las calles (MARQUES, 2001). En realidad, ese tipo de estrategia se aprendió en el campo cuando las madres y los padres, durante sus infancias, trabajaban para el patrón, propietario de la finca.

Por otro lado, el argumento de que es una estrategia de sobrevivencia para ayudar a la familia muestra que el modelo patriarcal asociado a la idea judeocristiana de una sagrada familia que es preciso preservarse a cualquier costo, también, oculta las desigualdades sociales que produce este tipo de fe- 
nómeno. En realidad, una familia en condiciones de vulnerabilidad extrema nunca logrará realizar el modelo patriarcal burgués, impuesto como modelo ideal y superior. Todos esos mitos de la modernidad colonial deben ser cuestionados y deconstruidos. Si analizamos las familias que dependen del trabajo infantil explotado, la mayoría se constituye por responsables familiares con baja escolaridad y, consecuentemente, sin cualificación profesional, debido a situaciones de subalternidad que enfrentaron en sus vidas, incluso por haber ocupado sus infancias con actividades laborales que comprometieron su escolarización, su vida familiar y su sociabilidad (MARQUES, 2001).

Además de eso, gran parte de esas familias se compone por personas negras y pardas, configurándose, una vez más, cuadros que remiten a una colinealidad presente en ese contexto de desigualdad social. La cuestión racial debe ser enfrentada en ese debate, pues, los estudios académicos, influenciados por teorías eurocéntricas, no discuten ese aspecto con vehemencia, en tanto enfatizan las distinciones de clase en detrimento de la cuestión racial. Es preciso evidenciar que el racismo determina la condición de clase del sujeto. Dentro del parámetro colonial, el color de la piel define quién está clasificado como gente y quién no. No se puede separar una condición de la otra. Ese problema epistemológico y político, que dicotomiza clase y raza, representa puntos que son destacados por pensadores decoloniales, como José Jorge de Carvalho (CARVALHO, 2018, p. 85), al observar lo siguiente:

Ese mito racista y xenófobo, resultado de los imperialismos, colonialismos y de la esclavitud atlántica de los siglos anteriores, fue trasplantado para Brasil en la creación de nuestras primeras universidades, en especial en su versión francófona, como fue el caso de la UFRJ y de la USP, fundadas por dos misiones francesas, instalando así a nuestra elite blanca académica como continuación o entrepuesto tropical de la elite académica europea. No dejemos de observar que nuestra colonización mental fue aún más completa porque el espacio social en el cual las universidades se instalaron era completamente blanco, lo que facilitó la identificación de nuestros académicos con sus (blancos) europeos.

Obviamente que esas prácticas racistas están atravesadas por relaciones de género, dentro de un modelo patriarcal y colonial, constituyendo una trama que el movimiento feminista de las mujeres afroamericanas, en los Estados Unidos, ha nombrado como opresiones interseccionales de raza, clase, género, sexualidad y nación (COLLINS, 2018). En verdad, hay una modernización selectiva que agrega esos componentes que integran el colonialismo, el patriarcalismo y el capitalismo (SOUZA, 2000). El modelo androcéntrico y 
europeo de regir las relaciones sociales eligió la figura masculina blanca y de élite como entidad superior que representa un modo noble de pensar, ser e imponer poder. Esos elementos interrelacionados deben participar del proceso de análisis de nuestros problemas sociales, por la vía decolonial.

En la investigación sobre trabajo infantil urbano, que cité más antes, pude constatar que el 68\% de las familias eran monoparentales femeninas y la mayoría de ellas eran lideradas por mujeres negras y pardas. Mientras los hombres, circulaban entre esas mujeres, reducidos a genitores, porque no lograban proveer el sustento familiar con su condición de subempleado o desempleado, y se volvían fragilizados en sus identidades ante la imposición de un modelo patriarcal prescriptivo para el ejercicio de la masculinidad tóxica. Frente a esa subalternidad, caían en el alcoholismo y fallecían precozmente. Los niños entraban en el hueco producido por la ausencia paterna, porque la madre, según el patriarcalismo, debe quedar en la condición de cuidadora. Entonces, en ese tejido familiar, se nota un entrecruce entre género, clase, raza, sexualidad y ciclos de vida familiar, en los cuales los niños son sacrificados para mantener su núcleo familiar que se encuentra vulnerable, en su historia transgeneracional. En realidad, los niños eran "adultizados" y los adultos infantilizados, pues era muy evidente el intercambio de atribuciones y responsabilidades en el contexto de esos grupos (MARQUES, 2001).

Frente a esas breves consideraciones, defiendo que todos esos elementos sean incluidos en la comprensión de las políticas públicas dirigidas a la erradicación del trabajo infantil explotado. Así siendo, en el próximo tema, discuto la necesidad de una mirada decolonial para pensar la relación de los niños y el trabajo, en una perspectiva decolonial.

\section{NIÑO Y TRABAJO: LA NECESIDAD DE UN GIRO DECO- LONIAL}

En la constitución del modelo occidental se produjo una relación estrecha entre infancia, trabajo, educación y disciplina, considerando a la familia como proceso de socialización primaria de esa trama enredo y a la escuela como responsable por la socialización secundaria, bajo el control del Estado, en carácter oficial, para consolidar el sistema capitalista (ARIÈS, 1981). Esa configuración se fundamentó en el culto al orden, entendido sinónimo de razón suprema, y asociado a la idolatría del trabajo capitalista como solución 
para todos los males debido al acceso de una felicidad a ser consumida (WEBER, 2004). Por otro lado, creó una aversión a lo lúdico, al ocio, a la contemplación, a la diversión, al no hacer nada y al entretenimiento, los cuales fueron percibidos como pasiones peligrosas situadas en el cuerpo y también como manifestaciones originarias de los pueblos primitivos (MELO, 2011; FOUCAULT, 1987). Dentro de esa lógica, el ocio se configuró como un territorio maldito, lugar de bandoleros, vagos y bribones. Basta observar los tiempos/ espacios escolares dedicados a la cultura y al ocio, en general restringidos o casi inexistentes. En la mayor parte del tiempo, los niños permanecen recluidos en salas cuadradas, en pupitres en línea recta, sentados y con sus cuerpos “subalternizados” (MALHEIROS, 2012; POUZAS, 2012).

Aunque la escolarización pueda representar una experiencia de aprendizaje importante para la ampliación del conocimiento del niño, en términos de sociabilidad y socialización, dentro de la perspectiva occidental-céntrica no se observa ese horizonte, ya que la transformación del niño en alumno destituyó la potencialidad del ser niño en cuanto sujeto activo, creativo, inventivo e interactivo (SARMENTO, 2015). En ese escenario de subalternidad, la actividad escolar pasó a configurarse como una forma oculta de trabajo infantil explotado, ya que el trabajo explotado se caracteriza por el ejercicio de actividades impuestas como obligatorias, independientemente de la elección del sujeto. La alienación por la vía del trabajo deriva de esa sumisión que prescribe al individuo la actividad que debe ejecutar, tornándolo extraño para sí mismo, actuando mecánicamente de forma servil al proceso productivo y consumista que sostiene la lógica capitalista. El aprendizaje de la escritura propuesto por la escuela occidental trajo, en sus contenidos, la ideología dominante del modelo eurocéntrico y no representó una práctica libertadora para sus practicantes. En ese encuadramiento, la alfabetización por la escritura no constituyó una posibilidad de liberación por medio de la discusión de la importancia de los saberes tradicionales, como tampoco de la historia de las tragedias de la colonización y de las formas de resistencia de los afro-pindorámicos frente a la violencia ejercida por los europeos (SANTOS, 2015).

En contrapunto a esa perspectiva alienante, es preciso evidenciar la dimensión educativa del trabajo cuando se convierte en una práctica activa y dialógica, en la cual el sujeto se reconoce en lo que hace, encontrando significados y sentidos en las actividades que expresan dimensiones de su subjetividad, configuradas dentro de sus experiencias personales y sociales 
compartidas con los demás participantes en el proceso de construcción del conocimiento producido. Ese es el desafío colocado para discusión en el campo del enfrentamiento al trabajo infantil explotado. En ese aspecto, el educador Miguel Arroyo (2015, p. 21), indaga: ¿Cuál es la agenda pedagógica para los niños en el Brasil actual? ¿Cómo sacarlos de esa masacre que subyuga sus potencialidades? Pienso que esa provocación debe ser debatida con ahínco por los practicantes de esa lucha que anhelan la liberación de los oprimidos, en un movimiento de contra-colonización y descolonización de nuestras prácticas sociales y educativas (SANTOS, 2015; CARVALHO, 2018).

En el campo de las pedagogías decoloniales, encontramos epistemologías pindorámicas, afro-pindorámicas y afro-diaspóricas que son distintas de la matriz eurocéntrica, pues sus fundamentos filosóficos desentonan de las premisas occidentales. El primer principio marcante de las pedagogías decoloniales es la circularidad o la pedagogía circular (COSTA JUNIOR; UDE, 2019), ya que la pedagogía occidental sigue el racionalismo cartesiano en una arquitectura cuadrada y lineal. La circularidad sigue el movimiento de los ciclos vitales del ecosistema, en su complejidad, integrando distintas dimensiones en sus procesos expresivos. Sigue el giro del planeta y propone un giro decolonial. Todos los rituales indígenas y africanos, así como de los demás pueblos orientales, ocurren en círculos y movimientos circulares. El fin se convierte en inicio y el inicio se hace por el fin de un momento vital, de forma inacabada y procesual, siguiendo tradiciones que se transmiten por los guardianes de la ancestralidad. No de modo efímero como propone la modernidad, en su carrera por el hiper consumismo espectacular, tan acelerado por las nuevas tecnologías.

Otro fundamento diferenciado del paradigma decolonial es el énfasis en la colectividad, una ética que define la existencia del sujeto en la relación con el otro, en su compromiso con la nación, en los modos de producir y compartir, sin maltratar la naturaleza, la cual también forma parte de la comunidad planetaria. Esos fundamentos se encuentran presentes en las prácticas afro-pindorámicas, ya que se produce aquello que es suficiente para sobrevivir sin generar excedentes, puesto que los excesos rompen el equilibrio de la dinámica vital. Los movimientos circulares siguen ese principio colectivo, a las rondas les siguen las palmas, los tambores, las danzas, las espiritualidades, las religiosidades, las comidas, las bebidas, los ramos, las sales, el fuego, las piedras y otros elementos que hacen a la danza circular sagrada (RAMOS, 
2015). Las cosechas son seguidas por cantos que son transmitidos de forma transgeneracional.

Esa forma de educar por medio de la danza circular, también apunta, para la cura y el contacto con lo transcendental. Una perspectiva diferenciada de la matriz occidental, pues su racionalismo materialista alejó la espiritualidad y la religiosidad, haciendo de la visión eurocéntrica el saber supremo y absoluto para la solución de todos los males. Como resalta José Jorge de Carvalho (2018), todo maestro o maestra de matriz afro-pindorámica cultiva su religiosidad, tornando un desafío el establecer un diálogo de saberes entre los intelectuales de la universidad colonizada. De la misma forma, los maestros no renuncian a sus tambores, palmas, batuques, inciensos y cantorías, promoviendo un ambiente poblado de entidades y barullos que son extraños al silencio impuesto por la razón occidental y su disciplina escolarizada.

El niño educado en una práctica cultural afro-diaspórica o pindorámica aprende con los más viejos, que son los representantes de la ancestralidad, y esos maestros y maestras enseñan haciendo. Ese modo de enseñar haciendo es muy distinto de la enseñanza occidental que realiza el aprendizaje por medio de la oratoria y de la retórica, tal como un profesor de la escuela occidental que se queda hablando frente a los alumnos, horas y horas, de forma distante de la realidad de los estudiantes. El maestro, con sus saberes ancestrales, enseña ejecutando junto al niño, en los bosques, en las plantaciones, en los rituales, en las percusiones, en las oraciones, en las danzas y demás actividades que componen el ethos del grupo. Un maestro de capoeira enseña un movimiento a través de su ejecución junto con su aprendiz, toma la mano del niño para enseñarle el balanceo y la técnica de la "ginga", toca el berimbau acompañado de las palmas, panderos, raspador, ganzá y atabaque, también ejecutados por los discípulos. Las ladainhas, chulas y corridos son cantados conforme el contexto del juego y las circunstancias de los acontecimientos, muchas veces, de forma metafórica. Siguiendo la tradición de la oralidad, cuentan de forma cantada historias de los antepasados, de sus luchas, contiendas, fiestas y conquistas. La oralidad representa un gran instrumento de esas pedagogías ancestrales. Sin embargo, los maestros de las matrices afro-pindorámicas también transmiten secretos que el lenguaje escrito no logra traducir, pues están en el "humo de la pipa", en las mandingas, en el axé, en las incorporaciones y en las otras experiencias místicas que se producen (KANITZ, 2011; SOUZA, 2016). 
Ese mismo proceso de enseñanza de la capoeira puede ser también observado nos "congados, candombes, jongos, candomblés, sambas" y otras manifestaciones afro-diaspóricas; teniendo en cuenta las diferencias entre las matrices étnicas y los significados singulares de sus manifestaciones. Aunque la capoeira contenga elementos del candomblé, ella no es el candomblé. Esas diferenciaciones son importantes para tratar de comprender la complejidad de esas epistemologías y sus fundamentos. De todos modos, esa espiritualidad que atraviesa esas expresiones es hechicera en el sentido del encantamiento que genera en su espectador y en su practicante, a pesar de que otros sentidos sean producidos. Es muy difícil aproximarse a una rueda de samba y no balancear el cuerpo, o ver una rueda de capoeira y no quedar encantado con su musicalidad y los movimientos expresados en la relación entre sus practicantes. Como dice la sabiduría del samba, "quem não gosta de samba bom sujeito não é, ou tá ruim da cabeça ou tá doente do pê" ("a quien no le gusta el samba, buen sujeto no es, o está mal de la cabeza o está enfermo de los pies”).

La alegría representa otro elemento de esas prácticas culturales, pues se canta al plantar, luchar, danzar, jugar, recoger, aprender, despedir a los muertos, orar y festejar. Esa forma de enfrentar la vida produce una subjetividad muy diferenciada del modo occidental de comprender la vida. El culto a un cuerpo contenido y disciplinado, rectilíneo y homogéneo, oriundo del modelo eurocéntrico se confronta con la calma y el gingado de una educación afrobrasileña que valoriza la expresión de la malicia en el juego astuto de enfrentar un sistema colonial, en sus brechas, tal como una cabeceada en un juego de capoeira mandingueira. "Malandragem" (astucia) aquí se comprende como sabiduría para enfrentar las adversidades. Sin embargo, esos modos de re-existir (resistir) son criminalizados y endemoniados. Las prácticas colonizadoras aún hoy alimentan fuertes prejuicios contra esas expresiones culturales de matriz afro-pindorámica y afro-diaspórica.

Ante eso, necesitamos confrontar los saberes de los maestros y sus modos de enseñar con las prácticas eurocéntricas coloniales, con una postura intercultural crítica, y no de sumisión. Aprendemos varias teorías de desarrollo del niño que están basadas en el referencial occidental-céntrico. Necesitamos evaluar sus hipótesis y tesis que presentan algún significado para nuestros niños, evaluando sus límites y posibilidades para la educación infantil. Las teorías occidentales están contaminadas por una tradición evolucionista de comprender el desarrollo humano, como si los sujetos pasasen por un 
desarrollo lineal y homogéneo, negando su subjetividad personal y social, tratándolos como pasivos y dejando de lado sus singularidades. Las familias son analizadas conforme el modelo patriarcal burgués, incluso perteneciendo a una periferia urbana o a un área rural de quilombolas, indígenas o afro-pindorámicos. La visión colonizada, la mayoría de las veces, oculta las cuestiones raciales, patriarcales y capitalistas presentes en esas configuraciones, contribuyendo para ofuscar el racismo y las desigualdades sociales oriundas de ese escenario económico e histórico-cultural.

Cuando combatimos el trabajo infantil explotado, implica que tenemos una concepción de niño a ser defendida. Entonces, es necesario pensar lo siguiente inspirados en Arroyo (2015): ¿Cuál es nuestra agenda pedagógica? ¿Cuáles son las premisas pedagógicas para el ejercicio de una práctica educativa liberadora? Aquí, en este pequeño texto, me propuse defender una pedagogía afro-diaspórica y afro-pindorámica, tan negada y criminalizada por las prácticas coloniales modernas y eurocéntricas. Esta lucha enfrenta tres oponentes fuertes que intentan dictar un verdadero imperio cognitivo: el colonialismo, el patriarcalismo y el capitalismo (SANTOS, 2019). El desafío está dado y representa una posibilidad de pensarse un giro decolonial posible frente a los males de esa tríada centenaria.

\section{CONSIDERACIONES FINALES}

El trabajo infantil explotado, en contraposición al trabajo educativo, constituye una práctica colonial moderna instalada desde el inicio del siglo XVI, en América Latina y en el denominado Brasil por los colonizadores portugueses. Fue a partir de ese marco histórico que intenté problematizar este fenómeno que, durante décadas, hemos tratado de combatir para consolidar una configuración sociopolítica que posibilite la liberación de los niños que se encuentran en condiciones de subalternidad. Esta elección implica un giro decolonial para comprender esa temática, pues si continuamos siguiendo pensamientos eurocéntricos para entender esa trama, nuestros análisis van a ocultar el racismo, el patriarcalismo, la diferencia de clases y aspectos étnicos, sin poder visualizar los modos opresivos interseccionales que se encuentran en ese contexto.

Esta propuesta, en consonancia con autores decoloniales del Hemisferio Sur, nos convoca a pensar y construir - una universidad diferente -, 
basada en epistemologías que parten del centro de nuestras prácticas cotidianas, las cuales se distinguen del modelo occidental eurocéntrico y colonial de percibir el mundo. Nuestras matrices interculturales críticas, presentan fundamentos filosóficos, culturales y políticos que desentonan del modelo dicotómico y racionalista de la matriz occidental, ya que parten de una pedagogía circular colectiva en oposición a una pedagogía cuadrada, lineal, individualista y competitiva, tan útil al sistema capitalista.

Obviamente que nos vamos a deparar con otras concepciones de niño que están configuradas en las pedagogías afro-diaspóricas y pindorámicas de las cuales necesitamos dialogar para promover un paradigma diferente, para producir un giro capaz de liberarnos de los resentimientos coloniales. Este enfrentamiento involucra discutir la importancia de promover encuentros de saberes en las universidades que incluyan a los maestros ancestrales y la defensa de cuotas epistémicas para garantizar la presencia de esos representantes de las comunidades afro-pindorámicas junto a los académicos de la universidad actual, en una dimensión pluriversal, en vez de seguir un raciocinio monolítico.

Como se ha expuesto más arriba, este pequeño texto fue producido con el objetivo de rever nuestros principios epistémicos y políticos, pues somos productos de la colonización, tanto como de otras matrices que resistieron y aún resisten ante este proceso opresivo y secular. Llegamos a un momento histórico en que necesitamos tomar una posición ante tantas barbaridades, a través de un giro decolonial. Ese giro decolonial ya estaba presente en un "rabo de arraia" (golpe dado con las piernas en círculo) de capoeira, en la cual el autor de este texto también se formó, y busca ampliar la pedagogía oculta en esa práctica. ¡Axé!

\section{NOTAS}

1 Pindorama - Segundo Antônio Bispo dos Santos (2015), termo tupi-guarani que significa Terra das Palmeiras.

\section{REFERENCIAS}

ARIÈS, Phillippe. História Social da Criança e da Família. 2. ${ }^{a}$ ed. Rio de Janeiro: Guanabara, 1981. 
ARROYO, Miguel G. O trabalho das crianças na agenda pedagógica. In: ARROYO, Miguel G et al.. Trabalho Infância: exercício tensos de ser criança. Haverá espaço na agenda pedagógica? Petrópolis - RJ: Ed. Vozes, 2015.

CARVALHO, José Jorge. Encontro de saberes e descolonização: para uma refundação étnica, racial e epistêmica das universidades brasileiras. In: BERNARDINO-COSTA, Joaze, MALDONADO-TORRES, Nelson e GROSFOGUEL, Ramón (orgs.). Decolonialidade e pensamento afrodiaspórico. Belo Horizonte: Autêntica, 2019.

COLLINS, Patrícia Hill. Epistemologia feminista negra. In: BERNARDINO-COSTA, Joaze, MALDONADO-TORRES, Nelson e GROSFOGUEL, Ramón (orgs.). Decolonialidade e pensamento afrodiaspórico. Belo Horizonte: Autêntica, 2018.

COSTA JUNIOR, Jair Mariano; UDE, Walter. Educação afrodiaspórica e transformações na prática universitária: o SULear como perspectiva decolonial entre saberes. In: Revista Interdisciplinar Sulear, Ibirité-MG, v. 2, série 2, 2019.

DUSSEL, Enrique. Filosofía de la liberación. México: FCE, 2011.

FALS BORDA, Orlando. Ciencia Propia y Colonialismo Intelectual. Ciudad de México: Editorial Nuestro Tiempo, 1970.

FANON, Frantz. Pele Negra, Máscaras Brancas. Salvador: EDUFBA, 2008.

FOUCAULT, Michel. Vigiar e Punir. 6. ${ }^{\mathrm{a}}$ ed. Petrópolis/RJ: Vozes, 1987.

FREIRE, Paulo. Pedagogia do Oprimido. Rio de Janeiro: Paz e Terra, 2005.

GOMES, Nilma Lino. O Movimento Negro e a intelectualidade negra descolonizando os currículos. In: BERNARDINO-COSTA, Joaze, MALDONADO-TORRES, Nelson e GROSFOGUEL, Ramón (orgs). Decolonialidade e pensamento afrodiaspórico. Belo Horizonte: Autêntica, 2019.

KANITZ, Roberto. Capoeira Angola na Favela: juventudes, sentidos e redes sociais. Dissertação. (Dissertação de Mestrado em Estudos do Lazer). Belo Horizonte: EEFFTO/UFMG, 2011. 
MALDONADO-TORRES. Analítica da colonialidade e da decolonialidade: algumas dimensões básicas. In: BERNARDINO-COSTA, Joaze, MALDONADO-TORRES, Nelson e GROSFOGUEL, Ramón (orgs). Decolonialidade e pensamento afrodiaspórico. Belo Horizonte: Autêntica, 2019.

MALHEIROS, João Carlos de Meneses. Percursos “de dentro" e “de fora": Juventudes, Bares e Escola. Dissertação (Dissertação de Mestrado em Estudos do Lazer). Belo Horizonte: EEFFTO/UFMG, 2012.

MARQUES, Walter Ernesto Ude. Infâncias (pre)ocupadas: trabalho infantil, família e identidade. Brasília/DF: Plano Editora, 2001.

MELO, Victor Andrade de. O lazer (ou a diversão) e os estudos históricos. In: ISAYAMA, Helder; SILVA, Silvio Ricardo. Estudos do lazer: um panorama. Rio de Janeiro: Apicuri, 2011.

MIGNOLO, Walter D. Desobediência epistêmica: opção descolonial e o significado de identidade em política. In: Caderno de Letras da UFF, Dossíe: Literatura, língua e identidade, Rio de Janeiro/RJ, n. ${ }^{\circ}$ 34, p. 287-324, 2008.

MOTA NETO, João Colares. Por uma pedagogia decolonial na América Latina: reflexões em torno do pensamento de Paulo Freire e Orlando Fals Borda. Curitiba-PR: Editora CRV, 2016.

POUZAS, Ubiratan Santos. Lazer, Juventude e Ensino Médio/Técnicos: um estudo sobre as tensões estabelecidas entre os processos de escolarização e lazer no Coltec. Dissertação (Dissertação de Mestrado em Estudos do Lazer). Belo Horizonte: EEFFTO/UFMG, 2012.

QUIJANO, Anibal. Colonialidade do Poder, eurocentrismo e América Latina. [S.1]: Clacso. 2005.

QUIJANO, Anibal. Colonialidade do poder e classificação social. In: SANTOS, Boaventura de Sousa; MENESES, Maria Paula. Epistemologias do Sul. Coimbra: Edições Almedina S.A, 2009.

RAMOS, Renata Carvalho Lima (org.). Danças Circulares Sagradas: uma proposta de Educação e Cura. 2. ed. São Paulo: Triom, 2015.

SAID, Edward W. Cultura e Imperialismo. São Paulo: Companhia das Letras, 2011. 
SANTOS, Antônio Bispo. Colonização, quilombismo: modos e significações. Brasília/DF: [s.n], 2015.

SANTOS, Boaventura de Sousa. O Fim do Império Cognitivo: a afirmação das epistemologias do Sul. Belo Horizonte: Autêntica, 2019.

SARMENTO, Manuel. O trabalho das crianças é na escola - Debates e controvérsias sobre o trabalho e a educação como trabalho. In: ARROYO, Miguel G., VILELLA, Maria dos Anjos Lopes \& SILVA, Mauricio Roberto da (orgs.). Trabalho Infância: exercício tensos de ser criança. Haverá espaço na agenda pedagógica? Petrópolis/RJ: Ed. Vozes, 2015.

SODRÉ, Muniz. Pensar Nagô. Petrópolis/RJ: Editora Vozes, 2017.

SOUZA, Dimas Antonio de. Campo de Mandinga: fundamentos estéticos, éticos e políticos da Capoeira Angola. Tese (Tese de Doutorado em Estudos Interdisciplinares em Lazer). Belo Horizonte: EEFFTO/UFMG, 2016.

SOUZA, Jessé. Modernização seletiva: uma reinterpretação do dilema brasileiro. Brasília: Editora UNB, 2000.

SOUZA, Jessé et al.. Ralé brasileira - quem é e como vive. Belo Horizonte: Editora UFMG, 2009.

SOUZA, Jessé. A construção social da subcidadania: para uma sociologia política da modernidade periférica. 2. ${ }^{\mathrm{a}}$ ed. Belo Horizonte: Editora UFMG, 2012.

TAYLOR, Charles. As Fontes do Self: a construção da identidade moderna. 4. ${ }^{\text {a }}$ ed. São Paulo: Edições Loyola, 2013.

WEBER, Max. A Ética Protestante e o "Espírito" do Capitalismo. São Paulo: Companhia das Letras, 2004. 


\section{EL DERECHO FUNDAMENTAL DEL NIÑO AL NO TRABAJO}

\section{XISTO TIAGO DE MEDEIROS NETO}

DOI: $10.51366 / 978-65-89468-10-3-c o o r d i n f a n c i a-31$

Resumen. La construcción histórico normativa del derecho fundamental del niño al no trabajo. Consideraciones iniciales. La protección en el derecho brasileño. Evolución constitucional. Marco legislativo. Las Convenciones n. ${ }^{\circ}$ 136 y 182 de la Organización Internacional del Trabajo. Fundamentos para la protección.

Palabras clave: Infancia. Derecho al no trabajo. Protección a la infancia.

\section{LA CONSTRUCCIÓN HISTÓRICO NORMATIVA DEL DERECHO FUNDAMENTAL DE LOS NIÑOS AL NO TRABAJO}

\subsection{Consideraciones iniciales}

La afirmación de la dignidad del ser humano - en las múltiples fases y proyecciones de su vivencia - es fruto de un lento y penoso proceso de conquistas históricas, permeado por avances y retrocesos.

Esa evolución gradual, para la cual contribuyeron, de manera decisiva, diversificados factores (políticos, económicos, sociales, filosóficos, morales e hasta religiosos), resultó en la consagración de la doctrina de los derechos humanos fundamentales, comprendidos como "el conjunto de facultades e instituciones que, en cada momento histórico, concretan las exigencias de la dignidad, libertad e igualdad humanas, las cuales deben ser reconocidas posi- 
tivamente por los ordenamientos jurídicos en nivel nacional e internacional" (LUÑO, 2004, p. 42).

Variados documentos políticos y declaraciones de derechos, producidos a lo largo de la historia, revelan la lucha por el respeto al ser humano, como individuo, en las perspectivas personal y social, teniendo por fundamento a su plena e inalienable dignidad.

El movimiento de proclamación y búsqueda de eficacia de los derechos fundamentales se dio en el rumbo de su universalización, ante la creciente generalización o internacionalización, y de su multiplicación o especificación en cuanto al género, a las etapas de la vida (infancia, adolescencia, vejez) y a los estados normales y excepcionales en la existencia humana (enfermedad y deficiencia), según lista Bobbio (1992).

En lo que respecta a los derechos del niño y del adolescente, se observa su reconocimiento y su particularización en varios instrumentos internacionales y en normas de estatura constitucional e infra constitucional, integrándolos inequívocamente al elenco de los derechos fundamentales, como resultado del proceso de valorización de la dignidad de la persona, en sus etapas iniciales de desarrollo y formación.

Se destaca, así, la construcción normativa de la protección imprescindible a los derechos del niño y del adolescente, sedimentada en el siglo $\mathrm{XX}$, con la fuerza de la proclamación de su esencialidad. Ese fue el siglo de la valorización y consenso sobre esa protección, cuando fueron positivados derechos básicos, bajo la consideración, también, de las evidencias presentadas por el avance científico en las áreas de la salud, pedagogía y psicología (MARCÍLIO; PUSSOLI, 1988).

En el campo laboral, se registra que el siglo XIX reflejó la cruel realidad de la libre explotación del trabajo infantojuvenil, acentuada a lo largo de la Revolución Industrial, en pleno régimen liberal, que se constituyó en un triste capítulo de la historia de la civilización.

En aquel tiempo, el incremento del trabajo infantil fue marcante, con la desconsideración de la condición peculiar de los niños y de la naturaleza del servicio a que eran obligados, prevaleciendo la visión unidireccional del patrón, centrada en la obtención de ganancia máxima, lo que era estimulado con el abaratamiento de la mano de obra y la vulnerabilidad e incapacidad 
reivindicativa propias de la tierna edad, y consecuente ausencia de madurez, física y psicosocial, para integrar una relación de trabajo. Se evidenció, así, el flagrante y la recurrente falta de respeto a los derechos más fundamentales del ser humano, con relación a su vida, libertad, salud, asistencia, educación y seguridad.

En Inglaterra, por ejemplo, ha ocurrido en gran escala la utilización de los niños en las actividades fabriles y de minería, sometidos a jornadas exhaustivas y condiciones de trabajo deshumanas. La necesidad de cohibir tales abusos generó, en aquel país, la primera ley de tutela laboral en el mundo, exactamente delante de la imperiosidad de protección a los niños: el Act for preservation of health and moral aprentices employed in cotton and others mills, de 1802, expedido por el ministro Robert Peel, fijando en 12 años la jornada laboral del menor de edad. Esta fue, sin duda, la primera norma positiva que señaló la concepción de una legislación social protectora del trabajo.

El relato del Profesor catedrático español Manoel Alonso Olea (1997, p. 333-335), con respecto a la realidad vivenciada de explotación del trabajo infantil, es impresionante:

Las jornadas de trabajo, de hasta catorce y dieciséis horas, monótonamente repetidas, son extremas para cualquier edad; aplicadas, como lo fueron muchas veces, a niños de ocho y nueve años, en talleres y minas, y aún de edades inferiores en la industria textil, constituyeron uno de los episodios más tristes y lamentables de la historia de la economía, el gran escándalo moral de la Revolución Industrial, y más, en el caso que se considere que la razón básica de su utilización fue rigurosamente económica, a saber, la de lograr economizar en los costes, por los bajos sueldos tradicionalmente pagados al trabajo infantil [...]. En la industria textil británica, les empezaban a enseñar a los siete años y, en determinadas comarcas, trabajaban desde los cuatro y cinco años, desde que los consideraran capaces de atención y obediencia, en situación de esclavitud virtual para que el capataz 'biciera con él lo que quisiera [...] (itálica nuestra)

Se presenció, en seguida, en escala mundial, la evolución de una línea legislativa direccionada a la creación de normas de protección al trabajo de los niños y adolescentes, y, posteriormente, a la conquista del estatus constitucional de esas reglas en la mayoría de los ordenamientos jurídicos - como se dio en Brasil -, que fueron integradas al rol de los derechos y garantías fundamentales, principalmente a partir del movimiento denominado de constitucionalismo social. 
Así se dio un cambio del perfil del Estado, pasando a intervenir en el dominio económico y social, con el fin de garantizar un mínimo de equilibrio y justicia en las relaciones privadas, de manera especial en el campo de la protección a los hipos suficientes, notoriamente los trabajadores, a vista de las condiciones degradantes evidenciadas en el espacio de las relaciones laborales. Esta nueva postura propició la inserción, en el texto de las Constituciones, de normas de protección a los derechos concebidos bajo la óptica social.

Se añade a eso, la producción de una serie de documentos de ámbito supraestatal, fruto de la actuación de organismos internacionales, en la búsqueda de incrementar y uniformizar la protección de los niños y adolescentes ante la explotación de su trabajo. Son ejemplos mayores de esa iniciativa las Convenciones y Recomendaciones adoptadas por la Organización Internacional del Trabajo (OIT), a partir de 1919, y, posteriormente, por la Organización de las Naciones Unidas (ONU).

En ese paso, ganó fuerza y aceptación la nueva perspectiva revelada por la doctrina socio jurídica de la protección integral, bajo la consideración de que el niño y el adolescente tienen derecho a una protección especial para asegurar su desarrollo físico, psíquico y social, por medio de una vida saludable, segura y digna. Ese principio basilar fue consagrado por la Convención sobre los Derechos del Niño adoptada por la Resolución L. 44 (XLIV), de la Asamblea General de las Naciones Unidas, el 20 de noviembre de 1989, ratificada por Brasil el 24 de septiembre de 1990.

El sistema jurídico de protección laboral a los niños y adolescentes encuentra fundamento, por lo tanto, en la proclamación y efectivación de los derechos humanos fundamentales, garantizados por instrumentos internacionales (Declaraciones, Convenciones, Tratados y Recomendaciones) y por normas constitucionales que confieren fundamento de validez a la legislación infra constitucional, como son ejemplos, en el Brasil, la Consolidación de las Leyes del Trabajo y el Estatuto del Niño y del Adolescente. Este conjunto normativo, armónico e integrado, dada la naturaleza y esencia del derecho tutelado, se compone, así, de reglas de orden público, de naturaleza imperativa.

Y, por eso, se afirma que la realidad del trabajo infantil traduce intolerable violación de derechos humanos y la negación de principios fundamentales de orden constitucional, como lo son los principios de protección integral y de la prioridad absoluta, que encuentran fundamento en la norma 
fuente de la dignidad humana, de modo a mostrar inmediata y eficaz reacción de los órganos de protección, especialmente aquellos incumbidos de asegurar y tutelar los derechos de los niños y adolescentes.

\subsection{La protección en el derecho brasileño}

\subsubsection{Evolución constitucional}

En análisis histórico, se registra, inicialmente, que no se encuentra, en la Constitución del Imperio de 1824, y en la primera Constitución Republicana de 1891, ninguna referencia pertinente a la tutela del niño.

Es en la Constitución de 1934 que, de forma innovadora, se incluyó el mandato de protección al niño, con la fijación de la edad mínima para el trabajo a los 14 años. Se estableció, en ese sentido, el artículo 121, línea "d", la "prohibición de trabajo a menores de catorce años, de trabajo nocturno a menores de dieciséis; y en industrias insalubres, a menores de dieciocho años y a mujeres".

La Constitución de 1937, otorgada por Getúlio Vargas, estableció como competencia privativa de la Unión legislar sobre normas de defensa y protección de la salud, incluso de los niños, disponiendo en su artículo 137, línea " $k$ ", sobre la prohibición del "trabajo de menores de catorce años; de trabajo nocturno a menores de dieciséis y, en industrias insalubres, a menores de dieciocho años y a las mujeres".

En la Constitución democrática de 1946 se reiteró el límite de edad mínima de 14 años para el trabajo, vedando el trabajo de menores de 18 años en industrias insalubres y en trabajos nocturnos. La disposición del artículo 157, inciso IX, prohibía el

trabajo de menores de catorce años en industrias insalubres, a mujeres y menores de dieciocho años; y de trabajo nocturno, a menores de dieciocho años, respetadas, en cualquier caso, las condiciones establecidas en ley y las excepciones admitidas por juez competente (BRASIL, 1946).

En las Cartas Políticas de 1967 y 1969, la edad mínima fue establecida en 12 años, condición que representó retrocesos, en términos de protección, a la luz de las Convenciones Internacionales existentes. En efecto, de la primera de esas Constituciones, se observaba la redacción del artículo 158, X, en 
el sentido de la "prohibición de trabajo a menores de doce años y de trabajo nocturno a menores de dieciocho años, en industrias insalubres a estos y a las mujeres".

Finalmente, la Constitución democrática de 1988, en el art. $7^{\circ}$, XXXIII, en sintonía con el avance en el campo da garantía de los derechos humanos fundamentales inherentes al niño y al adolescente (individuales y sociales), fijó la edad mínima para el trabajo en 16 años, salvo en la condición de aprendiz, a partir de los 14 años, y la prohibición de trabajo nocturno, peligroso o insalubre a menores de dieciocho años (BRASIL, 1988).

El nuevo Estatuto Constitucional acogió, en la estera de la normativa internacional, la doctrina socio jurídica de la protección integral, de la que es expresión su artículo 227, fruto de la enmienda popular suscrita por un milón y medio de ciudadanos. ${ }^{1}$

El niño y el adolescente, considerados, así, ciudadanos en condición peculiar de personas en desarrollo y no adultos en miniatura o personas incompletas o inacabadas -, se les atribuye la condición de sujetos de derechos, ${ }^{2}$ y no más de objeto de derechos, derrumbándose, así, la anticuada y equivocada doctrina asistencialista y sancionatoria que establecieron los Códigos de Menores de 1927 y 1979. ${ }^{3}$ El concepto de persona en condición peculiar de desarrollo complementa, de forma adecuada, la concepción del niño y del adolescente como sujetos de derechos, como detentores de todos los derechos de los adultos compatibles con la edad. Y, en consecuencia, de la condición inherente a la edad, no pueden proveer por sí mismos las necesidades básicas, sin perjuicio del desarrollo personal y social.

En suma, de un derecho de naturaleza tutelar/punitiva del niño, que caracterizó la "doctrina de la situación irregular", se adoptó el paradigma del derecho de protección/de responsabilización, inherente a la "doctrina de la protección integral".

La Constitución vigente, por lo tanto, al proclamar en su art. $1^{\circ}$ que la República Federativa de Brasil se constituyó en Estado Democrático de Derecho, eligió entre sus fundamentos la ciudadanía, la dignidad de la persona humana y el valor social del trabajo, como pilar esencial de todas las acciones emprendidas por el organismo estatal, principalmente las de índole legislativa pertinentes a la tutela laboral del niño y al adolescente. 
En ese marco, resalta que el elenco de las normas fundamentales de protección al niño y al adolescente es abierto, posibilitando la incorporación de otros derechos y garantías derivados del régimen y de principios adoptados por la propia Constitución de la República, en el art. $5^{\circ}, \$ 1^{\circ}$, o, aún, de los tratados internacionales adoptados por nuestro país.

Se constata, aun, que los derechos sociales básicos albergados en el texto constitucional integran el elenco de los derechos fundamentales (Título II), señalando el artículo $6^{\circ}$ que "son derechos sociales la educación, la salud, el trabajo, la vivienda, el ocio, la seguridad, la previsión social, la protección a la maternidad y a la infancia, la asistencia a los desamparados, en la forma de esta Constitución” (BRASIL, 1988).

Se ve, por fin, que el legislador constitucional, en el área de asistencia, eligió como uno de sus objetivos proteger a la infancia y a la adolescencia, al lado de la promoción de la integración al mercado de trabajo, según se observa del artículo 203, incisos I y III de la Carta Política. Igualmente es nítida la línea principio lógica abrazada por el ordenamiento jurídico patrio para incentivar y garantizar, con prioridad, la formación educacional básica y profesional del niño y del adolescente (arts. 205, 208, 212 y 214 de la CF). De eso resultará, siempre, la primacía del estímulo a la educación en detrimento de la realidad del trabajo.

\subsubsection{Marco legislativo}

La legislación infra constitucional brasileña en vigor, relativa al trabajo infantil, está en sintonía con los preceptos constitucionales que incorporaron los postulados de protección al niño erigidos en la Convención de derechos del niño, adoptada en 1989 por la Organización de las Naciones Unidas ONU, y que fija, en su artículo 32, las siguientes obligaciones:

Artículo 32

1. Los Estados Parte reconocen el derecho del niño de estar protegido contra la explotación económica y contra el desempeño de cualquier trabajo que pueda ser peligroso o interferir en su educación, o que sea nocivo para su salud o para su desarrollo físico, mental, espiritual, moral o social.

2. Los Estados Parte adoptarán medidas legislativas, administrativas, sociales y educacionales con vistas a asegurar la aplicación del presente artículo. Con tal propósito, y teniendo en consideración las disposiciones pertinentes de otros instrumentos internacionales, los Estados Parte deberán, en particular: 

a) establecer una edad o edades mínimas para la admisión en empleos;
b) establecer reglamentación apropiada relativa a horarios y condiciones de empleo;
c) establecer penalidades u otras sanciones apropiadas con el fin de asegu- rar el cumplimiento efectivo del presente artículo.

En ese sentido, la regla vector constitucional está encartada en el caput del artículo 227 (BRASIL, 1988):

Art. 227. Es deber de la familia, de la sociedad y del Estado asegurarle al niño y al adolescente, con absoluta prioridad, el derecho a la vida, a la salud, a la alimentación, a la educación, al ocio, a la profesionalización, a la cultura, a la dignidad, al respeto, a la libertad y a la convivencia familiar y comunitaria, además de colocarlos a salvo de toda forma de negligencia, discriminación, explotación, violencia, crueldad y opresión.

Y, en el artículo $7^{\circ}$, inciso XXXIII, con la alteración introducida por la Enmienda Constitucional n. ${ }^{\circ}$ 20/1998, ${ }^{4}$ la Carta Magna establece, conforme antes resaltado, la prohibición de (I) cualquier trabajo, a personas con edad inferior a 16 años, salvo en la condición de aprendiz, a partir de los 14 años; y de (II) trabajo nocturno, peligroso o insalubre a personas con edad inferior a 18 años.

Se trata de norma de naturaleza prohibitiva, con visible propósito de protección y de tutela, estableciendo el derecho fundamental al no trabajo en edad correspondiente a la etapa de desarrollo físico, psíquico, moral y social del ser humano, y al trabajo protegido, a partir de la edad mínima, con el objetivo de preservar la formación, la integridad, la educación, el ocio y la convivencia familiar del niño y del adolescente.

Hay, así, constitucionalmente, dos situaciones de protección al niño y al adolescente, frente al trabajo: en primer lugar, la regla general del derecho al no trabajo de la persona con edad inferior a 16 años; en segundo lugar, el derecho al trabajo protegido, a partir de los 16 hasta los 18 años, y, excepcionalmente, a contar desde los 14 años, en la condición de aprendiz.

La adecuada interpretación de ese precepto constitucional expresa que la prohibición a cualquier trabajo a menores de dieciséis años se extiende a todo el tipo de actividad laboral, como medida de protección de la integridad física, psíquica y social del niño/adolescente, no restringiendo solo al trabajo típicamente subordinado, una vez que la protección anhelada por la 
norma es amplia, al comprender todos los aspectos de la vida del niño y del adolescente (personal, familiar, educacional y social).

Este entendimiento deviene de la interpretación sistemática de la norma y del entendimiento del principio de protección integral, pues si diversa fuera la intención del legislador, habría utilizado, ciertamente, la expresión "prohibición a cualquier empleo", y no a "cualquier trabajo".

En efecto, es incontestable que el trabajo precoz interfiere directamente en todas las dimensiones de desarrollo del niño, perjudicando: (a) el desarrollo físico, ante la exposición a condiciones no compatibles con las naturales limitaciones y capacidad personal, así como a riesgos de accidentes, enfermedades y secuelas corporales; (b) el desarrollo psíquico emocional, dado que los niños sometidos al trabajo no es raro que presenten traumas, miedos, reacciones violentas y dificultades para establecer vínculos afectivos, por fuerza de las condiciones desfavorables e impropias presentes; y (c) el desarrollo social, pues los niños y adolescentes se ven obligados a realizar trabajos que requieren madurez y comportamiento típico del mundo adulto, además de convivir en ambiente inadecuado, y, en regla, no amigable o acogedora, que los aparta de la convivencia social con personas de la misma edad.

La prohibición constitucional, sin embargo, no es absoluta, comportando tres excepciones a la regla general del límite mínimo de 16 años para el trabajo, previstas en el sistema jurídico, pero con condicionantes para su validez. Esas excepciones se refieren a las siguientes actividades específicas:

- la de aprendizaje ${ }^{5}$ a partir de los 14 años, según ya fue expuesto, extendiéndose hasta los 18 años, marco de la adquisición de la capacidad laboral plena;

- la de naturaleza deportiva, en la hipótesis de atleta no profesional en formación, a partir de los 14 años, con previsión de recibir un auxilio financiero de la entidad de práctica deportiva formadora, bajo la forma de beca de aprendizaje, conforme previsto en el artículo $29, \int 4^{\circ}$, de la Ley n. ${ }^{\circ}$ 9.615/1998 (Ley Pelé); y

- la de naturaleza artística (p. ej: en el circo; en la publicidad; en la televisión y en el teatro), siempre que sean autorizadas por medio de autorización judicial, y atendiendo a los siguientes requisitos: (I) la demostración de que la manifestación artística no pueda ser desempeñada por mayor de 16 
años; (II) la existencia previa y expresa de autorización de los representantes legales del niño/adolescente; (III) la evidencia de que la manifestación artística no es perjudicial al desarrollo biopsicosocial del niño y del adolescente, debidamente comprobada esa condición por certificado médico y psicológico; (IV) la comprobación de la presentación de matrícula, frecuencia y aprovechamiento escolar; (V) la demostración de no coincidir el horario escolar con la actividad artística, resguardados los derechos de reposo, ocio y alimentación; (VI) la garantía de la efectiva y permanente asistencia médica y psicológica; (VII) la prohibición de actividades en locales y servicios peligrosos, nocturnos, insalubres, penosos, en condiciones de riesgo y perjudiciales a la moralidad; (VIII) la verificación de la jornada, carga horaria, intervalos de descanso, alimentación y medio ambiente compatibles con la condición de niño y de adolescente; (IX) el acompañamiento del responsable legal durante la realización de la actividad; y (X) la garantía del depósito del pago por el trabajo, en caja de ahorro, a nombre del niño o del adolescente, en porcentual incidente sobre la remuneración debida.

Sobre la exigencia legal de autorización judicial para la participación del niño y del adolescente en representaciones artísticas, hubo acentuada divergencia de posiciones jurídicas, sea por no aceptar el trabajo artístico como excepción a la regla general prohibitiva de trabajo en edad inferior a 16 años - haya vista la comprensión de la inconformidad con la norma constitucional (art. $7^{\circ}$, XXXIII) del referido artículo 149, II, del ECA, no se admiten excepciones que no tengan previsión expresa en la Carta Magna -, sea también en razón de entenderse que, hoy, la autoridad competente para autorizar la realización del trabajo artístico sería el Juez de trabajo - y no el Juez de derecho -, ante la ampliación de la competencia de la Justicia Laboral, promovida por la Enmienda Constitucional n. ${ }^{\circ}$ 45/2004 (art. 114), para abarcar todas las cuestiones derivadas de cualquier relación de trabajo.

Este tema fue definido en 2018, por el Supremo Tribunal Federal, en el juicio de la Medida Cautelar en la Acción Directa de Inconstitucionalidad n. ${ }^{\circ} 5326,{ }^{6}$ asentando que la competencia para la expedición de la autorización es del Juzgado de la Infancia y Juventud, tomando por base la disposición del artículo $149, \mathrm{II}, \mathrm{y} \iint 1^{\circ}$ y $2^{\circ}$, del ECA:

Art. 149. Compete a la autoridad judicial disciplinaria, a través de ordenanza, o, mediante autorización:

$[\ldots]$

II - la participación de niño y adolescente en: 
a) espectáculos públicos y sus ensayos;

b) concursos de belleza.

$\int 1^{\circ}$ para los fines de lo dispuesto en este artículo, la autoridad judicial tendrá en cuenta, entre otros factores:

a) los principios de esta ley;

b) las peculiaridades locales;

c) la existencia de instalaciones adecuadas;

d) el tipo de frecuencia habitual al local;

e) la adecuación del ambiente, la eventual participación o frecuencia de niños y adolescentes;

f) la naturaleza del espectáculo;

$\int 2^{\circ}$ las medidas adoptadas en la conformidad de este artículo deberán ser fundamentadas, caso a caso, vedadas las determinaciones de carácter general.

Importante es resaltar, aunque se encuentran revocados, inequívocamente, a partir del advenimiento de la Constitución Federal en vigor, los artículos $405, \S 2^{\circ}, \S 4^{\circ}$, y 406, de la Consolidación de las Leyes de Trabajo, que, en la época, en realidad de la década de 40, y bajo el amparo del vetusto Código de Menores de 1927, prevían la posibilidad de autorización judicial para el trabajo de niños y adolescentes, en las siguientes situaciones, por medio de autorización dada por el denominado Juez de Menores ${ }^{7}$ :

- trabajo ejercido en las calles, plazas y otros espacios públicos, siempre que sea verificada si la ocupación es indispensable a la propia subsistencia del menor o a la de sus padres, abuelos o hermanos, y si de esa ocupación no sobrevenga perjuicio a su formación moral;

- trabajo como jornalero, siempre que el menor se encuentre bajo patrocinio de entidades destinadas a su amparo, oficialmente reconocida;

- trabajo realizado en teatros de revistas, cines, clubes nocturnos, casinos, cabarets, dancings y establecimientos análogos, en empresas circenses, en funciones de acróbata, gimnasta y otras semejantes, siempre que la representación tenga fin educativo o la obra de que la que participa no sea perjudicial a su formación moral; y siempre que se certifique que la ocupación del menor es indispensable a la propia subsistencia o a la de sus padres, abuelos o hermanos y no derive en ningún perjuicio a su formación moral.

Apúntese, finalmente, que, fuera la hipótesis de trabajo artístico - y siempre que atendidas las condiciones antes listadas -, incurrirá en flagrante inconstitucionalidad, violando la norma del artículo $7^{\circ}$, XXXIII, cualquier autorización judicial concedida por medio de autorización permitiendo el tra- 
bajo del niño o adolescente con edad inferior a 16 años. En otros términos, "caracteriza grave violación a los derechos humanos infantojuveniles, como al ordenamiento jurídico brasileño, la concesión de autorización o autorización judicial para el trabajo de niños y adolescentes con edad inferior a 14 años, debiendo tal práctica ser vehementemente combatida por el Ministerio Público de los Estados y del Districto Federal, con la observación de que el trabajo de adolescentes entre 14 y 16 años solo es permitido en la condición de aprendiz, en los términos de la Ley n. ${ }^{\circ}$ 10.097/00.” 8

Retomando la línea del marco legal, adviene el Estatuto del niño y del Adolescente - ECA (Ley n. ${ }^{\circ}$ 8.069/1990), en compás con las disposiciones constitucionales, dedicando el Capítulo $\mathrm{V}$ a la protección al trabajo y al derecho a la profesionalización, y fijando, igualmente, límite para la edad mínima en cualquier trabajo (art. 60), correspondiente, hoy, a 16 años, salvo a partir de los 14, en la condición de aprendiz. Además de eso, esa ley reforzó la prohibición, al adolescente con edad entre los 16 y 18 años, de trabajo:

I - nocturno, realizado entre las 22 horas de un día y las 5 horas del día siguiente;

II - peligroso, insalubre o penoso;

III - realizado en locales perjudiciales a su formación y a su desarrollo físico, psíquico, moral y social;

IV - realizado en horarios y locales que no permitan la frecuencia a la escuela (art. 67). ${ }^{9}$

Resáltase, en el punto, que la Consolidación de las Leyes del trabajo CLT, desde su edición, contenía el Capítulo IV de su Título III, tratando de protección del trabajo del menor, así determinando en el artículo 403:

Art. 403. Está prohibido cualquier trabajo a menores de 16 años, salvo en la condición de aprendiz, a partir de los 14 años.

Parágrafo único. El trabajo del menor no podrá ser realizado en locales perjudiciales a su formación, a su desarrollo físico, psíquico, moral y social y en horarios y locales que no permitan la frecuencia a la escuela (redacción actualizada).

En conclusión, la base constitucional de nuestras normas de protección al niño y al adolescente, frente al trabajo:

- se compone de reglas imperativas, alineadas en el rol de los derechos fundamentales; 
- adopta, en plenitud, el principio de la protección integral, considerando la condición peculiar de los niños y adolescentes como personas en desarrollo;

- establece, por consecuencia, como reglas esenciales la prohibición de cualquier trabajo en edad inferior a 16 años, salvo a partir de los 14, en la condición de aprendiz, además de la prohibición para el trabajo nocturno, insalubre, peligroso o en situación de riesgo a la integridad física, moral y psíquica;

- admite, de forma excepcional, la realización de actividad de naturaleza artística por niños y adolescentes con edad inferior a 16 años, mediante la expedición de autorización judicial de competencia del Juzgado de la Infancia y Juventud, condicionando la autorización a la atención de los siguientes requisitos imprescindibles (a) la demostración de la manifestación artística no poder ser desempeñada por mayor de 16 años; (b) la existencia previa y expresa de autorización de los representantes legales del niño/adolescente; (c) la evidencia de que la manifestación artística no es perjudicial al desarrollo biopsicosocial del niño y del adolescente, debidamente comprobada esa condición por laudo médico y psicológico; (d) la comprobación de la presentación de matrícula, frecuencia y aprovechamiento escolar; (e) la demostración de no coincidir el horario escolar con la actividad artística, resguardados los derechos de reposo, ocio y alimentación; (f) la garantía de efectiva y permanente asistencia médica y psicológica; (g) la prohibición de actividades en locales y servicios peligrosos, nocturnos, insalubres, penosos, en condiciones de riesgo y perjudiciales a la moralidad; (h) la verificación de jornada, carga horaria, intervalos de descanso, alimentación y medio ambiente compatibles con la condición del niño y del adolescente; (i) el acompañamiento del responsable legal durante la realización de la actividad; y (j) la garantía del depósito del pago por el trabajo, en caja de ahorro, a nombre del niño o del adolescente, en porcentaje incidente sobre la remuneración debida.

- está integrada y en armonía con las normas de los tratados internacionales;

- asegura al niño y al adolescente, en caso de configuración de relación de trabajo, la percepción de los derechos laborales y jubilatorios ${ }^{10}$; y

- prioriza el acceso a la educación fundamental y a la formación, principalmente la profesional. 


\subsection{Las Convenciones n. ${ }^{\circ} 136$ y 182 de la Organización Internacio- nal del trabajo}

La fijación de la edad mínima para el trabajo es concebida como iniciativa de naturaleza de protección al adolescente y al niño, constituyendo parte integrante del conjunto de acciones y compromisos político jurídicos, que apunta a propiciar la tutela de sus derechos fundamentales, enfatizando, incluso, la educación fundamental y los medios y condiciones necesarios a la formación y cualificación profesional.

Importante registrar, inicialmente, que la Convención de los derechos del niño, adoptada por las Naciones Unidas el 20/09/1989, en su art. $1^{\circ}$, considera niño todo ser humano con menos de 18 años, mientras que nuestro Estatuto del niño y del Adolescente, adopta criterio distinto, considerando niño a la persona hasta 12 años incompletos, y adolescente a la persona entre 12 y 18 años.

Brasil es signatario de las Convenciones Internacionales del Trabajo n.os 136 y 182, adoptadas en el ámbito de la Organización Internacional del Trabajo - OIT, ambas enfocadas en la grave cuestión del trabajo infantil. La Convención n. ${ }^{\circ}$ 138, ratificada en 2001 (Decreto n. ${ }^{\circ}$ 4.134), definió la imposición de edad mínima para el trabajo, a partir de los 14 años o más, con base en factores como la escolaridad obligatoria, la protección a la salud y a la seguridad del niño.

La Convención n. ${ }^{\circ}$ 182, con ratificación en el año 2000 (Decreto n. ${ }^{\circ}$ 3.597), dispuso sobre la prohibición y acción inmediata para la eliminación de las peores formas de trabajo infantil, considerando, entre otros factores, que la efectiva eliminación de las peores formas de trabajo infantil requiere acción inmediata y global que tenga en cuenta la importancia de la educación fundamental y gratuita y la necesidad de retirar al niño de todos esos trabajos, la promoción de su rehabilitación e integración social, y al mismo tiempo, la atención a las necesidades de sus familias. En su artículo $3^{\circ}$, explicitó que la expresión peores formas de trabajo infantil comprende:

- todas las formas de esclavitud o prácticas análogas a la esclavitud, como venta y tráfico de niños, sometimiento por deuda y servidumbre, trabajo forzado o compulsorio, incluso reclutamiento forzado o compulsorio de niños para ser utilizados en conflictos armados. 
- la utilización, demanda y oferta de niños para fines de prostitución, producción de material o espectáculos pornográficos.

- la utilización, demanda y oferta de niños para actividades ilícitas, particularmente para la producción y tráfico de drogas conforme definidos en los tratados internacionales pertinentes.

- los trabajos que, por su naturaleza o por las circunstancias en que son ejecutados, son susceptibles de perjudicar la salud, seguridad y moral del niño.

Como resultado de ese compromiso internacional, ha sido editado por el Poder Ejecutivo el Decreto n. ${ }^{o}$ 6.481, de 12/06/2008, que aprobó, en nuestro país, la Lista de las Peores Formas de Trabajo Infantil.

\section{FUNDAMENTOS PARA LA PROTECCIÓN LABORAL}

Se afirma, con base científica, que la protección jurídica dispensada a los niños y a los adolescentes, con relación a la limitación de la edad mínima para el trabajo, se justifica por fundamentos de orden:

- fisiológica: debido a los daños irreversibles a la salud física y de los riesgos acentuados de accidentes de trabajo, enfermedades, contaminación y otras consecuencias perjudiciales a la integridad corporal del niño, a la vista de la condición peculiar de personas en desarrollo y, por lo tanto, de mayor vulnerabilidad biológica y corporal.

- moral y psíquica: ante la gravedad de sujetarlos a determinadas tareas, rutinas, condiciones o ambientes cuyas características comprometen y perjudican a su formación, además de posibilitar la práctica de abusos y acosos.

- económica: considerando que la ocupación por niños y adolescentes de puestos de trabajo o actividades propias para adultos constituye factor de incremento de la informalidad, fraude, e de malversación de renta y de tributos, generando distorsión y daños sociales, contribuyendo para el aumento de la escala de desempleo.

- cultural: teniendo en cuenta que privarlos de la instrucción, capacitación y cualificación adecuada para el ingreso en el mercado formal de trabajo, 
resulta en mantenerlos en el ciclo de exclusión, alimentando esa cadena de hipo suficiencia educacional e informacional.

- jurídica: a la vista de la inequívoca vulnerabilidad de los niños y adolescentes, considerada la ineptitud para comprender los términos de un contrato, derechos y deberes, y la consecuente incapacidad personal para la valoración de las condiciones laborales que les son impuestas o incluso exigidas.

Además de eso, en el librillo editado por el antiguo Ministerio del Trabajo y Empleo, titulado "Sepa todo sobre el trabajo infantil"11, ha sido hecha una lista con las siguientes razones de orden fisiológico para la condenación del trabajo infantil, basadas en evidencias médicas en cuanto a la estructura fisiológica del niño:

- no tiene los huesos ni los músculos completamente desarrollados; corre mayor riesgo, así, de sufrir deformaciones óseas, cansancio muscular y perjuicios al crecimiento y al desarrollo, dependiendo del ambiente y condiciones de trabajo a que sea sometido.

- la ventilación pulmonar es reducida; por eso, tiene mayor frecuencia respiratoria, lo que provoca mayor absorción de sustancias tóxicas y mayor desgaste de que los adultos, pudiendo, incluso, llevar a la muerte;

- tiene mayor frecuencia cardiaca que los adultos para el mismo esfuerzo (el corazón late más rápido para bombear la sangre para el cuerpo) y, por eso, se cansa más, aunque sea ejerciendo la misma actividad;

- la exposición a las presiones del trabajo puede provocar diversos síntomas, como dolores de cabeza, insomnios, mareos, irritabilidad, dificultad de concentración y memorización, taquicardia y, consecuentemente, bajo rendimiento escolar; eso ocurre porque el sistema nervioso no está totalmente desarrollado. Además, esas presiones pueden causar diversos problemas psicológicos, tales como miedo, tristeza e inseguridad;

- el hígado, bazo, riñones, estómago e intestino se encuentran en desarrollo, lo que provoca mayor contaminación por la absorción de sustancias tóxicas;

- posee cuerpo que produce más calor que el de los adultos cuando sometidos a trabajos pesados, lo que puede causar, entre otras cosas, deshidratación y mayor cansancio; 
- tiene la piel menos desarrollada, siendo más vulnerable que los adultos a los efectos de los agentes físicos, mecánicos, químicos y biológicos;

-posee visión periférica menor que el adulto, con menos percepción de lo queocurre a su alrededor. Además, los instrumentos de trabajo y los equipos de protección no fueron hechos para su tamaño sujetándose a la mayor posibilidad de sufrir accidentes de trabajo;

- tiene mayor sensibilidad a los ruidos que los adultos, lo que puede causar pérdidas auditivas más intensas y rápidas.

Este documento también registra que el trabajo infantil constituye causa de una triple exclusión: en la infancia, cuando el jugar, estudiar y aprender; en la edad adulta, cuando es descartado de las oportunidades de trabajo, por falta de cualificación profesional; en la vejez, ante la ausencia de condiciones dignas de supervivencia.

El trabajo infantil, en nuestro país, históricamente, nunca fue representado como fenómeno negativo en la mentalidad de la sociedad, conforme registra, con acierto, el Plan Nacional de Prevención y Erradicación del Trabajo Infantil y Protección al Trabajador Adolescente (MTE, 2004), elaborado en el año 2004 por la extinguida CONAETI (Comisión Nacional de Erradicación del trabajo Infantil) ${ }^{12}$, que actuaba bajo coordinación del Ministerio de Trabajo y Empleo.

El documento señala que, hasta la década de 1980, el consenso acerca de este tema reflejaba la percepción del trabajo como un factor positivo en el caso de niños que, dada su situación económica y social, vivían en condiciones de pobreza, exclusión y riesgo social. Tanto la élite como las clases más pobres compartían plenamente esa forma de concebir el trabajo infantil.

Un conjunto de ideas simples, pero de gran efecto, permaneció incuestionable durante siglos. Frases tales como: "Es natural que el padre le enseñe el trabajo al hijo", o "Es mejor que el niño trabaje a que se quede en la calle expuesto al crimen y a las malas costumbres", y, aún, "trabajar educa el carácter del niño", o "Es bueno que el niño ayude en la economía de la familia". Traducen la noción fuertemente arraigada de que el "trabajo es solución para el niño". 
El estudio aún registra que algunos empleadores expresaban que estaban haciendo un favor al niño al propiciarle una oportunidad de "aprender un oficio", "ganar unos pesos" o "aprovechar el tiempo en algo útil", e ya que "el trabajo es bueno por naturaleza”, no podría tener consecuencias negativas para el niño. Y asienta, además de forma contundente:

Si para la élite social el trabajo infantil era una medida de prevención, para los pobres era una manera de sobrevivir. Si un niño desocupado en la calle era un peligro que debía ser duramente combatido, para los otros era una oportunidad de trabajo. Para aquellos, la solución era el trabajo o la prisión; para estos, era encontrar una fuente permanente de rendimientos. Un caso de seguridad pública para los primeros y de destino para los segundos. Por razones distintas, élite y clases desfavorecidas estaban de acuerdo: el lugar de niño pobre es en el trabajo.

Por eso el niño trabajador era tenido como ejemplo de virtud, y el niño desocupado era visto como sinónimo de algo perdido, como síntoma de problema. La prensa frecuentemente celebraba los casos que eran colocados como ejemplo de niños y adolescentes trabajadores: su disciplina, seriedad, dedicación, coraje. Por otro lado, colocaba toda la negatividad en los casos de niños y adolescentes que habían cometido delitos en la calle: ellos no estaban trabajando y, por consiguiente, estaban delinquiendo y, en el peor de los casos, prostituyéndose. Ellos se volvían, casi por naturaleza, en deshonestos, perezosos, peligrosos, desorientados, arrojados.

Esos mitos culturales han funcionado como catalizadores de las acciones de las instituciones públicas y privadas con respecto a los niños y adolescentes trabajadores.

La educación, desvinculada de un usufructo económico inmediato era colocada como desnecesaria y hasta problemática. Aprender a jugar, divertirse y vivenciar el carácter lúdico y contemplativo de algunas actividades fue visto como total pérdida de tiempo o como actividad sin sentido. La educación que no enseñara a trabajar era tenida como una actividad que se desviaba de las tradiciones familiares (pues muchos padres, madres y abuelos tuvieron que trabajar al lado de sus padres), como también que se desviaba de la propia realidad económica de las familias de esos niños, pues la ecuación era trabajar para sobrevivir o pasar hambre.

La cultura de "aprovechar el tiempo" defendió al trabajo como fundamental para esa premisa. Todo trabajo significaba tiempo aprovechado, incluso cuando el trabajo no significara ganancia económica. Por otro lado, toda actividad educativa y lúdica carecía de legitimidad y era, por lo tanto, caracterizada como negativa y como una "pérdida de tiempo" de la cual no se obtenía ganancia o beneficio alguno. En sectores más tradicionales, lo lúdico estaba, incluso, relacionado al propio mal, y el trabajo, al bien, dando, así, un fondo religioso a la alternativa a favor del trabajo de los niños. Sufrimiento y sacrificio serán recompensados trascendentalmente. La diversión, en cambio, será castigada. En fin, toda esa polémica con respecto al trabajo infantil ha hecho que fuera visto, en el peor de los casos, como un problema menor, y no como un crimen o una violación de los derechos de los niños y adolescentes. La inercia secular de Brasil ante el trabajo social solo se puede entender cuando es 
considerada la fuerza de la mentalidad que albergaba el trabajo infantil en su seno como parte de la naturaleza de las cosas.

Dicha mentalidad mantuvo millones de niños y adolescentes ligados a actividades que, además de marginalizarlos de toda posibilidad de desarrollo físico, psíquico y espiritual, reproducían todos los vínculos de una sociedad desigual, excluyente, corrupta y antiética (MTE, 2014).

Es notorio, pues, que en nuestra cultura se encuentran aún arraigados falsos dogmas, que son utilizados hipócritamente para defender y tolerar el trabajo infantil, a pesar de las evidencias de la gravedad de sus perjuicios y riesgos a la vida y a la salud de niños y adolescentes, así como los efectos sociales y económicos de su existencia. De ahí el porqué, se hace necesario enumerarlos y desconstruirlos, con argumentos y datos reales, ${ }^{13}$ a la luz de la verdad:

- Al decir que "la inserción de los niños en el trabajo contribuye para su formación y constituye una escuela de vida para transformarse en un adulto más digno”, se refuta con la afirmación de que el trabajo precoz es deformador de la infancia, y las largas jornadas de trabajo, rutina, repetición, las herramientas y los utensilios y maquinarias propias para los adultos resultan en serios riesgos, daños físicos y psíquicos, problemas de salud y elevación de los índices de accidentes, enfermedades y mortalidad. El trabajo infantil, en su cara real, no representa elemento educacional y es directamente responsable por la reproducción del ciclo de explotación e indignidad que acompañará al niño hasta y durante la edad adulta.

- Al decir que "el trabajo infantil es un elemento positivo, ante la situación económica y social desfavorable, y de las condiciones de pobreza y riesgo social”, se refuta con la afirmación de que ese pensamiento ignora los derechos fundamentales del niño, discriminándolo y aceptando una condenación socioeconómica previa y determinista, refleja la miopía para la realidad científicamente comprobada de los daños y consecuencias del trabajo para la vida del niño.

- Al decir que "es mejor para el niño trabajar que quedarse en la calle, expuesto al crimen”, refuta con la afirmación de que la realidad del trabajo de niños y adolescentes retrata condiciones desfavorables, nocivas, inadecuadas, perjudiciales e inseguras, que generan perjuicios irreversibles a su desarrollo físico, psíquico, moral y social, y que el trabajo en las calles y espacios públi- 
cos, los sujeta a riesgos mucho más acentuados, representando un porcentaje significativo de niños sometidos al labor en nuestro país.

- Al decir que "el trabajo contribuye a la formación del carácter y a los valores morales del niño", refuta con la afirmación de que la infancia es el tiempo único y precioso para su formación física y psicológica, para jugar, aprender y crecer saludablemente. El trabajo precoz deforma y sustrae del niño esa etapa esencial de la vida, con secuelas irreversibles psicofísicas, incluso impidiendo la frecuencia escolar y perjudicando su formación, negándole el derecho a vivir la propia infancia, que es irrenunciable e inalienable.

- Al decir que "es bueno para el niño contribuir para la supervivencia de la familia", refuta con la afirmación de que, cuando la familia se vuelve incapaz de proveer su propio sustento, le cabe al Estado asistirla, por fuerza de la responsabilidad constitucional que le es atribuida, siendo una excrecencia lógica jurídica transferir ese deber al niño. Añádase, además, que, estadísticamente, más de $50 \%$ de los niños nada reciben por el trabajo realizado, y las que tienen alguna remuneración, en su mayoría el valor representa cerca del $10 \%$ de la renta familiar.

- Al decir que "el niño desocupado en la calle representa un peligro para la sociedad", refuta con la afirmación de que era ese el fundamento del vetusto Código de Menores de 1927 y de la doctrina anticuada de la situación irregular, atribuyendo la culpa al niño por su abandono del espacio familiar y educacional. El nuevo paradigma constitucional reconoce al niño como sujeto de derechos y de protección obligatoria, especial y prioritaria por el Estado y por la sociedad, y el derecho de ser cuidado y de tener seguridad.

- Al decir que "el niño que trabaja queda más listo, aprende a luchar por la vida y tiene condición de vencer profesionalmente cuando sea adulto", refuta con la afirmación de que la visión de la realidad es la de que el trabajo precoz no educa, no enseña y no trae cualificación profesional para la vida adulta, sino que impide y deforma el crecimiento educacional adecuado de niño, excluyendo la posibilidad futura de su inserción en el mercado de trabajo.

- Al decir que "es natural que los niños trabajen, aprendiendo un oficio con los padres, que deben incentivar esa labor, cuando no tienen donde dejar los hijos", refuta con la afirmación de que las actividades que el niño 
desarrolla en los locales de trabajo para donde, en regla, son conducidos por los familiares, a ejemplo las ferias libres, basurales, alfarerías, plantaciones y carbonerías, no posibilitan ninguna educación, aprendizaje o formación profesional. El niño sometido a esa situación pierde la chance y el derecho de estudiar, de profesionalizarse, y, cuando sea adulto estará perjudicado para ingresar al mercado de trabajo.

- Al decir, por último, que "niño trabajador es sinónimo de disciplina, seriedad y coraje, evitando la ociosidad y la pereza", refuta con la afirmación de que el trabajo infantil es, comprobadamente, la causa de graves trastornos psíquicos y comportamentales para el niño, que generan miedos, inseguridad, agresividad, rabia y dificultades emocionales y de relación social.

\section{CONCLUSIÓN}

La construcción teórica doctrinaria y normativa, en ámbito internacional y doméstico, de reconocimiento y protección al derecho fundamental del niño al no trabajo, se opone y refuta, de forma contundente, a cualesquiera justificativas o movimientos, de orden cultural o económico, direccionados a la defensa del trabajo precoz o de retroceso relativamente a los parámetros de protección establecidos en el ordenamiento jurídico.

Es imperioso comprender la falsa lógica del discurso irracional y discriminador, que justifican prácticas explotadoras del trabajo del niño, que aún insisten, lamentablemente, en permanecer naturalizadas en países subdesarrollados y emergentes, como el nuestro.

Las normas fundamentales de protección, emancipadoras de los derechos humanos del niño y del adolescente, no permiten flexibilización para reducir esa conquista civilizatoria, en especial con la finalidad de facilitar o incentivar el trabajo infantil.

Los derechos fundamentales reconocidos al niño y al adolescente están resguardados en la y por la ciudadela del respeto a la dignidad humana, como valor superior, indisponible y universal, y, por eso, mantenerla inexpugnable constituye responsabilidad del Estado, de la sociedad y de las familias, principalmente ante las tradiciones y patrones culturales supervivientes, anacrónicos y perversos. 


\section{NOTAS}

1 Ese dispositivo constitucional inspiró la norma grabada en el artículo $3^{\circ}$ del Estatuto del Niño y del Adolescente (Ley n. ${ }^{\circ}$ 8.069/90): "El niño y el adolescente gozan de todos los derechos fundamentales inherentes a la persona humana, sin perjuicio de la protección integral de que trata esta Ley, asegurándoles, por ley o por otros medios, todas las oportunidades y facilidades, con la finalidad de facultarles el desarrollo físico, mental, moral, espiritual y social, en condiciones de libertad y de dignidad”.

2 Apuntan Mônica Silva Ferreira y Patrícia Anido Noronha que "esta concepción reconoce al niño en cuanto ciudadano, confiriéndole todos los derechos necesarios para una evolución peculiar a sus necesidades, como el derecho al respeto, a la dignidad y a la libertad, datos que se debe tener en cuenta en el proceso de asistencia y protección de la misma y que confiere a otros, además del Juez, el poder de buscar la garantía de esos derechos." Y rematan resaltando que la "concepción del niño en cuanto sujeto de derechos ya era pleiteada por algunos juristas [...] tienen significado la atención del niño en cuanto ciudadano, no pudiendo más ser tratado como objeto pasivo de la intervención de la familia, de la sociedad y del Estado [...]. El hecho de ser considerada persona en condición peculiar de desarrollo tiene relación con los derechos que los niños y los adolescentes deben tener como los direccionados a los adultos y presentes en la formulación de los derechos humanos, sumados a los que estén de acuerdo con su edad, necesidad e interés, teniendo aún prioridad absoluta en cualesquiera acciones sociales” (BASÍLIO; EARP; NORONHA, 1998, p. 151 e 154). (negrita nuestra)

3 Tânia da Silva Pereira observa, con pertinencia, que "el Código de Menores de 1979 (Ley n. ${ }^{\circ}$ 6.697, del 10 de octubre de 1979) adoptó la Doctrina de protección al Menor en Situación Irregular, que abarca los casos de abandono, la práctica de la infracción penal, desviación de conducta, falta de asistencia o representación legal; en fin, la ley de menores era instrumento de control social de la infancia y del adolescente, víctimas de omisiones de la familia, de la sociedad y del Estado en sus derechos básicos." (BASÍLIO; EARP; NORONHA, 1998, p. 149).

$4 \quad$ El texto original de 1988 previa la edad mínima general de 14 años para el trabajo y el aprendizaje a partir de los 12 años.

5 El contrato de aprendizaje está previsto en los arts. 428 y siguientes de la CLT, definido como el contrato de trabajo especial, ajustado por escrito y por plazo determinado, en que el empleador se compromete a asegurar al mayor de 14 y menor de 24 años, inscrito en el programa de aprendizaje, formación técnico profesional metódica, compatible con su desarrollo físico, moral y psicológico, y el aprendiz, a ejecutar con celo y diligencia, las tareas necesarias a esa formación.

6 MC-ADI n. ${ }^{\circ}$ 5326-DF, Rel. Min. Marco Aurélio Mello, j. 27.09.2018. Disponible en: http:/ / portal.stf.jus.br/processos/downloadPeca.asp?id=15342702615\&ext=.pdf. Acceso en: 18 oct. 2020.

7 Los referidos dispositivos de la CLT así prevían: Art. 405. [...]. \2 20. El trabajo ejercido en las calles, plazas y otros espacios públicos dependerá de previa autorización del Juez de Menores, al cual cabe verificar si la ocupación es indispensable a su propia subsistencia o a la de sus padres, abuelos o hermanos y si de esa ocupación no podrá advenir perjuicio a su formación moral. $\int 4^{\circ}$. En las localidades en que existen, oficialmente reconocidas, instituciones destinadas al amparo de los menores jornaleros, solo a los que se encuentren bajo el patrocinio de esas entidades será otorgada la autorización de trabajo al que alude o $\int 2^{\circ}$. 
Art. 406. El Juez de Menores podrá autorizar al menor el trabajo a que se refieren las letras " $\mathrm{a}$ " e "b" del $\ 3^{\circ}$ del art. 405: I - siempre que la representación tenga fin educativo o la pieza de que participe no pueda ser perjudicial a su formación moral; II - y que se certifique ser la ocupación del menor indispensable a la propia subsistencia o a la de sus padres, abuelos o hermanos y no suceda ningún perjuicio a su formación moral.

8 Enunciado n. ${ }^{\circ}$ 2, aprobado en el Fórum Nacional de los Centros de Apoyo de la infancia y de la Juventud de los Ministerios Públicos Estaduales, en el XI Encuentro Nacional. Disponible en https://niño.mppr.mp.br/arquivos/File/idade_penal/xi_ foncaij.pdf. Acceso en: 18 oct. 2020.

9 La condición especial del niño y del adolescente - considerados personas en desarrollo a las cuales se confiere protección integral - se hace imperativo el resguardo absoluto a su salud física y mental, con relación a la actividad laboral. De esta manera, es fácil ver, primero, que la realización de trabajo en jornada nocturna es factor científicamente comprobado de mayor desgaste y negativos efectos físicos y psíquicos en el trabajador, frente a la inversión del reloj biológico, razón por la cual se impide que el adolescente con edad inferior a 18 años se someta a esa condición potencialmente dañosa. En cuanto a la prohibición de trabajo en actividades insalubres y peligrosas, aún más se revela como pertinente e imperioso el dispositivo en análisis. Sería en cualquier hipótesis inadmisible sujetar la salud y la integridad de niños y adolescentes a trabajos que, por su naturaleza, condiciones o métodos, fueran a exponerlos a agentes nocivos a la salud, sobre los límites de tolerancia fijados en razón de la naturaleza y de la intensidad del agente y del tiempo de exposición a los efectos (como es el caso de la actividad u operación insalubre), o aquellas que, por su naturaleza o métodos de trabajo, impliquen el contacto permanente con inflamables o explosivos en condiciones de riesgo acentuado (lo que ocurre con las actividades $u$ operaciones peligrosas). Bien se sabe que, incluso los adultos, cuya formación físicopsíquica ya está definida, cuando se someten continuamente a esas actividades, en regla, son víctimas de algún tipo de daño o perjuicio a la salud, y no es raro que resulte en secuelas comprometedoras de su salud. La contundencia relativa a la prohibición al menor de 18 años de trabajar en las condiciones descritas atiende al imperativo mayor de la preservación de su dignidad. Hay que resaltar, además, que, a la vista de la norma constitucional del art. 227, caput, está igualmente prohibido cualquier otro trabajo que caracterice situación de riesgo a la integridad física, moral y psíquica del adolescente con edad inferior a 18 años.

10 En decisión proferida por el STJ en el AgInt en el Agravado en Apelación Especial n. ${ }^{\circ}$ 956.558-SP (Rel. ministro Napoleão Nunes Maia Filho, DJe 17/06/2020) se asentó el siguiente entendimiento, extraído de los siguientes puntos del Registro. "3. En los términos de la jurisprudencia del Supremo Tribunal Federal, el art. $7^{\circ}$, XXXIII, de la Constitución no puede ser interpretado en perjuicio del niño y del adolescente que ejerce actividad laboral, haya vista que la regla constitucional fue creada para la protección y defensa de los Trabajadores, no pudiendo ser utilizada para privarlos de sus derechos (RE 537.040/SC, Rel. Min. DIAS TOFFOLI, DJe 9.8.2011). La interpretación de cualquier regla positivada debe atender a los propósitos de su edición; en el caso de reglas protectoras de derechos de menores, la comprensión jurídica no podrá, jamás, contrariar la finalidad de protección inspiradora de la regla jurídica. 4. En el mismo sentido, esta Corte ya asentó la orientación de que la legislación, al vedar el trabajo infantil, tuvo por propósito su protección, habiendo sido establecida la prohibición en beneficio del menor y no en su perjuicio. Reconociendo, así, que los menores de edad no pueden ser perjudicados en sus derechos laborales y de previsión social, cuando 
está comprobado el ejercicio de actividad laboral en la infancia. 5. De esta forma, no es admisible desconsiderar la actividad rural ejercida por un niño impelido a trabajar incluso antes de sus 12 años, bajo pena de punir doblemente al Trabajador, que tuvo la infancia sacrificada a raíz del trabajo en el quehacer rural y que no podría tener tal tiempo aprovechado en el momento de la concesión de su jubilación. La interpretación en sentido contrario sería infractora del propósito inspirador de la regla de protección. 6. En la hipótesis, el Tribunal de origen, soberano en el análisis del conjunto fáctico probatorio de los autos, aseveró que las pruebas materiales acarreadas aliadas a los testigos oídos, comprueban que el autor ejerció actividad campesina desde la infancia hasta 1978, aunque haya fijado como fecha inicial para aprovechamiento de tal tiempo el momento en que el autor implementó 14 años (1969). 7. En rigor, no hay que establecer una edad mínima para el reconocimiento de labor ejercido por niños y adolescentes, imponiéndose al juzgador analizar en cada caso concreto las pruebas acerca de la alegada actividad rural, estableciendo su fecha inicial de acuerdo con la realidad de los autos y no en un límite mínimo de edad abstractamente preestablecido. Se reafirma que el trabajo del niño y del adolescente debe ser reprimido con energía inflexible, no admitiendo excepción que lo justifique; sin embargo, una vez realizado la labor el respectivo tiempo debe ser computado, siendo este cómputo lo mínimo que se puede hacer para mitigar el perjuicio sufrido por el infante, pero esto sin exonerar al empleador de las puniciones legales a las que se expone quien emplea o explota el trabajo de menores." Disponible en: https://ww2.stj.jus.br/processo/ revista $/$ documento $/$ mediado $/$ ? componente $=I T A \& s e q u e n c i a l=1918142 \&$ num_ registro $=201601945439 \&$ data $=20200617 \&$ formato $=$ PDF. Acceso en: 18 oct. 2020.

11 Disponible en https://www.chegadetrabajoinfantil.org.br/wp-content/uploads/2017 /02/cartilha_trabajo_infantil-1.pdf. Acceso en: 19 oct. de 2020.

12 El Decreto federal n. ${ }^{0}$ 9.759, de 11/04/2019, ha extinguido injustificadamente el CONAETI, perjudicando y comprometiendo gravemente la actuación del país en el combate al trabajo infantil, al reflejar retroceso y consecuencias inestimables para la garantía de derechos fundamentales al niño y al adolescente, en el ámbito de la protección contra el trabajo precoz e ilícito.

13 Ese elenco fue pensado a partir del estudio de Vilani (2007).

\section{REFERENCIAS}

BOBBIO, Norberto. A Era dos direitos. Rio de Janeiro: Campos, 1992.

BRASIL. Constituição da República Federativa do Brasil. Brasília, 1988. Disponível en http://www.planalto.gov.br/ccivil_03/Constitución/Constitución.htm. Acceso en: 18 oct. 2020.

FERREIRA, Mônica Silva; NORONHA, Patrícia Anido. As legislações que tutelaram a infância e a juventude no Brasil. In: Infância Tutelada e educação: História, Política e legislação. BAZÍLIO, Luiz Cavalieri; EARP, Maria de Lourdes Sá; NORONHA, Patrícia Anido (org.). Rio de Janeiro: Ravil, 1998. 
LUÑO, Antonio Enrique Pérez. Los Derechos Fundamentales. Temas Clave de la Constitución Española, colección dirigida por Pedro de Veja. 6. ${ }^{a}$ ed. Madrid: Tecnos, 2004.

MARCÍLIO, Maria Luíza; PUSSOLI, Lafaiete (coord.). A Construção dos direitos da criança brasileira. In: Cultura dos Direitos Humanos. São Paulo: LTr, 1988, p. 77.

MINISTÉRIO DO TRABALHO E EMPREGO. Cartilha Saiba tudo sobre o trabalho infantil. Brasília/DF, [20--]. Disponível em https://www. chegadetrabajoinfantil.org.br/wp-content/uploads/2017/02/cartilha_trabajo_infantil-1.pdf. Acceso en: 18 ago. 2020.

MINISTÉRIO DO TRABALHO E EMPREGO. Plano Nacional de Prevenção e Erradicação do Trabalho Infantil e Proteção ao Trabalhador Adolescente. Brasília/DF, 2004. Disponível em http://www. tst.jus.br/documents / 2237892/0/Plano+Nacional+\%E2\%80\%93\%20 Preven $\%$ C3\%A7\%C3A3o+e +Erradica $\%$ C3\%A7\%C3\%A3o+do+trabajo + Infantil $+\mathrm{e}+$ Prote $\% \mathrm{C} 3 \% \mathrm{~A} 7 \% \mathrm{C} 3 \% \mathrm{~A} 3 \mathrm{o}+\mathrm{ao}+$ Trabalhador+Adolescente+-+2004. Acceso en: 18 ago. 2020.

OLEA, Manoel Alonso. Introdução ao direito do trabalho. Curitiba: Gênesis, 1997.

SUPERIOR TRIBUNAL DE JUSTIÇA. Agravo em Recurso Especial n. ${ }^{\circ}$ 956.558-SP, Rel. Ministro Napoleão Nunes Maia Filho, julgado em 02/06/2020. Disponível em https://ww2.stj.jus.br/processo/revista/documento $/$ mediado $/$ ?componente $=I T A \& s e q u e n c i a l=1918142 \&$ num_registro $=201601945439 \&$ data $=20200617 \&$ formato $=$ PDF. Acceso en: 18 ago. 2020.

SUPREMO TRIBUNAL FEDERAL. Medida Cautelar na Ação Direta de Inconstitucionalidade n. ${ }^{\mathbf{0}}$ 5326-DF, Relator Ministro Marco Aurélio Mello, julgado em 27/09/2018. Disponível em: http://portal.stf.jus.br/processos/ downloadPeca.asp?id=15342702615\&ext=.pdf. Acesso en: 18 ago. 2020.

VILANI, Jane Araújo dos Santos. A questão do trabalho infantil: mitos e verdades. In: Revista Inclusão Social, Brasília/DF, v. 2, n. ${ }^{\circ}$, out./2006mar./2007. 



\section{EL COMBATE AL TRABAJO INFANTIL EN EL TRÁFICO DE DROGAS: POR LA CONSTRUCCIÓN DE ALTERNATIVAS MÁS ALLÁ DEL ESTADO NEOLIBERAL}

\section{ZÉU PALMEIRA SOBRINHO}

DOI: $10.51366 / 978-65-89468-10-3$-coordinfancia-32

Resumen. Este artículo tiene por objetivo demostrar que la actividad de niños en el tráfico de drogas debe categorizarse como una de las peores formas de labor infantil como condición para la eficacia en el combate a la explotación ilegal de trabajadores infanto juveniles y para la efectivización de la política de protección integral prevista en el art. 227 de la Constitución Federal. Los estudios desarrollados en el presente texto pretenden también evidenciar que la lucha política por la superación del Estado neoliberal y de sus prácticas, en todas las esferas del convivio social, es una necesidad histórica para obtenerse cualquier éxito en el combate a la reproducción del trabajo infantil en el tráfico.

Palabras claves: Trabajo infantil. Tráfico de drogas. Estado neoliberal.

\section{INTRODUCCIÓN}

Este artículo busca identificar el trabajo infantil en el tráfico de drogas, bajo una perspectiva epistemológica, jurídica, cultural y socioeconómica, con el fin de demostrar los factores que influencian el reclutamiento de niños y adolescentes y las alternativas para la prevención y el combate al trabajo infantil en el tráfico de drogas.

A partir de la contextualización, que será explorada más adelante, se observa que el modo de producción capitalista articula la combinación de lo moderno y lo anticua1do, en lo que respecta a las formas de gestión de la 
fuerza de trabajo, razón por la cual la realidad está revelando la voracidad por el lucro de parte de las fracciones capitalistas que reproducen, en la cadena de producción, comercio y distribución de drogas, la explotación de trabajadores esclavizados, mujeres y niños. Ello revela, en principio, que el trabajo infantil nunca fue de hecho una fuente marginal de labor, sino una fuente de generación de riquezas que se presenta de forma destacada en el mundo del tráfico de drogas.

Se plantea aquí ante el lector la permisión para utilizarse el referencial etario de la Convención sobre los Derechos del Niño, de $1989^{1}$ (BRASIL, 1990a). A propósito, fijese, desde luego, que para los efectos de la citada Convención y, aún, conforme su art. $1^{\circ}$, el niño es todo ser humano con menos de 18 años de edad. Esto no exime decir que en el plano de la legislación infraconstitucional brasileña, el ECA - Estatuto da Criança e do Adolescente (BRASIL, 1990b), prevé en su art. $1^{\circ}$ que se considera como niño a la persona con hasta doce años de edad incompletos y al adolescente el que tenga entre doce y dieciocho años de edad. Así, contrastando el sistema normativo internacional y el ECA, siempre que el autor aquí hable de niño se referirá igualmente al adolescente.

Se pide, todavía, la atención al lector para la comprensión previa de algunas categorías nucleares. La primera es la categoría "zonas salvajes" como sinónimo de territorio periférico. La segunda categoría es la de "apartheid social", presentada en el contexto de crisis del contrato social y de emergencia del fascismo social, según las categorías exploradas por Boaventura de Sousa Santos, en su obra "A gramática do tempo". Según Santos (2008), el apartheid social es la forma de demarcación de los espacios territoriales de vigencia o de derogación del contrato social. Es la división del espacio urbano entre zonas civilizadas, donde el contrato social se observa, sin embargo, por encontrarse permanentemente bajo la amenaza de las zonas salvajes, tiene que erigirse en la forma de muros, enclaves y feudos súper vigilados y controlados; y las zonas salvajes son las que reeditan el estado salvaje hobbesiano. En una el Estado es de derecho; en la otra el estado es un predador (SANTOS, 2008).

El presente trabajo se estructura aún en la consideración sobre la categoría del trabajo infantil en el tráfico en cuatro temas.

El primer tema, objeto del ítem 2, busca discutir la relación entre la participación del niño en el tráfico y la categoría trabajo. 
En el segundo tema, la preocupación se vuelve a la identificación de los elementos, subjetivos y objetivos, que influencian la participación del niño en el trabajo infantil en el tráfico.

En el tercer tema se realizará un abordamiento sobre el trabajo infantil en el tráfico de drogas por la mediación de investigaciones de campo.

En el cuarto y último tema, objeto del ítem 5 de este texto, se discutirán las alternativas para el combate al trabajo infantil en el tráfico de drogas.

\section{EL TRABAJO INFANTIL EN EL TRÁFICO: UNA CATE- GORÍA PARA DESMISTIFICARSE}

Un problema central que afecta la política pública de combate al trabajo infantil en el tráfico de drogas empieza por la negación de la categoría del trabajo y, consecuentemente, por la negación de la condición de trabajador. Trabajo infantil es toda actividad desempeñada por personas abajo de la edad legal permitida y que compromete el pleno desarrollo del niño y del adolescente.

La categorización, en cuanto instrumento del lenguaje, si es construida de modo apurado, es una forma, previamente, de automatizarse y reducir el espacio de gravitación del problema y de inducir en el imaginario popular la manera más inmediata de enfrentarlo. Justo en esa perspectiva es que la categoría tráfico es un predicado utilizado peyorativamente para inducir al sujeto a, de forma prejuiciosa, condenar, combatir, reprimir y destruir a los involucrados con el tráfico.

El estigma del fenómeno social y el inmediatismo, como su reflejo directo, se convirtieron en una forma autoritaria de intentar negar la necesidad de poner a los niños, sobre todo los de familias empobrecidas, como destinatarios de las políticas públicas, con prioridad absoluta, tal cual dispone el art. 227 de la Constitución Federal (BRASIL, 1988). Bajo la senda de ese negacionismo es que el populismo penal, de índole represiva y centrada en la reclusión, pasó a ser apropiado por la necropolítica. Entiéndase aquí la necropolítica en el sentido que le atribuyó Achille Mbembe (2018), es decir, como siendo el poder de arbitrio del Estado decir quién debe seguir viviendo y quién debe morir. 
La necropolítica no es solo la extinción del cuerpo del otro; es antes la destrucción de la vida en su sentido pleno. La necropolítica es la acción u omisión que mata los derechos de las personas, provoca la segregación, la guerra, el odio, la intolerancia, la crueldad y el sufrimiento de las personas. Antes de matar la vida, la necropolítica mata la posibilidad de convivio civilizatorio por medio de la violencia, intolerancia y odio.

La Convención sobre los Derechos del Niño, de 1989, determina en su art. 33, que los Estados Partes adoptarán todas las medidas apropiadas, incluso medidas legislativas, administrativas, sociales y educacionales, para proteger al niño contra el uso ilícito de drogas y sustancias psicotrópicas y para impedir que niños sean utilizados en la producción y en el comercio de drogas (BRASIL, 1990a).

La Convención n. 182, de la OIT, considera el uso de la labor del niño en la cadena productiva y comercial del tráfico de drogas como una de las peores formas de trabajo infantil (BRASIL, 2019, Anexo LXVIII). Obsérvese que el texto convencional no está preocupado en culpabilizar a nadie, sino en reconocer como trabajo para entonces lograr consecuencias, entre ellas la mayor que es la protección integral al niño.

El trabajo infantil en el tráfico está mal comprendido al enfocarse bajo la perspectiva criminalizadora porque tal abordaje termina por disolver y negar el abordaje del fenómeno social en nombre de la supremacía del fenómeno jurídico-criminal. El trabajo bajo la perspectiva sociológica es un hecho, una realidad incontestable, a despecho de la forma como es tratado por el derecho, por la moral, por la religión etc. Es por esa vía que se considera trabajo toda actividad humana, tendencialmente onerosa, que involucra el dispendio de la energía humana y se reputa como medio de subsistencia.

El trabajo involucra concretamente una relación que, como regla, no se vacía por el simple hecho de ser un acto que permite la reprobación moral. Un ser humano, sea él adulto o niño, no pierde su condición de trabajador enajenado si lo que produce para otros, de forma eventual o continua, es el medio para proveer su subsistencia. En esa perspectiva es que el Derecho del Trabajo, bajo la influencia de la sociología y del realismo jurídico, adopta los principios de la primacía de la realidad y de la irretroactividad de las nulidades absolutas. 
La actividad de niños en el tráfico consiste en modalidad de trabajo, sea bajo el punto de vista sociológico o bajo el punto de vista jurídico, porque implica una división social del trabajo y un proceso de trabajo, aun cuando los involucrados asumen funciones de seguridad armada. En rigor, en la actividad del trabajador infantil en el tráfico están presentes todos los elementos caracterizadores de la relación de trabajo verticalizada, tales como: el dispendio de energía humana; la estructura de la división social del trabajo; la existencia de funciones, jornada, horario de trabajo y remuneración; la relación de subordinación del niño trabajador a su superior jerárquico; y la finalidad económica del negocio del contratante de servicios que consiste en la distribución y en el comercio de la droga.

El proceso de trabajo en el tráfico de drogas imputa ciertas condicionantes a los trabajadores infantiles. Por un lado, el trabajo en el tráfico implica la precarización laboral, la lealtad, los horarios híbridos, la remuneración variada y las posibilidades de movilidad jerárquica de corto y medio plazo. Por otro lado, implica disputas y competencia, venganza, además de relaciones marcadas por la violencia. Sobre las condiciones de trabajo infantil en el tráfico, se puede tener una referencia a partir de la investigación realizada por el Observatorio de favelas (2018). Ésta ha identificado que el 36,8\% de los entrevistados trabajaban de guardia 12 horas, sin embargo, la mayoría tenía horarios flexibles.

En la división social del trabajo del tráfico hay una actuación orgánica de personas y procesos que ponen en marcha funciones, a saber: el avión es el que hace el trabajo de mensajero, transmitiendo generalmente los recados al gerente del tráfico y al dueño de la boca de droga; el vapor, que es el vendedor de droga subordinado directamente al gerente; el campana, u operador de radio, que se encarga de monitorear el movimiento de personas en el territorio y a la vez emitir alarmas a los miembros del grupo, si desconfía que hay en el territorio miembros de facciones rivales o policías; el gerente del tráfico que hace negocios al por mayor con relación a la droga que está comercializada por los vendedores. El gerente en general también es el que define la ruta que se seguirá y el que autoriza los sobornos.

Los niños involucrados en el tráfico son trabajadores sometidos a una relación de subordinación. Ellos asimilan la fiducia y las responsabilidades de su oficio, lo que les permite una "inclusión" con permanencia condicionada al éxito del negocio del tráfico. Los niños también asumen atribuciones per- 
sonales, obedecen las reglas del territorio, observan el tiempo en que deben permanecer en actuación, se comprometen y se involucran en el servicio, de modo continuo, y obtienen remuneración, en utilidad (drogas, objetos productos de las acciones criminosas etc.) o aun en efectivo.

En lo que respecta a la remuneración, esta ha sido objetivamente mucho más elevada de la que se verifica en el mercado de trabajo formal. En una investigación relativamente reciente, el Observatorio de favelas (2008) ha constatado que el $57 \%$ de los adolescentes involucrados en el tráfico reciben entre 1 y 3 salarios mínimos por mes. En el estudio del CEBRAP (GALDEANO; ALMEIDA, 2018) se constató que un vendedor gana del 15\% al 20\% de la venta realizada en las "biqueiras" o puntos de venta, con posibilidad de recibir una renta mensual que varía entre $\mathrm{R} \$ 2.400$ a $\mathrm{R} \$ 9.600$.

Desde el punto de vista marxista, el trabajo es el intercambio entre el hombre y la naturaleza, de suerte que se califica como productivo solamente el trabajo que produce plusvalía en el proceso real de producción, lo que estaría más adecuado al trabajo en el narco plantío y en la industrialización de la droga.

El trabajo en el narcotráfico, al implicar el trabajo alienado, se enfrenta con la mercancía producida y él mismo también se considera una mercancía que se cambia por la remuneración paga. La propia relación de trabajo es también mercantilizada, es decir, en el modo de producción capitalista hay una relación entre personas que se transforma en una relación entre cosas.

La droga, en cuanto mercancía, tiene su valor de uso, pero el interés que tiene para el tráfico, se da por el valor de cambio. El narcotráfico, en su estructura y funcionamiento, desde las más complejas hasta las más sutiles modalidades de explotación, establece una remuneración para los que ejercen un trabajo alienado.

El niño involucrado en el tráfico emplea un tiempo de trabajo necesario no solo para el pago de su salario, sino también como trabajo excedente que es la parte que constituye la apropiación del trabajo no pago.

La prensa hegemónica y el sentido común de la sociedad perciben al niño que trabaja en el tráfico como un criminal. Esa postura alimenta una postura rabiosa de parte de la sociedad. De este modo, en general es objeto de desprecio cualquier habla que asocie las miserables condiciones socioe- 
conómicas de parte de la población brasileña y el aumento de la violencia involucrando a niños de los territorios periféricos.

Aunque exista una correlación entre el trabajo infantil en el tráfico y la ineficacia del sistema de inclusión social, el sentido común se inclina a ignorar este hecho ante la prevención que lo lleva a culpabilizar al miserable por su miseria. En este posicionamiento hay una mezcla de prejuicio y perversión porque se expresa a través de un discurso que trae implícita la idea ambigua de que todo miserable es rotundamente culpable por su miseria, por haber sido incapaz de resistir y superarla. Como si la resiliencia fuera un sacrificio o mortificación a exigirse solamente de los niños y de las familias empobrecidas.

\section{MOTIVOS QUE LLEVAN A LOS NIÑOS AL TRABAJO INFANTIL EN EL TRÁFICO: LA DETERMINACIÓN FAC- TORIAL DEL ESTADO REPRESIVO}

El trabajo infantil en el tráfico está sometido a la influencia de un conjunto de factores, de modo que la realidad de cada territorio periférico puede presentar mayor o menor oscilación en relación a los niveles y a los factores determinantes de este fenómeno.

A pesar de la multiplicidad de factores, hay motivaciones que se repiten y están identificadas en varios estudios. En un estudio publicado en 2002, por la OIT, coordinado por Jailson de Souza e Silva y André Urani, los principales motivos señalados por los mismos niños para el ingreso en el trabajo infantil en el tráfico de drogas son, en orden: la identidad con el grupo; la adrenalina; la posibilidad de ayudar financieramente a la familia; el deseo de ganar dinero; el prestigio y el poder; la limitación profesional y salarial; la defensa de la comunidad; la violencia familiar; la venganza o rebelión; la dificultad en la escuela; y el consumo de drogas (OIT, 2002).

El estudio publicado por la OIT (2002) revela que los niños de familias empobrecidas "ceden" a los reclutadores del tráfico de drogas porque ven en esa actividad una oportunidad. A despecho de las carencias económicas que afectan a las familias pobres, la violencia observada contra los habitantes de los territorios periféricos y la solidaridad que lleva a alguien a sentirse pro- 
tegido en una pandilla, por ejemplo, también incentivan a los niños y niñas a adherir al trabajo en el tráfico de drogas.

Los factores listados por el estudio publicado por la OIT (2002) son el resultado del conteo de las manifestaciones subjetivas de los entrevistados involucrados en el trabajo infantil en el tráfico de drogas. Sin embargo, hay varios factores objetivos que interfieren en el comprometimiento del niño y del adolescente en el trabajo infantil en el tráfico, entre los cuales se destacan: la falta de oportunidades de los individuos al acceso a los derechos sociales; la precarización del trabajo y el desempleo de los adultos; la falta de atracción de la escuela; la masculinidad tóxica que vincula la relación con el tráfico como un ritual de afirmación de la virilidad del muchacho; y las políticas económicas del Estado neoliberal. Se entiende aquí el Estado neoliberal como la estrategia de gestión de la política socioeconómica por el mercado y de desmantelamiento de las políticas públicas por medio de la privatización, de la mercantilización de los bienes sociales, de la desregulación de derechos sociales y de la rebaja del costo de reproducción de la fuerza de trabajo.

En territorios periféricos, tales como las áreas de ocupación precaria, favelas y asentamientos, la situación del trabajo infantil en el tráfico se agrava por el modo como el Estado neoliberal se niega a apoyar a las familias. Estas son ignoradas, vistas como un problema de ellas mismas, y no es raro que sus integrantes sean vistos como personas que, en vez de comprar un inmueble para vivir, perturban el orden y profanan el territorio ajeno en busca de habitación.

La presencia marcante de los aparatos represivos y la disputa por el dominio sobre los territorios en que viven las familias vulnerables se han hecho más importantes para el Estado que el respeto a los derechos humanos de los habitantes. A propósito, el Estado, los medios hegemónicos y las élites o bien consideran los derechos humanos como expresión del atrevimiento de grupos interesados en negar la superioridad moral de una clase o los consideran como un lujo para las poblaciones vulnerables.

La postura estatal, de criminalizar a quienes no pueden pagar por el derecho a una vivienda digna, se conjuga con otras dos posturas que avalan un verdadero apartheid social (SANTOS, 2008), a saber: la primera postura es el estigma de las llamadas "zonas salvajes", que coinciden con los territorios periféricos habitados por los empobrecidos, en contraste con las zonas civi- 
lizadas, habitadas por las personas de las clases medias y por los adinerados; y la segunda postura es la negación del acceso de las familias empobrecidas a derechos básicos, tales como: agua potable; energía; saneamiento básico; internet; equipamientos públicos; servicios de salud; escuelas; guarderías etc.

En los territorios periféricos, además de ser considerados por el aparato represivo los habitantes, el Estado adopta conductas de abordaje de guerra, en que la lógica del diálogo da lugar a la lógica del enfrentamiento indiscriminado. Con efecto, en uno de los episodios, el Poder Judicial carioca terminó concediendo mandato colectivo para autorizar a la policía a entrar en todas las casas, naturalizando la suspensión de los derechos constitucionales de los moradores.

El Estado, al comparecer ante las familias, solamente con la finalidad de reprimirlas, transformó los territorios periféricos en "plazas de guerra" o el locus de los vulnerables y susceptibles a abordaje, no solo por las personas ligadas al tráfico, sino también por políticos conservadores, líderes religiosos oportunistas, especuladores inmobiliarios, colonos usurpadores y paramilitares.

La criminalización de las drogas es también uno de los factores objetivos que influencian los siguientes aspectos: el aumento de la represión; la elevación de los homicidios; la pelea por puntos de comercio de drogas; la necesidad de las personas, vinculadas o no al crimen, de protegerse contra la acción policial; la carrera armamentista; la sensación de inseguridad; la elevación de la corrupción y de la violencia que está relacionada a la promiscuidad de los agentes del Estado con organizaciones criminales; el aumento de los gastos con el aparato represivo, de modo a agotar recursos que se podrían invertir en salud y educación (THORNTON, 2018). La criminalización viene alimentando la "guerra a las drogas" y ha servido como pretexto al Estado para, en lugar de amparar y proteger a las personas en territorios vulnerables, echar sobre estas una escalada de violencia y de exterminio.

Es notable que la sociabilidad en zonas controladas por el tráfico viene marcándose por la acción represiva del Estado neoliberal, que rompe el contrato social al negarse a asumir la condición de agente de inclusión social. El Estado neoliberal, por lo tanto, ha contribuido para profundizar el abismo social, de modo que la zona de tráfico pasa a ser caracterizada como el espacio de las ausencias, en donde están suspendidos los derechos de la ciudadanía. 
Regístrese aún que en los territorios periféricos hay respetabilidad y temor en relación a los implicados en el tráfico. Algunas comunidades se sienten en un momento protegidas, y en otro oprimidas por la violencia y temor diseminado por la red de tráfico. Es común observar el modo como la red de tráfico coopta a las personas de una comunidad, de modo que el traficante tiende a asumir la condición de un sujeto que oscila entre ser temido y ser admirado, llamando así la atención de niños y adolescentes.

El levantamiento del Observatorio de favelas (2018) revela que las personas involucradas en el tráfico no pueden liberarse de la represión y de la desigualdad social. No todos los trabajadores involucrados con el tráfico de drogas logran reproducir siquiera un patrón de consumo equivalente al de un integrante de la clase media.

La autoridad de los jefes de la red del tráfico, la disciplina jerárquica, basada en la lealtad y en la complicidad, y la capacidad de protección a los integrantes de la red son aspectos que pueden llevar a la imposición de la relación de dependencia de la comunidad en relación al tráfico de drogas. Respecto a la organización del tráfico, las normas de comportamiento tienden a ser orgánicamente asimiladas por la comunidad, de modo que hay en la mayoría de los casos una "aceptación natural" de la autoridad y de la disciplina.

Las normas y el sistema de justicia tienden a encararse como una necesidad a ser asimilada no solo por los integrantes de la red de tráfico, sino también por la comunidad. Es común que exista entre la comunidad y el control del tráfico un pacto implícito de "protección mutua", permeado por el cambio de favores. Sin embargo, tal adhesión tiende a ser fuertemente influenciada por la rutina de violencia protagonizada por los agentes del tráfico.

\section{LA COMPRENSIÓN DEL TRABAJO INFANTIL EN EL TRÁFICO DE DROGAS A PARTIR DEL TRABAJO DE CAMPO}

Para cualquier proceso de intervención de la realidad es importante un levantamiento previo de datos para conocer la dimensión del problema que se quiere comprender y enfrentar. De ahí la importancia de la investigación como una estrategia para que uno siga desarrollándose y transformando su mundo. La investigación, en las palabras de Paulo Freire, tiende a catapultar 
los temas generadores contemplados en el proceso de humanización y tiende a posibilitar el éxito en la intervención. Bajo ese aspecto, Freire (2017) dice: "investigo para constatar, constatando, intervengo, interviniendo educo y me educo. Investigo para conocer lo que aún no conozco y comunicar o anunciar la novedad" (FREIRE, 2017, p. 30).

Dos estudios recientes auxilian a la compresión sobre el trabajo infantil en el tráfico de drogas: el primero, realizado por el Observatorio de favelas (2018); y el segundo realizado por el CEBRAP (GALDEANO; ALMEIDA, 2018).

La investigación realizada por el Observatorio de favelas (2018), nombrada "Nuevas configuraciones de las redes criminosas después de la implantación de las UPPs", permite comprender los motivos por los cuales un niño puede involucrarse y puede retirarse del tráfico de drogas. El Observatorio de favelas es una ONG, con actuación en Rio de Janeiro, que realiza estudios e investigaciones sobre el derecho a la vida y sobre la seguridad pública en los territorios periféricos, con énfasis en la situación de los adolescentes y de los jóvenes.

El estudio en cuestión, involucrando a 261 personas, de las cuales el 62,8\% tenían entre 14 y 16 años, ha revelado que hubo un aumento del $50 \%$ del número de niños entre 10 y 12 años que entran a la red de tráfico de drogas. La mayor parte de los involucrados $(54,4 \%)$ está en la franja etaria entre 13 y 15 años, eran negros o pardos (74\%) y hombres (96,2\%), criados mayoritariamente en familias monoparentales en que la madre era la principal responsable (OBSERVATÓRIO DE FAVELAS, 2018).

A despecho de la fuerte presencia del Estado represor en los territorios periféricos, el estudio revela que en estos falta el Estado proveedor de políticas públicas, incluso en lo que respecta a los servicios de salud. Dicha ausencia explica en parte el motivo por el que tantos adolescentes, además de relacionarse con la adicción y la violencia, pasan a naturalizar la posibilidad de trabajo en el tráfico. De los entrevistados, 47,5\% afirmaron haber entrado en el tráfico a través del contacto con un amigo, 47,1\% dijeron que empezaron a drogarse entre 13 y 15 años y 75,9\% manifestaron haber sido víctimas de violencia policial. 
Uno de los datos más impactantes de la investigación del Observatorio de favelas (2018) respecta a la relación entre el compromiso con el tráfico de drogas, la debilidad económica de la familia y la evasión escolar. Entre los entrevistados $62,1 \%$ sostuvieron la necesidad de ayudar a la familia como principal factor que los hace seguir en el tráfico; $78,2 \%$ afirmaron que ya no iban la escuela, siendo que 34,5\% declararon haber dejado de estudiar entre los 15 y 16 años de edad; 22,6\% dijeron haber abandonado la escuela a partir de los 17 años. La mayoría (40,4\%) ha justificado el abandono escolar por razones económicas y $66,3 \%$ afirmaron que era preciso trabajar para ayudar en el sustento de la familia.

Según la Síntesis de los Indicadores Sociales, del IBGE (2019), que ha compilado los datos de 2016,11,8\% de los jóvenes más pobres, con edad entre 15 y 16 años, abandonaron la escuela sin concluir la enseñanza secundaria. La evasión escolar y los pésimos índices de la educación reflejan las condiciones de vida de los niños y adolescentes, así como el déficit social que el país tiene sobre todo hacia las familias empobrecidas. Según datos del IBGE, de 2018, en materia de educación el país presenta el siguiente cuadro: la evasión escolar en Brasil es 8 veces más alta en los adolescentes de familias empobrecidas; entre los países de Latinoamérica, Brasil tiene la quinta mayor tasa de analfabetismo (8\%) entre las personas de 15 años o más de edad; $24,1 \%$ de los alumnos no concluyen la enseñanza básica hasta los 16 años; aproximadamente 40,0\% de la población brasileña con 25 años de edad o más no concluyó la enseñanza básica (IBGE, 2019).

Un dato de la investigación del Observatorio das favelas (2018) trae una luz de esperanza al dar a saber que $54 \%$ de los entrevistados afirmaron que saldrían del tráfico si tuvieran la posibilidad de conseguir un empleo formal. En el citado estudio, cuando se les pregunta sobre sus sueños de vida, los entrevistados - en su mayoría - afirmaron que desean dejar el trabajo en el tráfico de drogas, conseguir un empleo formal y tener más tiempo para la familia.

Obsérvese que el estudio contempla un abordaje sobre las aspiraciones de los proyectos de los entrevistados, siendo que éstos encaran la actividad del tráfico de drogas como precaria y transitoria, teniendo en vista la necesidad de proveer sus carencias económicas y la de sus familias. Además, el estudio revela que las personas involucradas en el tráfico tienen sueños y 
deseos de vivir a partir de una centralidad basada en el trabajo formal y en la atención a la familia.

\section{LAS ALTERNATIVAS PARA EL COMBATE AL TRABAJO INFANTIL EN EL TRÁFICO}

Para discutir las alternativas es preciso partir de algunas premisas capaces de marcar la ruptura de un análisis sobre el trabajo infantil en el tráfico de forma prejuiciosa y no comprometida.

La primera premisa es la de que la represión y la criminalización de niños y adolescentes reproducen precisamente el trabajo infantil en el tráfico.

Estigmatizar como "bandido" o "bandida" al niño o al adolescente involucrado con el tráfico de drogas es la primera medida para condenar a los que se debería proteger y para hacer inviable la retirada o detener el ingreso de niños y niñas en dicha actividad. Un trabajador desprotegido es un trabajador, de modo que no puede ser condenado por el hecho de que es empujado a ejercer una actividad, sea esta peligrosa o insalubre, y no haber sido destinatario de derechos. Bajo ese aspecto, el ECA reproduce en su texto un pecado moralista al tratar al adolescente como autor de infracción, y no como trabajador infantil y como sujeto desprotegido al que se ha negado el conjunto de derechos reconocidos por la Constitución Federal.

La segunda premisa consiste en rechazar la mirada moralista que simplifica y estigmatiza al que debería ser el destinatario de la protección social. Más allá de los valores morales del que juzga, es urgente considerar que el trabajo infantil en el tráfico de drogas, aunque engañosamente se parezca a una libre elección del niño, no puede ser comprendido abstrayéndose la historia de privaciones, de frustraciones y de violencia, a la que están sometidas las personas y familias empobrecidas que viven en los territorios periféricos, y las condicionalidades materiales que convierten a los niños y niñas en sujetos apropiables antes de ser objetivamente sujetos apropiados por la red de tráfico de drogas.

La tercera premisa es comprender la actividad del niño y del adolescente en el tráfico como trabajo. Esta es una condición para viabilizar la plena protección que está albergada en el art. 227 de la Constitución Federal, y la otorga de derechos previstos en el ECA y en las leyes laborales. En rigor, 
estudios como los realizados por el Observatorio de favelas (2018) y por el CEBRAP (GALDEANO; ALMEIDA, 2018) revelan que la implicación en el tráfico de drogas se verifica por la necesidad de trabajo y como trabajo debe ser tratado. No por casualidad, la OIT - Organización Internacional del Trabajo -, por medio de la Convención n. 182, considera dicha implicación como labor humana en el tráfico y califica esa actividad como una de las peores formas de trabajo infantil (BRASIL, 2019, Anexo LXVIII).

La cuarta premisa es la de que no habrá solución de combate al trabajo infantil en el tráfico de drogas si no hay apoyo a las familias y a las comunidades de los territorios periféricos, además de los servicios de prevención y rehabilitación. La pobreza y el desempleo de los habitantes de las comunidades, la falta de acceso a la salud, a la educación, al trabajo y a la vivienda digna, propende a facilitar el crecimiento del tráfico y la atracción de niños y adolescentes (DOWDNEY, 2003).

La quinta premisa es la de que la lucha contra el trabajo infantil es una lucha política y, siendo de naturaleza política, no podrá enfrentarse si no es una lucha contra la prevalencia del Estado neoliberal. Es importante resaltar que bajo un Estado neoliberal, cuya preocupación es únicamente con la súper ganancia del mercado, se vuelve imposible una política pública de acogida y de inserción social. El éxito de cualquier acción, programas, proyectos o iniciativas de combate al trabajo infantil en el tráfico dependerá de una postura estatal que viabilice, más allá de la legislación, un plan confiable y la seria ejecución de un proyecto articulado con toda la red de protección.

La Ley n. ${ }^{\circ}$ 11.346/2006, que instituyó el Sistema Nacional de Políticas Públicas sobre Drogas, pareció al principio un avance para estimular la retirada del cariz represivo y para inaugurar un modelo de cuidado, atención e inclusión de los adictos a las drogas, creando oportunidades por ejemplo de que los adolescentes, en vez de ser estigmatizados como peligrosos, sean contemplados con acceso a los servicios de salud y al mercado de trabajo (BRASIL, 2006). Sin embargo, la influencia de elementos religiosos conservadores y de percepciones inmediatistas, patologizantes en el campo de la salud y reaccionarias en el campo específico de las políticas públicas, fortaleció una cultura moralista y criminalizadora que influenció el populismo penal. Este, al avalar una práctica social prohibicionista, busca, por un lado, desacreditar los abordajes terapéuticos humanizados y, por otro, preconizar una lógica encarceladora y centrada en la reclusión. 
El sistema represor del Estado ha contribuido para hacer más violentos los territorios periféricos. Los moradores de tales áreas, al asimilar la tensión y el miedo en relación a los conflictos causados por la represión, se inclinan la mayoría de las veces a hipotecar un apoyo silencioso al tráfico como imposición para la obtención de una protección mínima del poder paralelo y opresivo de las organizaciones locales implicadas en el comercio de drogas.

Tomando como base las reflexiones ya presentadas hasta aquí y, considerando la importancia de los abordajes teóricos y de las investigaciones de campo mencionadas en el presente trabajo, las alternativas de combate al trabajo infantil en el tráfico desafían la adopción de las siguientes medidas:

a) El mapeo del territorio, físico y virtual, de lo local a lo global, por donde fluye el tráfico de drogas, para obtención de información estratégica sobre el perfil de los involucrados y de la lógica del proceso del reclutamiento de personas en la actividad del tráfico;

b) El estudio para comprensión del modus operandi de abordaje y reclutamiento de los niños para el tráfico;

c) El levantamiento de estrategias para retirada y la independización de los niños involucrados en el tráfico de drogas;

d) La adopción de una política interdependiente que implique toda la red de protección al niño y al adolescente, además del apoyo y colaboración con las familias, la comunidad y la escuela;

e) La creación de canales de diálogo con la participación de niños de las comunidades más afectadas por el tráfico de drogas;

f) La realización de investigación acción continua que trace el perfil de los niños y de la comunidad y que levante informaciones sobre las causas más frecuentes de implicación del niño en el tráfico, considerando la diversidad y pluralidad de las regiones existentes en el país;

g) La adopción de un sistema de comunicación que establezca la tematización de asuntos de la protección jurídica con el fin de sensibilizar y concientizar las comunidades sobre los derechos del niño, inclusivo sobre las peores formas de trabajo; 
h) La estructuración del sistema de protección y la rehabilitación de la salud de niños involucrados en la red de tráfico de drogas;

i) El incentivo a la reforma del sistema legal, que sea más acogedor y menos represivo, para desestimular la inserción de jóvenes y niños en el tráfico de drogas;

J) La inversión y la capacitación para hacer las escuelas más atractivas y comprometidas en la evolución de los individuos y de las familias, además de crear un sistema de busca activa de niños involucrados en el tráfico de drogas;

1) El estímulo a la transacción penal y a la reducción de condena en los casos en que los adultos, implicados en la red del tráfico, se comprometan a no usar niños en las actividades ilícitas y no abordarlas para reclutamiento;

m) La implantación de un sistema de inteligencia que reciba y apure denuncias, incluso anónimas, con el fin de combatir la participación del niño con la red de tráfico de drogas;

n) Mecanismos para incrementar estrategias de educación preventiva con la articulación y la aproximación de las familias, de la red de protección al niño, de las escuelas y de las comunidades;

Todas las alternativas exigen como condición previa la ruptura con el Estado punitivista que estigmatiza a los que viven en los territorios periféricos y vuelve imputables a niños y adolescentes antes de ser imputados. La dialogicidad entre el Estado y la sociedad es fundamental para retomar la dirección de las alternativas propuestas y para romper el aislamiento que impide la inteligibilidad recíproca.

\section{CONSIDERACIONES FINALES}

La complejidad de las diversas situaciones que consustancian la historia de la protección al niño y de la represión del Estado en Brasil deja en abierto el debate y el abordaje sobre el trabajo infantil en el tráfico, pero señala las conclusiones provisionales que se pueden destacar, a saber:

a) La necesidad de reconocimiento interno de la actividad del niño en el tráfico como una de las peores formas de trabajo infantil, confor- 
me disciplina la Convención n. 182, de la OIT, es un desafío urgente para materializar la protección prevista en el art. 227 de la Constitución Federal (BRASIL, 2019, Anexo LXVIII; BRASIL, 1988);

b) La urgencia de una lucha política por la superación del Estado neoliberal y de sus prácticas, en todas las esferas de la convivialidad social es una necesidad histórica para obtenerse cualquier éxito en el combate a la reproducción del trabajo infantil en el tráfico;

c) El combate a la evasión escolar y el apoyo a las familias son medidas simples que tienden a evitar el reclutamiento de los niños por la red de tráfico de drogas, tal como demostraron los estudios más recientes que se inclinaron sobre el tema. Por esa razón, la adopción de políticas públicas de apoyo material a las familias y de combate a la evasión escolar son medidas urgentes en el horizonte inmediato de la lucha contra el trabajo infantil en el tráfico;

d) La ampliación, estructuración y articulación de la red de protección al niño y al adolescente deben coincidir con el empleo de estrategias de aproximación entre la red de asistencia y las familias, la comunidad y la escuela, de modo a permitir un diálogo que conceda vez y voz a los niños de los territorios periféricos;

e) La despenalización de las drogas puede ser un instrumento importante para financiar el combate al trabajo infantil en el tráfico, teniendo en cuenta que los recursos despendidos actualmente con la política de represión pueden revertirse para la promoción de la salud y de la educación de los habitantes de los territorios periféricos.

\section{NOTA}

1 La Convención sobre los Derechos del Niño fue ratificada por Brasil el 24.9.1990, conforme reconoce el Decreto presidencial n. ${ }^{\circ}$ 99.710, del 21/11/1990.

\section{REFERENCIAS}

BRAGA, Raquel Willadino et al. (coord.). Caminhada de crianças, adolescentes e jovens na rede de tráfico de drogas no varejo do Rio de Janeiro, 2004-2006. Rio de Janeiro/RJ: Observatório de Favelas, 2006. Disponible en: http://of.org.br/wp-content/uploads/2017/02/Pesquisa-Rotas-de-Fuga.pdf. Acesso en: 5 mar. 2020. 
BRAGA, Raquel Willadino et al. (coord.). Novas configurações das redes criminosas após a implantação das UPPS. Rio de Janeiro: Observatório de Favelas, 2018.

BRASIL. Constituição (1988). Brasília/DF, 1988. Disponible en: http:// www.planalto.gov.br/ccivil_03/constituicao/ConstituicaoCompilado.htm. Acceso en: 3 sept. 2020.

BRASIL. Decreto n. ${ }^{\circ}$ 99.710, de 21 de novembro de 1990. Promulga a Convenção sobre os direitos da criança. Brasília/DF, nov. 1990a. Disponible en: http://www.planalto.gov.br/ccivil_03/decreto/1990-1994/d99710.htm. Acceso en: 3 sept. 2020.

BRASIL. Lei n. ${ }^{\circ}$ 8.069, de 13 de julho de 1990. Dispõe sobre o Estatuto da Criança e do Adolescente e dá outras providências. Brasília/DF, jul. 1990b. Disponible en: http://www.planalto.gov.br/ccivil_03/leis/L8069compilado. htm. Acceso en: 3 sept. 2020.

BRASIL. Lei n. ${ }^{\circ}$ 11.346, de 15 de setembro de 2006. Cria o Sistema Nacional de Segurança Alimentar e Nutricional - SISAN com vistas em assegurar o direito humano à alimentação adequada e dá outras providências. Brasília/DF, set. 2006. Disponible en: http://www.planalto.gov.br/ccivil_03/_Ato20042006/2006/Lei/L11346.htm. Acceso en: 4 sept. 2020.

BRASIL. Ministerio de Desarrollo Social y Combate al Hambre (MDS); Organización Internacional del Trabajo (OIT). Buenas Prácticas: Combate al Trabajo Infantil en el Mundo / organizadores: Ministerio de Desarrollo Social y Combate al Hambre; Ministerio del Trabajo y Empleo; Ministerio de Relaciones Exteriores. Brasilia/DF: MDS; OIT, MTE; MRE, 2015.

BRASIL. Decreto n. ${ }^{\mathbf{1}} \mathbf{1 0 . 0 8 8}$, de 05 de novembro de 2019. Consolida atos normativos editados pelo Poder Executivo Federal que dispõem sobre a promulgação de convenções e recomendações da Organização Internacional do Trabalho - OIT - ratificadas pela República Federativa do Brasil. Brasília, nov. 2019. Disponible en: http://www.planalto.gov.br/ccivil_03/_Ato20192022/2019/Decreto/D10088.htm\#art5. Acceso en: 3 sept. 2020.

CRUZ NETO, Otávio; MOREIRA, Marcelo Rasga; SUCENA, Luiz Fernando Mazzei. Nem soldados nem inocentes: juventude e tráfico de drogas no Rio de Janeiro. Rio de Janeiro: Editora Fiocruz [online], 2001. 
DOWDNEY, Luck. Crianças do tráfico: um estudo de caso de crianças em violência armada organizada no Rio de Janeiro. Rio de Janeiro: Sete Letras, 2003.

FREIRE, Paulo. Pedagogia da Autonomia. 55. a ed. Rio de Janeiro: Paz e Terra, 2017.

GALDEANO, Ana Paula; ALMEIDA, Ronaldo (coord.). Tráfico de drogas entre as piores formas de trabalho infantil: mercados, famílias e rede de proteção social. São Paulo: CEBRAP, 2018.

IBGE. Síntese de indicadores sociais: uma análise das condições de vida da população brasileira. Rio de Janeiro: IBGE, 2019.

MBEMBE, Achille. Necropolítica. 3. a ed. São Paulo: Editora N-1, 2018.

ORGANIZAÇÃO INTERNACIONAL DO TRABALHO (OIT). Crianças no narcotráfico: um diagnóstico rápido. Brasília: OIT, 2002.

SANTOS, Boaventura de Sousa. Gramática do tempo: para uma nova cultura política. 2. ed. v. 4. São Paulo: Cortez, Col. Para um novo senso comum, 2008.

THORNTON, Mark. Criminalização: análise econômica da proibição das drogas. São Paulo: LVM Editora, 2018. 



\section{SOBRE LAS AUTORAS Y LOS AUTORES}

Ana Elisa Alves Brito Segatti. Fiscal del Trabajo del Ministerio Público del Trabajo en São Paulo. Graduada en la Pontificia Universidad Católica de São Paulo. Especialista en Derecho Constitucional en la Escuela Superior de Derecho Constitucional. Coordinadora de la Coordinación Regional de Combate contra la Explotación del Trabajo de Niñas, Niños y Adolescentes de la Fiscalía Regional del Trabajo de la $2^{a}$ Región.

Ana Maria Villa Real Ferreira Ramos. Fiscal del Trabajo. Especialista en Derecho Constitucional en la UnB. Miembro Auxiliar de la Inspección Nacional del Ministerio Público en los períodos de 2009 a 2013 y de 2015 a 2016. Coordinadora Nacional de Coordinfância desde 2019.

Antônio Alves Mendonça Júnior. Con Maestría en Derecho en la Universidad Federal de Minas Gerais. Especialista en Derecho y Proceso del Trabajo en la Universidad Anhanguera (2013). Graduado en Derecho en la Facultad de Pitágoras Divinópolis (2020) y en Letras en la Universidad Federal de Minas Gerais (2010). Auditor Fiscal del Trabajo, aprobado en el concurso público realizado en 2010 .

Antônio Gomes de Vasconcelos. Doctor en Derecho en la Universidad Federal de Minas Gerais (2007). Máster en Derecho en la Universidad Federal de Minas Gerais (2002). Especialista en Derecho Público en la FDMM (1989). Graduado en Derecho en la Universidad Federal de Minas Gerais (1987) y en Filosofía en la Pontificia Universidad Católica de Minas Gerais (1978). Profesor adjunto de la UFMG, en los cursos de graduación en Derecho y en Ciencias del Estado y en el Curso de Postgrado en Derecho (Maestría y Doctorado), de la Universidad Federal de Minas Gerais. Juez en el Tri- 


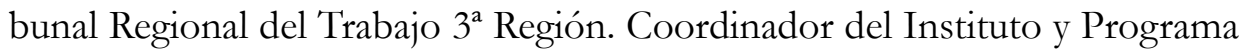
PRUNART-UFMG.

Christiana D'arc Damasceno Oliveira. Jueza Titular del Tribunal del Trabajo de Plácido de Castro, Acre, TRT 14. Doctora en Derecho - Universidad Católica de Santa Fé. Master en Teoría Crítica de los Derechos Humanos - Universidad Pablo de Olavide, Sevilla. Posgrado en Derecho del Trabajo y Proceso del Trabajo - PUC-MG. Especialista en Derecho Procesal - PUCMG. Ex-Auditora Fiscal del Trabajo - Rio Grande do Sul. Investigadora del Grupo de Investigación de Trabajo, Constitución y Ciudadanía - Universidad de Brasília (UnB). Autora de (El) Derecho del Trabajo Contemporáneo: eficacia de los derechos fundamentales y dignidad de la persona humana en el mundo del Trabajo (LTr Editorial); y de diversos artículos y capítulos en publicaciones jurídicas especializadas.

Cláudia Regina Lovato Franco. Fiscal del Trabajo del Ministerio Público del Trabajo en São Paulo. Con Maestría en Derecho en la Universidad Católica de Brasília. Especialista en Derecho del Trabajo PUC-São Paulo. Graduada en Derecho por la Facultad de Derecho de la Universidad Presbiteriana Mackenzie. $2^{\text {a }}$ Vicecoordinadora de la Coordinación Regional de Combate contra la Explotación del Trabajo de Niñas, Niños y Adolescentes de la Fiscalía Regional del Trabajo de la $2^{\text {a }}$ Región.

Dalliana Vilar-Lopes. Fiscal del Trabajo, actualmente ejerciendo la Vicecoordinación Nacional de la Coordinación Nacional del Trabajo Portuario y Acuaviario - Conatpa, como también la Vicegerencia del Proyecto Rescate la Infancia de Coordinfância del MPT. Con Maestría en Derechos Humanos y Desarrollo de la Justicia (DHJUS) en la Universidad Federal de Rondônia (UNIR) y discente de la Maestría en Derecho Constitucional de la Universidad de Sevilla, en España. Especialista en Derecho y Proceso del Trabajo en la Escuela de la Magistratura del Trabajo de la 10 Región (ESMAT-10) y en Derecho Aplicado al Ministerio Público del Trabajo por la Escuela Superior del Ministerio Público de la Unión (ESMPU). Estudió Licenciatura en Ciencias Jurídicas y Sociales en la Universidad Federal de Paraíba (UFPB).

Denise Ratmann Arruda Colin. Asistente social del Ministerio Público de Paraná. Actualmente ocupa el cargo de directora del Departamento de Planeamiento y Gestión de la Fiscalía Adjunta para Asuntos de Planeamiento Institucional del Ministerio Público de Paraná. Doctora en sociología política 
por la Universidad Federal de Paraná. Fue Secretaria Nacional de Asistencia Social en el Ministerio de Desarrollo Social y Combate al Hambre/MDS en el período de 2011 a 2014.

Dulce Martini Torzecki. Fiscal del Trabajo, actúa en el Ministerio Público de Trabajo de Rio de Janeiro. Especialista en Derecho del Niño y del Adolescente por la Escuela del Ministerio Público Estadual-RS. Con Maestría en Derechos Humanos, Interculturalidad y Desarrollo por la Universidad Pablo de Olavide (UPO) en Sevilla, en España.

Eliane Araque dos Santos. Fiscal General Adjunto del Trabajo (MPT). Licenciada en Derecho por la UFMG. Especialización en Política Social por la UNB, en Derechos Humanos por UNICEUB y en Procedimientos de Solución de Conflictos por Industrial Relations Research Institute de la Universidad de Wisconsin-Madison, Estados Unidos. Curso sobre Relaciones Industriales por el Ministerio del Trabajo del Gobierno de Japón, organizado por Japan International Cooperation Agency-JICA.

Elisiane dos Santos. Fiscal del Trabajo. Con Maestría en Filosofía en el Instituto de Estudios Brasileños de USP. Coordinadora del Grupo de Trabajo de Raza de la Coordigualdad en el Ministerio Público del Trabajo. Coordinadora Nacional de Coordinfância en los años 2015-2016. Coordinadora Regional de Coordinfância en São Paulo en los años 2012-2014. Representante del MPT en la coordinación del Fórum Paulista de Prevención y Erradicación del Trabajo Infantil de 2016-2019 y en el Fórum de Combate a la Discriminación Racial en el Trabajo en los años 2018-2019.

Felipe Caetano da Cunha. Estudiante de Derecho en la Universidad Federal de Ceará - UFC - y activista por los derechos de niños y adolescentes.

Fernanda Brito Pereira. Fiscal del Ministerio Público del Trabajo. Con Maestría en Educación en la Universidad Federal de Minas Gerais y cursa Maestría en Derecho en la Universidad Católica de Brasília.

Fernanda Pereira Barbosa. Fiscal del Trabajo en la Fiscalía Regional del Trabajo de la $10^{a}$ Región. Actualmente discente de LLM/MA en Derechos Humanos de Birkbeck, Universidad de Londres.

Gabriela Lenz de Lacerda. Jueza del Trabajo en el Tribunal Regional de la $4^{a}$ Región. Estudiante de maestría en Derechos Humanos, Interculturalidad 
y Desarrollo en la Universidad Pablo de Olavide - UPO. Es miembro de la Asociación de Jueces para la Democracia - AJD.

Ivan Roberto Capelatto. Psicoterapeuta de niños, adolescentes y familias. Con Maestría en Psicología Clínica en PUC-Campinas y Formación en Psicoanálisis en la Clínica Santa Fé y Comunidad Terapéutica ENFANCE. Profesor convidado del Curso de terapia breve familiar de The Milton H. Erickson Foundation Inc. (Phoenix, Arizona, y Nueva York, EE.UU), del Curso de Medicina de la Familia de UNICAMP y del Curso de Postgrado en Pediatría del Curso de Medicina de PUC-Paraná. Colaborador de la UNESCO con el Proyecto Vida, con apoyo del Periódico O Estado de São Paulo. Fundador de GEPAPI (Grupo de Estudios e Investigación (Pesquisa en portugués) en Autismos y otras Psicosis Infantiles). Escritor y Conferencista.

Jailda Eulidia da Silva Pinto. Fiscal del Trabajo, actúa en el Ministerio Público del Trabajo de Pernambuco. Especialista en Derechos Humanos y Trabajo en la Escuela Superior del Ministerio Público de la Unión (ESMPU). Con Maestría y Doctorado en Derecho del Trabajo y Teoría Social Crítica en la Universidad Federal de Pernambuco (UFPE).

Kátia Magalhães Arruda. Ministra del Tribunal Superior del Trabajo. Licenciada en Derecho y con Maestría en Derecho Constitucional en la Universidad Federal de Ceará - UFC. Es Doctora en Políticas Públicas en la Universidad Federal de Maranhão (UFMA) e investigadora de temas relacionados a la precarización del trabajo y eficacia de los derechos constitucionales del trabajo y trabajo infantil.

Lelio Bentes Correa. Ministro del Tribunal Superior del Trabajo. Perito de la Organización Internacional del Trabajo. Ex Coordinador Nacional de Coordinfância del Ministerio Público del Trabajo.

Luciana Marques Coutinho. Fiscal del Trabajo. Coordinadora Regional en Minas Gerais y Vicecoordinadora Nacional de la Coordinación del Combate contra la Explotación del Trabajo de Niñas, Niños y Adolescentes (Coordinfância).

Lydiane Machado e Silva. Fiscal del Trabajo, actualmente licenciada para el ejercicio de mandato clasista en la Asociación Nacional de los Fiscales del Trabajo. 
Márcio Rogério de Oliveira. Fiscal en Minas Gerais. Integró la dirección de la Asociación Brasileña de Magistrados, Fiscales y Defensores Públicos de la Infancia y de la Juventud (actual Ibdcria/ABMP) en las gestiones 2004/2006, 2006/2008 y 2016/2017. Participó de la creación e implantación del Centro Integrado de Atención al Adolescente Autor de Acto Infraccional de Belo Horizonte (CIA-BH), donde actúa desde 2008 en la atención al adolescente en conflicto con la ley penal.

Margaret Matos de Carvalho. Fiscal Regional del Trabajo en Paraná. Coordinadora Regional de la Coordinación de Combate contra la Explotación del Trabajo de Niñas, Niños y Adolescentes - Coordinfância. Coordinadora Ejecutiva del Fórum Estadual de Prevención y Erradicación del Trabajo Infantil. Actualmente Fiscal Jefe Administrativo de PRT de la 9a Región/PR.

Manuella Castelo Branco Pessoa. Profesora Adjunta del Departamento de Psicología de la Universidad Federal de Paraíba. Profesora colaboradora del Programa de Postgrado en Psicología de la Salud de la Universidad Estadual de Paraíba. Doctora en Psicología Social (UFPB). Vice Líder de NUPEDIA y miembro del Grupo de Estudios Subjetividad y Trabajo.

Maria de Fátima Pereira Alberto. Profesora Titular del Departamento de Psicología y del Programa de Postgrado en Psicología Social de la Universidad Federal de Paraíba. Doctora en Sociología (UFPE). Coordinadora del Núcleo de Investigación y Estudios sobre el Desarrollo de la Infancia y Adolescencia (NUPEDIA). Investigadora $1 \mathrm{D}$ de CNPq.

Mariane Josviak. Fiscal Regional del Trabajo en Paraná, ex-Coordinadora Nacional de Coordinfância y ex Gerente Nacional de Aprendizaje Profesional de Coordinfância - MPT. Especialista en Derecho del Trabajo en la Escuela de la Magistratura del Trabajo en Paraná y en Derecho Constitucional por el Instituto Brasileño de Derecho Constitucional - IBDConst. Con Maestría en Derecho Cooperativo y Ciudadanía por la Universidad Federal de Paraná - UFPR.

Marques Casara. Periodista. Director de Papel Social, agencia especializada en investigación de cadenas productivas.

Noemia Garcia Aparecida Porto. Jueza del Trabajo. Con Doctorado y Maestría en Derecho, Estado y Constitución en la Universidad de Brasília 
(UnB). Presidente de la Asociación Nacional de los Magistrados de la Justicia del Trabajo (ANAMATRA - bienio 2019-2021). Profesora universitaria.

Oscar Guardiola-Rivera. Profesor titular de Derecho en Birkbeck, Universidad de Londres. Se ha desempeñado como asistente del Congreso de Colombia y como consultor de las Naciones Unidas en América del Sur. Ha impartido clases de derecho, filosofía y política en tres continentes y es autor de What if Latin America Ruled the World?: How the South Will Take the North into the 22nd Century.

Patrícia de Mello Sanfelici Fleishmann. Fiscal del Trabajo en la Fiscalía Regional del Trabajo de la 4. ${ }^{a}$ Región - Porto Alegre. Coordinadora Nacional de Coordinfância de septiembre de 2017 a agosto de 2019. Actual Coordinadora Regional de Coordinfância/RS.

Rafaela Rocha da Costa. Profesora Efectiva del Curso de Psicología de la Universidad del Estado de Minas Gerais (UEMG). Cursa el Doctorado del Programa de Postgrado en Psicología Social de la Universidad Federal de Paraíba (UFPB). Miembro del Núcleo de Investigación y Estudios sobre el Desarrollo de la Infancia y Adolescencia (NUPEDIA).

Rafael Dias Marques. Fiscal del Trabajo. Coordinador Nacional de Coordinfância de 2010 a 2015. Jefe del Gabinete del Fiscal General del Trabajo de 2016 a 2019. Vicefiscal Jefe Administrativo de PRT de la 8 Región de 2015 a 2016. Fue Juez de Trabajo de 2003 a 2005 y Fiscal del Banco Central de Brasil en 2003.

Renata Queiroz Dutra. Profesora Adjunta de Derecho del Trabajo y Proceso del Trabajo de la Universidad de Brasília. Doctora y Máster en Derecho, Estado y Constitución en la UnB. Investigadora Integrante de los Grupos de Investigación "Transformaciones del trabajo, democracia y protección social” (CNPq/UFBA); “Trabajo, Precarización y Resistencias” (CNPq/UFBA) y "Trabajo, Constitución y Ciudadanía” (CNPq/UnB).

Roberto Padilha Guimarães. Auditor Fiscal del Trabajo. Especialista en Derecho del Trabajo en la UNISINOS. Fue Coordinador de la Actividad de Combate al Trabajo Infantil de la SRTb/RS.

Simone Beatriz Assis de Rezende. Fiscal Regional del Trabajo en el MPT de Mato Grosso do Sul. Actualmente Inspectora auxiliar del MPT. Doctora 
en Desarrollo Local por la Universidad Católica Dom Bosco (UCDB), con la tesis "Aprendizaje profesional para adolescentes en cumplimiento de medida socioeducativa con restricción de libertad: desarrollo humano y reintegración social". Becaria de Capes.

Thiago Augusto Pereira Malaquias. Cursando graduación en Psicología por la Universidad Federal de Paraíba (UFPB). Becario del Programa Institucional de Becas de Iniciación Científica (PIBIC/CNPq).

Valesca de Morais do Monte. Fiscal Jefe Administrativo de PRT $10^{a}$ Región (DF y Tocantins). Fue Coordinadora Nacional de Coordinfância. Fue Coordinadora Regional de Coordinfância de PRT $10^{a}$ Región. Fue Coordinadora del Fórum DF de Prevención y Erradicación del Trabajo Infantil. Fue Miembro Auxiliar en la Comisión de la Infancia y Juventud del Consejo Nacional del Ministerio Público. Cursando la Maestría en Derecho en la Universidad Católica de Brasília.

Valdemiro Xavier dos Santos Júnior. Cursando Maestría en Derechos Fundamentales y Justicia en la UFBA. Integrante del Grupo de Investigación "Transformaciones del Trabajo, democracia y protección social" (CNPq/ UFBA). Técnico de Seguro Social - INSS.

Walter Ude. Profesor Asociado de la UFMG. Miembro del Curso de postgrado en EJA - PROMESTRE/UFMG. Investigador de prácticas en el campo de Educación Social, dialogando con matrices pedagógicas afrodiaspóricas, en conexión con el sistema socioeducativo, jóvenes encarcelados y prevención al HIV con población adolescente y su diversidad de género, en la Facultad de Medicina/UFMG.

Wilson Guilherme Dias Pereira. Discente de Licenciatura en Derecho en la Facultad Interamericana de Porto Velho - UNIRON - con Pasantía en Derecho en el Ministerio Público del Trabajo - PRT de la 14a Región. Fue Asesor Estadual de Políticas Públicas para Niños y Adolescentes en la Secretaría de Estado de Asistencia y de Desarrollo Social - SEAS/Rondônia (2016-2019); Presidente del Consejo Estadual de los Derechos del Niño y del Adolescente de Rondônia (2019); Miembro del Grupo de Investigación y Activista Audre Lorde (2019).

Xisto Tiago de Medeiros Neto. Fiscal Regional del Ministerio Público de Trabajo. Profesor Adjunto de UFRN (Universidad Federal de Rio Grande do 
Norte) y de la ESMPU (Escuela Superior del Ministerio Público de la Unión). Especialista en Derecho del Trabajo y en Derecho Público. Con Maestría en Derecho Constitucional. Cursando Doctorado en Derecho en la UFPR.

Zeu Palmeira Sobrinho. Juez de Trabajo en el Tribunal Regional del Trabajo de Rio Grande do Norte, donde es Gestor regional del Programa de Combate al Trabajo Infantil. Profesor de la Universidad Federal de Rio Grande do Norte - UFRN. Con Maestría y Doctorado en Ciencias Sociales, en la UFRN, con pasantía postdoctoral en Sociología Jurídica, en la Universidad de Coimbra. 


\section{DIBUJOS DEL MPT EN LA ESCUELA}

\section{MPT EN LA ESCUELA 2019}

Estudiante: Felipe Ferreira Santiago; Adrian José Rocha

Escuela: Escola Municipal Frei Egídio Carloto

Año lectivo: $4^{\circ} / 5^{\circ}$

Municipio/Estado: Pinhais/PR

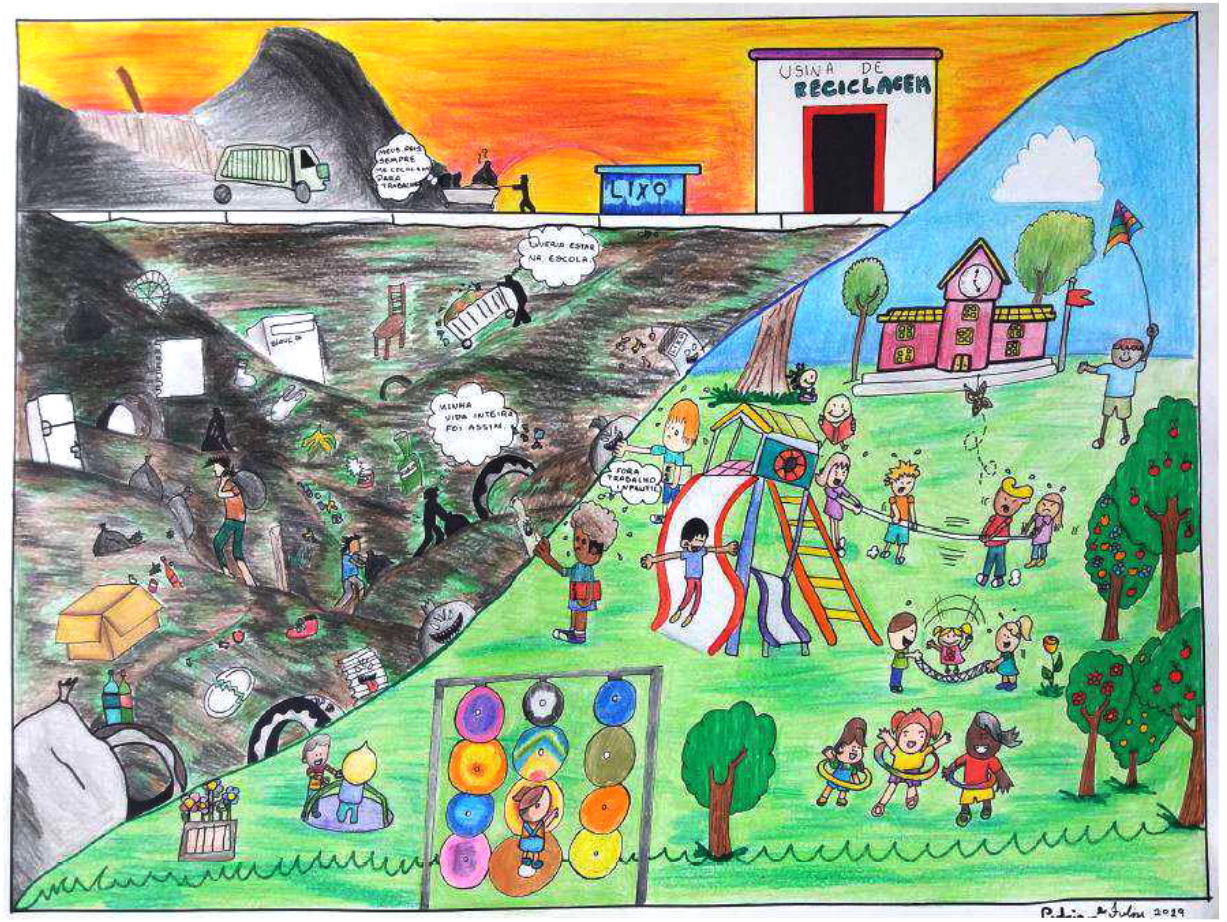




\section{MPT EN LA ESCUELA 2019}

Estudiante: Alan dos Santos Ferreira

Escuela: EMEIEF Professor José Justino Castilho

Año lectivo: $4^{\circ} / 5^{\circ}$

Municipio/Estado: Limeira/SP

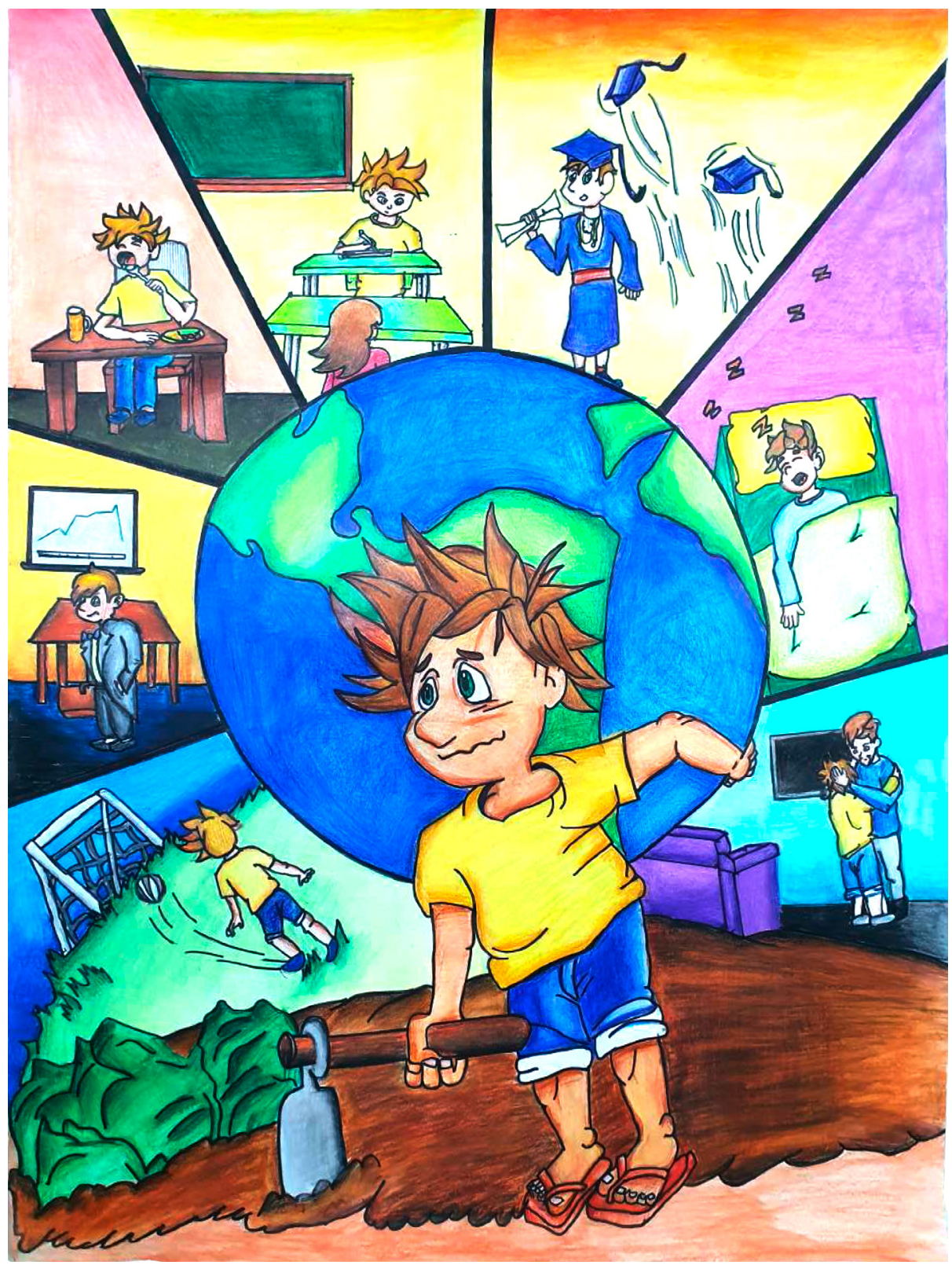




\section{MPT EN LA ESCUELA 2019}

Estudiante: Lauane Mirele dos Santos

Escuela: Escola Municipal Emília de Lima

Año lectivo: $4^{\circ} / 5^{\circ}$

Municipio/Estado: Nova Lima/MG

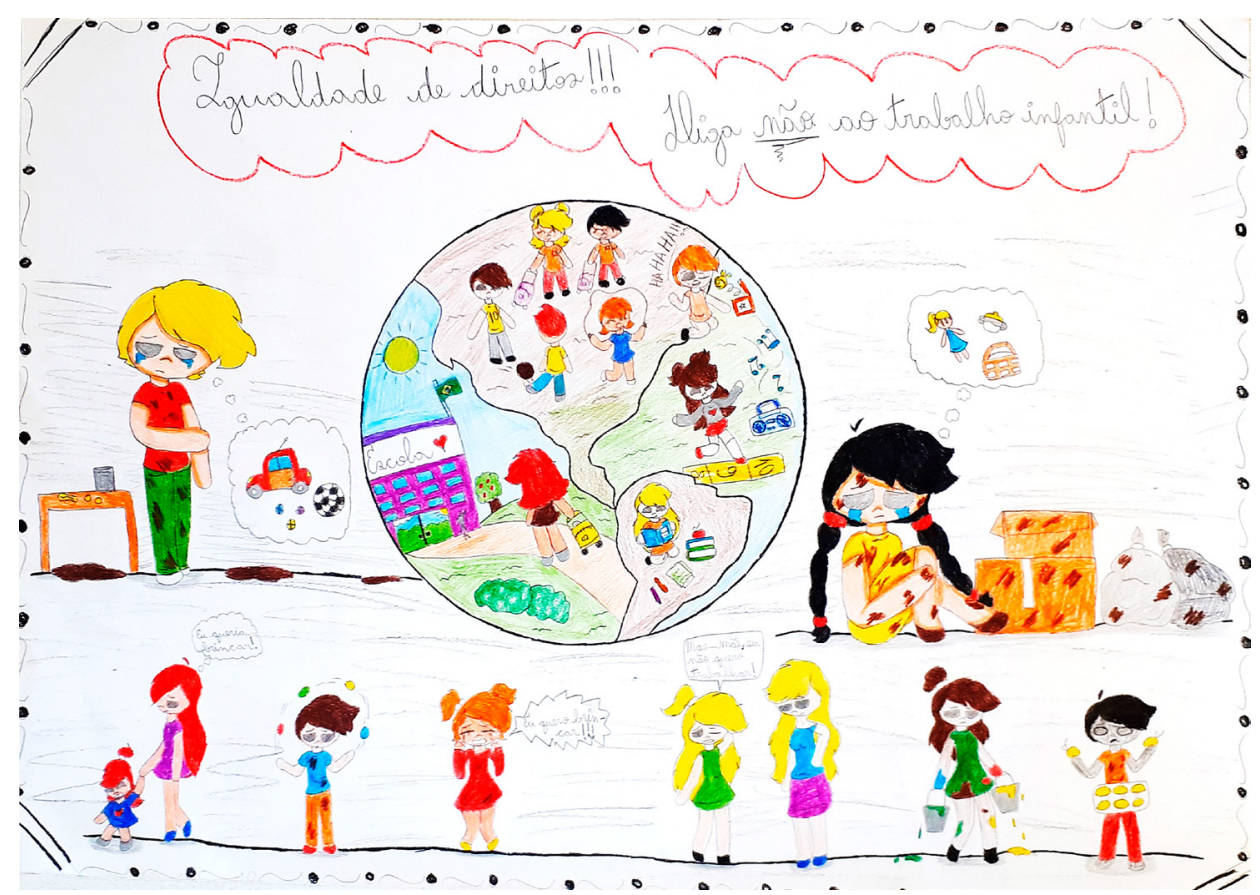




\section{MPT EN LA ESCUELA 2019}

Estudiante: Erick Cabral da Silva; Wanderson dos Santos Neves

Escuela: Escola Municipal Padre Donald R. Macgillivray

Año lectivo: $6^{\circ} / 7^{\circ}$

Municipio/Estado: União dos Palmares/AL

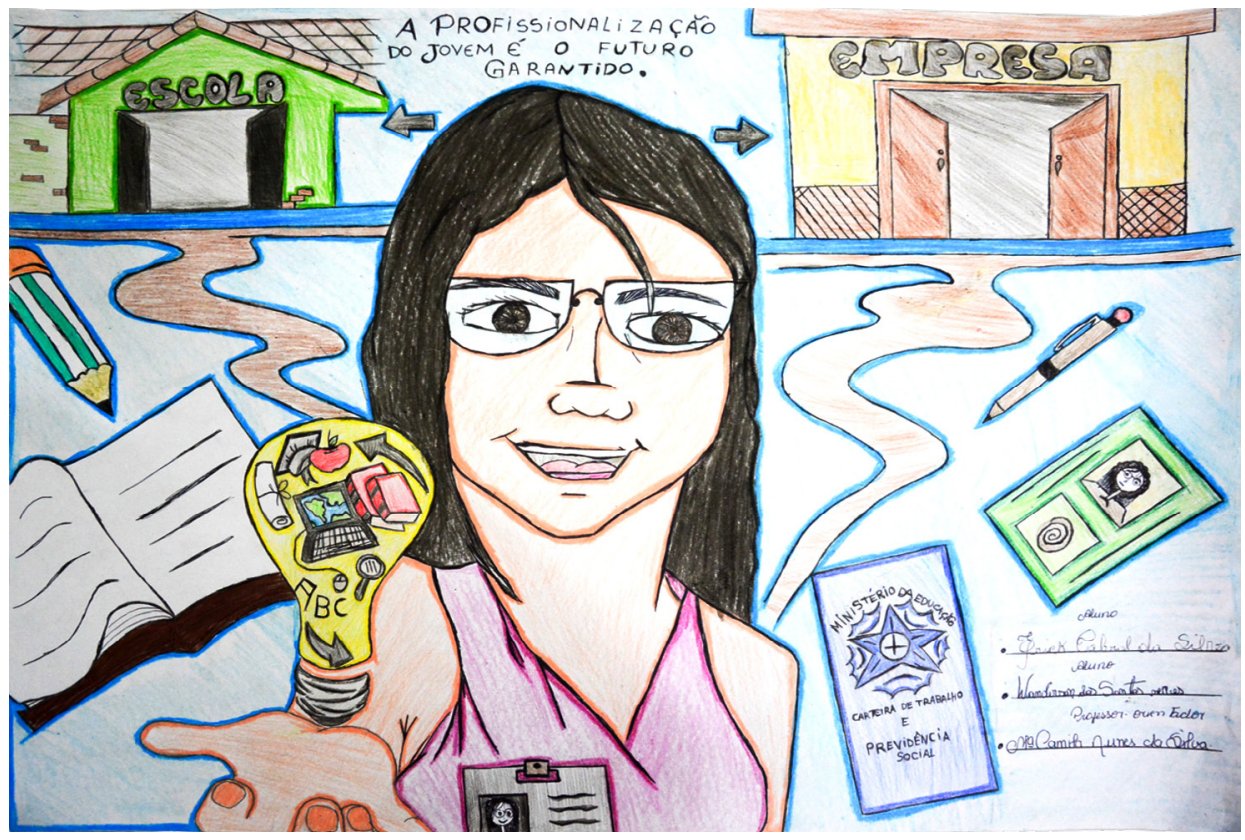




\section{MPT EN LA ESCUELA 2019}

Estudiante: Giovanna Victória Lacerda de Freitas; Gustavo Carvalho Lucio Rodrigues Amaral

Escuela: Escola Municipal Policena Alves Amorim

Año lectivo: $6^{\circ} / 7^{\circ}$

Municipio/Estado: Três Marias/MG

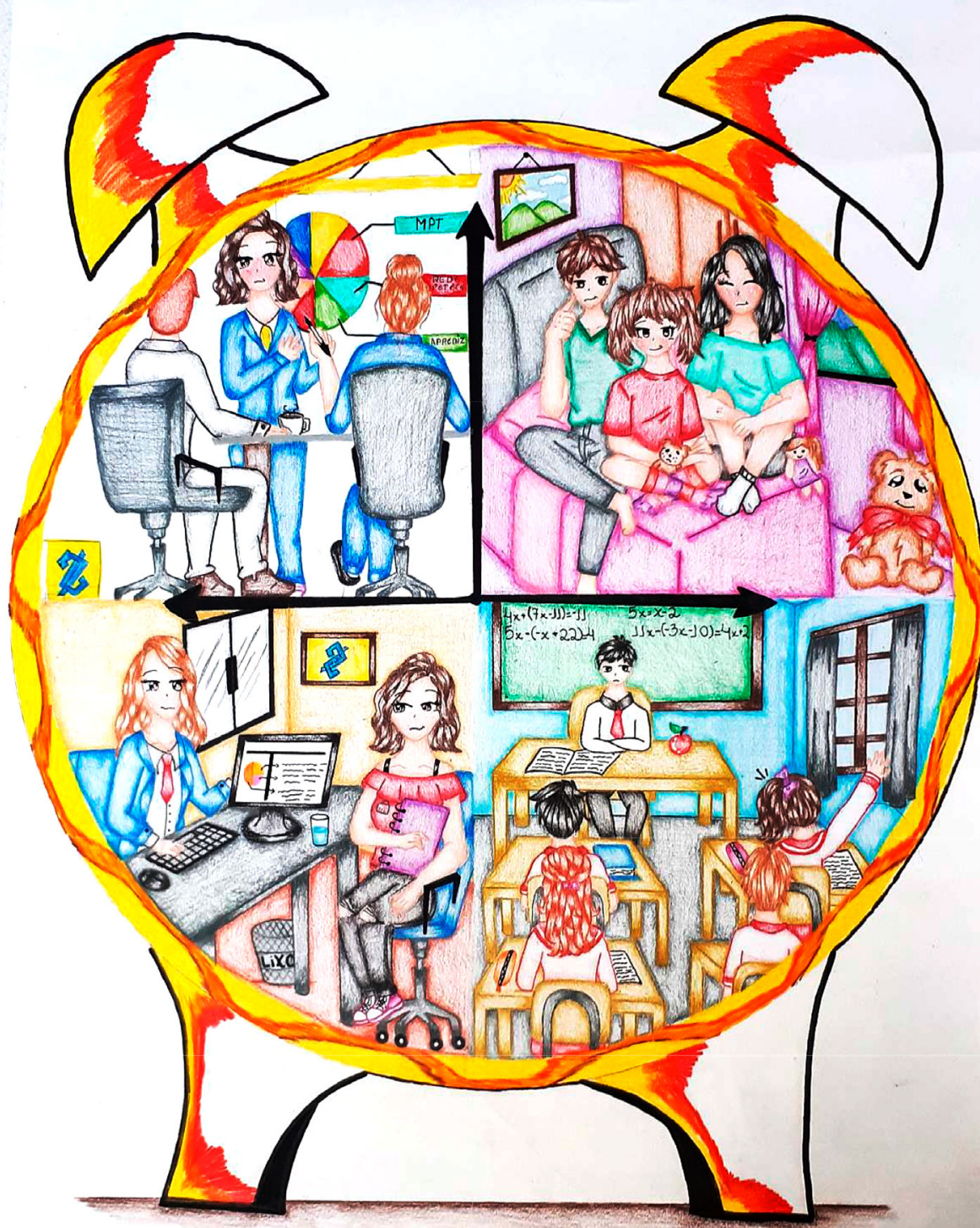




\section{MPT EN LA ESCUELA 2019}

Estudiante: Wesley Porcela Da Silva

Escuela: EMEF Mario Quintana

Año lectivo: $6^{\circ} / 7^{\circ}$

Municipio/Estado: Porto Alegre/RS

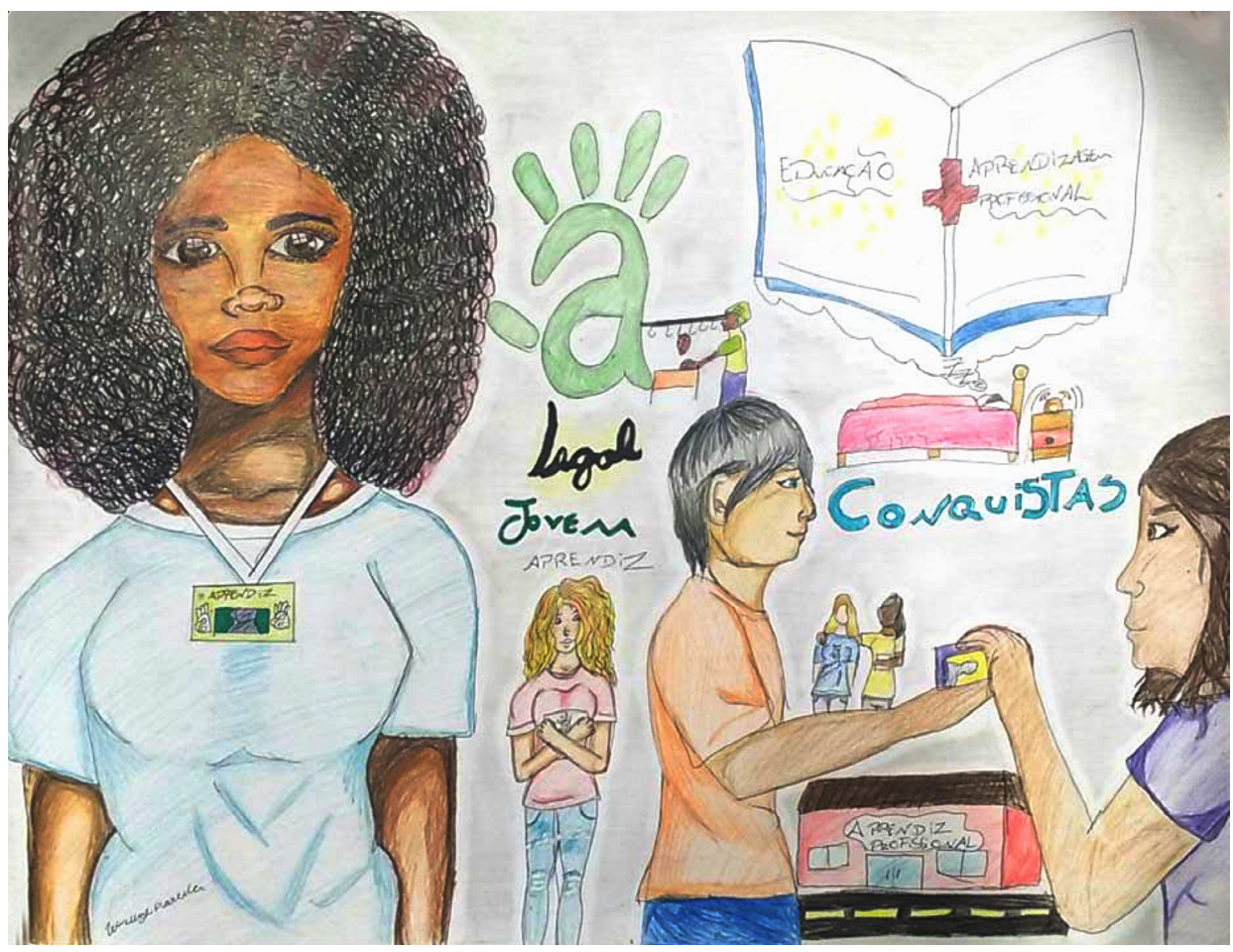




\section{MPT EN LA ESCUELA 2018}

Estudiante: Wallace Souza Santos; Clara Regina Rogeline; Valentina de Paula Escuela: Escola Municipal Professora Greuza Dal Molin

Año lectivo: $4^{\circ} / 5^{\circ}$

Municipio/Estado: Realeza/PR

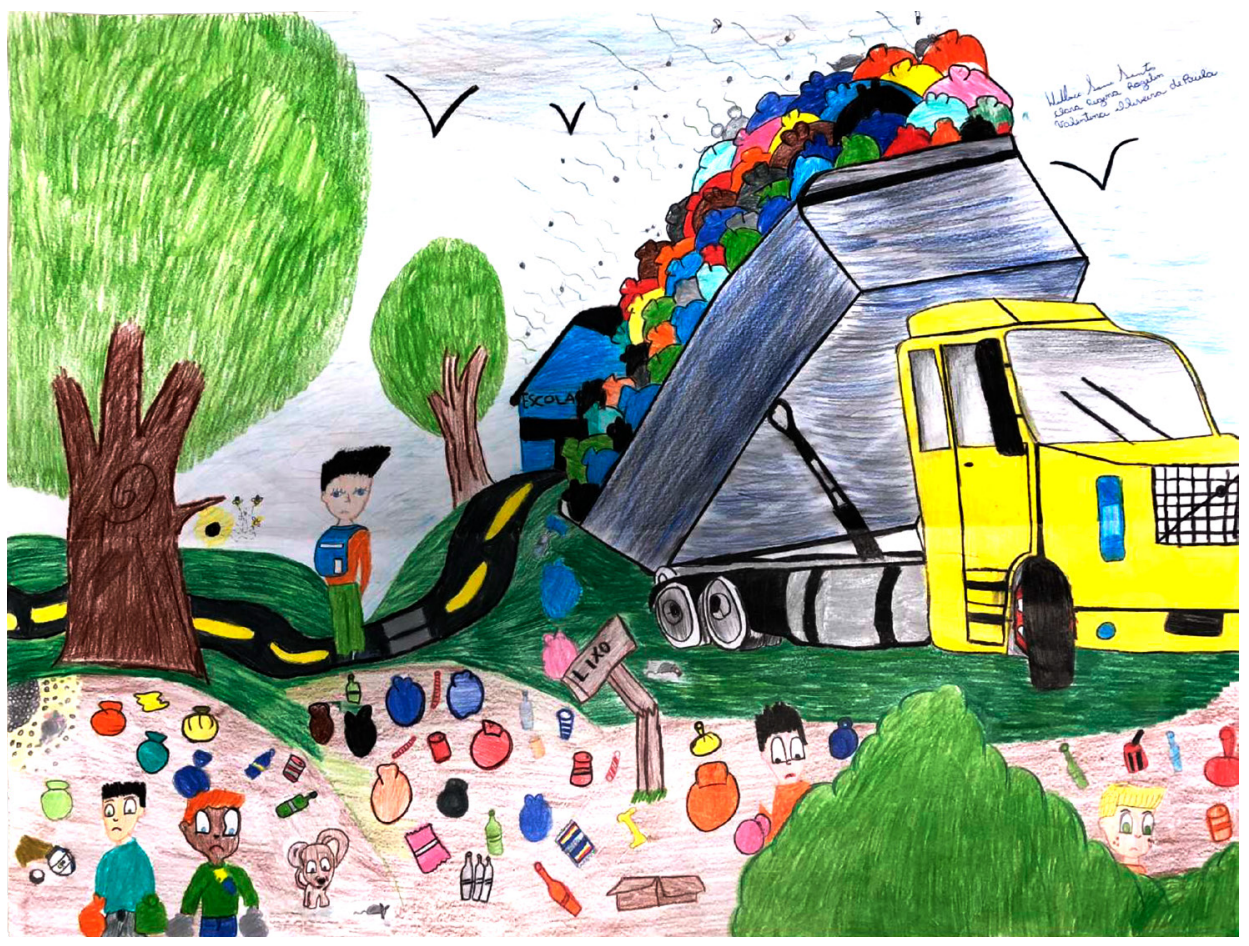




\section{MPT EN LA ESCUELA 2018}

Estudiante: Isabella Salomão de Paula

Escuela: Escola Municipal Professor Delmiro Salvione Bonin

Año lectivo: $4^{\circ} / 5^{\circ}$

Municipio/Estado: Nova Andradina/MS

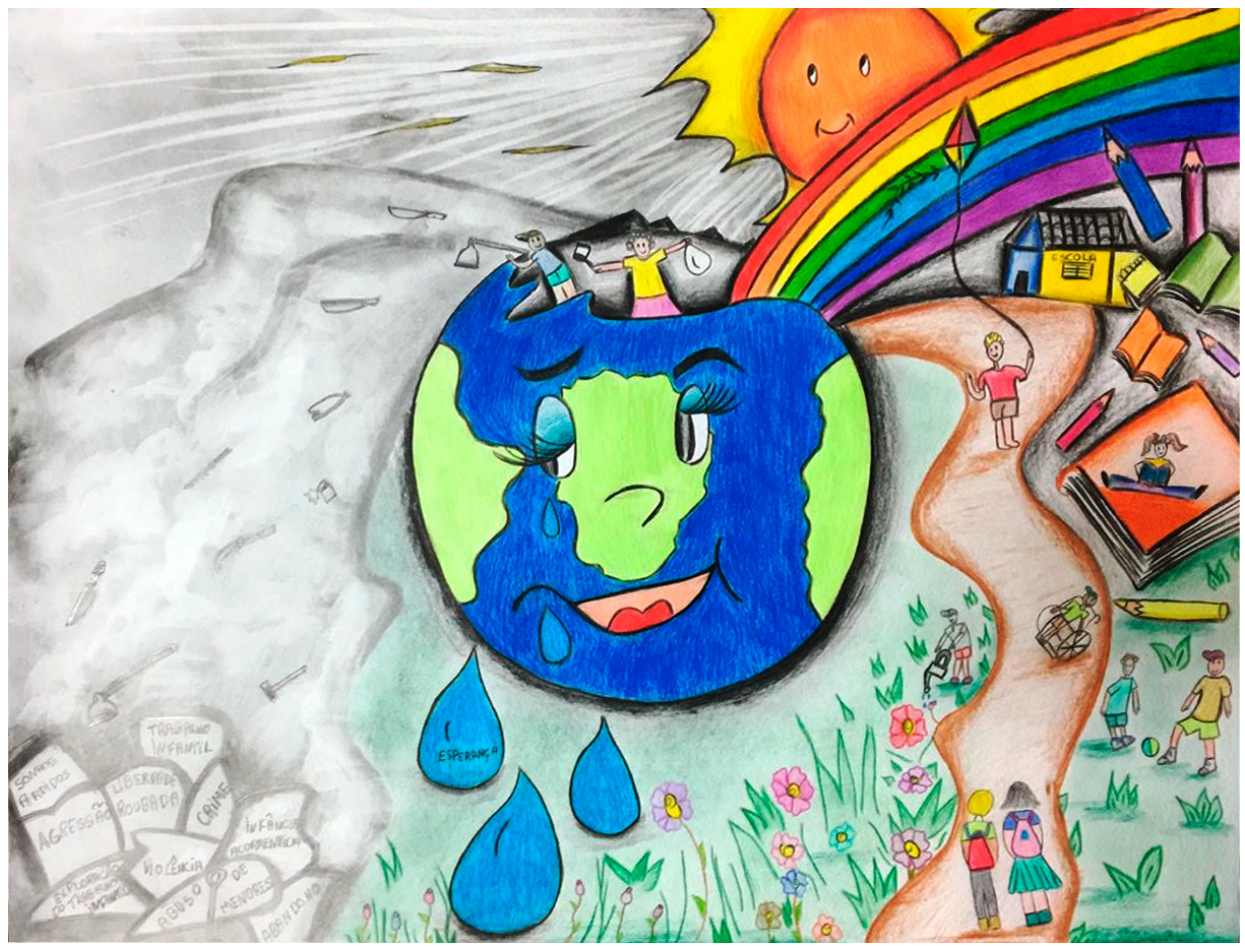




\section{MPT EN LA ESCUELA 2018}

Estudiante: Francisco Hugo Rodrigues Macedo

Escuela: Escola de Ensino Infantil e Fundamental Francisco Silveira

Año lectivo: $4^{\circ} / 5^{\circ}$

Municipio/Estado: Reriutuba/CE

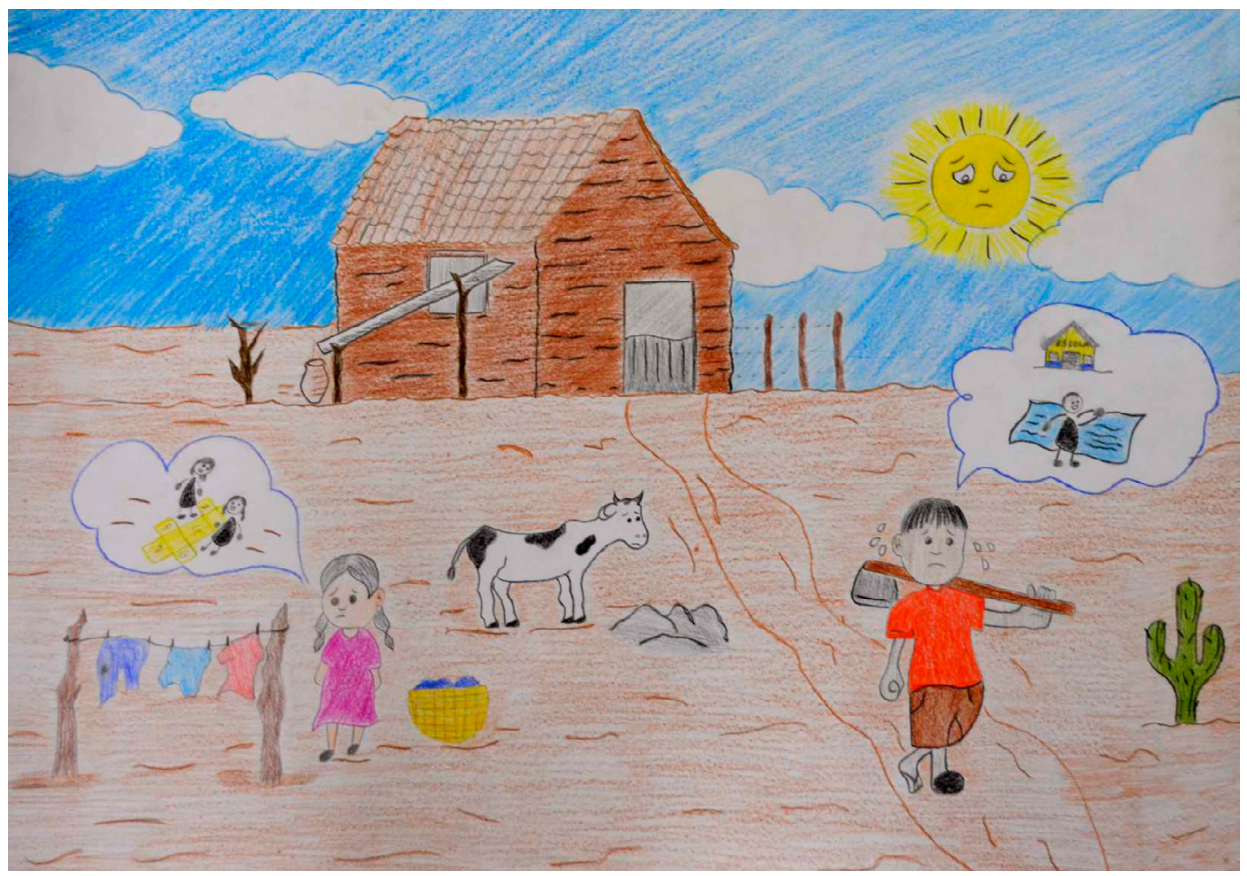




\section{MPT EN LA ESCUELA 2018}

Estudiante: Andre Sousa da Silva

Escuela: Escola de Ensino Fundamental Santa Adelaide

Año lectivo: $6^{\circ} / 7^{\circ}$

Municipio/Estado: Barroquina/CE

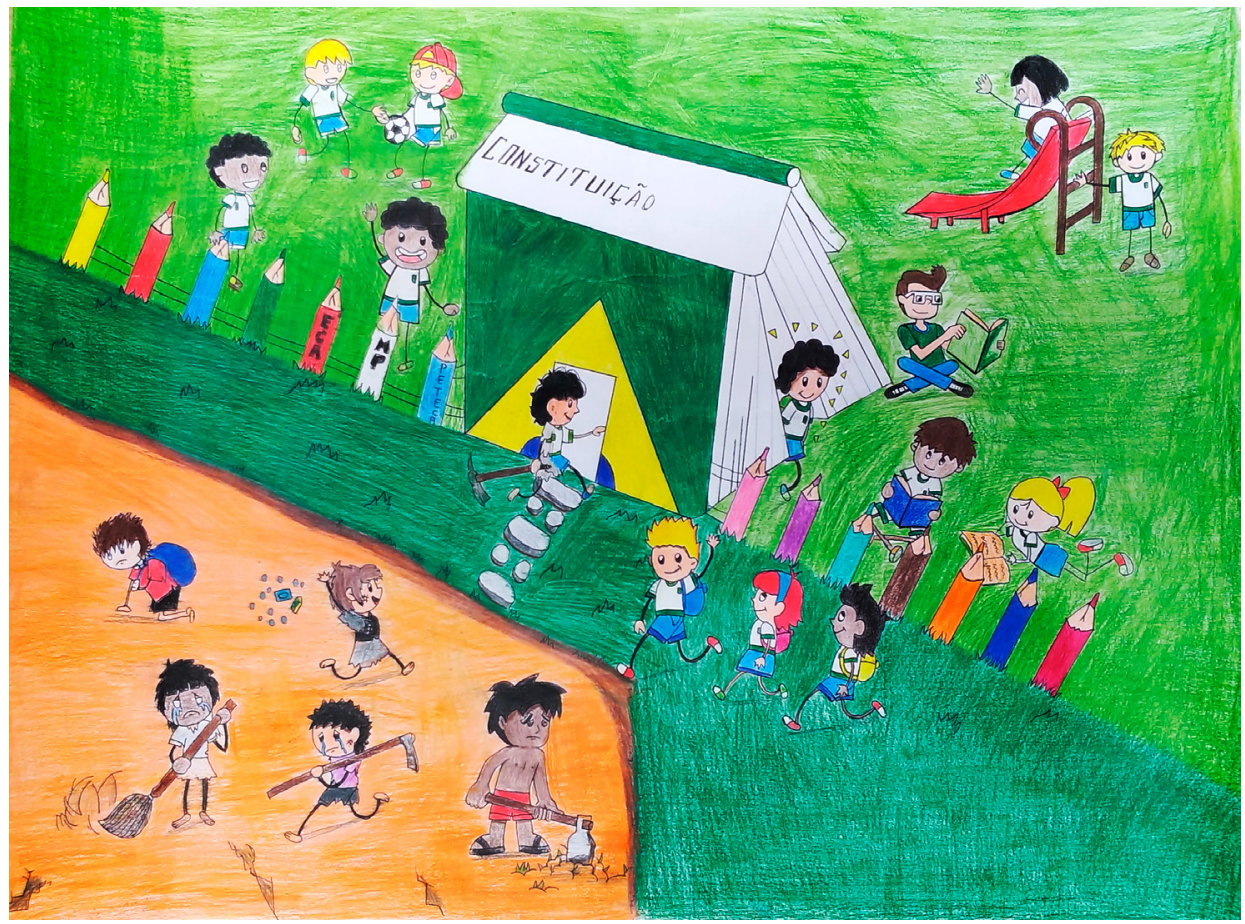




\section{MPT EN LA ESCUELA 2018}

Estudiante: Matheus Carvalho Dias

Escuela: Escola CEF 26 de Ceilândia

Año lectivo: $6^{\circ} / 7^{\circ}$

Municipio/Estado: Ceilândia/DF

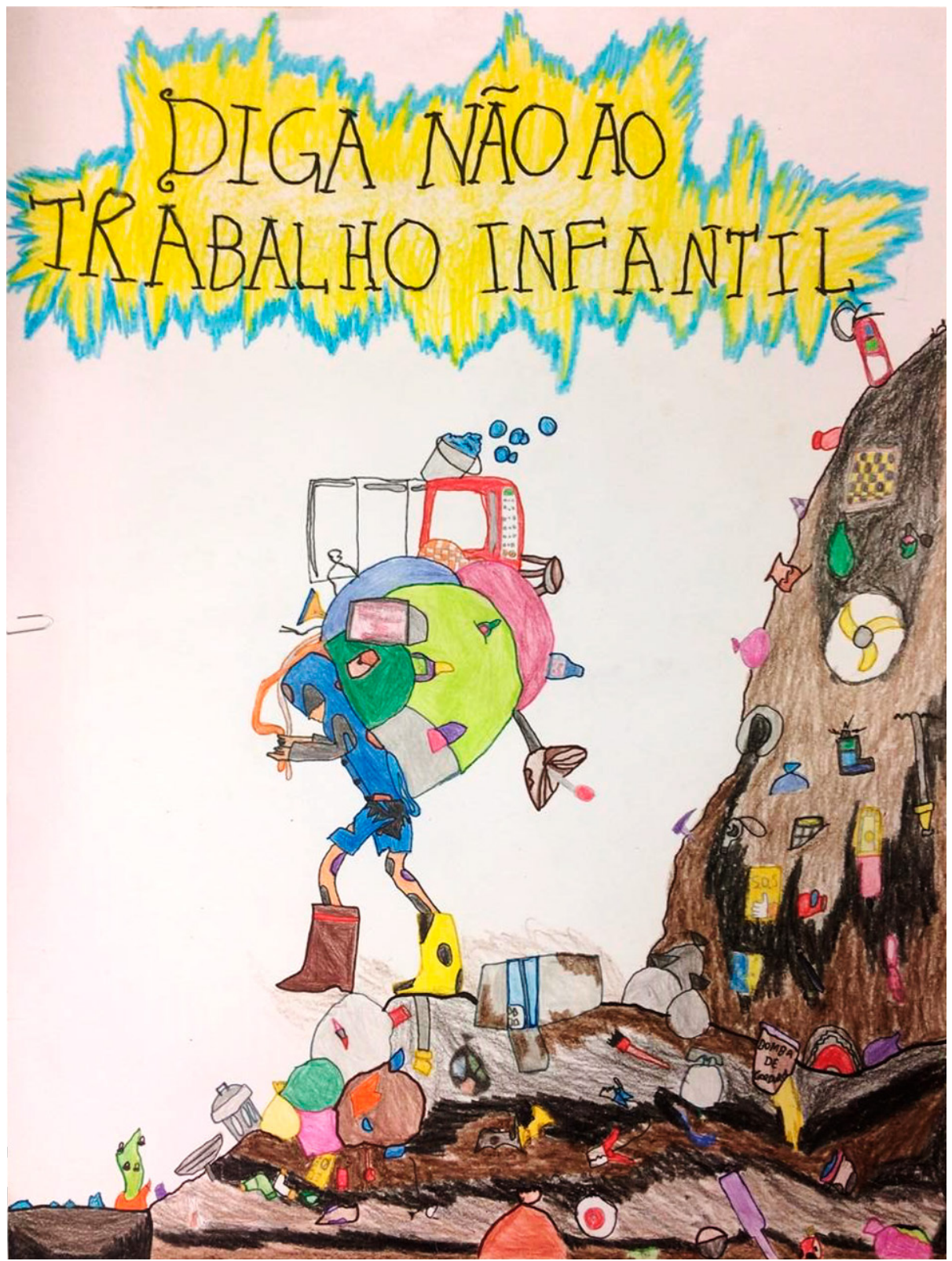




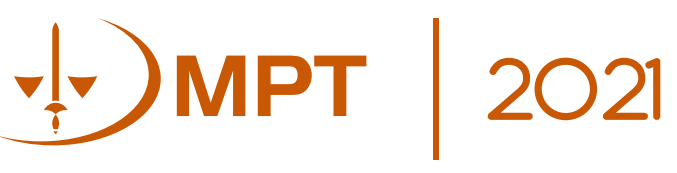

